UNIVERSIDADE DE SÃO PAULO

FACULDADE DE FILOSOFIA, LETRAS E CIÊNCIAS HUMANAS

DEPARTAMENTO DE HISTÓRIA

PROGRAMA DE PÓS-GRADUAÇÃO EM HISTÓRIA SOCIAL

\title{
O ISLAMISMO E SUAS IMPLICAÇÕES NO PROCESSO DEMOCRÁTICO LIBANÊS
}

\author{
Renato José da Costa
}

Dissertação apresentada ao Programa de PósGraduação em História Social, do Departamento de História da Faculdade de Filosofia, Letras e Ciências Humanas da Universidade de São Paulo, para a obtenção do título de Mestre em História.

Orientador: Prof. Dr. Peter Robert Demant 
UNIVERSIDADE DE SÃO PAULO

FACULDADE DE FILOSOFIA, LETRAS E CIÊNCIAS HUMANAS

DEPARTAMENTO DE HISTÓRIA

PROGRAMA DE PÓS-GRADUAÇÃO EM HISTÓRIA SOCIAL

\section{O ISLAMISMO E SUAS IMPLICAÇÕES NO PROCESSO DEMOCRÁTICO LIBANÊS}

Renato José da Costa 
Para minha filha, Ananda, $e$ Minha mãe, Sofia. Mulheres admiráveis... 


\section{AGRADECIMENTOS}

Desenvolver essa dissertação foi um grande desafio, no entanto, tive a felicidade de contar com o apoio de várias pessoas que puderam indicar-me o melhor caminho a seguir, ou, quando não sabiam, indicarem a quem eu deveria procurar. Quando se trabalha com questões tão complexas quanto às presentes nessa dissertação, conhecer as fontes e suas intenções torna-se extremamente necessário, caso contrário, ao invés de um trabalho acadêmico, poderia estar desenvolvendo uma obra panfletária e tendenciosa. Daí, mais uma vez, a grande relevância dos amigos e mestres que puderam indicar-me não somente o que determinado autor pensava, mas ajudar-me a desenvolver seu raciocínio dentro do contexto em que viveram (ou vivem).

Então, tenho de agradecer aos amigos e colegas de discussões sobre assuntos relativos ao Oriente Médio (e muitos mais!), Fábio Metzger e Marcos Toyansk. Ambos, nos momentos mais difíceis dessa dissertação, propuseram-se a discutir comigo 'as lacunas' que impediam o desenvolvimento do processo de pesquisa e, assim, consegui vislumbrar novos caminhos para alcançar meus objetivos.

Também, não posso deixar de agradecer aos professores Samuel Feldberg e Reginaldo Nasser, por terem participado da banca de qualificação desse trabalho e feito considerações que auxiliaram, e muito, no desenvolvimento final da dissertação.

Gostaria de agradecer, principalmente, a quem devo todo o conhecimento que venho adquirindo desde a graduação, Prof ${ }^{\circ}$ Peter Demant. Por continuar partilhando comigo todo o seu conhecimento e fazê-lo com uma gentileza sem igual. Alguém que aprendi a admirar e que, hoje, mais do que nunca, reconheço o diferencial por ter sido conduzido por ele à problemática do Oriente Médio. Sua grandeza reside, exatamente, na maneira de orientar no aspecto mais puro dessa palavra. Ele mostra os caminhos, faz os questionamentos e instiga-o a pensar. E vai além, possibilita a criação de um pensamento crítico... muitas vezes divergente do seu.

Dessa forma, preciso agradecê-lo por ter me orientado nesses últimos dois anos e espero que essa 'parceria' - apesar de desequilibrada, uma vez que sou seu grande ouvinte possa se repetir; porque tenho muito, ainda, a aprender. O Oriente Médio, e o Mundo Muçulmano, precisam ser entendidos pelo Ocidente e faz-se necessário que os pesquisadores aprofundem cada vez mais dos aspectos culturais para que prevaleça o respeito.

Renato J. Costa 


\section{SUMÁRIO}

Índice

Índice de Mapas e Tabelas

Índice de Imagens

Resumo

Abstract

Introdução

Capítulo 1 - Um Certo Líbano

Capítulo 2 - Um Estado Sem Nação

Capítulo 3 - Hizbullah

Capítulo 4 - Democracia

Considerações Finais

Apêndice

Referências Bibliográficas

Índice de Anexos

273 


\section{ÍNDICE}

INTRODUÇÃO

1. UM CERTO LÍBANO

1.1 - O INEXISTENTE LÍBANO... AINDA PARTE DA HISTÓRIA ÁRABE ................... 22

1.2 - OS POVOS DO MONTE LÍBANO E A BUSCA POR UMA IDENTIDADE .............. 30

1.3 - UM POSSÍVEL SENTIMENTO NACIONAL LIBANÊS ......................................... 33

1.4 - AS FACES DO NACIONALISMO NO MUNDO ÁRABE ...................................... 40

1.5 - A ERA DOS TRATADOS E ACORDOS: A DIVISÃO DO MUNDO ÁRABE ........... 47

1.6 - O GRANDE LÍBANO... A ERA CONSTITUCIONAL ......................................... 54

1.7 - LÍBANO, ESTADO INDEPENDENTE E SISTEMA ELEITORAL PRÓPRIO ........ 63

1.8 - PRIMEIRA GUERRA CIVIL: IDENTIDADE, POVO E NAÇÃO EM XEQUE ......... 70

1.9 - FIM DA ERA CHAMOUN, INÍCIO DA ERA SHIHAB: PAZ RELATIVA .............. 76

1.10 - 1964-70: A ERA HELOU E O RUMO PARA A DESINTEGRAÇÃO NACIONAL .. 78

2. UM ESTADO SEM NAÇÃO ............................................................................. 87

2.1 - EXPLODE A $2^{\mathrm{a}}$ GUERRA CIVIL - BANALIZAÇÃO DA NACIONALIDADE ........ 92

2.2 - 31 DE MAIO DE 1976 - SÍRIA EM BUSCA DA ‘GRANDE SÍRIA’......................... 102

2.3 - 1978, ISRAEL CONTRA-ATACA: OPERAÇÃO LITANI ..................................... 107

2.4 - 1982, UM NOVO REINÍCIO PARA UMA GUERRA SEM FIM ............................. 113

2.5 - OS XIITAS CLAMAM POR SEUS DIREITOS ..................................................... 119

2.6 - HIZBULLAH NASCE OFICIALMENTE EM 1985 ............................................ 123

2.7 - ACORDO DE TAIF - O REINÍCIO DO ESTADO? ............................................ 130

2.8 - O LÍBANO PÓS-TAIF, A RECONSTRUÇÃO SOB ERROS .................................... 132

2.9 - ISRAEL VOLTA A ATACAR... .................................................................... 135

2.10 - OSLO PARA OS PALESTINOS, VINHAS DA IRA PARA OS LIBANESES .......... 138

2.11 - 2000: ISRAEL SAI... SÍRIA FICA! SOBERANIA LIBANESA ALCANÇADA? ...... 143 
2.12 - 2005: SÍRIA DEIXA O LÍBANO _............................................................... 147

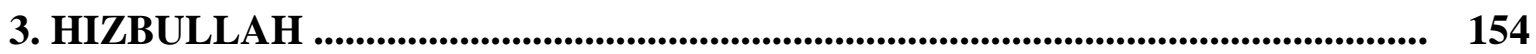

3.1 - O PODER: DOS TEMPOS DE MAOMÉ AO FINAL DO CALIFADO .................... 157

3.2 - O DESEMPENHO DO PODER: AOS OLHOS DOS XIITAS ............................... 160

3.3 - O SURGIMENTO DO PENSAMENTO ISLAMISTA .............................................. 161

3.4 - O XIISMO NO ESTADO LIBANÊS _................................................................ 167

3.5 - A LEGITIMIDADE DA LIDERANÇA DE KHOMEINI ........................................ 172

3.6 - HIZBULLAH, PROLONGAMENTO DA REVOLUÇÃO IRANIANA? .................. 174

3.7 - ACORDO DE TAIF DO HIZBULLAH ................................................................ 184

3.8 - O ‘PARTIDO DE DEUS’ NO JOGO DEMOCRÁTICO ............................................ 186

3.9 - NO CAMINHO DO ISLÃ OU DA DEMOCRACIA? ................................................ 197

4. DEMOCRACIA ...................................................................................... 200

4.1 - DEMOCRACIA, UM CONCEITO EM QUESTÃO ............................................... 202

4.2 - MEIOS PARA A REPRESENTATIVIDADE POLÍTICA ..................................... 206

4.3 - O SISTEMA CONFESSIONAL LIBANÊS _....................................................... 212

4.4 - O JOGO PARTIDÁRIO LIBANÊS ................................................................... 214

4.5 - 1975, GUERRA-CIVIL, FIM DAS INSTITUIÇÕES .......................................... 218

4.6 - O PENSAMENTO ISLAMISTA PRÉ-TAIF ................................................... 221

4.7 - ACORDO DE TAIF E OS NOVOS RUMOS DA DEMOCRACIA ............................ 226

4.8 - HIZBULLAH E AS ELEIÇÕES DE 1992, 1996 E 2000 .......................................... 230

4.9 - SOBERANIA RESTAURADA: ISRAEL FORA (2000), SÍRIA FORA (2005) ........... 233

4.10 - DAHL, LIJPHART E SARTORI: LÍBANO DEMOCRATA? ............................... 239

CONSIDERAÇÕES FINAIS ............................................................................... 252

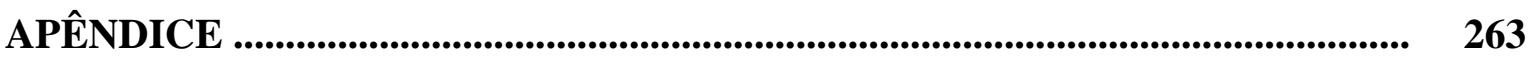

REFERÊNCIAS BIBLIOGRÁFICAS .................................................................. 267 


\section{ÍNDICE DE MAPAS E TABELAS}

1. Tabela da Família do Profeta Maomé

Fonte: (Hourani, 2001: 457)

2. Mapa da Era dos Califados

Fonte: http://upload.wikimedia.org/wikipedia/en/1/10/Age_of_Caliphs.gif

3. Mapa do Império Otomano - dimensão alcançada até 1856

Fonte: http://www.ottomansouvenir.com/General/maps_of_ottoman_empire.htm

4. Tabela das Dinastias que dominaram a Síria

Fonte: (Hourani, 2001: 459-62)

5. Mapa da Província libanesa sob o domínio otomano - 1910

Fonte: http://unimaps.com/lebanon1914/

6. Mapa da Província autônoma do Líbano - 1861 - 1915

Fonte: http://en.wikipedia.org/wiki/Lebanon

7. Mapa do Acordo Sykes-Picot - 1916

Fonte: http://www.vlaamspalestinakomitee.be/Geschiedenis/Kaarten/sykes_picot_agreement_1916\%20map.gif

8. Mapa dos territórios prometidos aos árabes pela Coroa Britânica - 1915

Fonte: http://www.dartmouth.edu/ gov46/uk-promis-arabs-1915.gif

9. Mapa dos Quatro Distritos criados no Líbano

Fonte: http://upload.wikimedia.org/wikipedia/en/d/db/Lebanon.geohive.gif

10. Tabela com a divisão da região sob Mandato francês

Fonte: http://www.library.uu.nl/wesp/populstat/Asia/syriap.htm

11. Tabela com o Censo Oficial libanês - 1932

Fonte: (McDowall, 1986: 12)

12. Mapa dos Campos de refugiados Palestinos - 1948

Fonte: http://www.dartmouth.edu/ gov46/pal-ref-camps-1948.gif

13. Mapa do conflito no Canal de Suez - 1956 
14. Mapa da região antes e pós “Guerra dos Seis Dias” - 1967

Fonte: http://www.jewishvirtuallibrary.org/jsource/History/67_War.html

15. Tabela com relação da imprensa escrita publicada no Líbano em 1975

Fonte: (Del Pino, 1989: 162-4)

16. Tabela da Daivisão das Milícias - 1975

Fonte: (McDowall, 1986: 14)

18. Mapa da cidade de Beirute

Fonte: http://www.liban-voyage.com/lebanon/maps.html

19. Mapa do Líbano com divisão por grupos religiosos - outubro/1976

Fonte: (C) 2000 Matthew White)

20. Mapa do Líbano com divisão por grupos religiosos - 1982

Fonte: http://www.lib.utexas.edu/maps/middle_east_and_asia/lebanon_religions_83.jpg

21. Tabela do Modelo teórico de Khomeini para Wilayat al-Faqih

Fonte: (Hamzeh, 2006: 32)

22. Tabela de Graus de Jihad para Hizbullah

Fonte: (Hamzeh, 2006: 36)

23. Tabela de Divisão Institucional e Territorial do Sistema Judicial

Fonte: (Hamzeh, 2006: 103)

24. Tabela da Estrutura Organizacional do Hizbullah

Fonte: (Hamzeh, 2006: 46)

25. Tabela da Estrutura de Governo da República Iraniana

Fonte: (Al-Khazraji, 2005: 66)

26. Tabela de Instituições Políticas que a Democracia em Larga Escala Exige .....

Fonte: (Dahl, 2001: 99-100)

27. Mapa do Plano Sionista para a Palestina - 1919

Fonte: (Brichs, 2002)

28. Tabela de Relação de Assentos destinados aos Grupos Religiosos

Fonte: http://en.wikipedia.org/wiki

29. Tabela da Distribuição dos Assentos Xiitas no Parlamento

Fonte: (Hamzeh, 2004: 113)

30. Mapa da Região de Shebaa Farms

Fonte: http://www.bbc.co.uk

31. Tabela Tipos de Regimes e Caminhos para a Poliarquia de Dahl

Fonte: (Dahl, 2005: 29-30)

32. Tabela de Distribuição de Assentos para o Parlamento (Eleição 2005)

Fonte: http:// ace.at.org/ero-en/regions/middle-east/LB/Loi\%20Electorale\%20Parlementaire.doc

33. Mapa da Distribuição dos Grupos Religiosos pelo território libanês 


\section{ÍNDICE DE IMAGENS}

1. Soldado Mameluco

Fonte: http://www.napoleon-series.org/military/organization/c_mameluks1.html

\section{Sultão Otomano Abdülhamid II}

Fonte: http://de.wikipedia.org/wiki/Osmanisches_Reich

3. Manifestação nas ruas de Beirute - 1943

Fonte: http://www.geocities.com/CapitolHill/Parliament/2587/warpixs.html

4. Manifestação nas ruas de Beirute - 1958

Fonte: http://www.geocities.com/CapitolHill/Parliament/2587/warpixs3a.html

5. Capa da revista Life $\mathbf{- 1 9 5 8}$

Fonte: http://www.oldlifemagazines.com/mag.php?d=072858

6. Rua Bechara el-Khoury - limite da 'Linha Verde'

Fonte: http://souwar.yaacoub.com/details.php?image_id=2720\&sessionid=faf234874329b91fadc6f4d3bbf4f130

7. Bombardeio à Ashrafieh, parte Oriental de Beirute - 1977

Fonte: http://www.liberty05.com/civilwar/civil77.html

8. Tropas israelenses entrando no Líbano (Operação Litani) - 1978

Fonte: http://www.geocities.com/CapitolHill/Parliament/2587/warpixs3a.html

9. Soldados franceses vítimas do “caminhão-bomba” - Beirute, 1983

Fonte: http://www.geocities.com/CapitolHill/Parliament/2587/warpixs2a.html

10. Símbolo do Hizbullah

Fonte: http://www.hizbollah.org

11. Manifestação em frente ao palácio de Baabda - 1989

Fonte: http://www.geocities.com/CapitolHill/Parliament/2587/warpixs3a.html

12. Palácio de Baabda sob cerco sírio - 1990

Fonte: http://www.generalaoun.org/october13_1.jpg

13. Capa da revista TIME (Guerra do Golfo) - 1991 
14. Camp David - Washington, 1994

Fonte: http://www.lasegunda.com/ediciononline/especiales/arafat/index.asp

15. Retirada israelense da "Zona de Segurança" - 2000

Fonte: http://www.geocities.com/CapitolHill/Parliament/2587/warpixs2a.html

16. Atentado ao ex-primeiro ministro Rafiq Hariri - 2005

Fonte: http://www.cedarland.org

16. Protesto durante o funeral de Rafiq Hariri - 2005

Fonte: http://www.cedarland.org

17. Musa al-Sadr, líder dos xiitas libaneses nas décadas de 1960 e 1970

Fonte: htt://www.angelfire.com/il2/redline/General.html

18. Aiatolá Muhammad Baqir al-Sadr, líder espiritual xiita

Fonte: http://www.victorynewsmagazine.com/ShahidBaqir1.htm

19. Quartel dos marines vítima de atentado com “homem-bomba” em 1983 ....

Fonte: http://www.geocities.com/CapitolHill/Parliament/2587/warpixs2_1.html

20. Capa da revista Veja (Democracia no Mundo Árabe)

Fonte: http://veja.com.br 


\section{RESUMO}

Este trabalho procura analisar a história libanesa (até abril de 2005), no intuito de encontrar subsídios para entender se o Estado que fora criado após o Mandato francês (1920-43), transformou-se numa Democracia. A discussão acerca de o Líbano ser considerado Estadonação, também está presente no contexto histórico desse trabalho.

Paralelamente aos questionamentos feitos sobre o sistema político libanês, analisam-se o surgimento do grupo xiita (Hizbullah), seu projeto islamista inicial e suas razões para transformar-se em partido político. Questionam-se as ligações: Hizbullah-Irã e HizbullahSíria.

Na conclusão questiona-se, a partir dos modelos de democracia de Dahl, Lijphart e Sartori, se o Líbano hoje é um país democrático e se houve transformação no sistema político libanês com a inserção de uma organização islamista.

\footnotetext{
ABSTRACT

This work analyzes Lebanon's history until April, 2005, with the objective to determine if the State that came into being at the end of the French Mandate (1943) evolved into a democracy. The historical introduction also discusses to what degree Lebanon can be considered a nationstate.

In parallel to the arguments about the Lebanese political system, we analyze the emergence of the Shiite group Hizbullah is analyzed, its initial Islamist project, and its transformation into a political party. Its links with Iran and Syria are also considered.
} 
In conclusion Dahl's, Lijphart's, and Sartori's models are applied to inquire if Lebanon today is a democratic country, and to what extent its political system had changed through the integration of an Islamist organization.

\section{PALAVRAS-CHAVE/KEY WORDS}

Democracia, Hizbullah, Islamismo, Israel e Líbano.

Aquele que foi assassinado também é responsável pelo seu próprio assassinato.

E aquele que foi roubado também é culpado por ter sido roubado.

Os corretos não são inocentes dos feitos dos maus, E os virtuosos não estão puros nos atos criminosos. 
Sim, o culpado é, com freqüência, a vítima dos

injuriados.

E ainda é mais freqüente que o condenado leve a

carga dos inocentes e não dos acusados.

Não podeis separar os justos dos injustos e os bons

dos maus;

Pois estão juntos frente ao sol, assim como o fio

branco e o fio preto são tecidos juntos.

E quando o fio preto se parte, o tecelão deve observar

todo o tecido, e também deve examinar o tear.

(Khalil Gibran, “O Profeta”)

\title{
INTRODUÇÃO
}

\author{
O ISLAMISMO E A \\ DEMOCRACIA OCIDENTAL
}

Terrorismo, Islã, islamismo ${ }^{1}$. Nunca essas palavras estiveram tão em voga quanto nos dias de hoje. Em partes, podemos dizer que isso ocorre devido ao envolvimento de uma organização islâmica - a al-Qaeda - nos atentados contra as Torres Gêmeas e o Pentágono,

\footnotetext{
${ }^{1}$ Nessa dissertação será utilizado o termo islamismo para designar o que mais comumente a mídia divulga como fundamentalismo islâmico - essa questão da diferença conceitual será retomada no capítulo Três, quando, analisar-se-á a organização libanesa Hizbullah. Tal opção encontra embasamento na explicação de Demant, segundo a qual, "o fundamentalismo, na verdade, refere-se a um movimento religioso que surgiu há um século dentro do protestantismo religioso norte-americano. Hoje, no entanto, o termo é também usado para movimentos vagamente paralelos em outras religiões.” (2004: 194), Lewis, assim complementa a questão do 'vagamente paralelo', abordado por Demant: "[o termo fundamentalismo] designa algumas igrejas e organizações protestantes, principalmente aquelas que mantêm a origem literal e infalível da bíblia. Neste ponto, opõem-se à atitude de teólogos liberais e modernistas, que tendem para uma visão mais crítica e histórica das Escrituras. Entre os teólogos muçulmanos, não existe ainda uma abordagem liberal ou modernista do Alcorão, e todos os muçulmanos, na sua atitude perante o texto do Alcorão são, em princípio pelo menos, fundamentalistas. Os chamados fundamentalistas muçulmanos diferem dos outros muçulmanos e ainda mais dos fundamentalistas cristãos no seu escolasticismo e no seu legalismo. Eles baseiam-se não só no Alcorão mas também nas Tradições do Profeta, e no corpus do saber teológico e legal. O seu objectivo consiste em nada mais do que na revogação de todos os códigos legais e normas sociais importadas e modernizadas, de modo a instalar e a reforçar toda a panóplia da sharia (a Lei revelada) - as suas regras e penalizações, a sua jurisdição e suas formas prescritas de governo.”. (2001a: 14) Assim, para designar o fenômeno que ocorre no mundo muçulmano, a melhor opção recai sob o termo utilizado pelos próprios árabes, qual seja, islamiyya, que, numa tradução literal para a língua portuguesa seria islamismo.
} 
em 2001. De uma hora para outra a al-Qaeda ganhou as capas de jornais e revistas, assim como noticiários em telejornais de repercussão internacional. Osama Bin-Laden, líder da organização, alcançou o status de herói - para alguns segmentos do islamismo - e sua proposta de uma doutrina baseada num sentimento de revanchismo passou a ser difundida ao mundo, qual seja, a destruição dos EUA (representante mor da decrepitude do Ocidente) para a restauração do Islã.

O efeito imediato dessa superexposição do tema nos meios de comunicação foi o alavancamento da discussão sobre islamismo, do restrito meio acadêmico, para o grande público. É inegável que a própria repercussão dos atentados proporcionou essa abertura, contudo, reforçou, também, o risco de os muçulmanos serem, coletivamente, estigmatizados como terroristas. Na prática, nem todos os muçulmanos que crêem num retorno aos fundamentos do Islã são terroristas, de fato, apenas uma pequena parcela deles parte para a luta armada e utiliza-se de ações terroristas para eliminar 'o modernismo ocidental', conforme se apregoa.

O desejo de retomada aos desígnios do Islã, seguindo os ditames do Corão, simplifica as intenções do islamismo, contudo, em linhas gerais podemos percebê-lo dessa maneira esse tema será retomado nesse estudo. Após a expansão histórica dos muçulmanos, com seu império alcançando o Oriente Médio, norte da África, leste europeu, península Ibérica e sudeste asiático, houve na Europa e no próprio Oriente Médio o início de sua retração embora o Islã continuasse expandindo em outras regiões, tais como o subcontinente indiano, o sudeste asiático e a áfrica subsaariana. Segundo Lewis, o encolhimento se devia ao 'encerramento em si' dos muçulmanos, rejeitando qualquer inovação que pudesse vir do Ocidente. Os muçulmanos, munidos de um pensamento exclusivista, gradualmente foram superados pelos europeus, que deixavam a Idade Média e entravam no período do Renascimento. (2002)

Ainda, conforme Lewis, os muçulmanos, devido a essa estratégia equivocada de 'fechamento cultural', abandonaram a vanguarda do mundo e, num momento posterior, foram sofrendo derrotas consecutivas até tornarem-se dependentes dos ocidentais. Essa dominação acabou sendo uma conseqüência previsível e, na década de 1920, o último império muçulmano desfazia-se com a derrota dos otomanos na Primeira Guerra Mundial² . A sujeição aos ocidentais gerou, num momento subseqüente, a rejeição dos mesmos e, para alguns, um desejo de restabelecer a época de glória do período do Profeta Maomé. Essa necessidade de

\footnotetext{
${ }^{2}$ O Império Persa ainda sobreviveu até 1925, contudo, não teve a mesma expressão do Otomano.
} 
'retorno às fontes' também pode ser justificada a partir do seguinte argumento: para alguns muçulmanos, aceitar sua inferioridade perante o Ocidente seria o mesmo que negar a perfeição do Islã, dessa forma, a melhor saída seria atribuir ‘a derrota temporária’ ao fato de os muçulmanos terem se afastado dos desígnios do Islã e passado a acreditar que a assimilação da cultura ocidental proporcionar-lhes-ia uma inserção igualitária no mundo ocidental. O que não aconteceu exatamente como o esperado, gerando o movimento rejeicionista.

Traídos, segundo a visão dos muçulmanos mais extremados, a saída seria retomar aos momentos de glória do Islã. É certo que essa visão de retomada acaba assumindo contornos subjetivos, inclusive com a idealização da era de Maomé como um período glorificado. Apesar desse aspecto fantasioso - a idealização de algo que nunca existiu na magnitude que é apregoado, na tentativa de restabelecer o que nunca foi estabelecido -, esse pensamento acabou tornando-se um dos pilares da doutrina do islamismo e, dificilmente conseguir-se-á abalá-la. Assim, repudia-se tudo que é ocidental e busca-se em suas fontes islâmicas o caminho para a retomada.

Tomando como base essa problemática, chega-se aos dias de hoje constatando que existe um movimento nascido no interior da comunidade muçulmana e que prega a negação dos valores ocidentais para sua auto-afirmação. Um movimento que já demonstrou seu potencial destrutivo com os atentados de 2001 nos Estados Unidos e que também trouxe para o debate questões acerca da relação desproporcional entre Islã e Ocidente.

A partir desse cenário de conflitos entre islamismo e Ocidente, essa dissertação propõe-se a fazer a análise de um ponto de tensão entre eles: a maneira com que o conceito de democracia é entendido pelos islamistas. A opção por esse recorte advém do fato de que, nos dias de hoje, a democracia é assumida por vários regimes ocidentais como um ideal universal - algo a ser difundido 'através de todas as armas possíveis' -, entretanto, nem sempre encontra ouvintes nas comunidades muçulmanas - pelo menos naquelas avessas ao secularismo.

Para que haja a possibilidade de analisar concretamente o fenômeno do islamismo, em seu surgimento e num momento posterior, assim como, em seu confronto com os ideais da democracia, a opção dessa dissertação recaiu-se sobre o Líbano. O país médio oriental configurou-se na melhor escolha devido aos seguintes fatores: ser um Estado relativamente novo, cuja independência data de 1943 e apresentar as características necessárias para perceber a inserção do islamismo em sua estrutura político-social. 
No Líbano é perceptível a ação das diversas forças que tensionaram o conflito IslãOcidente. Numa primeira etapa houve a influência proveniente do surgimento do Islã - que não converteu a população cristã maronita que ali habitava e gerou certa rivalidade com os muçulmanos -; depois, num segundo momento, a entrada em cena dos efeitos da colonização perpetrada pelas potências européias - pendendo a balança para o lado dos cristãos -; e, finalmente, quando houve o surgimento do Hizbullah xiita, uma organização eminentemente islamista, que foi criada para 'restaurar a soberania' do estado libanês com a proposta de estabelecer uma república islâmica no Líbano - aos moldes do vizinho Irã - mas, num segundo momento tornou-se um partido político e submeteu-se às regras do jogo democrático.

Assim, para que possamos entender a interação entre islamismo e democracia, o foco desse estudo recai-se com mais precisão ao período que abrange a história libanesa de 1975 (início da Segunda Guerra Civil), até o ano de 2005 (saída das tropas sírias do Líbano), o qual, em tese, representaria a efetiva restauração da soberania libanesa. Nesse período de trinta anos pudemos constatar a desconfiguração do conceito de estado-nação e sua posterior reconstrução. Sob as mesmas bases? Cabe o questionamento! No entanto, considerando que a raiz do desentendimento intrasocietário possa datar de período anterior a 1975, alguns outros episódios da história da região do Monte Líbano, depois somente Líbano, também merecerão atenção.

À luz dessa proposta, essa dissertação assim se estrutura: no capítulo 1 reconstitui-se a história da região onde, atualmente, encontra-se o Líbano, a partir do surgimento do Islã até o início da Segunda Guerra Civil libanesa (1975). Para esse capítulo, as análises históricas de Albert Hourani, Karen Armstrong, Bernard Lewis, John Esposito e Kamal Salibi, entre outros, são de fundamental importância. Segundo a perspectiva desses autores, algumas vezes conflituosos entre si, traça-se o caminho que o Islã percorreu, paralelamente e também tangenciando, o pensamento Ocidental. A partir do início do século XX insere-se a forma com que os pensadores árabes passaram a entender a relação entre Islã e Ocidente e sua conseqüente radicalização que levou à criação do islamismo.

O capítulo 2 é de importância fundamental para esse estudo. Nele aborda-se o panorama no qual a Segunda Guerra Civil se desenrolou com a inserção de novos atores e a ação das grandes potências da Guerra Fria - Estados Unidos e União Soviética. Novamente, para a reconstituição dos momentos capitais que permearam a guerra civil, Kamal Salibi, Thomas Friedman, Robert Fisk e Domingo Del Pino são as fontes principais. Salibi com sua reconstrução histórica, os demais, a partir de relatos jornalísticos que fizeram sobre o conflito. Nesse capítulo, também, devido à influência que o conflito Israel-Palestinos teve, direta e 
indiretamente, nas questões libanesas, as análises de Avi Shlaim e Edward Said são consultadas.

A partir do capítulo 3 essa dissertação aprofunda sua análise em um dos conceitos que é o objeto desse estudo, qual seja, o islamismo. Assim, analisa-se a organização islâmica Hizbullah, que surgiu oficialmente em 1985 no intuito de travar a luta pela soberania do Líbano - a parte do sul do país estava, naquele momento, sob ocupação dos israelenses. Esse capítulo apresenta os fatores que interferiram na criação da organização e como formou sua ideologia. A partir de estudos específicos de Hala Jaber, Ahamad Nizar Hamzeh, Judith Palmer Harik, Martin Kramer, entre outros, o Hizbullah é analisado como organização religiosa e como partido político. Quais as congruências e incongruências no pensamento de uma organização islâmica que faz essa transição? Uma questão a ser respondida. A estrutura hierárquica da organização, como instituição religiosa e partido político, também faz parte do foco de análise desse capítulo. A relevância disso aparecerá mais claramente ao confrontar-se com os modelos de democracia.

O capítulo 4 esclarece como funciona o sistema confessional libanês. Ele foi desenvolvido para representar proporcionalmente as comunidades religiosas existentes no Líbano. Apesar de incorporar elementos bastante sofisticados para o início do século XX, o modelo eleitoral e de representatividade foi facilmente assimilado pela população. Entretanto, as modificações que o país foi tendo no transcorrer de sua história acabaram gerando reivindicações de revisão do que fora estabelecido. Tais questionamentos visavam alcançar uma equidade maior entre os grupos religiosos. Nesse capítulo mostra-se como se baseava o modelo de representatividade, o que mudou e quais as atuais reivindicações dos grupos religiosos.

Para a complementação dos elementos de análise dessa dissertação, ainda, no mesmo capítulo 4, discute-se o que é democracia e como é possível estabelecer o nível democrático de um Estado. Para a efetiva análise, utilizamos os conceitos dos cientistas políticos Robert Dahl, Giovanni Sartori e Arend Lijphart. Sartori discute o que se entende por democracia e, utilizando complementarmente os modelos analíticos de Dahl e Lijphart torna-se possível verificar o grau de democracia do estado libanês.

Com base no conteúdo histórico e nas conceituações de islamismo e democracia, o último capítulo dessa dissertação utiliza esses elementos para discutir quais mudanças a democracia libanesa sofreu com a inserção do Hizbullah no seu sistema político. Questiona, ainda, se é possível haver a flexibilização do islamismo perante a democracia, encontrando, com isso, uma terceira via menos radical e mais tolerante. Ou será que a proposta de inserir-se 
no sistema democrático não passa de uma estratégia premeditada para alcançar o poder dentro dos parâmetros estabelecidos pelo jogo democrático - para depois subvertê-lo?

Por ora, desejo que esse estudo proporcione mais questionamentos e contribua para a discussão acerca da relação entre Islã e Ocidente, que traga luz às dúvidas e distorções conceituais utilizadas como recurso estratégico pelas partes para defenderem seus projetos. E, que gere reflexão e desdobramento em novos estudos.

\section{( 1 )}

\section{UM CERTO LÍBANO}

\section{PRIMÓRDIOS, CRIAÇÃO DO ESTADO E FALÊNCIA DO PROJETO NACIONAL}

O Líbano, como estado autônomo, somente passou a existir a partir de 1943, contudo, para que se possa ter uma visão mais abrangente dos processos históricos que a região sofreu, e, conseqüentemente, perceber que muitos eventos contribuíram para o atual status do país, esse capítulo pretende fazer uma abordagem dos principais eventos que marcaram a região. $\mathrm{O}$ surgimento dos povos que habitaram a outrora Síria (que continha o atual Líbano), a criação do Islã, movimentos nacionalistas em prol da independência e, por fim, a difícil manutenção da unidade nacional. A ênfase será dada às passagens que ilustrem a estrutura de governo imposta à região e como o poder político foi utilizado pelos grupos religiosos para que o estado continuasse existindo mesmo em períodos de forte tensão. Como conseqüência direta dessa análise, questionar-se-á a real soberania do estado libanês e a repercussão dessa "fraqueza” institucional no âmbito interno. 
Devido à proposta apresentada, o enfoque maior desse capítulo dar-se-á ao período que abrange o final do século XIX até o início da Segunda Guerra Civil, em $1975^{3}$. Isso porque, apesar de já encontrarmos indícios de uma "nação libanesa” um século antes, ainda não haviam sido criados os mecanismos legais, tampouco a unidade administrativa tinha se concretizado para falarmos em "Líbano”.

Como fora afirmado, a concepção do que entendemos por “estado libanês” somente tornou-se fático a partir de 1943, quando findou o Mandato francês sobre a região. Contudo, para se chegar à independência foi necessário que houvesse um pacto entre os grupos étnicoreligiosos que habitavam o Monte Líbano. Ali, cristãos maronitas e muçulmanos sunitas, na ocasião, detentores do maior prestígio político, idealizaram a divisão político-administrativa entre eles e os demais habitantes do Líbano, muçulmanos xiitas, drusos, ortodoxo gregos, cristãos ortodoxos, etc. $\mathrm{O}$ que veio a resultar no Pacto Nacional ${ }^{4}$ (al-mithaq al-watani), um mecanismo agregador que fora firmado no início da década de 1940 e progrediu para a elaboração de um modelo administrativo no qual os cargos deveriam ser ocupados por integrantes desses grupos religiosos de acordo com sua representação numérica no cômputo geral da população do Líbano. Foi utilizado como parâmetro para a divisão o Censo elaborado em 1932.

A fórmula que resultou no Pacto mostrou-se eficaz para atingir seu objetivo imediato, que era possibilitar a união da população do Monte Líbano com a finalidade de alcançar a independência, entretanto, a ausência de uma tradição democrática, assim como a criação de privilégios para alguns grupos em detrimento a outros, logo indicou que seria necessário fazer uma revisão do mecanismo. O sectarismo político-administrativo implementado pelos maronitas - então com maiores privilégios no governo -, que tornou-se uma constante na vida libanesa, gerou insatisfação por parte dos muçulmanos e serviria como argumento maior para iniciar os enfrentamentos militares de 1958 e 1975 (esse último será visto no próximo capítulo, ao tratarmos da Segunda Guerra Civil libanesa).

\footnotetext{
${ }^{3}$ Para efeito de análise e, seguindo a terminologia adotada pela maioria dos historiadores que narram a história libanesa, adotar-se-á o seguinte critério ao abordar as guerras civis vivenciadas pelo país: Primeira Guerra Civil (1958) e Segunda Guerra Civil (1975-90). Com relação aos eventos ocorridos no Monte Líbano em 1860, deixarse-á de considerá-los como a Primeira Guerra Civil libanesa por não ter sido instaurado, naquela data, o estado, conforme o concebemos nos dias de hoje, tampouco a independência havia sido proclamada. Contudo, ressalvase que alguns movimentos nacionalistas defendem a tese de que em 1860 já havia a configuração da nação libanesa, por conseguinte, teria ocorrido, assim, a Primeira Guerra Civil. Sobre os eventos de 1860, trataremos ainda nesse capítulo.

${ }^{4}$ Não se trata de um documento redigido e assinado, mas sim de um compromisso assumido pelas partes (muçulmanos e cristãos) interessadas em viabilizar uma forma de governo que pudesse representar os grupos religiosos de maneira proporcional. (Zuhur, 2003: 150)
} 
O Líbano, estado independente, passou a compreender dois grandes grupos religiosos: muçulmanos (xiitas, sunitas e drusos ${ }^{5}$ ) e cristãos - majoritariamente maronitas ${ }^{6}$ mas incluindo, também, ortodoxos gregos, cristãos ortodoxos, armênios e outras minorias. A tradição desses grupos religiosos nem sempre possibilitou o direcionamento para um mesmo objetivo. Suas raízes e perspectivas político-religiosas acabavam por indicar, algumas vezes, uma identificação com o mundo ocidental, o que era tido como inadmissível por parte daqueles que lutavam por uma identidade islâmica. O resultado final das divergências levou a atritos.

A formação do estado libanês, considerado por muitos um “organismo político artificial”, não conseguiu impingir a característica de nação a sua população. Essa análise parte da conceituação do que podemos entender como nação: uma comunidade que encontra denominadores comuns, tais como, identidade cultural, étnica, lingüística, modos de ver o mundo, em suma, uma comunidade disposta a cumprir um único desígnio, um único destino. Parcialmente essa afirmação pode ser ratificada analisando-se a trajetória histórica do Líbano, em que fica nítido o atrito provocado pela expectativa não compartilhada por todos que deveriam integrar a figura política “nação libanesa”, um conceito frágil, se ali aplicado.

\footnotetext{
${ }^{5}$ Apesar das divergências existentes entre os drusos e os demais muçulmanos no tocante à maneira com que esse pequeno grupo assimila a crença islâmica - tida como demasiadamente mística por parte do restante da ortodoxia -, o que muitas vezes faz com que não sejam considerados seguidores do Islã; para efeito de estabelecer a divisão política entre os credos, os drusos continuavam sendo considerados muçulmanos.

${ }^{6} \mathrm{O}$ cristianismo no Oriente não é novo e, na região da Antióquia (atual Turquia), os discípulos de Jesus, Paulo e Barnabé, pregaram sua fé. Segundo a tradição, a própria igreja de Antióquia foi fundada por Pedro, da qual foi bispo e, em seguida, partiu para Roma. Juntamente com Alexandria e Constantinopla, Antióquia foi um dos mais importantes centros espirituais da antiguidade tardia no mediterrâneo oriental. Dois fatores, entretanto, foram capitais para a queda da igreja de Antióquia: a posição política antagônica diante do Império Bizantino e sua divisão eclesiástica por cismas e heresias. Um dos motivos da divisão entre esta e a Igreja Ocidental foi a divergência com relação à natureza de Jesus. O nestorianismo reconhecia a natureza humana e divina de Cristo, enquanto o monofisismo defendia que havia nele uma só natureza e uma só pessoa: a divina. Em 451, diante do Concílio de Calcedônia, a ortodoxia bizantina estabeleceu a rejeição dos extremos do nestorianismo e do monofisismo, propondo em Jesus uma só pessoa e duas naturezas. Depois de Calcedônia, o nestorianismo que se propagara na parte oriental do Império Romano, tendo o seu centro em Edessa, foi difundido na Pérsia por Barsumas, surgindo assim a Igreja Cismática Persa (assíria). Os monofisistas continuaram fortes na Síria e no Egito. Zenon (imperador de 474 a 491) foi forçado a se exilar por dois anos, sendo o seu rival apoiado pelos monofisistas. O Henotikon (edito de reunião) buscava pôr fim ao cisma, que era um perigo político. Mas a sugestão do edito de que o Concílio de Calcedônia poderia ter errado levantou indignação no Ocidente e o Papa Simplício excomungou os Patriarcas de Alexandria e Constantinopla, bem como o próprio Imperador. Daí surgiu um cisma que durou até a subida de Justino ao poder, em 518, que reafirmou a definição de Calcedônia. Ainda no final do século IV, o eremita chamado Maron, descontente com as divergências religiosas em curso, refugiouse nas montanhas do Líbano e passou a pregar o que, para ele, seria o verdadeiro caminho - o mesmo reconhecido pelo Concílio de Calcedônia. Encontrou muitos seguidores, os quais passaram a ser conhecidos como maronitas, que sofreram com a perseguição dos monofisistas. Devido às divergências, os maronitas deixaram de reconhecer a supremacia do papa, o que só voltou a acontecer em 1736, através de uma concordata com Roma. Entretanto, esse fato não alterou algumas características já adquiridas, quais sejam: a preservação de sua liturgia própria e seu patriarca. (Cedarland)
} 
Kamal Salibi, historiador libanês, ao propor suas reflexões sobre a trajetória histórica libanesa em 'A House of many Mansions', ratifica a propositura acima apresentada e complementa seu raciocínio apontando para o fato de que um dos principais elementos que dificultam a integração nacional libanesa é a repulsa por uma identidade histórica coletiva entre os grupos religiosos ali presentes ou, tendo em vista essa impossibilidade, a dificuldade de estabelecer uma identidade única e comum, pós-independência, para o Líbano. A cada momento evidencia-se o fato de que "[...] each tribe forever suspicious and distrustful of the others; each tribe always alert, extending feelers to the outside world in different directions, probing for possible sources of external support in preparation for yet another round of open conflict.” (1988: 217-8). Dessa forma, a ausência de uma identidade coletiva passa a ser o maior obstáculo para podermos considerar os povos que vivem no Líbano como pertencentes a uma mesma nação. Opinião essa compartilhada por Thomas Friedman, jornalista norteamericano, em seu livro ‘De Beirute a Jerusalém’ - que aborda o período em que fez a cobertura da Segunda Guerra Civil libanesa na década de 1980:

O indivíduo libanês deriva tradicionalmente sua identidade social e apoio psicológico de suas filiações primordiais: família, bairro, ou comunidade religiosa; dificilmente da nação como um todo. Sempre fora druso, maronita ou sunita antes de se considerar libanês; e sempre membro dos clãs dos Arslan ou Jumblatt, antes de ser druso; ou parte dos clãs maronitas Gemayel ou Franjieh, antes de ser maronita. (1991: 56).

Isso posto, é possível apontar dois períodos como paradigmáticos para entendermos a dificuldade de se conceber o Líbano como um país cujos interesses dos grupos religiosos possam ser relegados a um segundo plano em prol da sustentação de um projeto de estadonação. O primeiro momento de grande relevância diz respeito ao surgimento do Islã e seu alastramento pelo Oriente Médio. Essa afirmativa encontra respaldo no seguinte argumento: É sabido que os "Povos do Livro" - judeus e cristãos - eram aceitos dentro das fronteiras do mundo islâmico e tinham a liberdade de praticar seus cultos; que muitos alcançaram postos de destaque junto ao Império Otomano; que a convivência pode ser considerada pacífica e que somente lhes eram cobrados impostos diferenciados por não serem muçulmanos - fato esse que deixou de existir em meados do século XIX com a implementação do Tanzimat $^{7}$-, porém, essa harmonia deixou de existir no século XX, quando o fator religião tornou-se elemento diferenciador dentro do estado libanês, gerando privilégios não mais aceitáveis se

\footnotetext{
7 “Tanzimat”, termo turco, cuja tradução seria "Reorganização”, remete ao período de transformações que o Império Otomano sofreu para adequar-se à realidade do Ocidente. As reformas transcorreram de 1839-1876 e, dentre outras modificações, em 1856 houve a equiparação política de todos os cidadãos do Império, independentemente da religião preferida.
} 
inseridos no conceito de estado-nação. Distinções essas, não mais cabíveis entre nacionais se havia a intenção de estabelecer um estado unitário. O Islã, que já vinha sofrendo um processo de desestabilização, e teve o ápice desse processo com a falência do Império Otomano, perdeu a supremacia política para os cristãos e o estado libanês absorveu essa diferença gerando ressentimentos. O segundo período histórico mencionado poderia ser entendido, também, como a reação à perda do status quo anterior dos muçulmanos que veio a resultar no surgimento de grupos fundamentalistas ${ }^{8}$. Esses, passaram a reivindicar uma estrutura de governo baseada no princípio religioso islâmico e não mais numa ordem estabelecida através de leis criadas pelo homem; fato esse que, por conseguinte, incorria na negação da existência de Estados - aos moldes ocidentais -, uma vez que toda a população muçulmana deveria pertencer à umma ${ }^{9}$. Uma doutrina que passou a ganhar mais força e adeptos a partir da segunda metade do século XX e encontrou no Líbano um representante altamente potencializado, o Hizbullah (Partido de Deus), que assumiu a função de orientar parte da comunidade xiita ao "retorno aos tempos do Profeta”. Mais especificamente sobre o Hizbullah e o islamismo trataremos nos capítulos 2 e 3.

A partir dessa breve introdução acerca da problemática que será discutida nesse capítulo, passaremos a compor as passagens históricas emblemáticas para sua análise. Dessa forma, a narrativa dar-se-á a partir do surgimento do Islã no século VII. Cabe a ressalva de que não se pretende, com isso, excluir outras possibilidades de leitura do surgimento da nação libanesa, como a proposta por alguns grupos maronitas - como o composto pela família Gemayel, que formaria o Kata'eb (Falange), milícia e partido político - que estabelecem seus vínculos com os fenícios que viveram na região costeira do atual Líbano por volta do século XVI a.C., o que lhes dariam o direito absoluto sobre a terra e seus desígnios - conforme sua linha de raciocínio. (Zuhur, 2003: 148) Contudo, a opção por abordar a construção nacional a partir do início da civilização islâmica apresenta-se com sendo mais objetiva e instrumental para compreender seus desdobramentos no Regime Democrático libanês atual.

\section{1 - O INEXISTENTE LÍBANO... AINDA PARTE DA HISTÓRIA ÁRABE}

\footnotetext{
${ }^{8} \mathrm{O}$ fundamentalismo islâmico deriva seu nome da aspiração de voltar às suas fontes, quais sejam: o Corão, a Suna (a tradição dos ditos e feitos pelo Profeta Maomé) e a Sharia (a Lei Revelada). Dentro dos planos do fundamentalismo estão o resgate dos valores próprios e intrínsecos ao Islã, a restauração do Estado Islâmico e a oposição a tudo que tenha entrado de novo na sociedade muçulmana (umma), como a bid'a (inovação). (Gúzman, 2000: 1)

9 “...comunidade única islâmica universal que abrange todos os territórios nos quais a lei muçulmana está estabelecida e a lei islâmica prevalece.” (Lewis, 2001: 53).
} 
A análise do primeiro momento elencado: surgimento do Islã, nos remete a fatos que ocorreram séculos antes da criação do Líbano, na então Arábia. Como nos apresenta Albert Hourani, historiador britânico, o surgimento do Islã foi precedido por um período de bastante turbulência política no mundo árabe, isso, devido aos atritos entre os dois grandes impérios que dominavam o mundo naquele momento histórico.

Por todo o Oriente Próximo, muita coisa estava mudando no século VI e início do VII. Os impérios Bizantino e Sassânida [seu domínio se estendia sobre o que é hoje o Irã e Iraque, e entrava pela Ásia Central adentro] empenhavam-se em longas guerras, que se estenderam, com intervalos, de 540 a 629. Guerras travadas sobretudo na Síria e no Iraque; em uma ocasião, os exércitos sassânidas chegaram até o Mediterrâneo, ocupando as grandes cidades da Antióquia e Alexandria, além da cidade santa de Jerusalém, mas na década de 620 foram repelidos pelo imperador Heráclio I. [...] As sociedades organizadas governadas pelos impérios fervilhavam de interrogações sobre o sentido da vida e a maneira correta de vivê-la, expressas nos idiomas das grandes religiões. (2001: 27)

Foi nesse cenário apresentado por Hourani que houve a criação do Islã e difusão de seus desígnios pelo Profeta Maomé. Em 609, iniciou-se o período de revelações que pautariam os fundamentos da religião cujo Deus teria poder e conhecimento ilimitados e inquestionáveis. Por princípio básico estabeleceu-se o monoteísmo e, findadas as 'revelações’, seu resultado foi apresentado aos fiéis através de uma codificação fechada, cujos princípios deveriam ser seguidos sem provocar questionamentos; uma legislação perfeita que regeria a vida terrena e espiritual da humanidade: o Corão. De fato essas podem ser classificadas como as características fundamentais do Corão, entretanto, ao mesmo tempo em que caracteriza-se pela idealização de um comportamento, abre a possibilidade para interpretações, tal a estrutura das suratas ${ }^{10}$. Mesmo nas próprias escrituras essa característica está presente, como

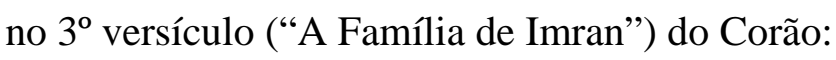

7. Ele foi Quem te revelou o Livro; nele há versículos fundamentais, que são a base do Livro, havendo outros alegóricos. Aqueles cujos abrigam a dúvida, seguem os alegóricos, a fim de causarem dissensões, interpretando-os capciosamente. Porém, ninguém, senão Deus, conhece a sua verdadeira interpretação. Os sábios dizem: Cremos nele (o Alcorão); tudo emana do nosso Senhor. Mas ninguém o admite, salvo os sensatos.

\footnotetext{
${ }^{10}$ Estrutura na qual o Corão está dividido, em 144 suratas. Cada uma delas aborda um determinado tema e é subdividida em versículos.
} 
Nem sempre coube uma interpretação literal dos fatos ali narrados, o que abriu a possibilidade para a criação de uma nova classe de especialistas no Corão, os Ulemás. Também, é de salientar que, diferentemente das demais religiões monoteístas, o Islã não estabelece uma hierarquia eclesiástica, o que dificulta saber quem tem a autoridade suprema para falar em seu nome e dispor as diretrizes de sua fé sem que haja qualquer oposição. Ressalva se faz ao

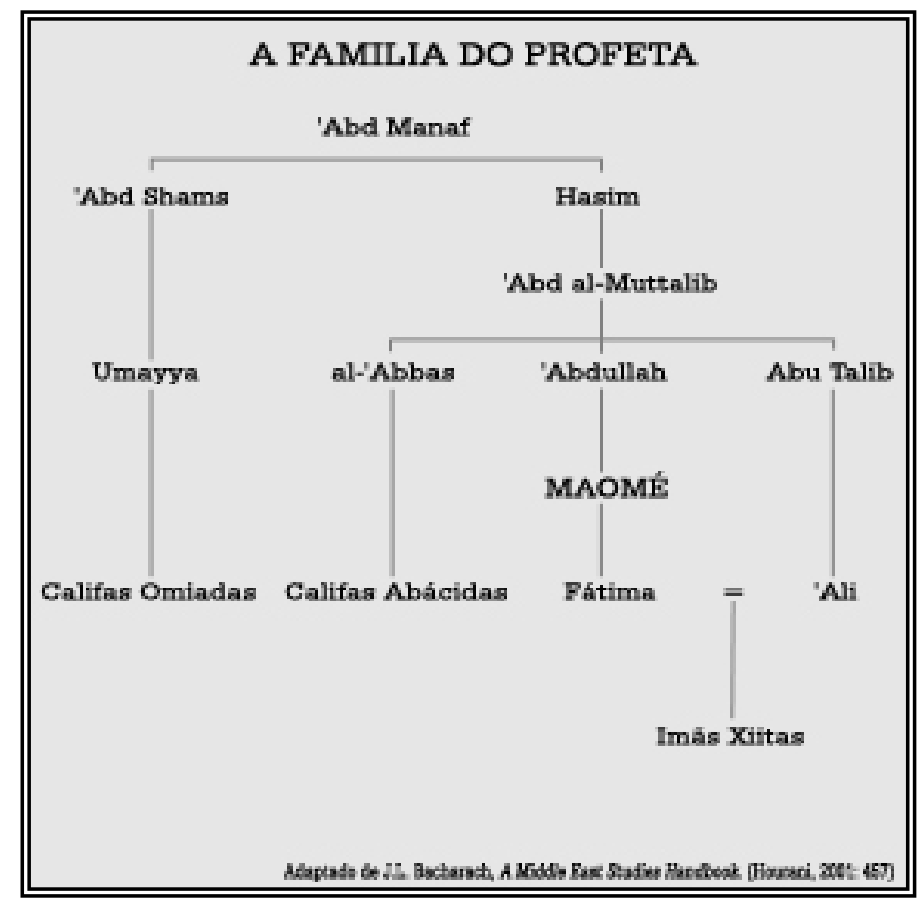
xiismo, que estabeleceu uma certa hierarquia de poderes, a qual será abordada adiante.

Um segundo fator que contribuiu para a união dos povos árabes foi a supremacia, nessa nova ordem política, dos representantes da Arábia Ocidental, sobretudo daqueles de Meca - até 750, quando houve a queda da Dinastia Omíada e ascensão dos Abássidas. (Hourani, 2001: 32) Isso porque foi a partir dali que o Profeta Maomé difundiu sua fé.

Durante o período em que o Profeta Maomé esteve vivo, até 632, sua autoridade não foi contestada dentre aqueles que abraçaram a crença islâmica. Apesar de a origem dos árabes apontar para uma estrutura descentralizada e o clã ter maior importância que qualquer outro vínculo externo, a difusão do Islã alterou essa perspectiva e foi estreitando laços para se configurar na umma - comunidade islâmica.

Mesmo diante das perseguições que Maomé e seus discípulos sofreram, o Islã sedimentou-se e só veio a sofrer a primeira crise com sua morte em 632, o que gerou a necessidade de eleger seu sucessor. Em princípio, os quatro sucessores imediatos, califas, encontraram alguma legitimidade junto à comunidade islâmica e tornaram-se conhecidos como Rashidun, ou “corretamente guiados”. Foram eles: Abu Bakr (623-4), Umar ibn alKhattab (634-44), Uthman ibn Affan (644-56) e Ali ibn Abi Talib (656-61).

Após a morte de Ali surgiram dois grupos que passaram a eleger seus sucessores levando em consideração fatores distintos. Os sunitas, ahl al-sunna (povo seguidor da Suna ${ }^{11}$ ), consideravam que qualquer muçulmano poderia ser califa, desde que possuísse

11 “'caminho trilhado'; costumes, maneira de fazer sancionada pela tradição e o precedente do profeta (sunnat alnabi)”. (Demant, 2004: 396) 
sabedoria e conhecimento acerca do Islã e do Corão, contudo, “...não encarava[m] o califa nem como profeta nem como intérprete infalível da fé, mas como um chefe cuja tarefa era manter a paz e a justiça na comunidade.” (Hourani, 2001: 78) Dessa maneira, a soberania verdadeira na umma continuava residindo em Alá - independentemente da transitoriedade do poder dos califas -, não apenas no sentido de que ele era a fonte de toda a autoridade, mas também no sentido de que ele a manejava, haja vista que seus desígnios deveriam ser obedecidos, acima da vontade de qualquer outro. $\mathrm{O}$ segundo grupo resultante do cisma foi o xiita, que, decepcionado com a conduta dos califas, optou por seguir a família do Profeta. Os xiitas elegeram Ali, marido da filha de Maomé, como seu legítimo sucessor, daí tornaram-se conhecidos por shiatu Ali (partido de Ali) e depois, somente shia - em português xiita. A partir dessa postura assumida, passaram a defender a tese de que a sucessão deveria permanecer dentro a família do Profeta. A autoridade suprema, na Terra, para os xiitas, tornou-se conhecida por Imã.

Com a sucessão dos califas houve atritos entre os fiéis - que divergiam acerca de sua legitimidade e escolhiam outros para seguir - e o mundo muçulmano não mais encontrava a harmonia do tempo do Profeta. Ainda, como fato relevante, deve-se ressaltar que foi nesse período de conturbações político-religiosas que o mundo muçulmano presenciou a ascensão ao poder da Dinastia Omíada (661-750), sunita, e a expansão de seus domínios até a Síria (incluindo o Líbano); logo em seguida, devido à localização e à importância, a cidade de Damasco foi assumida como capital de seu império. 
De fato, a supremacia dos sunitas esteve presente por muitos séculos - com o poder sendo exercido por dinastias poderosas como a dos Omíadas e dos Abássidas (749-1258), que reivindicavam para si o domínio universal sobre os muçulmanos -, havendo apenas algumas lacunas de poder em que dinastias xiitas e outras de menor expressão tiveram relevância. Apesar dos atritos existentes entre os povos muçulmanos, o Islã cada vez mais alargava suas fronteira e alcançava o norte da África, o sudoeste asiático e penetrava pelo leste europeu e península Ibérica. Grande parte do sucesso muçulmano se deveu ao enfraquecimento e declínio dos grandes impérios. Porém, o Islã passou a sofrer suas primeiras crises no século XI. "O Estado e a sociedade islâmicos demonstravam numerosos sinais de fraqueza interna. Os sintomas eram discerníveis até mesmo antes: a fragmentação em uma série de soberanias regionais autônomas; a redução do poder e prestígio dos califas; e o colapso de toda a estrutura política e administrativa construída pelo Império islâmico sobre alicerces herdados de Bizantinos e do Irã sassânida.” (Lewis, 1996: 88)

Durante o período posterior, até o século XIV, o mundo árabe se viu ameaçado por todos os lados. Na Europa, os cristãos ameaçavam na Espanha e Sicília, conquistando vasto território dos muçulmanos e que culminou na chegada das Cruzadas ao Oriente Próximo. A África sofreu com o novo movimento religioso berbere que resultou na efetivação de seu império na Espanha e norte da África. O norte do império muçulmano, já vulnerável por lutas travadas anteriormente com os bizantinos, sucumbiu diante dos cristãos georgianos que restabeleceram seu império, que, por sua vez, entendia-se do Mar

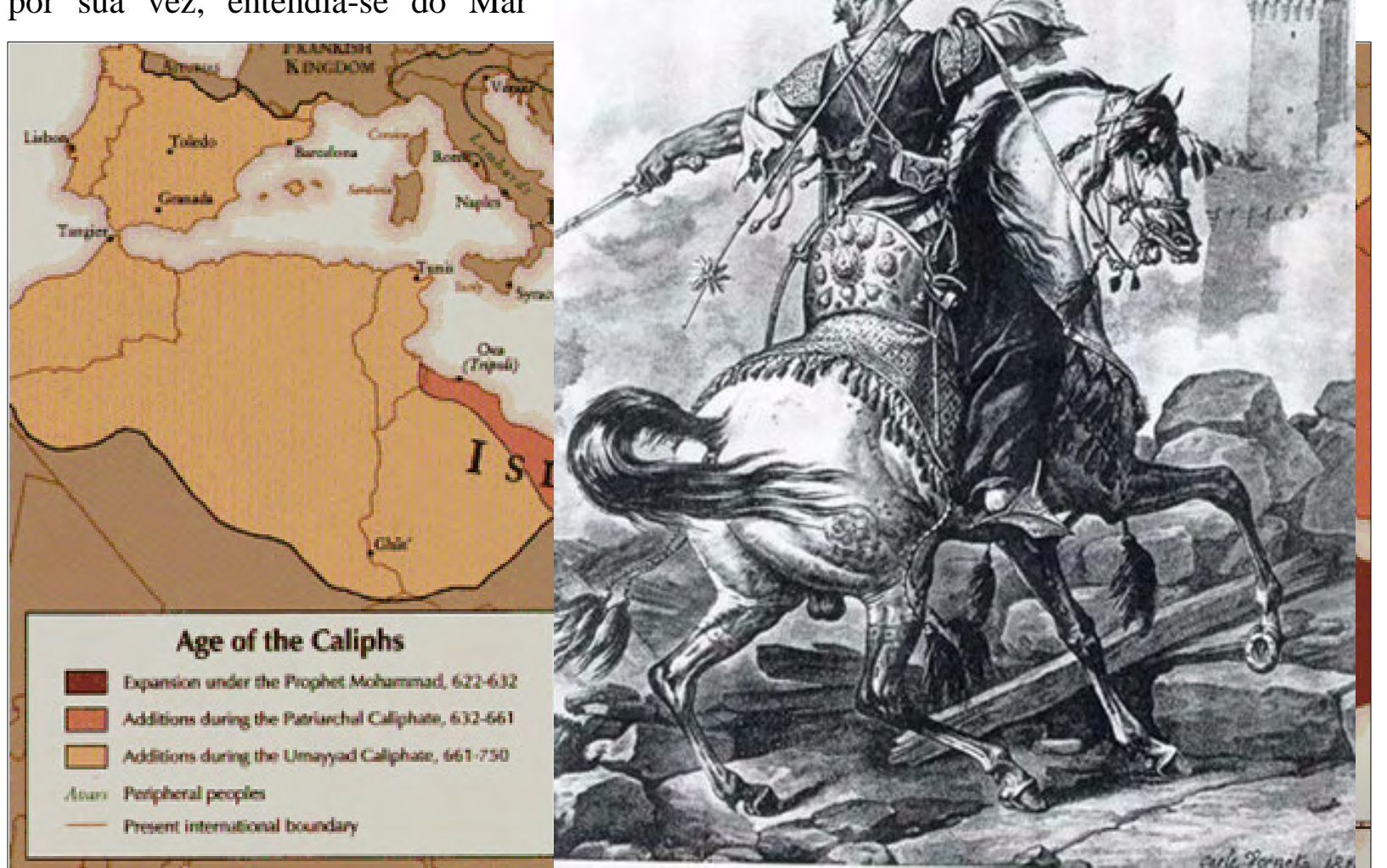


Negro ao Daguestão. Não bastasse as infiltrações que o Império muçulmano estava sofrendo, ainda estava por vir a mais marcante delas, ou seja, a chegada dos turcos. Primeiramente eles viviam nas margens do império muçulmano, mas se converteram ao Islã - tornando-se fiéis defensores da religião - e pouco a pouco foram assumindo o poder através de seus sultões.

Nesse período de conturbação houve, também, o florescimento das dinastias xiitas que afrontavam as sunitas. O Egito teve os Fatímidas (909-1171), que exerceram seu domínio até serem derrotados por Saladino (Salah al-Din), provocando, assim, o fim dessa dinastia xiita e sujeição à, então nascente, dinastia sunita Aiúbida ${ }^{12}$. Posteriormente, os Mamelucos (12501517), originários das estepes asiáticas, conseguiram estabelecer sua dinastia no Egito. Primeiramente serviram como soldados escravos para os Califas Abássidas, ainda no século IX, porém, alcançaram o poder devido às suas qualidades militares. Os mamelucos criaram uma dinastia e alastraram seus domínios do Egito à Síria.

Ainda, como eventos importantes do período considerado como o da 'Crise do Islã', não se pode deixar de elencar as invasões perpetuadas pelos Mongóis, em 1218, e as Cruzadas ${ }^{13}$ programas pelos cristãos com o intuito de retomar a cidade sagrada de Jerusalém. Em 1099 os primeiros cruzados chegaram ao Monte Líbano a caminho de Jerusalém. Passaram por Trípoli, Batroun, Biblos, Beirute, Sidon e Tiro - conquistando-as em seqüência. Na região do Monte Líbano que ocorreram os primeiros contatos Soldados mamelucos; antes, bárbaros das estepes, depois, ardorosos defensores do Islã e formadores de uma dinastia própria.

entre maronitas e cruzados, repercutindo numa identificação mútua devido à fé proferida. Por aproximadamente trezentos anos os maronitas ficaram escondidos nas montanhas, isolado do restante do mundo, e, acabaram sendo uma surpresa agradável para os 'Libertadores da Terra Santa'. A fé cristã, também, serviu para estabelecer a aproximação dos maronitas à cultura ocidental. E, concomitantemente, o início de uma relação bastante próxima com os franceses, que possuíam a maior quantidade de integrantes nas Cruzadas. No intuito de libertar a Cidade Sagrada de Jerusalém, muitos maronitas participaram das cruzadas e, estima-se que pode ter havido a morte de mais de 50.000 deles em batalhas contra os muçulmanos. (Cedarland)

De fato, não é possível mensurar, qualitativamente, o grau de transformação que o Islã sofreu com a absorção dos povos oriundos da Ásia para dentro de sua fé, o que se constata é que os árabes perderam a supremacia no mundo muçulmano e os turcos, que assimilaram a

\footnotetext{
12 “A dinastia fundada por Saladino, a dos aiúbidas, governou o Egito de 1169 a 1252, a Síria até 1260, e parte da Arábia Ocidental até 1229” (Hourani, 2001: 100)

${ }^{13}$ A decisão de criar as Cruzadas foi tomada durante o Concílio de Clermont-Ferrand, em 1095, na França, e fez com que oito expedições saíssem da Europa em direção ao Oriente; havia como objetivo principal à retomada de Jerusalém, porém, uma das grandes preocupações era deter o avanço dos Turcos Seljúcidas que já haviam tomado grandes áreas do Império Bizantino e já estavam se aproximando de Constantinopla.
} 
religião islâmica, configuraram-se nos maiores defensores do Islã. A restauração do império islâmico se deu com o fortalecimento dos turcos otomanos a partir do final do século XIII.

Na estrutura organizada pelos otomanos, a autoridade política era exercida pelo sultão, assim como a obrigatoriedade da defesa dos preceitos religiosos estabelecidos pela Sharia ${ }^{14}$. Contudo, por não serem especialistas na interpretação religiosa do Corão, muitas vezes utilizavam o poder político para terem a seu serviço os ulemás ${ }^{15}$. Os sultões aumentavam seu poder proporcionalmente à razão com que conseguiam preservar o império das ações dos xiitas persas e cristãos, mas mesmo diante das manobras políticas que faziam para preservar o poder, seguiam os mandamentos impostos pela Sharia, o que gerava maior reconhecimento e admiração perante os muçulmanos.

No início do século XV, sob a dinastia otomana, houve nova expansão dos domínios muçulmanos e a flagrante superioridade perante os demais povos. Primeiramente, sob o governo do sultão Murad II (1421-44 e 1446-51) ocorreram as grandes vitórias na Europa contra gregos, sérvios e húngaros; na Anatólia recuperou-se as terras que haviam sido perdidas pelo sultão Bayezid (1389-1403) contra Tamerlão (1402), porém, a conquista emblemática se deu em 1453 com a absorção do que restava do Império Bizantino, em decadência desde o século XII devido às fortes investidas em suas fronteiras pelos turcos, e tomada de sua capital, Constantinopla, que passou a chamar-se Istambul.

Num certo sentido, a formação do Estado Otomano foi mais um exemplo do processo que ocorrera muitas vezes na história dos povos muçulmanos, o desafio a dinastias estabelecidas por uma força militar oriunda de povos em grande parte nômades. Sua origem foi semelhante à dos dois outros grandes estados que surgiram mais ou menos ao mesmo tempo, o dos safávidas no Irã e dos mongóis na Índia. Todos os três baseavam sua força, no início, em áreas habitadas por tribos turcas, e todos deviam seu sucesso militar à adoção de armas que usavam a pólvora, já entrando em uso na metade ocidental do mundo. Todos conseguiram criar políticas estáveis e duradouras, militarmente poderosas, centralizadas e burocraticamente organizadas, capazes de coletar impostos e manter a lei e a ordem numa vasta área e por um longo tempo. O Império Otomano era uma das maiores estruturas políticas que a parte ocidental do mundo conhecera desde a desintegração do Império Romano: dominou a Europa Oriental, a Ásia Ocidental e a maior parte do Magreb, e manteve juntas terras de tradições políticas muito diferentes, muitos grupos étnicos - gregos, sérvios, búlgaros, romenos, armênios, turcos e árabes - e várias comunidades religiosas - muçulmanos sunitas e xiitas, cristãos de todas as Igrejas históricas, e

\footnotetext{
14 “Ao longo do tempo foi também se desenvolvendo a partir do Corão e do hadith [tradições] um sistema abrangente de moralidade ideal, uma classificação moral dos atos humanos que tornaria claro o modo como os homens poderiam caminhar agradavelmente aos olhos de Deus e esperar o paraíso” (Hourani, 2005: 22)

${ }^{15}$ Classe de estudiosos que nutria grande conhecimento das ciências religiosas, do Corão e suas interpretações, das tradições do Profeta, das vidas e antecedentes do Mensageiro e seus companheiros; em suma, conhecimento teológico que encontrava aplicação no Direito.
} 
judeus. Manteve seu domínio sobre a maioria deles por mais ou menos quatrocentos anos, e sobre alguns por até seiscentos anos. (Hourani, 2001: 224-5)

Dando prosseguimento às conquistas otomanas, na segunda década do século XVI, mais precisamente através das batalhas de Marj Dabiq e al-Raydaniyya (1516-17), Selim I, que havia assumido o sultanato em 1512 - com a abdicação forçada de seu pai, Bayezid II, e assassinato de seus irmãos -, venceu os Mamelucos e anexou ao Império às províncias da Síria, Palestina e Egito. Conseguiu, assim, estender seus domínios às cidades sagradas muçulmanas Meca e Medina. Também, no tocante às relações entre sunitas e xiitas, um segundo evento ocorrido durante o reinado de Selim I foi providencial para aumentar, ainda mais, a tensão entre os dois credos muçulmanos. Em 1514 houve uma tentativa de expandir o império Otomano sobre o Safávida (atual Irã); inicialmente Selim saiu vitorioso e conquistou a capital Tabriz, contudo, esse foi mais um ato gerador de ressentimentos entre xiitas e sunitas. 


\section{IMPÉRIO OTOMANO: dimensão alcançada até 1856}

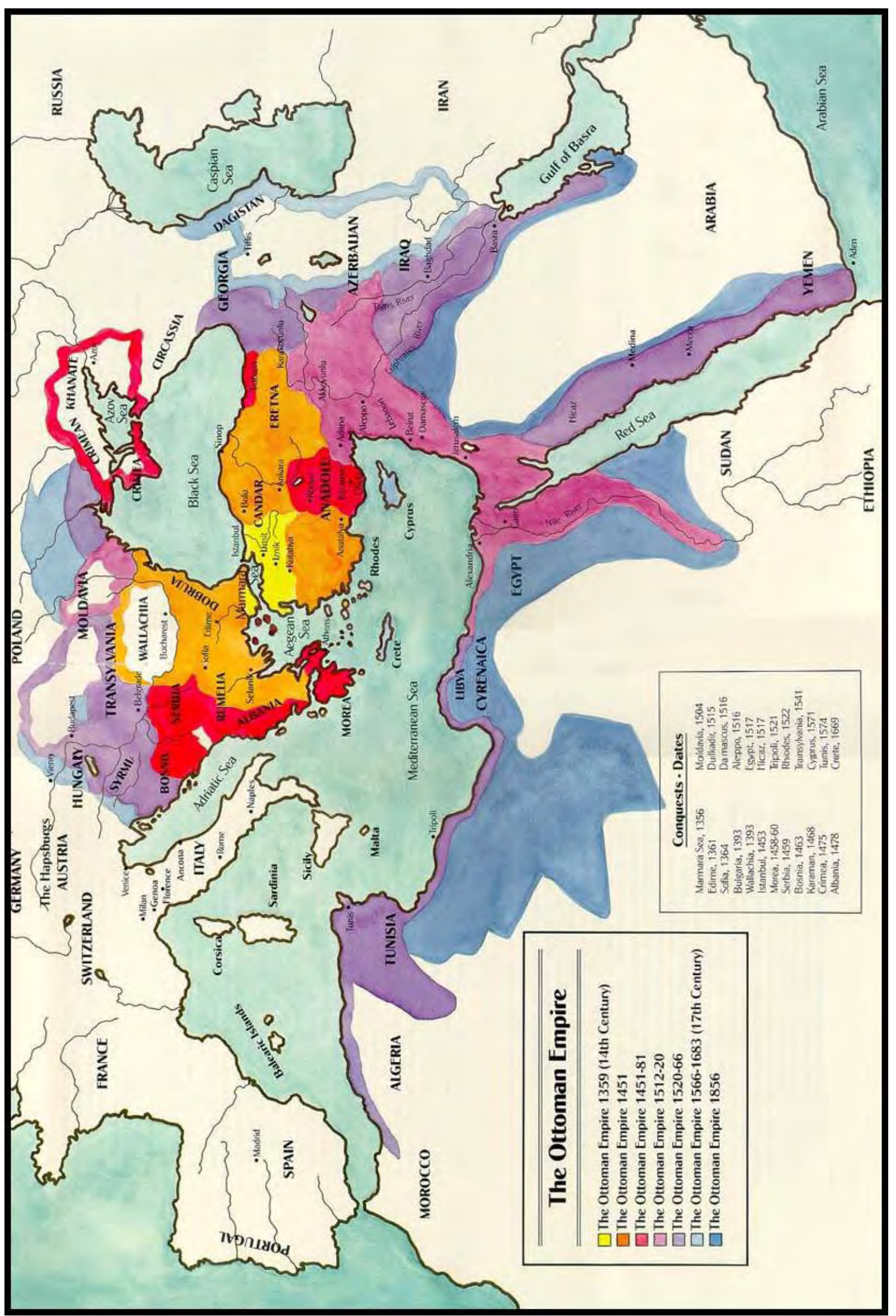




\section{2 - OS POVOS DO MONTE LÍBANO E A BUSCA POR UMA IDENTIDADE}

As transformações que ocorriam no Oriente Médio com a sucessão de dinastias e lutas político-religiosas sempre reverberavam na província libanesa. Foi sob o domínio da dinastia sunita Abássida (749-1258) que os muçulmanos enfrentaram o Império Bizantino e conquistaram a região englobada pelo Líbano e Síria. Também, para restabelecer o poder sunita no Egito, então sob o domínio dos Fatímidas (909-1171), muitas batalhas foram travadas entre esses e os Abássidas. O resultado imediato do conflito foi a fuga de grupos étnicos e religiosos - que eram perseguidos intensamente - de suas terras para o Monte Líbano. Um pequeno grupo de cristãos migrou para a província libanesa durante o período de conflitos com os Fatímidas e, posteriormente, incorporou-se ao Estado libanês. Eles eram chamados de Melquitas, mas passaram a ser conhecidos como Ortodoxos Gregos, haja vista que tinham toda sua liturgia em língua grega. A maior concentração desse grupo foi na parte central do Vale de Bekaa, leste do Líbano.

Outro grupo religioso de grande importância no panorama político libanês é o Druso. Ele surgiu a partir das pregações de Darazi, um dos formuladores do culto que proclamava o califa Fatímida do Egito, al Hakim, como a encarnação de Deus na Terra. Darazi deixou o Egito e estabeleceu-se à sudeste do

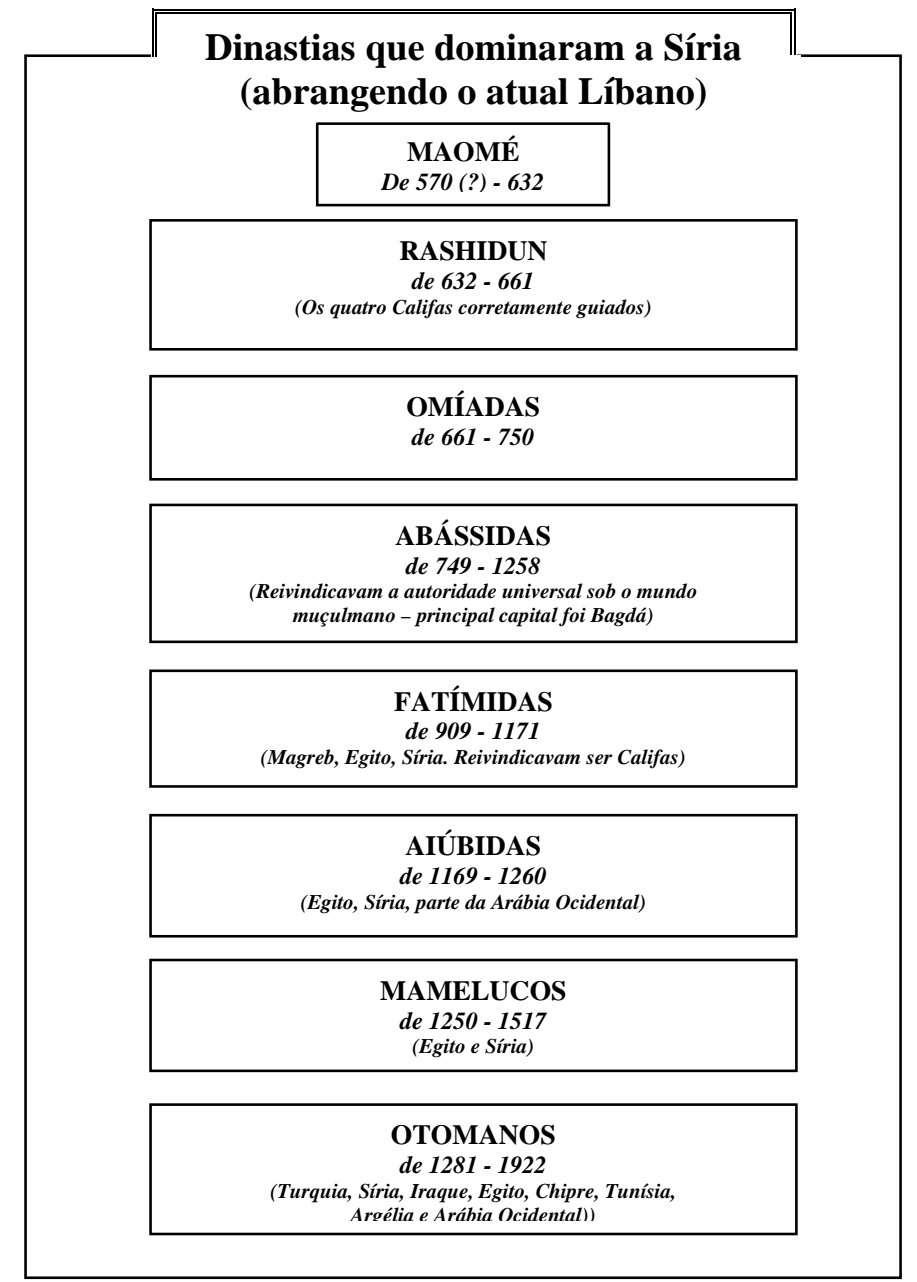
atual Líbano, nas montanhas do Shouf, pregando sua fé e entrando em conflito com a população local. Apesar dos drusos terem suas bases fundamentadas no Islã, nos dias de hoje, têm muita dificuldade de ser reconhecidos como tal devido ao aspecto heterodoxo e místico que sua crença assumiu. Também, devido as suas posições políticas assumidas, além da 
tendência isolacionista, acabam por sofrer perseguição por parte de libaneses, sírios e israelenses.

Ainda, sob o domínio do sultanato dos Mamelucos (1250-1517) que ocorreu a migração de xiitas para o Líbano. Eles saíram da Síria, do Iraque e da Península Arábica para a parte norte do Vale de Bekaa e região de Kisrawan, à noroeste das montanhas de Beirute. Em 1260, os xiitas se juntaram aos drusos e se rebelaram diante dos mamelucos que estavam lutando contra as Cruzadas Européias e os Mongóis (em Ain Jalut, na Palestina). A rebelião durou até 1308, quando os mamelucos conseguiram vencer os cruzados, os mongóis e, ainda, repeliram a revolta dos xiitas e drusos. Para evitar uma represália ainda mais violenta por parte dos mamelucos, os xiitas abandonaram Kisrawan e se refugiaram no sul do Líbano. (Collelo, 1987)

Como conseqüência direta da alternância de dominações que a região do Monte Líbano sofreu, sua economia também foi tendo as características modificadas. Se, durante o período em que esteve sob domínio dos mamelucos a produção da seda - cultivada principalmente na região do Shouf - não recebia grande estímulo e era destinada ao mercado interno, haja vista que os mamelucos estavam mais interessados no comércio de pimenta e especiarias $^{16}$, bem mais lucrativo -, a realidade local modificou-se com a conquista otomana.

Esse processo de mutação econômica foi percebido, principalmente, nas últimas décadas do século XVI, quando ingleses, alemães e franceses, além de outras companhias mercantes européias, tiveram a possibilidade de estabelecerem-se na região e aquecer o comércio local. A repercussão direta dessa transformação deu-se na produção e comercialização da seda, que, imediatamente, sofreu uma grande valorização por conta das disputas travadas pelos europeus em prol da exclusividade. (Salibi, 1988: 104) Por outro lado, o processo de valorização da seda também trouxe um histórico de disputas e modificação das relações entre cristãos e muçulmanos.

A seda, que primeiramente era cultivada na região drusa do Shouf e Kisrawan, não mais conseguia comportar a demanda européia. Os líderes regionais dos clãs Maan, primeiramente, e depois Shihab, abriram suas propriedades para a entrada dos maronitas provenientes do norte, que passaram a cultivar o commodity como meeiros. Sob o domínio druso, a região de Kisrawan, que inicialmente era dominada pela família maronita Hubayshe, foi doada aos Khazins, também maronitas mas subservientes aos interesses drusos. Pouco a pouco a família Khazin foi transformando-se na maior autoridade regional e suplantou os

\footnotetext{
${ }^{16}$ Tais produtos eram trazidos das Índias e os mamelucos utilizavam os portos da província (Monte Líbano) para estabelecer as conexões com os ocidentais através dos venezianos.
} 
Hubayshes; grande parte de seu poder também adveio da aproximação com a França, que passou a considerá-los amigos e delegar-lhes sua proteção. Outras ações de destaque, ainda, ocorreram sob o manto dos Maans e Shihabs. Os Khazins passaram a expulsar os xiitas da região de Kisrawan, através de batalhas ou impondo-lhes seu poderio econômico. O resultado imediato, e que repercutiria na condição política futura desse séqüito religioso, foi a atração de mais maronitas para a localidade e crescimento de seu poder regional. Também, o surgimento da aversão aos maronitas por parte dos xiitas, que foram degredados de sua região natal.

O progresso econômico vivenciado pelos habitantes do Monte Líbano, assim como o início da busca por uma identificação nacional na região, está ligado, diretamente, à política implementada pelos otomanos, a qual permitia que os povos sob seu domínio mantivessem sua religião e cultura - exceção feita aos xiitas, que eram perseguidos, efetivamente, no Egito e, ocasionalmente, em outras localidades -, isso é, contanto que não ferissem as Leis islâmicas e coletassem os impostos para o Império. Dessa maneira, a região que abrange o atual Líbano, na ocasião integrante da chamada Grande Síria, passou a vislumbrar a real possibilidade de tornar-se uma província autônoma. A prática otomana delegava à autoridade local a responsabilidade por cumprir as obrigações impostas pelo sultão, traduzia-se, assim, numa relação de confiança e lealdade entre o suserano e o vassalo.

Os otomanos organizaram a convivência da maioria com as minorias por meio do sistema de millets, ou seja, de nações religiosas: cada comunidade religiosa tinha sua autonomia interna reconhecida e funcionava como uma nação não-territorial, ou seja, uma pessoa jurídica coletiva, uma corporação dispersa, livre em seus regulamentos internos, participando das trocas econômicas com as outras comunidades e cujo líder espiritual era responsável frente ao sultão pelo bom comportamento de seus correligionários. (...) O sistema consociacional ${ }^{17}$ dos millets permitia a coexistência de vários grupos dentro de uma mesma estrutura políticoeconômica. As seitas tinhas seus preconceitos recíprocos e pouco socializavam entre si, mas, em geral, mantinham a paz entre si. (Demant, 2004: 60)

\footnotetext{
${ }^{17}$ A teoria consocionalista explica como sociedades plurais, religiosas ou etnicamente segmentadas, conseguem uma estabilidade "democrática" pela mobilização de suas populações dentro de "pilares" verticais que as organizam separadamente (em partidos políticos, sindicatos, escolas, hospitais, clubes, etc), de maneira que as comunidades não tenham muito contato entre si, e as decisões políticas sejam tomadas por suas respectivas elites com base em uma "chave" consensual de partilha do poder e dos recursos. A teoria é associada ao nome do cientista político holandês-americano Arend Lijphart, que a desenvolveu nos anos 60 baseado no caso da Holanda: The Politics of Accommodation: Pluralism and Democracy in the Netherlands, University of Califórnia, 1976. Em seu Democracy in Plural Societies: A Comparative Exploration, Yale University, 1980, aplicou o conceito também a outras sociedades como a Bélgica, a Áustria e o Líbano, entre outras. (Demant, 2004: 400)
} 
Um segundo fator também possibilitou essa semi-autonomia. No período final da guerra entre os mamelucos e os otomanos pela conquista da Síria (1516), o sultão Selim I (1516-20) contou com o auxílio do Emir da província libanesa, o druso Fakhr al-Din I (151644), para lutar ao seu lado contra os mamelucos. Como prova de gratidão e reconhecimento, foi concedida a semi-autonomia à província e sua administração à principal família feudal ${ }^{18}$ drusa da região, os Maans (1120-1697) e depois, aos Shihabs (1697-1842), muçulmanos sunitas. A supremacia desses clãs durou até meados do século XIX, período em que ocorreram novas transformações políticas - que serão abordadas a seguir - no Monte Líbano e as potências européias passaram a exercer maior influência junto a governantes locais, ao mesmo tempo em que o império otomano perdia seu poder de atuação.

\section{3 - UM POSSÍVEL SENTIMENTO NACIONAL LIBANÊS}

O período em que os clãs dos Maans e dos Shihabs estiveram no poder é de fundamental importância para a construção da narrativa de uma possível "nação libanesa”. Aliando a figura do mito histórico a dos grandes movimentos sociais, a história libanesa é narrada sempre através da alusão de suas grandes personalidades. Caso emblemático e merecedor de destaque é Fakhr al-Din II (1570-1635), dos Maans. Por muitos, considerado o autêntico idealizador da "nação libanesa”. Fakhr ad Din II nasceu druso mas converteu-se ao cristianismo maronita e, devido a esse fato, passou a agir sob grande influência ocidental, mais precisamente francesa. Em seu governo fez com que multiplicasse o número de missões religiosas católicas à região e houvesse a abertura de consulados europeus no país. A ambição do emir pode ser medida com a assinatura do acordo secreto com o Duque de Toscana, Itália, que visava estabelecer a colaboração militar entre as partes com o intuito de fazer frente aos Otomanos. (Collelo, 1987)

O projeto de independência do Líbano estava sendo desenvolvido de maneira bastante equilibrada. Conseguindo-se o apoio do xeque druso Ali Jumblatt, mais um degrau foi galgado no processo de autonomia. Entretanto, perante Constantinopla, tal situação já estava

\footnotetext{
${ }^{18}$ Pela estrutura organizacional dos drusos, também poderiam ser considerados clãs. Essa constatação pode ser conseguida partindo-se do princípio de que é grupo de parentes baseado numa regra de descendência, geralmente medida tanto pela linha masculina quanto pela linha feminina (parentesco através de um dos pais) e numa regra de residência (mesma localidade). Os membros do clã traçam a sua linha de ascendência a partir de um antepassado original, que pode existir somente no passado mitológico: um animal, um ser humano, um espírito ou uma característica da paisagem. O líder do clã exerce o poder de dominação sobre os demais, contudo, há a contrapartida com compromisso desse de proteger os demais membros de ações internas e externas.
} 
tornando-se desagradável e passando a incomodar o sultanato. Com a descoberta do acordo secreto que havia sido firmado, a repressão por parte dos otomanos foi extremamente violenta. Ahmad al Hafiz, paxá de Damasco recebeu ordens para enviar seus exércitos ao Líbano e restabelecer a supremacia do império. Reconhecendo a superioridade do exército de seu adversário, Fakhr al-Din II fugiu para Toscana, em 1613, onde se exilou.

Cinco anos depois Fakhr al-Din II retornou à sua região do Monte Líbano e passou a dar início ao seu projeto de retomada do poder e busca da autonomia para a província. Criou um exército regular utilizando grande recurso financeiro próprio e partiu para conquistar parte do norte do país, ocasião em que teve de entrar em combate contra o novo paxá de Damasco, Mustafá, em 1623. As conquistas de Fakhr al-Din II ocorreram de maneira tão devastadora que provocou certo receio por parte dos otomanos que, muito mais que lhe restituírem seu título de grande emir, o congratularam como Sultan al Barr (Sultão da Montanha), lhe proporcionando o direito de administrar uma extensa área do Alepo a Jerusalém. Tais atitudes por parte dos otomanos também se deram devido ao fato de Fakhr al-Din II ter surgido como um líder difícil de ser controlado pelos sultões otomanos; restando como solução tê-lo como aliado e, supostamente, sujeito aos desígnios do Império.

Sob o governo de Fakhr ad Din II a província libanesa vivenciou um período de progresso econômico - como fora mencionado anteriormente - e alimentou o sonho de converter o Monte Líbano num Estado independente. Contudo, não houve a concretização do projeto e, quando o Império se viu realmente ameaçado pela ambição do emir libanês, designou seu exército para destruí-lo. Como ato final para sepultar o projeto de independência libanesa, o sultão otomano, Murad IV, ordenou ao governador de Damasco que atacasse a província rebelde.

Fakhr ad Din II foi derrotado e executado em Constantinopla em 1635. No período posterior à sua morte, os otomanos tiveram muita dificuldade para manter o controle sobre as regiões do Shouf e Kisrawan. Sentiam a necessidade de encontrar uma figura do porte de Fakhr ad Din, porém, com grandes ambições e mais possível de ser controlado. Ahmad Maan assumiu o poder em 1667 com essa missão e foi designado para as montanhas do Shouf e Kisrawan, como multazim (quem deveria fazer a cobrança dos impostos). Obteve relativo sucesso, mas morreu em 1697 sem deixar descendentes homens como herdeiros, o quer inviabilizou a continuação das ações implementadas por ele. Assumiu o poder o descendente dos Maans da linhagem feminina da família, ou seja, os Shihabs. Originários do sudeste de Bekaa (Wadi al-Taym) e não do Shouf, como a grande maioria drusa, os Shihabs não proferiam essa fé e eram muçulmanos sunitas. 
O mais expressivo membro da dinastia Shihab (1697-1842), que sucedeu a anterior, foi Bashir II (primeiramente sunita, depois convertido ao cristianismo maronita), que, através de uma aliança com Muhammad Ali, fundador do moderno Egito, e seu filho, Ibrahim, conseguiu conquistar a cidade do Acre - de importância estratégica e econômica; localizada na região costeira da Palestina - e em seguida Damasco. No final da década de 1830, houve a tentativa de estabelecer na região da província libanesa e em outros distritos montanhosos, a prática de cobrança de impostos regulares - considerados altos pelos habitantes locais -, além das obrigações de desarmamento da população civil e a conscrição universal. Imposições tais que geraram a revolta de drusos e maronitas contra os egípcios. Essa união entre drusos e maronitas foi possível devido à narrativa histórica que já vinham tentando implementar uma tradição entre seus povos; estratégia essa que, segundo Hobsbawm, seria uma dos matizes na construção do nacionalismo ${ }^{19}$. Desde Istifanus al-Duwayhi (1603-1704), historiador e patriarca maronita, que já vinha sendo proposta uma história libanesa calcada em vínculos entre maronitas e drusos. Posteriormente, Tannus al-Shidyaq (1794-4861), também historiador, escreveu a história das famílias nobres do Líbano; “...o seu conceito de Líbano é de uma hierarquia de famílias, na qual as alianças entre elas e o interesse comum de impedir as invasões dos otomanos prevaleciam sobre as diferenças de religião.” (Hourani, 2005: 78)

Os drusos e maronitas, unidos em prol do ideal nacional de independência, puderam contar com o auxílio de tropas britânicas - que eram contra a política francesa pró-Egito e tinham a anuência do Império Otomano - para preservar sua autonomia; mesmo que temporária, como veremos a seguir. Os britânicos desembarcaram na costa libanesa em 10 de setembro de 1840 colocando fim ao domínio egípcio na região e fazendo com que Bashir II se rendesse e partisse para o exílio em seguida.

Apesar da situação ter retornado ao controle otomano, a província libanesa havia se transformado num perigo para o Império; a relação entre drusos e maronitas, fortalecida com a vitória sobre os egípcios, agora passara a ser vista como algo a ser extirpado em prol da manutenção da ordem otomana. O sultão designou governantes para restabelecer a ordem e evitar que ocorressem movimentos separatistas. Contudo, a incapacidade administrativa dos nomeados fez com que algumas diferenças entre drusos e maronitas revertessem seu relacionamento: primeiramente as medidas que foram tomadas e enfraqueceram o poder dos nobres drusos e, em segundo plano, mas não menos importante, o desenvolvimento

\footnotetext{
${ }^{19}$ Hobsbawm defende a tese de que a construção de uma identidade nacional pode ser feita através da utilização de elementos históricos comuns (reais ou imaginários) para a elaboração de uma narrativa única, o que aproximaria os povos e lhe proporcionaria o sentido de nação. Essa estratégia partiria de uma elite dominante, que estaria pautando a História com o intuito de atender seus interesses particulares. (2002)
} 
econômico - caracterizado pela força da produção de seda e tabaco - que os maronitas vinham tendo graças à assimilação de conhecimento adquirido com o fortalecimento de suas relações com o Ocidente, superando os drusos.

Onde antes existia o sentimento de colaboração voltado para um mesmo fim - o surgimento de uma nação libanesa -, reverteu-se em animosidades difíceis de serem contidas. No intuito de evitar que houvesse um conflito entre as comunidades do Monte Líbano, o sultão otomano indicou, em 1842, o Umar Pasha para governar a região, entretanto, os problemas se agravaram e, ainda no mesmo ano, diante da iminência de ocorrer um conflito armado, o sultão resolveu atender a sugestão das potências européias da época e dividiu o Monte Líbano em duas províncias - evento que ficou conhecido como Duplo Qaimaqamate (ou 'Dois Distritos'). O norte ficaria para os maronitas e o sul para os drusos. Designariam-se governantes distintos e de suas próprias religiões.

Num primeiro momento a finalidade foi alcançada - que era impedir um conflito na região -, mas não resultou exatamente como se planejava. Isso porque, àquela altura, a ação das potências européias sobre o Monte Líbano já era intensa. Os maronitas contavam com o apoio dos franceses - a quem eram tradicionalmente ligados devido às características religiosas e as relações comerciais que se davam entre $\operatorname{ambos}^{20}$ - e o drusos com o apoio britânico, que era dado para refrear a ação francesa na região e reduzir o poder do sultão otomano.

Apesar do arranjo político ter sido aceito pelos otomanos, não era uma situação confortável para o Império que, cada vez mais, estava perdendo a autonomia da região para as potências européias que exerciam influência no Monte Líbano. Nesse painel de tensão e desequilíbrio entre os grupos religiosos, o aumento dos conflitos acabou abrindo a possibilidade para que o Império Otomano pudesse interferir diretamente na área, restaurando, assim, seu poder.

\footnotetext{
${ }^{20}$ A aproximação com o ocidente, por parte dos maronitas, teve seu primeiro momento no período das Cruzadas - ocasião em que fizeram contato com os franceses, então com maior número de participantes nas expedições -, contudo, os laços passaram a estreitar-se com a gradual aproximação dos maronitas ao modo de vida ocidental. Um segundo momento relevante para o firmamento dessa relação se deu com a criação do Colégio Maronita em Roma, em 1584 - sob a bênção dos Papa Gregório. Dali abriu-se a possibilidade para que maronitas estudassem na Europa e adquirissem conhecimento técnico e científico. Com o interesse subjacente dos europeus em 'conhecer melhor os povos árabes', figuras importantes da comunidade maronita viram-se diante da possibilidade de prestar assessoria a governantes, tais como Luís XIII, da França, que contava com os serviços de tradução de Gabriel Sionite - que, após graduar-se no Colégio de Roma, passou a ocupar a cadeira de Línguas Semíticas, na atual Faculdade de França, em Paris. A proximidade entre franceses e maronitas cada vez mais se cristalizava com a implementação de relações comerciais e absorção da maneira de vida ocidental. Universidades, como a Université Saint-Joseph (fundada em 1875, em Beirute), fortaleceram os laços bilaterais.
} 
Paralelamente à crise entre drusos e maronitas, esses últimos, conforme salienta Hourani, também viviam inquietações internas:

As famílias proprietárias de terras na montanha estavam perdendo a sua autoridade local em face de dois desafios: o da hierarquia religiosa, de influência crescente e que às vezes a usava para apoiar os camponeses nos conflitos com os senhores; e o dos mercadores dos portos, tanto europeus como levantinos, que importavam bens manufaturados e exportavam seda, e estavam aos poucos assumindo as funções econômicas dos proprietários de terra. A classe culta cristã também crescia rapidamente. Sob os egípcios, as missões católicas e protestantes puderam trabalhar com mais liberdade do que antes. Começaram a fundar escolas [e universidades, como: American University of Beirut, em 1866 e Saint-Joseph University, em 1875] numa escala maior e num nível mais elevado, para escrever ou traduzir compêndios e imprimi-los nos seus prelos, e das escolas surgia uma nova classe de homens cultos com conhecimento não só do árabe, como de uma ou mais línguas européias, e também algum conhecimento - fosse essa a intenção de seus professores ou não - das idéias do século XIX. (2005: 83)

Devido ao alto grau de tensão que a região do Monte Líbano vivia, em 1858, um evento ocorrido ao norte, área sob influência dos maronitas, acabou por gerar um desfecho não esperado - considerando a proporção que assumiu. Naquela localidade, os camponeses maronitas se revoltaram contra o regime feudal que era praticado na região, o qual os empobrecia devido à cobrança de altas taxas pelos “senhores feudais”. Muitos clérigos se posicionaram a favor dos camponeses, enfraquecendo os proprietários de terras, mas esses não estavam dispostos e perder seus privilégios pois já sentiam-se prejudicados pela participação diminuta que vinham tendo nas relações comerciais com a Europa ${ }^{21}$. Quando houve a recusa em abolir as taxas, os camponeses maronitas se revoltaram, incendiaram as casas dos "senhores feudais" e pilharam suas posses. O conflito extrapolou as fronteiras maronitas e transformou-se num imenso massacre quando os drusos, receosos de que o mesmo pudesse ocorrer no sul - a perda do poder dos nobres para os camponeses - partiram para a ofensiva contra os cristãos. O atrito deu-se em 1860, na região drusa do Shouf, e o saldo final foi o massacre de aproximadamente 10.000 cristãos, dentre eles, maronitas, católicos gregos, ortodoxos gregos e armênios. Nesse momento de pânico para os cristãos que

\footnotetext{
${ }^{21}$ No momento histórico retratado, estava havendo uma modificação do perfil das pessoas que desenvolviam a atividade comercial na região dos portos libaneses. Com o incremento do intercâmbio cultural entre árabes e europeus, houve assimilação das línguas por ambos os lados, o que possibilitou o surgimento de uma nova classe de portuários que intermediavam as negociações (europeus e levantinos). O resultado imediato foi a redução de prestígio e ganhos dos "senhores feudais", que outrora negociavam diretamente - apesar de suas limitações lingüísticas. Também deve-se considerar que modificava-se consideravelmente o tipo de comércio que se fazia; agora, as negociações se davam com a exportação de seda e importação de produtos manufaturados, gerando uma balança comercial negativa. (Hourani, 2005: 83)
} 
ocorreram as primeiras 'grandes emigrações' de libaneses para a América do Sul e Norte. Grande parte deles assumiu como destino o Brasil ${ }^{22}$.

Para apaziguar a região, a França, ainda em 1860, durante o mês de julho, enviou uma força composta por 7.000 soldados ao Líbano; as demais potências tiveram participação diplomática na solução dos atritos. Tornava-se cada vez mais evidente que o Império Otomano não mais estava conseguindo administrar suas possessões e que a interferência ocidental era um fator irreversível.

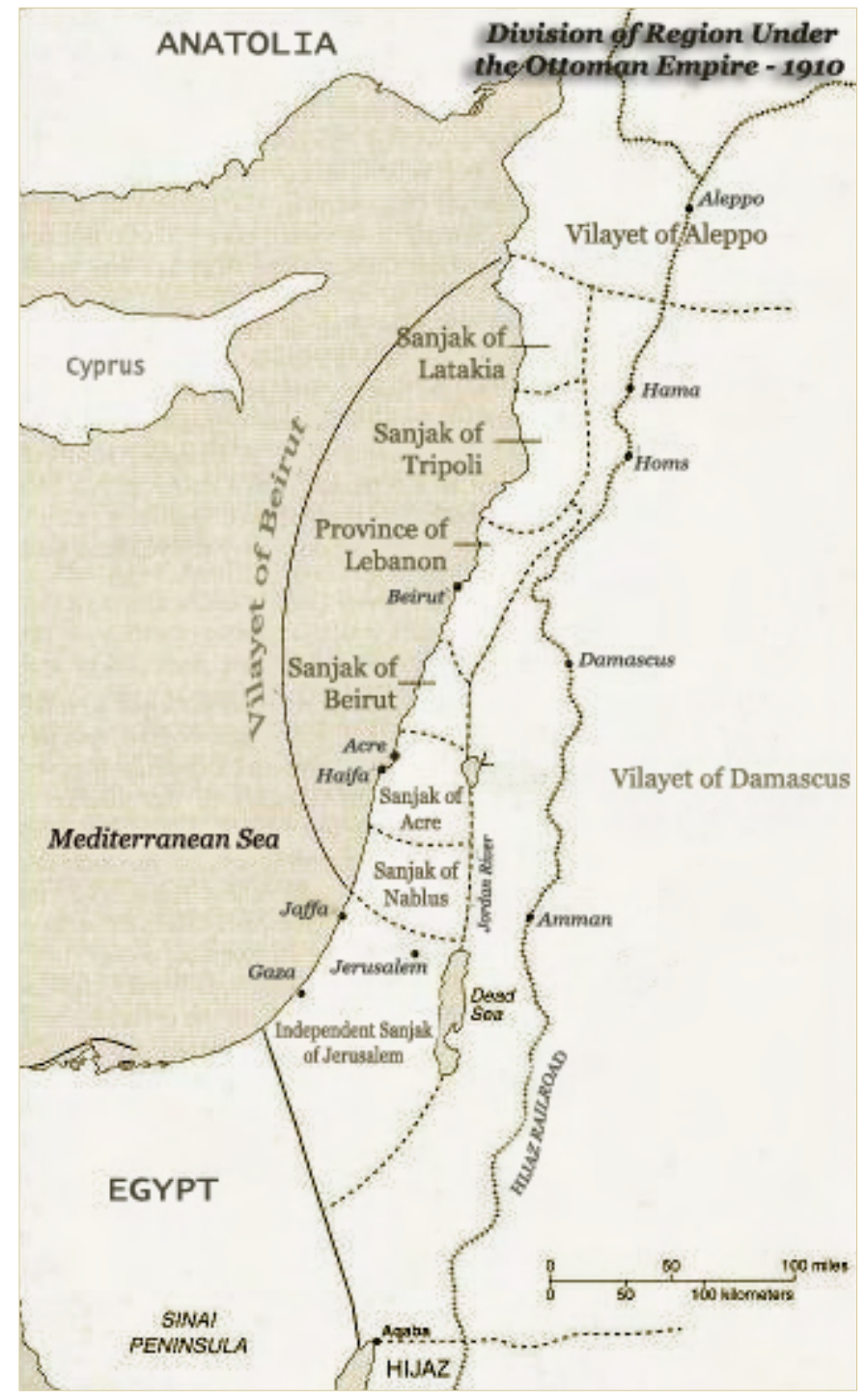

Refletindo a estrutura de poder que a nova ordem mundial apresentava, as seis potências da época: França, GrãBretanha, Áustria, Prússia (posterior Alemanha), Rússia e Sardenha (posterior Itália), além do Império Otomano, se reuniram em 05 de outubro de 1860 em busca de respostas para os eventos ocorridos no Monte Líbano. (Salibi, 1988: 69) Concluíram que a antiga divisão política fora a responsável pelos atritos e, com base nisso, estabeleceram uma nova divisão político-administrativa para a região. A sanjak (região administrativa; conforme era conhecida) não mais estaria ligada à Síria, passaria a ser governada por um mutasarrif (governador) otomano de ascendência cristã não-libanesa. Ele seria designado pelo sultão e deveria contar com o aval das potências européias. O mutasarrif seria assistido por um conselho administrativo formado por doze membros das diferentes comunidades religiosas do Líbano, representados igualitariamente.

\footnotetext{
${ }^{22}$ Nos dias de hoje o Brasil é o país com o maior contingente de descendentes de libaneses do mundo, contando com mais de sete milhões deles; número maior, inclusive, que o de habitantes da terra natal - estimados em 3.500.000 (2000), conforme dados oficiais da Embaixada libanesa. (www.libano.org.br)
} 
Devido à supressão das principais cidades portuárias (Trípoli, Beirute, Sidon e Tiro) ao se criar as novas delimitações do Monte Líbano - cabendo a seus habitantes apenas uma limitada faixa de terras nas montanhas -, supõe-se que a intenção dos Otomanos tenha sido gerar a própria falência dos libaneses e reintegrá-los ao Império sem seus privilégios políticos recém-adquiridos, contudo pode-se deduzir, também, que a intenção fora outra: extirpar de vez os rebeldes do Império para que suas idéias não se alastrassem e fossem implementadas em outras localidades. Independentemente de qual tenha sido a intenção otomana, a reivindicação maronita acerca dos territórios perdidos, que ficaram sob a administração de Damasco e, conseqüentemente, do Império Otomano, era sentida como uma violência, uma arbitrariedade do sultão.

Há de se considerar que muitos interesses concorriam à parte na questão da divisão do Monte Líbano, questões essas que somente viriam à tona com os desdobramentos políticos que o Império Otomano sofreria no futuro próximo. O que já não podia ser escondido e que, por isso mesmo, considerava-se preponderante, é o fato de que muitas relações que vinham sendo incrementadas através de vínculos econômicos e culturais não podiam ser interrompidas apenas pela vontade do sultão. A França já fazia planos para expandir sua zona de influência na região e o apoio aos maronitas apresentava-se com de grande valia na sua implementação.

In 1861, with the help of France, they [maronitas] had already secured a special political status for their historical homeland of Mount Lebanon as a mutesarrifate, or privileged sanjak (administrative region), within the Ottoman system, under an international guaranty. Since the turn of the century, however, the Maronites had pressed for the extension of this small Lebanese territory to what they argued were its natural and historical boundaries: it would then include the coastal towns of Tripoli, Beirut, Sidon and Tyre and their respective hinterlands, which belonged to the Vilayet of Beirut; and the fertile valley of the Bekaa (the four Kazas, or administrtative districts, of Baalbek, the Bekaa, Rashayya and Hasbayya), which belonged to the Vilayet of Damascus. According to the Maronite argument, this 'Greater Lebanon' had always had a special social and historical character, different from that of its surroundings, which made it necessary and indeed imperative for France to help establish it as an independent state. (Salibi, 1993: 25)

A semi-autonomia do Monte Líbano sob o governo do mutasarrif era algo de difícil aceitação para os maronitas que ambicionavam mais liberdade. Também, com a redução de suas propriedades e impossibilidade de acolher toda a comunidade maronita na região das montanhas, muitos optaram por deixar o Líbano e se refugiar em outros países até que houvesse condições para seu retorno. Novamente, o Brasil serviu como destino para grande 
parte dos emigrantes. Entretanto, contrariando as previsões pessimistas que apontavam para uma difícil recuperação econômica do Monte Líbano, essa passou a acontecer sob o governo de Daud Pasha e Naum Pasha.

Apesar de ser considerado como um período marcadamente relacionado a uma política de laissez-faire e corrupção; de 1861 a 1914 o Líbano tornou-se palco de muitas transformações que reverberaram no restante do Império. Como fora mencionado anteriormente, os maronitas já vinham mantendo uma relação

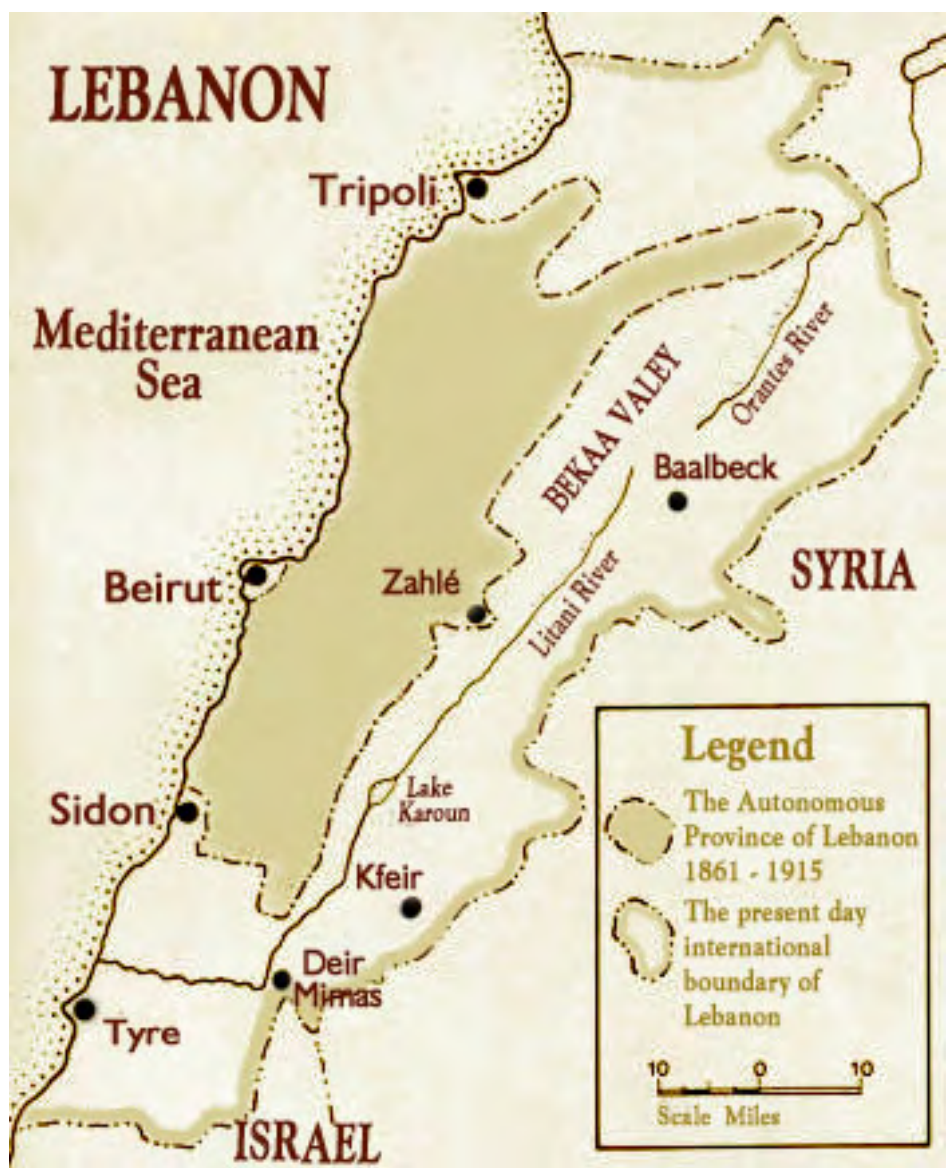
bastante próxima com o Ocidente, o que lhes conferiu o aprimoramento técnico e intelectual. O Monte Líbano já tinha proporcionado a entrada de universidades, escolas e grupos econômicos estrangeiros ao seu território, viabilizando, assim, o progresso através da construção de estradas de rodagem (como a ligação entre Beirute e Damasco e outras conexões com as principais áreas econômicas do país), estradas de ferro e investimento na melhoria da qualidade de vida da população (exclui-se, aqui, localidades com grande concentração de xiitas), o que, de fato, somente fortaleceu a região.

\section{4 - AS FACES DO NACIONALISMO NO MUNDO ÁRABE}

A partir dessas mudanças desencadeadas, uma nova maneira de ver o Império otomano estava sendo construída. Primeiramente pelos maronitas, que já haviam tido contato com as idéias nacionalistas emergentes na Europa e as assimilaram de maneira toda particular, principalmente por estarem vivendo sob um complexo dilema, como Salibi explicita:

...it [nacionalismo árabe] meant different things to its Muslim and Christian adherents. Although Muslim Arab nationalists, usually with great sincerity, spoke of Arabism as being 
secular, they could not dissociate it from Islam: if for no other reason, because Arab history is difficult to dissociate from Islamic history. The Christian view of Arabism could only be secular; but the Christian Arab nationalists could not deny that the central fact of Arab history was the mission of Muhammad, who was not only the Prophet of Islam but also the first leader to give the Arabs political unity under its religious and political banner. In this respect, he was the pre-eminent hero of historical Arabism, and they [maronitas] had to accept him as such. (Salibi, 1988: 48)

Partindo dessa difícil assimilação de nacionalismo árabe, para os maronitas, nem todo o grupo religioso o adotou da mesma maneira. A divergência surgia sob múltiplos aspectos e as respostas eram dissonantes. Tínhamos os 'pró-ocidentais', como Buluis Nujaym, literato maronita, que defendia a tese de um Líbano livre, um país cristão independente, mas sob a guarda da França. Contudo, cobrava a anexação das cidades que representavam valor histórico e econômico à emergente nação. Nesse aspecto, Nujaym apontava para o surgimento do que pode ser considerado um 'protonacionalismo libanês'. Contrariando os argumentos de Nujaym, havia os 'pró-autonomia total' ou 'nacionalistas libaneses', esses analisavam os fatos de maneira distinta e entendiam que estabelecer o desligamento total de suas origens árabes para vincular-se à cultura ocidental configurava-se numa escolha de alto risco agregado, uma atitude que não representaria a independência tão almejada pelos libaneses, seria, sim, apenas uma troca de dominação. O melhor caminho seria aquele que pudesse ser traçado preservando a autonomia do povo libanês e respeitando seu direito de autodeterminação.

Ainda, pensadores como Butrus Bustani, 'pan-arabistas', buscavam estabelecer ligações com os povos árabes antes do surgimento do Islã e, para isso, utilizavam da narrativa histórica árabe para dirimir diferenças entre muçulmanos e cristãos. Dessa maneira, mantinham o foco da discussão na dominação otomana e reforçavam a tese de que não mais cabia o domínio dos turcos sobre os árabes, um povo historicamente detentor de seus desígnios. Assim, os laços árabes apresentavam-se mais fortes, inclusive, que a presença francesa recente, o que, por conseguinte, possibilitaria a real criação de um Estado que abrangesse a ‘Grande Síria’ e estendesse seus domínios até o Sinai. Um país onde pudessem viver livremente cristãos, muçulmanos, judeus e drusos. Para os adeptos dessa corrente de pensamento o Islã não era tido como um obstáculo para a união, contudo, não se referiam ao Islã praticado pelo sultão - que estava impregnado de arbitrariedades - lançavam olhares para o Islã considerado justo, que respeitava o indivíduo; talvez, até um tanto idealizado para alcançar os objetivos dos defensores dessa proposta. 
Apesar da congregadora proposta de Bustani, não se pode afirmar que essa era a voz dominante junto à comunidade maronita, também havia aqueles que entendiam que a preservação cristã no mundo árabe somente se daria com o total abraçamento da cultura ocidental, os 'pró-ocidentais puros', e com o Líbano sendo transformado num prolongamento da França. A justificativa era simples: eram minoria no Oriente Médio muçulmano e não contavam com qualquer proteção especial que pudesse lhes proporcionar segurança, apesar disso, já haviam assumido a vanguarda econômica e intelectual na região, muitas vezes, com status político diferenciado. Por que, então, permanecerem ligados a um povo que culturalmente não os aceitavam e que era considerado inferior? A situação ideal acabava sendo a efetiva ligação à França - que lhes garantiria segurança - e, concomitantemente, os possibilitaria aprimoramento intelectual.

Para as questões e dilemas maronitas não havia respostas absolutas, apenas tentava-se defender suas idéias a partir de publicações e movimentos organizados. “As décadas de 1860 e 1870 foram anos em que havia certa liberdade de expressão, e encontramos periódicos árabes em Beirute que manifestavam idéias mais ou menos equivalentes às dos Jovens Otomanos $^{23}$ e de Midhat Paxá ${ }^{24}$, embora com aquele caráter secularista que era característico dos escritores cristãos” (Hourani, 2005: 278) Mesmo assim, nem sempre as idéias eram proferidas de maneira explícita devido a seu vanguardismo para o mundo árabe.

....os periódicos tendiam a evitar qualquer coisa que dissesse respeito diretamente à política local ou à religião, que poderia provocar hostilidade. Mas, por trás de ambos [Al-Manar e AlMuqtataf], e de outros desse tipo, havia certas idéias positivas sobre o que era a verdade, como devia ser buscada, e o que o público leitor árabe devia conhecer. Que a civilização era um bem em si mesma, e criá-la e mantê-la devia ser o critério da ação e a norma da moralidade; que a ciência era a base da civilização, e as ciências européias tinham valor universal; que podiam e deviam ser aceitas pela mente árabe por meio da língua árabe; que das descobertas da ciência se podia inferir um sistema de moralidade social que era o segredo da força social; e que a base desse sistema moral era o espírito público ou patriotismo, o amor ao país e aos conterrâneos que devia transcender todos os outros laços sociais, mesmo os da religião: foi em grande parte

\footnotetext{
${ }^{23}$ Grupo político formado por personalidades do império otomano - muçulmanos turcos - que, logo no seu surgimento, defendiam o pensamento liberal e contestavam a política imperial dos sultões. Devido a isso, o grupo foi perseguido e passou a difundir suas idéias a partir de Paris, Londres e do Cairo. Como proposta inicial, defendiam que o império só poderia ser mantido se fosse transformado numa monarquia constitucional, e cessasse a distinção entre muçulmanos e não-muçulmanos, assim como entre turcos e não-turcos, tratando todos como cidadãos do Império Otomano.

${ }^{24}$ Alto funcionário do Império Otomano, que serviu de influência para os “Jovens Otomanos”. Em 1876 liderou o golpe de Estado que depôs Abdülaziz e substituiu-o por seu sobrinho, Murad V e, posteriormente por Abdülhamid II. Reconhecido por ser um reformista do império, Midhat Paxá conseguiu influenciar politicamente para que fosse estabelecida uma constituição para o império. Em 1879, Midhat ocupou com cargo de governador de Damasco por alguns meses e difundiu suas idéias constitucionais, mesmo já sofrendo perseguição do sultão Abdülhamid II, que divergia completamente de sua visão constitucional.
} 
pelo trabalho desses periódicos que essas idéias mais tarde se tornaram lugares-comuns. (Hourani, 2005: 262)

Como campo para difusão de idéias e ideais, Beirute e Cairo foram cidades de fundamental importância devido à sua efervescência cultural. Contando com certa liberdade de imprensa, muitos jornais eram publicados defendendo suas causas e, algumas vezes, atacando o império através de Abdülhamid II. Alcançaram destaque na propagação dessas críticas, dois periódicos libaneses, publicados no Cairo, al-Muqattam e al-Ahram. Além dos periódicos contidos na citação de Hourani, Al-Hilal (Cairo, 1892-) e Al-Muqtataf (Beirute e Cairo 1876-1950), que não eram tão contundentes na crítica direta ao Império mas cumpriam sua função de difusores de idéias, ainda podemos elencar outro exemplar de grande importância para o período, e que surgiu sob o nome de Bustani, mas que na verdade era publicado por seu filho, Salim, trata-se do Al-Jinan (Beirute, 1870-85), grande propagador do nacionalismo árabe.

Junto às demais comunidades do Monte Líbano o nacionalismo também passou a florescer, mas não era uniforme em sua concepção e ambições. Os sunitas, já incorporados ao Monte Líbano e alcançando posições de destaques - como mutasarrif - em várias regiões, procuravam identificar-se com o nacionalismo islâmico que o sultanato tentou difundir no final do século XIX; de certa forma, ambos defendiam a figura do califado e mantinham laços religiosos em comum. Os drusos, por sua vez, partiam de um projeto nacionalista fundamentado na língua árabe, o que os ligavam à Síria e fazia com que defendessem uma nação sírio-libanesa. Na verdade, desconfiavam do projeto nacionalista puramente libanês e que contasse com o endosso da França, pois, acreditavam que seria a abertura do caminho para a dominação cristã e um possível sentimento revanchista.

O nacionalismo árabe, tão discutido e ambicionado como solução para suceder o

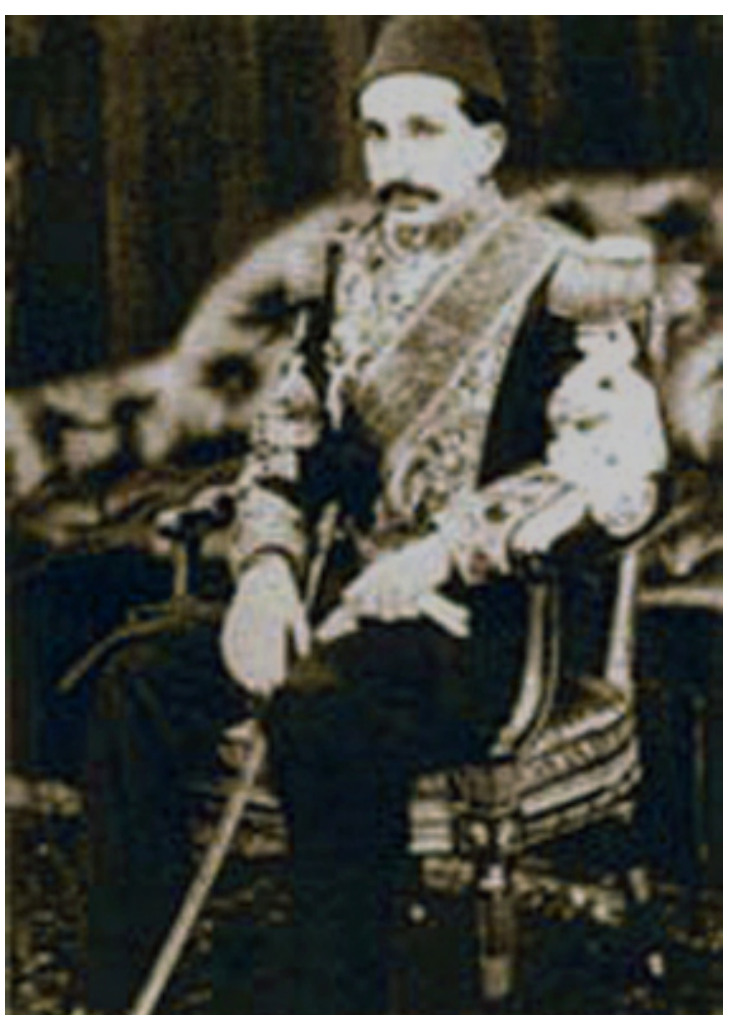

Sultão Otomano Abdülhamid II Império Otomano, também passou a sofrer reveses por parte do sultão. Durante o sultanato de Abdülhamid II (1876-1909) houve a promulgação da Constituição para o Império, em 1876, mas logo foi suspensa e o sultão passou a implementar sua política pan-islâmica. Percebendo 
a necessidade de arregimentar os árabes muçulmanos para o império, mais que os turcos - que já possuíam ligação bastante forte devido à descendência étnica - Abdülhamid utilizou o panislamismo para refrear as forças nacionalistas árabes que ambicionavam a fragmentação do império otomano. Uma estratégia política utilizada pelo sultão que não alcançou o resultado esperado e levou-o, assim, a partir para uma ofensiva mais enfática contra tais movimentos. Antes, contudo, há de salientar que ao assumir o poder, Abdülhamid deu continuidade à política de modernização do Império que vinha sendo implantada por seus antecessores, o Tanzimat. Colocou em prática a modernização do sistema de Justiça e da Administração; a centralização do poder foi facilitada pelo uso do telégrafo e da construção de ferrovias; a repressão aos beduínos e apoio às colônias agrícolas; e, criação de escolas primárias, secundárias e universidades. Entretanto, apesar da imagem liberal que transparecia, já não mais acreditava ser possível preservar a unidade imperial sob as mesmas bases. A tolerância para com os não-muçulmanos mudara de face e seu projeto se dava no sentido de que somente através da implementação de uma mudança radical seria possível manter unido o Império e evitar a ação das Potências européias. O projeto de Abdülhamid era ambicioso, primeiramente ele queria que o sultão sofresse uma modificação de status e passasse a ser reconhecido como califa. Entendia que tal fato repercutiria diretamente no fortalecimento do Islã e, para tanto, não negava esforços ao expressar-se como o autêntico detentor das virtudes necessárias de um califa. (Hourani, 2005: 124)

Os movimentos contrários à proposta do sultão já não mais podiam ser calados. Em grande parte porque a intelectualidade muçulmana já possuía veículos para manifestar suas inquietações e desejos. Jornais e livros eram publicados no Cairo, em Beirute e na Europa difundindo idéias de desaprovação ao projeto de Abdülhamid. Alguns, propunham que houvesse a transferência do sultanato para o Cairo e o califado para Meca. Dessa forma o Islã voltaria às mãos dos árabes, haja vista que congraçavam a idéia de que os turcos, por mais que tenham se dedicado à Fé, acabaram por desvirtuá-la. Uma segunda proposta também defendia que o poder temporal e espiritual poderia voltar a ser concentrado na figura do Califa retomando à Meca -, para tanto, os xarifes de Meca, tentando distanciar-se da situação de desprestígio e, muitas vezes, submissão aos sultões, utilizavam como analogia o período em que o Profeta Maomé era a única autoridade do Islã.

A conclusão a que muitos pensadores chegavam era de que o Islã estava em decadência; apontavam para vários fatores históricos, mas, de acordo com Abd al-Rahman alKawakibi (1849-1903), era evidente que “...o Islã decaiu por causa da inovação ilegal (bid’a), em particular da introdução de excessos místicos alheios ao seu espírito, e por causa da 
imitação (taqlid), da negação dos direitos da razão e do fracasso em distinguir o que é essencial do que não é...(...)...O Estado justo, em que os homens se realizam, é aquele em que o indivíduo é livre e serve livremente à comunidade, e em que o governo vigia essa liberdade, mas é ele próprio controlado pelo povo; isso é que é o verdadeiro Estado Islâmico.” (Hourani, 2005: 287) Em complementação a esse pensamento, Kawakibi salienta os males provocados pelos sultões que modificaram o Islã para que obtivessem o poder absoluto, mas que acabaram se transformando em déspotas.

Os governantes despóticos têm apoiado a falsa religião, mas os males que fizeram não se limitam a isso, o despotismo como tal corrompe a sociedade. (...) O Estado despótico (...) usurpa os direitos de seus cidadãos, mantém-nos ignorantes para que continuem passivos, nega-lhes o direito de participar ativamente na vida humana. No final, destrói a relação moral dos governantes com os governados e dos cidadãos uns com os outros; distorce a estrutura moral do indivíduo, destruindo a coragem, a integridade, a sensação de pertencer, tanto religiosa como nacional. (Hourani, 2005: 287)

Retomando à questão da política nacionalista turca implementada por Abdülhamid; dentro do Império e mesmo na França e Itália, um grupo de oponentes ganhava a simpatia dos nacionalistas árabes - os Jovens Turcos. Eles atacavam veemente o despotismo do sultão e clamavam pela volta do regime constitucional que havia sido extirpado. Com propostas que reforçavam o espírito de união dentro do Império, independentemente da religião confessa, representavam uma esperança de restauração do equilíbrio para os muçulmanos. Através de uma grande revolta em 1908 conseguiram depor o sultão e chegaram ao poder, entretanto, a realidade dos fatos falou mais alto que a ideologia.

Os Jovens Turcos, para colocar em vigor a Constituição que era emblemática em sua proposta, deveriam partir do pressuposto de que todos os cidadãos do Império eram iguais e gozavam dos menos direitos e deveres; que as diferenças religiosas e mesmo entre muçulmanos e não-muçulmanos não deveriam existir. Porém, não foi dessa maneira que ocorreu. Para a manutenção do Império, que também era parte integrante do projeto dos Jovens Turcos, houve a necessidade de preterirem turcos a outros cidadãos quaisquer do império. Essa prática se fazia necessária por eles acreditarem, mesmo que de maneira indireta, que a relação com o Império estaria mais enraizada no turco que em outro cidadão qualquer. Também, para a manutenção do Império não poderiam abrir mão da centralização administrativa, o que ia de encontro à ambição das várias províncias que buscavam com veemência a autonomia. 
Ao final do governo dos Jovens Turcos, em 1913, o Império estava bastante fragilizado e desacreditado devido à mudança radical pela qual as diretrizes governamentais sofreram e, naquela ocasião, a visão liberal do grupo se confundia com o antigo nacionalismo de Abdülhamid - tão contestado e renegado. Ziya Gökalp, ideólogo dos Jovens Turcos, procurou analisar onde o projeto político de seu grupo falhou.

O ponto de partida foi a idéia de que a única maneira de resolver o dilema inerente ao império era lhe impor um único sentimento nacional; mas aos poucos tornou-se claro que o sentimento nacional otomano não podia desempenhar esse papel, pois era demasiado fraco e artificial, e em última análise não se baseava em nada exceto na lealdade à família regente. (Hourani, 2005: 296)

No Líbano, onde ainda não havia uma única leitura para os acontecimentos inerentes ao Império, a frustração com a mudança política dos Jovens Turcos serviu para reforçar o "nacionalismo libanês" e apontar um caminho a ser seguido. A grande maioria cristã, e parte dos sunitas que ora habitavam o Monte Líbano, convalescidos e frustrados pela mudança dos Jovens Turcos, convictamente assumiram que deveriam trabalhar em prol da independência através de quaisquer meios que fossem necessários. Questionava-se se a ajuda deveria vir da Europa, onde as Potências facilmente se prontificariam a dar suporte militar; ou se a integração com a Síria, cujos laços históricos eram ressaltados, seria a melhor maneira de iniciar o movimento de independência.

A inquietação foi mantida até 1914, quando a Primeira Guerra Mundial teve início e o Império Otomano assumiu o posicionamento que o levaria à ruína total. Aliado da Alemanha e do Império Austro-húngaro, logo suspendeu a semi-autonomia do Monte Líbano e designou Jamal Pasha para assumir o governo daquela localidade, assim como da Síria. Jamal tentou buscar entendimento com os libaneses para que se sujeitassem à sua autoridade, mas a população não mais estava disposta a reverter o status quo adquirido. A saída encontrada por Jamal foi a tomada militar da região. Em pouco tempo a situação sócio-econômica libanesa sofreu um forte revés. Muitos habitantes da região foram obrigados a se alistar no exército otomano, enquanto outros passaram a desempenhar atividades estratégicas, como a derrubada de árvores para a construção da estrada de ferro até a Palestina, além de a construção de estradas de rodagem e campos de treinamento, ambos para fins militares. Também, animais cavalos, camelos e burros - foram confiscados para servir ao exército otomano. Médicos foram obrigados a deixar seus pacientes das cidades para prestar assistência aos soldados otomanos. De fato, a ação de Jamal Pasha sobre o Líbano demonstrava que o Império não 
mediria a força de suas ações para alcançar seus objetivos, que, naquele momento, era a manutenção da unidade imperial.

Em 1915, tendo suas expectativas frustradas com relação ao ataque às forças britânicas no canal de Suez - o que gerou o bloqueio da entrada de suprimentos para os turcos através da parte oriental do Mediterrâneo -, Jamal resolveu vingar-se dos libaneses e colocar um fim na soma de problemas que tinha naquela região, para tanto confiscou todo o suprimento de alimentos da população e direcionou-o aos turcos. A ação de Jamal gerou a morte de centenas de milhares de pessoas devido à fome e as doenças que lá se instalaram. Por fim, a grande exportadora de seda e tabaco de outrora, viu seus campos serem destruídos. A província otomana libanesa, ao final da guerra, havia perdido mais de um terço de sua população, aproximadamente 150.000 habitantes. Os libaneses que conseguiram, optaram por fugir do país e escolheram com destino a América do Sul e do Norte. (Collelo, 1987).

\section{5 - A ERA DOS TRATADOS E ACORDOS: A DIVISÃO DO MUNDO ÁRABE}

Para agravar a situação de franca decadência do Império Otomano, um evento integrado aos movimentos de reação à dominação turca ocorreu no ano de 1916. Vinte e um sírios e libaneses foram executados em Damasco e Beirute, acusados de atos antiturcos. A data de 6 de maio passou a ser celebrada, em ambos os países, como o "Dia dos Mártires” e o local onde ocorreu a execução, em Beirute, tornou-se conhecido como "Praça dos Mártires".

Na Europa, a certeza de que o Império Otomano não manteria sua integridade territorial por muito mais tempo era notória; em vista disso, as

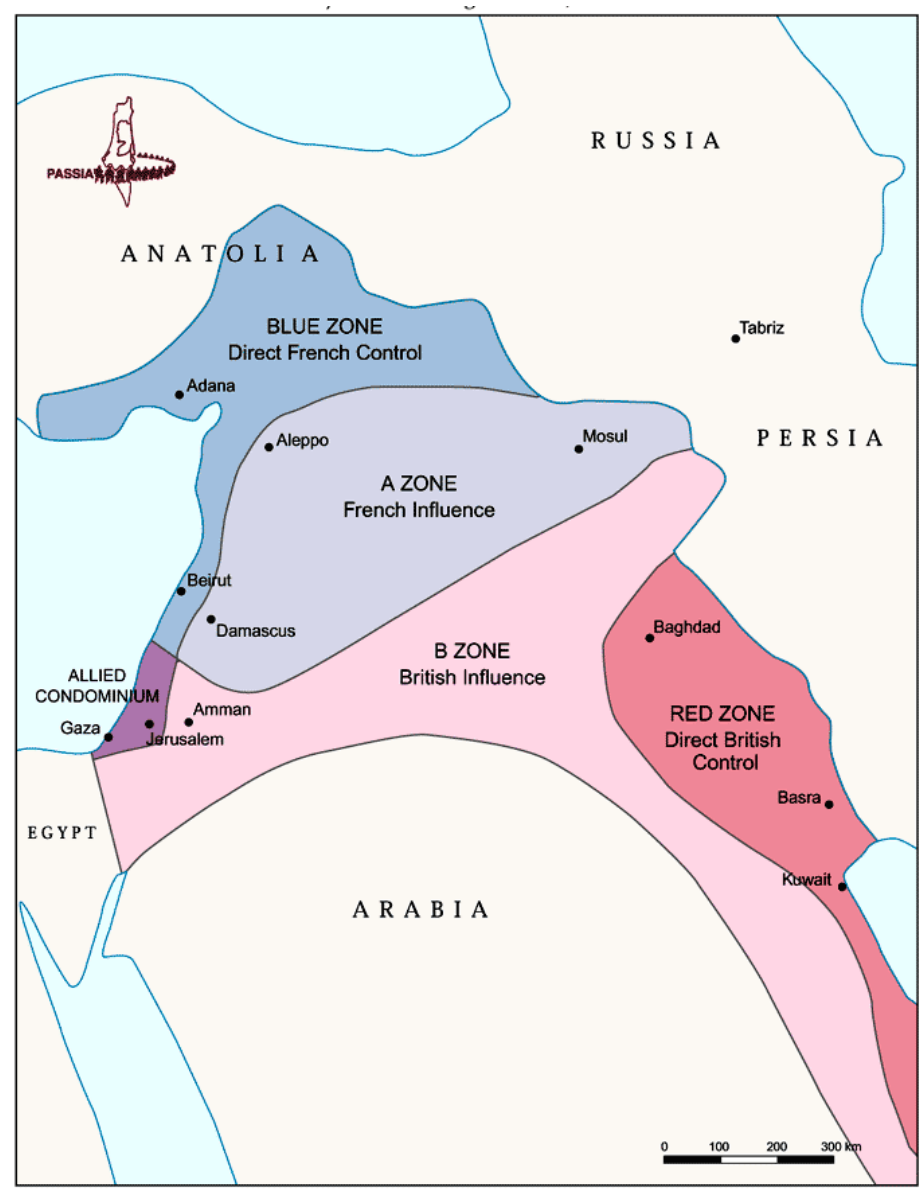
Potências procuravam estabelecer, rapidamente, acordos que lhes garantissem privilégios na 
região. Em 1916, a França e a Grã-Bretanha assinaram um acordo secreto ${ }^{25}$ que passou a ser conhecido como Sykes-Picot (nomes dos negociadores britânico e francês, respectivamente).

O Acordo almejava contemplar os interesses das Potências e cristalizar o poder que já era exercido de maneira indireta por elas. Havia dois tipos de poder que seriam exercidos na região: “direto” e através de "zona de influência”. Para que houvesse a anuência da Rússia no acordo, as regiões da Anatólia e Pérsia ficaram fora das negociações, sendo citadas como de administração internacional, conforme salienta o segundo parágrafo do acordo: “....that in the brown [na cor bege no mapa] area there shall be established an international administration, the form of which is to be decided upon after consultation with Russia, and subsequently in consultation with the other Allies, and the representatives of the Shereef of Mecca”. (Acordo Sykes-Picot) Tornava-se claro o interesse da Rússia de expandir seu território assim que o Império Otomano fosse derrubado. Também, como parte do acordo, os britânicos fizeram com que a região ora conhecida como Arábia Saudita ficasse fora da zona de atuação das Potências devido a acordos paralelos firmados com lideranças locais.

Apart from its agreement with France over the partition of the Arab provinces of the Ottoman Empire, Britain had made promises during the war to other parties concerning the same area. In central Arabia, there was a standing British alliance with Abdul-Aziz Ibn Saud, the Wahhabi Emir of Riyad who was subsequently to become the founder of the kingdom of Saudi Arabia. Wahhabism was a movement of militant Islamic religious revival which had appeared in central Arabia in the middle decades of the eighteenth century, and the house of Saud had been politically associated with it since that time. In conflict with this British-Saudi alliance was the wartime alliance reached between Britain and Sharif Husayn, the Emir of Mecca, who enjoyed a special Arab and Islamic prestige as a recognized descendant of the Prophet, and whose family were called the Hashemites. (Salibi, 1993: 21)

Ainda, conforme Salibi apresenta, a divisão do Oriente Médio em cinco Estados artificiais não foi algo facilmente assimilado pelos árabes. Contudo, a relação de quatro deles - Síria, Transjordânia, Iraque e Palestina - para com o Líbano foi diferenciada. Isso porque não havia uma proposta clara para os demais países recém-criados de se transformarem em estados independentes, haja vista que, dentre eles, havia o forte ideal do nacionalismo árabe. Quando o Líbano despontou como um Estado independente e deslocou-se do restante da comunidade árabe, a repercussão por parte dos demais Estados foi bastante negativa. A aceitação de uma nacionalidade libanesa, acima da árabe era algo inconcebível para grande parte dos habitantes dos recém-formados Estados. Os muçulmanos que viviam no Líbano

${ }^{25}$ O Acordo somente veio à tona após a Revolução Russa (1917), quando os bolcheviques publicaram documentos diplomáticos secretos nos quais a Rússia havia tomado parte. 
passaram a viver sob forte tensão de como seriam tratados diante da nova situação que estavam assumindo, em parte, esse receio advinha do forte apoio que a França estava dando para a criação do Estado libanês e privilegiando a comunidade maronita.

Para que prevalecesse a nacionalidade libanesa acima de qualquer outra, e nenhuma forma de pressão por parte dos demais árabes a enfraquecesse, principalmente dos sírios, que nutriam uma ligação bastante próxima dos libaneses, um alto preço teve de ser pago.

...this price was to be significantly heavier as the Maronites [que defendiam mais claramente a independência libanesa e criação de uma nacionalidade própria] had actively solicited the help of France to achieve their ends; even more so, because they had knowingly exhibited a marked insensitivity to Arab frustrations around then. In October 1918, when France forces landed in Beirut to put an end to the short-lived Arab government of Sharif Faysal there, Maronites and other Christians waving French flags had cheered their arrival at the port, hailing France as the "tender, loving mother" (Arabic, al-umm al-hanun) who was to be their saviour. (Salibi, 1993: 32)

Na Europa, as Potências, além de utilizarem manobras políticas para exercerem seu domínio sobre o Oriente Médio, também criavam mecanismos para ampliar suas possessões na África, e Ásia. Ao mesmo tempo em que demonstravam-se tributários de acordos pacíficos e davam apoio a regimes locais que lhes proporcionassem vantagens, não deixavam de implementar ações militares para alcançar seus objetivos. Mesmo dentre os países europeus as rivalidades levavam à criação de blocos políticos antagônicos. As fronteiras dos Estados ainda eram objeto de discussão e as fortes tensões que ocorriam nas regiões balcânicas, outrora sob domínio otomano, não aparentavam ser uma questão facilmente solucionável devido à diversidade étnica e religiosa ali presente. Também, com o intuito de angariar o apoio dos judeus para seus projetos nacionais, a Grã-Bretanha passou a defender oficialmente a idéia da criação de um lar-nacional judaico na Palestina.

Contando com o aval da Coroa britânica, em 2 de novembro de 1917 houve a divulgação da Declaração Balfour, porém, conforme Hourani salienta, a proposta não tinha o caráter sectarista que no futuro assumiu. “(...) o governo [britânico] via com bons olhos o estabelecimento de um lar nacional judeu na Palestina, contanto que isso não prejudicasse os direitos civis e religiosos dos outros habitantes do país [os palestinos]” (2001: 321).

De fato, o posicionamento assumido pelo governo britânico em prol do estabelecimento de um lar-nacional judaico na Palestina não teve repercussão direta no Monte Líbano naquele momento, apesar de, durante as negociações de paz em Versalhes (1919), a 
Organização Sionista Mundial ter ambicionado um traçado diferente do que resultou para seu território, conforme nos é apresentado por Ferran Izquierdo Brichs, cientista político:

Los primeros proyectos de la Organización Sionista Mundial ya dibujaban unas fronteras que abarcaban desde el norte del Litani hasta el este del Jordán, precisamente para conseguir el control de los recursos hídricos de la región y evitar la posible dependencia del exterior. Sin embargo, el primer mapa político de la región tras la creación del Estado de Israel no siguió el trazado de las aspiraciones sionistas de principios de siglo. (2002: 358)

Contudo, apesar da 'relativa vitória' libanesa, ao ter suas fronteiras ao sul preservadas, os desdobramentos do que convencionou-se chamar de ‘Questão Palestina’ se transformaria num dos maiores problemas vividos pelos libaneses. A criação do Estado de Israel aprofundaria as diferenças entre cristãos e muçulmanos - no período da Segunda Guerra civil (1975-90) - e criaria constrangimentos para o Líbano e sua identidade árabe durante as várias guerras que ocorreriam entre israelenses e árabes a partir de 1947.

Excluindo a magnitude que a 'Questão Palestina' assumiria com o posicionamento britânico, e seus difíceis encaminhamentos futuros, há de se considerar que os diversos acordos que os britânicos e franceses estavam firmando entre si e com as famílias influentes no Oriente Médio ajudaram a colocar fim na dominação otomana sobre o Monte Líbano. Jamal Pasha que, através da força, aplicava a perseguição aos movimentos nacionalista árabes em Beirute, Damasco e nas cidades do Monte Líbano, conseguiu resistir até 1918, quando tropas britânicas atravessaram a Palestina, entraram pelo Líbano e Síria e o depuseram. Era o fim de mais uma era de dominação para o povo libanês, entretanto, não representava a independência almejada.

Os primeiros problemas relativos aos acordos firmados entre a Grã-Bretanha e as famílias árabes surgiram logo após o final da Primeira Grande Guerra. Conforme Patrick Seale nos descreve, a família Hashemita, liderada pelo xarife de Meca, Hussayn, tinha a intenção de preservar para si a região conhecida como 'Grande Síria', e que englobaria os atuais Iraque, Síria, Líbano, Palestina e Península Arábica. O plano de Hussayan era que seu filho Faysal (o mais jovem dos três) assumisse o reinado da Síria, Ali (o mais velho) sucedesse o pai no Reinado de Hejaz e Abdullah (o filho do meio) se tornasse Rei do Iraque. A partir daí estabeler-se-ia o domínio hashemita sob o mundo árabe.

Os britânicos não se impuseram à proposta de Hussayn e lhe prometeram a Síria para que Faysal estabelecesse seu reinado. Satisfeito com a tratativa, Hussayn indicou seu filho, Faysal, para marchar ao lado dos britânicos. Alcançaram seus objetivos exterminando o exército otomano. Os britânicos, independentemente do que haviam acertado com a França no 
Acordo Sykes-Picot, cederam a Faysal a Síria. Os franceses se opuseram enfaticamente à negociação britânica e partiram para o enfrentamento militar com o intuito de restabelecer o que havia sido acertado em 1916. Devido ao poderio bélico francês, o reinado de Faysal teve a breve duração de 18 meses, de 1918 a 1920, quando ocorreu sua expulsão de Damasco.

A tensão entre os britânicos e a família hashemita assumiu grandes proporções e a Inglaterra foi obrigada a contornar o problema oferecendo o Iraque à Faysal. Ele, sem condições de enfrentar o exército francês sem o auxílio britânico, aceitou a proposta e, em seguida, lhe foi conferido o título de rei do Iraque. Contudo, ainda, segundo Seale, não foi uma solução que satisfez a todos, haja vista que gerou o ressentimento por parte de Hussayn - que acabou tendo um problema com seu segundo filho, que deveria assumir o reinado do Iraque e também com Faysal, que sentiu-se traído por não ter conseguido estabelecer seu reinado em Damasco. Um dos reflexos diretos do imbróglio britânico foi o surgimento de Faysal como uma liderança pan-arabista, movimento esse que geraria muitas transformações no cenário árabe do início do século XX. (1966: 6-8)

Recuperada a região da Síria, a

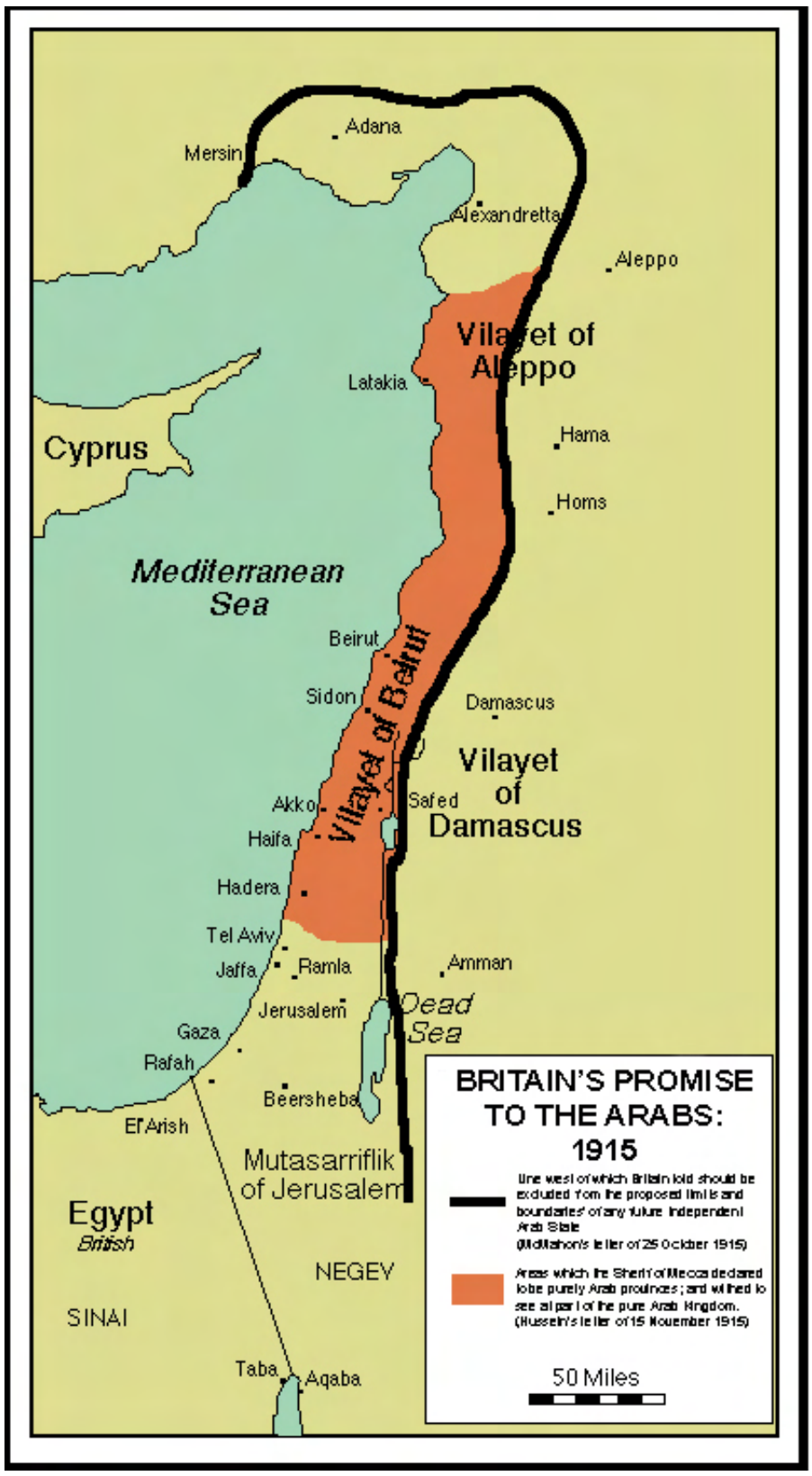

França pôde voltar suas atenções para ela e para o Monte Líbano. Para tanto, designou como Alto Comissário da Síria (abrangendo o Monte Líbano) e da região do Levante, o general Henri Gouraud, que lá permaneceu entre 1919-23. Em $1^{\circ}$ de setembro de 1920, Gouraud fez sua famosa proclamação de amizade para com o povo libanês, ressaltando as virtudes e ideais franceses de liberdade. 
Aos pés dessas majestosas montanhas, as quais têm sido a força de vosso país e reside a fortaleza irrefutável de sua fé e liberdade; às margens desse mar de muitas lendas que viram os trirremes da Fenícia, Grécia e Roma, e agora, por um feliz destino, vos traz a confirmação da grande e antiga amizade e benção da Paz Francesa. Eu, solenemente, saúdo o Grande Líbano, em sua glória e prosperidade, em nome do Governo da República Francesa. (Tanbourit)

Num Segundo momento, devido à situação precária encontrada pelos franceses, deu-se início ao processo de estruturação do Estado. Missões religiosas cristãs foram designadas para a região, assim como hospitais, escolas e orfanatos passaram a ser construídos.

Concluindo a etapa para a formalização do domínio francês sobre o Líbano, mais dois eventos foram marcantes. O primeiro foi a Conferência de San Remo, Itália, em 1920 que contou com a presença dos

Aliados. Ali houve a ratificação do que havia sido acordado em 1916, pelo Sykes-Picot. Mas a Conferência foi além e estabeleceu a divisão física entre o Monte Líbano e a Síria, fato que gerou repúdio de porcentagem da população síria e libanesa que entendia como sendo uma única região. Num momento posterior, a região sob o mandato francês foi dividida em cinco áreas administrativas e houve a transformação de o Monte

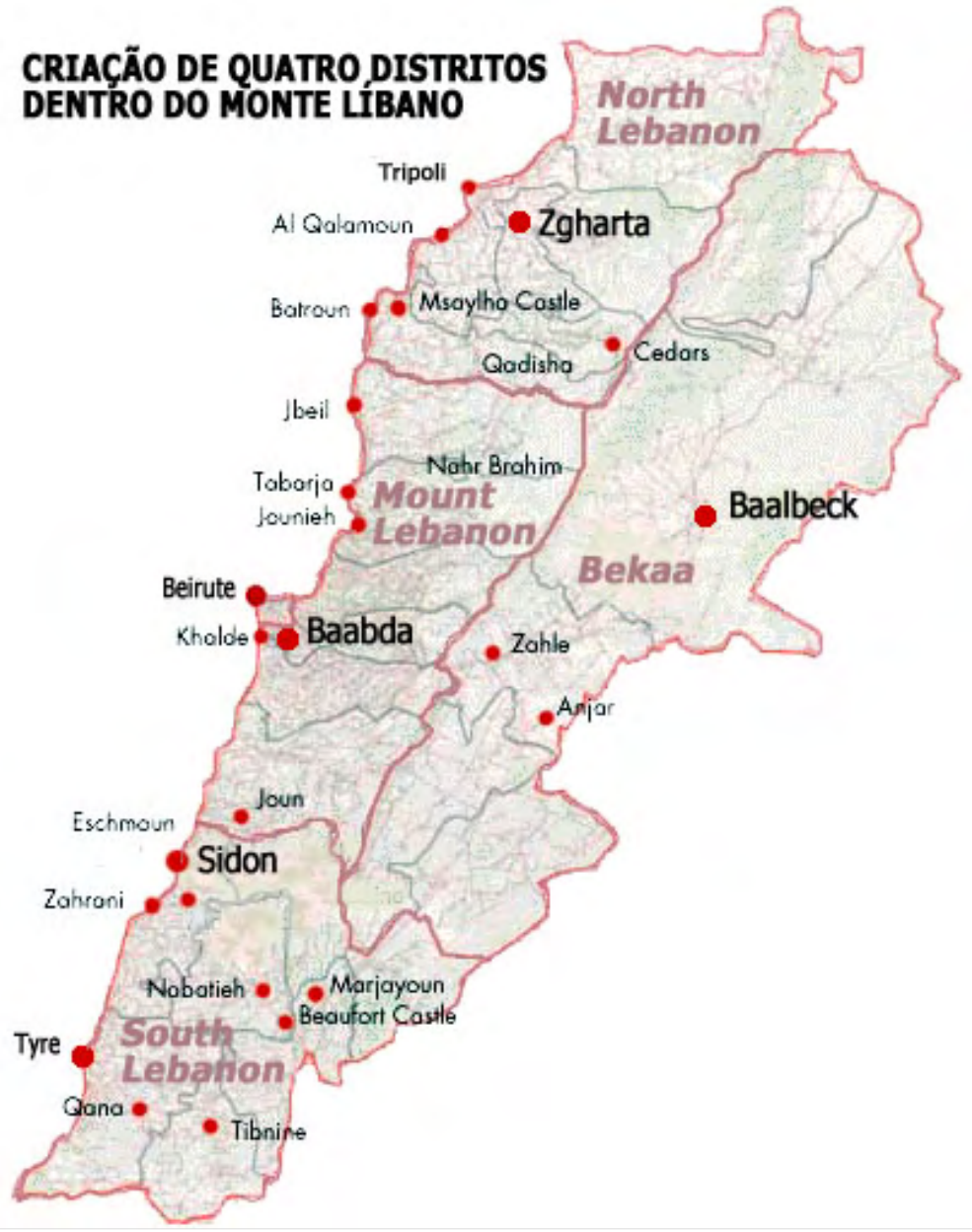
Líbano em 'Grande Líbano’ com a anexação das cidades que haviam sido separadas da província durante o Império otomano, assumindo assim sua dimensão atual - a capital passou a ser Beirute.

Com a nova divisão, a pior repercussão se deu no recém criado, Grande Líbano, ali, muitos muçulmanos, percebendo que o Estado poderia ficar sob o domínio maronita - devido aos fortes laços entre esses e os franceses -, preferiam que suas cidades continuassem 
integradas à Síria, ou mesmo fossem criados mecanismos que preservassem sua autonomia, como configurou-se na sub-divisão do 'Estado Druso'. Contudo, essa questão não foi resolvida e a discussão se arrastaria por muitos anos e, ainda nos dias de hoje, suscita discórdias acerca das ligações entre os dois países.

Os franceses continuaram sua implementação do plano de reestruturação do Grande Líbano. Para efeito de melhor administração da região, foi proposta uma nova divisão em distritos - Norte do Líbano, Sul do Líbano, Monte Líbano e Bekka -, estabelecendo suas 'capitais administrativas: Zgharta, Sidon, Baabda e Baalbek, respectivamente. Ao mesmo tempo, foi reestruturado o sistema de defesa com o fortalecimento da polícia local e a agricultura, assim como a confecção de bens manufaturados, receberam novos incentivos.

\begin{tabular}{|l|c|c|r|r|l|}
\hline \multicolumn{7}{|c|}{ DIVISÃO DA REGIÃO SOB MANDATO FRANCÊS } \\
\hline PROVÍNCIAS & $\begin{array}{c}\text { DATA DA } \\
\text { CRIAÇÃO }\end{array}$ & \multicolumn{1}{c|}{ CAPITAL } & $\begin{array}{c}\text { SUPERFÍCIE } \\
\text { (KM }^{\mathbf{2}} \text { ) }\end{array}$ & HABITANTES & SOB O DOMÍNIO \\
\hline DAMASCO & $18 / 08 / 1920$ & DAMASCO & 50.000 & 595.322 & SÍRIO \\
\hline ALEPO & $01 / 09 / 1920$ & ALEPO & 82.000 & 422.426 & SÍRIO \\
\hline ALAUÍTA & $23 / 09 / 1920$ & LATTAQUIÉ & 6.500 & 261.216 & FRANCÊS \\
\hline $\begin{array}{l}\text { MONTE } \\
\text { DRUSO }\end{array}$ & $01 / 03 / 1921$ & SUWAYDA & 6.990 & 50.000 & DRUSO E FRANCÊS \\
\hline $\begin{array}{l}\text { GRANDE } \\
\text { LÍBANO }\end{array}$ & $01 / 09 / 1920$ & BEIRUTE & 10.400 & 628.863 & FRANCÊS \\
\hline
\end{tabular}

Nesse ínterim, deu-se o segundo evento que pode ser considerado paradigmático para a efetivação do Mandato francês. Em 1923, a Liga das Nações, formalizou o que fora acordado em 1916. O documento apresentava características peculiares e contraditórias. Ao mesmo tempo em que se defendia o direito de “autodeterminação dos povos” também restringia-se a liberdade dos árabes, limitando-os política e administrativamente. Consideravase que algumas populações encontravam-se em nível de desenvolvimento inferior, por isso precisavam da tutela de um país desenvolvido. Não estabeleciam por quanto tempo o Mandato transcorreria e tampouco quais seriam os critérios para a emancipação dos recémcriados Estados. Em seu artigo 22, a Convenção da Liga das Nações expressava: “Certain communities formerly belonging to the Turkish Empire have reached a stage of development where their existence as independent nations can be provisionally recognized subject to the rendering of administrative advice and assistance by Mandatory until such time as they are able to stand alone. The wishes of these communities must be a principal consideration in the selection of the Mandatory.” (Convenção da Liga das Nações) No mesmo documento, ainda tratava-se de outro assunto: como seria a implantação do "lar nacional” para os judeus na Palestina, o futuro Estado de Israel. 
O surgimento do Estado libanês preponderantemente cristão numa região cercada de países árabes muçulmanos não se apresentava como algo facilmente aceito pelos vizinhos. Por um lado, continuava havendo a demanda entre Líbano e Síria, onde partidários da unificação, e conseqüentemente do nacionalismo árabe, tinham dificuldade em aceitar a supremacia maronita na região. Por outro lado, cada vez mais a identidade nacional libanesa passava a existir, provocando preocupação aos franceses que não pretendiam que a província se tornasse independente, haja vista que era uma região de grande interesse econômico e geopolítico.

Após a ratificação do regime de Mandatos, as subdivisões feitas pelos franceses a suas regiões ainda sofreram algumas alterações. Em 1925 as províncias de Damasco e Alepo se integraram e deram origem à Síria; ainda, no mesmo ano, a província drusa se rebelou contra os franceses e, com o apoio de nacionalistas do 'Partido do Povo', partiu para o enfrentamento. A revolta chegou até Damasco, quando os franceses bombardearam a cidade. Somente em 1927 a revolta teve fim e os drusos não mais tiveram autonomia sobre sua província, passaram a ter seu governador nomeado pela França.

\section{6 - O GRANDE LÍBANO... A ERA CONSTITUCIONAL}

No Líbano, devido às fortes pressões internas, a França resolveu nomear uma comissão para elaborar a Constituição do país. As reuniões e discussões estenderam-se de julho de 1925 a maio de 1926, quando houve a apresentação de um anteprojeto. Apesar da fachada democrática criada pelos franceses para o desenrolar dos trabalhos legislativos, contando com a participação de representantes de todos os grupos religiosos, a prerrogativa que a França possuía - por ser a detentora do Mandato -, possibilitava que vetasse os artigos que viessem a lhe prejudicar. Assim sendo, conseguiu que, através dos 'princípios democráticos’, fosse legitimado seu mandato sobre o Líbano. Em 23 de maio do mesmo ano, o Conselho Representativo - composto por lideranças libanesas eleitas para fazer parte na elaboração da Constituição - aprovou o anteprojeto.

Apesar de a promulgação da Constituição ser considerada um marco histórico na criação do Estado libanês, cabem algumas ressalvas acerca do que foi implementado, que, na verdade, como foi apontado anteriormente, fez com que a França preservasse seu status quo na região devido à manutenção de alguns segmentos estratégicos sob seu controle; quais sejam: as relações diplomáticas libanesas, assuntos militares e relativos à segurança interna. 
Mais alguns pontos suscitam melhor apreciação: a Constituição foi estruturada em seis partes; na parte Quatro encontram-se os artigos onde há a ratificação do Mandato francês sobre o Líbano e defesa de sua legitimidade pela Liga das Nações. Pelos artigos, o Alto Comissário francês exerceria o papel de consultor e supervisionaria as funções políticoadministrativas em 'tempos normais', entretanto, da maneira com que houve a estruturação do poder, era ele quem exercia o poder em última instância. Esse fato é facilmente constado ao percebermos a imponência das tropas francesas que estavam estacionadas no Líbano e sob a orientação do Alto Comissário. Dessa maneira, caso não houvesse consonância entre sua vontade e dos administradores locais, poderia haver a substituição do governo a qualquer momento.

Outra questão também provoca estranheza; apesar de ser uma Constituição com características liberais, as quais reservaria aos libaneses a garantia de liberdade de expressão, reunião e associação “...dentro dos limites estabelecidos pela lei” (Constituição Libanesa 1926), também continha fortes contradições: os artigos 7 e 12 sustentavam o direito de igualdade civil e política, assim como, de igual acesso aos postos públicos. Para tanto, fundamentam essa escolha unicamente no mérito, contudo, no artigo 95 há a afirmação do compromisso estatal para com o regime confessional, mas não a contextualização de como isso seria aplicado sem ferir os direitos antes elencados. É possível entender que o artigo 95 seja a legitimização do Pacto Nacional, que anos depois seria providencial para que o Líbano alcançasse sua independência.

A partir da promulgação da Constituição, o Líbano assumiu o modelo republicano parlamentarista da constituição francesa - estabelecida após a Terceira República -, dessa forma, passou a ter um parlamento unicameral, também chamado de Câmara dos Deputados; um presidente e um Conselho de Ministros, ou Gabinete. O presidente seria eleito pela Câmara dos Deputados para um mandato de seis anos - não cabendo a reeleição subseqüente, sendo necessário, assim, transcorrer um período de outro mandato para tornar-se elegível. Os deputados seriam eleitos de forma direta pela população, porém, respeitando a proporcionalidade confessional - cada comunidade religiosa teria o direito de eleger um determinado número de representantes para a Assembléia, contudo, essa quantidade seria diretamente proporcional ao seu número de representantes na população libanesa.

O primeiro presidente libanês foi Charles Dabbas, grego ortodoxo, que já havia ocupado o cargo de Alto Comissário por um breve período em 1926. Dabbas se apresentava como um nome conciliador, tendo em vista a concorrência entre maronitas e sunitas. 
Ressaltado-se o fato de que, àquele momento histórico, os sunitas já vinham se transformando numa comunidade cada vez mais relevante, numérica e politicamente.

É fundamental salientar que a sociedade libanesa ainda estava se adaptando às novas regras políticas que haviam sido estabelecidas para vigorar a ordem interna, entretanto as diferenças, discórdias e supostos sentimentos revanchistas não seriam sanados apenas com a promulgação da Constituição, havia a necessidade de serem estabelecidos projetos que congraçassem todas as comunidades pertencentes ao novo Estado que surgia. Por outro lado, supor que essas antigas comunidades religiosas abandonariam velhos ritos e costumes em prol da implementação das novas mudanças, parecia ser otimismo demasiado. Até porque, os antigos clãs do Monte Líbano já possuíam sua tradição no desempenho do poder, mesmo que muitas vezes tenha sido entendido como um vício prejudicial ao bom andamento da, ainda incipiente, república; haja vista seu caráter sectarista.

De fato, o governo libanês era exercido pela elite dos grupos religiosos, porém, o poder nos clãs era conquistado de maneiras distintas. A tradição era um elemento que estava presente em todos os grupos e não havia contestação quanto a isso, porém, para se alcançar à notabilidade e dirigir o clã, outros fatores eram agregados a essa fórmula. Os sunitas, que tiveram a possibilidade de participar da administração otomana, ocupando postos de destaque e tendo acesso à estrutura do poder imperial, assim como, aos ideais pan-arabistas do início do século XX, muitas vezes escolhiam suas lideranças dentre esses notáveis, não necessariamente o líder da localidade de onde a família provinha. Os drusos e xiitas, que exerciam o poder de acordo com suas fortes tradições - e elas apontavam para o chefe da família como sendo quem deveria guiar os demais membros do grupo -, por não terem tido muitas oportunidades de integrar-se à estrutura imperial e mesclar seus costumes com outros, acabaram por não estabelecer a delegação de poder a um suposto membro mais bem preparado intelectualmente, e sim preservando o desempenho da liderança ao próprio líder local. Mesmo que muitas vezes houvesse desacordo entre eles, talvez até mais incisivos que com outros grupos religiosos; como é o caso das famílias drusas Jumblatt e Arslan, sempre dispostas em lados opostos.

Os cristãos, educados nas escolas do Monte Líbano - com forte influência ocidental -, divergiam dos sunitas que estudaram em escolas otomanas. Muitos deles trilharam profissões liberais e encontraram reconhecimento em seu meio, o que lhes propiciou um status diferenciado e posterior liderança em seu grupo religioso; fato comum nas comunidades maronitas e ortodoxas. Contudo, o fundamental é salientar que mesmo havendo diferenças entre as personalidades que regiam a política libanesa, sem o poder da base de apoio - que 
encontrava-se em sua província, cidade, etc -, a capacidade de persuasão diminuía consideravelmente. (Salibi, 1988)

Apesar da intrincada política de clãs; na qualidade de um governo conciliador, Dabbas conseguiu manter o Líbano sob relativa tranqüilidade até $1932^{26}$, quando terminaria seu mandato e haveria a próxima eleição. Naquela ocasião, fortes divergências ocorriam entre seus prováveis sucessores, os maronitas Bishara al-Khouri - então Ministro do Interior, representante do sul do Líbano - e Émile Eddé, representante de Biblos. Sherifa Zuhur, historiadora norte-americana, apresenta o motivo pelo qual Khouri e Eddé divergiam, e que, para o período histórico em que viviam, apresentava-se como uma questão fundamentalmente importante:

They [Emil Eddé (Imil Iddi) of Byblos, and the first Minister of the Interior, Bishara al-Khuri of southern Lebanon] differed on key issues - the degree to which Lebanon should be separate from Syria, and also in personality. This conflict was important to the Mandate era. Eddé argued for complete separation, and his Unionist party represented ideas of Christian nationalism, while al-Khuri's Constitutionalists were more inclined to some ties with Syria, and policies emphasizing Arab unity or identity. (Zuhur, 2003: 147).

Devido à impossibilidade de acordo entre as partes, a Câmara dos Deputados dividiu-se entre os dois, fato esse que abriu a possibilidade para o surgimento de um terceiro nome, Sheik Muhammad al Jisr - muçulmano sunita da cidade de Trípoli, que já havia tido sua capacidade administrativa reconhecida ao prestar serviços ao Império Otomano e estar integrado à vida política libanesa desde 1926. Naquela ocasião exercia o cargo de chefe do Conselho dos Ministros -, para a presidência.

Reforçando a tese de que o Alto Comissário é quem realmente desempenhava o poder no Líbano, Auguste Henri Ponsot, que havia assumido o posto em 1926, suspendeu a Constituição em 9 de maio de 1932, com receio de que um muçulmano fosse eleito presidente. Também, segundo Ponsot, sua ação visava à preservação da ordem no país e, como desdobramento de seus atos, estendeu o mandato de Dabbas por mais um ano. Na verdade o ato de Ponsot ficou caracterizado por ser de extrema violência e autoritarismo para com o Líbano; isso porque, nenhum artigo da Constituição fazia ressalva com relação à eleição de um muçulmano para a presidência. Entretanto, Ponsot poderia estar agindo dessa

\footnotetext{
${ }^{26}$ A utilização do termo "relativa tranqüilidade" se dá devido a Dabbas ter conseguido concluir seu mandato, entretanto, o início da década de 1930 já apresentava fortes reações de alguns clãs contra a administração francesa na região. O surgimento de um sentimento 'nacionalista libanês' rejeitando a presença francesa, possibilitou a união de alguns grupos de muçulmanos, ortodoxos e drusos - esse último tendo como liderança Fu'ad Arslan - por um mesmo objetivo: a independência.
} 
maneira pautando suas preocupações em outro tipo de risco, tal qual: a aproximação entre os governos sírio e libanês, ambos presididos por muçulmanos, conforme narrou o embaixador americano em Beirute, H. S. Coold, para seu Secretário de Estado, em Washington:

The Syrian constitution expressly provides that the President of the Republic shall be a Muslim. Now, if the Lebanon were presided over by a [Muslim] at the very time when the new [Muslim] Republic just over the hills was getting into its stride, there might be an undue attraction on the smaller coastal State. The French are not anxious for this. (Browne, 1976: 49)

Para demonstrar que a França não pactuava com as ações de Ponsot, as autoridades francesas o depuseram e nomearam outro Alto Comissário para o Líbano, Comandante Damien de Martel (1932-38), que fora incumbido de restabelecer a ordem. Pelo breve período de 02 de janeiro de 1934 até 29 de janeiro do mesmo ano, Antoine Privat-Aubouard ocupou o cargo de presidente; depois foi substituído por Habib as Saad, em 30 de janeiro de 1934, que fora nomeado por Martel para cumprir o mandato de presidente por um ano, mas acabou sendo prorrogado por mais outro. À parte as questões relativas à sucessão presidencial e os poderes de influência e ação franceses; 1932 também foi um ano em que o Líbano viu o surgimento do Syrian Nationalist Party $(\mathrm{SNP})^{27}$ de Antun Saadeh, eminentemente multisectário, contando com partidários drusos e xiitas, além de gregos ortodoxos e maronitas - descontentes com o 'Libanismo’ e ‘Arabismo' - e, também, sunitas que reconheciam o valor do secularismo. Em organização e disciplina, o partido assemelhava-se a muitos grupos fascistas que disseminavam suas idéias pela Europa. No Líbano, o partido defendia como tese central a reunificação do país à Síria e, por fim, a criação de uma Estado englobando toda a Grande Síria - área que abrangeria as atuais Síria, Líbano, Kuwait, Iraque, Jordânia e Palestina. Mais precisamente acerca da estrutura do partido e sua inserção na política local, trataremos no capítulo referente à Política Libanesa, contudo, por ora cabe o destaque devido à importância que teve para os movimentos nacionalistas que efervesciam o debate político naquele momento e que, em parte, contribuíram para os movimentos de independência.

Retomando os fatos subseqüentes à mudança do Alto Comissariado para Martel; em 1936 o processo eleitoral voltou a transcorrer e Émile Eddé foi eleito presidente. No ano seguinte, conseguindo restaurar o diálogo e as negociações com as elites locais, inclusive com a França, Eddé restabeleceu a Constituição que havia sido suspensa. Mais efetiva foi sua atuação ao nomear como Primeiro-ministro um muçulmano sunita. Apesar de seu histórico

\footnotetext{
${ }^{27}$ Mais tarde se transformaria em Syrian Social Nationalist Party (SSNP). Tradução livre: Partido Social Nacionalista Sírio.
} 
apresentar soluções que não encaminhariam para essa ação ${ }^{28}$, ao buscar a aproximação com os sunitas, viabilizou uma nova fase política para o Líbano - que se configuraria no Pacto Nacional, firmado pouco antes da independência. Diante da relevância cada vez maior da comunidade sunita no Líbano, os maronitas fizeram o primeiro arranjo político para sua manutenção no poder. Segundo essa nova estruturação, a presidência seria exercida por um maronita e o cargo de Primeiro-ministro passaria a ser prerrogativa dos sunitas. Ainda, dando continuidade ao 'fortalecimento' da democracia libanesa, Eddé convocou eleições para a Câmara dos Deputados.

\begin{tabular}{|c|c|c|c|c|}
\hline \multicolumn{5}{|c|}{ CENSO OFICIAL LIBANÊS - $1932^{29}$} \\
\hline \multicolumn{2}{|c|}{ Grupos Religiosos } & \multirow{2}{*}{$\begin{array}{c}\text { População } \\
226.378\end{array}$} & \multirow{2}{*}{\begin{tabular}{|c|} 
Em (\%) \\
29
\end{tabular}} & \multirow{2}{*}{\begin{tabular}{|l|} 
Total (\%) \\
\end{tabular}} \\
\hline \multirow{5}{*}{ ת } & Maronitas & & & \\
\hline & Gregos Católicos & 45.999 & 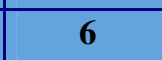 & \multirow[b]{4}{*}{52} \\
\hline & Gregos Ortodoxos & 76.522 & 10 & \\
\hline & Armênios & 31.156 & 4 & \\
\hline & $\begin{array}{l}\text { Outros (Judeus, } \\
\text { Latinos, Protestantes, } \\
\text { vários grupos de } \\
\text { Cristãos orientais) }\end{array}$ & 22.308 & 3 & \\
\hline \multirow{4}{*}{$\stackrel{\infty}{Z^{2}}$} & Sunitas & 175.925 & 22 & \multirow{4}{*}{48} \\
\hline & Xiitas & 154.208 & 19 & \\
\hline & Drusos & 53.047 & 7 & \\
\hline & Total & 785.543 & 100 & \\
\hline
\end{tabular}

A fórmula política negociada entre maronitas e sunitas necessitava de respaldo técnico para alcançar a legitimidade, dessa forma, para reforçar a característica confessional do Estado libanês e lhes garantir alguns privilégios, utilizou-se como parâmetro o Censo elaborado em 1932. Baseado em seus dados, detectou-se uma pequena supremacia dos cristãos sobre os muçulmanos, o que acabou por garantir aos maronitas o cargo de Presidente e aos sunitas o de Primeiroministro. Os xiitas, ainda lutando por uma participação mais efetiva na vida política, mas sem grande força, naquele momento não obtiveram qualquer vantagem, situação similar a dos

${ }^{28}$ Eddé foi um dos grandes defensores da não unificação do Grande Líbano com as demais províncias muçulmanas, segundo ele, não haveria grandes possibilidades de integração devido às diferenças culturais; dessa forma, a melhor saída seria o Monte Líbano anexar Beirute a algumas outras cidades e deixar de fora regiões como Bekka, preponderantemente muçulmana.

${ }^{29}$ Para a manutenção dos privilégios adquiridos, não mais foram feitos quaisquer Censos oficiais, permanecendo os dados de 1932, porém, o aumento da população era evidente e o predomínio dos muçulmanos ficava cada vez mais nítido. De maneira geral, em 1943 o Líbano já contava com 1 milhão de habitantes, em 1967, 1,6 milhão, em 1975, 2,6 milhões e nos dias de hoje aproximadamente 4,3 milhões (McDowall, 1986: 12). 
drusos, que gozavam de cada vez menos prestígio político e estavam vivendo a divisão interna no grupo. Também, com base na proporção da população libanesa, estabeleceu-se que as vagas no Legislativo seriam divididas na ordem de 6 para $5^{30}$ em favor dos cristãos.

Ao manter a posse da presidência, os maronitas conseguiram ratificar sua dominação política através das atribuições que o cargo oferecia, contudo, ainda assim não se pode dizer que o sistema utilizado tenha possibilitado a maior integração popular. A concentração de poder nas mãos das elites - fato recorrente desde o período otomano - continuava sendo preservada devido à grande preocupação dos governantes de não conseguirem conter as massas, o que acabaria por reduzir o prestígio político fundamentado no sectarismo. Ussama Makdisi, historiador da Princeton University, em seu estudo de 1996, para Middle East Report, analisa mais algumas características negativas do sistema político libanês surgido após entendimentos entre sunitas e maronitas:

The "sectarian balance," based on the 1932 population census, paralyzed the government and reinforced the system of patronage. Corruption served as the effective social security system of the Lebanese. Benefits could not be obtained simply on the basis of citizenship rights because jobs, housing, telephones and education were guaranteed not by the state but through appeals to deputies and ministers and presidents who were themselves appointed or elected according to sectarian laws. In this sense, sectarianism, which undermines the secular national ideal and creates subversive religious loyalties, is umbilically tied to the 1943 National Pact which institutionalized the modern, independent Lebanese state. (The Modernity of Sectarianism in Lebanon)

O mandato de Eddé deveria transcorrer até 1942, entretanto, em face das transformações políticas que a Europa passou a sofrer com o início da Segunda Grande Guerra, o Alto Comissário Gabriel Puaux, em setembro de 1939, suspendeu a Constituição libanesa. A medida visava impedir quaisquer movimentos que pudessem comprometer os interesses franceses na região - principalmente aqueles que clamavam por independência -; isso porque a sustentação do regime de Mandato vinha sendo contestada veementemente pelos libaneses. Outras medidas que Puaux decretou, com a mesma finalidade, foram: dissolução do Legislativo, restrição dos poderes presidenciais e decretação de Lei Marcial no Líbano e na Síria.

A pressão, por parte dos libaneses, contra as medidas autoritárias francesas acabou por resultar em várias manifestações, contudo, a situação tomou outros rumos a partir do momento que a França caiu sob a dominação nazista, passando a ser administrada a partir de

\footnotetext{
${ }^{30}$ O Primeiro Parlamento fora formado por 11 membros, posteriormente foi ampliada a quantidade de cadeiras mas preservada a proporção.
} 
Vichy. Imediatamente Eddé foi deposto e Alfred Georges Naqqache assumiu a presidência, em 09/04/1941. A Alemanha nomeou como Alto Comissário para Síria e Líbano o General Dentz, ao mesmo tempo, Puaux e os chefes em comando franceses capitularam perante o governo colaboracionista de Vichy. A população libanesa, que já sofria com a política sectarista em vigor, viu sua situação piorar consideravelmente; como aponta Zuhur: “...The British archives show us that the war created economic misery for the poor especially of the larger cities of the French mandate: Damascus, Aleppo, and Beirut. In the same period, a great deal of German and Italian propaganda was spread to prepare the population for an intended German victory.” (2003: 150).

Apesar de o Líbano e Síria estarem sob o domínio de Vichy, os franceses, contrários ao domínio e submissão à Alemanha, passaram a lutar pela reconquista da soberania através do movimento França Livre. Como liderança mor desses dissidentes, o General Charles de Gaulle tornou-se figura emblemática. Em julho de 1941, com o auxílio das tropas britânicas, a França Livre conseguiu depor o governo de Vichy e restabelecer seu domínio sobre o Líbano e a Síria. Para o posto de governante das províncias (Delegado-geral ${ }^{31}$ ), assim como de toda a região do Levante, de Gaulle nomeou o General Georges Catroux. Mesmo diante da perspectiva de um Líbano independente, as vontades internas, novamente, eram destoantes. $\mathrm{O}$ grande receio de que rumo o país assumiria num segundo momento, pós-independência, gerava medo e incerteza. Dentre os maronitas surgiam propostas distintas: os idealizadores do Bloco Nacional (1942), propunham a independência mas com o estabelecimento de um ‘tratado de amizade’ com a França. Criavam uma analogia entre Israel ser o 'lar nacional dos judeus’ na Palestina e o Líbano ser o 'lar nacional dos cristãos'; com relação à Síria, essa deveria ficar para os muçulmanos. Uma segunda corrente de pensamento maronita representada pelo Bloco Constitucional que havia sido fundado em 1936 - julgava que a independência deveria ser absoluta e não deveriam ser mantidas quaisquer ligações com a França, até porque, segundo seus observadores, já se tratava de um país em decadência que estaria sendo superado pela Inglaterra e, principalmente, pelos Estados Unidos, quem lhes interessava estreitar o relacionamento devido à promessa de investimentos econômicos. Esse agrupamento contava, também, com a participação de alguns representantes drusos e xiitas.

Quanto aos sunitas, também nutriam certo entusiasmo pela independência libanesa, contudo, sempre inserida num contexto que englobasse a proposta pan-arabista. Entendendo que o receio dos maronitas com relação à proposta sunita configurava-se num grande

\footnotetext{
${ }^{31}$ O cargo de Alto Comissário extinguiu-se com a queda do domínio alemão sobre a região e, a partir daquela ocasião, o representante francês passou a ser designado Delegado-geral.
} 
obstáculo para o fortalecimento do movimento pró-independência, lideranças do Bloco Constitucional, tais como os irmãos Khazin (maronitas) e Takieddine Solh (sunita) de Sidon, propuseram-se a promover reuniões entre sunitas e maronitas para estabelecer um diálogo em que as propostas Arabista e 'Libanista' tivessem seus extremos minimizados para que se alcançasse um consenso. As discussões tinham o intuito de reduzir o medo maronita quando à visão pan-arabista dos sunitas e, ao mesmo tempo, explicitar em que base se daria a criação de uma 'nação libanesa'. Os progressos foram alcançados e o acordo resultou no Pacto Nacional. (Salibi, 1988: 184-5)

A inquietação libanesa, no tocante à efetivação da independência, era notória e, investido do cargo de Delegado-geral, em 26 de novembro de 1941, Catroux decretou o fim do Mandato francês sobre o Líbano e Síria. Automaticamente a Grã-Bretanha reconheceu sua independência, assim como os Estados Unidos, União Soviética e os países árabes. Para respaldar o procedimento, passaram a nomear embaixadores para os recém-independentes países.

Apesar de 'independente’, a constituição que estava em vigor era a que atribuía à França grandes poderes sobre a política libanesa, o que fez com que os movimentos internos se articulassem para que o fim da interferência francesa sobre o Líbano se tornasse fato antes que houvesse um movimento de reação.

Em 1943, Catroux proclamou eleições gerais para o Líbano. A Câmara dos Deputados acabou por eleger Bishara al-Khouri como presidente que, na seqüência, indicou Riad Solh (Riyad Sulh) como primeiro ministro. Já sob a

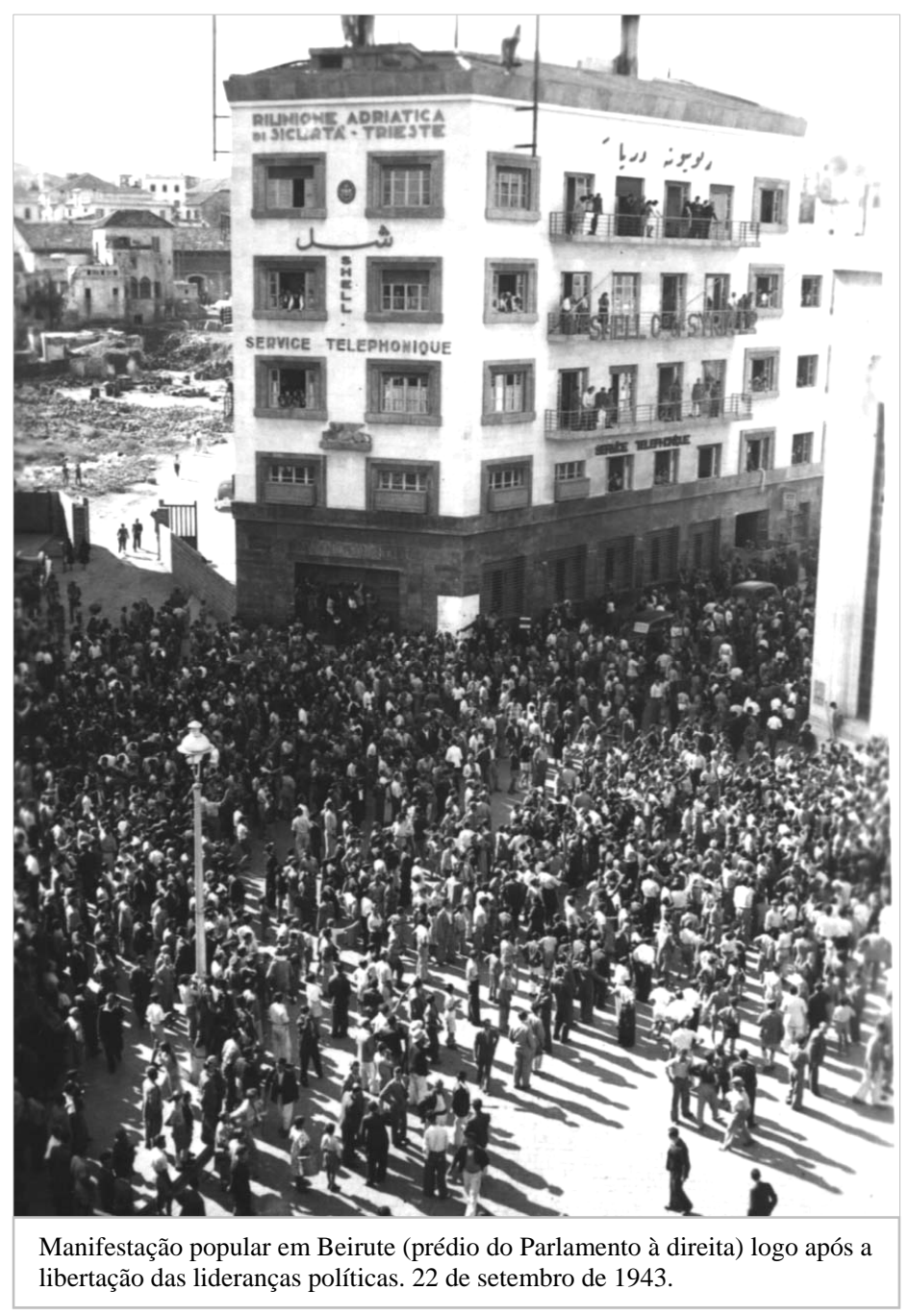
nova administração e, buscando formas de acabar com o jugo francês sobre o Líbano, foram propostas emendas para a Constituição. A Câmara dos Deputados, engajada no movimento em prol da independência - haja vista que estava sob o controle da grande maioria dos 
parlamentares que haviam sido eleitos pelo Bloco Nacional, partido de Khouri -, logo as aprovou. As tais emendas suprimiam completamente a possibilidade de uma intervenção francesa sobre Líbano - pelo menos com respaldo institucional - e abriam caminho para, definitivamente, encerrar o período de Mandato.

Já com o status diferenciado, de Estado soberano, o presidente Khouri e seu primeiroministro Solh transformaram a autoridade francesa na região de Delegado-geral em Embaixador, fato esse que gerou grande descontentamento por parte da França e provocou uma reação inesperada, considerando a violência com que ocorreu. A França, através de seu representante local, o Delegado-geral Jean Helleu, designou uma força tarefa para prender o presidente e suas principais lideranças políticas. Os prisioneiros foram mantidos no Castelo de Rashayya, o que levou partidários cristãos (Falange ou Kata’eb) e muçulmanos a se unirem em torno de um interesse comum: acabar com os desmandos franceses. Em 22 de novembro de 1943, sob pressão dos britânicos, dos norte-americanos e dos países árabes, a França libertou os prisioneiros e reconheceu a total autonomia do território libanês. A data da libertação dos prisioneiros passou a corresponder à celebração do “Dia da Independência”.

Em março de 1945 o Líbano tornou-se membro da Liga Árabe e, no mesmo ano, participou da Conferência de São Francisco, a qual criou a Organização das Nações Unidas (ONU), tornando-se membro. A conquista da soberania libanesa, entretanto, somente foi concretizada em 31 de dezembro de 1947, ocasião em que as tropas francesas deixaram o país.

\section{7 - LÍBANO, ESTADO INDEPENDENTE E SISTEMA ELEITORAL PRÓPRIO}

Sob as cinzas de um período bastante conturbado, o Mandato francês deixou de existir no Líbano, contudo, ainda permaneceria vivo por dois anos mais na vizinha Síria. O fato era apreciado com grande preocupação devido à proximidade latente entre os dois países e ainda haver questões a serem resolvidas por ambos. De certa forma, a identidade sírio-libanesa e a questão relativa territorialidade, dentre outras pendências, ainda viria a ser suscitada no transcorrer da história de ambos; servindo, inclusive, como motivação para o governo sírio negar com veemência a separação entre os dois territórios. Entretanto, o fato de o Líbano ter conseguido alcançar a independência não deixa de ser entendido como um elemento de fundamental importância para que a Síria a obtivesse também, porém, a trajetória política desses novos Estados seguiu caminhos distintos. A Síria viria a ter sua identidade árabe 
reforçada, enquanto no Líbano a forte presença cristã ainda lutava por uma ligação mais estreita com o mundo ocidental. A partir desse distanciamento, o transcorrer dos anos favoreceu o surgimento de forças políticas, em ambos os países, que passaram a se pronunciar acerca da questão da identidade sírio-libanesa - havendo grupos pró e contra a união -, muito embora o governo sírio sempre tenha deixado claro seu entendimento de que o Líbano faria parte da Síria.

De fato, um dos grandes catalisadores da independência libanesa foi o Pacto Nacional que fora firmado entre cristãos e muçulmanos. A partir dele foi possível vislumbrar a existência de interesses comuns entre grupos religiosos distintos e, ir além ao idealizar o nascimento de uma identidade nacional comum.

Pelo menos em tese os primeiros anos de independência libanesa transcorreram com alguma calmaria, apesar de a regra estabelecida pelo Pacto Nacional gerar muitos questionamentos e suscitar a existência de favorecimentos para cristãos maronitas e muçulmanos sunitas. Esse era o argumento principal advindo de drusos e xiitas.

O Pacto Nacional, como fora apresentando anteriormente, não é um documento formal assinado entre as partes, mais se caracterizava como um tratado estabelecido na base da confiança mútua. Seus pressupostos eram conhecidos por todos e tentavam contemplar a heterogeneidade cultural reinante no Líbano.

Como pressupostos básicos do Pacto Nacional, merecem destaque: 1) o Líbano deveria buscar sua identidade própria, não mais enfatizando serem, seus habitantes, descendentes de árabes ou ocidentais; 2) apesar de o Líbano ser considerado um país árabe, e esta ser sua língua oficial, não residiria nesses fatos razão suficiente para o rompimento com o ocidente, haja vista que o intercâmbio sempre fora de grande valia e contribuiu para o progresso econômico do país; 3) por outro lado, como o Líbano é um Estado árabe, havendo qualquer agressão a outro 'Estado irmão', a obrigação dos libaneses seria lutar ao seu lado, contra o inimigo. Porém, caso houvesse uma luta entre Estados árabes, o Líbano deveria permanecer neutro; e, 4) os cargos públicos deveriam ser distribuídos de acordo com a proporcionalidade populacional dos grupos religiosos, entretanto, no tocante aos cargos que exigissem capacidade técnica, estes deveriam ser entregues àqueles que fossem efetivamente competentes, independentemente da fé proferida. Esse último item do Pacto sempre fora objeto de discussão, porque abria a possibilidade de que os governantes cercarem-se de partidários seus, independentemente da ‘capacidade técnica’ necessária para o desempenho da função. 
A participação proporcional dos grupos religiosos nos cargos da administração pública nem sempre foi respeitada devido à própria facilitação que o acordo viabilizava por seu entendimento dúbio. Quando as minorias questionavam que não tinham participação, os maronitas - que assumiram o poder executivo - alegavam que estavam utilizado o critério de 'capacitação técnica', o que não podia ser contestado efetivamente, mas gerava insatisfação pelo alto grau de sectarismo político presente.

Ratificou-se, também, que a presidência seria exercida por um cristão maronita e o cargo de Primeiro-Ministro por um muçulmano sunita. Apenas em 1947, com o grande aumento populacional dos xiitas, e conseqüente maior participação na vida política libanesa, que esse grupo religioso conseguiu resguardar para si o cargo de Chefe do Parlamento.

À parte a gama de diferenças existentes entre os grupos religiosos libaneses, para a questão da representatividade política foi possível estabelecer com bastante clareza - para que houvesse governabilidade - as bases em que se daria a disputa pelas vagas no Parlamento. Para a eleição dos parlamentares criou-se uma fórmula bastante sofisticada para os padrões da época. O país foi dividido em múltiplas zonas eleitorais e assegurou-se determinada quantidade de cadeiras no Parlamento para muçulmanos e cristãos - respeitando o que fora acordado no Pacto Nacional, ou seja, a proporção de 6 para 5 em favor dos cristãos. Ocorre que muitas dessas zonas eleitorais eram compostas por grupos confessionais mistos e, para que seus representantes conseguissem vagas no Parlamento era necessário que houvesse o apoio recíproco das comunidades religiosas, ou seja, muçulmanos poderiam necessitar de votos cristãos para elegerem um parlamentar local, ou vice-versa. Isso se deve ao fato de que dentro das zonas eleitorais o voto poderia ser feito de duas maneiras: 1) através de uma cédula em que contivesse candidatos de diferentes religiões e seitas, os quais estariam concorrendo de forma independente; ou, 2) em cédulas que contemplassem apenas um grupo religioso.

Diante da opção de escolha das cédulas, o votante analisava o panorama eleitoral nacional e verificava como estava sendo formado o Parlamento, depois optava por aquela que suprisse suas necessidades - regionais ou de seu grupo religioso. Quando havia uma pequena participação dos representantes locais, podia-se votar em parlamentares de outra religião, mas que assegurassem a representatividade da região (zona eleitoral) no Parlamento, o que, em princípio, garantiria investimentos sociais e econômicos. Em tese a fórmula buscava fomentar a integração política entre as diversas comunidades religiosas e distribuir o poder de maneira proporcional à população de cada zona eleitoral. (Salibi, 1988: 186-7) Para o momento que foi criado, o sistema eleitoral se apresentara como bastante complexo e sofisticado, contudo, fora assimilado e, mesmo com as reformas subseqüentes, mantém a mesma base. 
Por outro lado, mesmo considerando que a intenção do sistema eleitoral possa ter sido gerar a interação entre os vários grupos religiosos em prol do fortalecimento da representatividade de sua região, o fato recorrente, e que tornou-se facilmente perceptível, é que somente as lideranças locais (zaim) conseguiam eleger-se e fortalecer seu poder, ratificando, assim, a velha estrutura 'feudal'.

Se, num primeiro momento, o Pacto Nacional viabilizou a independência do Líbano, as amarrações propostas por ele acabaram por gerar insatisfação. Principalmente por parte dos muçulmanos, que se viam limitados politicamente, uma vez que as diretrizes da nação estavam sendo traçadas pelos maronitas, que asseguraram para si o Poder Executivo.

A tensão não tardou a manifestar-se e o Líbano passou a viver um período de fortalecimento (talvez, renascimento) do sistema partidário. Em verdade, muitos partidos políticos já existiam desde final do século XIX, contudo, sua atuação estava limitada à questão relativa à inserção do Monte Líbano no panorama pan-arabista reinante à época. $\mathrm{O}$ novo perfil dos partidos políticos que estavam despontando dizia respeito às questões locais e à maneira com que a política interna estava sendo desenvolvida. Questionava-se, sim, e com veemência, os privilégios maronitas. Esse é o caso do primeiro partido druso que alcançou atuação em âmbito nacional, o Partido Progressivo Socialista, fundado em 1949 e comandado por Kamal Jumblatt. Líder controverso - árduo defensor dos ideais da Esquerda, contudo, detentor de prestígio alcançado graças ao sistema 'feudal' libanês (concentrador de poder junto às famílias e elitista) -, entretanto, reconhecido por sua capacidade intelectual e que conseguiu abarcar seguidores de outros grupos religiosos.

Concomitantemente ao desenvolvimento de uma oposição partidária, os maronitas também passaram a fortalecer-se. É o caso emblemático da transformação da milícia falangista (Kata'eb) no Partido Social Democrata; fato ocorrido em 1949, sob a liderança de Pierre Gemayel. Seu idealizador, que esteve na Alemanha durante os Jogos Olímpicos de Berlim (1936), demonstrou-se admirado com a disciplina alemã e idealizou a implementação de uma organização que tivesse uma estrutura similar no Líbano, conforme relatou a Robert Fisk, em entrevista no ano de 1982:

When I was in Berlin then, Nazism did not have the reputation which it has now (...) Nazism? In every system in the world, you can find something good. But Nazism was not Nazism at all. The word came afterwards. In their system, I saw discipline. And we in the Middle East, we need discipline more then anything else. (2001: 65) 
Também, no período pós-independência que o, já citado, Partido Nacionalista Sírio de Antun Saadeh alcançaria maior evidência, haja vista que contava com o segundo maior número de integrantes - perdendo apenas para a Falange - e tentava viabilizar seu projeto de unificação entre Líbano e Síria a qualquer custo. Assim, em 1948, temendo que o Partido pudesse implementar seus planos, o governo libanês perseguiu e prendeu suas lideranças. De certa forma, a ação governamental não foi suficiente e, no ano seguinte seus militantes tentaram chegar ao poder através de um golpe de Estado. Sem conseguir efetivar seus planos, o Partido - agora SSNP (Syrian Social Nationalist Party, Partido Social Nacionalista Sírio) -, tornou-se ilegal e Saadeh acabou sendo preso e executado. Contudo, o legado de Saadeh não se encerraria nesse momento e o partido voltaria a ter grande importância no transcorrer da história libanesa, como poderemos perceber, mais detalhadamente, ao abordarmos a estrutura política e eleitoral do país ${ }^{32}$.

Com a nova situação política emergente no Líbano, que, em tese, estaria vivendo um momento democrático, os governantes passaram a ser mais cobrados e questionados pelas lideranças políticas de oposição. Essa nova postura advinha do fato de que, muitas vezes, não havia unanimidade nem dentro da própria comunidade maronita, o que a deixava suscetível a fortes críticas e, até certo ponto, instável.

As ações assumidas pelo governo Khouri, apesar de terem ajudado a extinguir o Mandato francês sob o Líbano, na seqüência, já deixaram de agradar a totalidade da população libanesa. Esse fato

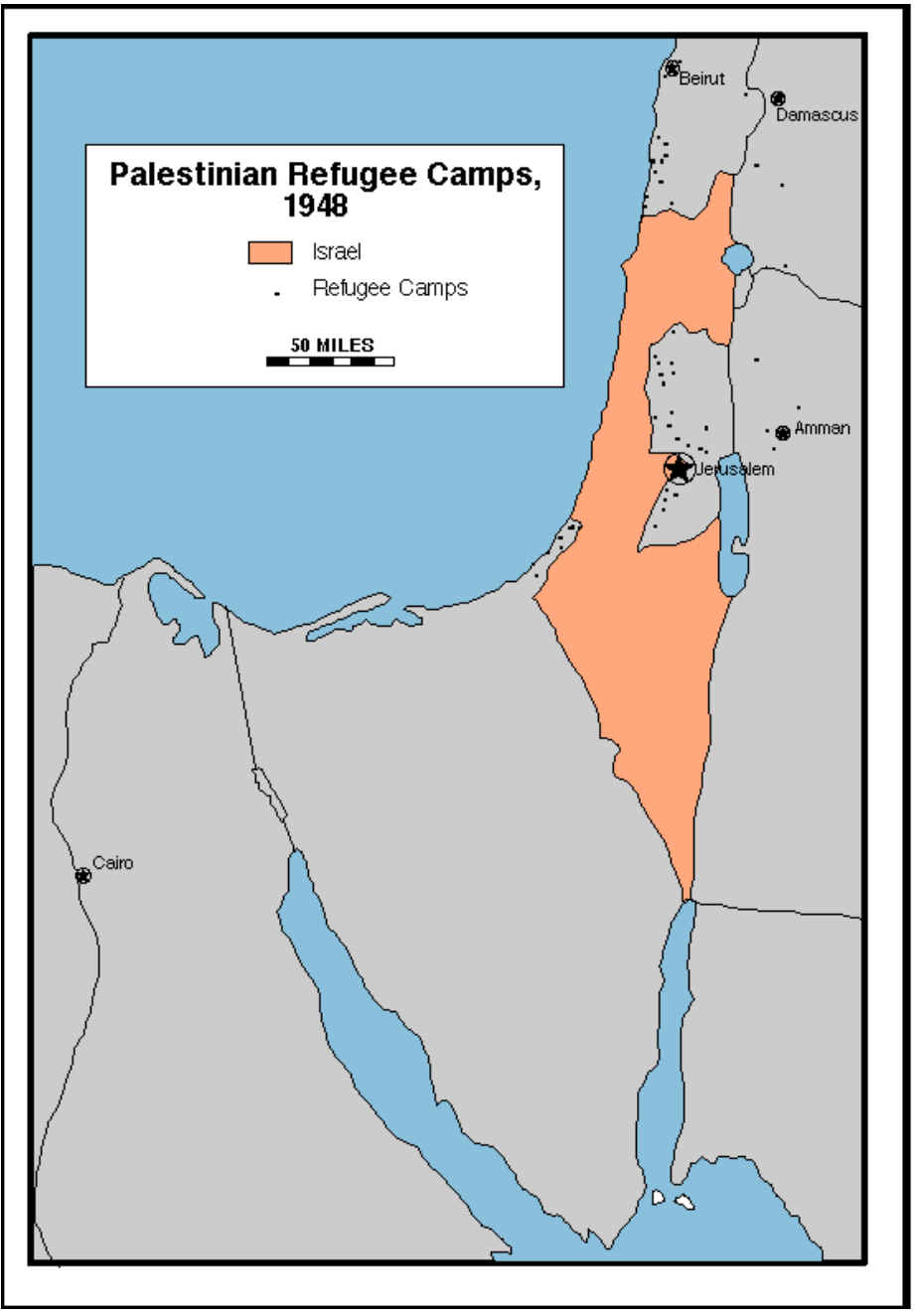
explicitava-se através da reação dos líderes regionais - impondo fortes críticas à presidência -

\footnotetext{
${ }^{32}$ Mais detalhes sobre Saadeh ver: ADJAMI, Fouad. The Dream Palace of the Arabs. New York: Vintage Books, 1998.
} 
e, no revide do governo, reprimindo fortemente seus oposicionistas. Também, há de salientar que os privilégios destinados aos cristãos na administração estatal voltaram a ser objeto de críticas enfáticas. Contudo, um acontecimento internacional abalou o governo Khouri, qual seja, a criação do Estado de Israel, em 1948.

A ligação entre maronitas e os sionistas não era recente, e já vinha estreitando-se desde 1920, quando fora assinado o Tratado de Cooperação entre a Organização Sionista e representantes da Comunidade Maronita. Essa ligação pode ser analisada a partir de uma tentativa de buscar similaridades entre as trajetórias dos povos cristão e judeu, inseridos numa região predominantemente muçulmana. Uma união que teria a intenção de autopreservação das minorias, como apregoava-se. Esses laços foram sendo estreitados através das lideranças maronitas, tanto religiosas quanto políticas, fato que não era muito bem aceito pelos muçulmanos libaneses e provocava suspeitas.

Diante da indefinição com relação ao destino do Estado libanês, no que tange a sua identidade, os maronitas trataram de estreitar, ainda mais, seus laços com o movimento sionista e apoiavam abertamente a criação do 'Lar Nacional Judeu na Palestina'. Essa relação tinha outros vieses, conforme nos apresenta Kirsten E. Schulze, professora de História Internacional da London School of Economics.

In the 1930s, the Maronite Church became actively involved in deepening relations with the Jewish community in Palestine in an attempt to formulate an alliance against Islam. Fear of loss of ethnic and religious identity in a "vast sea of Muslims" led to the concept of a natural alliance between ethnic and religious minorities. This concept was embraced by both the Maronite Church and the emerging Yishuv (Jewish population of Palestine). Indeed, Maronite Patriarch Antun Arida pursued a general partnership and Maronite politician Emile Eddé envisaged a political and even military union. When Eddé became president of the Lebanese Republic in 1936 he was presented by the Yishuv with a draft Treaty of Friendship.

A further manifestation of the budding minority-alliance was President Eddé's support of the Peel Commission report in 1937, which recommended the creation of a Jewish state in Palestine. In 1946, Arida went to Jerusalem where he signed an agreement on behalf of the Maronite Church with Chaim Weizmann on behalf of the Yishuv. This agreement reciprocally recognized the Jewish demand for independence in Palestine and the independent "Christian character" of Lebanon. A year later, in 1947, the Maronites' recognition of a Jewish state motivated the Maronite Archbishop of Beirut, Ignace Mubarak, to submit a memorandum to the United Nations supporting the creation of a Jewish state in Palestine.

The relationship between the Maronites and the Yishuv evolved around several concepts, the most important of which was the notion of a "natural" alliance between Israeli Jews and Lebanese Christians. (1997) 
Devido às relações muito próximas entre a comunidade maronita libanesa e os sionistas, em 1948, quando houve a declaração de guerra - parte de seus vizinhos árabes (Síria, Jordânia e Egito) - contra o recém-criado Estado de Israel, a situação política, interna, do Líbano tornou-se bastante delicada.

Como estabelecia o Pacto Nacional e, devido ao Líbano fazer parte da Liga Árabe, sua obrigação seria lutar ao lado dos demais países árabes contra Israel, contudo, Khouri optou por não participar militarmente da guerra, restringindo-se a posicionar-se ao lado dos árabes. A atitude de Khouri gerou fortes críticas de parte da população muçulmana libanesa. O resultado final do conflito entre árabes e israelense também foi significativo, haja vista que, finalizada a guerra - que estendeu-se de 15/05/1948 ${ }^{33}$ (um dia após a decretação do Estado de Israel) a meados de $1949^{34}$, ocasionando a vitória esmagadora dos israelenses -, também houve uma alteração significativamente da realidade libanesa com a entrada de mais de 170.000 refugiados palestinos no sul de seu território.

A governabilidade do Líbano ficou fortemente abalada devido à pressão que parte da população libanesa passou a exercer sobre o governo à medida que a entrada dos refugiados acarretava problemas sociais e empobrecimento - principalmente dos xiitas, que mais sofriam com a presença palestina no sul do Líbano - e, também, devido a Khouri, cada vez mais, transformar seu governou num sistema altamente sectário, deixando, inclusive, de considerar o poder dos zuama ${ }^{35}$. Por conseqüência desses fatores, acusações de corrupção e favorecimentos políticos passaram a tornar-se freqüentes.

O resultado imediato dessa repulsa por Khouri evidenciou-se durante o ano de 1952, quando formou-se uma aliança inesperada entre Kamal Jumblatt (druso, líder do Partido Socialista Progressivo), Camille Chamoun (maronita, embaixador que estava servindo no Reino-Unido) e Emile Bustani (parlamentar eleito em 1951 e conhecido pelo sucesso nos negócios, o que o tornara um milionário) na recém criada Frente Social Nacional (SNF) ${ }^{36}$.

\footnotetext{
33 A citada data corresponde à saída dos exércitos britânicos da Palestina, delegando a responsabilidade pelos acontecimentos futuros à ONU, contudo, os atritos entre judeus e árabes já vinham se alastrando desde novembro do ano anterior (1947), quando fora votada, na Assembléia Geral da ONU, a divisão da Palestina e, na seqüência, rejeitada pelos árabes.

${ }^{34}$ Durante o ano de 1949, conforme o Estado de Israel conseguia derrotar seus oponentes, armistícios iam sendo assinados. Em 24 de fevereiro de 1949 foi assinado o armistício com o Egito; em 23 de março, com o Líbano (Ras-el-Nakura); em 3 de abril, com a Jordânia; e em 20 de julho, com a Síria. Assim, após 15 meses de luta, Israel não apenas garantiu a sua existência como nação soberana no Oriente Médio, rechaçando os exércitos inimigos, mas também assumira o controle sobre uma área de cinco mil quilômetros quadrados, superior àquela que lhe fora concedida pelas Nações Unidas.

${ }^{35}$ Líderes regionais dos clãs, plural de zaim. Personalidades que deveriam dar suporte ao governo.

${ }^{36}$ Mais convencionalmente conhecida pela sigla em inglês SNF (Social Nacional Front).
} 
Essas lideranças uniram-se, deixando de lado suas divergências, em prol de por fim aos 'abusos' de Khouri.

Ainda em 1952, na cidade de Dayr al Qamar, Chamoun conclamou a população local a protestar contra Khouri, levando mais de 50.000 pessoas às ruas. A situação do governo estava insustentável, e só veio a se agravar com a adesão de Pierre Gemayel ao grupo dos insatisfeitos. Gemayel era o líder do Partido Falangista (Kata’eb) e exercia seu poder junto às comunidades de Beirute Oriental e do Monte Líbano.

Apesar da evidente rejeição que Khouri estava sofrendo da parte de quase todas as lideranças políticas libanesas, ele não aceitava renunciar ao mandato. Sua situação no governo tornou-se insustentável quando, em 11 de setembro de 1952, a SNF convocou uma greve geral que assumiu proporção nacional. Khouri, para impedir que lhe fosse aplicado um provável golpe de Estado, ordenou que o general Fuad Shihab, chefe do Exército, marchasse contra os grevistas. Shihab recusou-se a cumprir a ordem alegando tratar-se de "um assunto político”, portanto, não sendo da alçada militar. Por fim, Shihab manteve-se neutro no desencadear dos acontecimentos, fato esse que iria proporcionar-lhe vantagens no futuro.

Khouri conseguiu manter-se no poder até 18 de setembro de 1952, quando não mais suportou a pressão e renunciou. Todo o movimento que levou à renúncia do presidente passou a ser tratado pelos historiados como "Rosewater Revolution” devido a sua característica pacifista e congraçamento entre grupos religiosos que sempre atuavam de forma antagônica.

\section{8 - PRIMEIRA GUERRA CIVIL: IDENTIDADE, POVO E NAÇÃO EM XEQUE}

Em 23 de setembro de 1952 a Câmara dos Deputados elegeu o novo presidente do Líbano, Camille Chamoun. Seu período de tranqüilidade no governo logo foi afetado pela deterioração das relações entre as lideranças que haviam formado a SNF, principalmente no tocante ao líder druso, Kamal Jumblatt.

Chamoun passou a ser acusado de manter a mesma estrutura de poder sectarista que seu antecessor havia institucionalizado, privilegiando claramente os maronitas. Jumblatt ia além ao questionar a legitimidade dos maronitas no comando da nação, alegando que àquela época os muçulmanos já haviam se tornado a maior comunidade religiosa do país. O líder druso passou a clamar pela elaboração de um novo censo populacional. Por outro lado, os maronitas se recusavam a rever as bases do Pacto Nacional por entenderem que grande parte da comunidade muçulmana que alegava ser superior numericamente à cristã, de fato consistia 
em refugiados palestinos. Também, os maronitas adotavam uma segunda linha de argumentação para negarem-se a rever a proporção estabelecida de '6 x 5' em prol dos cristãos com relação aos representantes no Parlamento. Para eles, a comunidade maronita era quem contribuía com $80 \%$ das taxas arrecadadas no país, o que lhes daria certos privilégios políticos.

A instabilidade política interna do Líbano só veio a se agravar com um acontecimento que abalou o mundo árabe. Em julho de 1956, Gamal Abdel Nasser, o então presidente do Egito, para fazer frente à política colonialista francesa e britânica, resolveu nacionalizar o Canal de Suez $^{37}$ - que era controlado por empresas de capital francês e britânico, prioritariamente $^{38}$ - e dar andamento à sua política pan-arabista. A represália ocorreu quase que imediatamente; França, Inglaterra e Israel se uniram para impedir que Nasser ganhasse força em seu projeto político e, com isso, fizesse com que o movimento pan-arabista alcançasse outros Estados árabes. Em outubro do mesmo ano, Israel invadiu a península do Sinai e a conquistou. Em novembro, tropas britânicas e francesas foram destacadas para a região e assumiram o controle do Canal.

Apesar da aliança entre França, Grã-Bretanha e Israel, formada para enfrentar o Egito, suas razões advinham de diferentes motivações. França e Grã-Bretanha, duas potências coloniais que dominavam o

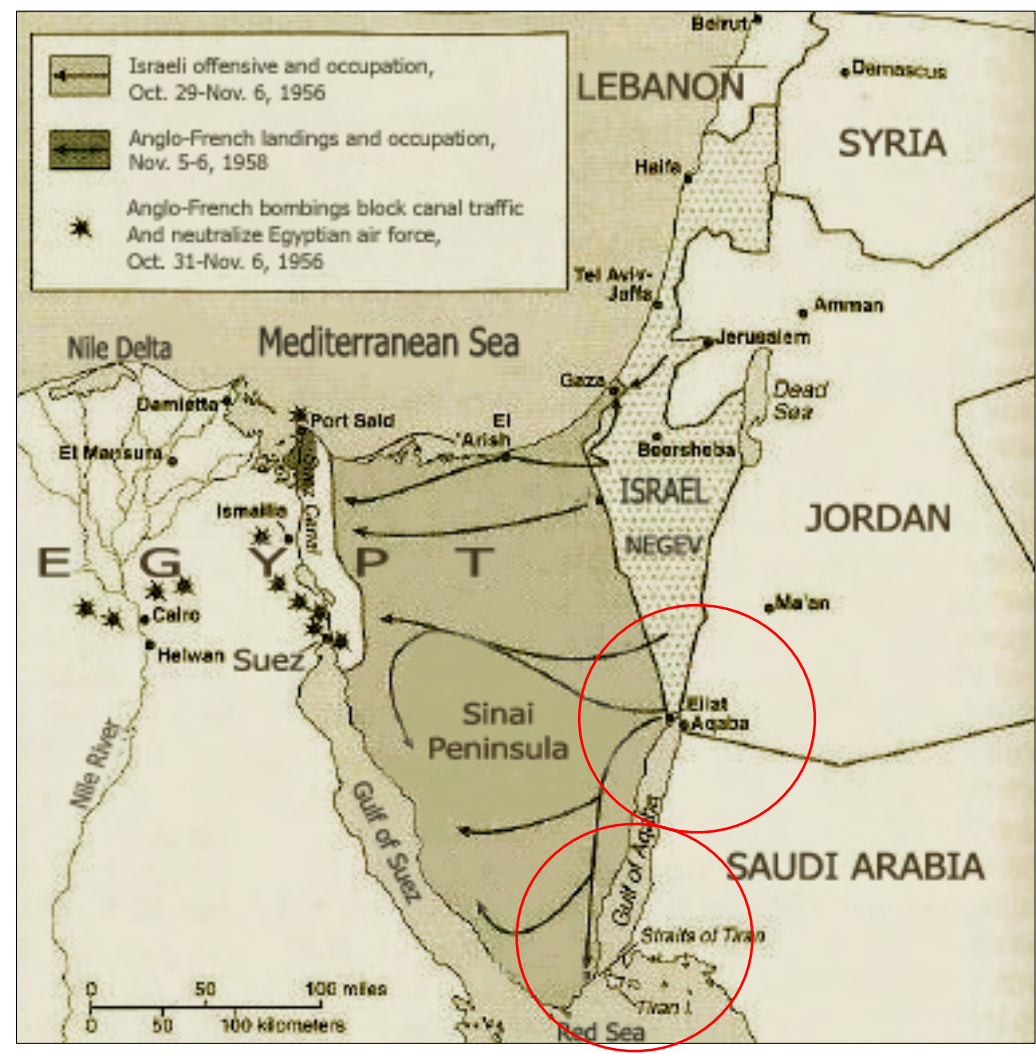
Canal através de empresas de suas nacionalidades ${ }^{39}$, viam com muito risco o domínio de Suez por parte de Nasser, uma vez que, a partir da nacionalização, as embarcações que supriam os países com petróleo dependeriam 'da vontade’ de Nasser para passar pelo Canal, o que o

${ }^{37}$ O canal era utilizado como melhor trajeto para o escoamento de mercadorias provenientes da Ásia, principalmente as mais rentáveis, como o petróleo que era produzido no Golfo Pérsico e na Península Arábica. ${ }^{38}$ Nasser comprometeu-se a compensar as empresas controladoras do Canal e alegou que utilizaria os rendimentos dele para construir a Represa de Aswan, que tinha o custo estimado em 1.3 bilhões de dólares. Um projeto que o Egito necessitava para irrigação e poder. (Bregman, 2004: 55)

${ }^{39} \mathrm{O}$ acordo deveria vigorar por 99 anos, a partir da data em que entrasse em atividade, ou seja, até 1968. 
geraria muitos riscos e grande margem de negociação para o líder árabe. Não é possível abstrair o fato de que àquela época o petróleo já se transformara num produto de extrema necessidade para o desenvolvimento econômico dos países consumidores, assim como para os produtores.

Por outro lado, Israel não precisava, necessariamente, unir seu território ao Canal de Suez, uma vez que tinha a opção de utilizar como rota para o leste africano e Ásia a passagem pelo Estreito de Tiran - que se transformaria, no futuro, na principal rota. Ao aceitar formar uma coalizão contra os egípcios, Israel percebeu uma oportunidade de dominar o Estreito, ter liberdade para que o porto de Eilat funcionasse normalmente e não mais dependesse da vontade de Nasser para as atividades navais israelenses. (Bregman, 2004: 56-7)

Externamente, para a comunidade internacional, a ação dos três países contou com péssima repercussão. França e Inglaterra acabaram sendo acusadas de agir com base numa política colonialista, que, àquela época, já estava sendo rechaçada. Exemplo claro dessa nova postura pôde ser percebido tomando como base o posicionamento das duas grandes potências que haviam emergido no pós-Segunda Grande Guerra. Estados Unidos e União Soviética assumiram o mesmo lado ao ser votada a Resolução de número 119 do Conselho de Segurança da ONU, a qual delegava a solução do conflito à Assembléia Geral, haja vista não ter havido unanimidade dentre os membros do Conselho de Segurança. Na Assembléia Geral foram convocadas Sessões de Emergência ${ }^{40}$ para analisar os incidentes e, por fim, ordenou-se a retirada da França, Inglaterra e Israel do território egípcio, com a finalidade de restaurar sua soberania. Também foi criada uma Força de Paz para a região. Os países envolvidos no conflito tiveram de recuar e o Canal de Suez voltou para a administração do governo egípcio, contudo, acertou-se a livre navegação pelo canal. Os israelenses, por outro lado, recuaram e deixaram livre a Península do Sinai, mas conseguiram a liberdade de navegação pelo Estreito de Tiran.

Inflamada, a população muçulmana libanesa, pelos acontecimentos recentes Revolução Egípcia de 1952 que levou Nasser ao poder, Revolução Argelina de 1954 e Crise do Canal de Suez - e pela insatisfação provocada à ocasião em que o presidente libanês deixou de cortar relações diplomáticas com a França e Inglaterra durante o conflito no Canal de Suez, a questão da 'identidade libanesa' voltou a ser o centro da atenção nacional. O efeito da ‘derrota com sabor de vitória’ obtida por Nasser reacendeu a discussão acerca do pan-

\footnotetext{
${ }^{40}$ A Assembléia Geral da ONU, seguindo a determinação de sua Resolução no 377 A, de 1950, foi convocada a reunir-se em caráter extraordinário para decidir quais medidas seriam empregadas na questão do Canal de Suez. Tais sessões ocorreram de $1^{\circ}$ a 10 de novembro de 1956 e, como resultado final da apreciação dos acontecimentos, foram aprovadas sete Resoluções (997 a 1003).
} 
arabismo e a ligação com o ocidente. O 'Libanismo' voltou a ser confrontado com o Arabismo e, grande parte dessa ressurreição se devia à política implementada por Chamoun, que era abertamente acusada de ser pró-Ocidente e pró-imperialista.

Chamoun, que havia obtido sucesso com a eleição de seus parlamentares no pleito de 1957 e, com isso, fora acusado de querer aprovar uma emenda constitucional que viabilizaria sua reeleição, não conseguia eliminar a forte pressão que sofria das lideranças políticas regionais. Os clãs libaneses, liderados por Jumblatt, sentiram-se ainda mais traídos pela postura de Chamoun, que, através de seu ministro de Relações Exteriores, Charles Malik, conseguiu obter apoio financeiro dos Estados Unidos para a campanha eleitoral de seus candidatos, fato esse que teria proporcionado-lhes a vitória em 1957. (Gerges)

Apesar de ter se alinhado à política estadunidense e passar a ser um defensor da "Doutrina Eisenhower”,41, essa postura não lhe trouxe grandes vantagens. Chamoun pretendia, assumindo as diretrizes da política externa norte-americana, proporcionar o crescimento econômico do Líbano com investimentos provenientes daquele país, contudo, estava desacreditado demais internamente e sem condições para permanecer à frente do governo.

Para um governo desacreditado, o panorama internacional não ajudava muito. Em 1958, o Pan-arabismo alcançou um de seus momentos de maior evidência ao proporcionar a criação da República Árabe Unida (RAU), que foi a união entre Síria e Egito. Imediatamente, temendo que o movimento assumisse maiores proporções no âmbito nacional, Chamoun pronunciou-se contra a RAU e questionou sua legitimidade. Por conseguinte, no Líbano, algumas forças políticas passaram a ganhar maior destaque. Adil Usayran, Chefe do Parlamento, declarava: “O Líbano marchará com a caravana árabe e, qualquer um que pense em trabalhar por interesses outros que aqueles dos árabes, não terá espaço no Líbano." ${ }^{42}$ (Gerges). Dessa forma, claramente a situação ia assumindo outras dimensões, haja vista que o suporte para ambos os lados estava ligado a forças político-ideológicas externas. Enquanto

\footnotetext{
${ }^{41}$ Em 5 de janeiro de 1957, o presidente dos Estados Unidos discursou no Congresso e, na ocasião, estabeleceu qual seria a política empregada pela nação com o intuito de 'deter o comunismo da União Soviética'. As diretrizes propostas por Eisenhower diziam respeito à ação que deveria ser empregada junto aos países do Oriente Médio para que pudessem manter sua independência. Abria a possibilidade, assim, para que fosse destinado apoio financeiro e militar a quaisquer Estados que estivessem correndo o risco de 'perder a liberdade' para os comunistas. A 'Doutrina Eisenhower' mudava radicalmente a política externa dos Estados Unidos, uma vez que, ao invés de manter a estratégia de Contenção (Doutrina Truman) - que consistia em criar 'diques' nas fronteiras do comunismo, oferecendo facilidades financeiras para que os países não sucumbissem a ele - passou a enfrentá-lo com a proposta de estabelecer um grande exército para a preservação dos valores estadunidenses. Em tese, a Doutrina Eisenhower, como passou a ser conhecida, somente dispunha a respeito de intervenções no caso de ameaça à segurança externa; daí a crítica no tocante aos Estados Unidos interferirem na política interna libanesa em 1958. Contudo, é fundamental perceber que ao 'se defenderem das ameaças externas', incluíam, com isso, a preservação dos valores estadunidenses que fazia parte da Doutrina. (Pecequilo, 2003)

42 Tradução do autor.
} 
Chamoun contava com o financiamento dos Estados Unidos, a oposição estreitava seus laços com a Síria e Egito (indiretamente com a União Soviética com quem estavam alinhados), através da RAU. Acusando a recém-criada organização de estar patrocinando os distúrbios internos libaneses, o governo Chamoun entrou com ações contra ela na Liga Árabe e no Conselho de Segurança das Nações Unidas. A Liga entendeu não possuir as ferramentas necessárias para resolver a questão e o Conselho de Segurança determinou o envio de uma equipe de observadores ao local.

Ainda, com relação à postura norte-americana, o presidente Eisenhower não estava convicto de que o envio de tropas ao Líbano seria a melhor saída para evitar as pressões que o governo Chamoun vinha sofrendo por parte de Nasser e seus correligionários - que pretendiam que o Líbano se integrasse à RAU. Questionava-se a eficiência de tal ação e o quão importante era o Líbano para a questão geopolítica do Oriente Médio. Também, se o envio de tropas para dar suporte ao governo maronita não poderia potencializar a disputa interna entre os grupos religiosos, haja vista que os cristãos sempre contaram com o apoio das potências ocidentais para intervir nas disputas com os muçulmanos.

A grande preocupação do governo Chamoun residia no perigo eminente que o panarabismo de Nasser representava para o Líbano. Ele apresentava a unificação da Síria e Egito como um forte exemplo que poderia alcançar os demais países árabes. Quando Nassib Matni, maronita (anti-Chamoun) e editor do diário At Telegraph, foi assassinado por defender as idéias pan-arabistas de Nasser, as suspeitas do crime recaíram sobre Chamoun e seus

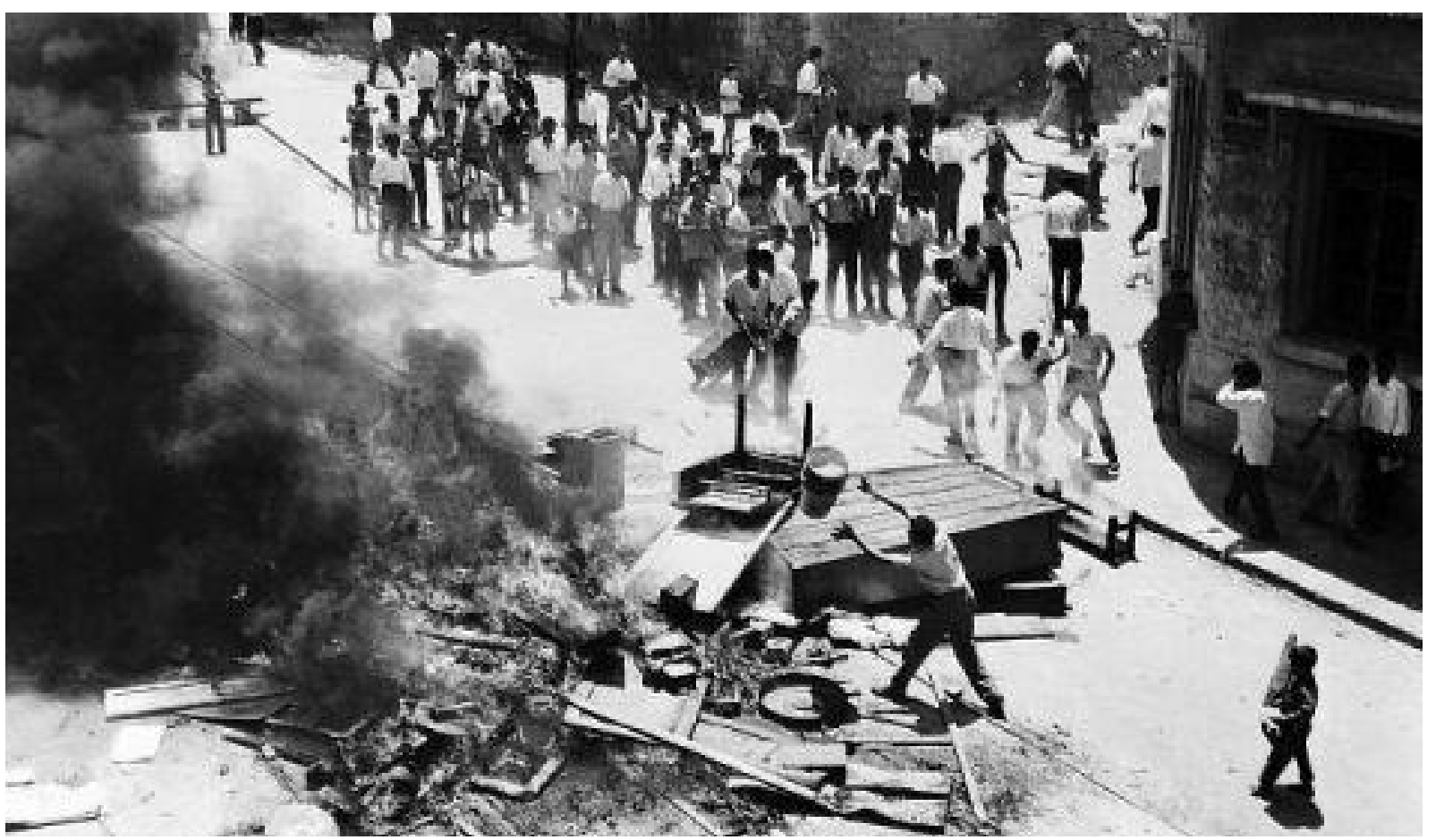

Apoiadores de Kamal Jumblatt (druso) e Rashid Karami (sunita) em protesto contra o governo. Beirute, 18 de maio de 1958. 
partidários. Imediatamente os conflitos tornaram-se mais intensos sob a liderança de Kamal Jumblatt e Suleiman Franjieh. De Trípoli, onde ocorreram os primeiros atritos, a guerra entre muçulmanos e maronitas passou a ser disseminada pelas principais cidades do Líbano, inclusive em sua capital, Beirute. Diante dos fatos, Chamoun viu-se acuado e, como sabia que não poderia contar com o exército regular do país, uma vez que o General Shihab havia negado a utilizá-lo contra o povo, a saída encontrada foi recorrer às milícias. Chamoun fortaleceu seus milicianos e buscou apoio dos clãs locais que ainda lhe davam algum suporte, iniciando, assim, os violentos conflitos que dariam início à Primeira Guerra Civil Libanesa.

Outro fator de grande relevância também repercutiu de maneira negativa para o governo maronita. Em 14 de julho, quando a Revolução no Iraque ${ }^{43}$ foi iniciada e a família real assassinada pelos revolucionários, Chamoun percebeu que os mesmos acontecimentos poderiam chegar ao Líbano e antecipou-se a eles. Aludindo o perigo que o país estava sofrendo de ser invadido pela Síria, pressionou

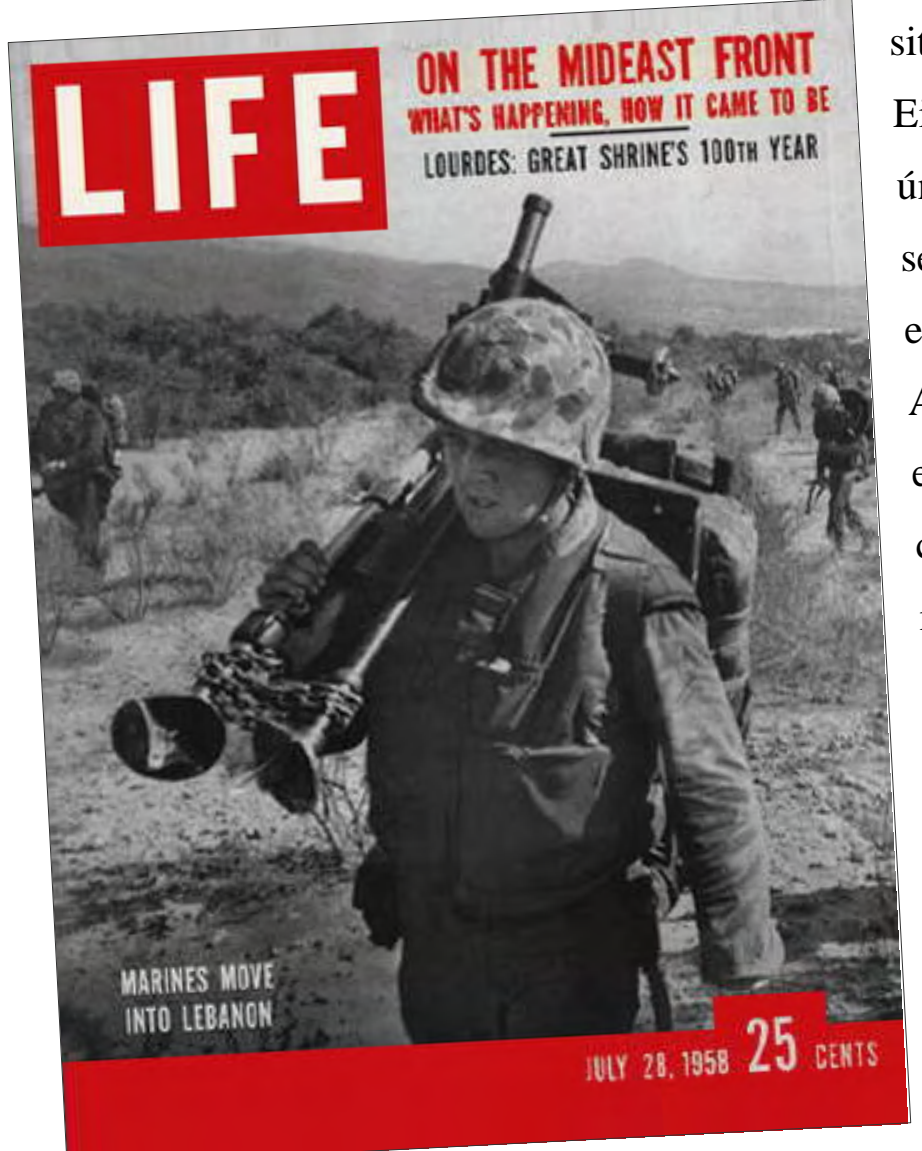

o governo norte-americano a intervir na situação e, para isso, evocou a "Doutrina Eisenhower”. Chamoun entendia que a única maneira de os conflitos internos serem interrompidos perpassava pelo envio imediato de tropas ao Líbano. Assim, sanaria o problema do risco eminente por que o governo estava correndo e, também, inviabilizaria, pelo menos temporariamente, qualquer pretensão do governo egípcio de anexar o Líbano à RAU.

Em 15 de julho as tropas estadunidenses desembarcaram em Beirute para tentar 'restabelecer a ordem local', porém, assumiram a postura de não se envolverem diretamente nos conflitos entre os clãs. A URSS, atônita com a incisiva ação norte-americana no Oriente Médio, reagiu imediatamente solicitando ao Conselho de Segurança da ONU que

\footnotetext{
${ }^{43}$ Os Hashemitas que governavam o Iraque desde de sua criação como Estado independente e, contavam para isso, primeiro com o apoio da Inglaterra e depois com os Estados Unidos. Ocorre que a partir da queda da família real, o presidente norte-americano vislumbrou a possibilidade de que pudesse haver uma alteração radical do equilíbrio de poder existente no Oriente Médio, situação que seria altamente favorável à União Soviética.
} 
se posicionasse contra o ato estadunidense através de uma Resolução. Contudo, mais uma vez, os Estados Unidos, tendo a certeza de que nada poderia ser votado contra sua ação (devido ao seu poder de veto, também compartilhado com as demais potências: URSS, China, França e Reino Unido), justificou seu ato como o auxílio a um aliado e estabeleceu como condição para deixar o Líbano que fosse criada uma força Militar Internacional que pudesse controlar e neutralizar a ameaça egípcia.

Com as tropas norte-americanas em solo libanês Chamoun conjeturou que sua situação política estivesse assegurada, ou seja, que poderia partir para a reeleição; contudo, o governo Eisenhower entendeu que a melhor estratégia local seria apoiar um candidato que pudesse congraçar a maioria dos grupos beligerantes, a escolha recaiu sobre o General Shihab, devido a sua imparcialidade. Chamoun, talvez tivesse supervalorizado sua importância, ou, quem sabe, agido com displicência ao negociar com uma Grande Potência o apoio a sua causa.

Like the monarchists in Iraq, Chamoun had expected the West to sustain and maintain his regime in power. This miscalculation casts light on the nature of the relationship between small and large states. In their dealings with the United States, Lebanese and Iraqi leaders behaved as if they were strategically indispensable to Western security. They also had a blind faith in the capability and reach of their superpower ally. But they failed to remember a crucial principle in world politics: big powers have no permanent friends, only perpetual interests. The importance of local actors depends on how the major powers perceive the configuration of power on the regional and international scenes at a given historical moment. (Gerges)

\section{9 - FIM DA ERA CHAMOUN, INÍCIO DA ERA SHIHAB: PAZ RELATIVA}

O General Fuad Shihab assumiu a presidência em 23 de setembro de 1958 e já iniciou as negociações com os Estados Unidos para a retirada de suas tropas de solo libanês. A guerra havia chegado ao fim com o número de baixas entre 2000 e 4000 libaneses, mas ainda não havia sido resolvida a questão relativa à maior participação muçulmana no governo. Ao invés de as lideranças locais se voltarem para o fortalecimento do Estado nacional, as desconfianças e a ambição entre os clãs faziam com que, cada vez mais, o Líbano fosse se fragmentando.

Internamente, o Líbano ainda não havia conseguido definir sua identidade e o "Libanismo" e Arabismo continuavam na pauta de quaisquer discussões. Ainda mais quando as tropas norte-americanas deixaram o país (final de outubro do mesmo ano) e o debate foi polarizado no campo político. Shihab que, para alcançar a presidência, teve que contar, além 
do apoio estadunidense, com o estabelecimento de compromissos com os vários grupos religiosos atuantes no país, tentou honrá-los. Os problemas surgiram já no início de seu mandato. Na ocasião em que houve a nomeação de Rashid Karami para o Gabinete, as forças políticas maronitas - principalmente a corrente liderada pelos Falangistas - se opuseram veementemente. Fundamentavam essa negativa em dois fatores: 1) Que o Gabinete formado por Shihab já contava com participação demasiada de muçulmanos, o que implicaria na alteração do equilíbrio de poder; e 2) Que Karami era um defensor ardoroso do pan-arabismo de Nasser e declarado aliado da Síria, o que o afastava dos interesses do povo libanês.

Shihab não teve como suportar a pressão maronita e reestruturou seu Gabinete, buscando, assim, alcançar um equilíbrio que mais se aproximasse de uma divisão equivalente de poder. Mesmo contra a vontade absoluta dos maronitas, a nova formação foi aceita e o governo pôde iniciar seu projeto de reestruturação do sistema eleitoral libanês, primeiramente aumentando o número de cadeiras no parlamento de 66 para 99. De certa forma, esse acréscimo de cadeiras também possibilitou que as lideranças locais que haviam participado da Guerra Civil conseguissem ampliar seus poderes tornando-se parlamentares, como no caso de Sabri Hamadeh $^{44}$, Kamal Jumblatt, Rashid Karami, Sa’ib Salam ${ }^{45}$.

Diferentemente de seu antecessor Chamoun, que criou o Partido Nacional Liberal e passou a fazer forte oposição ao governo, Shihab buscou implementar medidas que fortalecessem o poder central do governo e reduzisse a dependência com as lideranças dos clãs (zuama). Direcionou seu governo para que fosse implementada uma política de fortalecimento da economia e da infra-estrutura do país.

He [Shihab] was regarded as a leader who ameliorated Lebanon's relationship with the UAR [RAU] and other Arab states, and who emphasized the state's authority and goals, or a "statistperiod" in Lebanon's development, at a time when the economy was growing through its conversion into a banking and services center. Gilsenan, in his study of underdeveloped northern Lebanon, shows the way that "modernization" and "progress" were constructed under Chehab [Shihab] in the poor northern reaches of Lebanon. Unfortunately these efforts did not go far enough, and local social structures, which some termed "feudal" were problematic.

\footnotetext{
${ }^{44}$ Sabri Hamadeh foi uma figura legendária da cena política libanesa e considerado herói da independência, haja vista ter participado com grande empenho dos movimentos que levaram ao fim do Mandato francês. Morreu de ataque cardíaco em 1976. Ele nasceu em 1902 em Hermel - extremo norte do Vale de Bekaa - e entrou na arena política logo cedo, em 1925 foi eleito pela primeira vez deputado por Hermel. Seu mandato foi renovado várias vezes. Em 1944 tornou-se presidente do parlamento e, com isso, foi repetidas vezes vice-presidente do Conselho, assim como Ministro do Interior e Ministro dos Serviços Públicos e Transportes.

${ }^{45}$ Sa’ib Salam é sunita e uma das lideranças de Beirute (za'im). Posicionou-se claramente a favor das propostas nasseristas e, em várias ocasiões foi aliado de Jumblatt contra forças maronitas. Participou do Governo de Franjieh e Chamoun, como Ministro de pastas distintas. Considerado um dos grandes líderes da Frente da União Nacional (National Union Front).
} 
Development of the periphery could have had profound effects - promoting, at the very least, more social equity, and at the very best, a breakdown of the worst abuses of feudalism. (Zuhur, 2003: 154)

Contudo, por mais que o governo tenha ampliado a rede de saúde, educação, etc, e desenvolvido boa parte do Líbano, a grande reivindicação dos xiitas, que cada vez mais aumentava sua densidade populacional, continuava sendo a de que o sul - também chamado de Jabal Amil - continuava à esteira desse progresso. Apesar de Beirute ter conseguido retomar grande parte de seu status de 'a Paris do Oriente Médio’,

Beirut, by the 1960s, had four universities, two of them of long standing, attracting Arab students from al directions. Its free press stood in a class of its own in the Arab world, and Lebanese newspapers and magazines were wide read from the shores of the Arabian Sea to those of the Atlantic. Lebanon, meanwhile, was making some notable progress in the industrial sector, and its industry along with its fine agricultural products had ready Arab markets. Beirut, by day and night, became the playground for rich Arabs, and the mountain towns and villages around the capital, which had long been renowned as summer resorts, rapidly developed as centres for Arab aestivation. (Salibi, 1988: 191)

o mesmo não ocorreu com as cidades e vilas do sul do país, que continuavam sofrendo com a carência de saneamento, água e trabalho.

A pseudotranqüilidade que o Líbano viveu no período em que Shihab esteve no poder, também pode ser vista como um momento de acirramento nas relações entre muçulmanos e cristãos. Se muçulmanos e drusos conseguiram ampliar sua participação no cenário político local, o que pode ser entendido como uma vitória, as atitudes de Shihab eram vistas como uma traição aos maronitas, grupo do qual ele mesmo fazia parte.

O resultado final da Guerra Civil de 1958 fez com que alguns maronitas cogitassem a possibilidade de que quem acabou sendo vitorioso no conflito foram os muçulmanos, tal os privilégios que acabaram alcançando. Shihab, que nunca foi a principal opção maronita para assumir o poder com a saída de Chamoun, tornou-se uma figura controversa e, muitas vezes, vista como traidor dos interesses cristãos no Líbano.

\subsection{0 - 1964-70: A ERA HELOU E O RUMO PARA A DESINTEGRAÇÃO NACIONAL}

Charles Helou sucedeu Shihab na presidência em 18 de agosto de 1964. No campo da política interna, a questão entre "Libanismo" e Arabismo não deixou de ser o grande 
problema para a integração nacional, ainda mais quando a população xiita do sul do país já se tornara maior que a maronita e as reivindicações, mais intensas. As grandes famílias da região de Jabal Amil, os Assads, os Zeins e os Oseyrans, que preservavam seu prestígio político e militar à base dos rendimentos provenientes da monocultura do tabaco, se revoltavam com a pequena participação de seu grupo na política nacional.

O ‘esquecimento’ do sul do Líbano por parte dos governantes da nação não era um problema recente, e pode ser atribuído à posição política que os xiitas historicamente ocuparam no Islã, no Império Otomano e, posteriormente, no Estado libanês. Sendo deixados à parte das grandes questões e muitas vezes perseguidos, os xiitas acabaram por cultivar uma forma peculiar de se verem inseridos na realidade nacional - como “cidadãos de segunda classe”, ou seja, sem os mesmos direitos dos demais grupos religiosos -, o que acabaria por dificultar, ainda mais, sua integração e os levaria a buscar, no futuro próximo, uma identidade que não a libanesa.

O clamor de figuras iminentes denunciando a realidade que o povo xiita vivia não começara a surgir nos idos de 1960; desde de a década de 1940 já publicavam-se livros e jornais que denunciavam a pobreza e a miséria de Jabal Amil. Como fizera, em suas memórias, um dos grandes pensadores xiitas, Muhammad Jawad Mughniyya ${ }^{46}$, que denunciava a situação de sua terra: “Thus, in 1945, note Mughniyya, the cholera hit some of villages of the South so heavily that in a city of 400 inhabitants like Majdel Zanoiun, 70 perished without the central government sending one medic or a pill of quinine.” (Mallat) e incutia nos xiitas o sentimento de revolta contra o governo maronita "Worker [xiita], how can you spend the day at loss, and live throuh the night with hunger! You cannot even find work to buy a loaf of bread... And if for hunger you escape to Palestine, they throw you in dark prison... As if you were a war convict!”. (Mallat)

Quando Mughniyya suscita a dificuldade de locomoção dos xiitas do Líbano para a Palestina - na ocasião, sob o Mandato Britânico -, já dá sinais da opressão que sua comunidade sofria, haja vista que não podia recorrer ao auxílio do governo central dominado pelos maronitas - e, tampouco, buscar novas oportunidades na Palestina, que já vinha sendo projetada para ser um Estado para o povo judeu. Mughniyya, no início da década

\footnotetext{
${ }^{46}$ Mughniyya nasceu em 1904 e faleceu em 1979, formou-se em teologia em Najaf e, posteriormente, assumiu um cargo na Corte Religiosa da comunidade de Ja'fari (xiita). Ali, ficou sob a supervisão das poderosas famílias do sul do Líbano: Assad, Usayran e Zein. Em 1948 foi apontado juiz na Corte da Sharia em Beirute e tornou-se presidente do Tribunal no ano seguinte. Apesar do cargo que ocupava, não tinha a mesma força política do Mufti sunita e do Presidente Maronita, fato esse que lhe gerava bastante ressentimento. Contrário ao sistema de poder tradicional libanês, não sujeitou-se à sua lógica clientelista, o que levou a perder seu cargo. Mughniyya escreveu 61 livros sobre a desigualdade existente no sul do Líbano e a necessidade de o povo xiita conquistar seus direitos. (Mallat)
} 
de 1940, procurava sublinhar o abandono pelo qual seu povo passava e que, mais à frente, teria a situação política e social bastante prejudicada com a inserção da “Questão Palestina”; o segundo grande problema vivido pelo governo de Helou passou.

O período de 1948 (criação do Estado de Israel) a 1967 foi caracterizado pelo enfrentamento direto entre os árabes e o recém criado Estado de Israel. Conflitos constantes que alteravam as fronteiras do Oriente Médio e que estavam ligados, diretamente, às ações das potências da época (EUA e URSS), grandes polarizadoras da política internacional. Nesse cenário instável, o sul do Líbano passou a abrigar campos de refugiados palestinos que, muitos deles, vieram a se tornar campos de treinamentos para guerrilhas enfrentarem o Estado de Israel.

Em 1967, quando a tensão no Oriente Médio aumentou e configurava-se a iminente invasão que Egito, Síria e Jordânia pretendiam fazer contra Israel, esse foi mais perspicaz e atacou, preventivamente, os três países ao mesmo tempo. O evento passou a ser conhecido como "Guerra dos Seis Dias” e seu resultado foi calamitoso para os três Estados árabes derrotados, assim como, mesmo que indiretamente, para o Líbano.
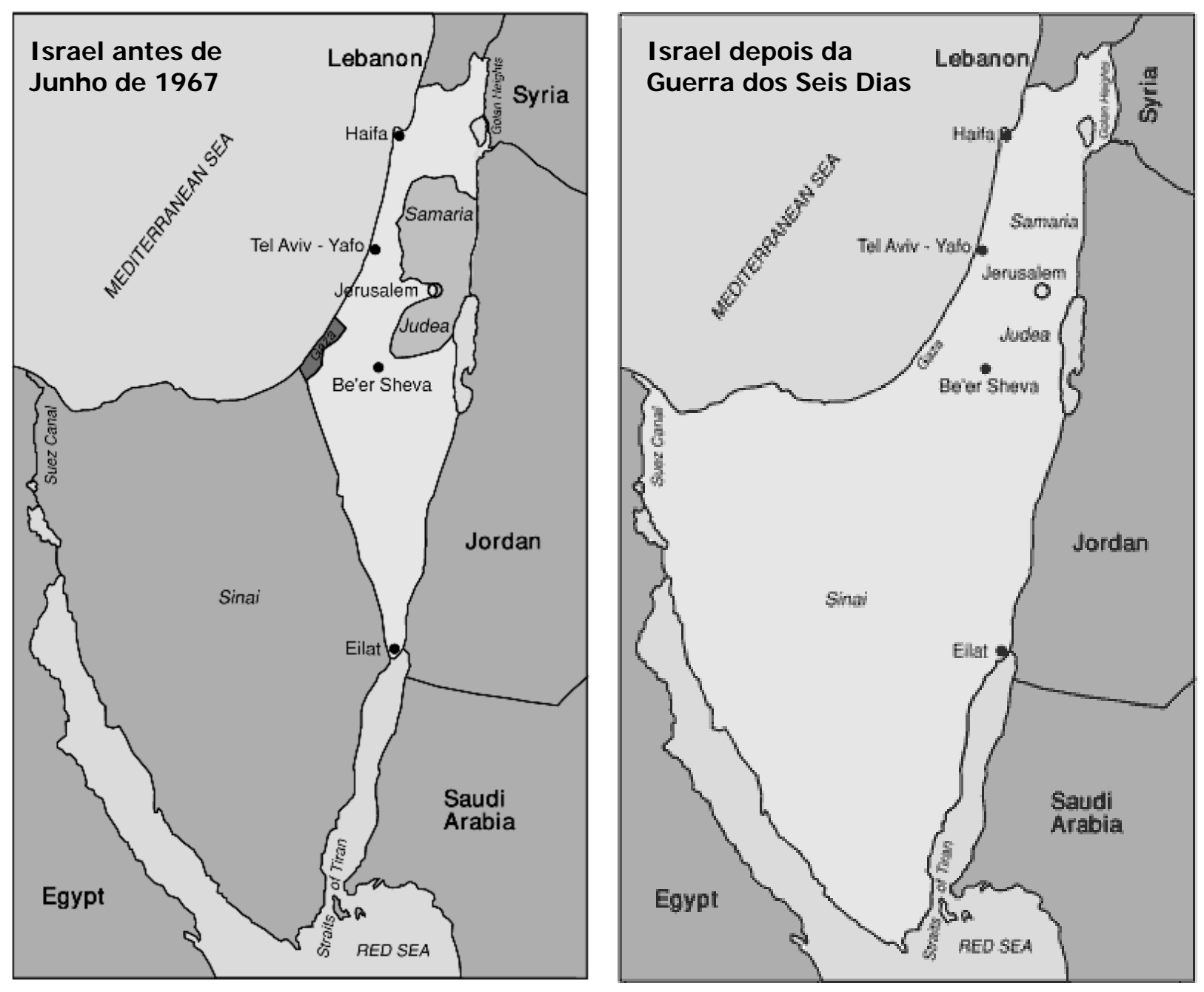
Helou, que acabou por assumir uma postura de neutralidade durante a guerra, sofreu as mais ferozes críticas por parte dos pan-arabistas libaneses. E, ao mesmo tempo, com a derrota árabe e ampliação do território de Israel, muitos palestinos refugiaram-se na Jordânia e no sul do Líbano, gerando conflitos ainda maiores com os xiitas e com a população libanesa; de acordo com Hala Jaber:

In 1968, de PLO began making raids into Israel from South Lebanon. A refugee population of Palestinians had lived in Lebanon since the establishment of the state of Israel in 1948. After the Six Day War in 1967, their number has swollen to 350,000. By the early seventies, Lebanon had become the PLO's only base, following its expulsion from Jordan, The Palestinian became deeply involved in the internal politics of Lebanon and the question of the PLO became the hottest issue on the agenda, further polarizing the Lebanese community. (1997: 11-2)

Em vista do status assumido pela OLP, repercutindo em ações mais radicais por parte da organização - marcadamente após a derrota árabe de 1967 -; Zuhur aponta para o que viria a ser característica da OLP nos anos posteriores, qual seja, o envolvimento em atos terroristas: "The Palestinian resistance in Lebanon began attacks on Israel in 1968, after the disastrous defeat of 1967 had convinced some that extreme tactics, acts of 'terrorism' and a military campaign independent of Arab governments was required.” (2003: 155)

A postura das lideranças regionais libanesas também divergia quanto à 'Questão Palestina', mais uma vez, Zuhur nos ajuda a definir como os clãs assumiam sua estratégia:

Opinions on the need to restrain the Palestinians, or support them, varied quite sharply from Christian right and moderates to Muslims, Druze and the Christian left. Helou had already encountered problems with Karami and Gemayel over this issue. Jumblatt formed a leftist front which expressed support for and solidarity with the Palestinians, while Jumayyil [Gemayel] allied with other Maronite leaders, Eddé and Chamoun against the Palestinians. Hostilities took place between the Lebanese army and Palestinian guerillas on April $15^{\text {th }}$ of 1969 and clashes continued on the $22^{\text {nd }}$, in the villages in the south, but also in Sidon and Beirut. (2003: 155-6)

Gozando de certa liberdade de ação no sul do Líbano, a OLP e as demais organizações que funcionavam como seus tentáculos, organizavam formas de retaliar a derrota que os palestinos haviam sofrido frente a Israel. As ações terroristas passaram a ser planejadas em solo libanês e executadas fora. Como não havia um consenso em como agir frente às organizações palestinas, seu poder no sul do Líbano foi sendo ampliado.

Em 1968, após um avião israelense ter sido seqüestrado em Atenas e o governo libanês não ter implementado qualquer represália contra os palestinos da Frente Popular para 
a Libertação da Palestina (FPLP) - organização considerada mais radical que a Fatah (a qual era liderada por Yasser Arafat), mas que agia integrada a OLP - que assumira a autoria do atentado; Israel demonstrou sua insatisfação com relação à postura libanesa bombardeando 13 aeronaves civis que encontravam-se no aeroporto de Beirute.

A ação israelense buscava respaldo no pressuposto básico de que, estando os refugiados palestinos em solo libanês, deveria, então, o governo do país, responsabilizar-se por seus atos e suas ações; impedindo, se fosse o caso, que atacassem Israel ou, se acontecesse, imputando duras penalidades aos transgressores. Entretanto, a situação pela qual o Líbano passava, com sua população divergindo sobre a questão dos refugiados palestinos parte dela entendia se tratar de uma luta legítima -, gerava fragilidade e impotência. Assim, restava ao governo libanês alegar impossibilidade e incapacidade de impedir as ações palestinas proferidas contra o Estado de Israel.

Com o cenário construído, a ‘Questão Palestina’ assumiu proporção não esperada pelo governo Helou e, a dificuldade de tratar o assunto de forma a atender aos interesses do governo e da população, fez com que as partes, pró e contra palestinos, implementassem sua luta com mais veemência. A partir do final do ano de 1968, Jumblatt, que representava a Esquerda e apoiava os palestinos, iniciou a fase de choques com o governo, que, por sua vez, encontrava certo apoio institucional na figura do, então Primeiro-ministro, Karami. A instabilidade política adentrou o ano de 1969 fazendo com que os fortes protestos e atritos paralisassem o país. O resultado final desse embate de forças foi que o governo libanês partiu para a negociação direta com a OLP.

Pressionado e com pouca margem para negociação, o governo Helou cedeu e aceitou discutir a presença palestina no Líbano. Para alguns, esse foi o ato que apontou o caminho que o Estado seguiria nos anos seguintes e o levaria à guerra civil. O Egito de Nasser, assumindo uma postura de liderança no cenário árabe e em busca da efetivação do pan-arabismo, patrocinou o encontro para as negociações em sua capital, no Cairo, em 1969. Durante as negociações, que visavam estabelecer as condições em que a OLP poderia permanecer em território libanês, o presidente Helou designou o General Emile Bustani para representar do governo e negociar com Yasser Arafat, que assumira a liderança da organização a partir daquele ano. Além deles, participaram do processo os ministros de governo egípcios Mahmud Riyad e General Muhammad Fawzi.

O resultado final do Acordo do Cairo - que proporcionou a liberdade de ação para a OLP no sul do Líbano e, por conseguinte, gerou o aquecimento da fronteira com Israel, modificando, assim, fundamentalmente o status da organização e transformando-a num 
“Estado dentro do Estado" - foi de encontro a qualquer proposta que pudesse unificar o Estado.

O fato, por si, demonstrou nitidamente que a parcela da população contrária à presença palestina no sul do Líbano havia perdido o embate e, na esteira dos acontecimentos, as bases em que foram estabelecidas as condições para que a OLP permanecesse em solo libanês proporcionaram-lhe amplas possibilidades para implementar ações militares contra o Estado de Israel. Isso posto, se por um lado não se pode afirmar que a facção libanesa que apoiava a causa palestina seja a maior responsável pela fragmentação com que o estado passaria a viver, por outro, não é possível negar que a soberania do Líbano ficou gravemente comprometida com a abertura dada à OLP.

\section{THE CAIRO AGREEMENT}

\section{The Palestinian Presence}

It was agreed to reorganize the Palestinian presence in Lebanon on the following bases:

1. The right to work, residence, and movement for Palestinians currently residing in Lebanon;

2. The formation of local committees composed of Palestinians in the camps to care for the interests of Palestinians residing in these camps in cooperation with the local Lebanese authorities within the framework of Lebanese sovereignty;

3. The establishment of posts of the Palestinian Armed Struggle [PASC] inside the camps for the purpose of cooperation with the local committees to ensure good relations with the Lebanese authorities. These posts shall undertake the task of regulating and determining the presence of arms in the camps within the framework of Lebanese security and the interests of the Palestinian revolution;

4. Palestinians resident in Lebanon are to be permitted to participate in the Palestinian revolution through the Armed Struggle and in accordance with the principles of the sovereignty and security of Lebanon.

\section{Commando Activity}

It was agreed to facilitate commando activity by means of:

1. Facilitating the passage of commandos and specifying points of passage and reconnaissance in the border areas;

2. Safeguarding the road to the 'Arqub region;

3. The Armed Struggle shall undertake to control the conduct of all the members of its organizations and [to ensure] their non-interference in Lebanese affairs;

4. Establishing a joint command control of the Armed Struggle and the Lebanese Army;

5. Ending the propaganda campaigns by both sides;

6. Conducting a census of Armed Struggle personnel in Lebanon by their command.

7. Appointing Armed Struggle representatives at Lebanese Army headquarters to participate in the resolution of all emergency matters;

8. Studying the distribution of all suitable points of concentration in border areas which will be agreed with the Lebanese Army command;

9. Regulating the entry, exit, and circulation of Armed Struggle personnel;

10. Removal of the Jiyrun base.

11. The Lebanese Army shall facilitate the operation of medical, evacuation, and supply centers for commando activity;

12. Releasing detained personnel and confiscated arms;

13. It is understood that the Lebanese authorities, both civil and military, shall continue to exercise all their prerogatives and responsibilities in all areas of Lebanon in all circumstances;

14. The two delegations affirm that the Palestinian armed struggle is in the interest of Lebanon as well as in that of the Palestinian revolution and all Arabs;

15. This agreement shall remain Top Secret and for the eyes of the commands only. 
A OLP surgira como um grande problema para o Líbano, porque, em tese, ela teria de agir de acordo com as normas estabelecidas pelo Estado libanês - apesar de sua autonomia, conforme estabelece o Acordo do Cairo -, todavia, na prática, isso não acontecia e o sul do país, cada vez mais, foi sendo absorvido pelas milícias palestinas. “According to Lebanese security sources, the number of guerrillas based in the south by mid-1969 was approximately 4000. The majority belonged to Sa'iqa and Fateh.” (Cedarland) O que, na seqüência, acabaria gerando atritos com os xiitas libaneses que moravam na região.

Os anos subseqüentes à assinatura do Acordo do Cairo geraram problemas irreparáveis para a situação política interna. Principalmente em 1970, quando os guerrilheiros palestinos foram expulsos da Jordânia e se refugiaram no Líbano. A posição do governo libanês frente à comunidade muçulmana residente no país o obrigava, de certa forma, a aceitar a entrada dos refugiados para evitar um confronto ainda maior. Entretanto, a presença palestina no sul acabou por gerar desequilíbrios sociais profundos, haja vista que o governo não tinha condições de suprir as necessidades sociais da população que ali se instalava.

Logo, diante do desequilíbrio regional provocado, muitos xiitas deixaram o sul e rumaram para Beirute em busca de melhores condições de vida, estima-se que apenas entre 1969-70, mais de 30.000 pessoas chegaram à capital. Por outro lado, os maronitas, que exerciam amplo domínio na cidade, sentiram-se acuados e reforçaram suas milícias para resguardar seus bairros. A cidade acabou sendo setorizada pelas comunidades religiosas e alguns conflitos começavam a pontuar.

Helou deixou o governo em 22 de setembro de 1970 e foi substituído por Sulayman Franjieh, líder regional de Zgharta, norte do Líbano, integrante do National Bloc Party na Câmara dos Deputados e que conseguiu eleger-se com apenas um voto de diferença sobre Elias Sarkis. Evidenciando o fato de que mesmo dentro do grupo religioso maronita havia diferenças difíceis de serem transpostas, ao assumir o governo, uma das primeiras ações de Franjieh foi acabar com todas as reminiscências do 'shihabismo' - o poder executivo enfraquecido e fortalecimento dos zuama. Todos os funcionários ligados à administração central, inteligência e exército foram demitidos, o poder voltou às mãos do presidente, pelo menos em tese.

O conflito interno entre muçulmanos e maronitas, com relação à presença palestina no Líbano, havia se intensificado com a entrada maciça ${ }^{47}$ de refugiados provenientes da Jordânia.

\footnotetext{
${ }^{47}$ Não é possível mensurar a quantidade exata de palestinos, haja vista o próprio dado ser objeto de manobra por ambas as partes - israelenses e OLP - que o utilizam para agravar ou amenizar as ações. Palestinos alegam que
} 
Por um lado, os maronitas exigiam que o governo utilizasse o exército contra a OLP antes que o inverso ocorresse. Por outro lado, os líderes muçulmanos se opunham à idéia e o governo sírio ameaçava intervir se o Presidente Franjieh utilizasse a Força Armada.

Gozando de grande liberdade para atuar no sul do Líbano, porém, não conseguindo alcançar o êxito desejado perante o governo israelense, a OLP passou a utilizar a estratégia de organizar seqüestros, atentados, etc, no intuito de atrair a atenção mundial para sua causa. Exemplo dessas ações foi a invasão à Vila Olímpica em Munique, em 1972, com o seqüestro e subseqüente assassinato dos atletas israelenses que ficaram em poder da Organização conhecida por 'Setembro Negro' - ligada a Fatah que, por suas vez, estava integrada à OLP. Os efeitos da ação foram desastrosos para os refugiados palestinos que viviam no Líbano devido à reação israelense - e, ao mesmo tempo, a possível legitimidade da causa palestina ficou abalada com a repercussão mundial negativa do ato terrorista.

Como retaliação à morte de onze membros da delegação israelense em Munique, as forças armadas israelenses invadiram os campos de refugiados no Líbano e mataram palestinos suspeitos de integrar grupos terroristas. Ainda, em 1973, agentes israelenses entraram em Beirute e assassinaram três líderes palestinos ${ }^{48}$.

Vivendo um momento político bastante instável, em que o governo não conseguia implementar ações, ou assumir posturas, sem que gerasse insatisfação por parte de segmentos da população, a governabilidade ficou gravemente comprometida. Não mais havia clara distinção entre questões de ordem interna e externa. A presença palestina no Líbano era fato e a divisão da população em prol de sua causa gerava fortes atritos. Ao mesmo tempo, Franjieh retomara à política sectarista que sempre gerara grande insatisfação por parte dos muçulmanos, amplificando sua revolta.

Nitidamente, o Líbano podia ser visto como um país dividido em regiões e as lideranças locais aumentando cada vez mais seu potencial de defesa através do fortalecimento das milícias.

\footnotetext{
houve a migração de mais de 300.000 refugiados para o Líbano, contudo, os israelenses contestam, alegando que não havia tal quantidade deles na Jordânia.

${ }^{48}$ Na madrugada de 9 para 10 de abril de 1973, comandos israelenses desembarcados de barcos próximos, levaram a cabo quatro operações diferentes em Dora, Uzai, a periferia de Beirute, no bairro de Tarik el Jadida, onde ficavam as sedes de várias organizações palestinas, em pleno centro da capital. Na rua Verdun dirigiram-se ao domicílio supostamente secreto de três importantes líderes palestinos: Abu Youssef, Kamal Aduan e Kamal Nasser, e os assassinaram. A operação foi perfeitamente planejada e sincronizada. Seis automóveis alugados esperavam na praia os comandos israelenses, que se dividiram em grupos, cumpriram suas missões e regressaram aos seus barcos da mesma maneira como haviam chegado, antes que alguém pudesse reagir. Algumas facções palestinas chegaram a sugerir que os israelenses pudessem ter agido sob a guarda do governo maronita. (Del Pino, 1989: 71)
} 
O passo seguinte para a explosão de um grande conflito que abarcasse todo o Líbano já era um fato esperado por todos, apenas não sabiam exatamente quando iria acontecer, dessa forma, sua inevitabilidade acirrava as tensões.

O inevitável aconteceu. Em Sidon, durante um protesto local dos pescadores contra a Protein Company, o político sunita Ma'ruf Sa'd foi baleado e morreu dias depois. Muitas acusações foram feitas contra o governo, contudo, nada foi provado. Entretanto o funeral de Sa'd acabou sendo utilizado para outra finalidade, ou seja, para expressar solidariedade à causa palestina defendida pela OLP. As Forças Armadas libanesas foram utilizadas para conter a reação do público e aí iniciou-se uma crise sem volta.

Por parte dos sunitas, diretamente evolvidos no fato devido à morte de Sa'd, havia forte crítica com relação à participação de Jumblatt, e dúvidas acerca de suas reais intenções. Questionava-se se a finalidade verdadeira do líder druso não era transformar o evento numa manifestação panfletária da Esquerda contra o governo, característica que não condizia com o posicionamento sunita - pelo menos não de sua grande maioria.

A morte de Sa'd, aliada ao assassinato de 27 palestinos que voltavam de Ain alRummanah (subúrbio de Beirute), em 13 de abril de 1975, foi o passo que faltava para que a Segunda Guerra Civil fosse detonada. Uma milícia Falangista explodiu o ônibus que transportava os palestinos sob a alegação de que eles estariam transportando armamento, mas o fato é que a partir desse evento, poucos quiseram saber quem estava certo. As milícias, que já eram uma realidade no cotidiano libanês, passaram a se enfrentar e transformar o Líbano num país cindido política, religiosa e militarmente. 


\section{( 2 )}

\section{UM ESTADO SEM NAÇÃO}

FRAGMENTAÇÃO DO ESTADO DIANTE DO PODER PERNICIOSO DOS CLÃS

Quando a História do Líbano chega ao ano de 1975, o Estado não tinha sequer completado meio século e a perspectiva de que pudesse comemorar essa data no futuro não era das mais otimistas. De fato, não se pode dizer que havia movimentos com características eminentemente separatistas atuando no Líbano, exceto, “(...) o Partido Popular Sírio (PPS) [que] havia sido acusado, sob a liderança de Anton Saadeh, de tentar um golpe de Estado para colocar em prática a união do Líbano com a Síria, preconizada no programa do partido.” (Del Pino, 1989: 37), contudo, a fragmentação do Estado era notória e podia ser entendida a partir de análises fundamentadas tanto na questão interna, quanto externa.

Esse capítulo propõe fazer uma análise mais focada no período que abrange os anos de 1975 a 1990, quando, oficialmente, a Segunda Guerra Civil libanesa teve fim, contudo, para que seja fechado o ciclo histórico em que o Líbano recupera sua soberania territorial, estenderemos a narrativa dos acontecimentos históricos até 2005. Pretende-se, com isso, revisitar os principais acontecimentos históricos do período para que eles sirvam como base analítica para a compreensão das transformações políticas que o país sofreu (e vem sofrendo). Isso porque, por mais que a história libanesa esteja ligada a períodos remotos, e a discussão da identidade perpasse pela herança fenícia ou árabe, foram nesses quinze anos de guerra que muitas outras questões vieram à tona e foram obrigadas a serem solucionadas - pelo menos em partes. Assim, muito mais que buscar soluções para problemas de âmbito interno, os libaneses acabaram ficando expostos à dura realidade internacional que via, ali, um campo de batalha onde havia a possibilidade de atacar seus adversários e preservar seus nacionais mesmo que não tenha acontecido exatamente como fora planejado, haja vista ter havido grande número de baixas entre israelenses e sírio (tanto militares quanto civis).

Diante desse painel sui generis, o Líbano tornou-se a arena ideal para discutir questões de difícil solução. Durante a década de 1970 o mundo ainda vivia sob os efeitos da Guerra 
Fria e a polarização através das duas grandes potências (Estados Unidos e União Soviética) forçava quase todos os demais países ao alinhamento ${ }^{49}$. Também; a discussão acerca do socialismo como a saída ideal para a opressão dos países do Terceiro Mundo, que não conseguiam encontrar o desenvolvimento pela via capitalista, era algo que acirrava os ânimos e fazia surgir movimentos de Esquerda fortemente engajados - tanto política quanto militarmente. De grande relevância para os acontecimentos relacionados ao Oriente Médio foi o surgimento de uma Esquerda antiimperialista não-controlada pela URSS ou China que, nessa época pós-Vietnã, acabou se identificando com os palestinos como bandeira antiimperialista por excelência.

Quando se buscam explicações para entender como o Líbano chegou a um estágio de ruptura social tão grande que o levou à guerra, a versão imediata retoma à eterna rivalidade entre os cristãos e muçulmanos que habitavam a região do Monte Líbano nos seus primórdios. Porém, uma breve revisada no capítulo anterior nos diria que essa rivalidade talvez não seja tão 'eterna' como é apontada, que a raiz dos problemas esteja fundamentada em outras questões. Até porque, facilmente encontraríamos elementos históricos que deporiam contra essa teoria de 'eterna rivalidade’. Dois exemplos são significativos: no período em que o Império Otomano exercia o domínio sobre a região do Monte Líbano, os grupos religiosos tinham liberdade de culto e certa autonomia política, fato que minimizava os conflitos. Talvez, pudéssemos, ainda, remeter-nos a períodos mais remotos, quando o Império Muçulmano estava se formando e os "Povos do Livro Sagrado" - cristãos e judeus - eram tratados como detentores do direto de proferirem sua fé, vivendo em relativa paz com os muçulmanos.

Trazendo para o debate a questão do relacionamento interseitas existente no panorama libanês, verificamos que mesmo entre drusos e maronitas, houve períodos de convivência pacífica e até cooperação. Então, isso posto, qual teria sido o motivo para a discórdia e direcionamento à guerra?

Poderíamos sugerir que a figura do colonizador ocidental fora o fator preponderante para a desestabilização, que a responsabilidade pelos atritos ocorridos estaria diretamente

\footnotetext{
${ }^{49}$ Diz-se que QUASE TODOS os países eram obrigados a buscar o alinhamento, devido à forte pressão exercida pelas Potências, contudo, desde 1955 já existia uma terceira via para que os atores estatais pudessem posicionarse, ou seja, o Movimento dos Países Não-Alinhados. Esse movimento materializou-se, enquanto espaço comum, na Conferencia África-Ásia, em Bandung, na Indonésia. O pano de fundo que o viabilizou era formado por questões pontuais no panorama internacional, tais como: o contexto da guerra fria, as agressões imperialistas ao Vietnã e ao Laos e, mais significativa ainda, a crise dos mísseis em Cuba (1962). Durante as décadas de 1960 e 1970, principalmente, o fórum assumiu, com bastante veemência a contestação das iniciativas imperialistas, em particular o norte-americano. O Egito exerceu forte liderança junto aos países Não-Alinhados, que contavam, basicamente, com representantes do Terceiro Mundo.
} 
ligada à ação das Potências do século XIX - Grã-Bretanha e França, principalmente - que, através da implementação de suas estratégias geopolíticas conseguiram provocar a divisão dos povos que habitavam o Monte Líbano, sem, com isso, considerar fatores de grande relevância, tais como, questões étnicas e religiosas. Nesse caso, teríamos uma forte crítica à política colonialista que perdurou até meados do século XX, depois entrando em decadência.

Partindo dessa visão colonialista empregada pelas Potências do século XIX, podemos perceber que a diferença nas relações dos ocidentais com os cristãos e muçulmanos libaneses sempre pendeu para o lado dos primeiros. Os cristãos acabaram obtendo privilégios comerciais e facilitações para o aprimoramento intelectual. Seria, então, essa a origem do ressentimento entre os libaneses e dos muçulmanos com os ocidentais?

Uma provável resposta para a instabilidade política que o Líbano estava vivendo pode contemplar, em partes, algumas dessas premissas anteriores. A supremacia cristã sobre o Líbano era evidente e tornou-se institucional com a aceitação do Pacto Nacional. Se, por um lado, os muçulmanos aceitaram a situação para que se alcançasse à independência, por outro, a criação do Estado libanês acabou não contemplando seus anseios - a liderança política do Líbano e ligação efetiva aos demais países árabes. A predominância da população cristã logo foi superada pelo aumento demográfico muçulmano, com isso, a divisão do poder político, que estava ligado a esse fator, deveria ser revista, o que não ocorreu. Assim, o ressentimento dos muçulmanos pela violação das regras estabelecidas tornou-se motivo suficiente para questionamentos mais tenazes. Se, em 1958, a guerra civil pôde ser contida devido à interferência estrangeira, tudo levava a crer que: se o mecanismo de divisão de poder político do país não fosse revisto urgentemente, o conflito entre os grupos étnico-religiosos se daria de fato num curto espaço de tempo. Assim, num contexto de extrema tensão interna, a presença palestina no Líbano serviu como catalisador e fez com que uma suposta causa da 'nação islâmica' - entendendo aqui a criação do Estado palestino e mesmo a expulsão dos israelenses de solo muçulmano - se misturasse aos anseios de alguns segmentos muçulmanos libaneses para que a guerra tivesse início.

Enfim, carregando toda essa carga de questões mal-resolvidas interna e externamente, o Líbano chega a 1975 depois de sofrer, juntamente com grande parte do mundo ocidental, os problemas advindos da crise do petróleo de 1973. A economia libanesa era fortemente dependente de capital internacional e, com a recessão que se abateu no país depois da alta do petróleo (1973), muitas empresas reduziram seus investimentos, e até deixaram o Líbano. Contudo, esses problemas somente eram percebidos por parte da sociedade libanesa, exatamente aquela que sempre fora excluída socialmente, os xiitas, os palestinos, os curdos, 
etc. (Del Pino, 1989) A elite libanesa, que vivia, principalmente, na capital, e que enriquecera devido à relação promíscua com o poder, continuava cega para a tensão que se alastrava pelo país e rompia a fronteira da racionalidade à cada dia, entretanto,

Beirute, sem dúvida, vivia uma autêntica festa, transformada numa torre de marfim confiante e insensível, que não percebia absolutamente os sinais de deterioração que a circundavam. A grande riqueza de alguns libaneses, com ostentação tipicamente oriental, coexistia com uma miséria impressionante, assentada nos subúrbios, e com o sul do país, sob as permanentes ameaças dos ataques israelenses. (Del Pino, 1989: 25)

À parte as diferenças internas, como foi dito, muitos preferiam influir indiretamente na política libanesa para que não precisassem se expor. Assim sendo, questões, talvez não ligadas diretamente à realidade do Líbano, sempre encontravam vozes para serem defendidas. Exemplos não faltam. Seguindo o embate entre capitalismo e socialismo, os partidos libaneses encontravam aliados fáceis dos dois lados e dispostos a financiar seus programas. Entretanto, o socialismo não era adotado de maneira uniforme pelos países árabes, haja vista o surgimento do partido político Baa’th no Iraque e na Síria, ambos lutando por uma mesma causa - o socialismo - contudo, polarizando o debate entre Bagdá e Damasco.

O Baa'th era tido por seus membros como um partido socialista, mas não comunista. Defendia a implementação da reforma agrária no país, assim como estatização dos recursos naturais, contudo, possibilitava a existência de propriedades privadas, em alguns casos. Seguindo a lógica do socialismo, permitia a associação de trabalhadores e camponeses em cooperativas e, até, no gerenciamento de indústrias. Por ideal, tendia a ignorar a divisão de classes, assim como as diferenças entre grupos religiosos, fato esse que possibilitou aos pequenos grupos religiosos se juntarem ao Baa’th e galgarem posição de destaque no partido. Exemplo claro desse fato, encontramos na ascensão dos alauítas ao poder na Síria, um pequeno segmento da comunidade muçulmana, em comparação à maioria sunita. (Härdig, 2002)

O pensamento baathista reverberava no Líbano, contudo, não era o único. O Panarabismo de Nasser ainda encontrava grande repercussão, e, com a repulsa por parte da população muçulmana, com relação à política maronita imposta pelo Poder Executivo, o nasserismo acabava sendo uma via interessante. Enquanto isso, no mundo árabe, duas personalidades lutavam pelo espólio ideológico de Nasser e não se furtavam a investir em quem quer que os apoiasse. Nesse cenário conturbado é que Muamar Kadafi, da Líbia, e Anwar Sadat, do Egito, travam a luta pela liderança no mundo árabe. 
Although Qaddafi had emulated the policies of his hero, Nasser, regarding religion, by the 1970's Qaddafi was reinforcing nationalist slogans and ideology with an espousal of Islam. Qaddafi embarked upon a series of reforms aimed at eradicating the vestiges of European colonialism and reaffirming Libya’s Arab-Islamic heritage. (Esposito, 2005: 176)

O aspecto pseudoliberal que a política libanesa possuíra, facilitava enormemente a defesa de discursos panfletários através da mídia. Com sua tradição intelectualizada e, gozando de liberdade de imprensa, o período que antecedeu à guerra civil já contava com “a publicação de trezentos jornais, entre eles mais de quarenta diários, em sua maioria financiados a partir do exterior, [o que] converteu o Líbano na caótica arena de todos os combates ideológicos entre árabes.” (Del Pino, 1989: 35)

Para complicar ainda mais as múltiplas possibilidades de discussões (militares ou intelectuais) reinantes no Líbano, a ‘Questão Palestina’ surge como um difícil ingrediente. A entrada de palestinos no sul do Líbano, após a expulsão deles da Jordânia (1970-71),

\begin{tabular}{|c|c|c|}
\hline \multicolumn{3}{|c|}{ IMPRENSA ESCRITA PUBLICADA NO LÍBANO EM 1975} \\
\hline ORIENTAÇÃO & NOME & CARACTERÍSTICA \\
\hline \multirow{6}{*}{ DE DIREITA } & NIDA AL WATAN & Porta-voz do Patriarcado maronita \\
\hline & AL BAYRAK & $\begin{array}{l}\text { Publicado pela Associação de Jornalistas e subsistiu como } \\
\text { jornal oficioso até seu desaparecimento. }\end{array}$ \\
\hline & $A L Z A M A N$ & Pró-saudita \\
\hline & AL HAWADESS & Semanário pró-cristão e pró-egipcío \\
\hline & AL HAYAT & Pró-saudita \\
\hline & $A L A M A L$ & Órgão da Falange de Pierre Gemayel \\
\hline \multirow{12}{*}{ DE ESQUERDA } & $A L A N B A$ & Do Partido Socialista Progressista de Kamal Jumblatt \\
\hline & AL NIDA & Do Partido Comunista Libanês \\
\hline & AL MOHARRER & Pró-palestino \\
\hline & $A L R A Y A$ & Semanário do Partido Baa’th pró-sírio, ala Saleh Jedid \\
\hline & $A L K I F A H$ & $\begin{array}{l}\text { De Riad Taha, Presidente da Associação de Imprensa, pró- } \\
\text { Baa'th iraquiano }\end{array}$ \\
\hline & AL HURRYA & $\begin{array}{llll}\text { Semanário marxista da OACL (Organização de Ação } \\
\text { Comunista Libanesa) e da Frente Democrática Palestina }\end{array}$ \\
\hline & $A D$ DESTUR & Semanário inicialmente pró-chinês \\
\hline & AR RASSED & Semanário pró-argelino \\
\hline & $A L B A L A G H$ & Semanário pró-argelino \\
\hline & BEIRUT & Diário pró-iraquiano \\
\hline & AS SAFIR & Diário pró-líbio \\
\hline & ACH CHARK & Diário pró-iraquiano \\
\hline \multirow{3}{*}{ INDEPENDENTE } & L'ORIENT LÊ JOUR & \\
\hline & AN NAHAR & Editado pelo ministro Ghassan Tueni \\
\hline & $A L A N U A R$ & \\
\hline \multirow{5}{*}{ PALESTINA } & FILISTIN AL SAURA & Semanário da Al Fatah \\
\hline & $A L H A D A F$ & Semanário da Frente Popular, de George Habache \\
\hline & $A L T A L A E J$ & $\begin{array}{l}\text { Semanário do Baa’th pró-sírio e da organização guerrilheira Al } \\
\text { Saika (também síria) }\end{array}$ \\
\hline & ILA AL AMAN & Semanário da Frente Popular, de Ahmed Jibril \\
\hline & CHUUN AL FILISTINIYA & $\begin{array}{l}\text { Trimestral. Órgão teórico, editado pelo Centro de Pesquisas } \\
\text { Palestino }\end{array}$ \\
\hline
\end{tabular}


transformou completamente o panorama sócio-econômico libanês e polarizou o debate interno entre aqueles que apoiavam sua presença ali e os que eram contrários. Quase que completamente a divisão podia ser vista como um embate de cristãos versus muçulmanos. Ressalvando, nesse primeiro momento, a objeção que os xiitas faziam à presença palestina em seu território, uma vez que gerava-lhes prejuízos de várias ordens: pela escassez de recursos naturais, deficiência de auxílios estatais, além de o considerável aumento do risco de sofrerem com as represálias militares israelenses.

Com base nessa problemática pré-conflito e, na existência de um panorama internacional propício à tensão, é possível constatar que o Líbano ainda não tinha conseguido resolver suas diferenças internas e já era obrigado a agregar novos fatores à discussão. Assim, com fortes doses de intransigência, a explosão de um ônibus de palestinos (no bairro de Ain Rumaneh) por parte dos milicianos da Falange, em 13 de abril de 1975, conseguiu alcançar seu objetivo imediato - que era vingar a morte de um membro da Falange que havia ocorrido pouco tempo antes, quando um carro palestino fora parado para averiguação e recusou-se a obedecer às ordens dos milicianos, o que propiciou uma discussão e, em seguida, um tiroteio que foi fatal para o membro da milícia cristã -, mas detonou uma avalanche de acontecimentos que explicitou a fragilidade política de um país que ainda engatinhava institucionalmente.

\section{1 - EXPLODE A 2 $2^{\mathrm{a}}$ GUERRA CIVIL - BANALIZAÇÃO DA NACIONALIDADE}

Depois do assassinato dos 27 palestinos no bairro de Ain Rumaneh não mais houve possibilidades de diálogo, pelo menos não num primeiro momento. Reflexos de questões que vinham se desenrolando internamente no Líbano surgiram com mais força. Em Sídon, ao sul do país, onde grupos de pescadores havia se manifestado contra a política monopolista da empresa norte-americana Proteine and Co., a situação já havia ultrapassado os limites do controle por parte do Estado e, diante dos protestos, o governo preferiu utilizar seu exército contra os manifestantes a reavaliar os direitos concedidos à empresa de pesca.

A partir do resultado final do conflito, de cunho fortemente econômico-trabalhista, Sídon mostrava com clareza quais seriam os caminhos que o Líbano seguiria nos próximos anos. Os pescadores da cidade, apoiados por palestinos de esquerda, conseguiram expulsar o 
exército libanês $^{50}$ e a cidade acabou por desligar-se do restante do país. Ao mesmo tempo, notícias pontuavam na imprensa local explicitando fatos que somente reforçavam a maneira com que a elite local utilizava seu poder político para benefício próprio. Dentre os fatos que vieram à tona, descobriu-se que o ex-presidente Pierre Chamoun era “(...) associado, acionista e diretor local da companhia norte-americana Proteine and Co.” (Del Pino, 1989: 80).

Os desentendimentos também se davam em esferas superiores do poder. O então primeiro-ministro, Rashid al Solh, pedia a demissão do general Iskandar Ghanem pelos incidentes de Sídon, e a discussão se dava devido à alegação do militar de que o primeiroministro havia lhe dado ordens contraditórias, o que fazia Solh revidar alegando que o general isolara-se e evitara qualquer contato que pudesse impedi-lo de agir contra os manifestantes de Sídon.

Mais uma vez, os conflitos de Sídon possibilitaram que houvesse maior tensão entre muçulmanos e cristãos no tocante ao direcionamento da política interna libanesa. Enquanto a cidade estava dominada por facções eminentemente de esquerda, contando com amplo apoio da OLP, os cristãos de direita viam no episódio mais uma oportunidade para questionar o Acordo do Cairo de 1969. Em verdade, por todo o desenrolar da guerra esse acordo, que deu amplas possibilidades de ação para os palestinos da OLP no sul do Líbano, foi um dos grandes entraves para se chegar a qualquer resultado que objetivasse o fim do conflito nacional.

Para evitar que o Líbano fosse catapultado à efetiva guerra civil, controlar a rebelião em Sídon não foi suficiente, isso porque, logo em seguida o incidente com o ônibus palestino mostrou que dali não haveria chance de retorno, o conflito seria inevitável; mesmo que intelectuais cristãos e muçulmanos exaltassem a diversidade libanesa e a necessidade de se encontrar uma fórmula política mais justa onde essa natureza ímpar fosse representada.

Enfim, a morte dos palestinos transformou-se na motivação principal para implementar uma sucessão de atos em represália aos cristãos. Logo no dia 16 de abril, militantes palestinos destruíram uma centena de empresas e estabelecimentos comerciais de propriedade de cristãos em Beirute. Chegou-se a estimar que o prejuízo causado em apenas uma noite tenha sido da ordem de mais de 50 milhões de dólares.

Não havia como parar a sucessão de revides. Nem mesmo com a tentativa frustrada de representantes da Liga Árabe que propunham o estabelecimento de acordos de cessar-fogo

\footnotetext{
${ }^{50} \mathrm{O}$ Exército libanês era formado majoritariamente por cristãos, isso porque havia o receio de que, caso houve a predominância muçulmana, poderia ser usado contra os maronitas. Também receava-se de que, caso o Líbano viesse a possuir um exército expressivo, teria de enviá-lo para lutar a favor dos árabes, contra os israelenses.
} 
entre a milícia falangista e os palestinos. Entretanto, Gemayel, para enfraquecer a "causa palestina”, buscava estabelecer diferenciações entre a OLP e a Frente de Rejeição ${ }^{51}$ e opor-se diretamente à segunda, aventando, inclusive, a possibilidade de acordo com Arafat. Gemayel, juntamente com outro dirigente falangista, Karim Pakraduni, alegavam que a Frente de Rejeição estaria sendo financiada por dinheiro proveniente da Líbia e que, com isso, atenderia aos interesses imediatos de Kadafi e não da comunidade libanesa, que seu objetivo era tomar o poder através da força e, para isso, contava com uma pequena minoria de apoiadores dentro do Líbano.

Alguns interesses mais começavam a pairar sob o conflito libanês. O segundo Acordo de Separação de Forças ${ }^{52}$ entre Egito e Israel com relação ao Sinai - também conhecido como Sinai II -, concluído em setembro de 1975, foi percebido pela Resistência palestina como uma traição, e pelo governo sírio como um rompimento dos laços árabes; isso porque, a resolução pacífica do conflito e subseqüente reconhecimento da intervenção israelense sobre parte do Sinai, eram entendidos, pelos sírios, como um fator que dificultaria reaver as Colinas de Golã, território, também, perdido durante as guerras de 1967 e 1973 contra Israel.

Independentemente dos desdobramentos que a relação abalada entre Síria e Egito teriam, no Líbano, os distúrbios que se seguiram por várias localidades do país deixavam

\footnotetext{
${ }^{51}$ A Frente de Rejeição foi formada em fins de julho de 1974 pela Frente Popular do doutor Georges Habache, a FPLP-Comando Geral, de Anhmed Jibril, a Frente de Libertação Árabe (pró-iraquiana) e a Frente de Luta Popular, contra a idéia de criar uma entidade palestina em Gaza e na Cisjordânia como etapa "intermediária" antes da suposta libertação de toda a Palestina, como o XII Congresso Nacional Palestino adotara no Cairo, em 1974. (Del Pino, 1989: 88) A idéia das etapas antecedeu a guerra de 1973.

${ }^{52}$ Após a Guerra dos Seis Dias, em 1967, Egito e Israel passaram a viver um período conhecido como 'Guerra de Atrito', no qual ambos lutavam nas fronteiras do Canal de Suez. Israel, que havia conquistado a Península do Sinai, alojara suas tropas na margem oriental do Canal e não demonstrava interesse em ceder território para o inimigo árabe. Grande parte do fracasso na negociação para uma suposta paz entre os Estados ocorrera devido à intransigência do governo da primeira-ministra israelense Golda Meir e seu Gabinete. A situação de tensão prolongou-se até 1973, quando, efetivamente encerraram-se quaisquer negociações e teve início a Guerra do Yom Kippur, para Israel ou, do Ramadan, para os árabes. Ali, sírios e egípcios partiram para o enfrentamento contra Israel. Acabaram sendo derrotados, contudo, demonstraram a Israel que seu potencial bélico não era indestrutível, como parecia ser ao rememorarem a derrota de 1967. A partir de 1974, com a mediação do Secretário de Estado americano Henry Kissinger, Egito e Israel chegaram ao Primeiro Acordo de Separação de Forças (ou SINAI I), estabelecendo a criação de regiões onde haveria limitação de força bélica às margens do Canal de Suez. Esse acordo teve sua continuidade em 1975, quando firmou-se o SINAI II, fundamentado nas mesmas bases do primeiro, contudo, onde os EUA se comprometiam em fornecer apoio militar e econômico à Israel diante de qualquer situação de risco. "O acordo entre Egito e Israel - ou Sinai II, como passou a ser conhecido - seguiu o padrão geral do primeiro acordo de desocupação militar de 18 de janeiro de 1974. Porém continha uma característica original: o desempenho americano tanto em relação ao acordo quanto a Israel, que concordou em se retirar dos campos petrolíferos de Abu Rodeis e dos desfiladeiros, mas manteve algumas montanhas na extremidade oriental do desfiladeiro de Gidi. Também manteve a sofisticada estação de radares em Um Hashiba, dentro dos desfiladeiros. A América comprometeu-se a construir uma estação semelhante para o Egito na mesma região, e as duas estações deveriam fazer parte da Missão da Campanha do Sinai, guarnecida unicamente com pessoal civil americano. Os campos petrolíferos e os desfiladeiros foram incluídos em uma zona neutra desmilitarizada sob o controle de forças da ONU. Em ambos os lados da zona neutra da ONU havia zonas de força limitada, como no acordo Sinai I. Em troca dessas vantagens, o Egito aceitou diversos itens de nãobeligerância, porém sem concordar com a eliminação total do estado de guerra.” (Shlaim, 2004: 382)
} 
claro que o governo de Franjieh não teria muitas possibilidades para contornar a situação caótica que havia se instalado. A divisão de poder ficava cada vez mais nítida entre o presidente (chefe de Estado) e o primeiro-ministro (chefe de governo). Mas não se tratava de um mero ajuste legal para esclarecer quais seriam as limitações de atuação de cada um, a questão retomava à raiz dos conflitos, qual seja, a predominância política dos maronitas no governo libanês.

O radicalismo era tanto que "a classe dominante [cristãos] do Líbano comportou-se na guerra como se fosse justamente ela a que não tinha nada a perder, ou como se preferisse perder tudo, ante a ceder um grão em privilégios [aos muçulmanos].” (Del Pino, 1989: 91) Tornara-se evidente, como pôde ser percebido no transcorrer de todo o conflito, que as partes envolvidas entendiam que tratava-se de um ‘jogo de soma zero’, em sua mais límpida concepção, conforme a visão Realista da política internacional, ou seja, necessariamente deveria haver a vitória de um lado e perda completa do adversário para que o conflito tivesse um fim.

Os atores envolvidos no conflito, sem vislumbrar grandes possibilidades de vitória imediata e contando exclusivamente com seus aparatos, haja vista que não acreditavam tratarse de um embate que teria curta duração, buscavam saídas mais viáveis e que poderiam representar um ganho substancial perante o inimigo, ou seja, alinhamento de forças. Assim, pelo menos nos primeiros momentos da Guerra Civil houve a polarização de forças através dos grupos beligerantes em duas facções: os pró e contra palestinos, ou, o Movimento Nacional (The National Movement) e a Frente Libanesa (The Lebanese Front), respectivamente.

\begin{tabular}{|c|c|c|}
\hline Organização & Base de Poder & Liderança \\
\hline \multicolumn{3}{|l|}{ FRENTE NACI ONAL } \\
\hline Kata'ib (Falange) & Maronita / Beirute e Monte Líbano & Família Gemayel \\
\hline Partido Liberal Nacional (Ahzar) & Maronita / Metn, Damour e Beirute & Família Chamoun \\
\hline Zghorta Exército para Liberação & Maronita / Zghorta & Família Franjieh \\
\hline \multicolumn{3}{|l|}{ MOVI MENTO NACI ONAL } \\
\hline Partido Progressista Socialista & Druso/Shouf e Metn & Kamal Jumblatt \\
\hline Partido Social Nacional Sírio & Ortodoxo e Muculmano / Beirute e Metn & In'am Ra'd \\
\hline Murabitun (Nasserista Independente) & Sunita / Beirute & I brahim Qulayl \\
\hline Partido Comunista Libanês & Vários & George Hawi \\
\hline Partido Socialista Baa'th & (Síria) & Asim Qansuh \\
\hline Partido Socialista Baa'th & (Iraque) & Abd al Majid Rafi'i \\
\hline Amal & Xiita / Beirute, Bekaa e sul do Líbano & Musa al-Sadr \\
\hline
\end{tabular}


De sua parte, o presidente Franjieh, contando com um aparato estatal restrito e apenas com o apoio de parte da comunidade cristã, não possuía mecanismos para a manutenção da ordem no Estado - independentemente de quais fossem suas intenções.

Utilizando-se de uma metáfora que representa com clareza a situação vivida no Líbano durante a guerra, ali, travava-se 'um diálogo de surdos'. Os muçulmanos queriam ser ouvidos para conseguirem mais espaço no governo, enquanto os cristãos somente discutiam a questão da perda de soberania do Estado com a presença palestina no sul do país. Falavam a mesma língua sem se entenderem. Diante da situação sui generis que se apresentava, logo, qualquer simples desentendimento era motivo suficiente para odiar o inimigo e tentar acertar as pendências que estavam em jogo na esfera nacional. De fato, foi assim que mais uma frente de batalha foi aberta no Líbano.

Numa estrada entre as cidades de Zghorta (predominância cristã) e Trípoli (predominância muçulmana), dois carros ficaram parados e impedidos de continuar o trajeto devido ao estreitamento da pista e, conseqüentemente, passagem somente para um deles de cada vez. Com a rivalidade latente, nenhum quis ceder passagem ao outro. A tensão entre as comunidades era tão acirrada que logo sacaram suas armas e o cidadão de Zghorta acabou por matar o muçulmano. Na mesma noite, os muçulmanos de Trípoli explodiram os estabelecimentos comerciais (de propriedade de cristãos de Zghorta) que havia na cidade. Não tardou a represália e logo as duas cidades refletiam o que ocorria em todo o Líbano. (Del Pino, 1989: 92) Odiava-se o muçulmano ou cristão, abstraindo sua nacionalidade libanesa.

Percebendo que os muçulmanos estavam cada vez menos participativos no governo oficial e que grande parte dessa culpa estava sendo atribuída à pouca eficiência das ações tomadas pelo primeiro-ministro, que mal conseguia fazer com que se respeitasse o cessarfogo, em 17 de maio, Rachid al-Solh demitiu-se e abriu caminho para mais uma tentativa do Executivo de reestruturar o governo. Franjieh anunciou a formação de um governo militar em 23 de maio, mas foi rechaçado pela esquerda, apesar de ter sido mantido um certo equilíbrio confessional entre seus sete membros.

O governo sírio, atento à reação negativa que a proposta de Franjieh acarretou, destacou seu ministro de Assuntos Exteriores, Abdelkhalim Khaddam, para reavaliar a situação e acabou fazendo com que o 'Governo Militar' se desfizesse, sem nem ter entrado em ação. Rashid Karami acabou sendo nomeado primeiro-ministro e conseguiu formar um Gabinete de seis membros ${ }^{53}$ - excluindo o líder druso Jumblatt e o líder falangista Gemayel;

\footnotetext{
${ }^{53}$ Contando com a participação igualitária de três muçulmanos e três cristãos.
} 
inconciliáveis num mesmo governo - que passou a ser conhecido por Governo de Salvação Nacional.

As mesmas dificuldades existentes entre muçulmanos e cristãos se refletiam na relação entre Karami e Camille Chamoun, que fora convidado a participar do Gabinete. As diferenças entre ambos eram nítidas e reforçavam os problemas de governabilidade. Contudo, o Gabinete conseguiu manter-se estável por dois meses, mesmo período em que o Líbano viveu em relativa paz, mas que possibilitou às milícias reforçar seu armamento.

Externamente outros fatores tencionavam a política local. Com o agravamento das relações entre Síria e Egito, ambos passaram a influir nos partidos políticos libaneses na tentativa de fazer com que prevalecesse sua liderança sob o mundo árabe. No entanto, em final de setembro, uma nova situação fez com que os combates na capital se intensificassem. Havia rumores de que, para o encerramento do conflito, o Líbano poderia ser dividido entre muçulmanos e cristãos, como já o fora no passado. Automaticamente as milícias passaram a se enfrentar com mais voracidade para que pudessem garantir maior território no caso de haver o fracionamento.

A Síria, gozando de influência sob o governo libanês, propôs mediar um acordo entre políticos e religiosos maronitas no que tange à divisão do Líbano, haja vista a ocorrência de freqüentes vinganças de origem confessional que se alastravam por todo o país.

Sob pressão dos mediadores de Damasco, os líderes políticos e religiosos maronitas haviam se reunido no dia anterior [23 de setembro] na sede do patriarcado maronita em Bkerke e haviam divulgado uma declaração em que afirmavam que rejeitavam a idéia de divisão do Líbano, que eles haviam exigido anteriormente, e aceitavam o princípio de introduzir reformas institucionais. Os cristãos, no entanto, mantinham nesse documento sua reivindicação de que fossem revogados os acordos do Cairo, de 1969. (Del Pino, 1989: 97)

Independentemente da boa-vontade (se é que realmente existia alguma de quaisquer das partes) do governo ou mesmo de lideranças que surgissem para ajudar na mediação dos problemas libaneses, nenhum cessar-fogo conseguia ser mantido por muito tempo e sempre se retomavam os conflitos a partir de ações calcadas em atos de extrema violência, como o ocorrido em 6 de dezembro de 1975.

Em 5 de dezembro, quatro milicianos da Falange foram assassinados no subúrbio de Beirute. No dia seguinte a Falange organizou barreiras em vários pontos da cidade e deteve aproximadamente 200 muçulmanos. "Muslims had been easily identifiable because Lebanese identification cards indicated religious affiliation. This was the first major massacre of civilians in the Civil War and started a vicious cycle of revenge and retaliation. From this 
point on, after combatants of each faction conquered territory from their rivals, they routinely killed civilians.” (The Library Of Congress Country Studies) Todos os muçulmanos presos naquele dia foram torturados, mutilados e assassinados. A data passou a ser conhecida como 'Sábado Negro’.

A escalada de violência cada vez mais se auto-superava e, devido a isso, no final de dezembro o presidente sírio, Hafez al-Assad, após consultar autoridades libanesas, propôs a implementação de um plano que poderia minimizar a tensão libanesa, consistindo em alguns pontos chave: 1) Representação paritária para cristãos e muçulmanos no Parlamento; 2) Eleição do Primeiro-ministro pela Câmara e não pelo Presidente; 3) Criação de um Conselho Econômico; e, 4) Abolição do confessionalismo na administração pública.

A proposta de Assad foi rejeitada tanto por cristãos quanto por muçulmanos e, a presença de Yasser Arafat na Síria, por ocasião da divulgação do Plano, acirrou a revolta cristã contra os palestinos que foram acusados de interferência em assuntos libaneses. Ainda que não fosse confirmada a participação efetiva de Arafat na elaboração da proposta.

Com os conflitos generalizados por todo o país, o Estado passou a viver um estágio de ingovernabilidade, onde os ministros não se reuniam e o Comitê de Coordenação Intercomunitário $^{54}$ estava paralisado com a saída da Frente Progressista Libanesa.

A crise libanesa começa a assumir novos contornos quando Israel e Síria passam a expor com mais veemência suas posições com relação a intervenções externas. Damasco alegava que não aceitaria a divisão do Líbano, como os cristãos haviam voltado a cogitar, ao passo que os israelenses enfatizavam que se a Síria invadisse o Líbano, Israel não assistiria à manobra como um espectador passivo, seria, sim, obrigado a utilizar os meios necessários para que não prevalecesse a vontade síria na região.

Sem condições para conter o avanço dos conflitos confessionais e, tentando recuperar o poder do governo, no início de 1976, o presidente Franjieh e o primeiro-ministro Karami dirigiram-se para Damasco para a obtenção do apoio de Assad para implementar uma estratégia que pudesse modificar o panorama político libanês. Em 14 de fevereiro divulgaram um plano que deveria fixar as bases para a convivência interconfessional futura no Líbano. $\mathrm{O}$ Programa de Ação Nacional (dos dezessete pontos), com passaria a ser conhecido, teria essa incumbência e seria utilizado em comunhão com o Pacto Nacional de 1943.

As alterações propostas seriam substanciais, se aplicadas integramente à política libanesa, contudo, não congraçavam as expectativas de todos. Como principais pontos da

\footnotetext{
${ }^{54} \mathrm{O}$ Comitê fora criado um ano antes, quando os primeiros choques confessionais começaram e contava com representantes das várias comunidades libanesas, divididas por religião e região.
} 
proposta, podem ser destacados: a) a manutenção da distribuição dos principais cargos governamentais como fora estabelecido no Pacto Nacional; b) o Primeiro-ministro passando a ser eleito pelo Parlamento; c) as decisões de maior envergadura deveriam ser ratificadas pelo Legislativo; d) o Presidente passaria a necessitar de 55\% dos votos do parlamentares para alcançar a eleição; e, um dos mais controversos pontos do documento e) o Parlamento deixaria de ser formado pela proporção de 6 para 5 em prol dos cristãos e assumiria a divisão igualitária das cadeiras entre cristãos e muçulmanos, além da eliminação do confessionalismo para a designação dos cargos públicos.

Os cristãos entenderam que seria uma grande concessão política aos muçulmanos e, indiretamente, aos palestinos; em contra partida, os muçulmanos entendiam que não tinham sido contemplados em sua maior reivindicação, qual seja, o fim da exclusividade de cristãos exercendo a chefia do poder executivo.

Em janeiro de 1976 já configurava-se a possibilidade de a Síria intervir militarmente no Líbano, mesmo correndo o risco de Israel reagir. No dia 20 daquele mês, o Exército de Libertação Palestina (ELP) - um braço armado da OLP, mas que era mantido pelo governo sírio, uma vez que possuía suas bases naquele país e contava com total apoio de Assad adentrou ao território libanês. O mesmo se deu com a guerrilha síria Al Saika, ligada ao partido Baa’th sírio.

Os movimentos subseqüentes fizeram com que o histórico dos confrontos assumisse novos rumos. Quando o tenente muçulmano, Ahmed el Khatib, sublevou-se e criou, com aproximadamente 1.000 homens, o Exército do Líbano Árabe, unindo forças com as alas de esquerda palestina, o mandato do presidente Franjieh passou a correr risco de ser perdido em nome de um Golpe de Estado. Franjieh refugiou-se em sua cidade, Zghorta, e passou a contar com a proteção de sua milícia, o Exército de Libertação de Zghorta.

A postura que as facções de esquerda palestinas estavam assumindo não apresentavase compatível com os entendimentos que o governo de Assad vinha tendo com os maronitas libaneses. Se, até então, o governo sírio havia implementado muitas ações em parceria com os palestinos de alas mais à esquerda, naquele episódio estava havendo uma discordância capital que poderia significar o rompimento.

A OLP descolara-se da Síria e passara a vislumbrar a possibilidade de assumir o governo libanês, o que não apresentava-se como uma proposta interessante para a Síria, haja vista que, se assim ocorresse, perderia o poder de influência sobre a política local e ainda 
correria o risco de ver tropas israelenses invadindo o Líbano para resolver, definitivamente, os problemas entre israelenses e palestinos ${ }^{55}$.

O que

sucedeu à tentativa

de Golpe de Estado

contra Franjieh foi

um momento de

rupturas

mudanças de lados no conflito libanês.

A Síria ordenou que

o Exército de

Libertação Palestina

(ELP), juntamente

com a al Saika,

avançasse contra a

OLP e impedisse

que o governo

libanês sofresse o

golpe de estado. A

Síria, efetivamente,

passou a ter a OLP

e seu líder Arafat

como adversários.

Jumblatt, o líder

druso, que fora

partidário da Síria,

tornara-se

um

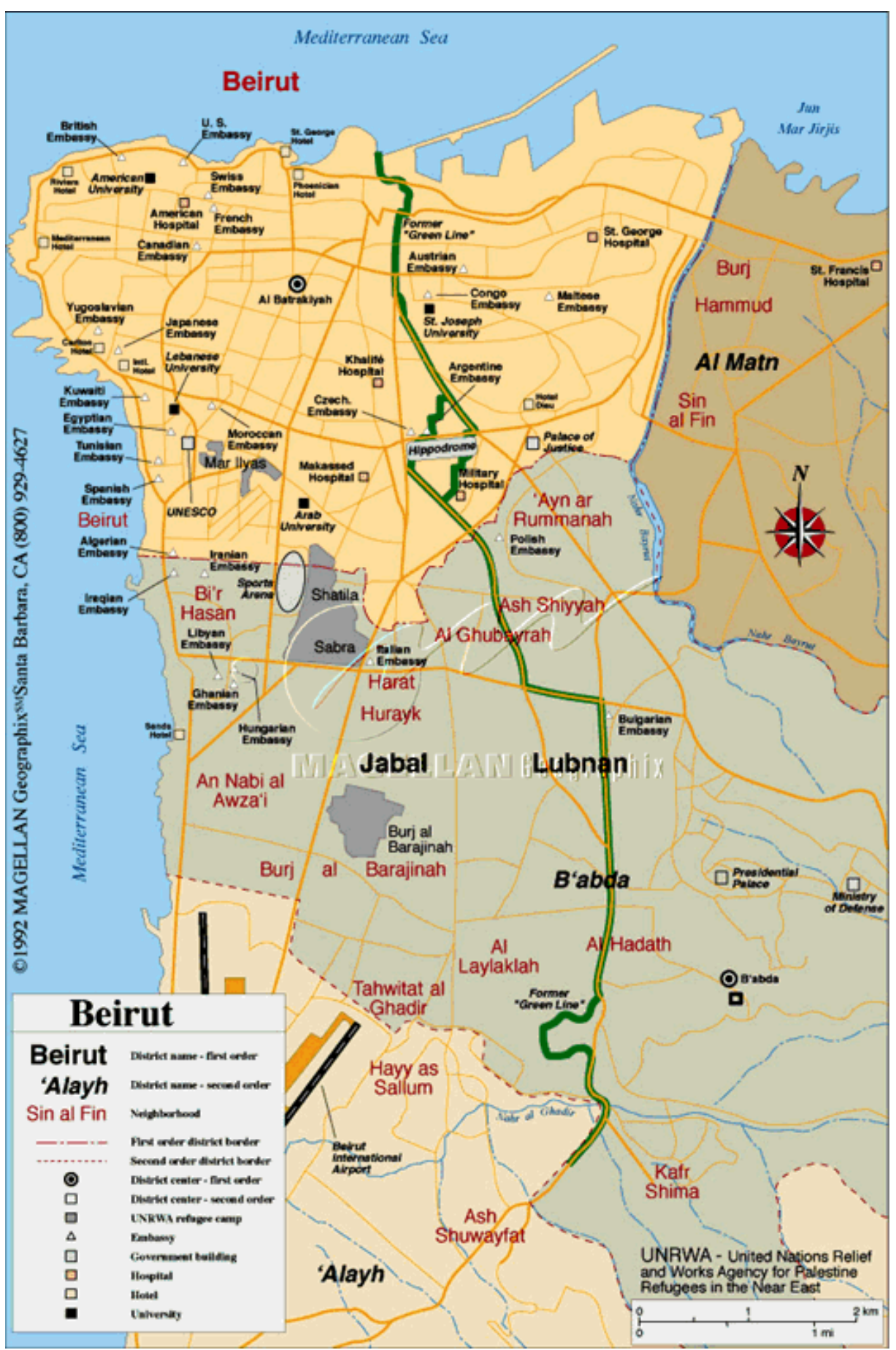

\footnotetext{
${ }^{55}$ Outras possibilidades para a Síria ter decidido pela invasão também podem ser cogitadas, tal qual a que estabelece o risco de uma minoria religiosa estar no poder. Segundo essa visão e, numa perspectiva não muito distante, Assad, poderia estar pensando que uma intervenção sobre o Líbano significaria a manutenção dos alauítas no poder, uma ação cuja única e exclusiva intenção seria a preservação do status quo. Essa possibilidade ganha força se estabelecermos uma analogia com a organização política libanesa. O Estado libanês era governado por uma minoria cristã, da mesma forma, a Síria era governada por uma minoria alauíta (apesar do secularismo do Partido Baa'th, no poder) e, caso houvesse a destituição dos cristãos do poder, o mesmo poderia ocorrer na Síria, de predominância sunita.
} 
desafeto, devido suas ligações com a esquerda palestina e sua negativa em aceitar as bases do que havia sido acordado no Programa de Ação Nacional.

Enquanto os conflitos intensificavam-se pelo país, a cidade de Beirute, por ser a capital do país, apresentava-se como um campo de batalha privilegiado - devido à estrutura existente e a atenção que recebia da comunidade internacional. Cada vez mais os clãs fortaleciam seu poder sob determinada região da capital e criavam 'postos de vigilância' algo como um pedágio para controlar a entrada e saída de pessoas - para evitar a ação de grupos rivais. A cidade estava sitiada e, conforme iam ocorrendo as alianças militares, Beirute acabou ficando dividia em duas partes. O lado oeste (Beirute Ocidental) com predominância de muçulmanos, e o lado leste (Beirute Oriental) abrigando os cristãos. Como divisa entre os grupo beligerantes, criou-se a "Linha Verde" ${ }^{, 56}$ - uma referência à pouca vegetação que sobressaia no percurso da rua (Rue Becharra el Khoury) que tornou-se o marco divisório.

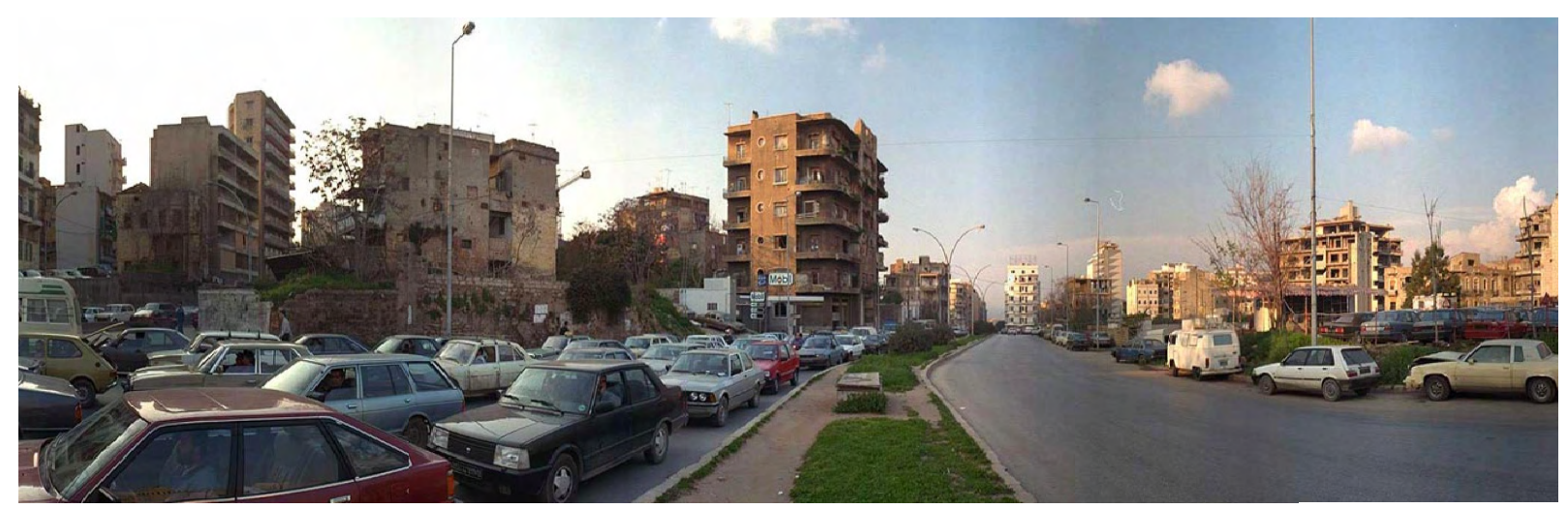

Rue Bechara el Khoury, marco divisório da cidade de Beirute em parte Oriental e Ocidental. Percurso da "Linha Verde”.

No cenário internacional, as posições dos atores mais diretamente envolvidos eram claras; “o que a Síria e Israel tinham em comum era o medo de que o Líbano fosse dominado por seus inimigos. A Síria queria cercar Israel e não ser cercada por ele. Israel não podia tolerar a perspectiva de tropas sírias em duas de suas fronteiras. Cada um dos países vigiava os movimentos do outro no Líbano, com inevitável suspeita.” (Shlaim, 2004: 387) Os Estados Unidos, devido aos desdobramentos do Acordo SINAI II, tinham sua posição bastante vinculada a dos israelenses, contudo, não pretendiam implementar qualquer intervenção militar para pacificar a região. Pelo menos até aquele momento. Entretanto, a deterioração das

\footnotetext{
${ }^{56}$ A primeira vez que utilizou-se o termo foi ao fazer uma alusão à linha divisória estabelecida entre Israel e as nações árabes (Líbano, Síria, Jordânia e Egito) após o armistício de 1949, resultado da Guerra de Independência do Estado de Israel iniciada em 1948. O termo foi utilizado até 1967, ocasião em que ocorreu a Guerra dos Seis Dias e Israel ampliou seus territórios. Uma segunda ocasião em que utilizou-se o mesmo termo foi para demarcar a divisão da capital cipriota, Nicosa, em norte e sul. O sul cabendo aos gregos cipriotas e o norte aos turcos cipriotas. Essa divisão ficou estabelecida após a invasão da Turquia ao Chipre e criação da República Turca do Norte do Chipre.
} 
relações políticas internas, no Líbano, já não mais dava condições para que se esperasse uma solução diplomática, apesar de os Estados Unidos e a ONU estarem empenhados nesse fim.

Num painel de incertezas e receios, a Síria aproveitou o impasse internacional, no tocante à melhor ação a ser empregada no Líbano, e, em 31 de maio, decidiu enviar seus exércitos para o Líbano em larga escala. Tinha início a intervenção síria que mudaria completamente a história libanesa.

\section{2 - 31 DE MAIO DE 1976 - SÍRIA EM BUSCA DA ‘GRANDE SÍRIA’}

O mandato de Franjieh foi salvo pelos sírios, mas, àquele momento, a manutenção do governo central não poderia ser entendido como a preservação da soberania estatal libanesa, também, essa não parecia ser a intenção de Hafez al-Assad ao aumentar, gradualmente, a presença militar de seu país no Líbano.

A aproximação de Franjieh e seus partidários à política síria de Assad não significava uma aliança entre cristãos e sírios, isso porque, mesmo na ocasião em que o país correu o risco de um golpe de Estado, outros clãs de cristãos se mostraram simpáticos à destituição do presidente. Defensor desse discurso, Pierre Gemayel sobressaia-se.

Contudo, mesmo antes de explodir um grave conflito entre Gemayel e Franjieh, dois novos acontecimentos fizeram com que os libaneses percebessem que o fim da guerra civil não seria tão breve. Primeiramente, é fundamental destacar a violenta censura que o

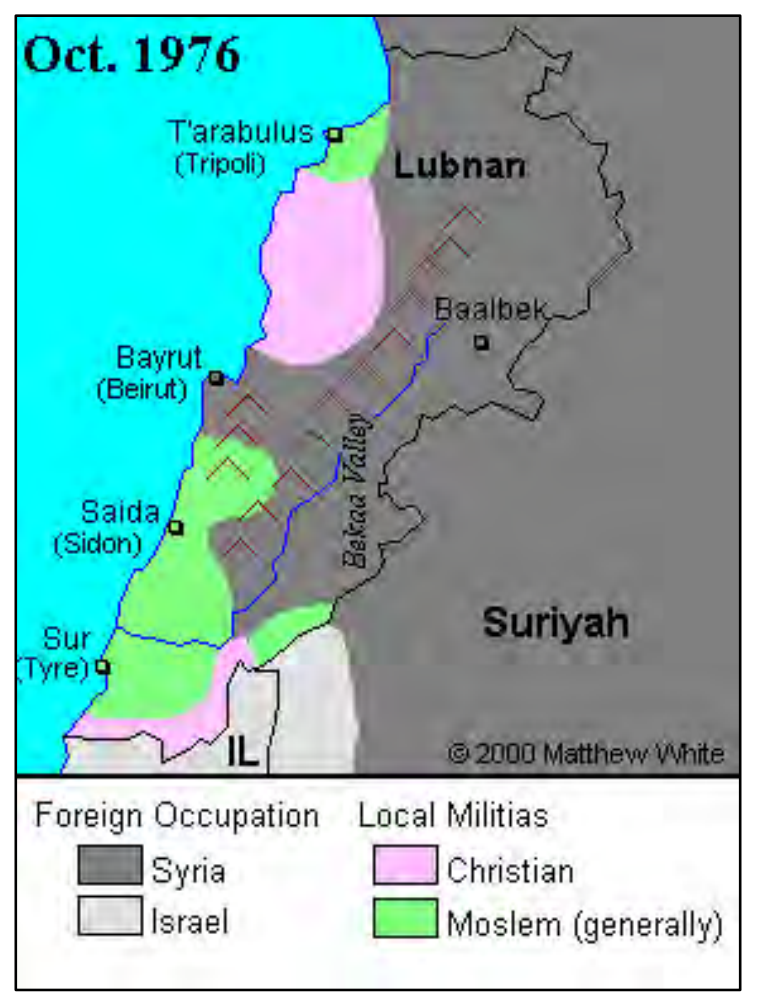
governo sírio passou a empregar contra a imprensa libanesa. Como pudemos perceber no capítulo anterior, o Líbano sempre fora um país de grande efervescência cultural e berço de pensadores ilustres, então, com o fechamento de vários jornais que se posicionavam contra a presença síria no país e controle severo sobre os que continuaram em funcionamento, a população viu-se agredida em mais um segmento de sua liberdade. 
O segundo evento a ser destacado, diz respeito à ação do general Saad Haddad, que comandava o Exército libanês no sul do país. Já na iminência da invasão síria ao Líbano, o general sublevou-se com os soldados cristãos que também compunham seu destacamento e formou o South Lebanon Army (SLA). Posteriormente ofereceu-se como aliado aos israelenses, prontificando-se a defender seus interesses no sul do país contra os sírios e palestinos.

De fato, a presença síria não trouxe a paz que se esperava, apenas fortaleceu a repressão contra os palestinos e a esquerda libanesa. Os conflitos continuavam por todo o país e, no sul, os palestinos implementavam sua luta contra o Estado de Israel através do lançamento de foguetes katyusha das cidades ao norte do país vizinho. Muitos dos campos de refugiados, conforme alegava o governo israelense, haviam se transformado em campos de treinamento para guerrilheiros terroristas.

Apesar da pouca eficiência, ou quase nenhuma, da figura do presidente, haja vista a fragmentação do Estado; em abril, os deputados conseguiram reunir-se no Parlamento para votar uma emenda ao artigo 73 da Constituição que viabilizaria a eleição do novo presidente com seis meses de antecedência do fim de seu mandato. Esse ato abriu a possibilidade para a eleição de Elias Sarkis à presidência - alcançada com a quantidade mínima de votos necessários (66 dos 99), e, obtidos com a pressão do governo sírio sobre os parlamentares.

A eleição de Sarkis não representou grandes mudanças no panorama local, haja vista à impossibilidade de implementar ações legais ou militares devido à ausência de instrumentos eficazes - não havia uma força armada regular atuando no país, apenas poucos soldados que não conseguiam fazer frente ao poderio das milícias locais e do aparato sírio. E, sem esperar que houvesse qualquer limitação as suas ações no Líbano, o governo sírio passou a implementar com mais veemências sua estratégia contra a OLP.

Em junho, durante o cerco da cidade cristã de Zahle (ao norte do país), foram destacadas tropas sírias para defender a localidade. Com a vitória arrasadora da Síria sobre os palestinos, suas tropas passaram a persegui-los em direção à Beirute. Evidentemente a comunidade cristã libanesa aplaudia a ação, contudo, a OLP recorreu à Liga Árabe para que cessassem os ataques sírios.

Em decorrência do pedido da OLP, os ministros de Assuntos Exteriores árabes se reuniram na cidade de Riad e votaram a criação de uma Força de Paz Árabe em substituição às tropas sírias. Chegou-se, inclusive, a ser destacado um pequeno contingente de soldados formados por sírios e líbios para executar tal função, entretanto, os cristãos, devido à forte repressão que os palestinos estavam sofrendo no Líbano, mostravam-se mais inclinados a 
permanecerem com as tropas de Assad em seu país, fato que acabou por proporcionar uma certa legitimidade, haja vista a complacência do governo libanês.

Mesmo diante das imposições da Liga Árabe, a Síria continuou a enviar soldados para o Líbano, fazendo com que, em fins de junho, superassem a quantidade de 12.000. Esse contingente dava respaldo às ações implementadas pelas milícias cristãs, como na ocasião do cerco ao campo de refugiados palestino de Tal Zaatar. Em final de julho os milicianos da Falange tentaram ocupar Tal Zaatar mas não obtiveram sucesso, recuaram e permaneceram em cerco ao campo de refugiados por 52 dias, quando, com o auxílio de tropas sírias, houve a invasão do campo, ocorreu o massacre de mais de 3.000 palestinos, conforme estimativa da Cruz Vermelha.

Esse ato não representou uma ação isolada na história da guerra civil libanesa, tampouco deixaria de ser repetida no futuro, às vezes, alterando os atores, mas com a mesma intensidade e violência. Característica que Del Pino tenta sintetizar: "Característico dessa guerra foi, depois das matanças, o fato de os vencedores ocasionais demonstrarem um prazer especial em que os outros soubessem os detalhes de todos os horrores que eles haviam cometido.” (1989: 113)

Em outubro, dando continuidade às negociações da Liga Árabe, houve uma segunda reunião no Cairo em que decidiu-se pela criação das Forças Árabes de Dissuasão (FAD), que, em verdade, tratava-se de mascarar uma situação e dar-lhe um véu de legitimidade. Com base no que fora acordado, as FAD’s seriam compostas pelos 25.000 soldados sírios que já estavam no Líbano, além de mais 5.000 fornecidos pela Arábia Saudita, Emirados Árabes Unidos e Iêmen do Norte. Em tese, a liderança dessa nova força ficaria a cargo do presidente Elias Sarkis, contudo, de fato, quem continuava dando as ordens era Assad, que sustentava Sarkis no governo.

Sarkis conseguiu obter um certo reconhecimento quando nomeou para o cargo de Primeiro-ministro o presidente do Banco de Desenvolvimento do Líbano, Selim al-Hoss, uma personalidade considerada neutra dentro da tão polarizada guerra civil. Hoss assume o cargo vinculando sua participação à implementação de uma estratégia que visasse a pacificação do sul do país, entretanto, logo evidenciou-se que tal ação não poderia ser colocada em prática devido ao compromisso assumido pela Síria, com Israel, de não ultrapassar os limites do Rio Litani - na ocasião em que interferira militarmente no Líbano.

Mesmo com os sírios sinalizando que não pretendiam ultrapassar os limites estabelecidos, os israelenses não se mantinham tranqüilos e buscavam maneiras de não aumentarem seus riscos de uma mudança de planos de Assad. No início de 1977, Israel, 
apoiando a milícia SLA do general Haddad, possibilita que este conquiste todas as aldeias cristãs do sul do país, ficando fora, apenas, Bint Jeibeil, reconquistada pelos muçulmanos e, Nakura, que servira de posto de observação da ONU.

Ainda, no mesmo ano de 1977, quando a Síria conseguia conciliar suas ações contra os palestinos, e, ao mesmo tempo, não gerar um confronto direto com os israelenses, um incidente em Fayadieh, no início de fevereiro, provocou o rompimento com parte dos cristãos. Enquanto o exército sírio atacou a Academia Militar daquela localidade, a milícia de Chamoun, os Tigres, entrou em atrito com as forças sírias. Assad, num ato desproporcional de uso da força, ordenou que bombardeasse o quartel general de Chamoun e o setor Oriental de Beirute, local onde residiam os cristãos.

Apesar da destruição provocada pelo bombardeio sírio, Assad exigiu que os culpados pelos atritos em Fayadieh fossem entregues à Síria para serem penalizados. Hoss, não querendo ceder completamente à Síria, na qualidade de primeiro-ministro, sugeriu a criação de um tribunal militar sírio-libanês para julgar os indiciados. Se, politicamente, a ação do governo sírio sobre o libanês evidenciava sua submissão, essa nova concessão somente deixou claro que a soberania do Líbano não mais era algo existente, isso em suas várias concepções: política, territorial, militar, etc.

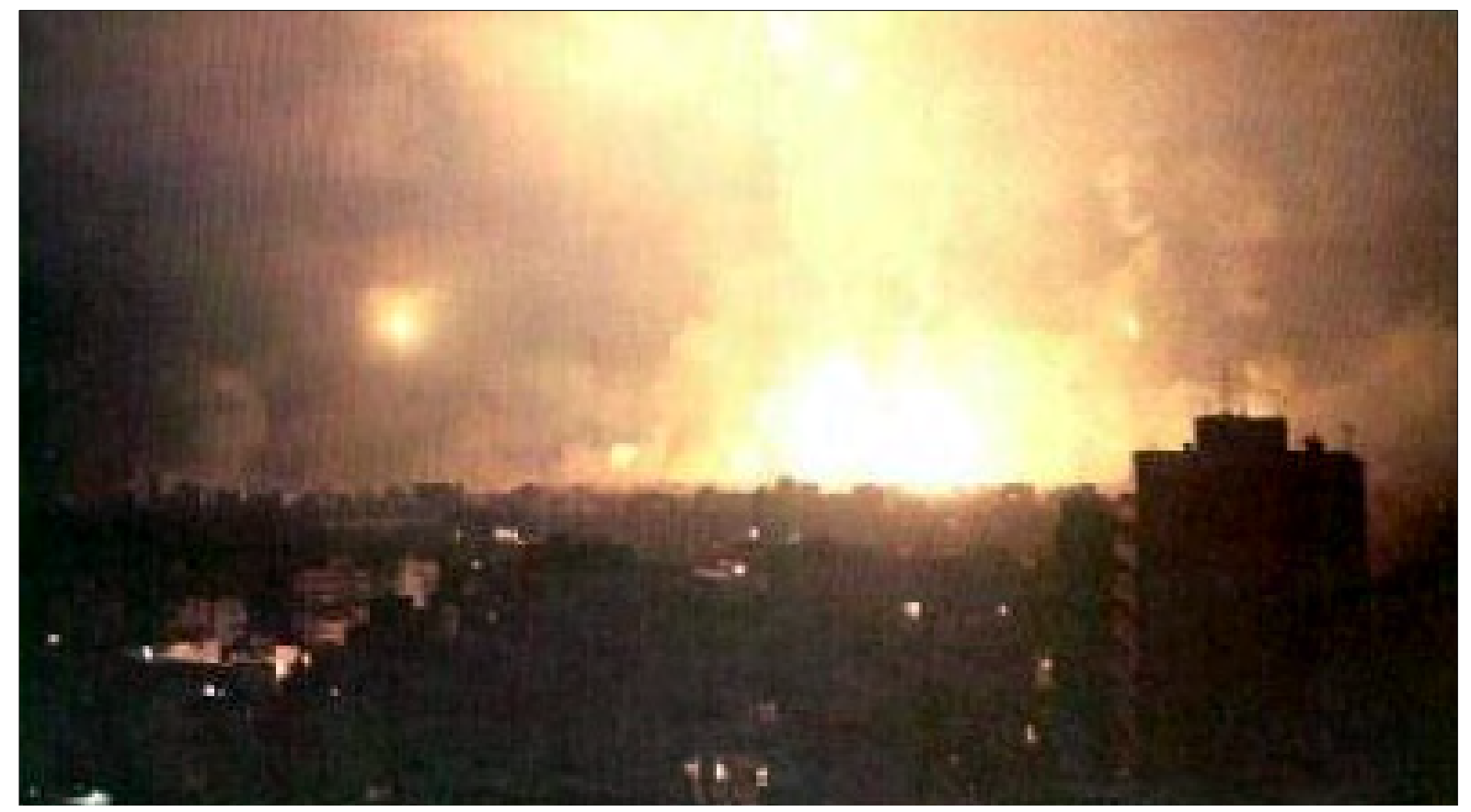

Pesado bombardeio à Ashrafieh, parte Oriental de Beirute, 1977.

A certeza de que não havia limites para as ações sírias no Líbano era fato notório e seus adversários mais ferozes acabavam por sofrer as conseqüências. Em 16 de março, um dos maiores críticos da presença síria no Líbano (depois de ter sido favorável a ela no início 
da invasão), considerado um líder nacionalista, o druso Kamal Jumblatt, foi assassinado próximo a um posto de checagem sírio. A comunidade drusa não resignou-se à perda de seu líder e elegeu Walid Jumblatt, seu filho, como sucessor.

Ao mesmo em tempo que a Síria perdia um aliado importante com o ataque aos cristãos de Beirute e retirava do jogo um forte antagonista a sua presença no Líbano, dava um passo a mais para alcançar seu provável objetivo - restabelecer as fronteiras do que já fora conhecido como a Grande Síria. Um projeto bem maior que simplesmente restaurar a paz no país vizinho. Assumindo a perspectiva da análise síria, com a reconquista do Líbano estaria resolvendo-se um problema que prolongava-se há séculos; enfim, a província que sempre fora objeto de litígio com os Impérios que dominaram o Oriente Médio estaria voltando a ser parte da Síria de Assad.

Conforme evidenciava-se a intenção síria de dominar o Líbano, mais preocupação gerava aos cristãos. Mesmo antes do ataque à Beirute Oriental, a estratégia de Assad já começava a entregá-lo. Ainda enquanto aliado dos cristãos, o exército sírio passou a deslocarse e ocupar regiões que eram predominantemente cristãs, isso, sem qualquer vestígio de risco de que viesse a haver confrontos com os esquerdistas ou mesmo com a OLP. Um dos primeiros a romper com a Síria foi Gemayel, que acabou sofrendo com os intensos ataques sírios a seus partidários.

Em 1977, Gemayel vislumbrou apenas uma única possibilidade para impedir que a Síria assumisse definitivamente o domínio do território libanês, via no Estado de Israel um aliado que teria condições de impor-se militarmente às tropas sírias. Coincidentemente, no mesmo ano o Partido de Direita, Likud, venceu as eleições israelenses e Menachem Begin tornou-se Primeiro-ministro.

Begin entendia que seu apoio aos maronitas poderia reverter a seu favor duplamente: num primeiro momento porque possibilitava fazer uma analogia entre a situação da minoria cristã no mundo árabe e dos judeus, assim, legitimava a tese de que não deixaria acontecer um 'genocídio' no Líbano; segundo, porque, conseguindo o apoio dos maronitas, teria maiores possibilidades para implementar o combate contra a OLP.

Apesar do risco iminente do crescimento do poder político e militar sírio no Líbano, ainda não configurava o momento ideal para que fosse implementada qualquer ação direta contra Assad. Em final de 1977, a Síria já não preocupava-se muito com a legitimidade de suas ações e, àquela altura, as FAD’s já não representavam uma força internacional como fora acordado com a Liga Árabe, todos os estrangeiros que a integraram já haviam voltado aos seus países e ela era composta, exclusivamente, por sírios. 


\section{3 - 1978, ISRAEL CONTRA-ATACA: OPERAÇÃO LITANI}

Mesmo diante da expansão do poderio sírio sobre o Líbano, o governo de Israel não implementou nenhuma ação militar que pudesse gerar um confronto direto entre ambos. Diplomaticamente o governo israelense deixava claro de que não pactuava com o tipo de intervenção militar que contava com o respaldo da Liga Árabe, e ia além ao questionar a ineficiência do governo libanês em aceitar a presença da OLP em seu território e permitir que dali fossem implementados ataques contra o norte de Israel.

A situação no sul do Líbano era controlada graças à presença da SLA dando suporte militar aos planos israelenses - que era estabelecer um limite territorial entre sua fronteira ao norte e o Rio Litani, de onde não poderiam ser atingidos pelo armamento dos palestinos -, entretanto, em 11 de março de 1978, integrantes da Fatah - organização ligada à OLP e comandada por Yasser Arafat - assassinaram vários turistas no litoral israelense e seqüestraram um ônibus na estrada entre Haifa e Tel Aviv. O ônibus foi tomado de assalto pelos soldados da IDF (Israel Defense Force) quando estava quase chegando em Tel Aviv. Os seqüestradores e 37 israelenses foram assassinados. (Fisk, 2001: 123)

Em represália à ação palestina, Israel, em 14 de março, programou a invasão do sul do Líbano no que chamou de Operação Litani. Para alcançar seus objetivos, os israelenses enviaram 28.000 soldados para o território libanês com o intuito de destruir todas as bases terroristas da OLP no sul daquele país. E, para que não houve dúvida com relação às intenções do Estado de Israel, seu Ministro da Defesa, Ezer Weizman, deixou claro que não pretendia entrar em conflito com as FAD’s e, tampouco, com o Exército libanês:

I hope, that Syria will understand that it is an operation limited to southern Lebanon, that the Lebanese government will understand that it is a preventive operation, and that the rest of the civilised world will realise that it is aimed essentially at preventing fresh attacks against Israel's civilian population like the ones we have suffered. (Fisk, 2001: 124)

Colocada em prática a estratégia militar israelense, em apenas quatro dias seu exército já havia conquistado uma extensa faixa do território libanês que avançava até o Rio Litani e cobria os cem quilômetros de fronteiras entre os dois países.

Diante da ação israelense uma questão tornou-se preocupante: estaria mesmo o Estado de Israel estendendo seus domínios até o Rio Litani para defender-se de futuros ataques palestinos ou tentando conquistar, à força, o território que era pretendido pelos sionistas desde a Conferência de Paz de Versailles? Porque, naquela ocasião, compreendendo que a escassez 
de água na região era um problema caótico, estabeleceram que ter uma fonte de abastecimento como o Rio Litani seria providencial. Também, devido à agressividade com que Israel adentrou em território libanês e violou sua soberania, logo suas intenções passaram a ser questionadas.

Em 19 de março, devido à invasão israelense ao Líbano, o Conselho de Segurança da ONU reuniu-se e publicou a Resolução n ${ }^{\circ} 425$. Conforme suas disposições, o Estado de Israel deveria deixar o território libanês imediatamente para que sua soberania fosse restaurada, também, o mesmo documento dispunha acerca da criação de uma Força de Paz para a região, a Union Nations Interim Force in Lebanon (UNIFIL). Apesar de a

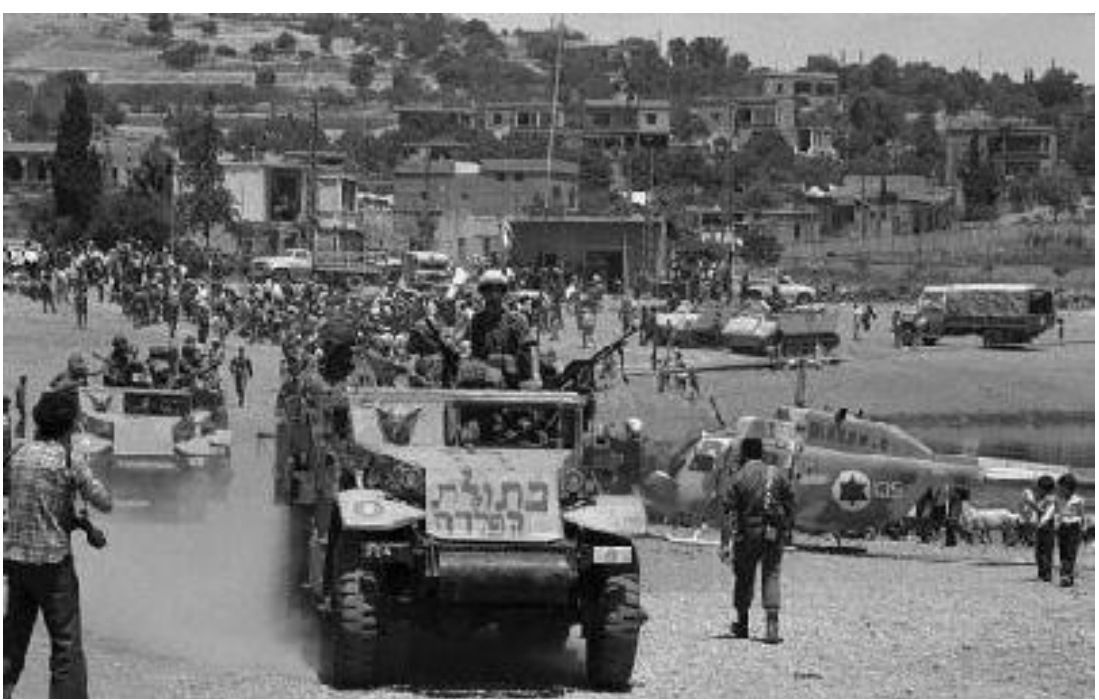

Resolução atribuir o Entrada de tropas israelenses em território libanês, 1978. Operação Litani. caráter emergencial à saída de Israel do Líbano, tal situação perdurou até 13 de junho, porém, apesar de sua retirada, o território que havia sido conquistado passou para a milícia SLA do general Haddad, aliado dos israelenses.

A presença israelense no sul do Líbano gerou grandes transformações sociais na região. Primeiramente por ter conseguido expulsar mais de 65.000 palestinos do sul do país para localidades acima do Rio Litani e, também, por ter deslocado mais de 250.000 libaneses de seu território. A comunidade xiita, que há muito vinha sofrendo com as ações palestinas e israelenses, foi uma das mais prejudicadas. Marginalizada pelo governo libanês e perseguida pelas milícias cristãs, tornou-se solo fértil para o florescimento de pensamentos que, cada vez mais, conseguiam responder aos seus anseios, quais sejam, o desejo de restaurar um status quo idealizado - mas não necessariamente existido em tempos passados, durante a presença do Profeta Maomé na Terra - e lutar para a criação de uma Estado Islâmico no Líbano ${ }^{57}$.

Perante essa nova realidade que transformava o sul do Líbano, um nome despontava como emblemático, o líder da Organização AMAL (Esperança, na sua tradução para o

\footnotetext{
${ }^{57}$ Essa proposta não era unanimidade junto aos xiitas, devido a esse fato que, posteriormente haveria a cisão do AMAL e a criação do Hizbullah.
} 
português), Musa al-Sadr ${ }^{58}$. Líder carismático, mantinha fortes ligações com as autoridades religiosas iranianas - dentre eles, o aiatolá Khomeini -, entretanto, ao mesmo tempo em que pautava sua trajetória nas questões religiosas, pairava sobre si a suspeita de que recebia auxílio financeiro da Líbia para enfrentar os israelenses.

Se, no sul do Líbano, havia um movimento xiita que iria tornar-se mais forte no futuro, no norte do país as relações no interior da comunidade cristã se deterioravam mais ainda. Em 31 de maio, na cidade de Chekka, partidários de Gemayel e Franjieh se enfrentaram numa disputa pelo domínio da região. Os falangistas de Gemayel pretendiam expandir seu poder até o 'feudo' de Franjieh. O resultado dos confrontos foi a morte de quatro membros da Falange. Com o pretexto de chegarem a um acordo com relação à região de litígio, em 13 de junho partidários de Gemayel se reuniram com Tony Franjieh em sua propriedade e, após o fim da reunião deixaram o local mas retornaram na mesma noite para assassiná-lo. Juntamente com a morte do filho de Suleiman Franjieh, foram assassinados sua nora, neta e 31 partidárias.

Como represália, em 18 de junho, Franjieh mandou aprisionar 22 falangistas. Em seguida eles foram assassinados e mutilados. A resposta serviu para que Gemayel não mais atacasse a região de Chekka, clamada por Franjieh como sendo pertencente a sua área de influência.

O ano de 1978 ainda seria marcante devido a dois eventos que teriam repercussão nos acontecimentos posteriores da história libanesa: em 25 de agosto, após uma viagem à Líbia, o líder espiritual dos xiitas, Imã Musa al-Sadr, desapareceu. Devido ao aspecto místico agregado ao fato, sua figura passou a ser ainda mais idolatrada e serviria como incentivo para o surgimento de movimentos fundamentalistas xiitas no Líbano. Também, com a anuência do presidente norte-americano, Jimmy Carter, iniciaram-se as reuniões em Camp David entre o presidente egípcio, Anwar Sadat e o primeiro-ministro israelense, Menachem Begin em 5 de setembro. A pretensão dos Acordos que ali nasceram deveriam ser o ponto de partida para a solução do conflito árabe-israelense, mas os desdobramentos históricos provam que não aconteceu exatamente como o esperado.

Depois de muita tensão e posições adversas no tocante às questões relacionadas à anexação do leste de Jerusalém à Cisjordânia e com relação à devolução dos territórios ocupados no Sinai para o Egito, devido à pressão estadunidense, chegou-se a assinatura de

\footnotetext{
58 Sobre Sadr, o Amal e os acontecimentos que levaram à criação do Hizbullah abordaremos no próximo capítulo, contudo, é fundamental salientar que Sadr transformou-se numa personalidade importante para a comunidade xiita e, quando, ainda em 1978, desapareceu, após uma viagem à Líbia, tornou-se uma figura idealizada e que fortaleceria o desejo de vitória dos xiitas perante seus algozes (os israelenses, conforme defenderão em seguida).
} 
dois documentos por parte de Sadat e Begin, que foram intitulados de "Um Plano para a Paz no Oriente Médio” e “Um Plano para a Conclusão de um Tratado de Paz entre Israel e Egito”, ambos foram assinados no último dia de Camp David, 17 de setembro de 1978.

O primeiro afirmava em seu preâmbulo: "A base estabelecida para um acordo de paz no conflito entre Israel e seus vizinhos é a Resolução 242 do Conselho de Segurança da ONU em todas as suas partes". O plano tratava da Cisjordânia e de Gaza e visava nada menos do que "à solução do problema palestino em todos os seus aspectos”. Egito, Israel, Jordânia e os representantes do povo palestino deveriam participar das negociações, que aconteceriam em três etapas. Na primeira, seriam estabelecidas regras básicas para eleger uma "autoridade soberana” para os territórios e seriam definidos os poderes dessa autoridade. Na segunda etapa, tendo sido estabelecida a autoridade soberana, começaria um período de transição. O governo militar de Israel e sua administração civil se retirariam; as forças armadas de Israel também se retirariam e as tropas remanescentes seriam reposicionadas em locais específicos de segurança. Na terceira etapa, que não deveria passar do terceiro ano após o início do período de transição, aconteceriam negociação para determinar a situação final da Cisjordânia e Gaza. As negociações teriam de reconhecer "os direitos legítimos do povo palestino e suas exigências justas”. (Shlaim, 2004: 423)

Apesar de os Acordos vincularem quaisquer possibilidades de paz à devolução da península do Sinai ao Egito e, ao reconhecimento da autonomia dos palestinos, internamente, em Israel, Begin passou a ser fortemente atacado por ter cedido em demasia durante as negociações. Concomitantemente, Sadat era atacado "tanto por pan-arabistas seculares quanto por islamistas [que] rejeitaram tal acomodação e a denunciaram como traição. Os espíritos se inquietaram ainda mais com a assinatura do acordo de paz em 1979. No mesmo ano, Sadat defendeu a separação entre Estado e religião. A oposição ao regime autoritário foi crescendo, tanto do lado de intelectuais progressistas, quanto de fundamentalistas. Paralelamente a repressão aumentou.” (Demant, 2004: 214)

O Líbano, cada vez mais imerso na guerra civil, com a OLP ganhando cada vez mais poder e autonomia em seu território, não conseguia vislumbrar uma saída para a crise que se abatia ao Estado. A forte repulsa dos países árabes pela posição assumida pelo Egito (ratificada pela expulsão do Egito da Liga Árabe, durante a convenção ocorrida em Bagdá, em 1980), no tocante à negociação com Israel, também estava presente nos grupos paramilitares em ação no Líbano. Sem conseguir resolver os problemas internos, os grupos que encontravam-se em estado de beligerância no Líbano, já encontravam outros pontos que aumentariam a divergência entre si. 
Durante os anos de 1979 e 1980, os atritos entre as milícias cristãs também se intensificaram e, dessas com os muçulmanos. Contudo, três novos ingredientes trouxeram mais problemas para a situação dos países do Oriente Médio: 1) Após a Revolução Iraniana e ascensão ao poder do aiatolá Khomeini, os grupos políticos que lhe faziam oposição foram eliminados, fato que fortaleceu o Estado Islâmico e dificultou a propagação de quaisquer idéias contrárias que pudessem nascer de seus nacionais; 2) A crise dos reféns norteamericanos que ficaram presos em Teerã e que acabou contando com o auxílio de Arafat como negociador, modificando a percepção internacional da $\mathrm{OLP}^{59}$; e 3) A criação de um ‘estado independente’ no sul do Líbano, governado pelo Comandante Saad Haddad, líder da SLA, aliada de Israel.

A essas três complicações que interferiam diretamente na problemática da guerra civil libanesa, outra questão pode ser incluída: a dificuldade de os libaneses estabelecerem um posicionamento político em quaisquer questões regionais sem que provocasse represálias por parte dos adversários. Isso tornou-se evidente durante a guerra entre Irã e Iraque, que teve início em 1980. O conflito, cuja motivação inicial pode ser classificada como uma luta pela hegemonia política regional, ampliou-se e passou a implicar em interesses estratégicos de outros países. Nesse contexto, os Estados Unidos surgiram como o principal interventor, entretanto, não é possível desconsiderar o apoio que o Iraque recebeu da União Soviética e França que, em um plano mais amplo de análise, temiam o alastramento da revolução islâmica e modificação na estrutura geopolítica do Oriente Médio. Antagonicamente à visão das potências européias, os xiitas libaneses se colocavam ao lado dos iranianos, devido, em

\footnotetext{
59 "Em 4 de novembro de 1979, estudantes invadiram a embaixada dos Estados Unidos em Teerã, fazendo 66 reféns por 444 dias. No momento da ação, havia 90 pessoas dentro, mas seis americanos fugiram e os nãoamericanos foram libertados. Os estudantes exibiram os reféns vendados para humilhar os EUA, chamado de 'grande satã'. Eles exigiam a expulsão do xá Reza Pahlev, que estava nos EUA em tratamento contra o câncer, depois de ter sido derrubado no Irã.

Manifestantes cercaram a embaixada depois de o novo líder, o aiatolá Khomeini, ter pedido que alvos israelenses e americanos fossem atacados.

A libertação dos reféns se tornou uma das prioridades do governo democrata de Jimmy Carter e seu fracasso contribuiu para sua derrota contra o republicano Ronald Reagan na eleição de 1980. Duas semanas depois, Khomeini mandou libertar 13 reféns: as mulheres e os negros. Em julho de 1980, com esclerose múltipla, o vicecônsul Richard Queen também foi libertado. Os demais permaneceram em cativeiro por 444 dias.

Em abril de 1980, os EUA tentaram uma operação de resgate que terminou em mais humilhação. Dois helicópteros quebraram durante uma tempestade de areia, e um terceiro se chocou contra um avião que estava decolando. Oito americanos morreram no choque entre o helicóptero e o avião.

Para evitar outra operação, os seqüestradores separaram os reféns e os espalharam por vários locais no Irã.

Os reféns foram libertados no dia da posse de Reagan (20 de janeiro de 1981) e depois da morte do xá Reza Pahlev. Os EUA desbloquearam fundos iranianos no valor de US\$ 8 bilhões e anistiaram os seqüestradores. Os reféns chegaram a Washington, onde tiveram uma recepção de heróis, com direito a desfile e a recepção na Casa Branca - já ocupada por Ronald Reagan.” (“Os 25 anos do seqüestro de 444 dias no Irã” in www.bbcbrasil.com, 06/11/2004)
} 
grande parte, à influência social e religiosa que o Irã passara a exercer junto à comunidade local.

Nesse ambiente conturbado interna e externamente, o Líbano acabou sendo cenário de mais uma crise internacional que se estenderia de dezembro de 1980 a junho de 1981. A Síria, para evitar que fosse construída uma estrada que ligasse Zahle (enclave cristão numa região predominantemente muçulmana) ao porto de Junieh, passou a implementar ataques aéreos à cidade. O receio sírio era de que, com a construção da estrada, facilitaria um ataque israelense surpresa por aquela localidade. Como estratégia para dominar Zahle, o governo de Assad construiu cinco rampas de foguete SAM-6, na planície de Bekaa, despertando preocupação aos israelenses e modificando o entendimento que existia entre os dois países desde a invasão síria ao Líbano, qual seja, de que a Síria não ultrapassaria o Rio Litani, tampouco colocaria em risco a segurança da região norte de Israel.

O risco de um enfrentamento maior entre Síria e Israel fez com que os Estados Unidos enviasse para o Oriente Médio Philip Habib, para mediar uma provável negociação entre as partes. Habib manteve contato com Assad e lideranças israelenses para que se chegasse a um consenso e evitasse a guerra. Não houve qualquer possibilidade de negociação e a tensão se estendeu até que Israel, numa ação arrasadora, enviou 80 aviões de combate para destruir as bases de mísseis sírios.

Após a destruição das baterias sírias e conseqüente reeleição de Begin ${ }^{60}$, a postura de Israel, no tocante à questão libanesa e aos palestinos, tornou-se mais incisiva. Tanto é fato que, logo no mês de julho de 1981 foi programada uma violenta ação militar contra as bases da OLP no sul do Líbano. E, diante do agravamento da situação política entre os atores, novamente, os Estados Unidos encarregaram Habib de negociar um cessar-fogo.

Habib conseguiu chegar a um entendimento e o cessar-fago foi estabelecido. Entretanto, a trégua passou a ser vista de maneira distinta pelas partes. Os palestinos entenderam que, devido aos Estados Unidos terem negociado diretamente com a OLP, tinham-na reconhecido tacitamente - uma vitória relevante e que poderia facilitar as relações como outros atores no futuro -; por outro lado, Israel também sentia-se vitorioso por ter conseguido destruir parte da Resistência da OLP e, com isso, ter ratificado seu poderio militar, talvez até, fazendo com que os palestinos pensassem duas vezes antes de iniciar qualquer ataque contra alvos israelenses.

\footnotetext{
${ }^{60}$ Sua reeleição também esteve apoiada na ação empregada contra o Iraque (1981), quando optou por destruir o reator nuclear de Osirak - construído com o apoio francês - que, segundo sua percepção, daria poderes para que Saddam Hussein destruísse o Estado de Israel. Diante do perigo iminente, Begin não viu outra possibilidade senão uma ação militar intensa e pontual. O reator nuclear de Osirak foi destruído e Begin reeleito.
} 
Ainda, antes do próximo acontecimento que mudaria drasticamente a história do conflito libanês, ocorreu um evento no cenário médio oriental que apontou para a intensificação do movimento fundamentalista: em 06 de outubro de 1981, na cidade do Cairo, o Presidente Anwar Sadat foi assassinado por extremistas que rejeitavam a aproximação que o Egito vinha tendo com Israel. "Em todos os campos de refugiados palestinos do Líbano as metralhadoras dispararam para o alto em sinal de festejo.” (Del Pino, 1989: 133)

\section{4 - 1982, UM NOVO REINÍCIO PARA UMA GUERRA SEM FIM}

Ainda, reflexo dos Acordos de Camp David, é possível concluir que o processo de paz iniciado entre Egito e Israel, de certa forma, enfraqueceu a OLP, haja vista a 'Questão Palestina' ser um elemento que unia os árabes na luta contra os israelenses. Aceitar as bases do acordo e iniciar o diálogo já era - segundo o ponto de vista de algumas organizações fundamentalistas islâmicas mais radicais -, por si só, um ato de traição. Que foi sublimado com o assassinato de Sadat.

Pensando nesse panorama adverso para os palestinos, o governo de Israel resolveu que deveria colocar em prática uma estratégia que visava retirar a OLP, definitivamente, do jogo político. Em junho de 1982 Israel resolveu invadir o Líbano.

Dois elementos da política israelense levaram à invasão em grande escala do Líbano, em junho de 1982: a aliança com os cristãos libaneses e o desejo de destruir a OLP. Menachem Begin apoiava fortemente esses dois elementos de sua política. Durante seus anos na oposição, desenvolvera uma concepção político-estratégica semelhante, em alguns aspectos, àquela de seu grande rival David Ben-Gurion. Essa concepção enfatizava os interesses comuns a Israel, aos países não-árabes ou não-muçulmanos e às minorias no Oriente Médio e em sua periferia. Dentro dessa concepção, os cristãos do Líbano tinham um lugar especial, porque alegadamente enfrentavam o perigo de destruição nas mãos de seus oponentes árabes e muçulmanos. (Shlaim, 2004: 447)

Com um contingente militar nunca antes empregado contra o Líbano, Israel colocou em prática a “Operação Paz na Galiléia”. Invadiu o sul do Líbano em 6 de junho e marchou rumo à capital. Num primeiro momento a intenção dos israelenses parecia ser destruir as bases da OLP no sul do país invadido de forma que Israel não mais tivesse sua integridade territorial violada, contudo, o plano de Ariel Sharon, ministro da defesa e responsável pela ação militar, era bem mais ambicioso e pretendia aniquilar as possibilidades de reação da 
organização palestina, expulsando-a do Líbano. A ação de Sharon acabou por desvirtuar as intenções de Begin - que restringia-se a destruir as bases da OLP no sul do Líbano -, então primeiro-ministro, fazendo com que ele se sentisse traído pelo ministro da defesa. Com isso, os efeitos negativos da “Operação Paz na Galiléia” e seus desdobramentos, também atingiram politicamente Begin.

Utilizando seu potencial bélico de maneira arrasadora, Israel colocou em prática sua estratégia militar bombardeando todas as localidades onde pudesse haver resistência palestina, inclusive os campos de refugiados nos subúrbios de Beirute. Gradualmente a conquista do sul foi se consumando e a marcha em direção a Beirute passou a representar um risco para o status quo sírio no Líbano. O que fora um "acordo de cavalheiros” - não ultrapassar as fronteira do Rio Litani -, e que a síria honrou para evitar o atrito direto com Israel, acabou sendo esquecido em prol dos interesses israelenses.

Diante da forte presença israelense no Líbano, as autoridades libanesas exigiram que o Conselho de Segurança da ONU se posicionasse de modo mais enfático (exigiam a restauração de sua soberania), haja vista, sua Resolução 508, divulgada um dia antes da invasão israelense, não ter sido eficaz. Em 6 de junho, no mesmo dia em que Israel adentrou o território libanês, o Conselho de Segurança divulgou a Resolução 509, com o seguinte teor:

Reaffirming the need for strict respect for the territorial integrity, sovereignty and political independence of Lebanon within its internationally recognized boundaries,

1. Demands that Israel withdraw all its military forces forthwith and unconditionally to the internationally recognized boundaries of Lebanon;

2. Demands that all parties observe strictly the terms of paragraph 1 of resolution 508 (1982) which called on them to cease immediately and simultaneously all military activities within Lebanon and across the Lebanese-Israeli border;

3. Calls on all parties to communicate to the Secretary-General their acceptance of the present resolution within 24 hours;

4. Decides to remain seized of the question.

(Fonte: www.un.org)

Apesar das exigências impostas a Israel, não houve qualquer mobilização internacional no intuito de fazer com que a Resolução fosse respeitada. Ariel Sharon continuou sua marcha rumo a Beirute e fez com que as forças sírias recuassem, porém, sem abandonar completamente a capital.

A entrada de mais um ator no conflito libanês, que prolongava-se desde 1975, provocou um desequilíbrio em prol dos cristãos, pelo menos parte deles, como o clã dos 
Gemayel, que era antigo aliado de Israel. Tal parceria tornara-se clara, quando, durante a entrada das tropas israelenses em Beirute os partidários da Falange foram saudá-las!

Enquanto Israel galgava cada vez mais território e forçava a OLP a refugiar-se em Beirute, seus governantes usavam como argumento para uma ação militar daquela magnitude a represália a um evento que ocorrera em 4 de junho, no Inglaterra. Segundo afirmavam os israelenses, seu embaixador em serviço no Reino Unido, Shlomo Argov, teria sido alvo de um atentando orientado pela OLP.

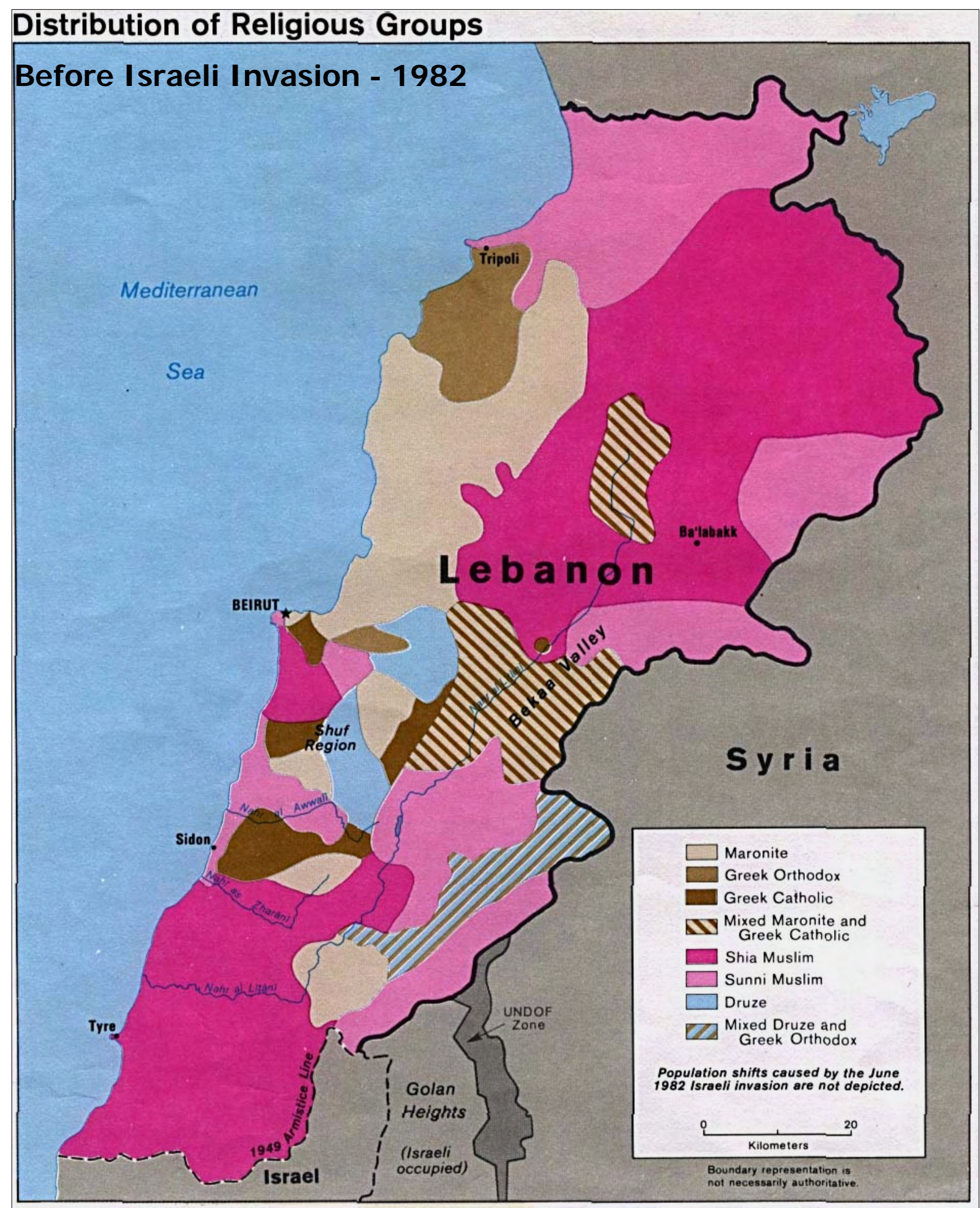


Yasser Arafat negou veemente ter a OLP tomado parte no atentando, contudo, serviu para que os planos de Begin e Sharon pudessem ter tido um start. A partir daí, mesmo com a organização Abu Nidal, com sede no Iraque, tendo assumido a autoria do atentando e alegado que teria o objetivo de "fazer com que fracassassem os planos norte-americano-sauditapalestino, destinados a impor condições de paz capitulacionistas à nação árabe”, os israelenses já tinham a desculpa necessária para agir. (Del Pino, 1989: 134)

Esse primeiro momento da presença israelense em solo libanês fez com que houvesse uma mudança substancial na guerra civil, isso porque, possibilitou a união - mesmo que temporária - de vários clãs rivais no Comitê Nacional de Salvação para discutir os riscos da presença da OLP no Líbano. A grande preocupação era de que Israel conseguisse tomar a capital, haja vista já estar sendo sitiada. O porta-voz da OLP em Beirute, Mahmud Labadi, reforçava sua posição de que não se renderia aos exércitos israelenses, mesmo que essa fosse a posição do líder da organização, Yasser Arafat. Por sua vez, Israel somente renunciaria à tomada da capital se os dois países chegassem a um acordo de segurança. Enquanto isso, o exército permaneceria mobilizado no Líbano.

O impasse permaneceu e a figura dos Estados Unidos, novamente, voltou a ganhar destaque no estabelecimento de um acordo de paz. Chegou-se à conclusão de que deveria ser criada uma força de paz multinacional que pudesse auxiliar na saída dos membros da OLP do Líbano, até porque, eles já estavam sem condições de permanecer em Beirute com o exército israelense ao seu redor.

Apesar desses acertos preliminares terem sido feitos no mês de agosto e parte dos palestinos estar rumando para a Tunísia, os acontecimentos do mês de setembro voltaram a apontar para mais um período de trevas na história libanesa. No início do mês, Bashir Gemayel foi eleito presidente. "His election had been backed by the Israelis and it marked the fulfilment of one of their aims when they invaded Lebanon: installing a Christian president who would be friendly to Israel.” (Jaber, 1997: 77), entretanto, apesar desse apoio, no dia 14 de setembro Bashir foi assassinado. Um atentando perpetrado contra a sede da Falange, no bairro cristão de Ashrafieh, que destruiu os três andares do edifício onde o presidente recémeleito se encontrava e, devido à relação altamente conflituosa dentre os cristãos, provocara reação de satisfação por parte de um de seus maiores inimigos políticos, Suleiman Franjieh, que assim pronunciara-se: "Só posso dizer que estou contente por ele ter morrido. Eu não o matei, nem ordenei que o fizessem, mas lamento não tê-lo feito.” (Del Pino, 1989: 143)

A postura de Franjieh somente corroborava com a tese de que Bashir Gemayel poderia ter sido assassinado por qualquer um dos muitos inimigos que vinha colecionando no 
transcorrer de sua carreira política. Mesmo o Estado de Israel, que parecia estar ao seu lado, poderia ser o autor do atentando, tendo em vista Gemayel estar protelando demais na assinatura do acordo de paz entre os países, o que, por sua vez, fazia com que Israel tivesse de manter o cerco sobre Beirute. Não é possível descartar a possibilidade de uma ação do governo sírio, o qual se via numa situação desconfortável com a forte ligação entre o clã dos Gemayel e os israelenses. E, se essa tese de conspiração síria fosse comprovada, daria credibilidade à confissão do armênio que fora capturado pela Falange e reconheceu estar a serviço da inteligência síria. Tudo era possível no intrincado relacionamento entre os clãs e seus aliados. (Fisk, 2001: 397) Entretanto, conforme Schiff e Ya'ari relatam em “Israel’s Lebanon War”, o atentado pode ter sido preparado por simpatizantes da causa palestina.

Bashir Gemayel's enemies also knew about his regular appearances at the Ashrafiya branch every Tuesday afternoon at four and that time was running out if they hoped to exploit it for their own ends. And so on the previous evening twenty-six-years-old Habib Tanious Shartouni, the nephew of the building's former owner, made his way up to his sister's apartment on the third floor to set up the murder of Bashir Gemayel. None of the guards in the building thought anything of Shartouni's presence. His family was renowned for its loyalty to the Phalange, and one of his cousins, who lost both legs in the civil war, was serving as Sheikh Pierre Gemayel's aide-de-camp. No one would have dreamed that the young Shartouni was a member of the clandestine Syrian National party, a small radical movement that have parted ways with the Phalange, espoused the cause of a Greater Syria, and was now fighting alongside the P.L.O. Habib Shartouni had the perfect cover. (Schiff e Ya’ari, 1986: 247)

O governo israelense, que havia se comprometido com os Estados Unidos, de que não entraria em Beirute até que a OLP deixasse o país, em apoio ao Falangistas (milícia da família Gemayel), ordenou que seus exércitos adentrassem à capital e, dentre os dias 16 e 18 de setembro, cercou os campos de refugiados de Sabra e Shatila - subúrbio de Beirute -, permitindo que a milícia falangista assassinasse mais de 2.000 pessoas. Grande maioria delas formada por palestinos.

O massacre que se deu somente fora possível devido ao exército israelense ter permitido que os falagistas entrassem no campo de refugiados e que ninguém saísse dele. Segundo Robert Fisk, jornalista que cobria os acontecimentos da guerra civil, o massacre somente teve fim porque alguns jornalistas conseguiram adentrar ao campo clandestinamente e passaram a enviar notícias para o mundo informando o que, ali, estaria ocorrendo.

They were everywhere [palestinos], in the road, in laneway, in back yards and broken rooms, beneath crumpled masonry and across the top of garbage tips. The murderers - the Christian 
militiamen whom Israel had let into the camp to 'flush out terrorists' - had only just left. In some cases, the blood was still wet on the ground. When we had seen a hundred bodies, we stopped counting. Down every alleyway, there were corpses - women, young men, babies and grandparents - lying together in lazy and terrible profusion where they had been knifed or machine-gunned to death. Each corridor through the rubble produced more bodies. The patients at a Palestinian hospital had disappeared after gunmen ordered the doctors to leave. Everywhere, we found signs of hastily dug mass graves. Perhaps a thousand people were butchered; probably half that number again. (Fisk, 2001: 359-60)

Ariel Sharon, que omitiu-se ao não prestar auxílio aos palestinos durante o massacre de Sabra e Shatila, com isso, acabou sendo percebido - internacionalmente e por setores israelenses - como co-responsável pelos acontecimentos. Segundo alguns analistas, o que ocorrera ali foi um “acerto de contas” devido ao assassinato de Bashir Gemayel, entretanto, como Sharon poderia ter evitado o massacre e não o fez, tornou-se alvo de investigações internas (em Israel) e por organizações internacionais. Em Israel, Sharon teve sua carreira política interrompida - mas voltaria no futuro e assumiria o cargo de primeiro-ministro devido à conjuntura política propícia e à ascendência da "linha dura” ao poder - com base nas constatações da Comissão Kahan, criada pelos israelenses para apurar responsabilidades.

The Commission determined that the massacre at Sabra and Shatilla was carried out by a Phalangist unit, acting on its own but its entry was known to Israel. No Israeli was directly responsible for the events which occurred in the camps. But the Commission asserted that Israel had indirect responsibility for the massacre since the I.D.F. held the area, Mr. Begin was found responsible for not exercising greater involvement and awareness in the matter of introducing the Phalangists into the camps. Mr. Sharon was found responsible for ignoring the danger of bloodshed and revenge when he approved the entry of the Phalangists into the camps as well as not taking appropriate measures to prevent bloodshed. (Comissão Kahan, 1983)

O massacre poderia ter sido evitado - opinião praticamente unânime -, se Sharon assim quisesse. Dias antes, Israel já alcançara seus objetivos quando, sob a proteção das forças internacionais - lideradas pelos Estados Unidos -, Yasser Arafat e seu staff deixaram Beirute rumo à Tunísia; onde seria rearticulada a cúpula da OLP. Diante desse fato, torna-se ainda mais questionável a postura da liderança israelense durante o massacre de Sabra e Shatila o que, em tese, explicaria a repulsa declarada pela opinião pública internacional quanto ao ato de barbárie.

No tocante à reação ao assassinato de Bashir Gemayel, seu irmão, Amin Gemayel, assumiu a presidência após nova eleição em 21 de setembro. Entretanto, mesmo com a saída da OLP e presença do exército israelense, os cristãos não tinham como controlar o país. As 
instituições continuavam existindo, mas o poder dos clãs ainda representava a verdadeira forma atuante no Estado. Além do fato de que a Síria passara a utilizar uma nova estratégia para evitar que Israel assumisse o controle do Líbano, estimulara a ação de organizações xiitas, mais precisamente, a mais poderosa delas, que já vinha incorporando vários adeptos para sua causa: o Hizbullah.

Outro aspecto relevante, e que deve ser mencionado, diz respeito aos acontecimentos pós-saída da OLP de Beirute. As Forças Internacionais, que tinham a função de evitar enfrentamentos maiores e preservar a paz no país, acabaram perdendo parte de sua legitimidade perante os muçulmanos. Em várias localidades no Líbano os conflitos interconfessionais não deixaram de existir e, gradualmente as tropas da ONU - com a maioria de seu contingente formada por norte-americanos - acabou por atacar os muçulmanos em defesa dos cristãos. Tal fato tornou-se flagrante durante a revolta ocorrida na região do Shouf, em que o navio de guerra norte-americano bombardeou os drusos para defender os cristão. A partir daquele posicionamento, a isenção das Forças de Paz passou a ser questionada e a reação muçulmana viria de maneira brutal.

\section{5 - OS XIITAS CLAMAM POR SEUS DIREITOS}

Em 11 de novembro de 1982, “a new style of warfare made its shocking debut when a young man drove a white Mercedes, filled with explosives, into Israel's military headquarters in Tyre. The blast destroyed the eight-storey and killed 141 people. It was the first human bomb.” (Jaber, 1997: 75). Naquela ocasião o Hizbullah ainda não existia oficialmente, porém assumiria a autoria do atentado alguns anos depois.

O vácuo de poder que surgiu com a saída da OLP do Líbano logo abriu perspectivas para que grupos rivais tentassem ocupá-lo. A presença israelense no Líbano não estava sendo aceita com muita facilidade pela opinião pública internacional, tampouco os Estados Unidos estariam dispostos a referendar tal ato, tendo em vista os riscos de sofrerem represálias. Num cenário adverso para Israel, como estava sendo mostrado, a saída do Líbano deveria ser muito bem pensada para que não viesse a trazer prejuízos políticos no âmbito interno e externo.

Para remontar esse novo momento da guerra civil libanesa é de fundamental importância revermos dois fatos que foram mencionados no transcorrer desse estudo. Primeiramente devemos relembrar que com a morte do Imã Musa Sadr, sua organização, o AMAL, passou por um período de transformações até que a liderança recaiu sobre Nabih 
Berri, “a lawyer who was born in the expatriate Shiite Lebanese community of Sierra Leone. He represented a new Shiite middle class and had succeeded in steering Amal away from its clerical origins towards a more secular platform.” (Jaber, 1997: 14), com isso, os integrantes da organização que não aceitavam o aspecto secularizante dela acabaram por buscar novas perspectivas. Segundo, com a afirmação da Revolução iraniana, o aiatolá Khomeini e suas lideranças passaram a apoiar mais efetivamente a comunidade xiita libanesa para que a revolução também alcançasse aquele país.

Tendo esses dois fatos em vista e, salientando que a comunidade xiita que vivia no sul do Líbano e nos subúrbios de Beirute estava sendo “esquecida” pelo ausente Estado, o veio da radicalização passou a ser um caminho que poderia resultar positivamente - até porque podiam espelhar-se no sucesso do Irã.

O Irã tinha suas próprias razões para apoiar a comunidade xiita que, cada vez mais, tornava-se numerosa no Líbano, entretanto, sem a contrapartida que a representatividade política que lhe caberia.

Although Iran never constituted a part of Israel's ill-fated plan, the movement across the borders of Western-armed and - supported Zionist state that had usurped Jerusalém from the Muslims roused the passions of Khomeini and the clerics. As a result, Lebanon, that small, riddled country on the shore of the Mediterranean, became the field on which the Islamic Revolution would again confront the West [numa menção à vitória contra o Xá que era apoiado pelos Estados Unidos]. (Mackey, 1998: 313)

A partir da postura assumida pelas autoridades iranianas, a ação posterior foi enviar um contingente da Guarda Revolucionária (aproximadamente 1500 soldados) para a região de Baalbeck, onde logo passou a ser criada uma infra-estrutura que pudesse difundir 'a revolução'. Mesquitas, hospitais e toda uma rede de assistência social foram criadas, além de estação de rádio para divulgar os pensamentos dos ideólogos iranianos. Em pouco tempo a região passou a ser conhecida como “pequena Teerã” e posters do aiatolá Khomeini transformaram-se em ornamentos para as ruas e casas da população xiita.

Reflexos da iranização de Baalbek, cada vez mais os preceitos islâmicos passaram a ser introduzidos de forma mais severa - alegando literalidade na interpretação do Corão e da Sharia. Bares foram fechados, vestimentas ocidentais banidas, as mulheres tendo sua liberdade - segundo preceito ocidental - reduzida e a repulsa pelos cristãos que dominavam o Estado libanês. Não tardou e a comunidade xiita que habitava os subúrbios de Beirute passou a ter contato com essa ideologia dos clérigos iranianos e iniciou um processo de assimilação, o que 
resultaria na radicalização dos movimentos contra a presença israelense no país e, conseqüentemente, a ocidental.

Se, por um lado, Israel havia conseguido alcançar seus objetivos com a expulsão da OLP de Beirute, por outro passou a ter muita dificuldade para sair do país com a assinatura de um acordo de paz. A fragmentação do poder não possibilitava que se firmasse um acordo e esse fosse aceito pelos demais grupos beligerantes.

A situação dos israelenses, assim como da Força de Paz da ONU, que encontrava-se no país mesmo após a retirada da OLP, passou a ficar mais complicada com a nova forma de ação implementada pelos xiitas. Em 18 de abril de 1983 um carro-bomba explodiu próximo à embaixada dos Estados Unidos, em Beirute, e provocou a morte de 58 pessoas - dentre norteamericanos e libaneses. Na ocasião, uma organização chamada Jihad Islâmica assumiu a autoria do atentado. No futuro saberia que essa organização fazia parte de um dos braços do Hizbullah.

A incômoda situação da presença israelense no Líbano forçou os Estados Unidos a tentar viabilizar um acordo que pudesse restabelecer 'a paz' no país. Para intermediar as negociações, o embaixador Philip Habib foi nomeado e, após 35 sessões alternadas entre as cidades de Khalde, Kiryat Shemona e Netanya, chegou-se às bases de um acordo final no dia 17 de maio de 1983.

Dentre as questões que estavam inclusas no acordo, ressalta-se: 1) reconhecimento das fronteiras entre os dois países conforme demarcação internacional; 2) prazo de um ano para que as partes pudessem implementar o que fora acordado; 3) criação de uma "região de segurança” entre os dois países; 4) proibição da utilização do território de ambas as parte por organizações terroristas; 5) fim de qualquer ação propagandista por parte do governo contra os países integrantes do acordo; e, 6) que o acordo deveria ser ratificado pelas partes seguindo seus procedimentos internos.

Os pressupostos que serviram de base para a elaboração do acordo de paz com Israel não geraram satisfação por parte dos vários segmentos políticos libaneses. No mesmo ano em que fora firmado o acordo, lideranças como Suleiman Franjieh, Walid Jumblatt e Rashid Karami se uniram para a criação da Frente de Salvação Nacional - também conhecido como Comitê de Salvação Nacional. Apesar da intenção de que se buscasse a melhor saída para o Líbano, interesses pessoais fizeram com que essa iniciativa das lideranças não resultasse positiva, exceto pelo fato de o Parlamento libanês não ter ratificado o acordo - entendendo-se como positiva, segundo visão das lideranças drusas e xiitas. Entretanto, grande empenho para 
que não houvesse a ratificação do acordo se deu à participação síria, que via seus interesses prejudicados com o acordo.

Na seqüência dos atentados que já vinham provocando pânico nas Forças de Paz presentes no Líbano, em 24 de outubro de 1983, um caminhão Mercedes, amarelo, estacionou em frente ao quartel dos marines, em Beirute e, com a explosão de nove toneladas de dinamite, provocou a morte de 241 soldados norte-americanos e 47 franceses. Novamente, a organização xiita, Jihad Islâmica, assumiu a autoria dos atentados. Para que o caos fosse generalizado e, para que houvesse uma mudança no status quo dos xiitas dentro do panorama da guerra civil, em 2 de novembro os israelenses foram atingidos, pela segunda vez, por um carro-bomba na cidade de Tiro, 29 soldados foram mortos.

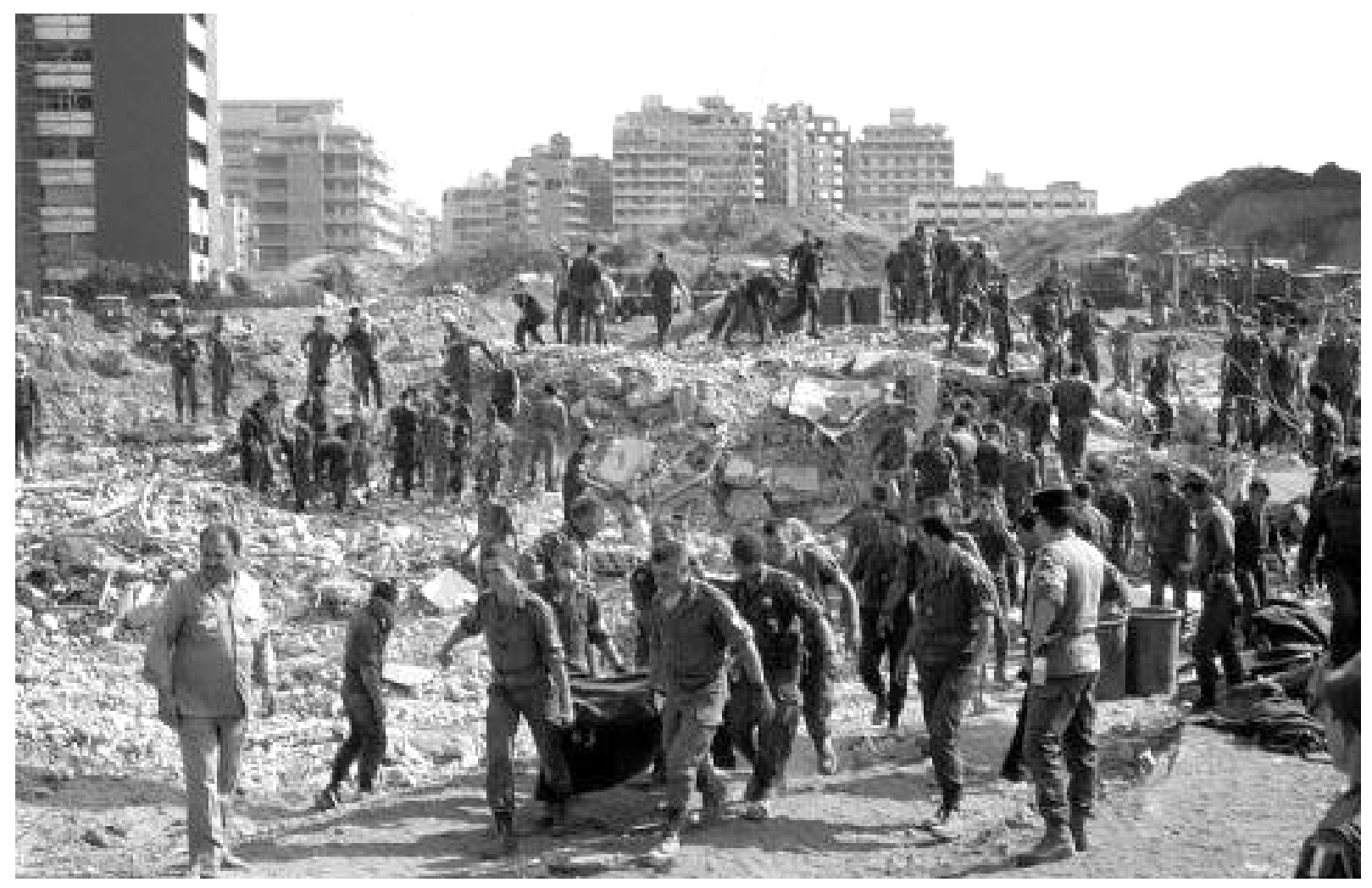

Soldados franceses retirando os corpos das vítimas do atentado ao quartel da Força Multinacional, Beirute, 1983. 47 Soldados franceses morreram na ação.

Gradativamente estava surgindo uma força que parecia ter condições de enfrentar o poderio bélico dos ocidentais: mobilização xiita impressionava pelo poder de destruição que provocava. Durante os anos de 1984/85 os israelenses acabaram por sentir o poder dos radicais muçulmanos devido aos vários atentados que se espalharam pelo Líbano, nem sempre com potencial avassalador e grande número de mortos, mas que acabou por mudar o conceito de guerra que até então travavam. Tendo essa preocupação em mente e sofrendo pressão interna por parte de sua população, que continuava sendo vítima de atentados - na fronteira norte pelo Hizbullah e, no interior do país, pelo Hamas e outras organizações palestinas -, 
Israel acabou sendo obrigado a estabelecer um programa de recuo dentro do território libanês. Essa nova estratégica de ação foi assumida pelo então recém eleito primeiro-ministro (1984), Shimon Peres (Partido Trabalhista), que, em comparação ao governo anterior, pode ser considerado mais à esquerda.

A retirada só não foi completa porque os israelenses estabeleceram-se no sul do país na divisa entre Israel e Líbano -, onde potencializaram suas forças na “Zona de Segurança”, a qual teria a função de impedir que palestinos e xiitas conseguissem alcançar alvos ao norte de Israel. A “Zona de Segurança” acabou por abranger aproximadamente 10\% do território libanês. Apesar de não ser a atitude esperada por grande para da comunidade internacional principalmente a Síria e seus aliados -, recuar além daquele ponto era algo que Israel não discutia, tratava como “uma questão de segurança nacional”.

\section{6 - HIZBULLAH NASCE OFICIALMENTE EM 1985}

A Resistência Nacional Libanesa (Lebanese National Resistance), organização que congregava vários grupos que faziam oposição à presença israelense, e que tinha como figura

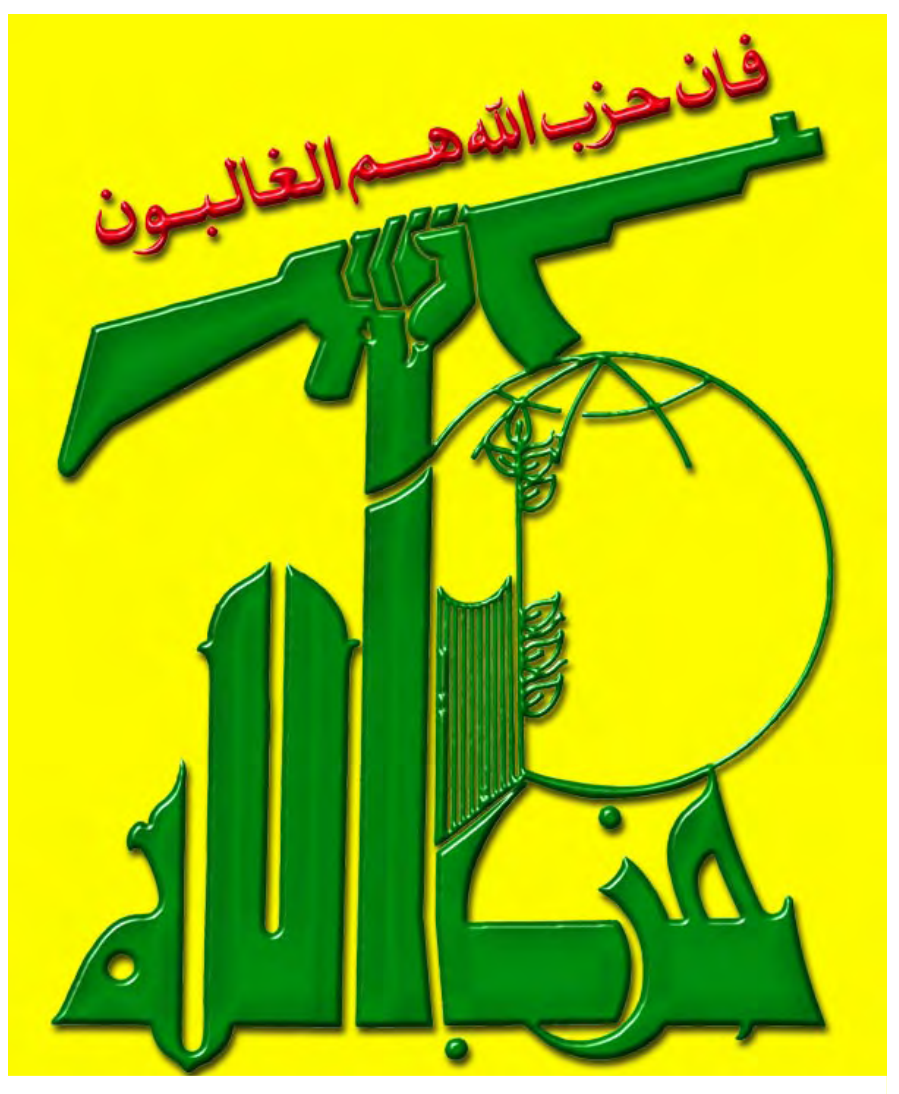

Mescla do nome de Alá com uma metralhadora. E, na tradução dos dizeres do símbolo: "Realmente, o Hizbullah é o que triunfa" principal o Amal, passou a não mais atender aos anseios de parte da comunidade xiita - aqueles contrários à sua secularização. Essa insatisfação vinha ocorrendo gradativamente, mas encontrava apoio e era amplamente difundida por membros do Amal. Com base nesse fato, a ligação com o Irã pode ser considerada o fator principal para que dali saísse a dissidência que iria formar o Hizbullah. Podemos aceitar essa argumentação se considerarmos que a revolução iraniana já difundia a valorização dos ideais islâmicos. Assim, para uma população oprimida, como a xiita, que nutria forte ressentimento contra os maronitas, a adesão à causa islâmica - nos moldes iranianos, também 
considerados fundamentalistas - significava a negação dos ideais ocidentais e tudo que a ele estivesse ligado - como o Estado de Israel, aliado dos Estados Unidos. Nessa visão, continuar no Amal seria como negar os princípios islâmicos - ausência de divisão entre poderes Temporal e Espiritual - e, ao mesmo tempo, pactuar com a dominação ocidental.

Nos anos que precederam ao anúncio oficial da criação do Hizbullah, em muitas localidades na região do Vale de Bekaa e sul do Líbano, a presença de líderes religiosos era uma constante. Eles seguiam a doutrina estabelecida em Teerã e a divulgavam aos xiitas libaneses. Nas várias comunidades onde havia a atuação desses líderes eram criados centros sociais e religiosos - conhecidos como Husseiniyahs - para difundir a fé e, ao mesmo tempo, cooptar membros para a causa xiita.

O governo israelense, com base no risco dos atentando que vinha sofrendo, passou a implementar uma ação mais efetiva para impedir que o movimento xiita se alastrasse. Os líderes religiosos passaram a ser deportados das regiões onde atuavam e, alguns, foram assassinados. Exemplo emblemático dessa estratégia pode ser citado o caso do Sheik Ragheb Harb, líder da comunidade de Jibsheet e que foi assassinado em 12 de fevereiro de 1984 com três tiros na cabeça enquanto caminhava para casa. Sua importância foi tão grande que passaria a constar na lista dos maiores mártires do Hizbullah. Harb “was well known as the brains behind the attacks made against Israeli soldiers and members of the National Guard. Under his supervision, Jibsheet was transformed from an insignificant, sleepy village into one of the fiercest Resistance strongholds facing the Israelis to this day.” (Jaber, 1997: 21)

Utilizando o acordo de paz estabelecido entre Israel e Líbano - mesmo que não tenha sido ratificado pelo Parlamento libanês -, Amin Gemayel deu início a uma tentativa de angariar fundos para a reconstrução do Líbano. A guerra ainda continuava em curso e sem perspectiva de que chegasse a um fim, contudo, a infra-estrutura do país necessitava urgentemente ser reconstruída. Gemayel planejava obter ajuda internacional aos moldes de um “Plano Marshall” para o Líbano, precisava ganhar a confiança de seus compatriotas para que tivesse legitimidade para propor algum projeto que visasse o fim da guerra. Mas o financiamento não saiu da maneira com que se esperava e, devido ao poder dos clãs detentores da máquina burocrática e beneficiários das redes de corrupção -, a reconstrução acabou atendendo a interesses de grupos restritos e não o da comunidade libanesa. Assim, mais uma vez as localidades mais miseráveis do Líbano, que eram habitadas, em sua maioria, por xiitas a palestinos, não beneficiaram-se de tal apoio.

Sentindo-se abandonada pelo governo cristão e num embate militar contra os israelenses, a comunidade xiita optou, num cenário repleto de incertezas, para aquele que mais 
lhe conviesse, ou seja, a formalização da existência de uma organização que pudesse defender os interesses dos xiitas e, ao mesmo tempo, erguesse a bandeira do Islã. Em 16 de fevereiro de 1985, o Hizbullah, que já existia extra-oficialmente através de outras organizações menores, tais como o “al-Da’wa”, “Islamic Amal”, e o “Hussein Suicide Squad”, divulgou seu Manifesto e proclamou qual seria a agenda política da organização:

We, the sons of Hizbullah's nation in Lebanon, whose vanguard God has given victory in Iran and which has established the nucleus of the world's central Islamic state, abide by the orders of a single wise and just command currently embodied in the supreme exemplar of Ayatollah Khomeini.

From this basis, we in Lebanon are not a closed organizational structural party, nor are a narrow political framework, but we are a nation interconnecting with all Muslims of the world. We are linked by a strong ideological and political connection - Islam.

(...) For we do not have a separate military wing which is independent from the parts of our bodies. Everyone of us is a fighting soldier when a call for jihad arises and each one of us carries out his mission in battle on the basis of his legal obligation. For Allah is behind us supporting and protecting us while instilling fear in the heart of our enemies. (Jaber, 1997: $54 / 5)$

Com a criação oficial do Hizbullah que, inicialmente, passou a ter como secretáriogeral o Sheik Na'im Qasim, o enfretamento entre israelenses e xiitas tornou-se mais constante na região sul do Líbano. O Hizbullah adotou uma estrutura organizacional fragmentada, modelo "guarda-chuva” - ou seja, vários grupos sob as ordens dele, gozando de certa independência -, para que as ações empregadas contra seus adversários fossem mais eficazes e seguras para a liderança central, o que, por sua vez, dificultava a interposição de represálias israelenses.

Paralelamente aos enfretamentos diretos entre ambas as partes, seqüestros de lideranças, soldados, diplomatas, etc, passou a ser a estratégica principal implementada por ambos no intuito de fragilizar o adversário, também para que pudesse servir como "moeda de troca" - negociando-se prisioneiros. Contudo, os desentendimentos no interior da comunidade xiita passaram a gerar atritos. O Amal, que até então fora o porta-voz da comunidade, perdia espaço gradativamente para o Hizbullah, que tinha amplo apoio dos aiatolás iranianos. A situação de tensão era flagrante e os enfrentamentos começaram no sul do país devido à presença palestina.

Amal's more moderate policy differed sharply from Hizbullah's determination to fight the occupation under the banners of Islam and Iran until all Lebanese soil was liberated. The two 
factions had also begun to clash over another issue that year. Palestinians guerrillas had begun returning to the refugee camps in Lebanon, and Amal was determined not to allow then to regain their hold on the country. With Syria's blessing, Amal began to attack the camps. Hizbullah strongly objected to Amal's actions and came to aid of the Palestinians. The fuse was finally lit between Hizbullah and Amal in South Lebanon on 17 February 1988, with the kidnap of the American Lieutenant-Colonel William Richard Higgins just outside the coastal town of Tyre. (Jaber, 1997: 32)

Oficialmente o Hizbullah não assumiu a autoria do seqüestro de Higgins, que estava a serviço da ONU. A ação acabou sendo reivindicada pela Organisation of the Oppressed on Earth, a qual vinculava à libertação de Higgins a retirada de Israel do sul do Líbano, a libertação de todos os libaneses e palestinos presos por israelenses, além do fim da “interferência” estadunidense no Oriente Médio. As negociações para a libertação do diplomata se estenderam até 1989, contudo não obtiveram sucesso e ele foi executado.

Se, por um lado, a ascensão do Hizbullah fortaleceu a comunidade xiita, por outro, os cristãos se viram ainda mais preocupados com a dificuldade de manutenção do poder. O período em que Amin Gemayel governou o país - utilizando uma política pragmática, onde os benefícios retornavam exclusivamente a seu clã e aliados -, foi repleto de acontecimentos que geraram a maior fragmentação do Estado. Ainda em 1987, para que houvesse o fortalecimento dos laços com os israelenses, Gemayel revogou o Acordo do Cairo de 1969, provocando repulsa por parte da comunidade muçulmana simpatizante da causa palestina.

A divisão político-estratégica do Líbano era bem clara: Israel dominando o sul do país, Síria a região de Bekaa e as demais localidades ficavam sob o domínio de aliados dos dois principais atores do conflito. Apenas alguns enclaves conseguiam manter neutralidade ou negociar com ambas as partes dependendo do momento do conflito.

O ano de 1987 também passou a ser de importância capital para a guerra civil libanesa. Primeiramente devido ao início da Intifada em Israel, que provocou o deslocamento de parte das unidades militares israelenses (IDF) - que encontravam-se instaladas na "Zona de Segurança” - de volta ao país, objetivando reprimir a revolta em curso.

Os casos de punição coletiva da população civil palestina tornaram-se mais freqüentes, incluindo toques de recolher e o fechamento de cidades, aldeias e campos de refugiados, demolição de casas, perseguição a sindicatos e comitês locais, fechamento de escolas e universidades, etc. Diante desse quadro de discriminação e repressão, não é de se espantar que a população palestina se levantasse em revolta, o que ocorreu em dezembro de 1987. No dia 8 daquele mês, quatro palestinos foram mortos e outros nove ficaram feridos em um bloqueio militar na Faixa de Gaza, desencadeando uma série de protestos por parte da população 
palestina naquele território. (...) É importante salientar que a Intifada não foi iniciada ou planejada pela liderança da OLP, que à época encontrava-se exilada em Túnis. Ao contrário, foi uma mobilização espontânea, que combinou o caráter de um movimento por direitos civis ao de uma luta nacional por independência, e foi conduzida por pessoas sem nenhuma experiência política ou militar - de fato, a maior parte da população palestina, nas cidades, aldeias e campos de refugiados, envolveu-se na resistência, de uma forma ou de outra. (Gattaz, 2003: 172-3)

E, em segundo lugar - provocando o caos político no Líbano -, o assassinato do Primeiroministro Rashid Karami, desencadeando uma luta acirrada pelo poder entre cristãos e muçulmanos.

Para a sucessão de Karami indicou-se Salim al-Hoss e, para a de Gemayel pretendia-se indicar o cristão Mikhail Daher. Gemayel e o Secretário de Estado norte-americano, Richard Murphy, haviam chegado ao nome de Daher após negociação com o governo sírio. A Síria já exercia forte influência sobre a política libanesa há vários anos, contudo, para a eleição do sucessor de Gemayel tornou-se flagrante sua interferência; a necessidade de Assad referendar a escolha da principal autoridade libanesa soava como uma afronta à soberania libanesa. Pelo menos essa era a percepção que a oposição à Gemayel tinha dos fatos.

Como o nome de Daher não era consenso, o Parlamento libanês resolveu não ratificar sua eleição, gerando um momento de pré-caos para o sistema político libanês que, apesar da guerra em curso desde 1975, sempre conseguira resolver suas questões e não interrompera o “processo democrático”.

Sem possibilidades para que Daher assumisse a presidência, comandante do Exército libanês, Michel Aoun, encontrou-se com Gemayel no palácio do governo e deu-lhe um ultimato. Percebendo os riscos de um golpe de estado, Gemayel optou por uma saída que lhe pareceu ser a mais

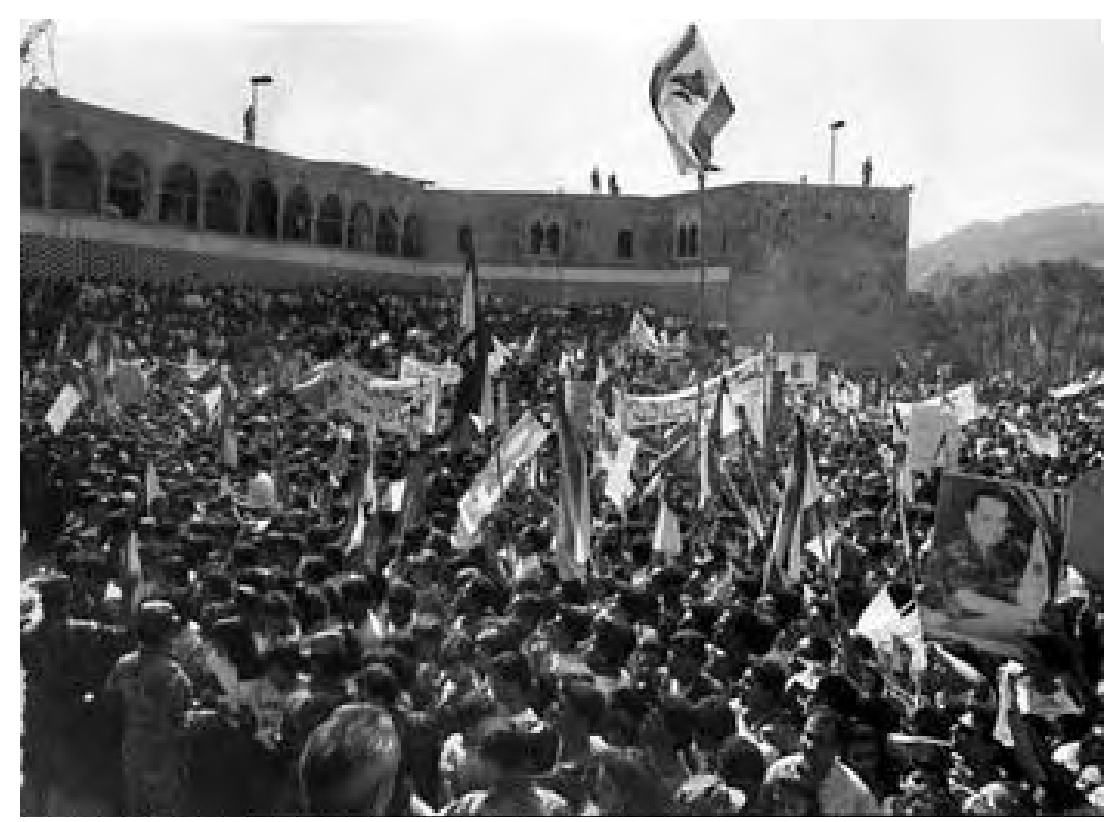

Manifestação em prol de Aoun, palácio de Baabda, dezembro de 1989. 
pacífica: nomear Aoun chefe do governo até que a crise pudesse ser resolvida e se elegesse o novo presidente. Automaticamente, toda a comunidade sunita, os sírios e seus aliados se opuseram. Desde o pacto Nacional de 1943 o cargo de Primeiro-ministro era exercido por um muçulmano sunita e a presença de um cristão era tida como uma afronta.

De fato já havia no cargo de Primeiro-ministro o sucessor de Karami, Salim al-Hoss, que passou a ser o único reconhecido pela população muçulmana. A situação criada por Aoun chegou a seu limite quando a cidade de Beirute foi dividida e criou-se um governo do lado oeste, liderado por Hoss e outro no lado leste, liderado por Aoun.

Aoun, com o intuito de impedir o crescimento da influência síria no país, que contava com apoio de algumas milícias drusas e muçulmanas, além de parte da comunidade maronita representada pela LF (Lebanese Force) ${ }^{61}$, partiu para a batalha dentro de Beirute. O rompimento de Aoun com sua própria comunidade maronita era a síntese dos conflitos libaneses, que muitas vezes assumiam interesses pessoais a objetivos nacionais, entretanto, devido ao forte apelo nacionalista, Aoun conseguiu muitos adeptos junto à população. Esse fato ficou evidente quando Aoun, já sem possibilidades de manter-se no governo, tinha grande número de populares dando-lhe suporte.

Hundreds of thousands of Lebanese flocked to the presidential palace in late December 1989 to form a "human shield" around the compound after Syrian military forces surrounding the free enclave began massing for an imminent invasion. The presence of thousands of Shi'ite and Sunni Muslim Lebanese at these demonstrations illustrated the multi-confessional appeal of Lebanon's first popular nationalist movement. Sunni religious leaders in West Beirut sent a "Muslim Solidarity Delegation," led by Sheikh Hassan Najar, who gave numerous rousing speeches during the demonstrations. (Gambill, 2001)

Indiferente à cisão ocorrida dentro da comunidade maronita, o Hizbullah, àquela altura, já contava com forte apoio do Irã e da Síria, o que representava um grande perigo para

${ }^{61}$ Fundada em agosto de 1976, a Lebanese Force (LB) pode ser entendida como uma coalizão de forças cristãs que objetivava criar uma estrutura em forma de 'guarda-chuvas' para lutar contra os palestinos. A coalizão era formada pela Falange (Kataeb), o National Party, o Tanzim e os Guardiões do Cedro. Em momentos específicos de sua trajetória, entrou em atrito direto com outras lideranças cristãs, como em 1978, na morte do filho de Suleiman Franjieh, Tony, e, em 1980, quando entrou em atrito com os Tigres de Chamoun.

Entre 1980-81, a LB aliou-se ao Estado de Israel, conseguindo, assim, governar de facto o Líbano. Com a morte de Bashir (1982), seu irmão, Amin, assumiu a liderança da LB, contudo, não tinha o mesmo grau de influência e, em 1985, após uma derrota para os drusos na região do Shouf, a LB passou a ser comandada por Samir Geagea. Após o Acordo de Taif, a LB entrou num processo de desestruturação que durou até 24 de março de 1994, ocasião em que foi extinta por uma decisão do governo. Como desdobramento de seu fim, Samir Geagea foi preso e os membros da LB foram perseguidos - muitos emigraram para a Europa, América e Austrália, inclusive Gemayel, que foi para o exílio e, somente retornou ao Líbano no final de 2000.

A partir de 1999 o partido tem sido revitalizado e vem exercendo forte influência sobre os estudantes. Juntamente com o partido do general Michael Aoun (Free National Current, FNC), tem organizado movimentações públicas, fato esse que resultou na prisão em massa dos estudantes, no verão de 2001. 
o governo cristão instituído. As ações do Hizbullah, concomitantemente, geravam problemas para o governo cristão - fortemente questionado em sua legitimidade - e para o governo israelense, haja vista a organização estar implementando ações de forma a intensificar seu poder e abranger cada vez mais o número de vítimas - principalmente militares, contudo, não excluindo eventuais baixas civis decorrentes da utilização dos mísseis katiusha. Como represália à organização, em 1989, Shaykh Abd al-Karim Ubayd, líder local do Hizbullah, foi abduzido por forças israelenses.

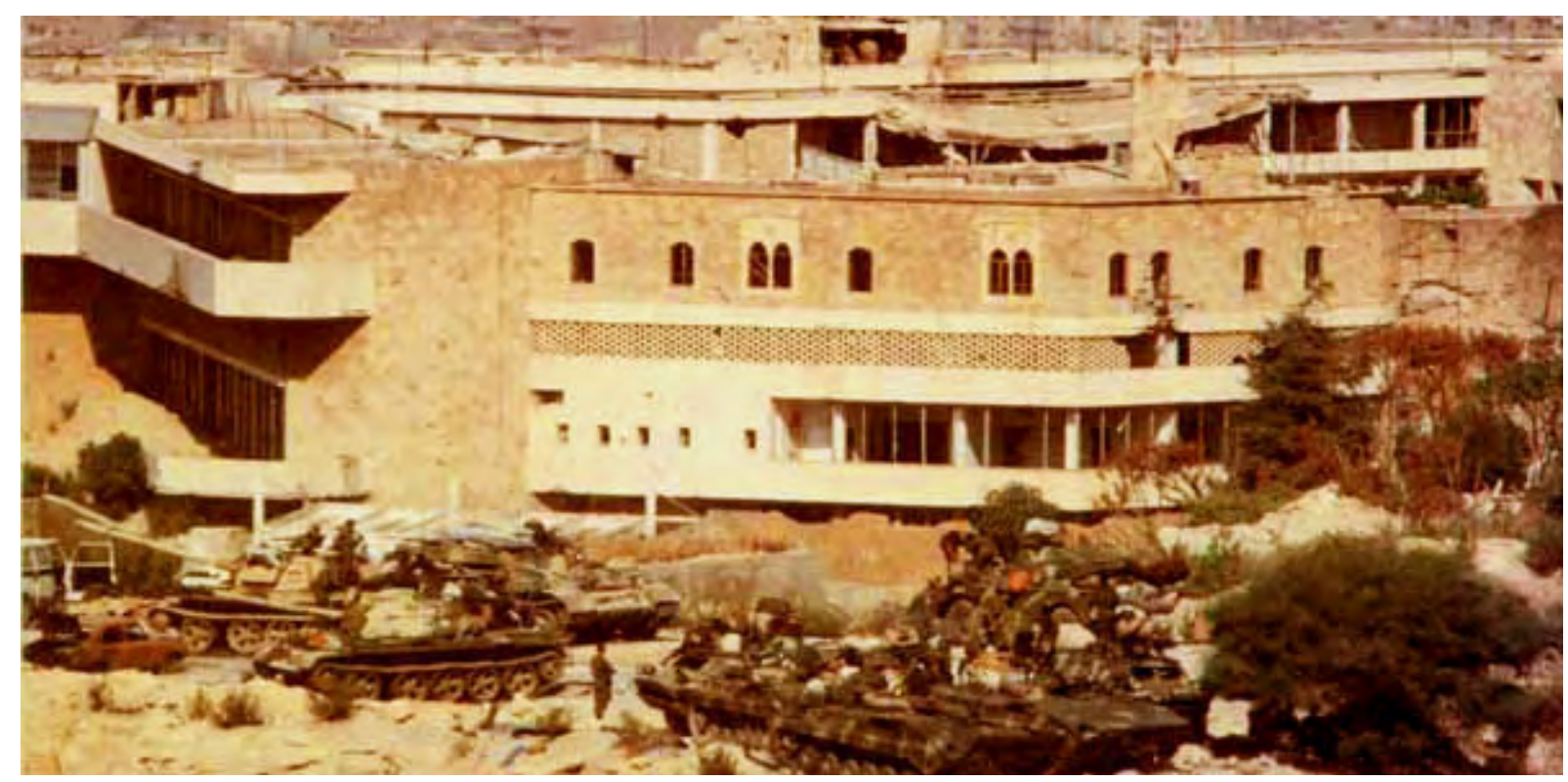

Palácio de Baabda durante o ataque sírio que depôs Michel Aoun e marcou o fim da Guerra Civil libanesa, 13 de outubro de 1990.

Na contra-mão dos conflitos, em Taif, Arábia Saudita, começou a ser negociado o acordo que visava por fim à guerra civil libanesa. A mediação do governo saudita e sírio abriu grandes possibilidades para que realmente houvesse a implementação do que ali viesse a ser pactuado. Em 22 de outubro de 1989 a Assembléia Nacional Libanesa concluiu o Acordo e estabeleceu que os poderes da presidência seriam transferidos para o Gabinete, que seria constituído por representantes muçulmanos e cristãos, divididos igualmente.

Ainda, diante de alguma resistência por parte dos drusos e xiitas, que entendiam que o Acordo somente havia melhorado as condições políticas dos sunitas, a implementação dele não se fez de modo efetivo. Isso porque, dentre às cláusulas do Acordo, havia a imposição de que as milícias depusessem às armas, o que não aconteceu por não haver confiança no governo que seria instituído.

Independentemente da oposição ao Acordo, e, apesar da forte resistência de algumas alas maronitas que não aceitavam abrir mão de sua supremacia, o governo sírio acabou optando por agir de forma incisiva e resolver a questão definitivamente. Em 13 de outubro de 1990, a força aérea síria bombardeou o palácio presidencial em Baabda e levou um dos 
últimos resistentes, o general Aoun, a refugiar-se na embaixada da França, partindo para exílio em seguida. A data passou a marcar o final da Guerra Civil no Líbano.

\section{7 - ACORDO DE TAIF - O REINÍCIO DO ESTADO?}

Para entendermos os fatores que levaram à assinatura do Acordo de Taif temos de reportar-nos às circunstâncias internas e externas. Primeiramente, considerar que, após 1982, com o recuo do exército israelense à "Zona de Segurança”, o controle sírio sobre o Líbano aumentou muito - política e militarmente. Houve a conquista das áreas evacuadas pelos israelenses e palestinos da OLP, assim como, expansão da rede de inteligência síria e interferência direta na escolha dos dirigentes políticos. Esse predomínio da Síria sobre as questões libanesas ficou ainda mais acentuado com o início da Intifada, em 1987, ocasião em os israelenses tiveram de deslocar parte de seus exércitos, do sul do Líbano, para Israel, assim, priorizando o enfrentamento com os palestinos e permitindo que a Síria expandisse seu poder.

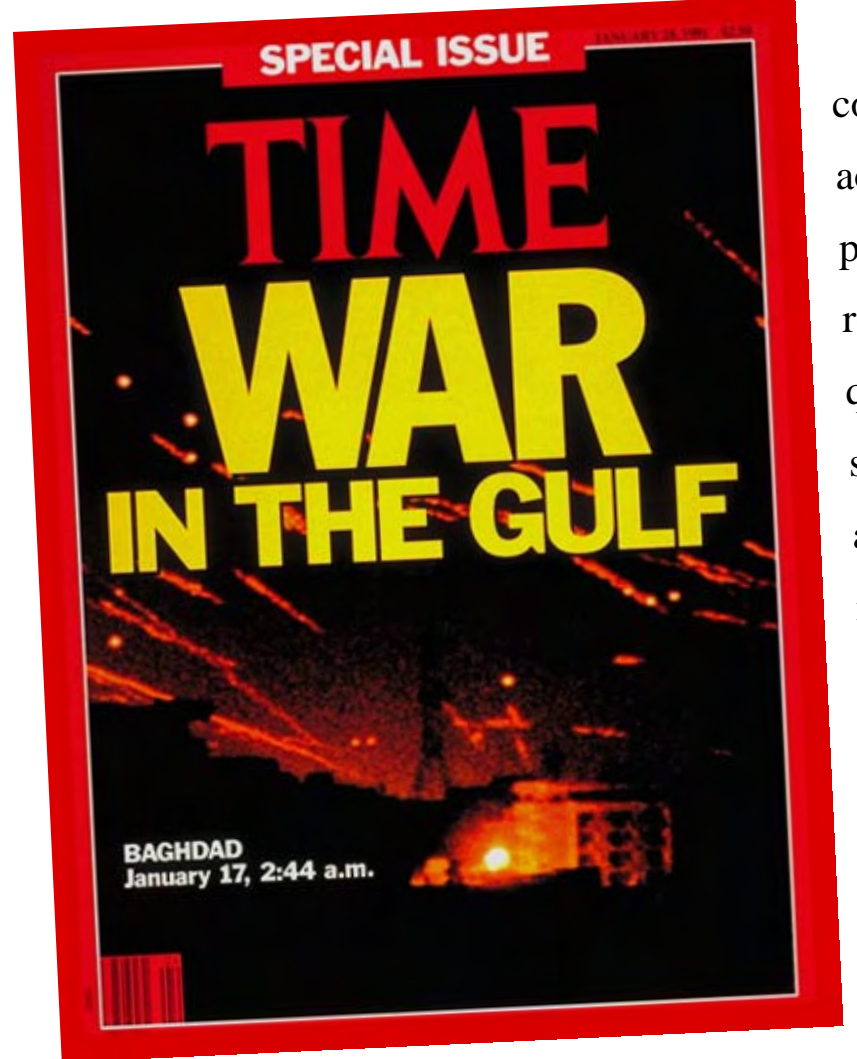

Num panorama totalmente adverso à conciliação, haja vista a tensão ser favorável aos interesses sírios, não havia qualquer possibilidade de chegar a um consenso e reestruturar o Estado. Mesmo os segmentos que, no início da Guerra Civil eram contra o sectarismo e a fragmentação do Estado, acabaram por desistir de lutar pela igualdade entre grupos religiosos.

Se, durante os anos de 1980 a Síria lutou contra qualquer proposta que visasse à fragmentação do Estado libanês ou sua federalização, assim agiu, somente, porque isso poderia dificultar seu controle sobre $o$ Líbano, entretanto, o final dessa década

trouxe novos fatores que pressionaram-na à mudança.

A tensão envolvendo os demais países do Oriente Médio e os Estados Unidos, ganhava bastante importância no panorama internacional e a própria disputa no âmbito interárabe possibilitava o estabelecimento de alianças estratégicas entre libaneses e atores externos. Essa 
tensão culminou na invasão do Kuwait pelos iraquianos e posterior ação militar norteamericana em sua defesa, em janeiro de 1991 - “Operação Tempestade no Deserto”.

Nesse ínterim, as intrincadas relações de desentendimentos entre os partidos Baa’th do Iraque e Síria levaram o líder iraquiano, Saddam Hussein, a prestar apoio ao grupo libanês de Jumblatt - inimigo político dos Assads -, o que proporciomou à Síria romper relações com o Iraque. Atentos aos desdobramentos dos fatos entre Síria e Iraque, os EUA vislumbraram a possibilidade de aproximação à Síria para que pudessem, assim, arquitetar um acordo de paz para a Guerra Civil libanesa. Essa aproximação trouxe facilitações para o início das negociações de paz que resultariam no Acordo de Taif.

Under the above mentioned circumstances, sixty-two Lebanese deputies (those still alive of the ninety-nine originally elected in 1972) met in the city of Taif in Saudi Arabia to discuss national reconciliation on the basis of a document that had already largely been prepared by the Arab Tripartite Committee [the Arab states, led by Saudi Arabia, held a summit meeting in Casablanca and formed a Tripartite Committee composed of King Fahd of Saudi Arabia, King Hassan of Morocco, and President Shadli Ben Jedid of Algeria to deal with the Lebanese crisis] after much consultation with Syria, the United States and various Lebanese leaders. The deputies, after twenty-two days of discussion and consultation with officials and leaders in Lebanon, reached agreement on October 22, 1989. The National Accord Document, or the Taif Agreement as it came to be known, constituted the outcome of a process of reconciliation among the Lebanese, with the effective support of the Syrians, the Arabs, and the international community. (Krayem)

Alguns pontos desse acordo merecem atenção especial: 1) a reafirmação da identidade árabe para o Líbano e conseqüente necessidade de manutenção da unidade/integridade do país; 2) o apelo para o restabelecimento da soberania libanesa; 3) a opção por um sistema político como Parlamentarista Democrático; 4) sistema econômico baseado na liberdade de mercado com o direito à propriedade privada; e, 5) a promessa de abolição do sistema sectarista que seria implementado gradualmente.

O Acordo de Taif introduziu trinta e uma importantes emendas constitucionais que foram aprovadas pelo Parlamento libanês em 21 de agosto de 1990 e transformadas em lei com a ratificação do Presidente Elias al-Hraoui em 21 de setembro do mesmo ano ${ }^{62}$.

Apesar de o Acordo prever a abolição do sistema confessional, não estabelecia prazos e a maneira pela qual chegaria a tal modelo. Sem grande transformação na maneira com que o

\footnotetext{
${ }^{62}$ Cópia do documento, na íntegra, encontra-se nos anexos dessa dissertação.
} 
poder vinha sendo distribuído, o acordo acabou gerando insatisfação por parte dos drusos e xiitas, que mantiveram o mesmo status quo anterior.

Um dos poucos pontos que apresentou mudança substancial na estrutura política foi no fortalecimento do Gabinete com a subtração de parte do poder do presidente, conforme a nova redação do artigo 17 da Constituição passou a explicitar: "O Poder Executivo será confiado ao Conselho de Ministros e, o Conselho exercê-lo-á de acordo com as condições declaradas nessa constituição.”.

O problema subseqüente ao que fora acordado em Taif dizia respeito à saída das tropas sírias e israelenses do Estado libanês para que sua soberania fosse retomada. Estrategicamente Israel não pretendia deixar o país sem que a Síria fizesse o mesmo. Por outro lado, no tocante ao desarme das milícias, houve um grande progresso, excetuando o poderoso Hizbullah que opunha-se veementemente à aceitação das cláusulas do Acordo de Taif, inclusive recusava-se a transformar-se num partido político para que pudesse participar do processo democrático que estava previsto para ter início na seqüência da ratificação do Acordo.

Apesar da relutância inicial do Hizbullah em aceitar as condições estabelecidas pelo Acordo de Taif, sua situação não era muito confortável devido à Síria ter sido uma das patrocinadoras das negociações. E, mesmo diante de um primeiro momento de negativa devido à incoerência de assumir pressupostos democráticos se clamava por uma República Islâmica; assunto que será abordado mais profundamente no próximo capítulo -, o momento não era propício para perder o apoio sírio e ainda tornar-se alvo dos Estados Unidos, que já criara a relação das organizações fundamentalistas/terroristas que deveriam ser perseguidas. O Hizbullah acabou aceitando a transformação em partido político, entretanto, não depôs as armas sob a alegação de que ainda estaria em luta contra Israel para readquirir a soberania do Estado libanês. Levantara, assim, a bandeira do que passou a chamar-se Resistência.

\section{8 - O LÍBANO PÓS-TAIF, A RECONSTRUÇÃO SOB ERROS}

Com o final da Guerra Civil o governo sírio continuo a exercer forte influência sob o Líbano. De fato, a soberania pela qual a população almejava não chegou a existir e, os governantes passaram a necessitar do aval de Assad para poder elaborar as diretrizes da política interna e externa do país. Grande parte desse poder se devia à permanência das tropas sírias no Líbano e a influência que exercia sobre o Hizbullah que, por sua vez, apesar de ter se transformado num partido político, mantinha suas ações militares contra as forças israelenses 
no sul do país, e contra a milícia cristã SLA (South Lebanon Army), patrocinada pelo governo de Israel.

Em 1991 o governo sírio deu mais um passo para controlar legalmente a política interna libanesa com o Acordo de Taif - em sua parte IV (Relações entre Síria e Líbano), o governo sírio conseguia manter seu status quo sobre o Líbano:

Lebanon which has Arab affinities and an Arab identity maintains loyal ties of brotherhood with all Arab states. It maintains preferred relations with Syria based on the roots of close affinity, history and common interests.

This is the basis for coordination and cooperation between the two states which shall sign agreements in various areas in such a manner as to realize the interests of both states within the framework of the sovereignty and independence of each.

On this basis and given that the security principles create the necessary climate for the development of these preferred relations, Lebanon cannot serve as the source of a threat against Syrian security nor can Syria serve as the source of a threat against Lebanese security. Hence Lebanon shall not allow itself to serve as the transit point or base for any force state or organization interested in harming its own security or the security of Syria.

Similarly Syria which meticulously upholds the security, independence, and unity of Lebanon, and the agreement between the two countries, shall not allow any activity that threatens (Lebanese) security independence or sovereignty. (Taif Agreement)

O passo seguinte foi a assinatura do Tratado de Fraternidade, Cooperação e Coordenação, em 20 de maio de 1991, que vinculou os desígnios da Síria aos do Líbano - e vice-versa. Através de cláusulas que não determinavam com objetividade o grau de interferência de um país sobre o outro, a Síria encontrou os mecanismos perfeitos para legitimar sua ação sobre o governo libanês. O acordo previa a criação de órgãos específicos para agirem em conjunto. Isso, em tese, preservaria os interesses da partes, contudo, o poder de influência e preponderância sírio, por si só, já evidenciava o desequilíbrio.

Basicamente o tratado vinculava a saída das tropas sírias do território libanês à consolidação da paz no Líbano; ainda, estabelecia que para a segurança da Síria haveria a necessidade de manutenção de tropas em solo libanês enquanto exércitos estrangeiros ameaçassem sua soberania. Esse aspecto do tratado dizia respeito diretamente à presença israelense no sul do Líbano.

The connection between the security of the two countries requires that Lebanon not become a threat to Syria's security and vice versa under any circumstances. Therefore Lebanon will not allow itself to become a transit point or base for any force state or organization that seeks to undermine its security or that of Syria. Syria which cherishes Lebanon's security 
independence and unity and the agreement among its people will not allow any action that threatens Lebanon's security independence and sovereignty. (Art. $3^{\circ}$ do Tratado de Fraternidade, Cooperação e Coordenação)

Praticamente sob o domínio sírio, o Líbano passou a viver um momento de reestruturação do país. A destruição que os quinze anos de Guerra Civil provocou, deixou o país com a infra-estrutura quase que completamente inutilizável, assim, aquele momento foi propício ao reaparecimento de figuras importantes no panorama político libanês. Personalidades essas que pretendiam restaurar os momentos de glória que o Líbano tivera no passado, quando ainda era conhecido como “a Suíça do Oriente Médio” e sua capital “a Paris do Oriente Médio”. Personalidade ímpar, nesse contexto, foi o bilionário Rafiq Hariri, que após ter auxiliado na realização das reuniões que resultaram no Acordo de Taif, conseguiu o apoio da Síria e tornou-se Primeiro-ministro, após as eleições de 1992, propondo uma reforma de base para o país, contudo, privilegiando setores e localidades de seu interesse; fato esse que reforçava a repulsa das comunidades excluídas, como a xiita:

In an effort to attract foreign and expatriate capital, Hariri slashed income and corporate taxes to a flat $10 \%$ and borrowed billions of dollars to rebuild the economic infrastructure of the country. It soon became evident that Hariri's reconstruction plan, called Horizon 2000, would focus on rebuilding Beirut at the expense of the country as a whole, prioritize the financial sector over agriculture and industry, and emphasize the development of physical infrastructure rather than human capital. Proponents of this plan argued that a revitalized financial sector would become an engine driving economic growth for the entire country. (Gambill e Abdelnour, 2001)

Apesar da "reconstrução” do Líbano ter significado uma vitória para o povo que vivia os martírios da guerra, a grande falha na elaboração dessa estratégia foi “excluir os excluídos”. Essa ação somente fortaleceu os movimentos fundamentalistas islâmicos. Onde o Estado não agia, o Hizbullah, através da forte inserção de capital iraniano, montava toda a estrutura social para que sua população tivesse condições de sobrevivência. (Mackey, 1998: 314) Mesquitas, hospitais, clínicas odontológicas, escolas, universidades, etc, continuavam a seu encargo. Apesar dos benefícios implantados no sul do país, a população local ainda vivia o resultado da tensão existente entre Hizbullah e exército israelense. Freqüentemente havia ataques de ambas as partes e, a reestruturação das bases palestinas na região, agravava a situação.

O ano de 1991 também ficou marcado pelo início das discussões que pretendiam conduzir israelenses e árabes/palestinos à paz e resolver definitivamente a "Questão 
Palestina”. Os Estados Unidos, imbuídos do afã da vitória na Guerra do Golfo e, percebendo que seus aliados locais - Arábia Saudita e Kuwait - tinham forte interesse na solução pacífica dos atritos regionais, resolveram pressionar tanto os árabes quanto o primeiro-ministro israelense Yitzhak Shamir a participar de um processo de negociação de paz.

Apesar de exercer grande pressão sobre Israel, o então presidente norte-americano George Bush, não conseguiu fazer com que Shamir aceitasse negociar com representantes da OLP. Para o primeiro-ministro israelense, a única maneira de que houvesse a cúpula de Madri seria se a OLP não tivesse representantes. Dessa forma, o encontro ocorreu, em outubro de 1991, com representantes da Síria e Líbano, contudo, com a ausência da OLP. Se a finalidade da Cúpula de Madri era alcançar a paz, pode-se dizer que não conseguiu seus objetivos, entretanto, as mudanças conjunturais fizeram com que Israel e OLP iniciassem novas negociações, secretamente, em Oslo, a partir de 1993.

\section{9 - ISRAEL VOLTA A ATACAR...}

O ano de 1992 começou com a expectativa de que o processo eleitoral libanês, que estava por vir, fosse o início de uma nova era para o país. As milícias haviam deposto as armas - com exceção do Hizbullah - e o maior problema para a população era a tensão que encontrava-se no sul do país, gerando contínuos ataques entre Israel e Hizbullah.

Numa tentativa de enfraquecer as ações do Hizbullah, o governo israelense, em 16 de fevereiro de 1992 - ocasião em que a organização preparava-se para participar de seu primeiro pleito eleitoral -, programou um atentado contra o então Secretário-geral, Sayyed Abbas Musawi. Para a ação contra Musawi Israel optou por um ataque aéreo através de um helicóptero e obteve êxito. Entretanto, além da morte de Musawi, sua esposa e seu filho de um ano acabaram sendo vitimados. Segundo Jaber, "the attack on Musawi coincided with a period when Hizbullah’s influence had begun to stagnate” (1997: 44), entretanto, a morte do líder xiita acabou tendo efeito contrário ao esperado pelos israelenses.

A morte de Musawi e sua família transformou-se num episódio emblemático que gerou comoção dentro da comunidade xiita, fortalecendo, assim, a resistência que o Hizbullah vinha pregando. A imagem de Israel como um inimigo a ser destruído tornou-se mais clara. Na 
seqüência dos acontecimentos, o Alto Conselho do Hizbullah ${ }^{63}$ reuniu-se em sessão de emergência e elegeu como novo Secretário-geral, Sayyed Hassan Nashallah, que já ocupava outro cargo de expressão na hierarquia da organização.

Nashallah manteve a mesma linha de ação de Musawi. Ele declarara que seguiria com a luta contra a presença israelense no país. Assim, os ataques contra a "Zona de Segurança” continuaram freqüentes e a população de Israel que habitava a região fronteiriça, ao sul dela, sentia-se fortemente ameaçada e cobrava uma ação mais enfática por parte do governo. O que viria na seqüência.

No primeiro processo eleitoral que o Líbano teve, após vinte anos de Guerra Civil, o partido político Hizbullah conseguiu eleger oito membros para o Parlamento, além de outros quatro deputados aliados que concorreram na mesma lista do Hizbullah ${ }^{64}$. (Jaber, 1997: 72)

Agindo como um partido político, sujeito às leis do Estado e, concomitantemente, lutando contra a presença israelense no sul do Líbano - respaldado pela legitimidade que a retomada da soberania estatal lhe proporcionava -, o Hizbullah conseguia aumentar seu número de membros e simpatizantes. Esse fortalecimento da organização reverberou em suas ações contra Israel e o SLA (South Lebanon Army). Em meados de 1993 os xiitas do Hizbullah, contando com o apoio da PFLP-GC (Popular Front for the Liberation of Palestine General Command) - grupo que havia surgido com a cisão da OLP $^{65}$ - executaram ações de grande envergadura na região da "Zona de Segurança”.

Não tendo como conter a tensão na fronteira libanesa e, sofrendo pressão de sua população, o governo israelense partiu para o contra-ataque e implementou uma ação militar, a “Operação Accountability”, em 25 de julho de 1993. No entanto, essa reação israelense pode

\footnotetext{
${ }^{63}$ Acerca da estrutura da organização e a função de cada um de seus órgãos, trataremos no próximo capítulo. Cabe salientar que o Alto Conselho é o responsável pela designação do Secretário-geral e, assim, foi seguida a hierarquia.

${ }^{64}$ No capítulo Quatro será abordado o funcionamento do processo eleitoral libanês e o sistema de listas, suas vantagens e desvantagens segundo modelos que serão discutidos.

${ }^{65}$ Em 1968, Ahmad Jibril formava, juntamente com George Habash, a FPLP (Frente Popular para a Libertação Palestina), contudo, desentendimentos acerca da maneira com que deveria ser tratado o Estado de Israel - o primeiro era partidário de ações militares e o segundo de entendimentos diplomáticos -, fizeram com que houvesse a cisão dessa organização e surgimento de uma segunda, liderada por Jibril. Assim, criou-se a FPLPCG (Frente Popular para a Libertação da Palestina - Comando Geral / PFLP-CG), com o auxílio da Síria e assumindo uma postura de enfretamento direto com o Estado de Israel, inclusive, durante os anos de 1970, com a utilização de ações terroristas. Posteriormente, a FPLP-CG assumiu um assento na Organização para a Libertação da Palestina e, em 1974, ratificou a Resolução da OLP que estabelecia uma autoridade nacional para a região da Palestina, entretanto, uma vez que não interessava-se por saídas diplomáticas e contava com apoio explícito do governo sírio, abandonou qualquer entendimento anterior assim que o acordo de paz entre Síria e Israel tornou-se inviável e o Egito passou a trilhar um caminho que o levaria a assinar um acordo em separado. Os desentendimentos entre OLP e a FPLP-CG tornaram-se flagrantes quando, em 1983, Yasser Arafat demonstrou interesse em negociar com Israel. Daí surgiram atritos militares entre as duas organizações e, com isso, a militância de Jibril passou a assumir, muito mais, a defesa de interesses sírios - inviabilização de uma paz negociada para que gerasse instabilidade no governo israelense - que dos próprios palestinos. (Gambill, 2002)
} 
ser vista sob outro prisma, se considerarmos a situação política em que viviam os governos libanês e israelense.

Considerando os laços históricos que maronitas e israelenses cultivavam, a transformação do Hizbullah em partido político tornou-se uma questão bastante delicada na relação entre os dois países. Israel cobrava do governo libanês uma posição mais enfática contra as ações militares que o Hizbullah efetuava na zona fronteiriça. Ao mesmo tempo, o Hizbullah gozava de certa legitimidade aos olhos do mundo árabe e países simpatizantes, por tentar restaurar a soberania do Estado.

Apesar da tensão criada entre maronitas e israelenses, no tocante à cobrança de ações restritivas/punitivas contra o Hizbullah, o governo libanês preferia não interferir diretamente nos problemas existentes no sul, mas, também, não permitia que o Hizbullah programasse movimentos em Beirute que pudessem ser confundidos com uma posição oficial do Estado. Todas as manifestações pró e contra eram suprimidas.

Por mais que o ministro das relações externas israelense, Shimon Peres, clamasse por uma ação contra o Hizbullah e vinculasse ao silêncio do governo libanês à cumplicidade nos atos da organização, Israel não conseguia persuadir os governantes libaneses a mudarem sua postura.

\footnotetext{
Beirut, however, did not cooperate. Instead, the Lebanese government pursued diplomatic efforts to end the conflict and limited its actions on the ground to assisting displaced people fleeing the South. The local press reported carping among cabinet members as how much resistance Lebanon could tolerate, given the damage the Israeli gunners, helicopters and airplanes were inflicting. But throughout the period of intensified conflict, the central authorities made no attempt to discourage Hizbullah's incessant shelling of the Galilee panhandle [região fronteiriça entre a Síria, Líbano e Israel, possuindo a forma de uma 'alça de panela’]. (Harik, 2004: 115)
}

Com a “Operação Accountability”, Israel conseguiu ultrapassar a “Zona de Segurança” e adentrar, mais ainda, em território libanês. A ação, como as anteriores, contou com grande aparato militar e destruiu bases palestinas e focos de resistência do Hizbullah. Contudo, a postura agressiva que o governo israelense assumiu ao invadir o Líbano não contou com o apoio da comunidade internacional, tampouco de seu aliado político, os Estados Unidos.

Para tentar restabelecer a ordem no sul do Líbano, os Estados Unidos passaram a intermediar um "entendimento" entre o Hizbullah e Israel, no qual o principal ponto seria a não mais utilização de alvos civis em suas ações. Com isso, Israel aceitou retornar à "Zona de Segurança”. 
Sem ter havido uma derrota ou vitória por parte dos atores envolvidos, a situação de beligerância continuou nas fronteiras entre os dois países, todavia, quem acabou saindo fortalecido foi o governo sírio. Durante todo o processo que culminou com a invasão israelense ao Líbano, a Síria possuía ferramentas suficientes para impedir sua ocorrência haja vista que controlava o governo libanês e o Hizbullah -, contudo, deixou que o enfretamento chegasse às vias de fato.

\subsection{0 - OSLO PARA OS PALESTINOS, VINHAS DA IRA PARA OS LIBANESES}

No período que se seguiu à Cúpula de Madri, chegando à Oslo, ocorreram sérias mudanças na maneira com que Israel trataria a questão relativa aos palestinos. Parte dessas mudanças deveu-se à pressão dos Estados Unidos e uma segunda parte, a pressões internas. Assim, a aceitação da

OLP na mesa de negociação foi o primeiro passo para que se iniciasse, efetivamente, os entendimentos que objetivavam à paz. As negociações começaram em reuniões secretas durante o ano de 1993 e foram concluídas,

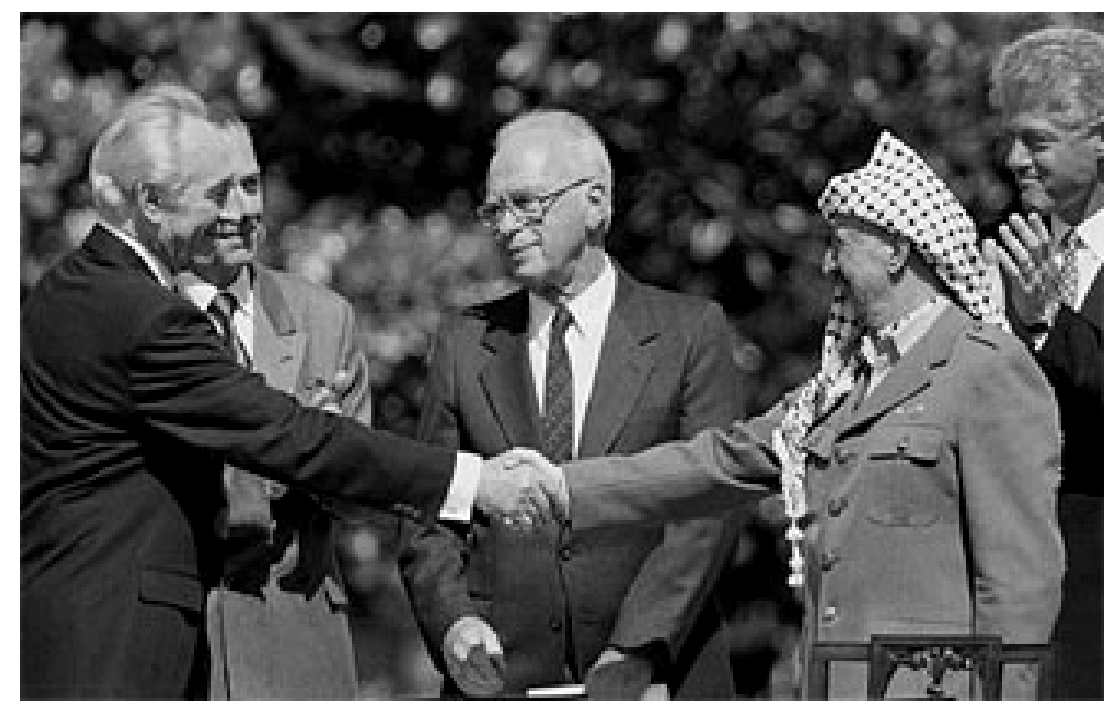

Washington, 1994 - Assinatura do Acordo resultante das negociações de Oslo. Peres, Rabin, Arafat e Clinton. formalmente, numa reunião nos jardins da Casa Branca, em Washington, no mês de setembro do mesmo ano, na qual encontravam-se presentes: Yasser Arafat, Yitzhak Rabin e Shimon Peres, esse último, ministro do exterior israelense.

O resultado a que chegaram - as lideranças da OLP e Israel - foi muito contestado pelos membros mais extremistas de ambas as partes, contudo, internacionalmente acabou assumindo o caráter de um efetivo início para se chegar à paz na região da Palestina. Tanto impacto teve a negociação que os signatários acabaram por receber o Prêmio Nobel da Paz no ano de 1994.

O documento assinado pelas partes passou a ser conhecido como Declaração de Princípios entre Israel e a OLP e suas negociações teriam seguimento em outras 
oportunidades: Cairo (1994), Oslo II (1995), Wye River (1998) e Sharm al Sheik (1999). Entretanto, a percepção de que ambas as partes estavam saindo em desvantagem nas negociações imperava. Os palestinos não sentiam-se completamente satisfeitos com a proporção de território que os israelenses estavam dispostos a conceder - que não era o retorno às fronteiras estabelecidas em 1947 -, assim como, vários segmentos da sociedade israelense não concebiam a idéia de deixar os assentamentos que já ocupavam há vários anos em prol de uma paz que, sequer, poderia ser garantida pela OLP - haja vista ela não ter o controle sobre todos os grupos islâmicos.

Um dos aspectos fundamentais da Declaração de Princípios foi o reconhecimento mútuo entre Israel e OLP, entretanto, a partir desse pressuposto, as dúvidas e questionamentos acerca do que fora acordado geraram questionamentos inflamados, “os dois homens [RabinArafat] foram acusados de deslealdade e traição. Os líderes do Likud e dos partidos nacionalistas de extrema direita atacaram Rabin por seu desvio abrupto da política bipartidária de recusa à negociação com a OLP e acusaram de abandonar os 120 mil colonos dos territórios ocupados à mercê dos terroristas.”. (Shlaim, 2004: 583)

Apesar das contestações por parte dos radicais, que não aceitavam quaisquer concessões, cabe salientar que essa não era a visão predominante. O reconhecimento mútuo entre a OLP e Israel teve aspectos positivos. Um deles advém do fato de que, a partir do momento em que a OLP reconheceu a existência do Estado israelense, houve o distensão nas relações entre os Estados árabes e Israel, repercutindo, assim, positivamente, no Líbano. Contudo, não se pode dizer que tenha havido qualquer mudança de pensamento no que tange à repulsa do Hizbullah por parte dos israelenses; esses, continuavam presentes em solo libanês e sujeitos às ações da Resistência.

À parte as negociações que sucederam à Oslo I, o início dos entendimentos possibilitou que Israel desse prosseguimento ao seu plano de estabelecer acordos de paz com seus vizinhos árabes, Síria e Jordânia. Com relação à Jordânia as negociações progrediram e foi possível chegar a um acordo de paz, entretanto, com a Síria a questão era mais complicada e as margens de negociação eram mínimas. Assad, que em 1967 comandava as tropas sírias que acabaram por perder as Colinas de Golã para Israel, não via qualquer possibilidade de acordo se não perpassasse pela devolução da região. As negociações acabaram não progredindo e, conseqüentemente, fracassando devido à divergência em estabelecer a extensão da retirada israelense de Golã.

Outro ponto que merece atenção para entender as razões que levaram o governo israelense a proferir novo ataque sobre o Líbano, diz respeito a essa irredutibilidade da Síria 
em assinar um acordo de paz. Primeiramente, Israel achava inadmissível que o governo sírio permitisse que organizações consideradas terroristas mantivessem suas bases naquele país como era o caso da FPLP (Frente para a Libertação da Palestina) e a FDLP (Frente Democrática para a Libertação da Palestina) que tinha quartéis em Damasco - e outras como o Hamas, Hizbullah e Jihad Islâmica, que tinham, ali, seus escritórios. Isso porque, todas essas organizações tinham como alvo preferencial Israel e, esporadicamente, instituições ou organismos ocidentais de maneira geral.

Shimon Peres, que em 1996 era o Primeiro-ministro israelense, passava por um período de baixa em sua credibilidade perante a população de seu país. O Hamas havia intensificado suas ações contra civis - em fevereiro daquele ano havia assassinado 64 israelenses em quatro atentados nas cidades de Tel Aviv, Jerusalém e Ashqelon - e o Hizbullah tinha voltado a utilizar mísseis katyusha contra alvos ao norte de Israel - alegando que os israelenses haviam assassinado um adolescente libanês que encontrava-se fora da “Zona de Segurança”. Essa dupla ação contra a população israelense gerava questionamentos com relação à eficiência das negociações de paz.

Percebendo que sua ação não iria reverter positivamente para que o partido Trabalhista obtivesse êxito na próxima eleição, Peres resolveu mudar sua estratégia para que não fosse percebido como um “articulador da paz” que negligenciava a segurança. Da mesma forma, Peres percebia-se duplamente prejudicado pela Síria. Primeiramente porque não conseguia chegar a um acordo de paz que contemplasse os interesses de ambos e, segundo, porque não conseguia fazer com que Assad interviesse junto ao Hizbullah e fizesse com que a organização honrasse o acordo verbal estabelecido em 1993 - com o auxílio dos Estados Unidos - o qual as partes se comprometiam a não atacar alvos civis.

Peres arquitetou uma operação militar que faria com que a população libanesa fosse expulsa do sul do país e passasse a pressionar o governo no intuito de agir contra as ações do Hizbullah. Alcançado seu primeiro objetivo - o êxodo -, as tropas israelenses teriam como destruir as bases do Hizbullah e as sírias, que encontravam-se posicionadas no sul do Líbano e na região do Vale de Bekaa.

A estratégia israelense contou com o apoio tácito dos Estados Unidos - somente no aspecto estratégico -, mas o resultado foi extremamente negativo junto à comunidade internacional. A ação militar, que ficou conhecida como "Operação Vinhas da Ira”, foi deflagrada em 11 de abril de 1996, após os feriados da Páscoa judaica. 
Um ataque com alta tecnologia aconteceu no sul do Líbano, em Beirute e no Vale Bekaa. Aproximadamente quatrocentos mil cidadãos libaneses foram expulsos de suas cidades e aldeias e transformados em refugiados. Um ataque combinado aéreo e de artilharia foi lançado contra o Hizbullah - dois mil ataques aéreos de surpresa e vinte mil obuses. O Hizbullah tinha cerca de trezentos combatentes em tempo integral. Sua arma mais potente eram os foguetes katyusha disparados de lançadores múltiplos, obsoletos, imprecisos e com alcance máximo com cerca de vinte quilômetros. A estratégia de Israel era equivalente a usar uma máquina de terraplanagem para capinar um jardim. (Shlaim, 2004: 626)

Apesar da diminuta possibilidade de que a estratégia israelense falhasse, a expectativa dos articuladores da ação começou a ruir no dia 18 de abril. Nessa data a vila de Qana - onde encontravam-se alguns refugiados libaneses sob a guarda da ONU - foi atacada por tanques israelenses e 109 refugiados foram mortos. As imagens do massacre correram o mundo e a ação militar sobre Qana gerou repúdio imediato contra Israel e seu governante, Shimon Peres.

O governo israelense argumentou que o ataque à Qana não foi um ato premeditado. Segundo sua visão dos fatos, guerrilheiros do Hizbullah haviam lançado cinco mísseis katyusha contra um comando israelense que havia acabado de adentrar à "Zona de Segurança" e, numa atitude de defesa, esse comando disparou contra os guerrilheiros mas errou o alvo e acabou atingindo a base da ONU na vila de Qana.

The purpose of the artillery barrage, they [israelenses] argued, was to provide protective fire to their commandos, not to hit the UN base. Very few Lebanese believed Israel's version, while UN soldiers were even more sceptical. A UN investigation, published the following month, concluded that it was "unlike” that the Israeli had hit the base in error. Amnesty International issued its own report in July and declared that the attack had been intentional. (Jaber, 1997: 171)

A reação interna, do governo e população libanesa, também foi de completo repúdio pelo que os israelenses estavam fazendo com o país. Em menos de três anos o Líbano voltava a sentir o poder com que Israel tratava suas questões e a maneira com que procurava impor sua vontade. Nesse aspecto, o então primeiro-ministro libanês, Rafiq Hariri, pronunciou-se à imprensa internacional: "Nobody can put the Resistance in jail... the duty of the Lebanese army is to guard the security of the Lebanese, not guard the Israeli border... it is not the government’s duty to stop the Resistance.” (Jaber, 1997: 173)

Diante da violência e arbitrariedade com que Israel estava tratando a situação em curso, o governo libanês vislumbrou a possibilidade de solicitar que o Conselho de Segurança se pronunciasse através de uma Resolução ou fizesse com que a ${ }^{\circ} 425$ fosse cumprida, assim, 
restabeleceria a soberania do Estado libanês, contudo, os Estados Unidos não pretendiam que a situação chegasse a essa instância e, para isso, incumbira à Secretária de Estado, Madeleine Albright, que providenciasse reuniões para que se alcançasse um entendimento.

Os Estados Unidos foram além e, percebendo que o governo libanês tinha reais intenções de solicitar o auxílio do Conselho de Segurança, ameaçaram utilizar seu direito a veto para impedir quaisquer ações contra Israel. O governo norte-americano argumentava que os israelenses estavam, legitimamente, defendendo-se de ataques que violavam o acordo de 1993. Contudo, a realidade mostrava que a violação provinha de ambas as partes e que Israel também proferia ataques contra localidades ao sul do Líbano. Intencionalmente ou não, o fato é que tais ações acabavam por atingir, eventualmente, alvos civis.

As dificuldades para negociar um cessar-fogo entre Hizbullah e Israel advinham da desconfiança dos agentes imbuídos da intermediação. O Hizbullah não confiava nos agentes nomeados pelos Estados Unidos devido serem demasiadamente parciais a Israel, por outro lado, os israelenses só aceitariam a retirada do Líbano se houvessem garantias reais de que não voltariam a sofrer ataques terroristas.

Percebendo que as negociações não prosperariam sem que um ator de confiança do Hizbullah viesse a intermediar o cessar-fogo, os Estados Unidos tiveram de render-se a Assad, e a Síria assumiu esse papel. Por fim, o que acabou por prevalecer foi o entendimento que haviam chegado em 1993, no qual fica explícito

the Party of God's right to continue resistance activities against Israeli and SLA combatants within the 'Security Zone'. Affirmation of Hizbullah's right to resist Israeli occupation in an agreement signed by USA, France and Israel seemed to deal quite a blow to the terrorist image the Party of God had been trying to shed. With international recognition of the role it was playing in the South, the Party of God seemed well placed to continue its armed struggle against Israel without further challenges based on alleged terrorist activities. (Harik, 2004: 122123)

O exército israelense recuou à "Zona de Segurança”, contudo, para Peres, que pretendia fazer com que a “Operação Vinhas da Ira” se tornasse um passaporte para a sua reeleição, o efeito foi completamente adverso. Os israelenses judaicos desconfiaram da autenticidade de sua "linha dura” sem resultados práticos e os israelenses árabes, que tinham direito a voto em Israel, fizeram a diferença para a derrota de Shimon Peres. Para sucedê-lo, em 31 de maio de 1996, os israelenses voltaram-se para a real "linha dura” do Likud e acabaram por eleger Binyamin Netanyahu como primeiro-ministro. 


\subsection{1 - 2000: ISRAEL SAI... SÍRIA FICA! SOBERANIA LIBANESA ALCANÇADA?}

A aceitação do “Entendimento de Abril”, entre Hizbullah e Israel, acabou por ser bastante negativa para o estado judaico, isso porque, houve a ascendência política do governo sírio nas questões relativas ao Líbano - as quais o Estado de Israel já não tinha muito poder de influenciar, exceto através do emprego da força. Conseqüência direta da mudança de status de Assad - agora caracterizado como um mediador de peso e com poderes efetivos para implementar 'a paz' - foi o surgimento de melhores possibilidades de negociação para um futuro acordo de paz entre Israel e Síria, vislumbrando, inclusive, reaver as Colinas de Golã. Entretanto, nem tudo seguia conforme os interesses sírios e, a emergência de uma maior fricção entre o governo de Rafiq Hariri, então primeiro-ministro, e Nasrallah, secretário-geral do Hizbullah, passou a assumir a ordem do dia.

Durante os ataques israelenses ao sul do Líbano, seguindo sua estratégia recorrente, os israelenses haviam destruído quase que completamente a infra-estrutura da região e, a partir daquele momento se fazia necessário um plano de reconstrução. Para dar início a essa nova etapa de paz no Líbano, Hariri indicou o “Conselho para o Sul” para receber as verbas e designá-las para as famílias atingidas, assim como efetivar o programa de reconstrução. A partir desse fato começou a haver um choque de interesses. O “Conselho para o Sul” era gerido por Nabih Berri, líder do Amal, principal adversário do Hizbullah no sul do país.

Para boicotar o processo de reconstrução do sul, o Hizbullah incentivava a população xiita a não aceitar qualquer indenização do Estado e alegava que quem deveria responsabilizar-se pela região deveria ser o Hizbullah, haja vista ter sido o mais atingido e que tornara-se a ‘verdadeira’ Resistência. (Harik, 2004: 124) A disputa pelo poder do sul era bastante significativa, isso porque o país estava passando por um processo de reestruturação política e a formação de uma base de sustentação eleitoral também era um fator preponderante para o fortalecimento dos partidos. De acordo com a legislação eleitoral, cada região tem direito a eleger uma quantia específica de parlamentares e seu número varia de acordo com a divisão religiosa, ou seja, destinam-se cadeiras para cristãos, xiitas, drusos, sunitas, etc. Assim, os xiitas do Hizbullah competem, diretamente, pelas mesmas cadeiras do Amal.

Apesar de estar havendo uma disputa regionalizada, ao sul do país, entre o Hizbullah e seu adversário Amal, o prestígio político do primeiro ganhava conforme havia o recuo das tropas israelenses. A Resistência acabara por assumir um verniz de legitimidade e a população libanesa, de forma geral - muçulmanos e cristãos - percebeu que poderia contribuir para a 
'causa libanesa', que naquele momento caracterizava-se como a 'retirada de Israel' de solo libanês.

Recebendo apoio financeiro, político e militar de vários setores da sociedade, além dos antigos aliados - Síria e Irã -, o Hizbullah continuou a fazer inserções na "Zona de Segurança” e conquistar bases estratégicas. Para os israelenses, essas derrotas geravam ainda mais preocupações, isso porque, o SLA não mais estava conseguindo conter o avanço da Resistência.

Esse era apenas um dos muitos problemas relativos à segurança que o Estado de Israel necessitava resolver. Entretanto, grande parte deles também era proveniente da forte disputa interna entre os partidos políticos. Convém lembrar que, em 1996, Benyamin Netanyahu havia alcançado o poder após seu antecessor ter sido derrotado devido aos conturbados efeitos decorrentes da “Operação Vinhas da Ira” e, como plataforma de seu governo, deixava claro que não estaria disposto a ceder qualquer parcela do território conquistado em 1967 para a Síria, tampouco estremeceria em sua luta contra o terrorismo. Contudo, conforme Pipes ressalta, Netanyahu não teria agido exatamente como apresentava sua plataforma política. Ele iniciara negociações com Assad que visavam o estabelecimento de um acordo de paz com base na devolução das Colinas de Golã. (1999)

Pipes, ainda, nos apresenta quais devem ter sido os motivos que levaram o primeiroministro israelense a iniciar esse processo de negociação - que fora travado, em grande parte, de forma secreta: "First, he feared that the Americans would ram a deal with the Palestinians down his throat (as indeed happened at Wye in October 1998) unless he could produce a deal with Syria. Second, his government was reeling from a succession of crises, domestic and foreign, mostly of its own making. Netanyahu wanted to reestablish himself with a major, world-shaking event.” (1999)

O fracasso de Netanyahu abriu a possibilidade para que Ehud Barak, do partido Trabalhista, alcançasse o poder nas eleições de 1999, sendo eleito o primeiro-ministro mais jovem do estado de Israel. Com uma plataforma política mais conciliadora, conseguiu formar uma coalizão com sete partidos políticos, o que lhe dava certa liberdade de ação. Barak deu início ao processo de negociações que pretendia chegar à assinatura de um acordo de paz com o governo sírio. No transcorrer de a "Trilha Síria”, como tornou-se conhecido o processo de negociação, Barak dispôs-se a devolver as Colinas de Golã em troca da paz, contudo, Assad sentia-se numa posição privilegiada - por ter domínio da situação libanesa, o que possibilitava-lhe aferir ataques contra Israel - e adiou qualquer acerto diplomático. Diante da impossibilidade de chegar-se a um acordo com a Síria e, sofrendo pressões internas dos que 
eram contrários à devolução das Colinas de Golã, Barak deixou as negociações e passou a investir em outro front, os palestinos.

Apesar da intenção de negociar com os palestinos, Barak não conseguia estabelecer uma situação análoga diante dos libaneses e, conforme o Hizbullah ganhava mais território no sul - atacando com mais freqüência a "Zona de Segurança” - Israel percebia que não poderia mais contar com o SLA, que, por sua vez, fragmentava-se com a fuga de seus integrantes. Razão forte para essa deserção encontrava-se no receio de sofrer as penalizações provenientes do apoio dado a Israel.

Como nos lembra Harik, o SLA já não tinha como fazer qualquer resistência aos xiitas e, com o desmembramento da milícia, o risco de represálias transpassava aos pequenos enclaves cristãos que existiam no sul, como a cidade de Jezzine. Não tendo quem pudesse protegê-la, haja vista o Estado não possuir condições para tal, sua população poderia ser objeto de atrocidades - como as que marcaram as passagens mais cruéis da Guerra Civil libanesa. Por outro lado, apontando para uma nova fase na história libanesa, o Hizbullah declarava que quem desertasse antes da retirada israelense da "Zona de Segurança” não seria julgado como traidor. Essa estratégia demonstrava ser eficiente, haja vista desestimular qualquer tentativa de reestruturação da milícia e acelerar seu fim, há de se considerar, também, o fato de que abria a real possibilidade de salvação para os milicianos cristãos do SLA, algo que o governo israelense não estava em condições de garantir. (2004: 125-30)

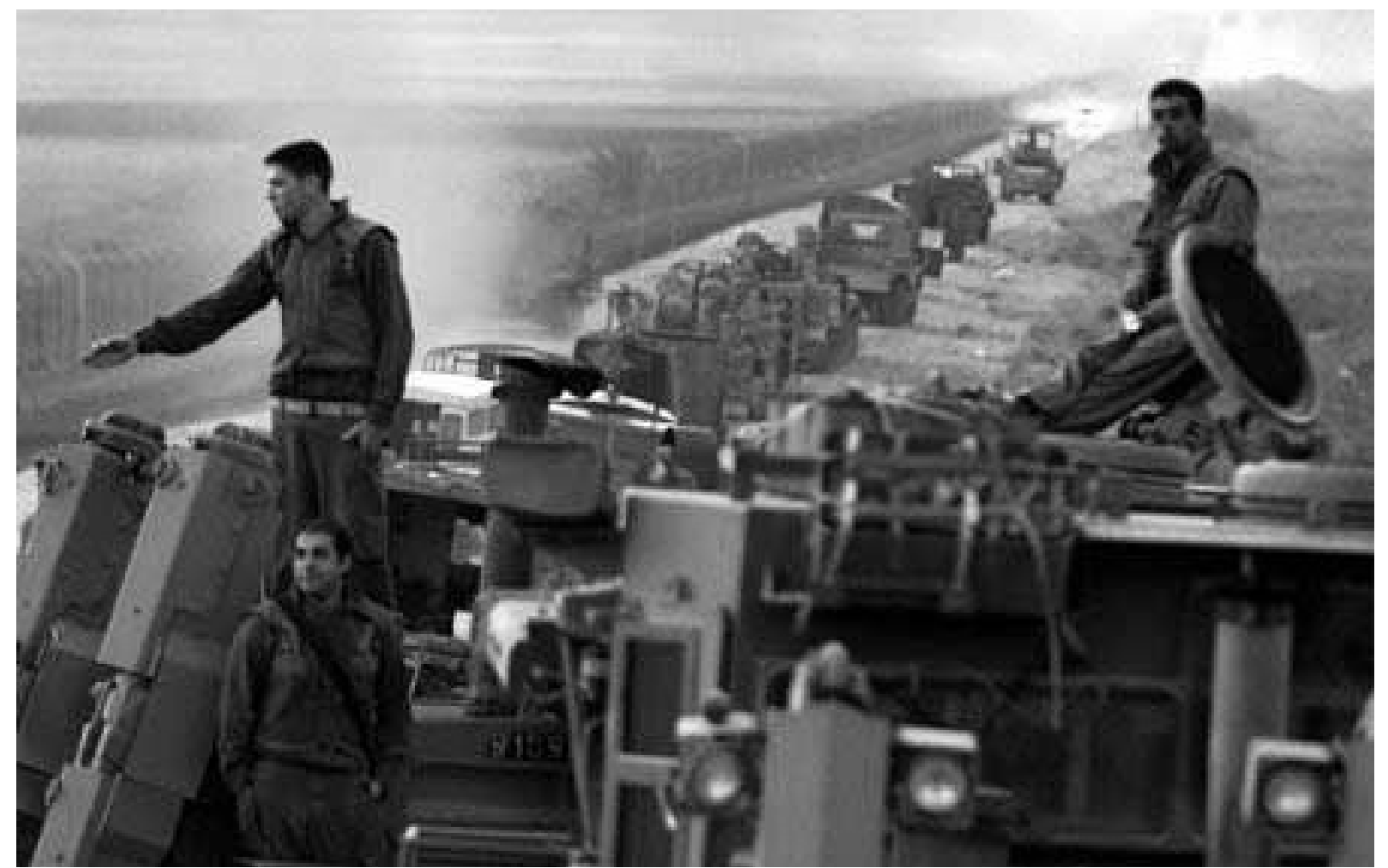

Exércitos israelenses deixando a “Zona de Segurança” - retirada se deu dentre os dias 22 e 24 de maio de 2000. 
Em fevereiro de 2000, o primeiro-ministro Barak tinha a nítida percepção de que a situação na fronteira com o Líbano já chegara ao patamar máximo de sustentabilidade e seria necessária uma ação imediata para revertê-la a seu favor. O “Entendimento de Abril” já não era cumprido pelas partes - ambos atingiam alvos civis em suas ações, apesar de terem acordado o contrário -, entretanto, a legitimidade da luta do Hizbullah pela soberania do Estado dava-lhe maior sustentação internacional e regional. Assim, se, por um lado as ações do Hizbullah contra alvos civis israelenses tinham o impacto reduzido e eram entendidas como uma eventualidade, por outro lado, as baixas provocadas pelas ações israelenses eram entendidas de maneira diferenciada, extremamente agressivas e inadmissíveis. Prova disso, ainda em fevereiro, Uri Appenzeller, analisando a situação libanesa para o Middle East Intelligence Bulletin, assim descrevia as razões para Israel deixar o Líbano:

The Israeli public (...) [in] recent polls show[s] that public support has grown tremendously for a unilateral withdrawal from Southern Lebanon. For this there are several reasons. First, the April Understanding is now perceived by most Israelis as an unacceptable threat to the lives of IDF soldiers in Lebanon because it legitimizes Hizbullah attacks and limits the IDF's ability to act. Second, it is now clear to most Israelis that staying in Lebanon allows Syria to put pressure on Israel at the negotiation table by pushing Hizbullah to attack Israeli soldiers. And third, the Israeli public is striving to get back the sentimental comfort of policy making that is grounded on a national consensus. Israelis are tired of appearing as the "aggressor" and want to return to the moral high ground by dispelling once and for all the myth of Israeli expansionism. However, many government representatives and army officials still hold the position that a unilateral withdrawal from Lebanon would put Israel's security at risk and would harm the ongoing attempts to resume talks with Syria. (2000)

Pressionado pela situação adversa, Barak não teve outra possibilidade de ação senão criar um plano de retirada gradual do Líbano, contudo, considerando a intensificação das ações do Hizbullah e a fragilidade dos poucos milicianos do SLA, a retirada teve de ser antecipada. Seis semanas antes do que fora previamente estabelecido, os exércitos israelenses deixaram a "Zona de Segurança” e os membros do Hizbullah assumiram suas posições. Em 25 de maio o sul do Líbano fora reconquistado - segundo terminologia utilizada pela organização xiita.

Apesar da reintegração territorial, a situação interna libanesa ainda inspirava cuidados devido à fragilidade das instituições e a necessidade de sedimentação do processo democrático. O Hizbullah, sem sombra de dúvida, saiu fortalecido com a vitória sobre Israel, entretanto, concomitantemente, assumira a incumbência de projetar seus próximos passos 
dentro de uma nova realidade ainda não vivida pela organização. Seus dilemas logo tornariam mais evidentes nos momentos posteriores e a necessidade de assumir uma postura menos radical colocaria o Hizbullah em xeque com seus próprios ideais.

Se, para o Líbano abria-se uma nova esperança na busca da real soberania, a presença síria ainda representava resquícios do passado que não parecia condizente com a vontade popular, pelo menos não em sua grande maioria. A Síria, que acabou saindo politicamente vitoriosa com a derrota israelense, ainda veria mais dois golpes sendo proferidos contra o Estado de Israel: 1) A falência das negociações de paz em Camp David (2000) - assim descrita pelo presidente norte-americano, Bill Clinton, patrocinador da cúpula: "Under the operating rules that nothing is agreed until everything is agreed, they are of course not bound by any proposal discussed at the summit." (www.bbc.co.uk, 26/07/2000) - e, 2) O início da chamada segunda intifada pelos palestinos, em setembro do mesmo ano.

\subsection{2 - 2005: SÍRIA DEIXA O LÍBANO}

A primeira questão a ser resolvida pelo Hizbullah, no pós-conquista do sul, dizia respeito diretamente ao Acordo de Taif, assinado em 1990 e que pôs fim à Guerra Civil. Segundo o que ali fora acordado, todas a milícias deveriam depor as armas e o monopólio da violência deveria retornar ao Estado. Naquela ocasião o Hizbullah não aceitou as cláusulas que dispunham a esse respeito e fundamentou sua recusa no fato de ainda haver a necessidade de restaurar a soberania libanesa e expulsar os israelenses do sul do país.

Com a reconquista da soberania - desconsiderando o fato de que as tropas sírias ainda permaneciam no país e esse não era um questionamento feito pelos membros do Hizbullah -, a organização xiita, para não depor as armas, passou a alegar que a retirada israelense não ocorrera completamente e que ainda haveria a necessidade de o exército de Israel deixar Sheeba Farms, um enclave nas proximidades do Monte Hermon.

A questão acerca dessa região é um tanto controversa, segundo os israelenses, Sheeba Farms pertencia à Síria e fora conquistada durante a Guerra dos Seis Dias, em 1967, assim sendo, não haveria porque dali sair enquanto não fossem acertados os termos para um acordo de paz com o governo sírio. Entretanto, o Hizbullah passou a alegar que tais terras sempre foram libanesas, o que era referendado pela Síria. O impasse proporcionava ao Hizbullah a possibilidade de manter-se armado, apesar de os relatórios de ONU ratificarem o fato de Israel ter completado a retirada do território libanês. 
Esse foi somente o início de um longo processo de luta - por parte do governo sírio e também pelos aliados iranianos - pela não desmilitarização do Hizbullah. Manter um partido político e uma milícia armada não parece ser o melhor caminho para alcançar a democracia, entretanto, naquele momento específico, não havia um ator que pudesse fazer frente aos atores externos (Síria e Irã), que dominavam a política libanesa.

Apesar do não desarmamento do Hizbullah, sua vitória contra os israelenses foi percebida de maneira muito positiva pela população libanesa. Tal foi a grandeza do ato que na eleição subseqüente à reconquista do sul (2000), o Hizbullah conseguiu obter grande sucesso nas urnas e elegeu mais parlamentares que seu maior concorrente xiita, o Amal. Desde o restabelecimento do processo eleitoral (1992) o partido de Nabih Berri vinha obtendo maior sucesso que o Hizbullah, apesar de que, em algumas circunstâncias, formavam um bloco único no parlamento ${ }^{66}$.

A influência sobre o Hizbullah por parte da Síria sempre foi grande, graças, em parte, às relações de poder que Hafez al-Assad mantinha com sua cúpula e também com os demais políticos libaneses. Contudo, com sua morte em 2002, e conseqüente subida ao poder de seu filho, Bashar al-Assad, houve uma certa liberalização do Hizbullah. A capacidade de influência de Bashar não era tão grande quanto de seu pai, o que possibilitou ao Hizbullah inclinar-se para o Irã de Khamenei. Sob a influência mais efetiva da autoridade iraniana o Hizbullah conseguia desenvolver melhor sua orientação fundamentalista, contudo, a Síria não viu como perdidos os laços que vinham sendo estabelecidos há muitos anos. (Hamzeh, 2004: 116) Em determinadas regiões, Assad tinha poder de influência e indicava membros que formariam a lista do Hizbullah durante a eleição.

A maneira com que a Síria interferia no Líbano era latente e, para a preservação desse status, o governo de Assad se via obrigado a 'aparelhar' o Estado, ou seja, manter pessoas de sua confiança em postos-chave do governo. Essa estratégia síria inchava a máquina estatal libanesa e tornava-a muito dispendiosa. Hariri, primeiro-ministro libanês, então em seu segundo mandato (iniciado em 2000), percebia o custo de manter o ‘aparelhamento’ do Estado e propunha uma reestruturação que visava reduzir os gastos. Segundo sua estratégia, essa seria uma maneira para conseguir fundos para o pagamento da divida externa que o Líbano vinha adquirindo desde o início de seu primeiro mandato. Àquela altura dos acontecimentos, Hariri não mais mantinha indelével a imagem de criador do ‘milagre econômico libanês’.

\footnotetext{
${ }^{66}$ Sobre a formação de blocos e as estratégias políticas do Hizbullah, veremos mais detalhadamente no capítulo Três, quando analisar-se-á a organização religiosa e o partido político.
} 
A proposta de Hariri, de reduzir a maquina estatal, seria perfeitamente cabível, se inserida num contexto político normal, entretanto, num modelo de Estado em que a autonomia não era exatamente o objetivo a ser alcançado, era tida, por Assad, como de risco. Ainda que o governo de Hariri não alcançasse a unanimidade e muitas de suas ações tivessem sido questionadas por serem parciais, a proposta do primeiro-ministro surgia como uma das poucas possibilidades de o Líbano reduzir suas dívidas e continuar seu crescimento.

À parte as divergências anteriores, as diferenças de interesses entre Assad e Hariri tornaram-se evidentes quando o primeiro-ministro declarou que Michel Aoun poderia retornar de seu exílio que não seria preso. De certa forma, anistiava-o por ter liderado o golpe de Estado em 1990. Provando que os aliados políticos do governo sírio estavam em todas as esferas do poder, o Ministro da Justiça libanês, Samir Jisr, desautorizou Hariri a fazer qualquer promessa de retorno de Aoun e declarou que ele deveria cuidar das questões de governo e que quem deveria deliberar acerca das questões judiciais seria o Poder Judiciário. (Gambill e Abdelnour, 2001) Aoun não retornou ao Líbano, reforçando o poder de persuasão de Assad.

Apesar do surgimento de tensões e divergências, as relações entre Assad e Hariri ainda eram mantidas dentro das expectativas do governo sírio. Até porque, como primeiro-ministro, Hariri conseguia articular muito bem as questões políticas e implementar o crescimento econômico do Líbano, principalmente de sua capital, Beirute. Contudo, um dos maiores problemas de Hariri era sua incapacidade de exercer influência junto ao Hizbullah. Para Hariri seria de extrema necessidade que o Líbano fosse percebido pela comunidade internacional como um país sem conflitos militares, assim, abriria mais possibilidades para a entrada de investimentos externos no país, entretanto, devido à tensão freqüente entre Hizbullah e Israel, sua estratégia ficava parcialmente prejudicada. Por outro lado, sabendo que o Hizbullah agia, também, de acordo com os interesses políticos da Síria, não restava muito a fazer contra a organização xiita, exceto repudiar suas ações.

Assim, mesmo agindo dentro dos limites estabelecidos pelo governo sírio, Hariri tinha planos para um Líbano livre de sua intervenção militar e, quando, em setembro de 2004, a ONU publicou sua Resolução 1559, na qual decretava que todas as tropas estrangeiras deveriam deixar o país para o restabelecimento de sua soberania territorial, o primeiroministro passou a assumir, com mais ênfase, suas reais intenções para o futuro do Líbano.

\section{Resolution 1559 (2004)}

Adopted by the Security Council at its 5028th meeting, on 2 September 2004

The Security Council, 
Recalling all its previous resolutions on Lebanon, in particular resolutions 425 (1978) and 426 (1978) of 19 March 1978, resolution 520 (1982) of 17 September 1982, and resolution 1553 (2004) of 29 July 2004 as well as the statements of its President on the situation in Lebanon, in particular the statement of 18 June 2000 (S/PRST/2000/21),

Reiterating its strong support for the territorial integrity, sovereignty and political independence of Lebanon within its internationally recognized borders,

Noting the determination of Lebanon to ensure the withdrawal of all non-Lebanese forces from Lebanon,

Gravely concerned at the continued presence of armed militias in Lebanon, which prevent the Lebanese Government from exercising its full sovereignty over all Lebanese territory,

Reaffirming the importance of the extension of the control of the Government of Lebanon over all Lebanese territory,

Mindful of the upcoming Lebanese presidential elections and underlining the importance of free and fair elections according to Lebanese constitutional rules devised without foreign interference or influence,

1. Reaffirms its call for the strict respect of the sovereignty, territorial integrity, unity, and political independence of Lebanon under the sole and exclusive authority of the Government of Lebanon throughout Lebanon;

2. Calls upon all remaining foreign forces to withdraw from Lebanon;

3. Calls for the disbanding and disarmament of all Lebanese and non-Lebanese militias;

4. Supports the extension of the control of the Government of Lebanon over all Lebanese territory;

5. Declares its support for a free and fair electoral process in Lebanon's upcoming presidential election conducted according to Lebanese constitutional rules devised without foreign interference or influence;

6. Calls upon all parties concerned to cooperate fully and urgently with the Security Council for the full implementation of this and all relevant resolutions concerning the restoration of the territorial integrity, full sovereignty, and political independence of Lebanon;

7. Requests that the Secretary-General report to the Security Council within thirty days on the implementation by the parties of this resolution and decides to remain actively seized of the matter.

(Fonte: www.un.org)

Com a iniciativa internacional da ONU, muitas alas políticas descontentes com a intervenção síria passaram a mobilizar-se para encontrar uma maneira de implementar a saída das tropas sírias do país, contudo, o governo de Assad não estava disposto a ‘entregar’ o Líbano facilmente e, numa tentativa de preservar-se no poder, apoiou a promulgação da emenda constitucional que prorrogaria o mandato do presidente Emile Lahoud - notoriamente pró-Síria - por mais três anos. Como reação imediata, Hariri deixou o cargo de primeiroministro e passou a atacar vorazmente a presença síria no Líbano. 
O inesperado aconteceu em 14 de fevereiro de 2005, quando, às 12h55, Hariri foi vítima de um atentado. Apesar de seu automóvel ser dotado de vários mecanismos para detectar bombas, os perpetradores do atentado foram mais eficientes ao utilizarem um sistema altamente sofisticado para explodir a limusine que o levava. No atentado, 17 pessoas morreram e mais 134 ficaram feridas.

Explosive experts said that Hariri was killed by a one-ton charge rigged into underground sewage or city water pipes that was mechanically detonated once his motorcade was spotted passing over the bomb. This explains why the sophisticated jamming systems installed in Hariri's armor-plated limousines had failed to neutralize the bomb. (Cedarland)

A situação política libanesa, ao contrário do que o autor do atentado contra Hariri pudesse esperar $^{67}$, tornou-se mais contundente, uma vez que a população saiu às ruas para protestar contra 0 assassinato do "Sr. Líbano” (Fisk, 2005), como Hariri era conhecido por ter sido um dos principais

'reconstrutores' do Líbano no pós-guerra civil. Grande parcela da população receava que o país pudesse imergir no caos que o consumiu por quase quinze anos, devido a

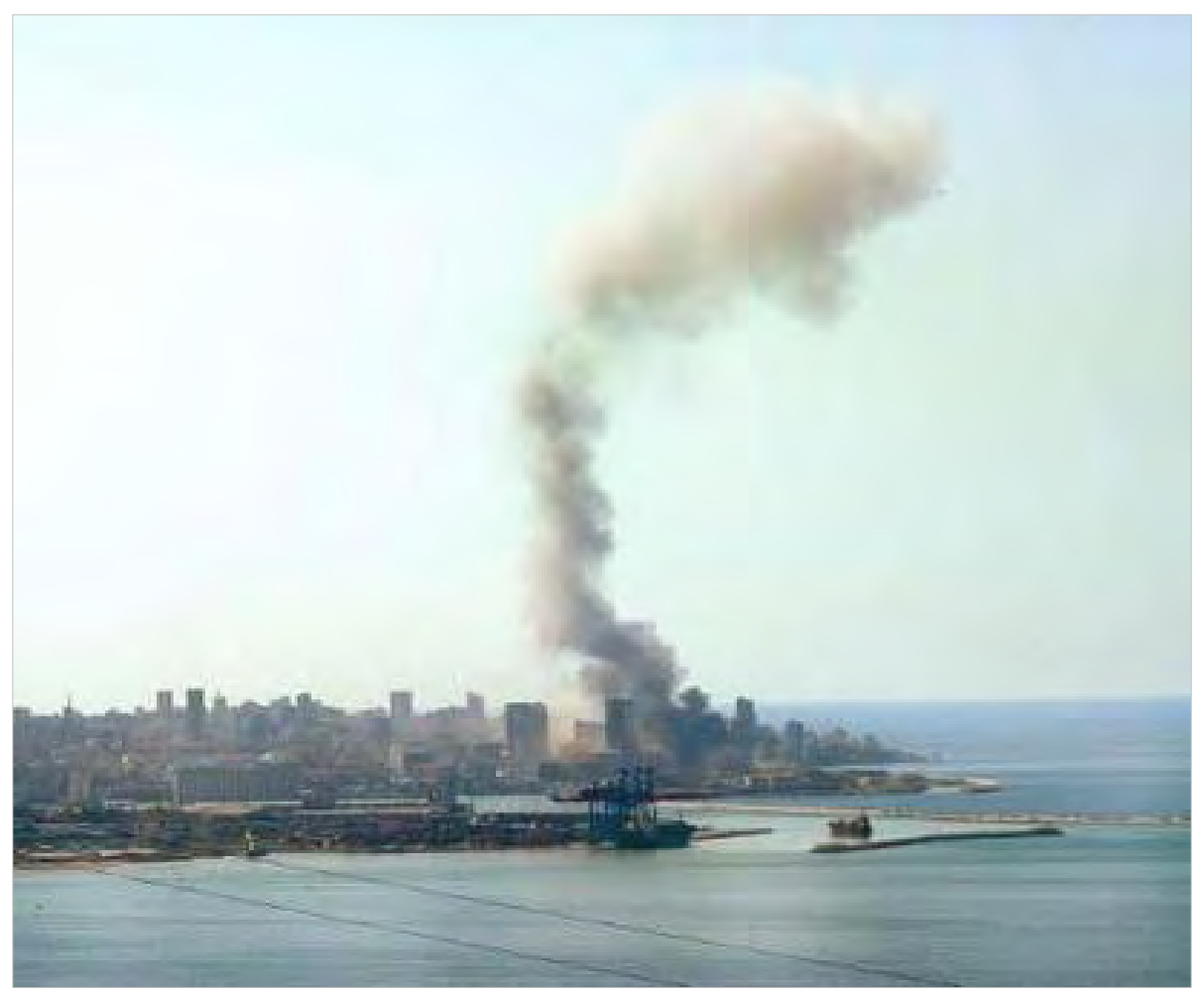

Beirute, atentado contra Rafiq Hariri pôde ser visto à distância, devido à potência dos explosivos. isso, a morte de Hariri tornou-se emblemática como modelo do que os libaneses não mais aceitariam.

Politicamente a situação do presidente Lahoud ficou bastante corrompida, entretanto, manteve o protocolo e nomeou para o cargo de primeiro-ministro Omar Karami. A situação de Karami era extremamente delicada para liderar o governo porque não possuía apoio do

\footnotetext{
${ }^{67}$ Entendendo, aqui, que a intenção desse atentando seria calar os partidários da causa que Hariri defendia, ou seja, a saída imediata das tropas sírias do território libanês e restabelecimento da soberania do Estado.
} 
Parlamento e, diante da pressão imposta pela população - através de protestos de rua clamando pela saída da Síria - acabou renunciando ao cargo em 28 de fevereiro. Contudo, uma semana depois Karami reassumiu o cargo perante o compromisso de que fosse criado um governo de unidade nacional. (Blanford, 2005)

Diante da instabilidade latente, grande parte da população libanesa propôs-se a amenizar suas diferenças religiosas e passou a clamar pela saída das tropas síria do Líbano. Nos vários movimentos populares que tomaram as cidades - principalmente a capital -, um detalhe que saltava aos olhos era a presença maciça de bandeiras do Líbano. Um nacionalismo que poucas vezes o país teve a oportunidade de presenciar devido ao forte sectarismo reinante. Um sentimento nacional que brotou durante no enterro de Rafiq Hariri e estendeu-se por vários dias até alcançar seu fim: a saída das tropas sírias do Líbano. Entretanto, não se pode dizer que não tenha havia movimentos contrários à saída das tropas sírias do Líbano. Dias após as primeiras manifestações de rua contra a presença síria, os partidários de sua permanência mobilizaram um grande número de populares e saíram às ruas para protestar. Nesse caso, a predominância era de bandeiras do Hizbullah.

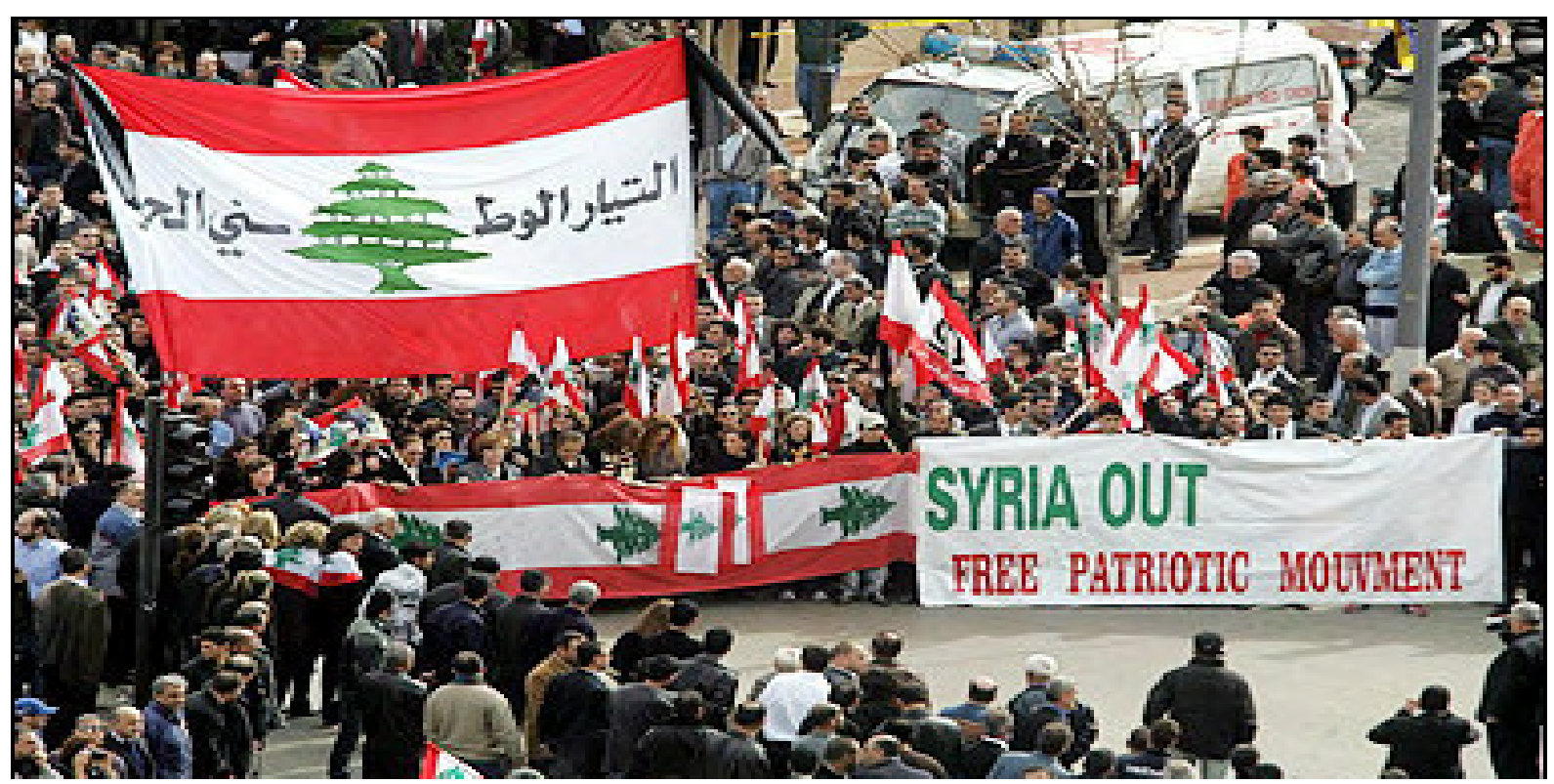

Libaneses protestam contra presença síria no país durante o funeral de Hariri.

Nesse turbilhão de acontecimentos, um aliado de peso ajudou a implementar a saída das tropas sírias do Líbano. Os Estados Unidos passaram a agir com mais veemência contra a violação da soberania libanesa por parte da Síria e exigir que a Resolução $\mathrm{n}^{\circ} 1559$ fosse cumprida imediatamente.

Sem muita margem para manobra e, percebendo que os Estados Unidos poderiam implementar represálias contra a Síria - inclusive uma ação armada -, Assad preferiu agir de maneira que conseguisse preservar-se no poder e tentar a manutenção de sua influência sob o 
governo libanês através de outros mecanismos. Primeiramente negociou uma retirada gradual e, em 26 de abril de 2005, os últimos soldados sírios deixaram o país. Como parte do acordo, os agentes da inteligência síria também deveriam deixar o Líbano, entretanto, apesar de afirmarem ter cumprido, na íntegra, o que fora acordado, muitas suspeitas são levantadas com relação à permanência desses agentes para que, assim sendo, Assad pudesse preservar sua influência no país vizinho.

A retirada das tropas sírias, apesar de gerar uma celeuma, não pode ser considerada unanimidade. Ao mesmo tempo em que contou com árduos defensores, ouviu vozes libanesas clamarem por sua permanência. Muitos aliados de outrora continuaram em postos estratégicos dentro da hierarquia libanesa, além do fato que seu sistema democrático ainda apresenta-se bastante maleável, a ponto de a síria conseguir defender seus interesses através de seus aliados, mas particularmente, o Hizbullah.

De fato, a soberania territorial foi alcançada, entretanto, reminiscências do antigo regime imposto pela Síria ainda continuam presentes no Líbano e somente a maior integração a população poderá criar um momento ideal para que os interesses nacionais se sobreponham ao antigo sistema feudal.

Galgar os degraus que levou à soberania territorial foi imprescindível para o Líbano poder aventurar-se no próximo desafio, qual seja, estabelecer as diretrizes que pautarão seu sistema democrático. Agora, teoricamente sem a interferência de um ator externo em seu sistema político, os libaneses terão de decidir como tratar as correntes mais extremistas, como é o caso do Hizbullah e sua proposta eminentemente fundamentalista. Como poderia ser inserida essa proposta dentro do jogo democrático?

Com base nesse questionamento, o próximo capítulo fará a análise da estrutura da organização religiosa e política conhecida por Hizbullah ou, Partido de Deus. 


\section{( 3 )}

\section{HIZBULLAH}

\section{O MOVIMENTO RELIGIOSO E O PARTIDO POLÍTICO}

A história do Hizbullah, como foi vista, parcialmente, no capítulo anterior, está fortemente ligada à própria história do Líbano e, como é inegável, ao xiismo. Por mais que a organização tenha nascido, oficialmente, em 1985, para entendê-la se faz necessário retomar a fatos que remontam às raízes do xiismo e suas propostas: religiosa e política - se é que podemos fazer distinção entre esses dois elementos ao tratarmos do Islã!

Se, nos capítulos anteriores, recriou-se a história do Líbano e dos principais fatos que repercutiram sob a comunidade muçulmana, agora, neste, passaremos a analisar o processo de transformação pelo qual o Hizbullah sofreu. Primeiramente caracterizado como um movimento religioso (mas também uma milícia) criado para lutar pela soberania do Estado libanês e, depois, transformado num partido político. Não é possível desconsiderar que, para muitos países ocidentais, o Hizbullah nunca foi visto como um movimento de resistência, mas, sim, como uma organização terrorista.

Em que pese a dificuldade de conceituação do fenômeno político-social terrorismo e as áridas discussões que provoca, o grande problema talvez resida no fato de que, muitas vezes o grupo que utilizada de uma estratégia dita terrorista o faz em oposição ao establishment. Segundo Diniz,

\footnotetext{
podemos entender terrorismo como sendo o emprego do terror contra um determinado público, cuja meta é induzir (e não compelir nem dissuadir) num outro público (que pode, mas não precisa, coincidir com o primeiro) um determinado comportamento cujo resultado esperado é alterar a relação de forças em favor do ator que emprega o terrorismo, permitindo-lhe no futuro alcançar seu objetivo político - qualquer que este seja. (2002) (grifos do autor)
}

A partir da definição de Diniz já podemos verificar onde reside o impasse entre o ator que utiliza a estratégia terrorista para alcançar seus objetivos e aquele que é objeto dela. Não se 
questiona o valor da causa pela qual o grupo terrorista luta, ou seja, sua legitimidade. Por ser uma estratégia caracteristicamente usada por grupos que não têm como enfrentar o Estado seu próprio ou estrangeiro - dentro dos parâmetros de uma guerra tradicional, mais nitidamente surge o paradigma do forte contra fraco. No caso do Hizbullah o maior questionamento se dava no tocante à legitimidade de sua causa, a restauração da soberania do Estado libanês. Isso porque, segundo observa o especialista em Relações Internacionais, Ivan Witker,

la Convención de Ginebra establece ciertas garantías a combatientes irregulares de naturaleza guerrillera, homologables al de uno regular, siempre y cuando su causa sea en contra de una ocupación armada (occupatio bellica), son numerosos los casos en que la frontera entre un terrorista y un guerrillero, o un terrorista y un insurgente, es extremadamente tenue. La mayoría de los casos corresponden a un mismo modus operandi, signado por el terror en contra de la población civil, y como parte de un enfrentamiento político con el adversario. (2005)

E, ainda teríamos que acrescentar outro elemento que gera muita controvérsia, qual seja, se as mortes provocadas por operações militares israelenses contra a população civil libanesa poderiam ser consideradas um ato terrorista. Se há diferença entre a morte provocada por um bombardeio israelense a um povoado civil libanês e a de civis israelenses gerada pela explosão de um homem-bomba ou métodos similares. Poderíamos, a partir do modelo analítico proposto por Diniz, entender que ambas as ações teriam a intenção de, atacando a população civil, fazer com que houvesse o recuo dos verdadeiros atores beligerantes, nesse caso, Israel e Hizbullah. Qual seria a diferença?

Se (1) terrorismo é identificado à guerrilha e (2) o uso de terrorismo (de Estado) por um justificasse o uso de terrorismo pelo outro, então poderíamos encerrar a discussão sem terrorismo ser jamais injustificado._A Lei Internacional e a moralidade não reconhecem a legitimidade da represália que alveja civis não-combatentes. Isto sem falar da diferença crucial entre vítimas civis colaterais, lamentáveis, mas inevitáveis numa ação contra combatentes, e um ato que intenciona matar inocentes. Ao constatar que essa foi a principal argumentação do Hizbullah. Há de se considerar que dificilmente matar pessoas indefesas e inocentes intencionalmente poderá ser legítimo. Dessa opinião partilha a Anistia Internacional, a qual condenou tanto Israel quanto Hizbullah

Essa foi a argumentação principal do Hizbullah para continuar sua luta contra Israel, entretanto, o fator que mais pesava (e pesa) para a comunidade internacional é considerar até que ponto a legitimidade de uma luta pode ultrapassar o direito à vida. Mas também deve-se levar em consideração que a partir de 2000, com a saída do Estado de Israel do sul do Líbano 
a tensão entre as partes não acabou, mas os alvos restringiram-se, basicamente, a militares, o que foge do modelo de Diniz e nos abre mais questionamentos acerca da questão: quando o alvo não é civil, temos um atentado terrorista? De modo geral, como é entendimento dos especialistas no assunto, quando o alvo é militar (como no caso de soldados israelenses armados) não é possivel considerar o ataque como terrorista.

Como é possível perceber através dessa breve discussão acerca do terrorismo, a questão relativa à caracterização da organização é bastante controversa e encontra defensores de ambos os lados. Vários analistas já se dedicaram ao estudo do Hizbullah e chegaram a conclusões diversas, muitas delas contaminadas por posicionamentos políticos. Assim, a luta do Hizbullah encontrava legitimidade por objetivar a restauração da soberania de seu Estado, entretanto, legitimidade deve ser atribuída por alguém e, na grande maioria das vezes, ela só era referendada pela comunidade árabe, melhor ainda, por alguns grupos islamistas.

Num complicado jogo de conceituações e interesses, o Hizbullah acabava não alcançando o apoio da comunidade internacional em sua totalidade, principalmente por utilizar métodos contestáveis em sua luta com Israel, tais como, atentados como homensbomba, seqüestros, etc, esses sim, considerados terroristas devido à sua finalidade. Aqui, não se faz a defesa dessa estratégia de ação (ou reação, como alguns diriam), tampouco da organização, entretanto, é fundamental esclarecer que o Estado de Israel também utilizava métodos semelhantes quando seqüestrava lideranças palestinas ou do Hizbullah, torturava e mesmo provocava a morte de civis com suas ações militares - cabe relembrar as emblemáticas operações militares de 1978, 1982, 1993 e 1996 no Líbano.

Isso posto, o que se propõe a analisar nesse capítulo é como foi estruturada a organização e se sua motivação para transformar-se num partido político significou a flexibilização do que entendemos por islamismo, ou, ainda, se trata-se de uma estratégia para alcançar o poder e instituir uma República Islâmica no Líbano, aos moldes do Estado iraniano - cuja ligação com a comunidade xiita libanesa também será alvo de estudo nesse capítulo.

Para entender esse processo de transformação, primeiramente, analisar-se-á a estrutura de poder dentro do xiismo e, posteriormente, na organização e no partido político Hizbullah. Com base nesses dados, poder-se-á, nos capítulos seguintes, estabelecer a discussão acerca da influência das idéias islamistas no sistema democrático libanês. 


\section{1 - O PODER: DOS TEMPOS DE MAOMÉ AO FINAL DO CALIFADO}

O poder se adquire pelo reconhecimento, mas também pode ser imposto. Ao ser exercido reconhecidamente, tem a capacidade de unir povos em torno de uma liderança, mas também pode unir opositores a ele. Em ambos os casos, a existência de um poder sendo contestado ou referendado acaba assumindo valor agregador. Com base nisso é possível entender ainda melhor qual foi o efeito do surgimento do Islã numa Arábia de tribos beduínas - muitas delas nômades -, em que seu aspecto climático não possibilitava grandes facilidades para o estabelecimento de comunidades, dificultando, inclusive, o surgimento de laços sociais.

Dessa forma, o advento do Islã foi um fator que contribuiu para a integração dos povos e para o surgimento de uma nação unida através de uma mesma fé. É bem certo que algumas características tribais, ou dos clãs, já eram comuns a muitos habitantes da Arábia, o que, em tese, facilitou a assimilação do novo modus vivendi.

Whether nomadic or sedentary, the people of Arabia lived in a Bedouin tribal society and culture. Social organization and identity were rooted in membership in an extended family. A grouping of several related families comprised a clan. A cluster of several clans constituted a tribe. Tribes were led by a chief (shaykh) who was selected by a consensus of his peers - that is, the heads of leading clans or families. These tribal elders formed an advisory council within which the tribal chief exercised his leadership and authority as the first among equals. Muhammad belonged to the Banu Hashim (sons of Hashim), lesser clan of the powerful Quraysh tribe which dominated Meccan society. (Esposito, 2005: 03)

A partir dessa estrutura organizacional exposta por Esposito, é possível perceber que os árabes davam grande valor aos laços tribais e ao conhecimento dos anciãos. Nesse contexto, dois fundamentos se destacavam: lealdade e solidariedade, que eram as fontes para o poder dos clãs ou das tribos. "Tribal affiliation and law were the basis not only for identity but also for protection.” (Esposito, 2005: 03) No que tange à religião, prevalecia a crença de que Deus servia como protetor de cada tribo e seu espírito estava associado a objetos sagrados.

Assim, na cidade de Meca, onde encontrava-se a pedra Caaba, as imagens dos deuses ficavam expostos, contudo, segundo Espósito, mesmo dentre as tribos politeístas, havia a crença de um deus maior, Alá. “Allah, the supreme high god, was the creator and sustainer of life but remote from everyday concerns and thus not the object of cult or ritual. Associated with Allah were three goddesses who were the daughters of Allah: al-Lat, Manat, and alUzza.”. (Esposito, 2005: 03) 
O ‘sistema de valores’ ou ‘código ético’ dos árabes era amplamente conhecido como 'humanismo tribal'. (Espósito, 2005: 03) Um modo de vida que não foi estabelecido pela vontade de Deus, mas sim, alcançado graças à experiência de vida da tribo além da incorporação de suas tradições. Como fruto desse 'código', surgiram os seguintes princípios: bravura nas batalhas, lealdade à família e proteção aos seus membros, hospitalidade, paciência e persistência. A partir desses princípios evidenciam-se as duas motivações maiores que pautavam a vida dos árabes, quais sejam, preservação da tribo e da honra da família.

Quando Maomé inicia o recebimento de seu 'chamamento’, em 609 d.C., dois problemas se impõem à ordem regional. Primeiramente, a dificuldade de aceitação, por parte dos líderes tribais, da liderança de Maomé - que se autoclamava o profeta de Deus -, haja vista não ser comum entre as tribos árabes a aceitação de uma autoridade central, e, segundo, o risco que a expansão do movimento liderado por Maomé representava ao Império Bizantino - oficialmente cristão.

Apesar da grande dificuldade vivenciada por Maomé para expandir os desígnios do Islã, seu esforço proporcionou a unificação de grande parte dos povos árabes em nome de uma mesma religião. E, no período em que o profeta esteve vivo, sua liderança não foi questionada pelos fiéis. Muito claramente os seguidores do Islã tinham Alá como deus único e supremo, e Maomé como seu profeta.

Os líderes tribais que aderiram à religião não questionavam a autoridade de Maomé, o que facilitou a difusão da fé. Entretanto, com sua morte, em 632, o mundo muçulmano viu-se diante de um grande problema a resolver: quem assumiria seu lugar? Podemos considerar um grande problema, devido ao fato de que, segundo nos apresenta Ruthven, "There is no 'church' in Islam, no formally instituted body empowered to survive or dictate the religious agenda, to articulate an 'official' Islamic view comparable to that of the Papacy or the appointed or elected leadership of Protestant denominations.”. (2000: 09) Sendo assim, houve a primeira cisão dentro do mundo muçulmano por fatores ligados diretamente ao exercício do poder.

A separação dos muçulmanos em sunitas e xiitas gerou duas maneiras distintas para se entender o poder sucessório. Para os sunitas, qualquer muçulmano poderia alcançar a liderança da umma desde que possuísse grande conhecimento das leis islâmicas (Corão e Sunna) e vivesse segundo os parâmetros estipulados por elas, e, para os xiitas, a sucessão estaria ligada a fatores de ordem familiar, assim, o líder da umma deveria continuar pertencendo à família do profeta. 
Reiterando a afirmação de Ruthven, de que a ausência de uma hierarquia ajudou na fragmentação do Islã, esse efeito foi potencializado quando xiitas e sunitas surgiram como grupos rivais e passaram a lutar pela supremacia do poder no mundo muçulmano. Pelos sunitas, os xiitas eram considerados hereges e deviam ser perseguidos. E, considerando que a grande maioria dos muçulmanos acabou assimilando o sunismo, as possibilidades que surgiram para os xiitas foram restritas: seguir os ensinamentos quietistas do sexto imã, Já’far al-Sadiq “que pregava a seus seguidores a resistência passiva até o advento do mahdi, aquele que Deus enviaria a fim de restaurar o reinado da religião e da justiça.” (Hourani, 2001: 56), ou partir para a radicalização, no intuito de alcançar seus fins - a preservação da verdadeira forma de compreender o Islã. Exemplo notório do segmento que optou pela radicalização, temos os ismaelitas que passaram a ser conhecidos por Assassinos ${ }^{68}$. Também, concomitantemente a cisão dos muçulmanos, sua liderança passou a ser vista de outra maneira; não mais havia um califado que correspondesse aos anseios da umma de maneira geral.

Assim, conforme ampliava a divergência dentre os muçulmanos, surgiam lideranças que reivindicavam a autoridade suprema sobre os seguidores da religião. Esse processo também se tornaria mais complexo com o surgimento de reivindicações pelo poder no interior das próprias comunidades. Dessa forma, em momentos distintos da história muçulmana a autoridade deixou de ser exercida por um único Califa.

Conforme Hourani expõe, essa fragmentação do poder dentre os muçulmanos propiciou o enfraquecimento da figura do califa e fortalecimento do sultão, que passou a exercer o poder militar dentro do império, mas que, ao assumi-lo, acabou ocupando uma posição privilegiada e teve a possibilidade de influir, também, nos aspectos políticos e religiosos. De maneira geral,

O Califado (ou imamato, como os teóricos em geral chamavam) tinha três elementos: o da sucessão legítima do Profeta, o da direção dos assuntos do mundo, e o da vigilância sobre a fé. Ghazali afirmava que, idealmente, esses três aspectos deviam ser unidos numa pessoa, mas em caso de necessidade podiam ser separados, e essa era a situação em sua época [1085-1111]. O califa incorporava a sucessão do Profeta; o sultão, detentor do poder militar, exercia funções de governo; e os ulemás vigiavam a crença e a prática religiosa. (Hourani, 2001: 155)

Durante o último grande império que dominou o mundo muçulmano, aquele conhecido como Império Otomano, de fato, o poder era exercido pelo sultão, que, por sua vez,

\footnotetext{
${ }^{68}$ Os ismaelitas formam uma subdivisão do xiismo. Sobre os Assassinos, ver: LEWIS, Bernard. Os Assassinos os primórdios do terrorismo no Islã. Rio de Janeiro: Jorge Zahar Editor, 2003.
} 
mantinha um conselho de sábios sobre o Islã, os ulemás, para dar-lhe assessoramento. Em tese esses sábios na religião islâmica deveriam auxiliar o sultão para que não agisse em desconformidade com o Corão e a Sharia, entretanto, é sabido que o poder exercido pelos sultões era tamanho que, muitas vezes, tinha os ulemás trabalhando para si e fazendo com que eles encontrassem embasamento religioso nas suas ações.

O último califado conseguiu se manter até a década de 1920, quando os interesses políticos e econômicos das potências européias passaram a influir com mais veemência sob o Oriente Médio, daí houve a fragmentação do Império Otomano. O resultado dessa transformação deu-se na partilha do mundo árabe pelas potências coloniais do ocidente, contudo, uma das poucas regiões que conseguiu manter-se independente da ação foi a Turquia, que iniciou um processo de ocidentalização do país sob o governo de Mustafá Kemal (Atatürk, 1881-1938).

\section{2 - O DESEMPENHO DO PODER: AOS OLHOS DOS XIITAS}

Reger a comunidade muçulmana significava poder, contudo, o líder não era visto da mesma maneira por xiitas e sunitas. Os xiitas tinham na figura do Imã (líder) o regente dos fiéis. Entretanto, embora não fosse o profeta, era divinamente inspirado, sem pecados, infalível, e, assim, alcançava a prerrogativa necessária para tornar-se político e religiosamente o líder da comunidade. Ele devia ser um descendente direto do Profeta Maomé e de Ali, o primeiro Imã. Era visto, ao mesmo tempo, como líder político e guia religioso; a autoridade final para interpretar a vontade de Deus que está formulada nas Leis Islâmicas. Por outro lado, os sunitas optaram pelo califado. Nessa concepção de poder, o califa era selecionado ou eleito para suceder o Profeta - o sucedia político e militarmente -, contudo, não possuía a autoridade religiosa de Maomé. (Espósito, 2005: 43)

O processo sucessório dentro da comunidade xiita não transcorreu de maneira conciliatória, ou seja, em momentos específicos da história xiita, aconteceram cismas internos e alguns grupos elegeram Imãs distintos. Em 740, houve o cisma dos Zaydidas, que reconheciam a legitimidade de apenas quatro Imãs, até Ali Zayn al-Abidin; em 760, mais outra cisão, surge o grupo que passaria a ser conhecido como Ismaelita, que reconhece a legitimidade da sucessão até o sexto Imã, Já'far al-Sadiq, depois elege Ismail, divergindo da seqüência reconhecida pelo último grupo resultante dos cismas - que considera o sétimo imã, Musa al-Kazim -, o qual acabou sendo o que mais fiéis aglutinou. Ele passou a ser conhecido 
por Duodécimo, devido reconhecer a sucessão até o décimo segundo Imã, Muhammad alMuntazar, que teria entrado no estado de ‘ocultamento’ (ghayba), em 874. Segundo, ainda, a crença dos duodécimos, somente no momento do retorno do 'Imã Desaparecido' haveria a instituição da harmonia e justiça na Terra.

A partir do momento em que os xiitas passaram a não ter mais a presença de um Imã na Terra, buscaram saídas para resolver desentendimentos. Partindo do pressuposto de que Ali e os outros Imãs eram modelos divinamente inspirados, e serviram como guias e intermediários entre Deus e seus fiéis, na sua ausência, os ulemás ou mujtahids e líderes locais (mullas) serviriam à comunidade como guias. Assim, na ausência do Imã, um distinto clero poderia servir como guia supremo e autoridade legal.

No nível teológico, existem algumas grandes e muitas pequenas diferenças entre sunitas e xiitas. Os dois ramos partilham apenas três doutrinas: a unicidade de Deus, a crença nas revelações de Maomé e a crença na ressurreição do profeta no Dia do Julgamento. Entretanto, devido às divergências que os xiitas passaram a serem considerados hereges pela maioria sunita. Conseqüentemente, alguns aspectos que os xiitas incorporaram à maneira de entender e praticar o Islã, tais como, a visão divinificada do imã, o não reconhecimento de alguns hadith, dentre outras, levaram-nos a perseguições e massacres. Sob as dinastias sunitas, os xiitas eram obrigados a fugir constantemente.

Esse tipo de perseguição fez com que os xiitas, com a queda da dinastia Fatímida (909-1171) no Egito, rumassem para o Líbano. Ali, encontrando a supremacia dos maronitas, acabaram estabelecendo-se no sul da província e também no Vale do Bekaa. A participação na vida política do Império Otomano era limitada e, mesmo quando teve início o processo de independência libanês, os xiitas não tiveram participação significativa.

\section{3 - O SURGIMENTO DO PENSAMENTO ISLAMISTA}

É importante salientar que, apesar do sucesso alcançado pelo governo turco de Aratürk - analisando somente o aspecto econômico - com a secularização do Estado e limitação da religião à vida privada de seus nacionais, seu modelo administrativo não foi adotado pelos demais Estados com maioria muçulmana devido a alguns fatores preponderantes. Primeiramente, havia a repulsa por parte de alguns segmentos da comunidade islâmica que condenavam a ocidentalização do Islã - processo que já vinha transcorrendo no Império Otomano desde a implantação das reformas através do Tanzimat (1839-1876). Esses 
movimentos contrários às reformas entendiam que na própria secularização do Estado já subsistia um profundo contra-senso, qual seja, separar Política e Religião. Ao se adotar tal política estaria praticando a violação do entendimento dos ditames do Corão.

Em segundo lugar podemos observar que o modelo de Estado de Atatürk também não se consistia em unanimidade devido às críticas a ele feitas pelos movimentos nacionalistas árabes que alcançavam maior repercussão no Oriente Médio. Em muitos aspectos, esses ideólogos do nacionalismo árabe buscavam diferenciações dos turcos pois percebiam neles o estigma de terem sido aqueles que impuseram a dominação sobre os árabes por vários séculos. Por outro lado, o sucesso de Atatürk também se deu devido ao fortalecimento do pensamento nacionalista turco - privilegiando a população turca em detrimento à umma - e a maneira de tratar a oposição, seja ela formada pelas minorias étnicas ou políticas. Assim, o processo de limpeza étnica que já vinha sendo implementada na Turquia desde seus antecessores continuou em progresso e reduziu o poder da oposição ao regime.

Se, por um lado, a Turquia conseguiu obter êxito em suas reformas, como foi dito, por outro, a fórmula advinda da ocidentalização não repercutiu tão bem nos países árabes ao seu redor. Na comunidade sunita, maior representante do mundo muçulmano, começaram a surgir movimentos que questionavam a ocidentalização da cultura islâmica. Sob duas vertentes principais, uma que pregava a assimilação da modernidade com a preservação dos valores islâmicos e a outra que repudiava completamente quaisquer traços dessa ocidentalização. Com vistas nesse panorama conflituoso, o Egito, que no início do século XX encontrava-se sob o domínio britânico, tentou assimilar os ideais de democracia e pluralismo difundidos pela potência ocidental, contudo, a postura dos ingleses, visando preservar seu status quo no local, nem sempre comportou-se condizentemente com seus ideais e isso fomentou ainda mais o desenvolvimento da radicalização do pensamento islamista.

Em 1922 a Inglaterra concedeu ao Egito uma certa autonomia. O quediva Fuad subiu ao trono; o país ganhou uma constituição liberal e um organismo parlamentar representativo. Mas não era uma verdadeira democracia. Londres continuava controlando a defesa e a política externa. Entre 1923 e 1932 o popular partido Wafd, que reclamava o fim da ocupação britânica, obteve três grandes vitórias eleitorais sob a constituição liberal, porém nas três ocasiões teve de renunciar ao mandato, pressionado pelos ingleses ou pelo rei. As novas estruturas democráticas eram ilusórias, e essa dependência não ajudava os egípcios a conquistar a autonomia essencial ao espírito moderno. Além disso, quanto mais os ingleses adulteravam o processo eleitoral, mais corrompido parecia o ideal democrático. (Armstrong, 2001a: 221/2) 
Dessa disparidade de comportamento com relação à teoria e à prática, a insatisfação começou a brotar junto à comunidade muçulmana. No Egito controlado pelos britânicos, ou mesmo nos países árabes sob seu mandato - ou da França -, os muçulmanos questionavam com veemência o posicionamento ambíguo das potências. É evidente que não era uma postura compartilhada por todos os segmentos sociais; aqueles que obtinham benefícios com a presença estrangeira em seu país não faziam muitos questionamentos acerca da ambigüidade. Um caso emblemático pode ser ilustrado com a postura dos cristãos maronitas que contavam com o apoio dos franceses no Líbano embora tenha sido dessa comunidade que o pensamento nacionalista árabe teve início.

Para a assimilação da modernidade ${ }^{69}$ proposta pelo ocidente, a qual alavancaria a vida dos muçulmanos na direção do progresso, concessões poderiam ser feitas, inclusive pensando numa interpretação menos literal do Corão e absorção de ideais ocidentais, contudo, a prática mostrava que o poder permanecia estratificado e apenas uma pequena parcela de muçulmanos tinha acesso às benesses ocidentais.

Ainda que o nacionalismo egípcio exercesse mais influência sob a população que o próprio Islã, pensadores sunitas, como Rashid Rida, ainda tentava encontrar maneiras para conciliar Islã e modernidade. Rida, em sua obra, al-Khalifa (1923), defende a restauração do califado, baseado na sharia, contudo, assimilando a modernização ocidental, mas não a secularização. Conforme a visão de Rida, “O estabelecimento de um califado verdadeiramente moderno requeria um demorado período de preparação. O futuro califa seria uma grande mujtahid $^{70}$, tão versado na lei islâmica que modernizaria a Shariah sem diluí-la. Assim conceberia leis que os muçulmanos modernos poderiam realmente seguir, porque seriam baseadas em suas próprias tradições, e não importadas do exterior.” (Armstrong, 2001a: 222223)

\footnotetext{
${ }^{69}$ Ahmed, adotando o conceito de modernidade segundo o ponto de vista de Anthony Giddens, parte do pressuposto de que sua concepção advém do ocidente: Um período posterior à Revolução Industrial e mesmo à Revolução Francesa e a Independência das treze colônias britânicas da América do Norte que deram origem aos Estados Unidos. Portanto, modernidade não seria um fenômeno ligado à história islâmica, entretanto, o mesmo conceito é utilizado para servir de contra-ponto entre o que os muçulmanos percebiam do modo de vida ocidental e o seu. Algo até certo ponto idealizado, portanto, passível de nunca ser alcançado. Assim, para Ahmed, "a modernidade passou a significar a mais recente fase da história do mundo, marcada pela crença na ciência, no planeamento, no secularismo e no progresso. Os desejos de simetria e ordem, de equilíbrio e autoridade também o caracterizam. O período é notado pela sua confiança no futuro, por uma convicção de que a Utopia é realizável, de que existe uma ordem mundial natural, que é possível concretizar. Pensava-se que a máquina, os projectos industriais gigantescos, o aço, o ferro e a eletricidade se encontravam à disposição da humanidade, para realizar esse objetivo. A tendência para a industrialização e a confiança no físico criou uma ideologia que enfatizou o materialismo como modo de vida.” (Ahmed, 1992; 21/22)

${ }^{70}$ Legista religioso reconhecidamente qualificado a divulgar interpretações próprias sobre as Leis islâmicas.
} 
Paralelamente ao processo de questionamentos que os muçulmanos sunitas faziam com relação à política britânica implementada no Egito, os ulemás iranianos a faziam no tocante ao regime do Xá - que era fortemente influenciado pelos russos e britânicos. Segundo o entendimento dos clérigos, instituir uma constituição para o país limitaria o autoritarismo do Xá e essa reivindicação foi levada até as últimas conseqüências, quando, em 1905, irrompeu a Revolução Constitucional. Assim, foi criada a Majlis (Assembléia Representativa) que ganhou ainda mais poder com a assinatura da Lei Fundamental, com ela, “o monarca tinha de pedir a aprovação da Majlis em todas as questões importantes; todos o cidadãos (inclusive os que professavam outra fé) eram iguais perante a lei; a Constituição garantia os direitos e liberdades pessoais.” (Armstrong, 2001a: 224) Se, por um lado os mullas conseguiram reduzir o poder do Xá, por outro, acabaram se frustrando devido ao fato de que a Majlis não buscou criar uma constituição nos moldes da sharia. Assim, apesar da forte contestação por parte da classe religiosa iraniana, o processo não mais retroagiria.

Com a implantação do modelo constitucional de governo, os clérigos xiitas iranianos entenderam que poderiam restabelecer seu domínio perante o Estado, entretanto, os desentendimentos dentro da Majlis, que era composta por membros de vários segmentos sociais, inclusive não-muçulmanos, suscitou questões ainda mais difíceis para serem respondidas, as quais atingiam a doutrina islâmica. Shaykh Fadlullah Nuri (1843-1909), um dos três clérigos mais influentes de Teerã, alegava que quem representava o Imã, na sua ausência, eram os mujtahids e não a Majlis, e somente, aos primeiros, caberia legislar e proteger os direitos dos muçulmanos. Nuri, abertamente apresentava-se contra a secularização e o regime constitucional.

O modelo constitucional não alcançou o resultado esperado e, em junho de 1908 houve um primeiro golpe de Estado que levou ao fechamento da Majlis. Na ocasião o Xá contou com o apoio de tropas russas para sua empreitada. No entanto, no mês seguinte houve um contra-golpe e refreou o projeto do Xá. Ele foi deposto e seu filho alçado ao poder como rei, porém, o governo passou a ser exercido por um regente liberal. Em dezembro de 1911, quando a Majlis tentou implementar leis que reduziriam a influência dos russos e ingleses sobre os assuntos iranianos; novamente, as tropas russas marcharam sobre o Teerã e fecharam a assembléia. No período posterior, o Irã ainda seria invadido por russos e ingleses em 1917, entretanto, com a revolução Bolchevique, os primeiros se retirariam do território.

A partir das transformações geopolíticas da região do Oriente Médio, outra potência passou a ganhar mais destaque até conseguir influir diretamente no sistema políticoeconômico iraniano, os Estados Unidos. Em negociações entre as partes, os estadunidenses 
receberam a concessão para explorar o petróleo iraniano em troca de investimentos no país. Assim, os ingleses perderam a supremacia e teve início uma nova era para o país sob o governo do Xá Reza, francamente apoiado pelo ocidente.

A dificuldade de integração entre modernidade e preceitos islâmicos cada vez mais ficava acentuada e gerava insatisfação. Se, no início do século XX, ainda havia pensadores islâmicos que entendiam que a modernidade traria benefícios para os muçulmanos, a violenta colonização do Oriente Médio e norte da África - por parte das potências ocidentais européias - começou a colocar em dúvida tal possibilidade. Muitos dos preceitos ocidentais somente serviam como propaganda, mas não eram praticados.

Se os xiitas do Irã passavam pelo dilema entre modernidade e rigor religioso do Islã, a comunidade xiita iraquiana sofria, ainda, outro tipo de problema, e com a ascensão do Baath ao poder - imbuído de ideologia socialista -, passou a ter seus direitos políticos limitados, assim como a liberdade da prática religiosa.

Desse contexto impregnado de perda de identidade (ou busca de uma nova), alguns pensadores passaram a aventar a possibilidade de que o retorno à fonte seria a saída para os anos de decadência que os muçulmanos estavam vivendo. Tanto sunitas quanto xiitas buscavam rever suas trajetória para encontrar respostas. Segundo sua maneira de entender o que estava acontecendo, a culpa para os muçulmanos estarem vivendo submissos aos ocidentais recaia ao fato de terem se afastado dos mandamentos do Corão e da sharia.

No tocante à rejeição ao Ocidente havia uma diferença de procedimento por parte das duas linhas de pensamento islâmicas: secularista e modernista. Ambas tinham a percepção da fraqueza da comunidade muçulmana e a ameaça que o imperialismo ocidental representava, e, mesmo assim, reconheciam o valor das ciências e tecnologia. A divergência se dava na forma de reagir ao Ocidente. Os secularistas contestavam a hegemonia política ocidental, no entanto assumiam seu modo de vida e viam naquele modelo algo a ser alcançado pelos muçulmanos. No entanto, no Egito, da Irmandade Muçulmana (orientada por Hasan al-Banna e que, a partir de 1953 contou com as idéias mais radicais de Sayyid Qutb ${ }^{71}$ ) e na Índia, da Jamaat-i-Islami

\footnotetext{
${ }^{71}$ Qutb (1906-66) inicialmente não era um extremista, contudo, “em 1956 ele foi preso por al-Nasser por ser membro da Irmandade [Muçulmana] e, no campo de concentração, convenceu-se de que as pessoas religiosas e as partidárias do laicismo não podiam viver em paz na mesma sociedade. Ao testemunhar a tortura e a execução dos irmãos, e ao refletir sobre a confessada determinação de al-Nasser de jogar a religião na marginalidade, no Egito, ele pôde ver todas as características de jahiliyyah [a 'ignorância’ e o barbarismo do período pré-islâmico], o que ele definia como o barbarismo que seria sempre e durante todo o tempo o inimigo da fé, e contra o qual os muçulmanos, seguindo o exemplo do profeta Maomé, estavam destinados a lutar até a morte. [...] Qutb aplicava o termo jahiliyyah, que na historiografia muçulmana convencional tinha sido utilizada somente para descrever o período pré-islâmico na Arábia, à sociedade muçulmana contemporânea. Embora um governante como al-Nasser professasse externamente o islamismo, suas palavras e ações demonstravam que era um apóstata e que os
} 
(Sociedade Islâmica), dois representantes do neorevivalismo, a forma para entender Islã era muito mais clara e objetiva:

Both capitalism and Marxism represented man-made secular paths that were alien to the God-ordained, straight path to Islam. If Muslims were to remain faithful to God and His divine will, they must reject Western secularism and materialism and return solely to Islam, whose perfection assured guidance in all aspects of life. (Esposito, 2005: 149)

Ao contestarem esses valores ocidentais, reafirmavam que o Islã não era apenas mais um elemento da vida social ou política de seus membros, era uma ideologia que compreendia a vida pública e privada das pessoas, a fundação para a sociedade e Estado muçulmano. (Espósito, 2005: 149)

A Irmandade Muçulmana acabou sendo perseguida, seus líderes aprisionados ou executados e a organização banida do Egito em meados dos anos de 1960 - sob o governo de Nasser. Entretanto, estendeu seus braços para outras localidades: Sudão, Síria, Jordânia, Kuwait e também Palestina.

Se a comunidade sunita passava pelos dilemas relativos à modernidade e sua inserção nos ditames do Corão, os xiitas também viviam tal ansiedade e colocavam à prova a relação com o Ocidente. No entanto, a discussão dava-se de forma mais pontual. Em Najaf (Iraque) e Qom (Irã), onde estudavam os teólogos xiitas, a insatisfação com o Ocidente também era objeto de questionamentos, contudo, a esse problema agregava-se o fato de os xiitas continuarem sendo discriminados no mundo muçulmano e, mais particularmente, no Líbano e Iraque.

Em Najaf, durante o período em que o Partido Baath assumira o poder, muitos clérigos xiitas confrontaram-se com o regime, dentre eles, Muhammad Baqir al-Sadr, que claramente expunha sua insatisfação com relação à discriminação dos xiitas e também por não entender o socialismo do Baath como um regime islâmico. Al-Sadr tornou-se um difusor de suas idéias através do periódico al-Awa' (as luzes), nele, defendia o ideal islâmico contra a política baathista que havia alçado ao poder com o Golpe de 1958.

Nesse mesmo período, al-Sadr escreveria duas obras que influenciariam na doutrina de Khomeini, futuramente, Falsafatuna (Nossa Filosofia, 1959) e Iqtisaduna (Nossa Economia, 1961). No primeiro al-Sadr fazia uma crítica ao comunismo, à escola do pensamento materialista e ao materialismo dialético. Segundo suas ponderações, o comunismo teria muitas

muçulmanos tinha o dever de derrubar esse governo, exatamente como Maomé tinha forçado a sociedade pagã de Meca (a jahiliyyah do seu tempo) à submissão.” (Armstrong, 2001b: 225) 
falhas e deficiências para ser considerado a 'verdade final para a humanidade'. Em sua segunda obra, al-Sadr criticava a teoria econômica no comunismo e no capitalismo e introduzia uma Teoria Islâmica de Política Econômica. Esforçava-se, assim, para conter os argumentos dos secularistas e comunistas de que o Islã carecia de soluções para os problemas do homem da atualidade. Al-Sadr ainda criou o Partido Da'wa (Chamado), que futuramente estabelecer-se-ia no Líbano, para difundir a proposta islamista xiita.

The aim of the Da'wa was to organize dedicated Muslim believers with the goal of seizing power and establishing an Islamic state. To achieve that goal it would indoctrinate revolutionaries, fight the corrupt regime, and establish an Islamic state; then it would go on to implement Islamic laws and export the Islamic revolution to the rest of the world. This grand plan was said to be Sadr's idea. The first stage had to be clandestine to secure the party against a crackdown, so the party was organized in a hierarchical multi-branch cell structure. Its activities were not to be limited to Iraq only, but were to go on in other Shi'a communities around the world. To that end, branches were secretly formed in the Gulf States and in Lebanon; attempts to form them in Iran were unsuccessful. (Aziz)

Al-Sadr foi aprisionado em 1980, depois de assumir publicamente o apoio à Revolução Islâmica Iraniana, e condenado à morte. Entretanto, seu legado seria defendido por seu companheiro de Najaf, Aiatolá Khomeini, que assumira o poder no Irã e desenvolveria sua doutrina utilizando fundamentos de al-Sadr.

\section{4 - O XIISMO NO ESTADO LIBANÊS}

Apesar de sofrer muitas influências dos movimentos políticos e religiosos que efervesciam no mundo árabe, os xiitas que viviam no Líbano tinham algumas particularidades - como o reconhecimento da liderança do wali al-faqih (Aiatolá Khomeini; que será discutida a seguir) e os próprios laços religiosos do xiismo - que acabaram encaminhando-lhes para uma ligação mais íntima com o Irã e, conseqüentemente, com a radicalização ali proposta.

Sem dúvida, o ressentimento por parte de seus dominadores também teve grande influência nessas opções. Assim, é importante salientar que, concomitantemente às perseguições, a liberdade de culto era bastante cerceada. No Império Otomano e, mesmo no Iraque, ambos governados por sunitas, as xiitas eram proibidos de celebrar sua principal 
comemoração religiosa, Ashura ${ }^{72}$, tendo de fazê-lo secretamente. Um processo de exclusão social que agravou-se como a instituição do Estado libanês - tendo de subordinar-se ao governo maronita - e fez com que a camada da população xiita libanesa buscasse outras maneiras de proteger-se, ou mesmo identificar-se.

Para tentar entender o processo de segregação que viviam, os xiitas libaneses, cada vez mais, apegavam-se a seus modelos de sofrimento e martírio - segundo o legado do Imã Hussein - para explicar a exclusão político-social. A grande esperança de restauração do poder xiita somente se daria com o retorno do 'Imã Desaparecido', mahdi. De certa maneira, o que reinava era o sentimento de resignação e, assim, mesmo com o processo de independência libanês em curso - e depois efetivado -, o domínio político se dava por outros grupos religiosos mais representativos, como maronitas, sunitas e drusos ${ }^{73}$. A comunidade xiita permanecia excluída das questões nacionais e o poder dos zuama (autoridades locais) xiitas acabava restringindo-se às suas regiões, sem esperar por uma melhora na qualidade de vida de sua comunidade.

The Shiites, meanwhile, continued to trail behind the rest of the country. The government neglected then and the Shiites' own feudal, landowning leaders were more interested in their personal pursuit of power than welfare of their community. The Shiites not only lacked representation, but the basic necessities of modern life, such as schools, hospitals, roads and running water. In comparison with the prospering areas of the Sunnis and Christians, their standard of living was medieval. (Jaber, 1997: 10-1)

A situação dos xiitas passou a sofrer uma transformação mais radical com a ascendência de Musa al-Sadr à liderança da comunidade libanesa, em 1959. De acordo com Hamzeh, essa data é fundamental porque esclarece a origem do islamismo xiita.

The origins of Shi'i Islamism in Lebanon go back not to Iran, as is commonly thought, but to Iraq in the 1960s where a Shi'i religio-political revival took place in the "circles of learning" (hawzat al-'ilmiya) in Najaf, led by the charismatic Ayatollah Muhammad Baqir as-Sadr. These circles became the epicenter of Shi'i activism and the home base of the Party of Islamic Call (Hizb ad-Da'wa al-Islamiya), which propagated a revivalist message calling for a revolutionary transformation of society among Shi'i communities in Iraq, Iran, the Persian Gulf, and Lebanon. Virtually all of Lebanon's major Shi'i leaders came out of this circle in Najaf. (1997)

\footnotetext{
${ }^{72}$ Celebração do martírio do Imã Hussein, ocorrido em Karbala, Iraque, no final do século VII. Data marcada por festividades e ocorre todo dia 10 do mês de Muharram.

${ }^{73}$ Esse último não conseguindo preservar o mesmo status que possuía no período em que a província libanesa ainda fazia parte do Império Otomano, conforme foi narrado nos capítulos anteriores.
} 
Tendo nascido em Qom, Sadr recebeu educação religiosa em Najaf, Iraque. Por isso seu pensamento político-religioso estava impregnado das idéias propagadas pelos ideólogos xiitas. Essas cidades eram os dois maiores centros teológicos xiitas da época. Líder carismático, Sadr mantinha relações de amizade com o Aiatolá Khomeini e com o presidente sírio, Hafez al-Assad; fato esse que viabilizaria seu projeto de fortalecimento da comunidade xiita libanesa.

O processo de revitalização do xiismo no Líbano perpassava pela reinterpretação de Sadr dos eventos que compunham a História xiita. Segundo sua visão, os eventos marcantes de sua comunidade tinham sido interpretados de forma a mantê-la submissa a terceiros e alheia ao processo político que se desenrolava. A partir da constatação dessa

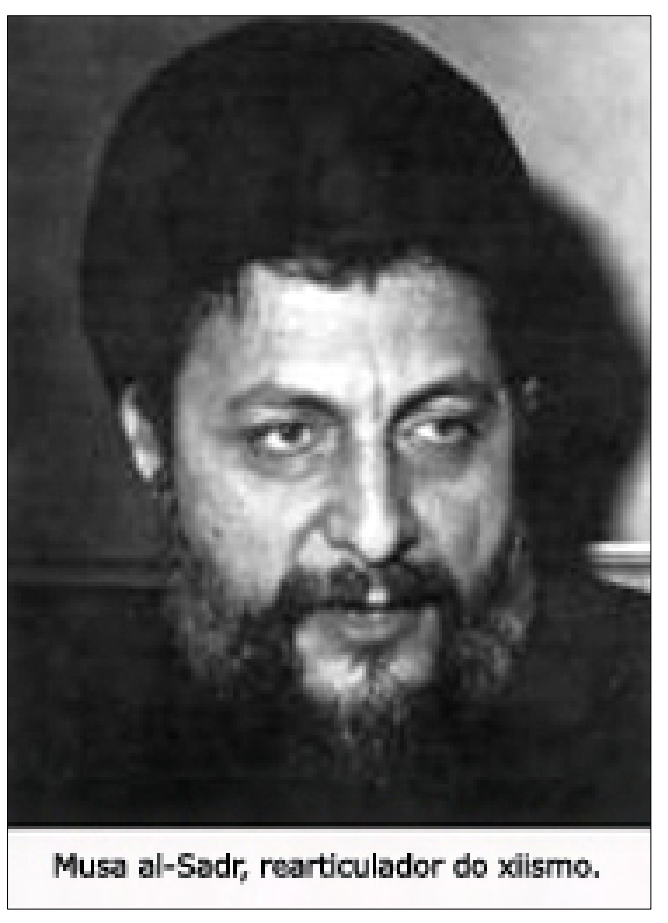
problemática, Sadr buscou uma nova interpretação para os eventos emblemáticos xiitas e transformou-os em atos de resistência e devoção. Um exemplo dessa releitura histórica foi o entendimento que o martírio do Imã Hussein passou ter. Deixou de ser um momento de derrota, lamentação e sujeição para passar a ser entendido como uma ação de resistência, uma vitória da vontade dos bravos que não se submeteram aos hereges. Morreram sim, mas mantiveram-se fiéis aos desígnios de Alá. (Hamzeh, 2004: 21) O martírio do Imã Hussein também assumiu contornos de exemplo a ser seguido para lutar contra os infiéis. Algo a servir de modelo para os fiéis.

Paralelamente ao desenvolvimento da nova mentalidade xiita, Sadr passou a criar instituições que facilitassem sua propagação e alcançassem representação junto ao Estado libanês. Em 1967, Sadr criou o Alto Conselho Islâmico dos Xiitas Libaneses (Lebanese Shiite Islamic Higher Council, majlis al-Shii al-Aala) e foi designado seu presidente. Com essa instituição, pela primeira vez os xiitas passaram a ter uma representação oficial perante o Estado. Dando continuidade ao processo de fortalecimento da comunidade xiita, em 1974 Sadr criou o 'Movimento dos Necessitados' (Movement of the Deprived, Harakat alMahrouumeen), um movimento sócio-religioso que forçou o governo libanês a reconhecer a comunidade xiita como realmente participante da nação libanesa. Contudo, apesar da relativa vitória alcançada, no ano seguinte o Líbano foi catapultado à guerra civil e muito do que fora conseguido deixou de ter valor. O panorama estabelecido pela guerra civil fez com que Sadr 
modificasse sua linha de atuação e autorizasse a criação de um braço armado do 'Movimento dos Necessitados', assim, foi criado o AMAL - 'esperança' em português, abreviatura de “Afwaj al Muqawama al Lubnaniya” cuja tradução seria "Destacamentos da Resistência Libanesa”.

O Amal, assim como as organizações anteriormente lideradas por Sadr, assumia muitas das funções do Estado, haja vista o governo libanês não delegar a devida atenção aos xiitas. Por conseguinte, a organização político-religiosa criava escolas, mesquitas, hospitais, centros odontológicos, etc. Tentava suprir a ausência do Estado e, talvez, projetar um modelo de novo Estado a ser instituído.

Com o desenrolar da guerra civil, o Amal tornou-se reconhecido como o autêntico defensor dos xiitas do sul e contava com o apoio sírio, principalmente depois da invasão israelense ao sul do Líbano em 1978, quando grande parte da comunidade xiita foi vitimada pelos ataques de Israel e teve de migrar para Beirute - estabelecendo-se nos subúrbios da capital, local que ficou conhecido como 'bolsão de miséria’.

O ano de 1978 também é de extrema importância para o movimento xiita libanês porque foi nesse ano, no mês de agosto, que Sadr, em viagem à Líbia - na qual foi recebido por Muamar Kadafi -, acabou 'desaparecendo’. O misterioso sumiço de Sadr passou a ser relacionado ao ‘ocultamento’ do décimo segundo Imã. Isso deu-se devido à crença de que na sucessão de Imãs, o décimo segundo (Muhammad al-Muntazar) teria entrado num estado de 'ocultamento' e somente retornaria à Terra para restabelecer a ordem islâmica. Não havendo uma explicação para o desaparecimento de Sadr, tampouco seu corpo fora encontrado, os xiitas passaram a relacionar esse fato ao sumiço do Imã Muntazar. Assim, Sadr tornou-se venerado como um mártir. (Jaber, 1997: 13) Entretanto, não conseguiu presenciar uma das maiores transformações que a comunidade xiita veria, a Revolução Islâmica - ocorrida no Irã em 1979.

A queda do Xá e ascensão ao poder do Aiatolá Khomeini, no Irã, fez com que a população xiita libanesa vislumbrasse a possibilidade de fazer com que o mesmo acontecesse em seu Estado. É evidente que nem todos os segmentos xiitas tinham interesse em estabelecer uma República islâmica no Líbano, contudo, os menos privilegiados socialmente, que viviam à margem do Estado, passaram a abraçar os ideais que Khomeini pregava. Assim, a partir da abertura que a crise social libanesa propiciava e, aliada à desestruturação que o Estado libanês vivia com a guerra civil em curso, Khomeini procurou criar meios que viabilizassem a criação de uma organização que pudesse defender, com mais ênfase, seu ideais. 
Dessa forma, no início da década de 1980, houve uma série de conversões de interesses entre Síria e Irã que favoreceram à criação da organização xiita - que posteriormente viria a ser o Hizbullah. A Síria receava que Líbano e Israel pudessem chegar a um acordo de paz e que isso viesse a prejudicar sua influência no Estado libanês - de fato houve um acordo efêmero em $1983^{74}$. Assim, o governo sírio viu-se numa situação complicada que poderia levá-lo ao isolamento. Nesse contexto, qualquer ajuda externa que pudesse auxiliar na luta contra Israel, e mesmo contra o Ocidente, seria bem vinda. Pensando sob esse prisma, a ajuda do Irã passou a ser vista como estrategicamente interessante. Os sírios poderiam receber auxílio econômico e mesmo no suprimento de petróleo, reduzindo a dependência do Ocidente e, em contrapartida, os iranianos teriam autorização para agir no Líbano, apoiando as milícias xiitas. A Síria entendia que mesmo que houvesse um risco ao aliar-se ao Irã, haja vista ser um Estado cuja bandeira principal era a difusão da Revolução Islâmica, era menor e mais suscetível ao controle que o isolamento. (Hamzeh, 2004: 26)

Com os acertos feitos entre Síria e Irã, a Guarda Revolucionária iraniana (Pasdaran) teve condições de agir em solo libanês e dar sustentação às milícias xiitas que se formavam. Entretanto, a liderança da comunidade xiita libanesa não partilhava de consenso. Após a

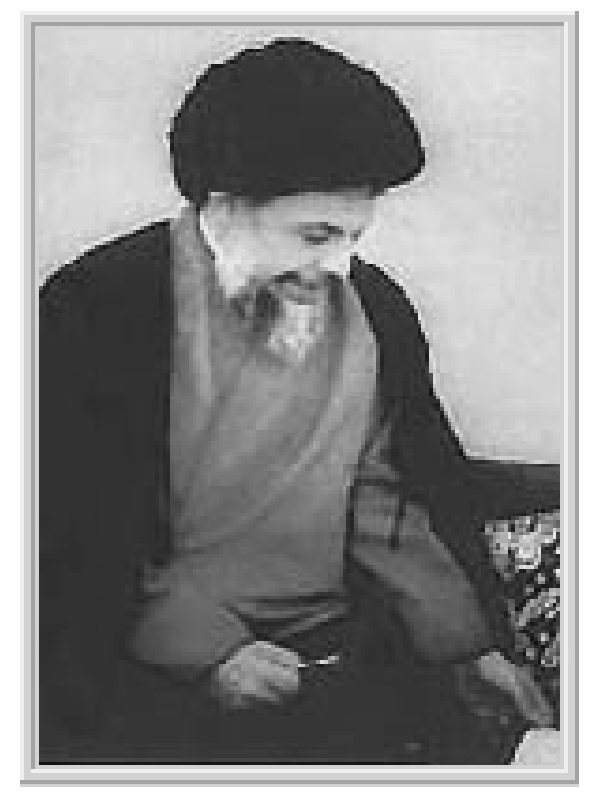

Aiatolá Muhammad Baqir al-Sadr morte de Sadr, o Amal teve Husayn al-Husayni como líder, contudo, posteriormente a direção da organização passou para Nabih Berri.

Sob a liderança de Berri o ideal islâmico tornou-se menos enfático e emergiu uma organização com postura secularizante, disposta a participar, juntamente com outros segmentos sociais libaneses, do Comitê de Salvação Nacional - que visava estabelecer as diretrizes para o período pós-saída da OLP do Líbano, 1982. Entretanto, participar do Comitê significava sentar-se à mesma mesa com Gemayel - dentre outras lideranças repudiáveis pela linha de pensamento islâmico defendida por Sadr -, fato esse, inconcebível para alguns membros do Amal. Não havendo mais maneira para conciliar os interesses de seus integrantes, Husayn al-Mussawi deixou a organização e fundou o Amal Islâmico (Islamic Amal), com o qual pretendia manter a linha de atuação de Sadr.

\footnotetext{
${ }^{74}$ Mais detalhes sobre o Acordo, ver página 115.
} 
Na seqüência dos acontecimentos, outros membros graduados do Amal também optaram por deixar a organização, foram eles: Sayyid Hasan Nasrallah, Shaykh Subhi alTufayli, Shaykh Muhammad Yazbak, Shaykh Na'im Qaim, Sayyid Abbas al-Musawi e Sayyid Ibrahim Amin al-Sayyid. (Hamzeh, 2004: 23-4) Nomes esses que já tinham tido contato com a doutrina de Khomeini.

Na década de 1960, com a ascensão do Baath ao poder no Iraque, muitos estudantes libaneses deixaram Najaf - devido à perseguição aos xiitas - e foram obrigados a retornar ao seu país. Alguns optaram por continuar seus estudos em Qom, Irã, outra fonte de difusão da ideologia islamista. Entretanto, a situação dos clérigos xiitas tornou-se ainda mais difícil no início dos anos 1980, quando Saddam Hussein ordenou a execução do Aiatolá Muhammad Baqir al-Sadr e sua irmã (abril de 1980) - devido ao fato de ele ter reconhecido e dado total suporte à Revolução Iraniana.

\section{5 - A LEGITIMIDADE DA LIDERANÇA DE KHOMEINI}

À parte a identificação que a comunidade muçulmana xiita passou a nutrir pelo Irã no momento pós-Revolução Islâmica (1979) e, conseqüentemente por seu líder e mentor, Aiatolá Khomeini, outros aspectos dessa liderança já vinham sendo arquitetados para alcançar esse objetivo. E, não é possível desassociar a doutrina elaborada por Khomeini dos resultados positivos a que chegaram.

Segundo a doutrina khomeiniana, o cidadão comum é inatamente falível e carece de capacidade moral e intelectual para entender os significados esotéricos do Corão, da Sunna do Profeta e das Tradições dos Imãs. Com base nessa elitização do conhecimento religioso, a incumbência para guiar os fiéis, até o momento do retorno do 'Imã Oculto', recairia aos mujtahids e, com isso, eles acabariam exercendo as funções dos Imãs. Ocorre que, para os xiitas tradicionalistas, os mujtahids não eram infalíveis, assim, cada grupo poderia escolher aquele que coadunasse com sua maneira de pensar e agir. E, dentre os mujtahids, haveria um que seria aclamado como o maior deles, o ‘vice-governador do Imã', a 'fonte de imitação' (marja' al-taqlid). No entanto, o diferencial da interpretação de Khomeini advém do fato de que possuir o maior conhecimento religioso não é o suficiente para guiar os xiitas, faz-se necessário ser o a'lamîiah (ser o sábio islâmico mais qualificado) também em assuntos políticos e sociais. Dessa forma, nem sempre ao membro mais velho da ulama recairia o título de wilayat al-faqih (aquele que possui a supremacia do conhecimento). (Zâdeh, 2005) 
Khomeini, em várias ocasiões, teve concorrentes para o mais alto posto do xiismo, entretanto, acabou prevalecendo sua autoridade. Daí, a doutrina de Khomeini acrescentava que quando se alcançava o grau maior entre os mujtahids, os demais deveriam segui-lo. Surge, dessa maneira, o desenho de um Estado prescrito pelo líder político e religioso. “O governo de um tal Estado islâmico teria que se basear no princípio da vilayat-e faqih [também é utilizada nessa dissertação a forma adaptada da língua inglesa: wilayat al-faqih], a viceregência (esperando o imã), do faqih, ou seja, legista-mor do fiqh, que concentraria poderes em suas mãos, assegurando a concordância das leis.” (Demant, 2004: 229)

O modelo teórico de wilayat alfaqih que Khomeini propõem deriva do Corão (5:44): "Revelamos a Tora, que encerra Orientação e Luz, com a qual os profetas, submetidos a Deus, julgam os judeus, bem como os rabinos e os doutos, aos quais estavam recomendadas a observância e a custódia do Livro de Deus. Não temais, pois, os homens, e temei a Mim, e não negocieis as Minhas leis a vil preço. Aqueles que ao julgarem, conforme o que Deus tem revelado, serão incrédulos.”. A partir dela,

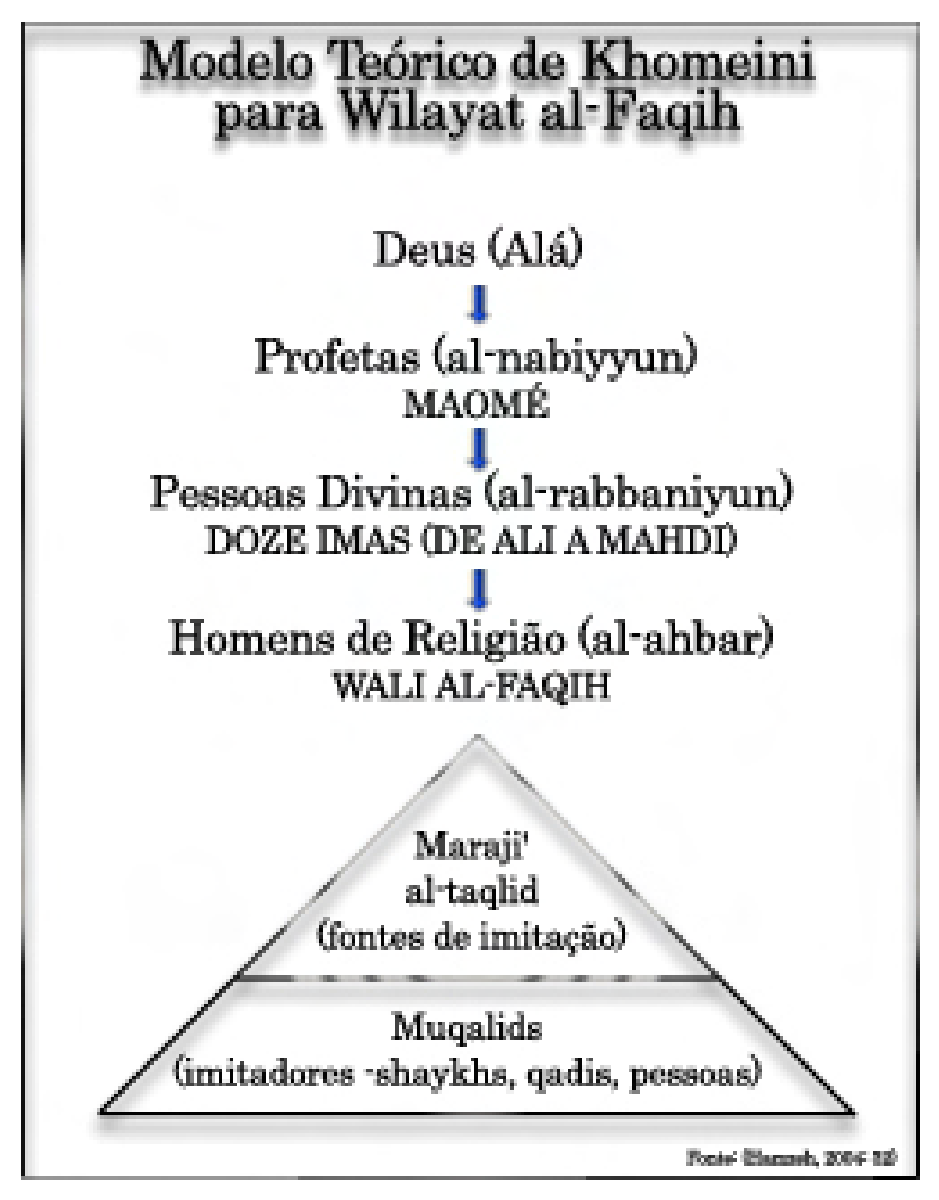
Khomeini teria buscado o embasamento para estabelecer os níveis de poder e hierarquia a serem seguidos.

Tendo sua teoria formulada e aceita pelos xiitas, o processo de aplicação dava-se conforme a República Islâmica iraniana ia confrontando-se com os problemas relativos às questões jurídicas. Assim, Khomeini podia estabelecer quais diretrizes deveriam ser seguidas. Contudo, há de ressaltar o fato de que havia um segmento de personalidades xiitas, de relevância, como Aiatolás Khu’i e Muntazari, Shaykh Murtada Mutahhari e Sayyid Fadlullah, que questionavam a autoridade suprema do Faqih e, mais precisamente, de Khomeini perante a umma. 
Mesmo assumindo para si o direito de falar em nome de toda a umma, no momento seguinte ao estabelecimento do regime islâmico, Khomeini e seus correligionários optaram pela criação de um modelo misto de governo, uma república teocrática com instrumentos democráticos. Segundo Demant, o modelo proposto por Khomeini era algo novo até então:

Neste regime misto teocrático-democrático, mas com maior influência teocrática, os poderes legislativo e judiciário se concentravam no jurista supremo, o faqih. Não surpreende que tal jurista supremo tenha sido o próprio Khomeini. A administração cotidiana do Irã ficava, no entanto, com um governo e um presidente responsáveis perante o parlamento, o majlis, eleito por voto universal. Partidos políticos foram legitimados (contanto que respeitassem a constituição). Os candidatos, porém, precisavam do aval prévio de uma comissão que os avaliava segundo critérios islâmicos. Esse multipartidarismo muçulmano representava o lado democrático do novo sistema. O outro lado, teocrático, consistia no Conselho dos Guardiões, uma comissão (a metade composta de ulemás e presidido pelo próprio Khomeini) que conferia as leis do parlamento e que podia vetá-las caso não condissessem com as normas do Islã. (2004: 233)

Com o modelo teórico do xiismo khomeinista em funcionamento no Irã, o passo seguinte seria difundir a Revolução e, nesse aspecto, o Líbano demonstrava-se bastante propício a recebê-la - pelo menos de acordo com a vontade de grande parte dos xiitas que, em 1979, continuava excluída pelo governo e sofrendo com a guerra civil que devastava o país.

\section{6 - HIZBULLAH, PROLONGAMENTO DA REVOLUÇÃO IRANIANA?}

O início dos anos 1980 não trouxe muitas expectativas para a guerra civil alcançar fim. O país continuava fragmentado, o governo não conseguia exercer suas funções e as ações da OLP (Organização para a Libertação da Palestina) - instalada em solo libanês - continuaram em curso até que houve a assinatura do Acordo Habib ${ }^{75}$ que levou a sua saída do Líbano em setembro de 1982.

\footnotetext{
${ }^{75}$ Segundo o que fora negociado, o exército israelense abster-se-ia de ocupar Beirute Ocidental (parte predominantemente muçulmana da cidade) e uma Força Multinacional - liderada pelos Estados Unidos - seria estabelecida para acompanhar a saída dos fedayeen palestinos de solo libanês. Também, a mesma força Multinacional deveria zelar pela segurança dos civis palestinos instalados nos campos de refugiados de Beirute. No entanto, Ariel Sharon, então comandante na invasão ao território libanês, violou o acordo marchando em direção ao subúrbio de Bir Hassan. A partir daí o lado oeste de Beirute foi tomado e, na seqüência, ocorreu o massacre de palestinos nos subúrbios de Sabra e Shatila. Executado pela milícia falangista, no entanto, contando com a presença passiva dos militares israelenses que haviam controlado a região.
} 
A organização xiita que existia oficialmente até aquela data, o Amal, já não mais conseguia congraçar o desejo da maioria dos xiitas libaneses. Claramente havia duas propostas em jogo naquele momento: uma primeira que ambicionava a coexistência pacífica dentro do Estado libanês - defendida por Nabih Berri -, e outra que pregava uma ação direta contra os opressores (maronitas e, também, os israelenses). Também, não é possível abstrair o fato de que havia uma forte divergência ideológica. A secularização do Amal confrontava com as expectativas dos xiitas que defendiam a instauração de uma república islâmica no país.

Não tardou para que essa tensão chegasse ao seu clímax e, por conseguinte, a divergência dentro do grupo levou a pequenos cismas. Desde os acordos entre Síria e Irã, alguns grupos de xiitas leais à doutrina de Khomeini passaram a ser treinados militarmente pelos pasdaran (guarda iraniana) na região do Vale de Bekaa. Dali surgiram pequenas organizações que recebiam a incumbência de implementar ações contra os inimigos - os ocidentais e o Estado de Israel.

Between 1982 and 1985, the Party of God was training hundreds of Young men, spreading the Word amongst the population and working on creating a political agenda of its own. It had also established several social services for the inhabitants of its main base in the Bekaa Valley and in the city of Baalbeck.

In early 1983, Hizbullah formed a central leadership which incorporated three members. They became Hizbullah's first shoura, council, and were responsible for the Bekaa, Beirut and the South. The shoura's job was to initiate and decide on all military, political and social issues. It also delegated the task of recruitment to other officials, leaving itself more able to contrite on setting up its political and social agenda. (Jaber, 1997: 52)

Oficialmente ainda não era possível dizer que o Hizbullah ${ }^{76}$ existia, entretanto, através de uma estrutura que começava a ser formada para maximizar seus objetivos militares; ações terroristas contra ocidentais e israelenses tornavam-se as principais armas dos grupos extremistas xiitas. A insatisfação com a presença israelense no Líbano - invadido em 1982, pela segunda vez -, com a inoperância das tropas da ONU e com o governo maronita, levou à radicalização da estratégia de enfrentamento.

Os Estados Unidos e a França haviam enviados suas tropas para auxiliar na saída dos palestinos no Líbano. Concluída a operação, ambas as tropas permaneceram no Líbano no intuito de evitar que houvesse mais ataques entre os grupos religiosos que continuavam guerrilhando. No entanto, após o exército estadunidense ter partido em defesa dos

\footnotetext{
${ }^{76} \mathrm{O}$ nome do Hizbullah provém da surata 5:56 do Corão: “Quanto àqueles que se voltam (em companheirismo) para Deus, Seu Mensageiro e os fiéis, saibam que os Partidos de Deus [grifo meu] serão os vencedores.”
} 
paramilitares da falange, contra os drusos, na região do Shouf, houve uma mudança substancial da forma com que passaram a serem vistos. (Jaber, 1997: 79)

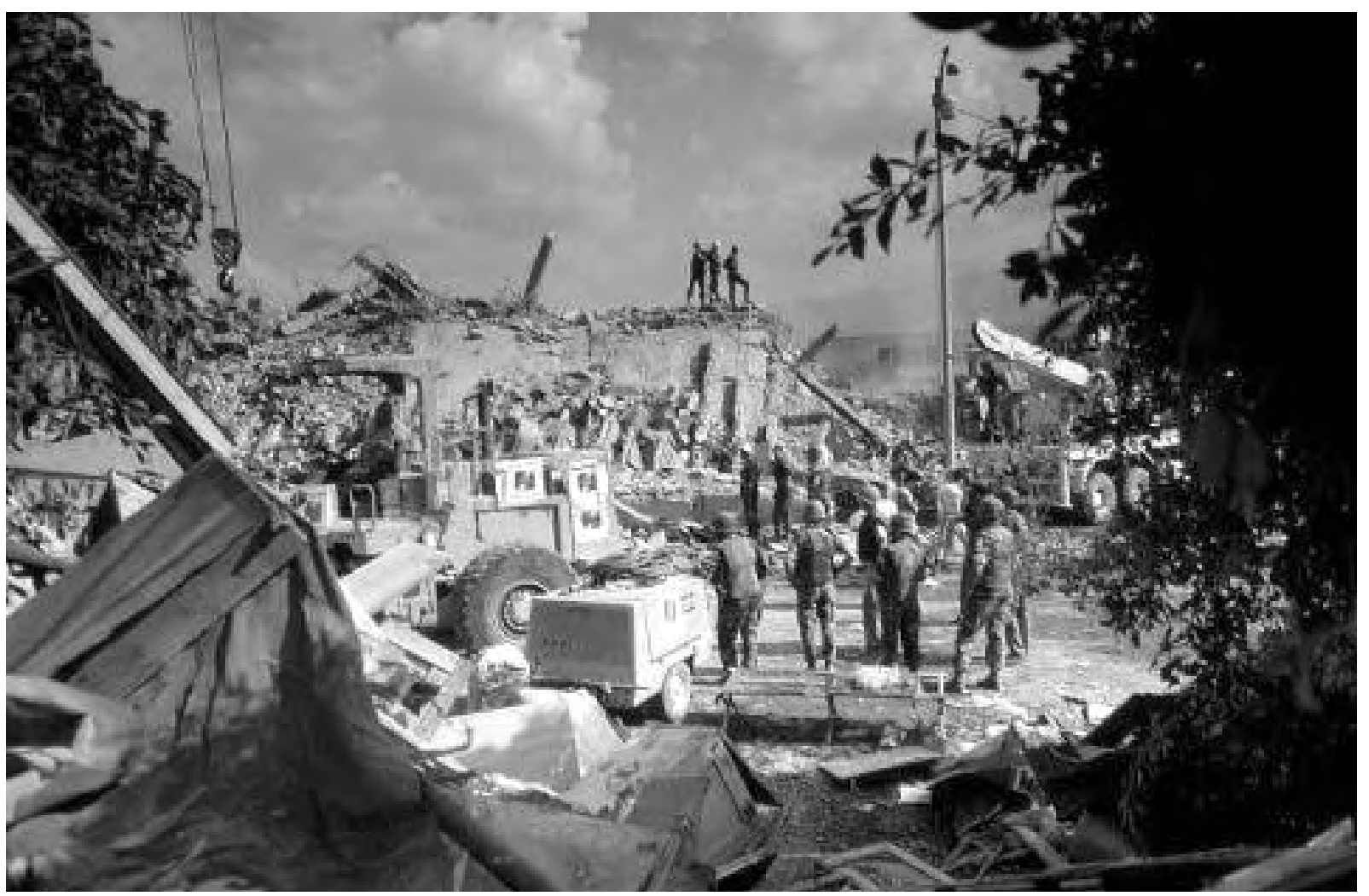

Destroços do quartel dos marines que havia sido alvo de atentado com "homem-bomba” em 1983.

Os xiitas entenderam-nos como aliados dos maronitas e, por isso, passíveis de represálias. Assim, em um ataque com caminhão-bomba ao quartel dos marines dos EUA, em 1983, foram vitimadas 241 pessoas, além de inúmeras outras terem sido gravemente feridas. Em seguida aconteceram ataques às forças francesas e israelenses, na cidade de Tiro. Ambas com muitas baixas e gerando pânico; até porque, pela primeira vez, usavam-se "homensbomba” contra as forças armadas regulares. Em tese, os marines e os israelenses tinham um potencial bélico muito superior a qualquer milícia atuante no Líbano, mas não estavam preparadas para agir diante de uma guerra não-convencional, como aquela que iniciava-se.

E, para justificar a utilização de um 'homem-bomba' (através de um ato de 'automartírio’) na ação, procedimento que iria contra os princípios islâmicos por tratar-se de um suicídio, um dos principais clérigos do Hizbullah, Sayyid Ibrahim al-Amin, justificou:

those who blew up the [U.S.] Marines headquarters and the Israeli military governate in Tyre [Ahmad Qasir] did not martyr themselves in accord with a decision by a political party or movement. They martyred themselves because the Imam Khomeini permitted them to do so. They saw nothing before them but God, and they defeated Israel and America for God. It was the Imam of the Nation [Khomeini] who showed them this path and instilled this spirit in them. (Kramer, 1991) 
Em vista dos fatos, o presidente dos Estados Unidos, Ronald Reagan, abalado com os acontecimentos e sofrendo fortes pressões internas, foi obrigado a retirar seus soldados do Líbano. O mesmo não chegou a acontecer com o Israel que, apesar de ser fortemente criticado por suas ações estratégico-militares no Estado libanês, continuava mantendo forças militares no local, estabelecendo, inclusive, a 'Zona de Segurança' - ocupando quase 10\% do território libanês.

Em 1985, quando já evidenciava-se o fato de que havia uma organização maior que controlava as ações de represálias contra os israelenses no Líbano, ocorreu a oficialização da existência do Hizbullah. (Kramer, 1990) Seu Secretário-geral da época, Shaykh Na’im Qaim, através de um manifesto, divulgou a 'Carta Aberta' do Hizbullah, um documento formal que apresentava, parcialmente, como a organização pretendia agir: “a program that didn’t intent to address in a detailed way Hizbullah ideology and its modes of action in particular, but what one can under certain circumstances.” (Hamzeh, 2004: 27) Devido a essa subjetividade, ou mesmo ausência de clareza de procedimentos, para compreender o Hizbullah não é possível ater-se, unicamente à 'Carta Aberta’, faz-se necessário analisar sua doutrina. E essa doutrina acabou sendo construída com base no pensamento de seus principais ideólogos, Aiatolá Khomeini, posteriormente, Khamenei, e, mais particularmente, Sayyid Hasan Nasrallah e Shaykh Na'im Qasim.

Considerando que o Líbano vivia sob a ocupação israelense (desde 1982, de fato), o Hizbullah, inicialmente, fundamentou sua existência num projeto que visava restabelecer a soberania do país e, para tanto, justificava que a opção pela via de ações terroristas dava-se devido ao forte impacto que provocava no inimigo.

Hizbullah also used one of its own special types of resistance against the Zionist [israelenses] enemy that is the suicide attacks. These attacks dealt great losses to the enemy on all thinkable levels such as militarily and mentally. The attacks also raised the morale across the whole Islamic nation.

It is also vital to state here, that the resistance gained high credibility amongst the people and in all official statuses, both locally and internationally. The US also once stated that the resistance is a justified movement in facing the "Israeli” occupation. (Hizbollah.org)

Apesar de o Hizbullah partir de uma premissa amplamente defendida - lutar pela soberania ser um ato legítimo -, e que encontraria defensores em várias localidades do mundo, o fato de utilizar-se de uma estratégia terrorista contra seus inimigos acabou não atraindo tantos adeptos para a causa quanto o esperado, exceto os islamistas extremados. 
Aqui, há a necessidade de fazermos algumas considerações acerca do que classificamos como islamistas. De fato, o processo de negação dos valores ocidentais e mesmo a suposta idealização do retorno ‘aos tempos do Profeta’ ocasionaram o surgimento de grupos que hastearam a bandeira contra o Ocidente, no entanto, muitos desses grupos de muçulmanos utilizaram a propaganda política e outros meios pacíficos para promoverem sua campanha contra o processo de ocidentalização do Islã. A adoção do jihad de forma que ele levasse à prática de ações terroristas acabou sendo uma interpretação dos clérigos do Hizbullah - mas não somente deles, outras organizações sunitas também fazem a mesma leitura, a mais notória nos dias de hoje é a Al-Qaeda, de Osama Bin-Laden.

Segundo Kramer, o ímpeto do Hizbullah transformar o Líbano num Estado islâmico proporciona essa visão pragmática da ação a ser empregada para alcançar seus fins, assim, "the young men and women of Hizballah are fired by the pure image of a future Lebanon which will regain stability through Islamic law and justice, and embark on a redeeming struggle against those who would banish Islam from this Earth.” (1990)

Na outra vertente da luta empenhada pelo Hizbullah encontram-se a contestação do imperialismo dos Estados Unidos e do projeto expansionista de Israel. A utilização de técnicas terroristas para enfrentá-los, inclusive com o emprego do suicido dos homens-bomba, é uma questão resolvida pelos ideólogos xiitas ligados à organização. De acordo com Fadlallah (em entrevista dada à imprensa em 1985), citado por Kramer:

When a conflict breaks out between oppressed nations and imperialism, or between two hostile governments, the parties to the conflict seek ways to complete the elements of their power and to neutralize the weapons used by the other side. For example, the oppressed nations do not have the technology and destructive weapons America and Europe have. They must thus fight with special means of their own. [We] recognize the right of nations to use every unconventional method to fight these aggressor nations, and do not regard what oppressed Muslims of the world do with primitive and unconventional means to confront aggressor powers as terrorism. We view this as religiously lawful warfare against the world's imperialist and domineering powers. (Kramer, 1990)

Com isso, uma das formas utilizadas pelo Hizbullah para implementar sua estratégia de ataque aos inimigos foi o uso dos 'homens-bomba'. E para resolver a questão relativa à proibição que o Corão faz do suicídio; conforme Jaber nos apresenta, o Hizbullah entende, que desde que ele (o suicídio) seja em nome de uma ação que constranja o inimigo, passa a ser permitido, mas somente se houver a sanção de um clérigo islâmico. (1997: 89) 
Perante esse arranjo ideológico montado pelo Hizbullah para legitimar suas ações, a menção da organização (citação acima) de que os Estados Unidos atribuir-lhe-iam uma suposta legitimidade, não parece ser uma afirmação verdadeira devido ao fato de o Hizbullah constar na lista de organizações consideradas terroristas pelo governo estadunidense.

Durante o período que a guerra civil libanesa transcorreu (1975-90), o Hizbullah - de acordo com seu ponto de vista -, no intuito de respaldar sua causa, travou sua luta em duas frentes: defendendo a tese da legitimidade de suas ações para restaurar a soberania do Líbano e, concomitantemente, abraçando a causa islâmica contra o inimigo sionista, usurpador das terras sagradas. Daí, pretendia utilizar o entendimento ocidental do Direito para salvaguardar a soberania do Estado libanês e, para justificar suas ações contra Israel ou as forças ocidentais, trabalhava com o conceito de jihad.

No entanto, a concepção de jihad adotada pelo Hizbullah para travar sua luta contra Israel, conforme Saad-Ghorayeb, seria no sentido defensivo. O Hizbullah parte do princípio de que qualquer ato feito em nome da causa de Deus é jihad. E, por 'causa de Deus'

Hizbu'llah does not imply God's personal cause, since God does not need the individual's jihad, but the cause of making. God's cause is 'the cause of people, the cause of oppressed, the cause of pride, honour and glory, the cause of the defense the land, the cause of the defense the sacred, of religion and the values of humanity'. Jihad is therefore an essentially defensive, as opposed to an offensive, activity in Hizbu'llah's conception. (2005: 122)

O jihad deveria ser depreendido contra os usurpadores, os apóstatas e os infiéis. Num sentido religioso, significaria “esforçara-se” no caminho de Deus, ou seja, agir de acordo com os preceitos do Corão e da sharia. Entretanto, o jihad, para os islamistas, passou a ter um significado diferenciado: de "guerra santa”. Legitimava, com ele, a luta contra os nãomuçulmanos. A partir desse conceito dúbio, contudo de fundamental importância, o Hizbullah formulou seu entendimento próprio acerca de como deveria ser aplicado o jihad. Um elemento doutrinário tão importante que, para alguns teóricos islamistas, deveria ser incorporado aos cinco pilares ${ }^{77}$ do Islã.

Hamzeh, a partir de suas pesquisas e entrevistas com as lideranças do Hizbullah, nos apresenta o que seria o entendimento desenvolvido pela organização xiita acerca do jihad e também como funcionaria a estrutura da organização xiita. No entanto, seu ponto de vista não

\footnotetext{
77 Todo muçulmano tem a obrigação de seguir os cinco preceitos básicos da religião islâmica, são eles: 1) Shahara ou Testemunho, confissão que efetua a conversão; 2) Salat,obrigação de fazer cinco orações ao dia; 3) Zakat ou Esmola, obrigação de dar esmolas e contribuir com parte de seus rendimentos; 4) Ramadã, mês que deve-se jejuar do nascer ao pôr-do-sol; e, 5) Hajj, peregrinar, pelo menos uma vez na vida, até Meca, cidade sagrada, onde encontra-se a Caaba.
} 
é unânime dentre os scholars e, sendo assim, juntamente com suas constatações serão apresentadas outras opiniões complementares ou antagônicos.

O Jihad estaria dividida em dois níveis (Grande $e$ Pequeno Jihad) e, o Pequeno Jihad compreenderia outros dois sub-níveis (Jihad Elementar $e$ Jihad Defensivo).

Através do Grande Jihad (al-Jihad al-Akbar) o indivíduo é preparado para os ensinamentos do Profeta e confrontado consigo. Somente superando seus medos e tendo aceito plenamente os ensinamentos islâmicos que o indivíduo estará preparado para seguir em frente e ter condições de implementar o jihad defensivo. É nesse nível que as lideranças do Hizbullah entendem ser o ponto de partida para o jihad Armado, porque é onde distingue-se o que é ensinamento de Alá do que é satânico. Assim, superando essa etapa, o muçulmano estaria preparado para seguir no caminho do Islã.

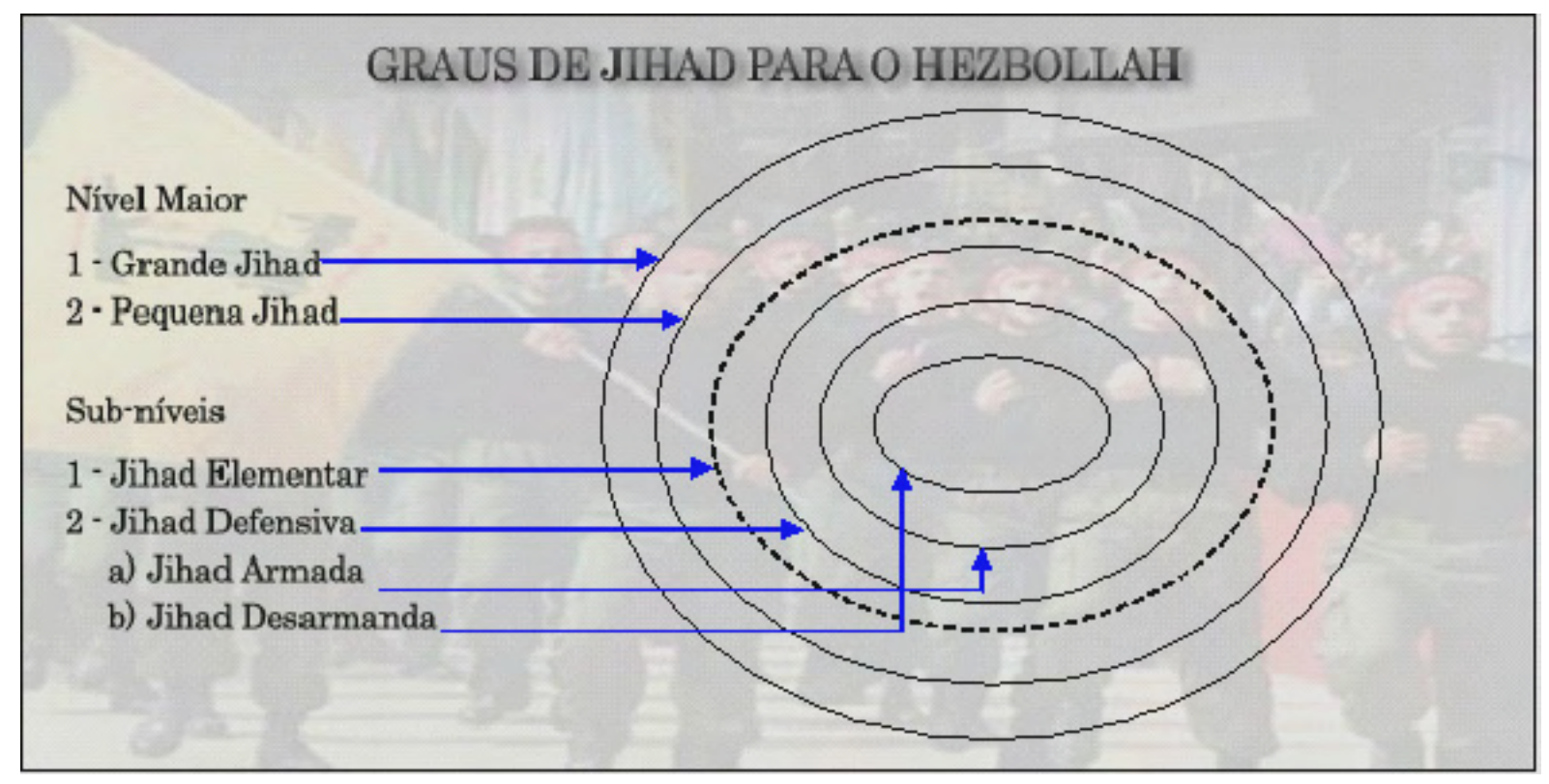

O Pequeno Jihad (al-Jihad al-Asghar) está dividido em dois sub-níveis. O Jihad Elementar (al-Jihad al-Ibtida'i), que é comumente conhecido por 'guerra santa' ou 'guerra ofensiva', e é entendido como uma guerra em escala mundial contra os infiéis. No entanto, devido ao grau de abrangência e às implicações contidas no Jihad Elementar, os ideólogos do Hizbullah entendem que somente o Profeta ou o ‘Imã Desaparecido’ teriam atribuição para decretá-lo. O segundo sub-nível do Pequeno Jihad é o Jihad Defensivo (al-Jihad al-Difa’i). Nesse nível de jihad que se travaria a luta contra aqueles que agridem os fiéis, o país e a umma. Aqui, não haveria a necessidade da autorização do 'Imã Desaparecido’ para deflagrálo, bastaria o entendimento do wali al-faqih. Segundo Nasrallah, “The defensive jihad constitutes armed and unarmed struggle. An armed struggle means fighting the enemy with blood and involves martyrdom. An unarmed struggle involves political, economic, and 
cultural means. Our defensive jihad in Lebanon involves both forms.” (Hamzeh, 2004: 38) O jihad armado seria contra os israelenses e o desarmado, contra os cristãos, os quais seriam contrários à instauração de um regime islâmico no Líbano. Conforme Saad-Ghorayeb aponta, de acordo com a liderança do Hizbullah, a opção por priorizar a luta contra Israel, ao invés de estabelecê-la contra o sistema político secular e sectarista libanês, deu-se - durante a Guerra Civil e hodierno - devido ao fato de Israel representar o supremo usurpador. Ainda, de acordo com Saad-Ghorayeb, essa postura difere da implementada por Qutb no Egito, quando o inimigo interno (Nasser por seu 'paganismo') era considerado mais mordaz que o externo, a presença israelense no Sinai (pós-Guerra dos Seis Dias, 1967). (2002: 133-4)

A afirmação de Nasrallah é de grande relevância para perceber o pragmatismo do Hizbullah, haja vista ser perceptível, também, que o uso de armas, ou não, ocorre simplesmente por uma interpretação do conceito de jihad. Assim, prevalece o valor da conveniência e da circunstância em jogo na tomada de decisão. Contudo, apesar de haver essa possibilidade interpretativa, tanto Nasrallah quanto os demais ideólogos do Hizbullah, asseguram estarem respaldando suas decisões nos desígnios do Corão, com o qual, de acordo com o entendimento das escrituras, “quer estejais leve ou fortemente (armados), marchai (para o combate) e sacrificai vossos bens e pessoas pela causa de Deus! Isso será preferível para vós, se quereis saber.” (Corão, 9:41) Haveria, assim, a justificativa para se depreender o jihad armado. E, em "não dês ouvido aos incrédulos; mas combate-os com denoda, com este (o Alcorão).” (Corão, 25:52), haveria a justificativa para o jihad desarmado. Nele faz-se uma alusão à proibição que havia em Meca da utilização de armas e que as lutas travavam-se política, econômica e culturalmente.

Com base na leitura incorporada pelo Hizbullah do entendimento de jihad, é possível afirmar que sua amplitude pode variar de acordo com o interprete. Como os ideólogos do Hizbullah seguiam os ditames do Aiatolá Khomeini e, para ele o muçulmano deveria aplicar o jihad contra o Ocidente e o Estado de Israel - usurpador das Terras Sagradas, Jerusalém -, a legitimidade da luta do Hizbullah contra os israelenses encontrava sua legitimidade.

Ainda, acreditando que todo muçulmano deveria aplicar-se nessa luta da mesma forma que o Imã Hussein o fez em Karbala, a figura do mártir ganhou projeção. Morrer na defesa dos ideais islâmicos passou a ser valorizado e transformado num ato de honraria, assegurando ao mártir seu lugar no Paraíso. Considerando, ainda, que os xiitas libaneses sempre foram excluídos socialmente, a quantidade de muçulmanos disposta a lutar para reverter essa ‘injustiça’ proporcionava grande número de fiéis imbuídos da proposta de morrer pelo jihad. 
Sobre a motivação dos 'homens-bomba' (mártires), Witker, fazendo alusão ao modelo desenvolvido por Shaul Kimhi e Shemuel Even para aos atentados impetrados por organizações palestinas, mostra-nos cinco possibilidades que levariam uma pessoa a participar de uma ação suicida. Com base nelas é possível perceber a diferença entre o pensamento xiita do Hizbullah e o sunita das demais organizações palestinas, como Jihad Islâmica ou Hamas. No caso do Hizbullah, provavelmente somente a primeira motivação teria alguma ligação com o grupo xiita, devido ao forte doutrinamento religioso que os mártires recebem.

a) No caso do primeiro [o religioso], o modelo está representado por terroristas dispostos ao martírio, se trata de pessoas que tiveram em sua infância, ou adolescência, uma forte preparação religiosa, assim como de militantes de grupos onde a religião exerce um papel central (Yihad, Hamas). Em geral são homens solteiros e jovens que tiveram necessidade de entrar na religião com a ajuda de um guia espiritual muito próximo, e que tiveram alguma participação (relativamente marginal, mas ativa) na Primeira Intifada, no geral, em desordens de rua. Nos casos estudados por Kimhi e Even, trata-se de jovens, cujas famílias (no geral muito numerosas) recebem um importante apoio material.

b) No segundo caso [o socialmente devastado], se trata de jovens recrutados que se encontram em estado de profunda depressão, e cuja vida tem estado marcada por momentos extraordinariamente dolorosos e traumáticos, por fatalidades de diversos tipos, que acabam minando sua fortaleza emocional, e se encontram ansiosos por vingança. Por outro lado, tratase de integrantes de famílias desintegradas ou que padecem de aguda violência intrafamiliar. O grupo recrutador, nesses casos, realiza uma paciente preparação que põe ênfase na comemoração de marcos políticos e religiosos, e em gestos de admiração pessoal para com a sua pessoa. Aqui também se observa o apoio econômico à família ou ao ser querido mais próximo emocionalmente.

c) O modelo nacionalista está representado essencialmente por militantes fanáticos com certa formação política básica. Esse terrorista suicida provém, de modo geral, de grupos seculares como Al Aksa (a ala militar da Al Fatah) e teve uma ativa participação na Primeira Intifada. Neste grupo se registra a maior presença de mulheres suicidas.

d) O modelo manipulado corresponde, de modo geral, a terroristas extremamente jovens menores de 18 anos - sujeitos a fortes pressões familiares e grupais das mais diversas índoles. Trata-se de moços e moças que têm sofrido acusações graves em seu meio mais próximo (por homossexualismo, desonra familiar, colaboracionismo com Israel ou atos imorais). A preparação tornar-se um deles é muito severa e focada, a fim de colocar o suicídio terrorista a serviço da causa palestina é a maneira mais idônea de reivindicação familiar ou grupal.

e) Por último, o modelo circunstancial (random protitype) corresponde a terroristas que optam por um suicídio por conjunturas fortuitas (curiosidade pelo tema, desejo de transcendência, carência de perspectivas para a realização pessoal ou demora [na realização] de projetos pessoais por causas alheias a ele). São pessoas, as quais, preparam-lhes reforçando sua imagem 
social e exaltando o exemplo da conduta terrorista suicida. Por inferência, este tipo deveria corresponder ao grosso dos voluntários da al-Qaeda e seus grupos satélites. (Witker, 2005: 241-2) (grifos meus)

A figura do mártir, para o sucesso do jihad tornou-se emblemática, no entanto, outro aspecto relevante que passou a incorporar o pensamento islamista xiita foi o conceito de “explorados e exploradores”, que, apesar de muitas vezes ser entendido como assimilado do pensamento marxista; segundo Saad-Ghorayeb, é tratado de maneira distinta pelo Hizbullah. No Corão esse conflito não é percebido como uma mera luta de classes, conforme a visão marxista. Para os islamistas, o jihad deveria ser empregado contra qualquer regime, cidadão ou instituição que oprima. E sua compreensão não é limitada à luta de muçulmanos contra não-muçulmanos. Qualquer lugar onde haja a opressão, caberia o jihad. (2002: 17-19) Com base nesses apontamentos, é possível concluir que, no tocante à ideologia do Hizbullah, ela é

[...] essentially juristical, where the mujtahid, particularly wali al-faqih, participates in the final revelation of the world of the God. Thus, the clerical elite can legitimately elaborate, mold, or alter the party's ideological components - that is, the establishment of the Islamic order, the jihad, the unity of the Islamic ummah, and social justice - to fit circumstances. The legitimacy of ijtihad (authoritative interpretation of Islamic law) provides not only a potential source for Islamic legislation but flexibility in the face of changing political circumstances. [...] In short, Hizbullah has elaborated an ideology in which the role of the jurist is determinant to the party’s future survivability or decay. (Hamzeh, 2004: 43)

Imbuído do pensamento islamista, o Hizbullah, cada vez mais intensificou sua luta contra Israel no sul do Líbano, referendado pela presença xiita na região. Entretanto, com o final da guerra civil (1990), a organização viu-se diante de um dilema: aceitar participar do processo eleitoral que restituiria a democracia ao Estado ou continuar travando sua luta contra Israel somente no plano militar? Não se tratava de uma escolha simples, porque para aceitar a transformação do Hizbullah em um partido político - nos moldes ocidentais - seria necessário reavaliar muitos dos conceitos islamistas que não coadunam com o princípio de democracia e Estado Liberal. Entretanto, conforme pôde ser visto na citação de Hamzeh, acima, muito do trabalho de adequação do pensamento caberia ao wali al-faqih. 


\section{7 - ACORDO DE TAIF DO HIZBULLAH}

No ano de 1989 foram feitas as tratativas para que a guerra civil libanesa chegasse ao fim. Em Taif, representantes de vários segmentos da sociedade libanesa, além de lideranças do mundo árabe, buscavam maneiras para que se alcançasse o entendimento. Um dos articuladores do Acordo foi Hafez al-Assad, presidente da Síria.

A intenção da Síria, por trás do estímulo à negociação, era não permitir que sua influência no Líbano cessasse, para tanto, precisaria articular muito bem o acordo. Também havia uma segunda intenção, com o fim da Guerra Fria, a Síria não mais poderia contar com o apoio soviético e procurava agir de maneira que não entrasse em confronto direto com os Estados Unidos. Assim, trabalhando em prol da paz no Líbano, conseguiria mudar 'relativamente' sua imagem de país interventor.

Quando chegou-se ao acordo final, seu resultado não agradou ao Hizbullah e aos drusos libaneses. Ambos alegavam que as modificações que seriam colocadas em prática participação igualitária entre muçulmanos e cristãos no parlamento e transferência de poderes da presidência para o gabinete, dentre outros de menor importância - com o Acordo, somente fortaleciam a participação sunita no governo. Na época da negociação do Acordo, personalidades como Shaykh Subhi al-Tufayli, que havia sido Secretário-geral do Hizbullah, via com muitas dúvidas a aceitação de Taif. Contudo, seguindo um procedimento padrão do Hizbullah, nunca externou suas idéias para a imprensa ou ao público. Utilizava os momentos adequados, dentro das reuniões da organização para fazê-lo. (Jaber, 1997: 72)

Essa controvérsia dentro da organização exemplifica que muitos de seus membros não entendiam que poderia haver a flexibilização do pensamento islamista para que houvesse a aceitação de Taif. Eles percebiam o Acordo como um desvio da proposta islamista e entendiam que aceitá-lo seria assimilar a ocidentalização da organização. Entretanto, a Síria, que já influía sob parte da comunidade cristã, da sunita e, mesmo nos integrantes do Hizbullah, com o apoio do Irã conseguiu fazer com que a organização xiita evitasse o isolamento e aceitasse as regras de Taif.

Por outro lado, os integrantes menos radicais do Hizbullah - notoriamente analisando a situação de maneira pragmática -, passaram a perceber no Acordo de Taif algumas propostas que não eram negativas para o Líbano e que correspondiam ao pensamento islamista. Primeiramente a formalização do final da guerra, ambicionado por todos os libaneses e, também, o entendimento de que a política sectarista deveria ter um fim (mesmo que não especificando exatamente como seria feito). (Saad-Ghorayeb, 2002: 27) 
Perante a dúvida em aceitar, ou não, do Acordo - o que implicaria na transformação do Hizbullah de milícia, em partido político, sujeito, portanto, às regras pré-estabelecidas por uma legislação eleitoral e uma Constituição -, a influência do governo sírio, respaldado pelo interesse iraniano do Aiatolá Khomeini fez com que se concretizasse o fato. Com a determinação do wali al-faqih, o Hizbullah transformou-se em partido político. Contudo, não aceitou completamente o que ditava o Acordo de Taif - no que tange à deposição de armas por parte das milícias - por entender que enquanto houvesse a presença israelense no Líbano, a Resistência deveria continuar armada e atuando.

O Acordo possibilitava à Síria que, juntamente com o governo libanês, implantasse o processo de desmilitarização das milícias e permanecesse no Líbano com suas tropas até que fosse constituída uma força nacional. Na ocasião, com vistas à destruição que a guerra civil causou ao país, dificilmente havia alguém que tivesse interesse na sua continuidade, assim, contando com o apoio dos sunitas, e segmentos da comunidade cristã - que não era unida e tampouco poderia fazer frente à desmilitarização -, Assad pôde impor a aceitação do Acordo conforme foi estipulado, inclusive como suas exceções.

Nesse contexto, não havia muitas possibilidades para enfrentar as tropas sírias. Então, muitos líderes cristãos tiveram que capitular ou fugir para o exílio, como fizera Michel Aoun após enfrentar o exército sírio no palácio de Baabda. O Hizbullah fora a exceção à regra - não depôs as armas -, no entanto, sendo um aliado forte da Síria na luta contra Israel, não teve sua desmilitarização questionada. Ainda, essa situação de exceção tampouco foi questionada pelas potências ocidentais, como os Estados Unidos, uma vez que a tranqüilidade provocada pelo fim da guerra civil libanesa abria caminho para o estabelecimento do processo de negociação de paz entre árabes e israelenses. (Harik, 2004: 45) Também, outras questões ligadas a países do Oriente Médio fizeram com que os Estados Unidos aceitassem a maneira com que a Síria estabeleceu as regras do jogo, tais como:

After the development of the Gulf crisis in 1990, the U.S. had the added concern of containing Iraq and gaining Syrian support for the Gulf war coalition. The end of the Cold War and the break up of the Soviet Union strengthened American influence in the region and allowed it to pursue its policy objectives with fewer: global obstacles. The U.S. supported the Taif negotiations and lent its support both in Arab circles and vis-à-vis Syria toward the successful completion of those talks. (Krayem)

Apesar de a transformação do Hizbullah em partido político atender aos objetivos do governo sírio, pois passaria a contar com legitimidade política para disputar espaço no 
governo e também para continuar lutando pelo restabelecimento da soberania do Estado libanês, a assimilação do modelo partidário ocidental não foi algo facilmente aceito por todas as lideranças do Hizbullah. No entanto, com o apoio e intermediação dos clérigos iranianos, a milícia libanesa foi convencida de que a transformação do Hizbullah em partido político não seria a aceitação completa do sistema democrático ocidental. No entanto, o segmento liderado pelo Shaykh Subhi al-Tufayli, adepto de um posicionamento mais duro e contra a transição, acabou perdendo força no poder decisório do Hizbullah. No caso de Tufayli, continuou como membro da shura - mais alta instância dentro do partido -, mas não mais no cargo de Secretário-geral. Conforme salienta Saad-Ghorayeb, a postura da organização poderia encaixar-se no que Sartori classifica como um partido 'anti-sistema' (2002: 26), ou seja, integrado ao sistema político partidário no intuito de contestá-lo.

No intuito de preservar os interesses dos patrocinadores - Síria e Irã - do Hizbullah, Sayyed Abbas Musawi assumiu a liderança da organização e deu início ao seu processo de institucionalização. A partir de 1990 o ‘Partido de Deus’ iniciou seu processo de preparação para as eleições que viriam em 1992.

No que tange à estrutura da antiga organização, foram incorporados outros órgãos e passou a implementar uma campanha junto à sua base, principalmente nas comunidades xiitas dos subúrbios de Beirute, do Vale do Bekaa e do sul do Líbano.

\section{8 - O ‘PARTIDO DE DEUS’ NO JOGO DEMOCRÁTICO}

Para fazer a transição, de milícia religiosa, para partido político, o Hizbullah precisaria resolver seu dilema acerca da identidade: nacionalista ou islâmica - que parecia inconciliável dentro da organização -, e buscar uma maneira para continuar legitimando suas ações contra o Estado de Israel após ser incluído ao processo eleitoral. O dilema vivido pelo Hizbullah não era de fácil solução porque implicava também num posicionamento estratégico. Renegar uma ou outra identidade significaria a perda de aliados dos dois lados (Estados árabes e comunidade islâmica). Contudo, o ‘nacionalismo árabe’ e a 'universalidade do Islã' pareciam incompatíveis. Segundo a doutrina islâmica tradicional, não haveria espaço para o pensamento nacionalista árabe na umma, haja vista seu secularismo ser conflitante com o entendimento de que política e religião fazem parte de um mesmo corpo legal.

A resolução dos dois problemas ocorreu com o posicionamento da organização perante a Causa Palestina. Nesse episódio necessitava angariar apoio contra Israel e, ao mesmo 
tempo, não perder sua dupla identificação (com os árabes e com os muçulmanos). Assim, passou a entender a Causa Palestina como um movimento Nacionalista Árabe, no qual todos os povos árabes teriam direito à Jerusalém (independentemente de não serem muçulmanos), e não um movimento pan-islâmico - restrito a uma religião. Com isso o Hizbullah entendia que ampliaria sua área de influência, inclusive junto aos sunitas. O imbróglio teológico ficou por conta dos ideólogos da organização resolver, e Muhammad Fnaysh expôs, assim, sua argumentação para o fato:

Arab nationalism can only be considered antithetical to Islam insofar as it is espoused as a system of 'managing social affairs'. So long as Arab nationalism is not elevated to the status ideology, it can be encompassed by Islam. Therefore, Hizbu'llah does not view its quest for Arab unity as an obstacle to the universalism of Islam. (Saad-Ghorayeb, 2002: 80-1)

E, o Secretário-geral do Hizbullah, Nasrallah, completou o raciocínio de Fnaysh, justificando que esse conceito poderia ser estendido ao Libanismo (nacionalismo libanês):

[...] just as the affiliation to Christianity, Communism or any other belief system does not conflict with one's Lebanese identity, Hizbu'llah's affiliation to Islam, and by implication its allegiance to the Wilayat al-Faqih, does not undermine its 'Lebanese identity or patriotism'. In a similar vein, just as other Lebanese groups are not deemed any less nationalist on account of political and material support they once received from foreign powers, Iran's support for Hizbu'llah does not render the party any less nationalist than these other groups. (SaadGhorayeb, 2002: 82-3)

Resolvida a questão da identidade, ou pelo menos, apresentados os argumentos para justificar a complexa caracterização do Hizbullah em uma organização islamista, nacionalista árabe e Libanista, a transição para Partido Político acabou aproveitando a estrutura organizacional que já vinha sendo utilizada e aperfeiçoada desde a cisão com o Amal. Uma estrutura totalmente diferente dos partidos convencionais do Ocidente, ou regimes socialistas, no entanto, semelhante ao modelo iraniano.

- CONSELHO DA SHURA (Majlis al-Shura): É formado por sete membros - eleitos pelo Conselho Central - para um mandato de três anos, sendo possível a reeleição por uma vez. Basicamente seus membros são clérigos, na proporção de seis para um. No entanto, atualmente, o membro leigo, possui o título de Hajj. Honraria de quem já realizou a peregrinação à Meca e, por conseguinte, delega grande devoção ao Islã.

O processo de eleição consiste de três etapas: apresentação, nomeação e eleição. Assim, as qualidades dos candidatos são avaliadas pelos membros do Conselho Geral, no que tange 
à capacidade de liderança e conhecimento do Islã. Após a eleição dos sete membros, os próprios, escolhem seu Secretário-geral, Deputado do Partido e os Presidentes dos cinco Conselhos que compõem o 'Aparato Político e Administrativo’.

À Shura compete as decisões acerca das questões administrativa, de planejamento e Política. Seus resultados são alcançados através de votações, prevalecendo o critério de maioria. Havendo impasse entre seus membros, a questão será levada ao wali al-faqih, a mais alta autoridade religiosa e legal do partido. Após seu pronunciamento, a aceitação é obrigatória.

O atual Secretário-geral do Hizbullah é Sayyid Hasan Nasrallah, no cargo desde 1992, e que conta com o total apoio de Khamenei, inclusive, que o referendou para que pudesse ser eleito para o cargo por cinco vezes, independentemente de o regulamento de o partido permitir apenas duas.

- CONSELHO CENTRAL (Majlis al-Markazi): Uma assembléia composta por quase 200 membros fundadores do Hizbullah.

- CONSELHO EXECUTIVO (Majlis al-Tanfizi): É gerido por um dos membros da Shura e está dividido em oito Unidades. A esse Conselho compete acompanhar o desenvolvimento das atividades em seus vários níveis de atuação, ou seja, nas Regiões, Setores e Agências.

- Unidade Social: compete prover os serviços que proporcionem o bem-estar social aos membros do Hizbullah e aprimoramento técnico, além de dar apoio às famílias dos mártires. Gerencia quatro fundações sociais semi-autônomas, cujo financiamento advém do Irã. Holy Struggle Construction Foundation (Mu'assasat Jihad al-Bina'), fundada em 1988, é uma das mais ativas e dá suporte às famílias excluídas pelo governo libanês. Atua nos subúrbios de Beirute, no Vale do Bekaa e no sul do Líbano. The Martyrs Foundation (Mu'assasat al-Shahid), fundada em 1982 pelo Aiatolá Khomeini, tem como função prioritária dar suporte às famílias dos mártires, dos detidos e dos guerrilheiros da Resistência. Proporciona ensino e saúde para as crianças dessas famílias. Mais de duas mil famílias de mártires e detidos, além de outras mil e quinhentas crianças, recebem o auxílio da Fundação. Foundation for the Wounded (Mu'assasat al-Jarha), fundada em 1990, tem como finalidade dar suporte às pessoas que ficaram feridas ou tornaram-se incapazes (fisicamente) com os ataques provenientes de Israel. Além de proporcionar moradia, saúde e educação para 
guerrilheiros e civis, efetua pagamentos mensais a esses e assistência psicológica, visando reintegrá-los à sociedade. Auxilia mais de onze mil pessoas. Khomeini Support Committee (Lujnat Imdad al-Khomeini), estabelecida imediatamente após a invasão israelense de 1982, tem como finalidade dar suporte médico, social e financeiro às famílias que sofreram com a invasão. Por ano, o Comitê proporciona mais de 112.500 atendimentos médicos e presta assistência a mais de 3.500 órfãos. Assim, atende a mais de 8.400 famílias e 2.000 estudantes

The activities of Hizbullah's Social Unit emanate from a strong ideological commitment because social service is fundamental tenet of the faith. This committee has contributed to the success of Hizbullah in boosting the size of its constituency and skillful penetration of Lebanon's society, in particular the Shi'ite community. While the Lebanese government has almost ceased to offer social welfare services, Hizbullah has been delivering such services, thus increasing its popularity at the expense of both the Lebanese government and the Amal movement. (Hamzeh, 2004: 53-4)

- Unidade Islâmica de Saúde: proporciona assistência médica e também desenvolve campanhas de saúde preventiva para os membros do Hizbullah e as pessoas que habitam as regiões mais necessitadas - Subúrbios de Beirute; Vale do Bekaa (Baalbek e Hermil); Sul do Líbano (Nabatiyyah e Toul). É estimado que a Unidade atenda mais de 400.000 pessoas nessas regiões e despenda de aproximadamente U\$ 5 milhões.

The financial and technical inability of the Lebanese government, in particular the Ministry of Health, to run its state hospitals has cause Hizbullah to take over the hospitals of South Lebanon and Bint Jbeil and operate them under its Islamic Health Unit. While the government has made rhetorical promises to provide basic health care services, Hizbullah's Islamic Health Unit has filled the vacuum and responded to health emergencies and the needs of people before and after the Israeli withdrawal from South Lebanon. [...] Hizbullah has increased its popularity, thus exposing the ineffectiveness and ineffectiveness of the Lebanese government. (Hamzeh, 2004: 55)

- Unidade de Educação: é a responsável por prover ajuda financeira e educação para os estudantes necessitados do Hizbullah. Com a deficiência na qualidade da educação disponibilizada pelo Estado, cada vez mais o Hizbullah investe nesse segmento. Mantém escolas e universidades próprias, onde ministra disciplinas técnicas mas também o ensinamento islâmico. Contudo, também proporciona bolsas de estudos e apoio financeiro para estudantes em outras universidades. Visando aprimorar a qualidade técnica e científica da comunidade xiita. 
- Unidade de Informação: responsável pela divulgação da propaganda política do Hizbullah. Possuindo uma rede de televisão (al-Manar), quatro estações de rádio (alNour, al-Iman, al-Islam e Sawt al-Mustad'afin) e cinco jornais (al-Ahd, a-Bilad, alMuntalaq, al-Sabil e Baqiatou Allah), algumas sem autorização oficial do governo para funcionar, caracterizá-se por ter a maior estrutura de comunicação dentre os demais partidos políticos. Durante a ocupação israelense a rede de televisão al-Manar teve papel de grande relevância para os membros da Resistência ao divulgar mensagens em favor da luta e tentar desmoralizar o Estado de Israel exibindo fotos de seus soldados capturados ou mortos pela Resistência. Mantida por fundos iranianos, donativos de muçulmanos expatriados e por grande quantidade de anúncios comerciais, a al-Manar opera com milhões de dólares e possui mais de dez milhões de espectadores. Seu sinal é retransmitido para a África, Europa, América do Norte e América latina, com boletins em inglês e francês. Com o fim da invasão israelense ao Líbano (2000), a rede de televisão passou a dedicar-se a outra causa: apoiar a intifada palestina.

- Unidade Sindical: essa é a mais nova unidade do Conselho, criada em 1996, tem a função de orientar os membros do Hizbullah nos vários sindicatos e associações de advogados, médicos, engenheiros, trabalhadores, comerciantes, faculdades e estudantes. "The Syndicate Unit thus hopes to penetrate and create autonomous enclaves in the civil society that work to serve the party’s cause” (Hamzeh, 2004: 61)

- Unidade de Relações Exteriores: também é uma unidade nova e sua função principal é acompanhar o dia-a-dia das relações exteriores do partido. Conseqüentemente, interage diretamente com Agências, partidos políticos, governos, Organizações Internacionais e ONG's. Funciona como um Ministério de Relações Exteriores e recebe quaisquer delegações exteriores que pretendam manter contato com o Hizbullah.

- Unidade de Finanças: é a responsável pelas reservas do partido, auditorias operacionais e empenho de gastos. Seu planejamento necessita da aprovação do presidente do Conselho Executivo. É a partir dessa Unidade que são pagos os salários dos membros do partido e onde são empenhados os valores para gastos em operações. Segundo observa Hamzeh, não é clara a proveniência dos fundos que mantém essa estrutura, haja vista seu orçamento não ser divulgado oficialmente. Especula-se que 
seja resultado da coleta e recebimento de recursos externos, basicamente do Irã, proveniente do pagamento do khums (espécie de dízimo pago pelos fiéis). Também de donativos do governo iraniano; de governos, fundações e instituições interessadas no projeto islâmico do Hizbullah; e, finalmente, de investimentos no mercado financeiro internacional.

- Unidade de Comprometimento e Coordenação: funciona como um serviço de inteligência do partido, responsável por coletar informações que possam reverter em ameaça para os interesses do partido e de seus membros. Com base nas informações recebidas é feito o julgamento e o acusado - por traição, espionagem, etc -, é aprisionado. Após o final da invasão israelense os prisioneiros passaram a ser entregues ao governo libanês para cumprir a pena de prisão. Contudo, se o acusado for estrangeiro ainda fica sob a guarda do Hizbullah. Nessa unidade que, também, procuram-se resolver os problemas de desentendimentos entre os membros do partido.

- POlitburo: é formado por um número de membros que pode variar entre onze e quatorze. Não é um instrumento de decisão, mas serve para assistir o Secretário-geral e a Shura. Funcionalmente tem de acompanhar o dia-a-dia das atividades políticas do partido. É de vital importância nos processos eleitorais porque divulga o programa do partido, cria comitês de campanha e articula alianças. Assim, de forma sucinta, cabe a ele divulgar o programa político do partido e articular alianças. Dentre os vários comitês criados pelo Politburo, três deles têm grande importância para o programa do partido: o Comitê Cultural, o Comitê de Relações Palestinas e o Comitê da 'Zona de Segurança'. Ao primeiro cabe angariar membros que sejam contra o reconhecimento do Estado de Israel, assim, professores, jornalistas, empresários, dentre outros membros de vários segmentos sociais, são contatados para mobilizarem-se contra o reconhecimento de Israel e a influência da educação e cultura americana; ao segundo, cabe estabelecer fortes laços com organizações palestinas rejeicionistas, tais como Islamic Jihad e Hamas, a esse comitê também compete organizar atividades políticas nos campos de refugiados palestinos instalados no Líbano; e, ao Comitê da 'Zona de Segurança', até maio de 2005 cabia administrar a Resistência contra Israel e prestar assistência às regiões 'libertadas', no entanto, após essa data os membros do comitê deixaram o sul do Líbano e voltaram para suas cidades. Assim, o comitê foi desativado. 
- CONSELHO PARLAMENTAR: esse Conselho foi criado após as eleições parlamentares de 2000, com a intenção de dar assistência aos representantes do Hizbullah no Parlamento. Segundo afirmação de Nasrallah: "being a Member of Parliament does not means that Hizbullah's elected representatives are above the Shura Council's authority.” (Hamzeh, 2004: 68) Isso porque, é a Shura a responsável pela indicação dos membros do partido que concorrerão à eleição e, uma vez eleitos, devem seguir as diretrizes do partido e não a vontade própria. Nesse aspecto, lembra muito a estrutura de 'Partidos Único' implantado em Cuba, União Soviética, etc, onde os membros devem lealdade à instituição e não contam com liberdade de expressão e contestação das diretrizes impostas. O número de membros do Conselho Parlamentar expressa a quantidade de eleitos pelo partido no pleito eleitoral. Das 128 cadeiras do Parlamento, os xiitas concorrem às 27 que são destinadas ao seu grupo religioso. Assim, em 1992 o Hizbullah tinha sete cadeiras no Parlamento, em 1996, oito cadeiras, e, em 2000, oito cadeiras. A próximas eleições estão programadas para abril de 2005.

By having a parliamentary council, the party's leadership has made it clear that its members in Parliament act collectively under the instructions of the Shura Council. Their main function is to follow up, inside and outside the Parliament, on decisions and policies made by the Shura Council. They are not to make individual decisions or to take a stance that is independent from the party leadership’s decision. (grifo meu) (Hamzeh, 2004: 68)

- CONSELHO JUDICIAL: formado por juízes e oficiais de justiça do Hizbullah, a função prioritária desse Conselho é gerenciar e resolver as questões de conflito na comunidade xiita. O Conselho atua nas áreas sob influência do partido e julga questões de violação das leis da sharia e também de violação de direitos civis. Para julgar essas questões o

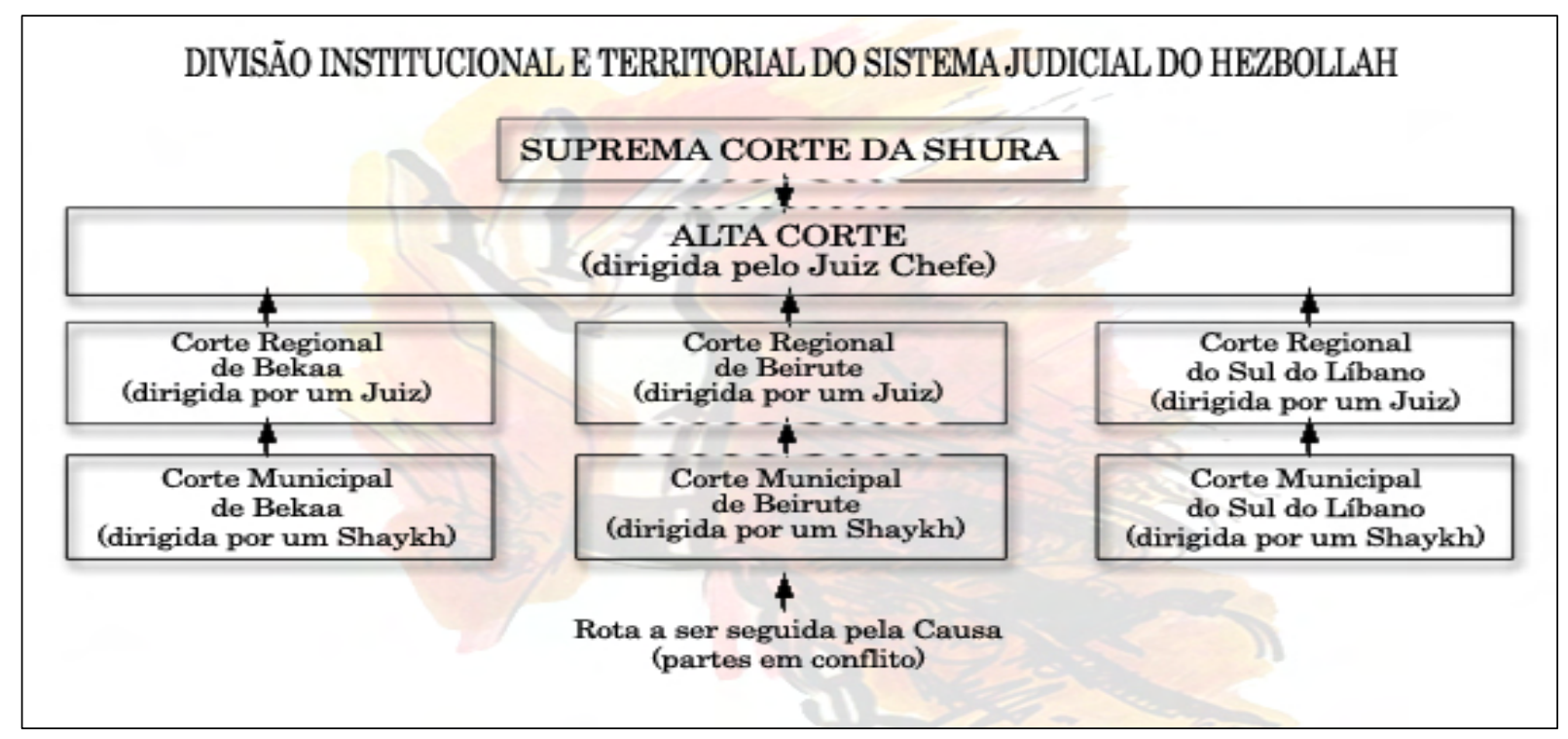


Hizbullah estabeleceu três mecanismos legais: Julgamento, Arbitramento e Mediação. Diferentemente do Código de Leis Ocidental, a sharia não faz distinção entre obrigações civis e religiosas. Assim, a Corte da Sharia e o qadi (juiz), têm jurisdição sob todos os campos legais. A divisão institucional, territorial e jurisdicional das cortes é estabelecida conforme dispõe a figura a seguir:

- CONSELHO DO JIHAD: ratificando o comprometimento do Hizbullah com a Jihad, em meados da década de 1990 foi criado esse Conselho. Formado por membros graduados do partido e também comandantes da Resistência Islâmica, além de um oficial sênior da Guarda Revolucionária Iraniana. Cabe a esse Conselho estabelecer as estratégias e táticas que serão implementadas no Jihad. Contudo, atendo-se a parte analítica de sua implementação, ou seja, identificando os perigos frente ao partido e à umma, os atores por trás dos riscos - sejam eles, local, regional ou internacional -, a iminência do risco e seu imediato impacto sob o partido. No entanto, no caso de jihad armado, a incumbência recai ao Aparato Militar do Partido. Enfim, esse Conselho diagnostica o perigo, estabelece que tipo de Jihad deve ser implementada - fundamentando seus atos em análise minuciosa - e, caso recomende o Jihad Armado, com a utilização, inclusive, de mártires, é necessário que haja o encaminhamento da decisão para o Conselho da Shura e a ratificação pelo wali al-faqih.

- APARATO MiLiTAR E DE SEGURANÇA: essa é o segmento do partido que menos tem sua estrutura divulgada, basicamente, para prevenir a entrada de estranhos nela. Os dados utilizados para elaborar sua estrutura, segundo Hamzeh, provêm de três fontes: o jornal al-Ahd, comunicados e publicações da Resistência Islâmica e entrevistas com líderes do partido. Assim, chegou-se a conclusão de que essa estrutura seria composta por dois órgãos principais: a Resistência Islâmica (al-Muqawamah al-Islamiyyah) e o Grupo de Segurança (Amn al-Hizb). Diferentemente dos demais órgãos do partido, esse fica sob o controle direto do Conselho da Shura e, mais precisamente, de seu Secretário-geral.

- Resistência Islâmica: esse segmento é dividido em duas partes: 'Seção de Recrutamento' e 'Seção de Combate'. À primeira compete fazer o recrutamento dos guerrilheiros, preparar seu endoutrinamento para seguir as diretrizes do partido, reconhecer a superior liderança do wilayat al-faqih, e, por último, lutar contra os inimigos identificados. À 'Seção de Combate' recai a obrigação de preparar os guerrilheiros nas artes marciais, torná-los bons atiradores, prestar-lhes suporte médico 
e dar-lhes conhecimento sobre armamentos. O resultado do treinamento determina a qual dos quatro órgãos da Seção de Combate o guerrilheiro será incorporado. O primeiro é conhecido pela ação dos mártires, onde os indivíduos integram atividades suicidas e são informados de que a chance de sair vivo é praticamente nula. O segundo consiste nas 'Forças Especiais', uma elite de combatentes distinta da convencional. O terceiro órgão incorpora guerrilheiros especialistas em armas, mais precisamente em lançamento de morteiros e mísseis terra-terra ou terra-ar. E, finalmente, o quarto órgão, que agrega os guerrilheiros convencionais do partido. Para dificultar o desmantelamento da estrutura militar do Hizbullah, seus agentes atuam em células com semi-autonomia. As ações delas não são compartilhadas pelas demais e, tampouco, os membros de uma conhecem os da outra. Em tese, essas células deveriam estar diretamente ligadas a Shura, contudo, segundo Hamzeh, elas acabam estando sob o controle direto do Secretário-geral do partido. Como os guerrilheiros do Hizbullah são, basicamente, civis, torna-se mais difícil para Israel distingui-los dentre a população comum.

- Órgão de Segurança: os integrantes desse órgão têm grande experiência em segurança e inteligência, contudo, o fator primordial para integrá-lo é ter um perfil de liderança e delegar total lealdade ao Secretário-geral e a Shura. Normalmente os membros desse órgão trabalham disfarçados em todas as instâncias do partido. O Órgão de Segurança é subdividido em duas seções: Grupo de Segurança, responsável por prevenir a infiltração de estranhos na estrutura do partido e, para tanto, faz um levantamento da vida de todos os membros e mantém dossiês deles que são atualizados constantemente; e, Segurança Externa, sua função é prevenir o partido dos prováveis agentes inimigos que pretendam penetrar em sua estrutura, para tanto, mantém células no Chipre, Bélgica, Suíça Alemanha, Inglaterra e Estados Unidos (ou Canadá, como é especulado por jornalistas).

Apesar de essa análise acerca da estrutura organizacional do Hizbullah contar com dados provenientes, basicamente, da pesquisa desenvolvida pelo Prof ${ }^{o}$ Ahmad Nizar Hamzeh, da Universidade Americana de Beirute, outros autores como Hala Jaber, Judith Palmer Harik e Amal Saad-Ghorayeb, dentre outros, também fazem referência a alguns órgãos e seus membros. Dessa forma, mais uma vez a pesquisa de Hamzeh acaba obtendo mais respaldo. E, ao perceber a maneira com que o Hizbullah se estrutura torna-se possível aprofundar em algumas questões relacionas à ideologia do partido e sua maneira de atuação. 


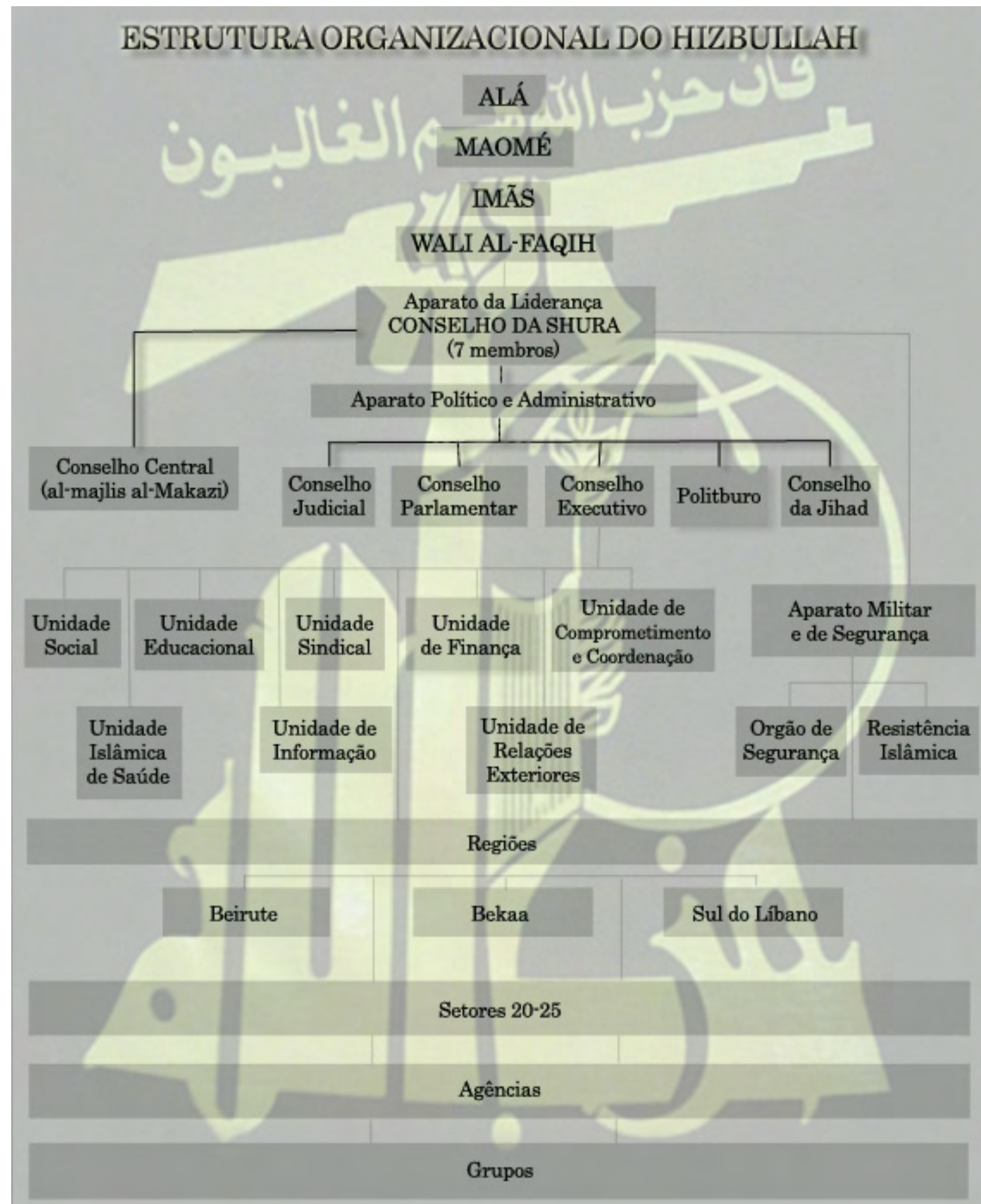

Fonte: (Hammeh, 2004: 46)

Hamzeh, em estudos anteriores, já vinha mapeando a estrutura do Hizbullah e, para isso, conforme ele mesmo salienta, contou com dados provenientes de entrevistas feitas com lideranças e membros do partido, além de dados colhidos em jornais e estudos direcionados. 
Outro ponto que reforça a tese de que o Hizbullah possua uma estrutura partidária semelhante à sugerida por Hamzeh diz respeito ao fato de que o Irã também conta com um modelo parecido, no entanto, mais simplificado.

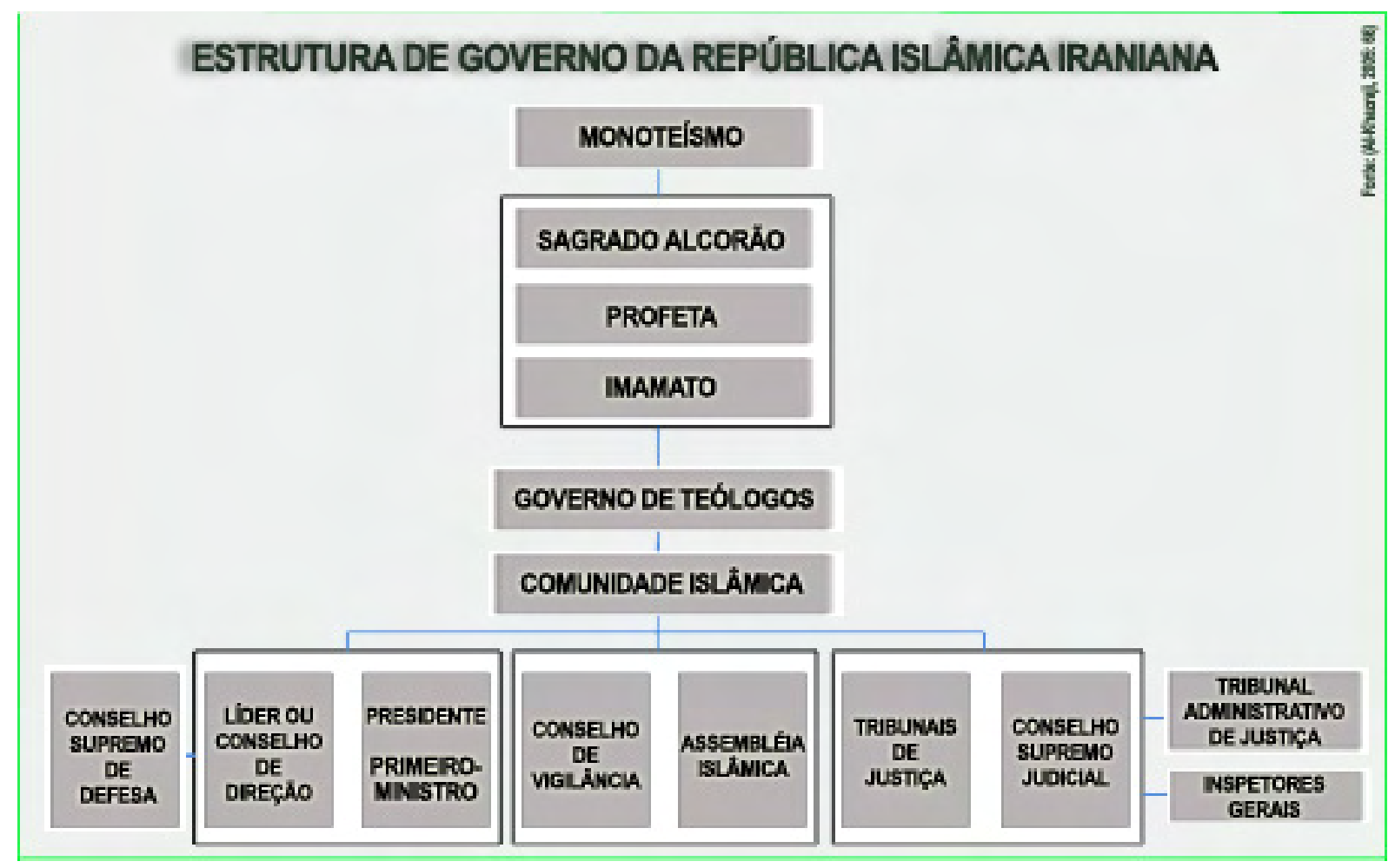

Tomando por base os dados obtidos a partir dessa estrutura apresentada, algumas características chamam a atenção e suscitam questionamentos. Será que a maneira com que a cúpula do Hizbullah controla a opinião dos parlamentares eleitos não elimina o valor democrático de sua representatividade? De acordo com o Hizbullah, a resposta seria 'não', haja vista os parlamentares serem um prolongamento do projeto do partido e não haver discórdia nesse ponto. Também poderíamos pensar que, uma vez que a cadeira pertence ao partido, a obrigação de seu parlamentar é coadunar à ideologia partidária ou não fazer parte dele. Nesse ponto, o sistema eleitoral libanês permite a participação de candidatos independentes e não seria uma barreira.

Outro ponto que chama a atenção para uma estrutura tão complexa como essa diz respeito à proveniência de capital para financiá-la. Nesse aspecto, Jaber nos mostra que o maior responsável pelo sucesso do Hizbullah é o Irã,

Iran's theological leadership also supports Hizbullah financially. These contributions have always been independent of those made by the country's official authorities. According to Islamic law, every Muslim in the world is under religious obligation to pay religious taxes: zakat, a tax on assets and khoms, a tax on net incomes. The taxes are paid to the marja altaqleed, a religious leader who advises Shiites on the application of Islamic law, and 
distributed to charitable organizations and religious leaders around the world to spend on the poor and oppressed. (...) Hizbullah receives considerable sums from 'legal rights or alms', as they are known. Some of the money is sent directly to the group's leadership which in turn allocates it to specific projects and transfers funds to the directors of Hizbullah's charitable organisations to finance the social services. The group also has collections boxes distributed in shops, neighbourhoods, banks, on streets corners and in mosques all over Lebanon. (1997: 151)

Partindo de uma base sólida de financiamento - contribuições obrigatórias e donativos de pessoas e/ou grupos interessados na causa islâmica - para seus empreendimentos sociais ou para o desenvolvimento de seu conteúdo programático - a doutrina islâmica - e, contando com a entrada do capital iraniano proveniente do petróleo, o Hizbullah conseguiu montar uma rede de assistência que, em muitos aspectos, supera a do Estado libanês. Juntamente como ela, criou escolas que transmitem o ensinamento religioso doutrinário. Agregando a isso, há a constatação de que a estrutura organizacional do Hizbullah proporciona-lhe autonomia semelhante a de um Estado. Então, isso nos leva à constatação de que devido aos anos em que a comunidade xiita foi desprezada pelo Estado, o Hizbullah conseguiu estabelecer-se num Estado Islâmico dentro do Estado libanês. Cabe questionar se ele estará interessado em ser absorvido pelo Estado legal ou tentará absorvê-lo para desenvolver um sistema islâmico de governo.

\section{9 - NO CAMINHO DO ISLÃ OU DA DEMOCRACIA?}

Com um aparato superior a qualquer outro partido político libanês e, em alguns segmentos, mais ativo e eficiente que o próprio Estado, o Hizbullah chegou a um momento de confronto de ideais com a realidade. Tornando necessário esclarecer quais são seus reais objetivos e se eles são os mesmos do Estado libanês.

Como foi possível perceber no transcorrer desse capítulo, a estrutura organizacional do Hizbullah foi sendo moldada de acordo com a conveniência do momento, assim, de uma organização eminentemente islamista, chegou a um partido político e, aos poucos, assume cada vez mais as funções do Estado - no que tange ao bem-estar social.

A principal dúvida que surge diz respeito à trajetória que o partido irá trilhar na seqüência. Isso porque, é notório seu crescimento nas eleições legislativas que voltaram a transcorrer democraticamente após o final da guerra civil (essa questão será abordada no 
próximo capítulo). Entretanto, esse crescimento acaba sendo limitado pelas regras impostas através da legislação eleitoral. O limite de crescimento do Hizbullah seria a ocupação das 27 das cadeiras destinadas à comunidade xiita, no entanto, esse mesmo sistema eleitoral que utiliza o voto distrital, faz com que o Hizbullah não possua representantes em todas as localidades do Líbano.

A partir do momento em que a comunidade xiita se transformou no maior segmento religioso do país, o Hizbullah passou a questionar o modelo de democracia libanesa. No qual sua participação política não corresponde à proporção representativa na sociedade. Esse seria um primeiro momento de questionamentos que implicariam em modificações e levariam a instauração de uma República Islâmica no Líbano. As lideranças do Hizbullah sabem que haveria grande relutância por parte dos sunitas e dos cristãos, contudo, devido à taxa de natalidade xiita ser muito maior que dos demais grupos religiosos, num futuro próximo o Hizbullah poderia alcançar a maioria absoluta de cidadãos libaneses e se a representação parlamentar fosse proporcional, não mais precisaria fazer alianças para aplicar o regime islâmico.

Essa é um tanto simplista porque mesmo dentro da comunidade xiita não há consenso acerca de o Líbano transformar-se numa República Islâmica, o próprio Amal, que disputa com o Hizbullah as vagas no Parlamento, possui uma plataforma política secularizante.

Apesar de o projeto do Hizbullah existir, a liderança do partido sabe das limitações que a legislação eleitoral impõe e, dessa maneira, acaba entendendo o momento atual como não sendo o ideal para mudanças, mas, sim, o possível para questionar. O projeto do Hizbullah não deixa de ser o estabelecimento de um regime islâmico - em tese, dando liberdade de culto para os demais grupos religiosos desde que submetidos às regras da sharia -, o qual comporta a 'justiça absoluta’, conforme expõe Saad-Ghorayeb:

The 'absolute justice' represented by the Islamic state would remain a central pillar of Hizbu'llah's intellectual structure, but the indefinite postponement of its implementation would exclude it from the party's political discourse. Conversely, the 'greatest possible extent of justice', which could be secured through a democracy, would feature prominently in the party's political discourse, but would not be elevated to the status of intellectual structure. Thus, Hizbu'llah would integrate itself into political system, but its intellectual commitment to the concept of the Islamic state would prevent it from imbibing the democratic basis of the system and from being politically assimilated by it. (2002: 50)

O pragmatismo, que vem pautando as ações do Hizbullah desde sua fundação, acaba gerando questionamentos acerca de sua integração ao regime democrático libanês. Será que 
essas transformações percebidas até o momento podem ser integradas ao pensamento do partido e, assim, teríamos a flexibilização do pensamento islamista? Ainda, será que a estrutura partidária tem condições de deter o crescimento do Hizbullah? Até quando conseguiria suportar o crescimento do partido?

Essas questões poderão encontrar respostas no capítulo seguinte, o qual será analisada a estrutura político-partidária libanesa, assim como seu sistema eleitoral. Também, discutirse-ão os conceitos de democracia, política partidária e modelos democráticos, para que sejam empregados no pensamento do Hizbullah. 


\section{( 4 )}

\section{DEMOCRACIA}

\section{LÍBANO E SEU SISTEMA POLÍTICO-ELEITORAL DIFERENCIADO}

Esse capítulo dedicar-se-á ao estudo do terceiro pilar que constitui a base analítica dessa dissertação. Se, nos dois primeiros foram apresentadas as características históricas que levaram à constituição do Estado libanês, na seqüência, apresentou-se a base filosófica/religiosa/ideológica do Hizbullah, representante do que atribuímos como sendo uma organização islamista, agora, nesse capítulo, será feita a análise do que entende-se por Democracia, seus modelos e como eles poderiam ser empregados no Caso Libanês.

Assim, por essa dissertação adotar o entendimento de Democracia como um fim, e não como um meio, conforme Schumpeter expõe: “[a democracia é um] método político, [...] enquanto tal [...] incapaz de ser um fim em si mesmo"78, sua contribuição, por mais valiosa que seja, poderia prejudicar a comparação que se pretende estabelecer com a afirmação corrente de que “o Líbano é um Estado democrático”.

Por sua vez, a opção de utilizar três cientistas políticos reconhecidos mundialmente para estabelecer a discussão proposta deu-se devido a caracteristicas específicas de suas obras. A saber, Robert Dahl por sua contribuição acerca do modelo de poliarquia, também por ser um expoente da Escola norte-americana; Arend Lijphart por discutir o sistema consociacional e esse ser muito próximo da realidade libanesa - formada por múltiplos grupos religiosos -; e, Giovanni Sartori por fazer parte da Escola européia e ser considerado um liberal em suas propostas, abrindo com isso, a possibilidade de que o Líbano não seja uma democracia, mas possua um regime liberal.

Nossa análise iniciar-se-á com a discussão acerca da conceituação do que vem a ser Democracia e, na seqüência serão revistos os principais episódios da história política libanesa e analisados os documentos que a constituem. Buscando, assim, estabelecer a relação histórica

\footnotetext{
${ }^{78}$ Schumpeter. Joseph. Capitalism, Socialism and Democracy. New York: Harper and Row, 1975, p. 242
} 
entre o pensamento ocidental e o árabe (em algumas circunstâncias, o islâmico), como em 1926, data da promulgação da Constituição libanesa.

A intenção, ao utilizar essa metodologia, é viabilizar o desencadeamento lógico que possibilite responder à questão proposta: Qual a influência do islamismo no sistema democrático libanês? Com base nessa opção metodológica, adotar-se-á procedimento similar ao analisar Acordos bilaterais, Constituições, Emendas constitucionais, Pronunciamentos de lideranças, dentre outros documentos que sejam relevantes e que tenham sido produzidos nos séculos XX e XXI - desde que estejam ligados direta ou indiretamente ao sistema político libanês.

Muitos dos fatos que serão abordados nesse capítulo já foram mencionados anteriormente, contudo, agora, faz-se necessária uma análise sob o ponto de vista da Teoria Democrática. Mais uma vez convém salientar que a opção por esse tipo de análise recai-se sob o fato de que, apesar de ter sido utilizado, no transcorrer dessa dissertação, a expressão ‘processo democrático’ para a 'situação política libanesa', ainda não havia sido estabelecido um parâmetro mais rigoroso para a amplitude dessa terminologia. O que, por sua vez, permitiu não considerar as implicações políticas geradas pelo privilégio de um único grupo religioso - maronita - ter o direito de exercer a presidência do Estado libanês. Assim, para o início desse processo analítico a conceituação de democracia torna-se fundamental, até porque, conforme ressalta Sartori, há de distinguir que tipo de democracia está servindo de modelo, a idealizada ou a real.

Em geral, a teoria normativa trata dos ideais e valores da democracia, e os elabora. Quer suas prescrições sejam ou não deliberadas, desemboca com certeza numa definição prescritiva de democracia. Inversamente, a teoria empírica trata dos fatos e generaliza a partir deles: como a democracia se concretiza e o que as democracias são realmente no mundo real. Em conseqüência, a teoria empírica acaba em definições descritivas de democracia. (1994: 13)

Também, como foi possível perceber pela exposição feita nos capítulos anteriores, o processo eleitoral libanês transcorreu com certa fluência mesmo nos momentos de profunda crise - apesar da interrupção nas eleições dos parlamentares entre 1972 e 1987 -, havendo a alternância de presidentes e primeiros-ministros. Entretanto, somente com base nesses fatos não é possível atribuir ao Líbano o título de Estado democrático, haja vista, muitas dessas alternâncias terem ocorrido por interesses outros, que não os princípios democráticos.

Assim, para uma análise mais objetiva do processo político libanês, é de fundamental importância conhecer suas peculiaridades e questioná-las à luz das teorias. Isso porque, 
muitas vezes, apesar do verniz democrático que de um determinado sistema político, são nas suas sutilezas que residem as características que possibilitariam classificarmos o Líbano como um Estado democrático, ou não.

Isso posto e, com base no pressuposto de que o sistema político libanês possa ter mais nuanças do que as perceptíveis numa análise mais superficial, dar-se-á início a esse capítulo com o estudo do conceito de Democracia.

\section{1 - DEMOCRACIA, UM CONCEITO EM QUESTÃO}

Numa tradução literal do termo Democracia, do grego ${ }^{79}$ para o português, chega-se à expressão “poder do povo”. Assim, por conseguinte, poderíamos entender que onde o sistema democrático viesse a ser implantado, o poder deveria ser exercido segundo os interesses da população. Nas palavras de Kelsen, “democracia significa identidade entre governantes e governados, entre sujeito e objeto do poder, governo do povo sobre o povo.” (2000: 35) Ocorre que, segundo Sartori, “...embora a democracia tenha um sentido literal preciso, não nos ajuda realmente a entender o que é de fato uma democracia.” (1994: 23) Isso porque, “poder do povo” implica num entendimento de que haveria a sujeição dos governantes em favor da população, ou, de acordo com Kelsen, numa conexão de interesse entre seus atores. Contudo, não é possível afirmar que um regime democrático ocorra dessa maneira.

Então, se Democracia não deve ser entendida somente a partir de seu significado literal, devemos, dessa forma, buscar a resposta para sua utilização no que ela representa. Entender o que nos leva a pensar que esse é o melhor sistema de governo a ser adotado pelos Estados. Para Kelsen, democracia - como ideal e não como sistema político - traz consigo os sentimentos de liberdade e igualdade. Por isso seria aclamada pelo povo como sistema mais justo. No entanto, numa análise pormenorizada, podemos perceber que essa liberdade é restritiva, uma vez que pode significar a imposição de uma maioria sobre a minoria, também,

\footnotetext{
${ }^{79}$ A palavra Democracia é de origem grega e foi utilizada para designar o sistema político que certas cidades da Grécia utilizaram, ainda no século VI a.C., para se organizarem. Tal transformação no pensamento grego teria surgido devido ao fato de que, naquele momento histórico uma extensa camada de cidadãos alcançou a autonomia e passou a questionar o antigo regime, tirano e autocrático, imposto pelos antigos senhores que dominavam as terras e/ou detinham o monopólio do comércio. Nesse contexto, uma camada social livre passou a buscar maior participação no processo decisório. Esse processo de transformação política e cultural passou a ser objeto de estudo de historiadores e filósofos, tais como Tucídides (460-399 a.C.), Platão (427-347 a.C.) e Aristóteles (384-322 a.C.), e seus pensamentos serviram de base para o modelo adotado pelo mundo ocidental, basicamente. Sobre esse tema, ver: Held, David. Models of Democracy. Oxford: Polity Press, 1987, p.11-35.
} 
o sentimento de igualdade pode ser corrompido pela distinção de quem governa e quem é governado. (2000: 27-8)

Sobre essa propositura, cabe salientar que o entendimento de que se tem de Democracia, hoje, não é o mesmo que havia na Grécia antiga, no Império Romano, ou mesmo em séculos mais recentes - em eventos como a Independência dos Estados Unidos (1776), a Revolução Francesa (1789), por exemplo. Esse conceito foi sendo trabalhado e transformado de acordo com as necessidades e ambições de determinados segmentos sociais.

Para efeito ilustrativo, convém lembrar que na Grécia antiga o sistema democrático não era representativo, ou seja, toda a população tinha direito a voto - não empregava-se o 'voto universal' -, comparecia à praça e tinha a possibilidade, e o direito, de externar seus pensamentos e suas vontades com relação aos temas propostos. Porém, mesmo nesse entendimento de universalidade do voto, havia aqueles que eram excluídos do processo, tais como escravos, mulheres e estrangeiros.

Os gregos não entendiam a representação como algo democrático, os cidadãos deveriam expressar suas vontades individualmente e não delegá-las a terceiros. Entretanto, com o desenvolvimento das sociedades e, principalmente com o crescimento das populações, o fator da representatividade passou a ser de grande relevância e foi democratizado, ou seja, assumiu o caráter de imprescindível. Contudo, a representatividade política não pode ser considerada como um modelo sem falhas - mais adiante voltaremos a discutir essa questão da representatividade.

Mas qual o critério utilizado para atribuir o direito de voto? Nem sempre houve o entendimento de que para existir um regime democrático haveria a necessidade de que toda a população tivesse direito ao sufrágio. Mesmo os Estados Unidos, que serviram como exemplo de democracia para Tocqueville ${ }^{80}$, nos estados do sul não havia o direito de voto para mulheres e negros. No entanto, essas restrições feitas à liberdade de participação política dos cidadãos estadunidenses - percebidas pela visão aristocrática européia de Tocqueville -, não o impediu de considerá-lo um Estado democrático, uma vez que suas atenções estavam voltadas para um fator mais significativo, qual seja, a inexistência de uma aristocracia nos moldes europeus. Essas sim, inibidoras do desenvolvimento democrático.

Então, um dos primeiros aspectos da democracia a que devemos nos ater diz respeito ao seu processo de transformação e sua adequação ao meio a que destina. Não é possível

\footnotetext{
${ }^{80}$ Para uma explanação mais detalhada sobre a Democracia Estadunidense do século XIX, ver: Tocqueville, Alexis de. A Democracia na América - Livro 01. São Paulo: Martins Fontes, 2005; e, Tocqueville, Alexis de. A Democracia na América - Livro 02. São Paulo: Martins Fontes, 2000.
} 
afirmar que trata-se de um conceito restrito. Não, pelo menos, se estivermos aplicando a regimes de facto e não a sistemas utópicos. Assim, mesmo em democracias, ditas avançadas e estáveis - como os Estados Unidos -, os negros só conseguiram alcançar o direito ao voto (nos estados sulistas) com a assinatura do Ato dos Direitos Civis, em 1964-65, e nem por isso o Estado norte-americano deixou de ser considerado como um modelo de democracia a ser almejado. Mas também contestado por vários scholars.

Para Dahl, a Democracia, em seu sentido estrito, é um modelo idealizado e que ainda não conseguiu ser colocado em prática em qualquer Estado, moderno, ou não. Existem parâmetros - universalidade de voto, liberdade de contestação, eleições livres, alternância no poder, etc, e outros que serão mencionados ainda nesse capítulo - para estabelecer se um regime é democrático, ou não. E, existem fatores que ratificam a importância de se ter um regime democrático sendo implementado num determinado Estado, em detrimento a outro autoritário.

Segundo o cientista político Dahl, a Democracia seria um regime idealizado, então, o que existem são poliarquias, sistemas políticos que possuem graus variáveis de participação da sociedade nos desígnios do Estado. Dahl desenvolve seu modelo e possibilita com que se atribua a um determinado Estado a característica de democrático, ou não. Mais adiante retornaremos a discussão acerca de poliarquia e outros modelos democráticos. Por ora, cabe nos atermos às razões elencadas por Dahl que contariam a favor da opção pela democracia, são elas:

a) Evita a tirania - porque atribui a decisão à população e não centraliza numa autocracia, que, como é possível constatar historicamente, gerou ditadores (tanto em regimes de esquerda, quanto de direita. Hitler, Mussolini, Pol Pot, etc).

b) Direitos Essenciais - para o exercício da própria democracia, os cidadãos possuem os direitos de participação efetiva (expressando e ouvindo as opiniões políticas de seus pares); igualdade de voto (sem distinção para quaisquer cidadãos adultos); entendimento esclarecido (acesso aos meios que proporcionem esclarecimentos para a tomada de decisões); dentre outros.

c) Liberdade Geral - como balizador do regime, há o peso inerente da liberdade de expressão por parte dos cidadãos. A possibilidade de posicionar-se contra ou a favor de seus membros e das instituições garante o aspecto crítico do sistema. 
d) Autodeterminação - somente no regime democrático seus membros encontram proteção para seus interesses e, ao mesmo tempo, se protegem da ação de seus pares. Cabe ao Estado estabelecer os limites para os cidadãos. Assim, como eles interagem com o sistema, as medidas tendem a não ser unilaterais. Somente nesse sistema seus membros têm a possibilidade de escolher que tipo de leis querem seguir, o que estabelece o princípio de autodeterminação.

e) Autonomia Moral - esse conceito parte do pressuposto de que, se os cidadãos podem estabelecer o regime de leis que pretendem viver, por analogia, também estabelecem os princípios morais a que deverão seguir.

f) Desenvolvimento Humano - apesar de não haver como comprovar empiricamente que a qualidade do desenvolvimento humano num regime democrático encontra melhores índices que em outros, o fato de que ao ser humano se atribuem características que podem ser mais bem desenvolvidas quando estimuladas e gozando de plena liberdade, faz com que se chegue a essa conclusão.

g) Igualdade Política - considerando que todos os integrantes do Estado têm os mesmos direitos, dirime a possibilidade de que segmentos específicos acabem sendo preteridos. Contudo, é fato que o exercício dos direitos políticos ainda não assegura plenamente às minorias (religiosas, étnicas, etc) a efetiva participação no governo. Essa questão diz respeito, diretamente a situação da comunidade xiita libanesa e voltará a ser discutida mais detalhadamente no transcorrer desse capítulo ${ }^{81}$.

A implementação de um regime democrático não é um processo simples e, por isso, normalmente é feito de forma gradual com a criação de instituições que possam sustentá-lo. Quando o regime democrático não é alicerçado em instituições políticas estáveis, o que ocorre muitas vezes em transições geradas por revoluções (mesmo que a proposta seja a transição de um regime totalitário para outro democrático), a dificuldade de implementação do novo regime pode fazer com que haja um retrocesso momentâneo para sua estabilização.

\footnotetext{
${ }^{81}$ A essas razões, Dahl acrescentou mais duas, as quais atribuiu a constatações mais recentes, quais sejam: 1) a de que países com regimes democráticos não tendem a guerrilharem entre si, contudo, entram em guerra com outros não democráticos. Um dos fatos que poderiam contribuir para essa paz entre as democracias seria o aumento do fluxo de trocas comerciais; e, 2) países com governos democráticos tendem a ser mais prósperos do que os não-democráticos, isso porque, a prosperidade estaria ligada diretamente as facilidades que a economia de mercado proporciona para as empresas e os trabalhadores em geral. Essas duas observações de Dahl encontrariam respaldo no pensamento neoliberal.
} 
A linha de raciocínio estabelecida por Dahl considera que a prática da democracia está alicerçada no valor das instituições.

\begin{tabular}{|c|c|}
\hline \multicolumn{2}{|c|}{ INSTITUIÇÕES POLÍTICAS QUE A DEMOCRACIA EM LARGA ESCALA EXIGE } \\
\hline Funcionários Eleitos & $\begin{array}{l}\text { O controle das decisões do governo sobre a política é investido } \\
\text { constitucionalmente a funcionários eleitos pelos cidadãos. }\end{array}$ \\
\hline $\begin{array}{l}\text { Eleições Livres, Justas e } \\
\text { Freqüentes }\end{array}$ & $\begin{array}{l}\text { Funcionários eleitos são escolhidos em eleições freqüentes e justas em que a } \\
\text { coerção é relativamente incomum. }\end{array}$ \\
\hline Liberdade de Expressão & $\begin{array}{l}\text { Os cidadãos têm o direito de se expressarem sem o risco de sérias punições em } \\
\text { questões políticas amplamente definidas, incluindo a crítica aos funcionários, ao } \\
\text { governo, ao regime, à ordem socioeconômica e à ideologia prevalecente. }\end{array}$ \\
\hline $\begin{array}{l}\text { Fontes de Informações } \\
\text { Diversificadas }\end{array}$ & $\begin{array}{l}\text { Os cidadãos têm o direito de buscar fontes de informação diversificadas e } \\
\text { independentes de outros cidadãos, especialistas, jornais, revistas, livros, } \\
\text { telecomunicações e afins. }\end{array}$ \\
\hline $\begin{array}{l}\text { Autonomia as } \\
\text { Associações }\end{array}$ & $\begin{array}{l}\text { Para obter seus vários direitos, até mesmo os necessários para o funcionamento } \\
\text { eficaz das instituições políticas democráticas, os cidadãos também têm o direito } \\
\text { de formar associações ou organizações relativamente independentes, como } \\
\text { também partidos políticos e grupos de interesses. }\end{array}$ \\
\hline Cidadania Inclusiva & $\begin{array}{l}\text { A nenhum adulto, com residência permanente no país e sujeito a sua lei, podem } \\
\text { ser negados os direitos disponíveis para os outros e necessários as cinco } \\
\text { instituições políticas anteriormente listadas. }\end{array}$ \\
\hline & Fonte: (Dahl, 2001: 99-100) \\
\hline
\end{tabular}

As instituições políticas também devem ser percebidas como o mecanismo para representar os cidadãos de um determinado Estado. Isso porque, a representatividade tornouse o método mais eficaz para atender aos anseios da população, contudo, mesmo assim ainda apresenta algumas imperfeições. Encontrar a melhor maneira para que todos os segmentos sociais sejam representados num governo torna-se o foco de nossa próxima discussão. Ainda mais se considerarmos que, em Estados como o libanês, onde a população é altamente heterogênea e as diferenças religiosas chegam a estabelecer outros padrões morais, a necessidade de encontrar uma fórmula que não exclua segmentos sociais da vida política apresenta-se como um grande desafio.

\section{2 - MEIOS PARA A REPRESENTATIVIDADE POLÍTICA}

Como fazer prevalecer a vontade da população perante o Estado? Mesmo que haja entendimentos distintos acerta do regime democrático e variações em seus níveis, de forma geral, não há questionamentos sobre o fato de que um governo democrático deve refletir a vontade do povo. Sobre essa premissa, Sartori expôs que 
O poder perten[cer] ao povo estabelece um princípio relativo às origens e à legitimidade do poder. Significa que o poder só é legítimo quando é realmente concedido de baixo, só quando é uma emanação da vontade popular e só quando repousa em um consenso básico expresso.

Considerando uma teoria sobre as origens do poder e um título de direito a esse, o conceito literal de democracia indica também que esperamos e exigimos de uma forma democrática que a sociedade tenha precedência sobre o Estado, que os governados e o governo aceitem o princípio de que o Estado está a serviço dos cidadãos, e não os cidadãos a serviço do Estado, que o governo existe para o povo, e não vice-versa. (1994: 57)

No caso libanês, a possibilidade de o governo estar a serviço do povo sempre foi um desafio. A própria identidade libanesa, como foi discutido nos capítulos iniciais, demanda questionamentos. Teria sido forjada no intuito de atender aos interesses coloniais da França no início do século XX? Seria a mesma da Síria, conforme os defensores da 'Grande Síria' aludiam? Ou estaria ligada ao Libanismo, que surgiu em contra-partido ao Arabismo, também no início do século passado?

A concepção de 'povo', significando 'nação', é muito difícil de ser empregada ao Líbano, inclusive nos dias de hoje. Basta, para isso, considerarmos a estrutura organizacional do Hizbullah que foi apresentada no capítulo anterior.

Assim, quando Sartori nos diz que "o poder pertença ao povo”, nos vemos diante de um dos maiores problemas ao analisar a questão libanesa. Primeiramente porque a noção de povo como um grupo homogêneo e detentor de interesses comuns, nunca foi possível ser empregado ao Líbano e, segundo, devido ao fato de a região sempre estar sob o domínio de terceiros. No período em que ainda não havia um Estado porém os grupos religiosos - drusos e maronitas - estavam agregados numa mesma região, esses estiveram sob o julgo do Império Otomano.

A impossibilidade de estabelecer um projeto nacional para os povos do Monte Líbano - por não compartilharem de objetivos comuns -, agregado ao fato de que no início do século XX as potências ocidentais passaram a influir diretamente sobre determinados grupos religiosos libaneses - mais precisamente, os franceses exerciam certa ascendência sobre a comunidade cristã maronita -, fez com que a queda do Império Otomano - no pós-Primeira Guerra Mundial - não levasse grandes esperanças de mudança para o restante da população muçulmana local. Haja vista os ingleses e franceses já terem dividido o Oriente Médio de acordo com seus interesses geopolíticos e sem levar em consideração as características sócioculturais das populações locais. 
A partir de 1923, com base na legitimação dada pela Liga das Nações, o Líbano passou a fazer parte do território sob mandato francês. Obstante ao direito de autodeterminação dos povos, em seu artigo 22, a Convenção da Liga das Nações anunciava:

To those colonies and territories which as a consequence of the late war have ceased to be under the sovereignty of the States which formerly governed them and which are inhabited by peoples not yet able to stand by themselves under the strenuous conditions of the modern world, there should be applied the principle that the well-being and development of such peoples form a sacred trust of civilisation and that securities for the performance of this trust should be embodied in this Covenant.

The best method of giving practical effect to this principle is that the tutelage of such peoples should be entrusted to advanced nations who by reason of their resources, their experience or their geographical position can best undertake this responsibility, and who are willing to accept it, and that this tutelage should be exercised by them as Mandatories on behalf of the League.

The character of the mandate must differ according to the stage of the development of the people, the geographical situation of the territory, its economic conditions, and other similar circumstances.

Certain communities formerly belonging to the Turkish Empire have reached a stage of development where their existence as independent nations can be provisionally recognised subject to the rendering of administrative advice and assistance by a Mandatory until such time as they are able to stand alone. The wishes of these communities must be a principal consideration in the selection of the Mandatory. (grifo meu)

De fato, o Líbano passou a ser tutelado pela França e não conseguiu alcançar a independência que alguns Estados árabes já pleiteavam naquele momento histórico. Também, a relação de poder estabelecida dentro do Estado libanês foi desigual, privilegiando a comunidade maronita, que era vista como pró-Ocidente. Acerca do sistema de tutela estabelecido por parte de outro Estado ou mesmo por uma determinada camada social sobre as demais, Dahl apresenta amplas críticas e estabelece as conseqüências negativas para o valor democrático.

Por mais instruídos e confiáveis que sejam inicialmente os membros de uma elite governante dotada do poder de governar um estado, em poucos anos ou em poucas gerações, é muito provável que abusem dele. Se podemos dizer que a história da humanidade nos proporciona algumas lições, certamente uma destas é o fato de que, pela corrupção, pelo nepotismo, pela promoção dos interesses do indivíduo e seu grupo, pelo abuso de seu monopólio da força coercitiva do estado para reprimir a crítica, extrair riqueza dos súditos ou governados e garantir sua obediência pela força, é muito provável que os tutores de um estado se transformem em déspotas. (2001: 88) 
Ainda, na tentativa de criar um viés democrático para o sistema de Mandato - não violando o pensamento liberal francês defendido em sua constituição - e, concomitantemente, atender aos anseios da população libanesa, em 1926, sob a supervisão da França, foi promulgada a Constituição do Líbano. É possível perceber que, segundo a análise de David Held acerca do que seria uma "Democracia em Desenvolvimento", a Constituição libanesa proporcionaria ao Estado algumas dessas características - eleição de lideranças através de pleitos regulares e com voto secreto; delimitação do campo de atuação dos Poderes; liberdade de pensamento; de propagação das idéias; demarcação clara da área de atuação da Assembléia e da burocracia estatal, delimitando os papéis de ambas; dentre outras -, entretanto, havia um conflito no que tange à letra da lei e a realidade de fato. Também, não é possível deixar de considerar que, mesmo com esses direitos assegurados pela Constituição, em sua parte “E”, nos artigos 90 a 94, o mesmo governo instituído reconhecia o sistema de mandato francês sobre o Líbano, comprometendo o princípio da soberania das decisões dos cidadãos.

Se considerarmos o fato de que princípios tais como: soberania, livre participação popular nos desígnios do Estado, regularidade de eleições livres, demarcação dos limites de atuação dos Poderes - Executivo, Legislativo e Judiciário -, dentre outros, já vinham sendo incorporados ao pensamento europeu desde o século XVIII e idealizados como paradigma de organização social - democracia - (Held, 1987: 71-104), a maneira com que os franceses impuseram sua dominação sobre o Líbano abriu caminho para que, num futuro próximo, surgissem movimentos árabes que expusessem essa ambigüidade de procedimentos - um ideal forjado para ser defendido mas não para ser aplicado.

A insatisfação frente aos dominadores trouxesse à cena ideólogos de doutrinas que passaram a questionar se os princípios democráticos eram, de fato, universais, por isso, também inerentes ao mundo árabe ou uma doutrina cujo objetivo principal seria a sublimação do Ocidente sobre os povos do Oriente Médio através de sua cultura.

Ainda, dentro desse viés liberal que a Constituição libanesa expressava, havia uma característica bem peculiar sua que era a adoção do sistema confessional de representatividade política. Essa opção se deveu devido ao fato de o Líbano ser um Estado com vários grupos religiosos representativos. Ao optar por esse sistema de representatividade defendia-se o direito das minorias participarem do governo, entretanto, preservava no poder quem de fato vinha exercendo-o até aquele momento, ou seja, a comunidade cristã maronita.

A legitimidade para que a comunidade maronita se mantivesse no poder e viesse a exercer a presidência do Estado acabou sendo ancorada nos dados constantes no Censo de 1932, o qual indicou que $52 \%$ da população libanesa era formada por cristãos, contra $48 \%$ de 
muçulmanos. Dentre os cristãos, a comunidade maronita era a maior, e dentre os muçulmanos, os sunitas se destacavam.

Num primeiro momento a Constituição não assegurava a nenhum dos grupos religiosos o direito de exercer a presidência, contudo, já realçava a necessidade de que fosse implementado um sistema político confessional. A efetivação do direito maronita de exercer a presidência somente deu-se com as modificações constitucionais de 1943 e, de fato, desde a independência nenhum muçulmano exerceu tal cargo. Isso ocorreu, em parte, devido ao receio de que a presença de um muçulmano no poder pudesse aproximar o Estado libanês dos demais vizinhos árabes e, também, porque a relação entre franceses e maronitas dava-se de forma bastante estreita e era compensadora para ambas partes.

Assim, independentemente de o Líbano possuir uma Constituição com características liberais e essa aludir a defesa do sistema confessional no intuito de 'assegurar o direito de todos no Estado', esse mecanismo só foi motivador para que os libaneses conseguissem alcançar a independência. O reconhecimento do direito inalienável dos maronitas de exercer o cargo de Presidente abriu um sério precedente para o desequilíbrio do Estado. Inclusive, com o risco de ser rompido por não atender a dois pressupostos básicos num regime democrático: a alternância no poder e o risco do 'poder ilimitado da maioria', nesse caso, a cristã.

A efetivação de apenas um grupo no poder, como foi exposto, acima, por Dahl, pode levar ao estabelecimento de debilidades (corrupção, nepotismo, promoção dos interesses do indivíduo e seu grupo, abuso do monopólio da força coercitiva do Estado para reprimir críticas, extração riqueza dos governados, etc) que venham a ruir o sistema democrático e colocar em risco o equilíbrio inicialmente proposto. Aliado ao fato de que, no Líbano, a comunidade cristã passou a ampliar seus direitos com base no pressuposto de que atendia aos anseios da maioria, o prognóstico para o futuro do Estado não era salutar. Sobretudo se for confrontado com o que Sartori nos apresenta acerca do risco de haver o exercício do poder absoluto pela maioria:

Se o critério da maioria é transformado (erroneamente) num poder absoluto da maioria, a implicação dessa distorção no mundo real é que uma parte do povo (em geral uma parte bem grande) torna-se não-povo, uma parte excluída. Aqui, então, o argumento é que quando a democracia é equiparada ao poder puro e simples da maioria, essa equiparação converte eo ipso uma parcela do demos em não-demos. Inversamente, a democracia concebida como poder da maioria limitado pelos direitos da minoria, corresponde ao povo todo, isto é, à soma da maioria com a minoria. É precisamente porque o poder da maioria é restringido que todo o povo (todos aqueles que têm direito de voto) está sempre incluído no demos. (1994: 55) 
Exercendo grande pressão sobre o Líbano, a França conseguiu preservar seu status de Estado Mandatário até o final da Segunda Guerra Mundial. Durante esse período eram nomeados Altos Comissários que detinham mais poder que o presidente e primeiro-ministro, assim, suspenderam a Constituição por determinados períodos e chegaram a fechar o Parlamento.

Para se chegar à independência de facto, foi necessário que houve um acerto entre as lideranças cristã maronita e muçulmana sunita acerca da maneira como seria exercido o governo $^{82}$. Nesse momento que foi firmado o Pacto Nacional. Um acordo verbal onde ratificava-se o direito de os maronitas exercerem a presidência do Estado. Os sunitas teriam o cargo de primeiro-ministro para si e, posteriormente, os xiitas obtiveram o direito de exercer o cargo de chefe do Parlamento.

Juntamente com esse acerto, havia a implicação de que a representação parlamentar, e mesmo na burocracia estatal, deveria seguir a fórmula de 6 para 5 em favor dos cristãos ${ }^{83}$. Ou seja, abria-se a possibilidade para que a maioria cristã ampliasse ainda mais seus poderes dentro do Estado, instituindo o sectarismo nos serviços públicos. Dessa forma, o sistema confessional conseguia atender perfeitamente aos interesses daqueles que foram contemplados com o poder, entretanto, para os que ficaram fora do Pacto Nacional, como drusos e xiitas, o sectarismo imposto pela elite dominante passou a ditar as regras no tipo de relações que seriam desenvolvidas com o governo. A insatisfação foi tão grande que inviabilizo, ali, que a democracia encontrasse solo fértil.

Ainda que consideremos o sistema político adotado pelos libaneses - nos primeiros anos de independência - um modelo que evitou o surgimento de um regime ditatorial e também proporcionou a coexistência relativamente pacífica entre os diversos grupos religiosos, a própria ausência de revisão de seus princípios (fórmula da representação proporcional, mecanismos de nomeação para a máquina burocrática, exclusividade de cargos para determinados grupos religiosos, dentre outros) o levou ao colapso. Evidenciados durante as contestações que levaram à Primeira Guerra Civil em 1958.

Exemplo dessa manipulação do Estado por parte dos grupos que detinham o poder no governo, temos na própria Constituição libanesa que, até o fim do período de Mandato sofreu

\footnotetext{
${ }^{82}$ Eram os dois maiores grupos, individualmente, dentre as demais comunidades religiosas. Também, as que melhor se articulavam no poder. Os sunitas chegaram a ter alguns privilégios durante o Império Otomano e os maronitas, durante o período de 1860-1920 e Mandato francês.

83 De acordo com o resultado do Censo de 1932, que apontava para uma ligeira maioria da população cristã (52\%) sobre a muçulmana (48\%).
} 
quatro reformas (17/10/27, 08/05/29, 09/11/43 e 07/12/43); todas elas na tentativa de fortalecer o sistema confessional que já era aplicado.

\section{3 - O SISTEMA CONFESSIONAL LIBANÊS}

Devido aos laços históricos entre a comunidade cristã e o Ocidente, não surpreende que o Líbano seja considerado o país do Oriente Médio com mais características ocidentais. Em parte, esse fato se deve à ligação que a comunidade maronita manteve com a França, e depois com os Estados Unidos. A partir dessa constatação, poderia aventar-se à possibilidade de que a assimilação do ideal democrático também possa ter sido incorporado através desse contato com o Ocidente, no entanto, com algumas reservas que manter-lhes-iam os desígnios do Estado. Além desse pressuposto pragmatismo ao lidar com a democracia, há de se considerar que nas comunidades libanesas o poder sempre esteve ligado à figura do zaim, líder de cada grupo religioso. O que, de maneira geral também é percebido em muitas outras comunidades médio orientais, onde os clãs ditavam as regras desde os períodos pré-islâmicos. (Lewis, 2002: 24)

Para a preservação do status quo de uma elite cristã, o sistema confessional surgiu como um modelo perfeito. Nele estava inserida uma fórmula bastante complexa para aquele momento histórico, mas que acabou sendo assimilada pelos libaneses e foi colocada em prática amplamente.

Um dos primeiros ajustes feito na Constituição libanesa após a independência ocorreu na reforma de 1947, que pôs fim ao sistema bicameral. Adotou-se, assim, o modelo unicameral de representatividade e foi abolida a figura do Senado com a supressão dos artigos 96 ao 100.

Dentro do parlamento fora mantida a fórmula estipulada pelo Pacto Nacional, ou seja, haveria uma maioria de cristãos na proporção de 6 para 5. Naquela oportunidade a quantidade de parlamentares era de $66^{84}$, ou seja 36 cristãos e 30 muçulmanos. A maneira com que eles seriam eleitos estava diretamente ligada à distribuição dos grupos religiosos pelo país.

\footnotetext{
${ }^{84}$ O Parlamento perdurou com essa quantidade de representantes até a década e 1950, quando o então presidente, Camille Chamoun, alterou o número de parlamentares para 99, entretanto, preservou a proporção de 6:5, atribuindo 54 cadeiras aos cristãos e 45 aos muçulmanos. A intenção de Chamoun era ampliar a representatividade dos cristãos no governo, entendia que deveria passar a 80\%, contudo, não obteve êxito e as tensões provocadas por seu governo levaram à Primeira Guerra Civil libanesa em 1958.
} 
Primeiramente era verificada qual a representatividade que cada subgrupo religioso tinha dentro das comunidades cristã e muçulmana. Ou seja, se os muçulmanos tinham direito a 30 cadeiras no Parlamento, deveria verificar a proporção que cada subgrupo (sunitas, xiitas, drusos) religioso teria direito de eleger. A partir daí, com base nas características de cada distrito, estabelecia-se quantos membros seriam eleitos de cada grupo.

Nas regiões onde havia maior concentração de muçulmanos eles teriam maior representatividade no Parlamento, contudo, a proporção de 6 para 5 não deveria ser alterada. Outra característica do sistema eleitoral libanês, que Salibi enfatiza, diz respeito à universalidade do voto, assim, apesar de haver a necessidade de eleger uma determinada quantidade de parlamentares de cada grupo religioso, os votos eram destinados a eles tanto pelos cristãos quanto pelos muçulmanos que tinham direito de voto num determinado distrito.

The country, in a succession of electoral laws, was divided into multi-member constituencies, most of them confessionally mixed, and seats in parliament were reserved for members of the different confessions in the mixed constituencies. This was carried out with a view to promoting political integration among the different communities, as Christian deputies for these constituencies had to secure Muslim votes, and Muslims Christian votes, for their election. (...) A more intelligent plan for political integration at the electoral level could hardly have been devised. In the short term, it seemed to work. In the long term, however, it became increasingly clear that it involved a political vision too subtle for the actual social structure of the country. Within a decade, dissatisfaction was already being expressed. (Salibi, 1988: 186187)

Ratificando o que Salibi afirmara acerca do risco de que a escolha do sistema eleitoral geraria problemas futuros nas relações políticas e sociais do Estado libanês, Ussama Makidisi, salienta que apesar da intenção de que ali fosse estabelecida a integração entre as comunidades religiosas, a questão do sectarismo acabou prevalecendo e impedindo o surgimento de um Estado unitário:

Given the failure of state officials to extend their reach to predominantly Shi'a areas in southern Lebanon and northern regions like Akkar, the nationalist project of Lebanon remained inseparably linked to state-affiliated elites, who dispensed jobs, paved roads and brought electricity to their own regions. The "sectarian balance," based on the 1932 population census, paralyzed the government and reinforced the system of patronage. Corruption served as the effective social security system of the Lebanese. Benefits could not be obtained simply on the basis of citizenship rights because jobs, housing, telephones and education were guaranteed not by the state but through appeals to deputies and ministers and presidents who were themselves appointed or elected according to sectarian laws. In this sense, sectarianism, which undermines the secular national ideal and creates subversive religious loyalties, is 
umbilically tied to the 1943 National Pact which institutionalized the modern, independent Lebanese state. (Makidisi, 1996)

Um segundo problema que interferiu diretamente na instabilidade do sistema político libanês diz respeito ao fato de que com a adoção do sistema confessional, indubitavelmente fazia prevalecer a vontade da maioria cristã e excluía as minorias do processo decisório. Sobre o risco de não haver alternância no governo e a efetivação da vontade da maioria, através do sistema majoritário, Lijphart esclarece que

Nas sociedades pluralistas - sociedades intensamente compartimentadas quanto a diferenças religiosas, ideológicas, lingüísticas, culturais, étnicas ou raciais, originando subgrupos sociais separados, com seus próprios partidos políticos, grupos de interesses e meios de comunicação -, provavelmente estará ausente a flexibilidade necessária para a democracia de modelo majoritário. Sob tais condições, a prevalência da regra da maioria não será apenas antidemocrática, mas também perigosa, uma vez que as minorias que têm seu acesso ao poder sistematicamente negado irão sentir-se excluídas e discriminadas, podendo perder o senso de lealdade ao regime. (Lijphart, 2003: 52) [grifo meu]

A intrínseca ligação entre o sistema confessional e o majoritário, de fato, colocou parte da população à margem do processo político decisório, assim como, criou uma lacuna entre aqueles que eram atendidos pelo Estado e os que apenas detinham o direito de voto.

A situação política no Líbano conseguiu manter-se com certa estabilidade até o ano de 1958, quando foram colocados diretamente em xeque os privilégios dos cristãos sobre a comunidade muçulmana - que àquela época alcançara praticamente o mesmo número de cidadãos - e teve início uma séria de confrontos que desencadearam na Primeira Guerra Civil.

A situação conseguiu ser controlada com a interferência dos Estados Unidos ${ }^{85}$, contudo, as mudanças que os vários segmentos sociais cobravam não foram atendidas e a tensão prevaleceu até que o Estado viu-se diante da ruína provocada pelo maior confronto de sua história, a Segunda Guerra Civil, que teria início em 1975.

\section{4 - O JOGO PARTIDÁRIO LIBANÊS}

Por volta dos anos de 1920, os partidos políticos começaram a surgir no Líbano, alguns buscando identificação com o pan-arabismo, que defendia os laços culturais entre os

\footnotetext{
${ }^{85}$ Solicitada pelo presidente maronita que, à época, suscitou o uso da 'Doutrina Eisenhower' que visava proteger os Estados do Oriente Médio do 'perigo comunista' imposto pela URSS. Sobre esse acontecimento histórico, ver página 73.
} 
povos árabes, e outros influenciados pelo pensamento comunista, então fortalecido pela Revolução Russa de 1917.

Nessa primeira etapa de atividade partidária as grandes questões que se impunham aos partidos diziam respeito à identificação dos libaneses. Alguns partidos conclamavam a ligação histórica entre Líbano e Síria como fator preponderante para contestar a divisão de seu território estabelecida pelos franceses e ingleses, outros buscavam uma ligação mais ampla com o mundo árabe, de modo geral. Ainda, havia aqueles que buscavam uma via diferenciada para a trajetória do país e defendiam o nacionalismo libanês, 'libanismo'. A questão da preservação do vínculo com o Ocidente também era objeto de discussões nas comunidades muçulmana e cristã - e dentro delas, inclusive ${ }^{86}$.

Na efervescência de movimentos e propostas que a comunidade libanesa vivia, a necessidade de que o Líbano tivesse o caráter secularista e não confessional tornou-se uma das bandeiras hasteadas por Anton Saadeh, que conseguiu agregar seguidores de vários grupos religiosos - drusos, gregos ortodoxos, protestantes e alguns poucos xiitas - para seu Partido Nacional Sírio (fundado em 1932), mas também gerou insatisfação por parte da comunidade cristã maronita e dos sunitas.

A proposta de Saadeh era (re)criar a 'Grande Síria', um Estado que abrangesse a Síria, Líbano, Iraque e Palestina. A idealização desse Estado, cuja proposta política conseguia agregar cada vez mais discípulos, passou a chamar a atenção dos franceses - então detentores do mandato sob o Líbano e Síria - temerosos de sua pregação nacionalista.

Saadeh, para a recriação de um vínculo territorial único para 'os sírios', buscou estabelecer laços étnicos-psicológicos-históricos-culturais entre os povos que viviam na 'Grande Síria’ desde os tempos dos Cananitas, Caldeus, Assírios, Amoritas, etc. (Seale, 1966: 66) A proposta de Saadeh, em alguns aspectos, era bastante rígida e assemelhava-se aos regimes fascistas que já despontavam na Europa.

Devido, também, à rigidez de seu projeto nacionalista, muitas vezes entrou em confronto direto com outros partidos políticos, como o Falangista (fundado em 1936, liderando por Pierre Chamoun, cristão maronita). A tensão que se manifestava entre os grupos religiosos, aliada à tradição 'feudal' dos zuama de criar seus próprios mecanismos de defesa, fez com que muitos partidos políticos criassem suas próprias milícias.

Em 1958 o Líbano já possuía vários partidos políticos ligados às famílias, os quais, por sua vez estavam ligadas a grupos religiosos que também podiam professar ideologias políticas

\footnotetext{
${ }^{86}$ Sobre a discussão acerca da identidade libanesa, rever item 2.4 dessa dissertação.
} 
ou serem meramente defender de seu espaço dentro do sistema político libanês. A estrutura dos partidos políticos assemelhava-se à forma com que os clãs se organizavam, ou seja, centralizada na figura do patriarca.

O Líbano também desenvolveu seus partidos comunistas e socialistas. Muitas vezes apoiados diretamente pela União Soviética - ou através da Síria e Egito - para contrabalançar o poder de influência que os Estados Unidos exerciam junto à comunidade cristã local. Destaque dentre os movimentos de esquerda, cabe ao liderado por Kamal Jumblatt, figura proeminente na comunidade drusa, que fundou o Partido Socialista Progressista, em 1949.

Muitas vezes, apesar da existência dos partidos políticos, havia (e ainda há) a organização desses em blocos políticos que se agrupam dentro do parlamento de forma a defenderem interesses comuns. Entretanto, não atribuem fidelidade maior ao Bloco que aos seus próprios líderes regionais - normalmente também são membros do Parlamento.

A partir desse panorama suscitado é possível perceber que os partidos políticos nada mais representavam que seus próprios grupos religiosos e/ou étnicos, e, como as comunidades religiosas exerciam grande dominação em suas bases eleitorais através do poder dos zuama, os parlamentares acabavam sendo eleitos dentro da família de maior poder ${ }^{87}$. Um procedimento que nada tinha a acrescentar à incipiente 'democracia libanesa', e mais, questionando, inclusive o valor democrático do processo estabelecido. O poder dos zuama representa o contra-senso da democracia, porque "a democracia exige a individualização. Não há democracia se não há indivíduos, ou quando há clãs, tribos, grupos étnicos ou religiosos fortes.” (Ribeiro, 2005)

Apesar de haver esse grande entrave para a real efetivação do sistema democrático, a legislação eleitoral procurava amparar-se em alguns modelos utilizados por democracias estáveis ocidentais, para isso criava leis que fixavam o mandato parlamentar em quatro anos cabendo o direito à candidatura a qualquer libanês com mais de 21 anos - e do Presidente em seis - sem direito de reeleição subseqüente. A nomeação do Primeiro-ministro seria feita pelo Presidente e, esse, eleito pelo Parlamento. Como já foi mencionado anteriormente, os parlamentares eram eleitos de forma direta pela população. Essa, por sua vez, tinha a possibilidade de escolher entre votar numa lista com candidatos pré-definidos - que contemplava a quantidade que cada grupo religioso tinha direito de eleger naquela localidade - ou escolhê-los individualmente.

\footnotetext{
${ }^{87}$ Até as eleições de 1992, os parlamentares eleitos eram provenientes de apenas 200 famílias. (Krayem)
} 
De certa forma, o sistema confessional impôs aos zuama a necessidade de se organizarem em partidos políticos para a preservação do poder de influência, isso porque, somente através de representação no Parlamento teriam como obter ganhos para suas regiões.

Percebendo a função dos partidos políticos como um mero mecanismo para a obtenção de vantagens pessoais, uma questão torna-se relevante se pensarmos neles como instituições democráticas: qual seria a relação entre a liderança e seus filiados?

A relação servil dos membros do partido, proveniente do sentimento de lealdade para com o zaim (no caso libanês), reduz a necessidade de que haja uma proposta partidária vinculada a uma ideologia ou projeto de governo para o Estado. Os membros do partido servem ao zaim, no entanto, também recebem benefícios por isso. A função do partido tornase meramente coadjuvante no cenário político. Um meio para alcançar o poder.

Dessa forma, com um grau de institucionalização ainda incipiente para os partidos políticos, a maneira utilizada para a manutenção dos privilégios dos grupos dominantes foi estabelecer que os principais cargos ficaram para os maronitas (Presidente) e para os sunitas (Primeiro-ministro). Aos grupos que ficaram fora dessa divisão de poder, caberia compensar a deficiência tentando assegurar o maior número possível de representantes no Parlamento para que seu apoio pudesse utilizado como 'moeda de troca'. Com isso, as disputas davam-se mais no interior dos próprios grupos religiosos que necessariamente entre eles, haja vista ser previamente determinado o número de cadeiras destina para cada grupo. Assim, cristãos não competiam com muçulmanos por suas vagas, no entanto, drusos da família Jumblatt poderiam concorrer com outros drusos da família Arslan por uma determinada vaga, caso habitassem o mesmo distrito eleitoral.

Dentro de um sistema fortemente sectarista como o libanês, ter um representante no Parlamento configurava-se na única maneira para que sua região obtivesse algum privilégio do governo, dessa forma, fortalecia, também, o clientelismo e abria caminho para a corrupção, que passou a caracterizar o governo de vários presidentes e levou o país aos conflitos de 1958 e 1975-90. Num sistema altamente corrompido, no qual o detentor de privilégios procurava não proporcionar qualquer benefício aos demais grupos exceto o seu, a sub-representatividade de alguns segmentos sociais, como o xiita, representava um risco para a preservação de um Estado unitário. Isso porque tornava-se cada vez mais perceptível que o equilíbrio estabelecido pelo Censo de 1932 não mais representava a realidade social do Líbano e que precisaria ser revisto.

Ao mesmo tempo, aceitar tal questionamento e aventar a possibilidade de estabelecer outro tipo de fórmula para o sistema político-eleitoral significava a perda de poder, o que 
nenhum líder regional estava propenso a fazer. Dessa forma, evidenciava-se a diferença de tratamento dada às diversas comunidades religiosas libanesas e afastava do Estado a responsabilidade sobre os xiitas - que viviam nas localidades mais pobres do país: sul do Líbano, Vale do Bekaa e subúrbios de Beirute - e não recebiam assistência. Abria, também, caminho para a difusão do pensamento islamista xiita, cujo propagador principal, a partir do final da década de 1950, foi Musa al-Sadr, idealizador do Movement of the Deprived (Movimento dos Necessitados), em 1974, e que, com o início da Segunda Guerra Civil militarizou o movimento e criou o Amal. Segundo seus ensinamentos, "os tiranos que oprimiam os xiitas eram yazids ${ }^{88}$ modernos, o jihad consiste na batalha contra a injustiça dos poucos contra os muitos, [e] o jihad agrada a Deus e Ele ajudará a quem ajuda a si mesmo.” (Demant, 2004: 241)

De certa forma a tensão estabelecida pelo sistema político-eleitoral libanês já explicitava suas fraquezas e evidenciava o que iria acontecer. Porque, conforme salienta Renato Janine Ribeiro, “é da natureza da democracia que parte de uma etnia, de uma seita ou classe fique fora do poder - mas não que grupos inteiros sejam excluídos. Quando isso acontece, temos uma bomba-relógio. Ora, quando a individuação é pequena, ou se excluem alas inteiras da sociedade ou se negocia e reparte o poder. Mas isso torna difícil decidir.” (Ribeiro, 2005)

\section{5 - 1975, GUERRA CIVIL, FIM DAS INSTITUIÇÕES}

Se o Líbano conseguiu manter suas instituições, mesmo diante da evidência de que não funcionavam conforme uma proposta democrática estabelece - uma vez que suprimia o direito de participação de vários segmentos sociais libanês -, com o início da Segunda Guerra Civil o Estado perdeu quaisquer características que pudesse classificá-lo como democrático. Mais ainda, poderia questionar se o Líbano preservou as características de um Estado, haja vista ter perdido o domínio do monopólio da violência, o reconhecimento do governo central (presidência) por parte de grande parte da população e a soberania territorial (com a entrada da Síria no país em 1976 e de Israel em 1978 e, mais efetivamente a partir de 1982, ocasião

\footnotetext{
${ }^{88}$ Yazid foi filho do califa Omíada Muawiya e assumiu o califado em 680, ocasião em que ocorreu o massacre na cidade de Karbalah, Iraque. Nesse episódio o imã Ali resolveu enfrentar as tropas de Yazid e foi assassinado, juntamente com seus seguidores. O efeito mítico da morte de Ali repercute até os dias de hoje como símbolo de martírio e não resignação perante os poderosos. A figura de Yazid passou a ser relacionada a um mal que deva ser suprimido.
} 
que assumiu o controle de aproximadamente 10\% do território libanês com a criação da 'Zona de Segurança').

Os momentos que antecederam à Guerra Civil já apresentavam um Estado tomado por milícias. Praticamente todos os partidos políticos possuíam grupos paramilitares que davam sustentação ao poder regional das famílias. O poder central do Presidente já não atingia a maior parte da população e nem mesmo dentro da comunidade maronita conseguia ser consensual. Grupos maronitas digladiavam-se pelo poder e não deixavam de praticar as maiores atrocidades, uns contra os outros.

Também, não é possível deixar de mencionar o profundo desequilíbrio regional que a entrada da OLP (Organização para a Libertação da Palestina), e dos palestinos, acarretou ao Líbano com sua migração, primeiro da Palestina e depois da Jordânia. Um dos problemas mais perceptíveis foi o aumento desmedido de muçulmanos perante os cristãos. Mas também provocou atritos com a comunidade xiitas do sul do Líbano por estar disputando os mesmos parcos recursos locais, além de transformá-la em alvo de represálias israelenses.

A situação libanesa agravou-se com a assinatura do Acordo do Cairo (1969), quando a OLP teve sua ação legitimada no Líbano e acabou criando estruturas de um Estado dentro de outro Estado. Conforme pode ser percebido pela redação de alguns itens do Acordo:

\section{A Presença Palestina}

Foi acordado o reconhecimento da presença palestina no Líbano sobre as seguintes bases:

1) É reconhecido o direito dos palestinos que vivem atualmente no Líbano ao trabalho, residência e deslocamento.

2) Criam-se comissões palestinas dentro dos campos de refugiados para garantir os interesses palestinos dentro deles, em colaboração com as autoridades locais, e dentro do quadro de soberania libanesa.

3) Sobre a presença das unidades de Comando para a Luta Armada Palestina $\left(\right.$ CLAP $\left.^{89}\right)$ no interior dos campos, estabelece se o seguinte:

- Estas unidades, em colaboração com as unidades mencionadas, garantirão as boas relações com as autoridades locais. As unidades do CLAP serão igualmente responsáveis pelo cuidado na distribuição e determinação da quantidade de armas que existirão nesses campos, e isso no quadro da segurança do Líbano e no interesse da revolução palestina.

4) Autoriza-se aos palestinos que residem no Líbano participarem da Revolução Palestina, no âmbito da Luta Armada, e dentro do quadro dos princípios de soberania e segurança do Líbano.

\section{As Atividades da Resistência}

Decidiu-se facilitar a ação da Resistência através dos seguintes meios:

\footnotetext{
${ }^{89}$ Mais comumente conhecida por sua sigla em inglês PASC (Palestinian Armed Struggle).
} 
1) Facilitar a passagem dos fedayn e fixar os pontos de observação desses nas regiões fronteiriças.

12) Serão colocados em liberdade todos os detidos e devolvidas suas armas.

14) As duas delegações [libanesa e palestina] reafirmam que as ações dos combatentes contribuem tanto para a salvaguarda do interesse do Líbano como da revolução palestina, e de todos os países árabes. (Del Pino, 1989: 166-7)

Assim, o governo libanês deixou de exercer qualquer ascendência sobre a OLP, uma vez que as cláusulas do Acordo que diziam respeito à preservação de seus interesses transformaram-se em letra morta, com isso as represálias israelenses voltaram a acontecer a partir de 1978.

No início dos anos de 1980, já sob a influência dos teocratas iranianos que haviam chegado ao poder com a Revolução Islâmica de 1979, o Hizbullah passou a questionar os valores ocidentais que pautaram a vida libanesa, além da presença israelense no sul do Líbano. Para reforçar os valores islâmicos o Hizbullah implantou uma disciplina mais rígida da sharia nos bairros xiitas de Beirute e nas cidades onde controlava.

À parte essa transformação que o Hizbullah procurava fazer na estrutura social libanesa, as instituições políticas continuaram existindo, mas não houve eleição de novos parlamentares nos anos de guerra civil. Ainda assim, com os grupos religiosos desacreditando da efetividade das instituições, procuravam elaborar novas propostas que pudessem melhorar a qualidade da representatividade da população e pusesse fim à guerra.

Como não parecia haver uma fórmula comum que contemplasse aos anseios de todos os grupos em litígio, durante os 15 anos de guerra civil a população teve praticamente toda a infra-estrutura do país destruída, houve a emigração de grande parte de seu povo para países do Ocidente, e, milhares de pessoas foram mortas em conflitos diretos, atentados, seqüestros, etc.

Os problemas relacionados aos atores externos tiveram de entrar na agenda de negociações e foram resolvidos gradualmente para que o Líbano conseguisse chegar a um acordo que pusesse fim à Guerra Civil. Quanto à OLP, com a entrada de Israel no país, em 1982, a liderança da organização teve de fugir para a Tunísia e suas bases no sul do Líbano foram desativadas - pelo menos temporariamente. Entretanto, o enorme contingente de refugiados palestinos permaneceu no Líbano sem ter como voltar para a Palestina. Também, muitos deles acabaram incorporando-se à vida libanesa e não mais tinham interesse de voltar, apesar de não possuírem os mesmos direitos dos cidadãos libaneses. Essa distinção era defendida pelas comunidades cristãs libanesas que viam na presença palestina um grande 
risco para sua representatividade, haja vista a aceitação dos palestinos com direitos iguais aos dos cidadãos libaneses geraria o aumento desmedido de muçulmano no país.

Nesse panorama de negociações, a Síria tornou-se o ator com maior poder de influência no Líbano após sua entrada no país em 1976 devido a sua estratégia que privilegiava o pragmatismo a qualquer conceito religioso ou nacionalista.

\section{6 - O PENSAMENTO ISLAMISTA PRÉ-TAIF}

Como vimos, o Estado libanês surgiu de um movimento de libertação localizado em duas comunidades distintas, porém, caracterizadas por pertencerem à elite do país, a cristã maronita e a muçulmana sunita. Suas elites dividiram o poder e a estrutura do Estado para si, entretanto, na ocasião em que a independência ocorreu (1943), eram, de fato, as duas maiores comunidades religiosas presentes no Líbano.

O sistema confessional tinha a intenção de preservar a participação de todos os grupos religiosos nas decisões políticas do Estado; pelo menos essa foi a motivação difundida para tal acerto. Contudo, o que caracterizou esse modelo foi a exclusão de determinados grupos sociais do poder decisório do Estado. O sectarismo passou a reinar nas relações públicas e privadas afastando ainda mais a comunidade xiita do poder.

O pertencimento ao Estado demanda mais que simplesmente possuir o direito ao voto - o qual todos os libaneses sempre tiveram -, é necessário que não haja diferenciação entre os cidadãos. E essa condição não existia no Líbano. Cabe ressaltar que as regiões onde habitavam os xiitas sempre foram as mais pobres, sem infra-estrutura e relegadas pelo Estado. Assim, o sentimento de pertencer ao mesmo grupo que dirigia o país e considerar-se cidadão igual ao dele tornava-se um exercício bastante difícil de ser feito pelos xiitas.

Nos intensos questionamentos dos anos de 1950, quando o nasserismo ditava as regras no mundo árabe e o Ocidente via com preocupação a inclinação do Egito à União Soviética, a comunidade xiita libanesa passava à margem dessa discussão. Os xiitas ainda percebiam no sistema confessional libanês seu maior problema e, por isso, centravam nele sua luta. A equiparação de seus direitos ao dos demais membros do Estado, com a possibilidade de participação efetiva em todas as instâncias de poder, além da ampliação das políticas públicas às regiões xiitas, era a principal demanda. 
Paralelamente aos questionamentos internos, parte dos xiitas libaneses apoiava a proposta nasserista de restauração do ‘poder árabe’ na península, apesar de ser eminentemente secularista e não agregar qualquer mudança específica na qualidade de vida dos xiitas.

Mas o nasserismo não era único nesse cenário, enquanto a comunidade xiita libanesa passara a ter como referência religiosa Musa al-Sadr, que havia sido formado pelas principais escolas do xiismo de Najaf e Qom, o Egito via a radicalização do pensamento de Banna pelas mãos de Qutb.

A ideologia de Qutb é expressamente antiocidental; ela rejeita não apenas o modo de viver "dissoluto" e "blasfemo" da civilização ocidental, mas igualmente a sua maneira de organizar a sociedade e o governo. Este ponto é crucial: a democracia, produto ocidental por excelência, seria o resultado da premissa antropocêntrica errônea do Iluminismo de que o homem pertence a si mesmo. (...) Qutb rejeita veemente essa base: a soberania não pertence ao homem mas só a Deus. Ao homem, mero makhlub, criatura (como o resto da criação), não cabe se arrogar mais do que servir ao seu Criador. Qutb está ligado aqui a Ibn Hanbal, o pai da escola mais rigorosa da xaria, a hanbalita, que recusa tanto a filosofia especulativa quanto misticismo: o objetivo do homem não seria conhecer a Deus nem amar a Deus, mas servir a Deus. A primeira etapa do pensamento fundamentalista insiste, portanto, na hakimiyyat Allah, governo de Deus. (Demant, 2004: 209)

Diferentemente de Qutb, Sadr partia de uma proposta que em muitos aspectos estava ligada ao pensamento de Esquerda da época. Isso porque, os xiitas não só sentiam a ausência de representatividade política, mas também não possuíam o básico das necessidades para a vida moderna, tais como escolas, hospitais, estradas e sistema de água e esgotos. (Jaber, 1997: 10-11) Assim, Sadr iniciou um processo de identificação dos xiitas como uma classe social que teria poderes de reivindicação por ser numerosa e fazer parte do Estado libanês.

Agregando a esses questionamentos sociais o pensamento de Khomeini e Baqir alSadr, Musa al-Sadr unia a trajetória da população xiita libanesa a dos persas xiitas do Irã. Confrontava, assim, o nacionalismo árabe e estabelecia como prioritário o vínculo religioso. Sadr, mesmo diante do adverso contesto político libanês, tentava encontrar mecanismos para que a população xiita alcançasse uma maior representatividade ${ }^{90}$, para isso, em 1967 criou o Alto Conselho Islâmico dos Xiitas Libaneses (Majlis al-Shii al-Aala), tornou-se presidente dele e conseguiu fazer a comunidade xiita ser mais bem representada perante as demais. Em 1974, um ano antes do início da Segunda Guerra Civil, Sadr criou o Movimento dos

\footnotetext{
${ }^{90}$ Diz-se "maior representatividade" devido ao fato de que, apesar de o cargo de 'Chefe do Parlamento' ser de exclusividade dos xiitas, ele era desempenhado por um zaim e, como havia forte competição entre os zuama, apenas um segmento de xiitas acabava sendo contemplado.
} 
Necessitados (Harakat al-Mahroumeen), o qual reivindicava a igualdade de direitos entre os grupos religiosos libaneses. O movimento começou a ganhar mais força e a comunidade xiita vislumbrava a possibilidade de alcançar um status melhorado na sociedade libanesa, porém, com o início da guerra civil (1975) toda e qualquer possibilidade de reestruturação do sistema político se perdeu.

Sadr ainda criaria o Amal - uma milícia que servia para defender os interesses da comunidade xiita libanesa - durante a guerra civil, entretanto, não viveu para testemunhar a concretização do projeto político e religioso de seus ideólogos. Em 1979 o Irã tem sua revolução islâmica e o país adota um sistema político baseado na sharia. Apesar de apresentar um programa islamista, parte para um regime misto, no qual há a eleição de um presidente e de um parlamento. Obviamente, todos contando com o aval da liderança religiosa que passa a reger o país.

Com a morte de Sadr o Amal passou por uma crise de identidade e, ao ser assumindo por Nabih Berri, afastou-se completamente do pensamento islâmico de Sadr e tornou-se secularista. Essa mudança de postura gerou insatisfação em parte da população xiita, haja vista não ter agregado vantagens aparentes, exceto para aqueles que advinham de grupos mais ricos e que já tinham alcançado algum poder estando próximo ao Chefe do Parlamento.

Os membros da organização xiita, insatisfeitos com a política secularista de Berri, deixaram o Amal e fundaram outras organizações como o Amal Islâmico, al-Da’wa, dentre outras. Em ambas havia a intenção de lutar contra a presença israelense no Líbano (já instalada desde 1982) e implementar um programa que levasse o país a alcançar o mesmo destino que o Irã teve, ou seja, instaurar uma República Islâmica no Líbano.

No transcorrer da Segunda Guerra Civil, mais precisamente no início dos anos de 1980, as organizações xiitas passaram a receber maior apoio - financeiro, logístico e estratégico - do Irã, possibilitando, assim, o surgimento de uma organização mais bem estruturada, o Hizbullah.

Tendo como guia espiritual o Aiatolá Khomeini e também o Aiatolá Fadlallah o Hizbullah estabeleceu-se como o principal porta-voz do regime iraniano. Quanto à ligação do Hizbullah com Fadlallah, esse alega ser apenas um mentor espiritual da organização e coincidir com ela em alguns pontos de vista. he preached the doctrine of the Islamic state in Lebanon since he returned to the country in the sixties, long before the Iranian Revolution. He is without doubt the most eloquent speaker and 
defender of the Islamic cause in Lebanon. He has on many occasions openly identified with Hezbollah, but he also opposed their position. (Jaber, 1997: 67)

Com base no pensamento de Fadlallah mas reverenciando o regime implementado no Irã de Khomeini, o Hizbullah passou a ditar sua doutrina e defender uma visão própria com relação ao pensamento islamista em voga. Aqui, caracterizo como ‘uma visão própria’ devido à transformação que a doutrina foi tendo até possibilitar com que a organização islamista se transformasse num partido político e se integrasse ao jogo democrático libanês. Uma postura, sem dúvida nenhuma, pautada pelo pragmatismo da organização.

Apesar do pragmatismo, alguns aspectos da doutrina do Hizbullah merecem destaque e suscitam questionamentos, dentre elas podemos destacar:

O Antiocidentalismo - assumindo a identidade islâmica - e não libanesa -, o Hizbullah reitera sua aversão aos países do Ocidente, assim como a sua cultura. A justificativa está enraizada em momentos históricos que remontam às Cruzadas e, posteriormente, à política colonialista européia. Nesses períodos a cultura cristã teria tentando destruir os valores muçulmanos através da evangelização da região islâmica. Dentro dessa perspectiva, os Estados Unidos, no século XX, devido à sua política externa para o Oriente Médio entendida como prejudicial aos interesses econômicos dos muçulmanos, além de perniciosa no sentido de contrariar seus princípios religiosos -, assumiram a postura de maior inimigo da organização. A alegação de que o Ocidente pretende sobrepor-se aos muçulmanos encontra respaldo para sua argumentação principal no início dos anos 1900, quando as potências européias - França e Inglaterra - dividiram o mundo árabe sem considerarem as características das populações nativas. Ademais, de acordo com Fadlallah e o Hizbullah

the US' regional policy is not based don real US interests but on Israeli interests. Therefore, the US does not have an American policy to the Middle East, but an 'Israeli policy', which stems from the US' ideological commitment to Israel. So closely intertwined are Israel's and US' interests that the two states are deemed identical and are alternately cast as being the other's instrument. On the one hand, Israel is depicted as US' 'spearhead' in the region, while on the other, US is portrayed as Israel’s ‘tool’. (Saad-Ghorayeb, 2002: 91)

Ainda, conforme Saad-Ghorayeb desenvolve o raciocínio do Hizbullah, com base nessa sugerida união entre Estados Unidos e Israel haveria uma conspiração para destruir os valores muçulmanos. Dessa forma, as ações israelenses contra os Estados árabes estariam sendo subsidiadas pelos estadunidenses. Como exemplo, também é suscitada a ação israelense contra o Líbano (1982), na qual o país árabe perdeu sua soberania e, mesmo após a ONU ter 
ordenado que Israel deixasse o país (através da resolução 425), os Estados Unidos nunca implementaram qualquer ação para que a resolução tivesse efeito.

O Anti-sionismo e o anti-Israel - a aversão perante o Estado de Israel não reside somente no fato de o Líbano estar sofrendo uma invasão quando o Hizbullah foi criado. Segundo as lideranças da organização, a própria criação do Estado israelense já representa a usurpação do território dos palestinos e, por si só, rende a ele a característica de ter sido criado ‘originalmente com base na agressão’. Assim, o Hizbullah não reconhece Israel e nem o trata como Estado, mas somente como 'a palestina ocupada'.

Segundo Saad-Ghorayeb, mencionando fontes árabes: "as a racist state and society, Israel attempts to 'enslave' the Arabs and Muslims, whom it regards as culturally inferior, by perpetrating the 'worst kind of terrorism and massacres' against them. Accordingly, the party likens Israel's racist crimes to Nazism, and even claims they are 'worse' than Hitler's persecution of the Jews.” (2002: 135-6) Também, para o grupo xiita, o Estado israelense ainda preserva o projeto expansionista que os Sionistas defendiam no pósPrimeira Guerra Mundial Conferência de Paz de Paris -, ocasião em que idealizavam um Estado judaico cujas fronteiras se estenderiam do Rio Litani ao Sinai. (Brichs, 2002: 250)

A Resistência - o Hizbullah utiliza uma linha de raciocínio que inicia seu desencadeamento a partir da justificativa de que ele nasceu de um clamor popular - por parte população

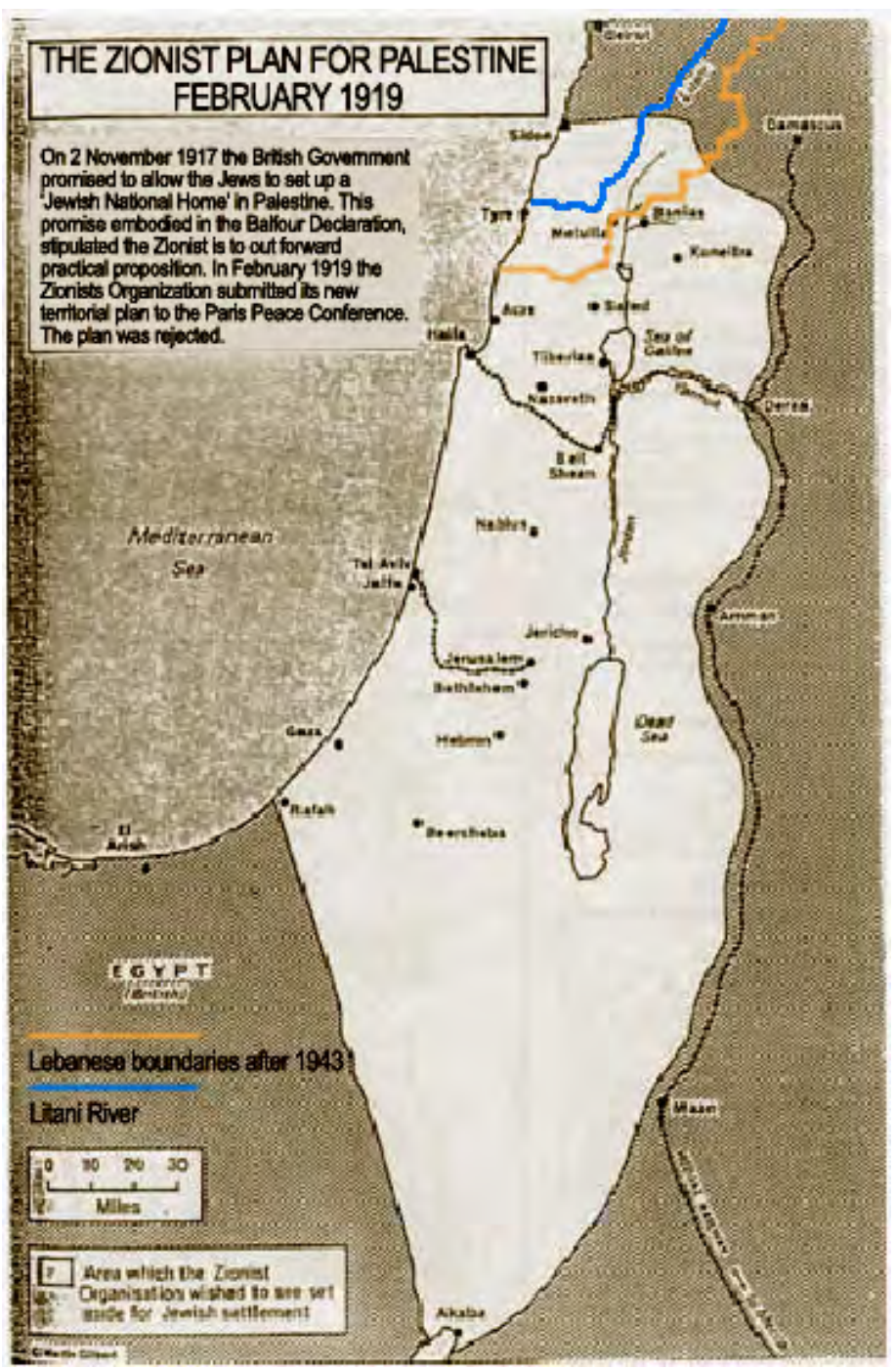
xiita libanesa - proveniente de um segmento social desvalorizado dentro da sociedade libanesa. A opressão por parte dos cristãos levou os xiitas a buscarem uma nova forma de entendimento de sua situação perante a sociedade libanesa e também num contexto mais 
amplo - que seria a função dos muçulmanos na ordem global. A presença israelense em território libanês fez com que esse sentimento - que estava sendo elaborado e podemos entendê-lo como o islamismo - fosse potencializado e surgissem vozes contra tal situação. Com um inimigo mais bem definido, a liderança do Hizbullah passou a priorizar a retomada da soberania do Estado a travar uma luta contra os cristãos opressores.

Sob essa bandeira, a argumentação do Hizbullah tornava-se amplamente aceita pelos países árabes - em luta contra Israel desde sua criação - e também em conformidade com o Direito Internacional - criado pelo Ocidente - que resguarda ao Estado o direito de zelar e lutar por sua soberania. Com base nessa argumentação, o Hizbullah passou a autoproclamar-se como um exército de Resistência.

\section{7 - ACORDO DE TAIF E OS NOVOS RUMOS DA DEMOCRACIA}

Em 1989, ano que foi assinado o Acordo de Taif - cidade da Arábia Saudita onde aconteceram as reuniões de negociação do acordo -, o Líbano encontrava-se sem eleições para o parlamento desde 1972, entretanto, os cargos de Presidente e Primeiro-ministro vinham sendo alternados dentro de uma lógica de exceção estabelecida pela guerra civil.

Outra característica do final dos anos de 1980 era a presença síria no Estado libanês de maneira quase que institucionalizada, exercendo poder de influência junto à presidência e ao Primeiro-ministro. Hafez al-Assad, governante da Síria, também conseguia manter sua capacidade de persuasão graças ao forte aparato militar que mantinha no país vizinho, contando com aproximadamente 40.000 soldados. Tal era a força de Assad que a presença síria no Líbano não era percebida como uma violação de sua soberania. Alguns entendiam como sendo um mesmo povo divido pela ação do Ocidente, outros alegavam que para efeito da preservação da paz, sua presença tornara imprescindível. Havia, ainda, aqueles que se posicionavam contra a violação da soberania - como Kamal Jumblatt ${ }^{91}$-, no entanto, corriam o sério risco de represálias.

\footnotetext{
${ }^{91}$ Tradicional líder da comunidade drusa, durante os anos de 1975-6 também esteve à frente dos grupos libaneses que contestavam Israel e sua política. Na ocasião da entrada das tropas sírias no Líbano, posicionou-se contra Assad veementemente. Em 16 de março de 1977 Jumblatt foi assassinado por milícias pró-Síria em colaboração com o Partido Baath. Perante a impossibilidade de qualquer investigação, em vista de o Líbano estar passando um período de guerra civil e suas próprias instituições estarem sendo questionadas, o envolvimento sírio apenas foi aventado. No entanto, em 2005, seu filho, Walid Jumblatt acusou abertamente os agentes do serviço secreto sírio de terem cometido o assassinato de seu pai.
} 
A situação gerada pela guerra civil libanesa já havia destruído o país e não apresentava grandes perspectivas para que houvesse uma mudança no panorama local exceto se a comunidade cristã aceitasse rever as bases do Pacto Nacional. Para isso a Liga Árabe organizou uma reunião na Tunísia no intuito de encontrar uma saída para o problema libanês. A intenção dos membros era trazer para a mesa de negociação os parlamentares libaneses e dar início a um processo de paz. Rafiq Hariri, figura proeminente na comunidade sunita foi um dos membros que trabalhou em prol de levar os parlamentares à mesa de negociação.

O resultado da intermediação feita pela Liga Árabe foi a reunião que ocorreu em Taif, ainda em 1989, e contou com a participação de 62 parlamentares libaneses. Desses, apenas uma pequena parte era formada por cristãos, o que deu um aspecto parcialmente legal à negociação que ali seria desenvolvida.

Por fim, apesar das abstenções, conseguiu-se assinar o Acordo de Taif que previa emendas à Constituição estabelecendo um novo equilíbrio de forças entre muçulmanos e cristãos - agora ambos seriam representados igualmente no Parlamento - e transferir-se-ia poderes da presidência para o Gabinete. O preâmbulo, que foi emendado à Constituição, já trazia novas características para o Estado que visava extinguir as diferenças religiosas e, num futuro não estabelecido, deixar de ser regido pelo sistema confessional.

\section{Preamble}

a. Lebanon is a sovereign, free, and independent country. It is a final homeland for all its citizens. It is unified in its territory, people, and institutions within the boundaries defined in this constitution and recognized internationally.

b. Lebanon is Arab in its identity and in its association. It is a founding and active member of the League of Arab States and abides by its pacts and covenants. Lebanon is also a founding and active member of the United Nations Organization and abides by its covenants and by the Universal Declaration of Human Rights. The Government shall embody these principles in all fields and areas without exception.

c. Lebanon is a parliamentary democratic republic based on respect for public liberties, especially the freedom of opinion and belief, and respect for social justice and equality of rights and duties among all citizens without discrimination.

d. The people are the source of authority and sovereignty; they shall exercise these powers through the constitutional institutions.

e. The political system is established on the principle of separation, balance, and cooperation amongst the various branches of Government.

f. The economic system is free and ensures private initiative and the right to private property.

g. The even development among regions on the educational, social, and economic levels shall be a basic pillar of the unity of the state and the stability of the system. 
h. The abolition of political confessionalism is a basic national goal and shall be achieved according to a gradual plan.

i. Lebanese territory is one for all Lebanese. Every Lebanese has the right to live in any part of it and to enjoy the sovereignty of law wherever he resides. There is no segregation of the people on the basis of any type of belonging, and no fragmentation, partition, or colonization.

j. There is no constitutional legitimacy for any authority which contradicts the 'pact of communal coexistence'. This Constitutional Law shall be published in the Official Gazette.

Apesar de a Constituição apresentar um aspecto democrático, reforçando princípios amplamente defendidos pelas democracias ocidentais, a comunidade cristã viu-se prejudicada pelo novo equilíbrio de poderes entre os grupos religiosos e, como resultado, o General Michel Aoun partiu para a contestação do Acordo e iniciou uma rebelião que o levou à presidência do Líbano por um breve período de tempo. A não aceitação das bases do Acordo, que era amplamente a favor do governo sírio - uma vez que em sua parte Quatro ratificava os laços fraternais entre os dois paises e apontava para a assinatura de um futuro acordo que institucionalizaria o poder sírio sobre o Líbano - fez com que a guerra civil se arrastasse por mais um ano após a conclusão das negociações de Taif.

\section{Fourth, Lebanese-Syrian Relations:}

Lebanon, with its Arab identity, is tied to all the Arab countries by true fraternal relations. Between Lebanon and Syria there is a special relationship that derives its strength from the roots of blood relationships, history, and joint fraternal interests. This is the concept on which the two countries' coordination and cooperation is founded, and which will be embodied by the agreements between the two countries in all areas, in a manner that accomplishes the two fraternal countries' interests within the framework of the sovereignty and independence of each of them. Therefore, and because strengthening the bases of security creates the climate needed to develop these bonds, Lebanon should not be allowed to constitute a source of threat to Syria's security, and Syria should not be allowed to constitute a source of threat to Lebanon's security under any circumstances. Consequently, Lebanon should not allow itself to become a pathway or a base for any force, state, or organization seeking to undermine its security or Syria's security. Syria, which is eager for Lebanon's security, independence, and unity and for harmony among its citizens, should not permit any act that poses a threat to Lebanon's security, independence, and sovereignty. (TAIF AGREEMENT, 1989)

Apesar da insatisfação da comunidade cristã, de drusos e de xiitas com relação à base do acordo, o governo sírio entendeu que nada mais havia para ser discutido exceto a implementação do que ali tinha sido acordado. Assim, em 13 de outubro de 1990 Hafez alAssad tomou a decisão que pôs fim ao levante do general Aoun e encerrou a Segunda Guerra Civil Libanesa. O palácio de Baabda, sede da presidência, foi bombardeado pela força aérea 
síria levando Aoun a refugiar-se na embaixada da França. Na qualidade de um dos maiores críticos da presença síria no Líbano, Aoun permaneceria no exílio - na França - até 2005, quando a Síria deixaria o país e ele poderia participar das eleições daquele ano.

Ainda, na Segunda parte do Acordo de Taif, uma cláusula conclamava, para o bem do Estado e sua unidade, que as milícias nacionais ou estrangeiras depusessem as armas. De fato, seria a restauração do monopólio da violência para as mãos do Estado - uma das características primordiais do Estado moderno.

A. Disbanding of all Lebanese and non-Lebanese militias shall be announced. The militias' weapons shall be delivered to the State of Lebanon within a period of 6 months, beginning with the approval of the national accord charter. The president of the republic shall be elected. A national accord cabinet shall be formed, and the political reforms shall be approved constitutionally.

Apesar do que estabelecia o Acordo, o Hizbullah acabou por não aceitar desmilitarizar-se. Segundo suas alegações, enquanto houvesse a presença israelense em território libanês a função da Resistência era opor-se a ela. A manutenção do jihad contra Israel, ao mesmo tempo em que encontrava respaldo em sua doutrina, servia para a Síria continuar lutando contra os israelenses indiretamente. Assim, Assad intencionava alcançar a um acordo que fizesse com que as Colinas de Golã voltasse ao seu domínio.

The authority the Assad government had garnered through the Taif Accord and its military presence in Lebanon were important guarantors of foreign policy continuity, yet Damascus took no risk where government endorsement of Hizbullah's armed resistance activities was concerned. Thus, as the post-war period began, it was quickly understood by Lebanese politicians in search of top governmental positions, that no individual would secure any of the five most important governmental posts - president, speaker of the house, prime minister, minister of defense and of the interior - without total commitment to all aspects of the 'joint Lebanese-Syrian foreign policy’ begin orchestrated. Only those who would unswervingly support this strategy would receive the Syrian backing essential for election or appointment to those key posts. (Harik, 2004: 46)

Com base no novo panorama político que o governo sírio estabelecera para o Líbano; à parte a negativa do Hizbullah em depor as armas, as demais milícias seguiram os ditames da lei pois vislumbraram a possibilidade de galgarem poder dentro das novas regras impostas ao jogo político, ou seja, participando das eleições que estavam sendo programadas para o ano de 1992. A grande incógnita era saber como o Hizbullah faria para integrar-se ao novo sistema democrático e, ao mesmo tempo, preservar a base islamista da organização. Como preservar a 
legitimidade da causa islamista sem aderir à roupagem democrática que o Acordo de Taif trouxera ao país?

Ainda, durante o período em a população libanesa teve para assimilar as mudanças programadas pelo Acordo Taif - além das mencionadas: a alteração na quantidade de parlamentares de 99 para 128 e as novas divisões dos distritos eleitorais -, a Síria aproveitou para assinar o ‘Tratado de Fraternidade, Cooperação e Coordenação’, em 20 de maio de 1991, com o qual vinculou os desígnios da Síria aos do Líbano - e vice-versa.

Com base em cláusulas que permitiam uma interpretação subjetiva do grau de interferência de um país sobre o outro, a Síria encontrou o mecanismo perfeito para legitimar sua ação sobre o governo libanês. O principal foi o estabelecimento do Conselho Supremo formado pelos dois presidentes além de mais alguns membros dos Estados, segundo o texto do Acordo, as decisões seriam em conjunto, entretanto, como é sabido, o governo de Assad exercia grande influência sobre a política libanesa e, dessa forma, inibia qualquer posicionamento contrário. Assim, a letra da lei evocava uma situação pautada pela democracia e cooperação, contudo, as decisões eram unilaterais. Os Órgãos criados pelo Acordo seguiam o mesmo modelo do Conselho Supremo e destinavam à Síria as decisões.

\section{8 - HIZBULLAH E AS ELEIÇÕES DE 1992, 1996 E 2000}

O reconhecimento do Hizbullah como partido político deu-se pelas mãos de Assad, que negociou, sua transição, diretamente com as lideranças libanesas. Assim, a organização conseguia legitimar-se como partido político mas preservava a característica de Resistência contra a ocupação israelense. Até porque, conforme ressalta Harik, entre 1985 e 1990 o Hizbullah foi praticamente o único grupo que se opôs à invasão israelense ao Líbano, alcançando, dessa forma, a simpatia de setores da população que não somente o xiita. Por outro lado, para facilitar a transformação do Hizbullah em partido político sem que isso ferisse a ideologia islamista, o partido assumiria uma postura de oposição ao governo, defendendo os valores de um Estado Islâmico. Considerando as limitações impostas à participação de cada grupo religioso no Parlamento, o Hizbullah teria que estabelecer uma forte estratégia para enfrentar o Amal, principal rival pelos votos da comunidade xiita. 


\begin{tabular}{|l|l|l|}
\hline \multicolumn{3}{|c|}{ Relação de assentos destinados aos grupos religiosos } \\
\hline Religião & Antes de Taif & Depois de Taif \\
\hline Maronita & 30 & 34 \\
\hline Grego Ortodoxo & 11 & 14 \\
\hline Grego Católico & 6 & 8 \\
\hline Armênio Ortodoxo & 4 & 5 \\
\hline Armênio Católico & 1 & 1 \\
\hline Protestante & 1 & 1 \\
\hline Outros grupos cristãos & 1 & 1 \\
\hline Total de cristãos & $\mathbf{5 4}$ & $\mathbf{6 4}$ \\
\hline Sunita & 20 & 27 \\
\hline Xiita & 19 & 27 \\
\hline Druso & 6 & 8 \\
\hline Alauíta & 0 & 2 \\
\hline Total de muçulmanos & $\mathbf{4 5}$ & $\mathbf{6 4}$ \\
\hline TOTAL & $\mathbf{9 9}$ & $\mathbf{1 2 8}$ \\
\hline
\end{tabular}

Durante os anos que antecederam a primeira eleição de 1992 o Hizbullah intensificou seu programa social na região do Vale do Bekaa e nos subúrbios de Beirute, além, é claro, de sua base natal no sul do país. As regiões que haviam sido destruídas pelos anos de guerra civil e pelo 'esquecimento' do Estado puderam ser reconstruídas graças aos programas assistenciais do Hizbullah financiados pelo Irã.

A primeira eleição pós-Guerra Civil, em 1992, foi considerada um sucesso pelos membros do Hizbullah que conseguiram eleger oito parlamentares. Segundo Hamzeh, cinco fatores contribuíram nesse acontecimento, quais sejam:

1) A presença de trabalho ideológico promovido pelos comitês dos parlamentares instalados nos subúrbios de Beirute, Vale do Bekaa e no sul do Líbano que difundiam a idéia de que os candidatos estavam sobre taklif al-shari (legítimo comando) do wilayat (Guardião). Essa campanha resultou em maciça votação nesses candidatos do Hizbullah.

2) Os serviços sociais prestados pelo Hizbullah à comunidade xiita, mas não somente a ela, haja vista em muitas localidades ao sul do país, cristãos e sunitas também se beneficiavam das redes de escolas, hospitais, clínicas odontológicas, etc, patrocinados pela organização.

3) A luta contra Israel pela soberania do Líbano muitas vezes era percebida como algo sincero, honesto e, em muitos aspectos, um ato heróico, comparado à luta das organizações palestinas contra Israel. 
4) A força da estrutura política do Hizbullah possibilitou que fossem organizados vários comitês que difundiam os nomes dos candidatos do partido, assim como reforçavam seus valores islamistas. Muitas vezes o Hizbullah entrava em confronto pelos votos de seu maior rival nas eleições, o Amal, mas mesmo assim seus candidatos recebiam total apoio político e psicológico.

5) O já mencionado boicote dos cristãos à eleição, no entanto, independentemente desse fato, por contar com uma base forte de simpatizantes nos distritos de maioria xiitas como BaalbekHirmil, South Lebanon e subúrbios de Beirute o Hizbullah conseguiria eleger seus candidatos. Ainda que os cristãos tivessem participado e feito oposição ao Hizbullah. (Hamzeh, 2004: 113-14)

A eleição subseqüente ocorreu sob a pressão de mais uma operação israelense contra a comunidade libanesa, “Operação Vinhas da Ira”"92, a qual provocou a morte de mais de duas mil pessoas. De certa forma, o Hizbullah ganhou maior notoriedade por sua luta contra Israel, entretanto, da mesma forma, também acirrou a disputa com o Amal pelas vagas no Parlamento, haja vista os xiitas liderados por Berri aliarem-se aos cristãos em algumas localidades ou mesmo os cristãos apoiarem candidatos de famílias tradicionais em suas listas.

Em 2000 o Hizbullah conseguiu sua maior vitória sobre seu rival Amal. Isso porque pôde contabilizar dois fatores a seu favor: primeiro, a vitória sobre Israel - que deixou o sul do Líbano naquele ano -; e, segundo, com a morte de Hafez al-Assad o Hizbullah conseguiu maior autonomia, considerando que seu sucessor, Bashar al-Assad não exercia o mesmo poder sobre os partidos políticos libaneses.

\begin{tabular}{|c|c|c|c|c|}
\hline \multicolumn{5}{|c|}{$\begin{array}{l}\text { DISTRIBUIÇÃO DOS ASSENTOS XIITAS NO PARLAMENTO } \\
\text { ENTRE HIZBULLAH, AMAL E AS FAMÍLIAS XIITAS (ZUAMA) }\end{array}$} \\
\hline ANO & HIZBULLAH & AMAL & FAMÍLIAS & TOTAL \\
\hline 1992 & 8 & 9 & 10 & 27 \\
\hline 1996 & 7 & 8 & 13 & 27 \\
\hline 2000 & 9 & 6 & 12 & 27 \\
\hline
\end{tabular}

\footnotetext{
${ }^{92}$ Para mais detalhes, rever sub-capítulo 2.10 dessa dissertação.
} 


\section{9 - SOBERANIA RESTAURADA: ISRAEL FORA (2000), SÍRIA FORA (2005)}

As negociações de paz entre OLP e o Estado de Israel, que se estenderam a partir de 1993, refletiam o ânimo dos demais países do Oriente Médio e repercutiam no Líbano. Isso porque, a aproximação entre Egito e Israel poderia significar o isolamento da Síria, ou mesmo, caso o Líbano conseguisse firmar um acordo que estripasse a tensão entre os dois Estados, novamente a Síria ficaria sem 'moeda de troca' para reivindicar seus territórios perdidos para Israel durante a guerra de 1967.

Dessa forma, o Líbano, por mais que tentasse negociar a paz com Israel, como o vez no "Entendimento de Abril" "33 (1996), sempre tinha de considerar se os objetivos sírios estavam sendo contemplados nos acordos, caso contrário, era levado a não assiná-lo ou, diante dessa impossibilidade, a boicotá-lo.

Assim, o ânimo dos principais atores (Israel, Síria e Líbano) era fortemente influenciado pelas negociações entre Israel e OLP promovidas pelos Estados Unidos principalmente no período de governo de Bill Clinton. Quanto mais próximo se chegava de um acordo, mais complicada a situação se apresentava para o governo de Assad, dessa forma, como sua ascendência sobre o Hizbullah e o governo libanês era grande, as negociações para acordos acabavam sendo prejudicadas ou, no caso do "Entendimento de Abril”, assinado mas não sendo respeitado por muito tempo.

Com o rompimento das negociações de paz entre Israel e Síria (1996-1998), a única maneira de a Síria continuar pressionando os israelenses sem correr o risco de sofrer um ataque em seu território era influir sobre o Hizbullah, que já lutava contra o Estado vizinho e tinha a seu favor a 'legitimidade’ para restaurar a soberania do Líbano.

O fortalecimento do Hizbullah como partido político e como milícia fizeram com que os ataques à 'Zona de Segurança' tornasse mais intensos. O que veio a gerar protestos por parte de setores políticos e também da população israelense. Na seqüência, em 2000, com o início da Segunda Intifada, as questões de segurança se voltaram para dentro do país, dessa maneira, Israel foi obrigado a estabelecer um programa de retirada de suas tropas do Líbano. Decisão tardia se considerarmos que desde 1978 o Conselho de Segurança da ONU já havia exigido a saída de Israel do território libanês, através da Resolução 425.

\footnotetext{
${ }^{93}$ Acordo de Cessar Fogo desenvolvido entre Israel e Hizbullah, sob o auspício dos EUA. O Hizbullah se comprometia a não lançar mísseis contra o Estado de Israel, tampouco outro tipo qualquer de armamento. Por sua vez, o exército israelense comprometia-se a não efetuar ataques contra civis ou localidades civis libanesas. Ambas as partes ratificavam o comprometimento de não usarem como alvo, povoados civis, instalações elétricas ou industriais. Havendo a violação por quaisquer das partes de algum item desse acordo, o mesmo perderia sua validade. Também, assegurava à parte atacada o direito de exercer sua autodefesa.
} 
Entre 22 e 24 de maio de 2000, antes do prazo estabelecido no programa de retirada, Israel deixou o Líbano e abriu caminho para novos questionamentos acerca do futuro do Estado libanês e da função do Hizbullah a partir de então. Contudo, conforme nos apresenta Laura Deeb, em seu artigo para “Middle East Report” publicado poucos dias após a retirada (31/05/2000), a desmilitarização do Hizbullah não aconteceria tão facilmente conforme determinava o Acordo de Taif.

Sayyid Hasan Nasrallah, leader of Hizbullah, has stated on several occasions that Hizbullah will not consider the withdrawal complete until the Shibaa Farms-a water-rich area on the Lebanese-Syrian border that Lebanon and Syria both assert falls within the Lebanese bordershas been liberated and Lebanese detainees inside Israel, including resistance leaders Hajj AbuAli Dirani of Amal, Shaykh Abdel-Karim Obeid of Hizbullah and Samir Qintari of the Communist party, have been released. It is impossible to neglect mention of the few hundred thousand Palestinian refugees still stuck living in miserable conditions in Lebanon. Thus far, their likely fate after the withdrawal has met with media silence. (Deeb, 2000)

Assim, o único ator a capitalizar lucro na saída de Israel do sul do Líbano foi o Hizbullah. A milícia passou a atribuir-se o título de único ator árabe que fora capaz de derrotar os israelenses. Como vimos anteriormente, grande

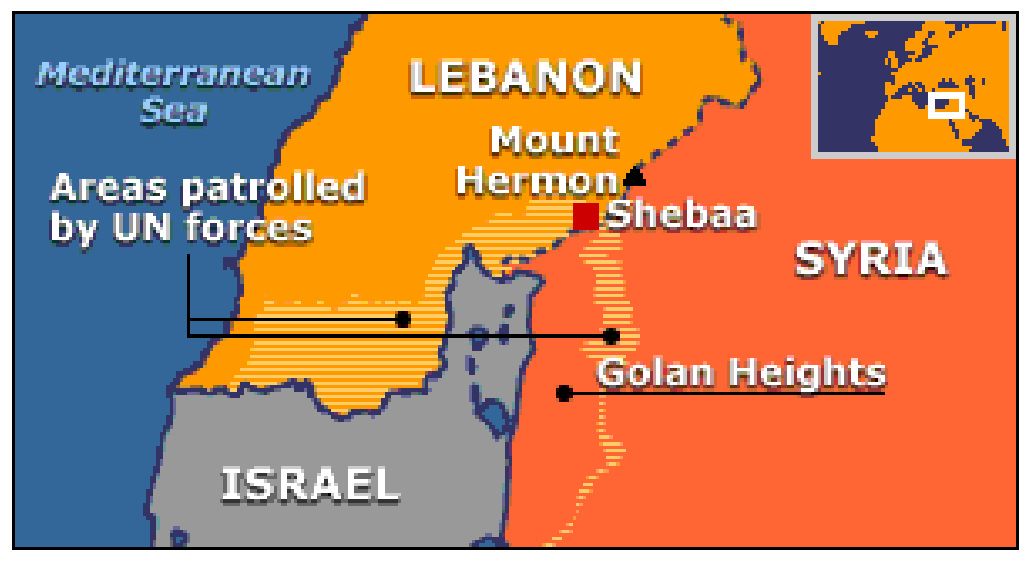
parte desse status reverteu em votos nas eleições de 2000. Por outro lado, abriu-se uma porta para questionamentos acerca da legitimidade da milícia, haja vista a própria ONU reconhecer que Israel já havia se retirado do país e, com isso, o Líbano tivera sua soberania restaurada pelo menos no tocante ao sul do país.

A questão relativa à região de Shebaa Farms tornou-se um imbróglio de difícil solução devido ao papel que passou a exercer no conflito Síria-Líbano-Hizbullah-Israel. De acordo com as alegações israelenses, Shebaa Farms foi conquistada da Síria, juntamente com as Colinas de Golã, no final da Guerra dos Seis Dias (1967), entretanto, o governo sírio nega que o território pertença a ele e afirma que faz parte do Líbano.

Com a situação posta dessa maneira o Hizbullah entende que a legitimidade de sua luta contra Israel está preservada porque continua em busca da restauração da soberania do Líbano. Segundo o posicionamento do governo libanês, a região de Shebaa Farms, de fato, 
pertenceria ao Líbano. Cabe salientar que, como expusemos anteriormente, o governo libanês sofre grande influência da Síria e, muitas vezes, apenas referenda o que é decidido por Assad.

The UN argues that Lebanon is unable to present documentation of the 1951 LebaneseSyrian "oral agreement" in which Syria says it ceded the farms. But no one disputes that the Shebaa villagers who worked the farms prior to their occupation by Israel in 1967 live in Lebanon. It is also curious that the UN has treated the occupation of what it says are Syrian lands so casually. Of course, with its generous assertion of Lebanese sovereignty over the farms, the Syrian government retains what is called the "Lebanon card" in Arab-Israeli diplomacy. (Abukhalil, 2001)

Independentemente da questão relacionada à soberania sobre Shebaa Farms, a saída de Israel do Líbano provocou grandes mudanças no panorama político libanês; houve a supervalorização do Hizbullah e a ampliação de sua base de apoio no parlamento. Também não é possível deixar de considerar que, independentemente de o Líbano haver restaurado sua completa soberania, a saída dos israelenses de solo libanês trouxe mais tranqüilidade para a população do sul do país e fez com que mais investimentos fossem trazidos para o Líbano. Parte do mérito relativo ao crescimento econômico libanês deve-se à presença do bilionário sunita, Rafiq al-Hariri, no cargo de Primeiro-ministro a partir de 2000, então ocupando-o pela segunda vez (1992-98). Ele foi um forte aliado da Síria naquele momento.

Entre 2000 e 2004 o Líbano viu-se diante do desafio de assumir um partido político que era considerado, também, um grupo terrorista por parte da comunidade internacional. Apesar da legitimidade alegada pelo Hizbullah em continuar sua luta por Shebaa Farms, o panorama político internacional mudou muito com os atentados contra o WTC (Nova Iorque) e o Pentágono (Washington), em 2001. O Hizbullah, assim como a al-Qaeda (que assumiu a autoria dos

"Estados como esses [Irã, Iraque e Coréia do Norte], e seus aliados terroristas, eonstituem um eixo do mal, armando para ameạ̧ar a paz do mundo. Por busear armas de destruição em massa, esses regimes posam como um grave e erescente perigo. Eles podem suprir de armas os terroristas, dando a eles os meios para destilar seu ódio. Eles podem atakar nossos aliados ou tentar chantagear os Estados Unidos. Em quaisquer desses casos, o prȩ̣o pela indiferen६̧a poderia ser eatastrófiøo." George W. Bush [29/01/2002]

atentados nos EUA), passaram a ser vistos como organizações terroristas de alto risco para a comunidade internacional.

No início de 2002, num momento de tensão internacional - agravado pelas declarações do presidente dos Estados Unidos, George W. Bush -, foi declarada a 'guerra contra o terror' e veio à tona a questão dos países que supostamente apoiariam organizações terroristas. $\mathrm{O}$ 
Afeganistão foi a primeira vítima de Bush e, por abrigar Osama Bin-Laden (líder da alQaeda), acabou sendo invadido pelos Estados Unidos e teve seu governo destituído.

Segundo Bush, havia um 'eixo do mal' que deveria ser combatido pois era formado por países que apoiavam organizações terroristas. Em sua declaração Bush deixava claro qual seria seu próximo passo: enfrentar Irã, Iraque e Coréia do Norte.

Os EUA, após implementarem suas ações militares no Afeganistão, voltaram-se para o ditador iraquiano Saddam Hussein. Entretanto, a situação do governo sírio não era muito tranqüila, ainda mais quando Assad prestou solidariedade aos iraquianos e permitiu que muitos líderes do governo de Saddam Hussein fugissem para a Síria após os Estados Unidos iniciarem seus ataques.

Havendo o risco de os Estados Unidos incluírem a Síria no 'eixo do mal', Assad procurou preservar seu status no Líbano através da manutenção de seus aliados no poder. Emile Lahoud, que havia sido eleito presidente em 1998, portanto teria seu mandato findado em 2004, era um grande apoiador da política de Assad no Líbano. Militar reformado, Lahoud era visto por Assad como um aliado mais forte e manipulável que o então primeiro-ministro Rafiq Hariri, exatamente pelo fato de Lahoud ser maronita. Assad acreditava que o apoiando conseguiria fazer com que a comunidade maronita referendasse a presença militar síria no Líbano, no entanto, por ter uma base regional fraca, não conseguiu atender aos anseios de Assad, mas continuou agindo de acordo com os interesses sírios.

Para que Assad não tivesse sua influência sobre o governo libanês alterada, havia a necessidade de que o mandato de Lahoud fosse prorrogado por mais três anos, no entanto, para esse tipo de modificação na legislação seria necessário que a Constituição sofresse uma emendada.

Assim, o Parlamento propôs uma emenda constitucional estendendo o mandato do presidente, excepcionalmente, por mais três anos. Os dois terços da maioria, requeridos para a aprovação da emenda, foram facilmente alcançados. Somente vinte e nove parlamentares votaram contra e três se abstiveram, entretanto, quatro ministros demitiram-se em protesto contra o que chamavam de 'uma intervenção externa nos assuntos internos do Líbano'. Explicitaram, com isso, que o governo sírio via com grande interesse a prorrogação do mandato de seu aliado político, Lahoud.

Pesquisas de opinião pública também indicaram que uma substancial maioria da população libanesa posicionava-se contra a emenda. Como ato de repúdio à interferência síria no governo libanês, em 2 de setembro de 2004, um dia antes de o Parlamento votar a emenda, o Conselho de Segurança das ONU votou - nove a zero (China, Rússia, Argélia, Brasil, 
Paquistão e Filipinas abstiveram-se) - a aprovação da Resolução 1559, co-patrocinada pela França, Inglaterra e Alemanha, a qual requeria o "estrito respeito à soberania do Líbano, integridade territorial, unidade e independência política do Líbano,” e, conseqüentemente, o comprometimento com as eleições presidenciais conforme estipulava a Constituição, além da retirada de todas as tropas estrangeiras do Líbano - naquela ocasião apenas a Síria mantinha tropas no país.

Reiterating its strong support for the territorial integrity, sovereignty and political independence of Lebanon within its internationally recognized borders,

Noting the determination of Lebanon to ensure the withdrawal of all non-Lebanese forces [Síria] from Lebanon,

Gravely concerned at the continued presence of armed militias [Hizbullah] in Lebanon, which prevent the Lebanese Government from exercising its full sovereignty over all Lebanese territory,

Reaffirming the importance of the extension of the control of the Government of Lebanon over all Lebanese territory,

Mindful of the upcoming Lebanese presidential elections and underlining the importance of free and fair elections according to Lebanese constitutional rules devised without foreign interference or influence, (Fragmento da Resolução do Conselho de Segurança da ONU n ${ }^{\circ}$ 1559, 02/09/2004)

Por outro lado, a Liga Árabe, influenciada pelo Egito e Arábia Saudita, assim como pela Síria, entendeu que a decisão do Parlamento libanês tratava de um assunto de ordem interna e de exercício pleno da soberania do Estado, não cabendo qualquer comentário a respeito.

Com a prorrogação do mandato de Lahoud, Rafiq Hariri abandonou o cargo de Primeiro-ministro (04/10/2004) e deixou de apoiar a presença síria no Líbano, passando a fazer campanha pela soberania total do Estado libanês. Movimentos populares começaram a ganhar mais espaço nas ruas - anteriormente havia muito receio em manifestar-se contra a Síria devido ao risco de represálias - e a comunidade internacional voltou-se para a Questão Libanesa.

Desde 1978 a resolução 425 da ONU já exigia a restauração da soberania do Estado libanês, no transcorrer dos anos outras também seguiram a mesma linha. A saída de Israel do sul do Líbano fez com que a presença síria no país ganhasse muito destaque devido à interferência que praticava em sua política interna. Com a resolução 1559 e a união de Estados Unidos e França - muitas vezes em campos opostos no tocante à política para Oriente Médio - em prol da restauração da soberania do Líbano, a Síria não teve muito que fazer 
exceto tentar articular seus apoiadores libaneses para que também se manifestassem em favor de sua permanência no país.

Em 14 de fevereiro de 2005 foi perpetrado um atentado contra Rafiq Hariri que o levou à morte e também de mais dezessete pessoas. Apesar de destruir um dos pilares do movimento contra a presença síria no Líbano, a morte de Hariri, ao invés de inibir qualquer

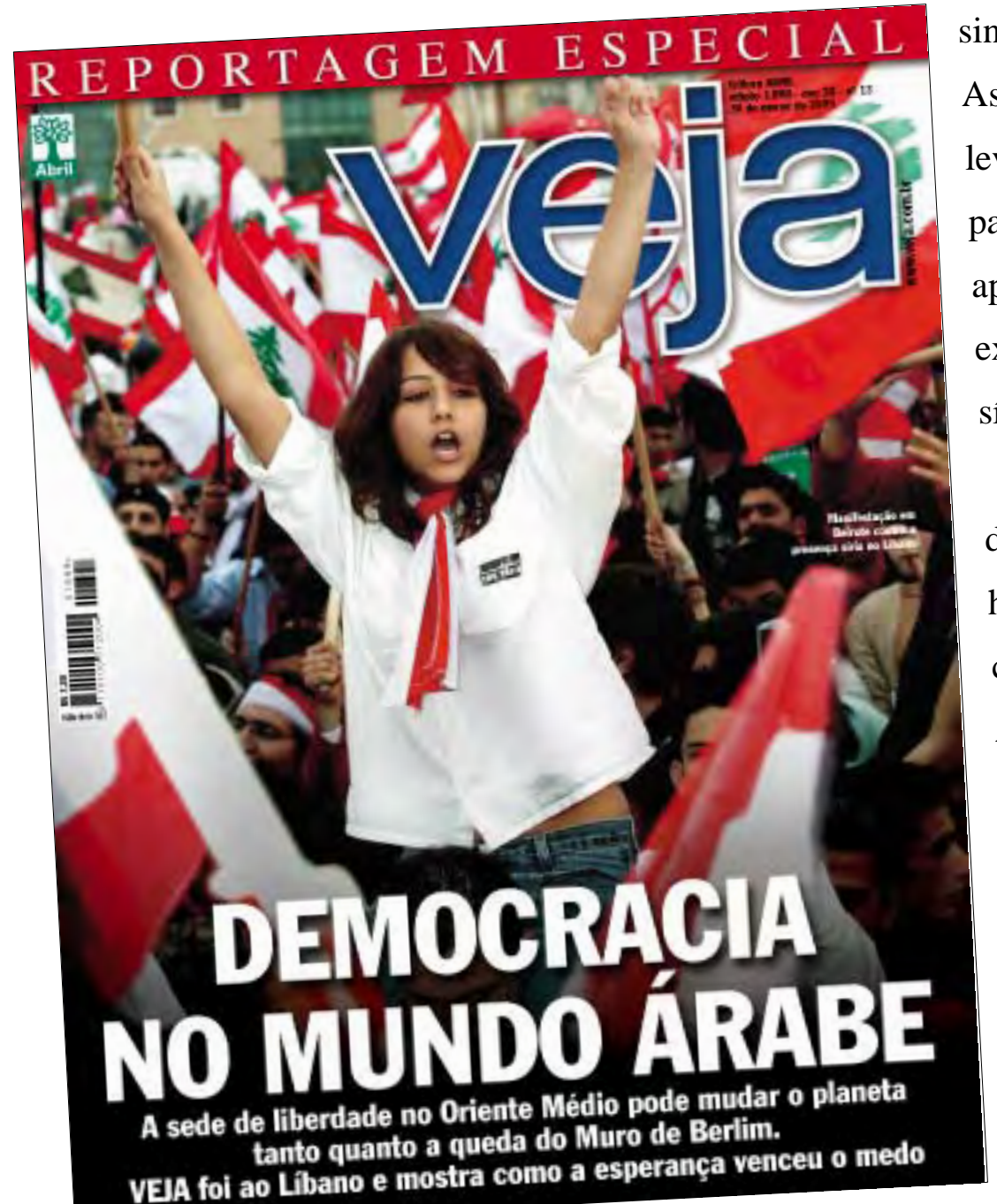
sinal de protesto contra Assad, teve efeito contrário e levou a população às ruas para cobrar por uma apuração do atentado e exigir a saída das tropas sírias do país.

O clamor de parte da população libanesa haja vista a Síria ainda contar com o apoio do Amal, Hizbullah, setores da comunidade sunita e maronita - pela restauração da soberania do país, aliado à pressão exercida pela ONU mais particularmente 0 receio de que a Síria viesse a ser o próximo alvo dos Estados Unidos - fez com que Assad resignasse e estabelecesse um plano de retirada do Líbano.

Nos movimentos populares - pró e contra a presença síria no Líbano - o que mais chamava a atenção era o sentimento de patriotismo da população, independentemente de serem xiitas ou maronitas, drusos ou armênios, a bandeira libanesa estava nas mãos do povo. A “Revolução do Cedro” levou a Síria para fora do Líbano e trouxe grandes expectativas para os próximos passos da política libanesa. As eleições parlamentares de 2005 ainda apresentavam-se como uma incógnita pois não contariam com interferência direta do governo sírio. 


\subsection{0 - DAHL, LIJPHART E SARTORI: LÍBANO DEMOCRATA?}

O Líbano chega ao ano de 2005 às vésperas de mais uma eleição para o Parlamento e o grande questionamento que se faz é se o modelo político adotado pelo país pode ser considerado democrático. Possuidor de uma história bastante curta como país independente, as transformações na legislação, no processo eleitoral e mesmo na participação de seus membros, suscitam questões que requerem um embasamento teórico para serem respondidas.

Ao optar pela utilização de modelos propostos por Robert Dahl, Arend Lijphart e Giovanni Sartori tenta-se estabelecer delimitações do que seria democracia e quais seriam as instituições necessárias para a existência de um Estado democrático.

É de Dahl o conceito de poliarquia, o qual ele prefere utilizar para os regimes políticos que mais de aproximam do ideal de democracia. Explica-se, para Dahl a democracia seria um sistema perfeito de representação, um ideal ainda não alcançado por qualquer Estado, então, diante da impossibilidade de classificar qualquer Estado com essa terminologia, a opção foi criar outro conceito que contemplasse as caracteristicas da democracia, mas de forma imperfeita. Criou-se poliarquia. Assim, os sistemas poliarquicos passaram a servir como meio para alcançar a democracia.

Para a conceituação de poliarquia Dahl trabalha com duas variáveis básicas, quais sejam, a Contestação Pública e a Participação Inclusiva. A primeira estaria ligada diretamente ao direito de voto, eleições livres, etc, e a segunda ao direito de participação das diversas camadas sociais na contestação pública. No gráfico proposto por Dahl é possível perceber quais caminhos levariam à poliarquia e quais as vantagens e desvantagens deles.

Segundo Dahl, o mais seguro para que haja estabilidade na transição de um regime autoritário (Hegemonias Fechadas ${ }^{94}$ ) para um poliárquico seria que ocorresse através de etapas. Primeiramente transformando-se em Oligarquias Competitivas ${ }^{95}$ ou Hegemonias Inclusivas $^{96}$ (indicados pela seta azul no gráfico) somente para, no futuro, transformarem-se em poliarquias. O caminho ' 3 ' significaria uma ruptura de sistema nos moldes da Revolução Francesa ou da Guerra da Independência dos Estados Unidos. Com ele, alcançar-se-ia alto grau de participação popular e amplos direitos para a população, entretanto, conforme salienta Dahl, muitas vezes pode gerar retrocessos. Com base nessas primeiras observações, chegar-

\footnotetext{
${ }^{94}$ Sistema de governo no qual o poder encontra-se centralizado em apenas um grupo (ou poucos) e não há direito pleno de contestação (p.ex., através do voto). Regimes caracteristicamente autoritários.

${ }_{95}$ Sistema de governo no qual o poder está concentrado em um pequeno grupo, no entanto, para seus membros há um alto grau de contestação e alternância no poder. Regimes caracteristicamente aristocráticos.

${ }^{96}$ Regimes onde há uma grande participação popular, no entanto, sem possibilidade de contestação. Algo semelhante a um sistema de partido único.
} 
se-ia à conclusão de que "as poliarquias podem ser pensadas então como regimes relativamente (mas incompletamente) democratizados, ou, em outros termos, as poliarquias são regimes que foram substancialmente popularizados e liberarizados, isto é, fortemente inclusivos e amplamente abertos à contestação pública.” (Dahl, 2005: 31)

No caso libanês seria imprescindível analisar três momentos distintos de sua história para verificar se houve algum tipo de transição nos moldes do esquema proposto por Dahl e, havendo, em qual direção se deu. Considerando apenas o histórico do Líbano como Estado independente (a partir de 1943), seria proveitoso para essa análise verificar como se deu esse processo; na seqüência, um segundo momento para ser

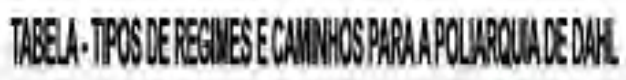

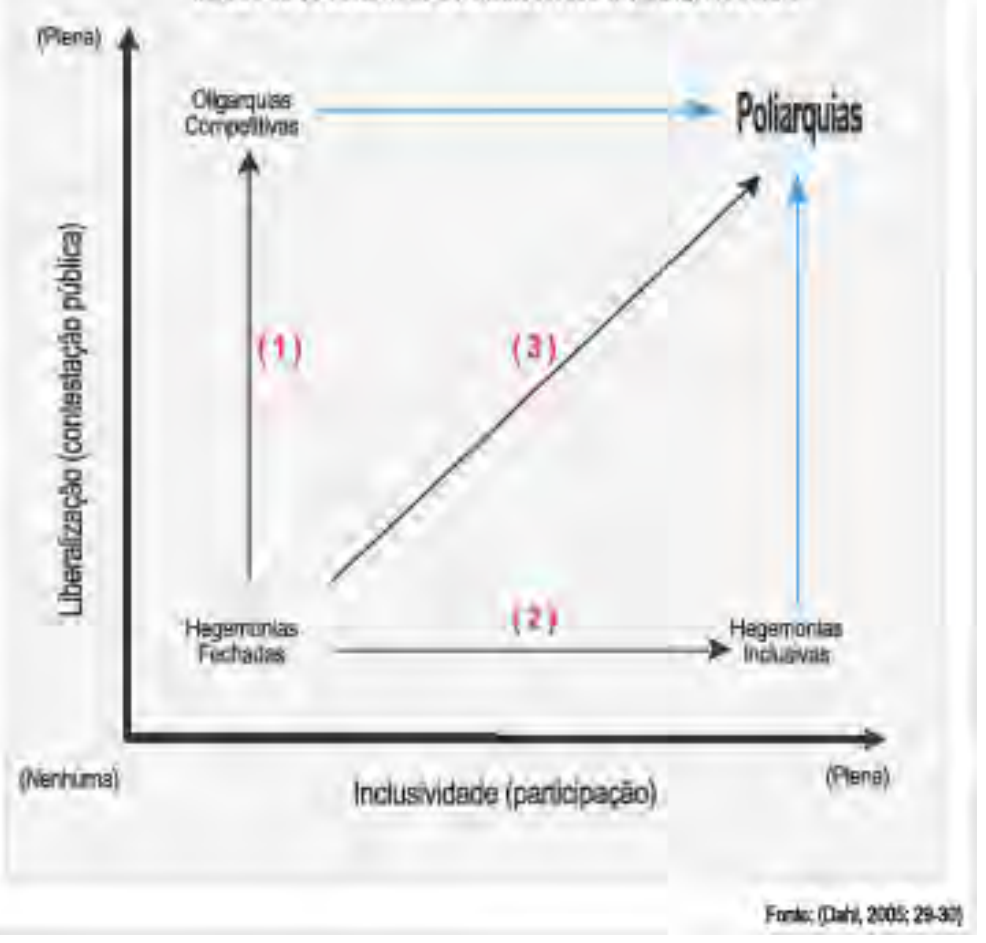
analisado seria o final da Segunda Guerra Civil e assinatura do Acordo de Taif (1990) e, por último, a saída das tropas sírias do Líbano (2005), em tese, a restauração de sua soberania.

Com o final do sistema de Mandatos o Líbano saiu do que poderia ser entendido como um sistema 'hegemônico fechado’ e, graças aos arranjos institucionais estabelecidos pelos maronitas, elevou o Estado à categoria de 'oligarquia competitiva'. Segundo Dahl, um caminho que poderia levar à Poliarquia. Entretanto, apesar de a população libanesa ter alcançado o direito pleno de voto - exceção feita aos menores de 21 anos -, o modelo confessional adotado acabou por inibir o desenvolvimento de uma oposição.

Ao assegurarem os cargos de presidente aos maronitas e o de primeiro-ministro aos sunitas, estabeleceu-se uma barreira intransponível ao sistema que era a possibilidade de que uma oposição conseguisse alcançar o poder. Assim, conforme o modelo de Dahl, o Líbano estagnou num estágio antes de chegar à Poliarquia e, muito distante de ser considerado um regime democrático.

Apesar de Dahl alegar que “quando o sufrágio vai além dos notáveis e de sua clientela, os velhos partidos e facções baseados principalmente nas relações sociais entre os notáveis - 
em laços de família, de classe, residência, estilo de vida e tradição - são substituídos ou suplementados por partidos mais eficazes em atrair as classes médias.” (2005: 44) os fatos subseqüentes à independência não ratificam essa afirmação. O sistema confessional fortaleceu o poder dos zuama e gerou disputas somente dentro dos próprios grupos religiosos para alcançarem representatividade no Parlamento. Outra característica da política libanesa que pode ter prejudicado no desenvolvimento de classes sociais mais questionadoras foi o sectarismo que passou a reger as relações entre os que detinham o poder e os outros.

Todas as demais premissas estabelecidas por Dahl para classificar o estado libanês ficam prejudicadas devido ao fato de que, nitidamente, havia um Estado para os cristãos e outro para os muçulmanos. O poder era dividido entre maronitas e sunitas e os benefícios gerados pelo Estado somente repercutiam dentro de suas comunidades. Se utilizarmos os índices relativos ao crescimento econômico, melhora da qualidade de vida, urbanização, etc bastante positivos para o Líbano -, sempre estaremos considerado 'o país dos maronitas', ‘a Suíça do Oriente Médio', como era conhecido o Estado libanês. O sectarismo era tal que o desenvolvimento do Estado se dava somente onde havia interesses dos membros do governo.

Os partidos políticos libaneses, mais que ligados a ideologias, representavam os interesses de seus grupos sociais e eram ligados, por laços de fidelidade, aos 'senhores feudais’ (zuama). Independentemente de, com isso, constituir-se num sistema multipartidário - que em tese dificultaria o fortalecimento do sistema democrático, uma vez que requereria a prática do modelo consensual -, os arranjos de interesses faziam com que fossem formados blocos políticos no Parlamento mas o pragmatismo continuava prevalecendo.

Outra mácula na política libanesa dava-se na manipulação do sistema eleitoral. Com freqüência esse vício esteve presente em vários momentos da história libanesa, sempre no intuito de facilitar a eleição de determinados notáveis. Grande parte dessa maleabilidade do sistema provinha do esquema de distritos eleitorais - sempre modificados para que alguns candidatos conseguissem eleger-se. Isso porque, conforme estabelecia a lei eleitoral, cada grupo religioso tinha direito de eleger um determinado número de parlamentares por distrito. Por sua vez, esse número estava diretamente ligado à quantidade de seus membros de habitavam no distrito. Assim, quando se pretendia eleger dois parlamentares do mesmo grupo religioso porém o distrito deles dava direito a apenas um, modificava-se o desenho dos distritos e abria a possibilidade de elegerem os dois. 


\begin{tabular}{|c|c|c|c|c|c|c|c|c|c|c|}
\hline \multicolumn{2}{|c|}{$\begin{array}{l}\text { Distribuição dos assentos para a } \\
\text { eleição de } 2005 \text { para o Parlamento } \\
\text { do Líbano (Majlis an-Nuwwab) }\end{array}$} & \multirow[t]{2}{*}{$\stackrel{\text { : }}{:}$} & \multirow{2}{*}{$\frac{\stackrel{\mathscr{C}}{\mathscr{B}}}{2}$} & \multirow[t]{2}{*}{ 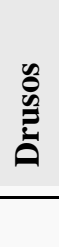 } & \multirow[t]{2}{*}{ 莺 } & \multirow{2}{*}{ 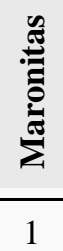 } & \multirow{2}{*}{ 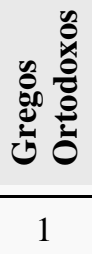 } & \multirow{2}{*}{ 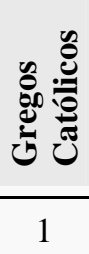 } & \multirow[t]{2}{*}{ 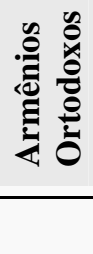 } & \multirow{2}{*}{$\frac{1}{1}$} \\
\hline \multirow{3}{*}{$\begin{array}{c}\text { Beirut } \\
\text { (19) }\end{array}$} & Beirut 1 & & & & & & & & & \\
\hline & Beirut 2 & 1 & 2 & & & & 1 & & 1 & 1 \\
\hline & Beirut 3 & 1 & 2 & 1 & & & & & 2 & 1 \\
\hline \multirow{3}{*}{$\begin{array}{c}\text { Bekaa } \\
\text { (23) }\end{array}$} & Bekaa+Hermel & 6 & 2 & & & 1 & & 1 & & \\
\hline & Zahlah & 1 & 1 & & & 1 & 1 & 2 & 1 & \\
\hline & Rashaya+West Bekaa & 1 & 2 & 1 & & 1 & 1 & & & \\
\hline \multirow{4}{*}{$\begin{array}{c}\text { Mount } \\
\text { Lebanon } \\
\text { (35) }\end{array}$} & Jbeil+Kisrawan & 1 & & & & 7 & & & & \\
\hline & North Metn & & & & & 4 & 2 & 1 & 1 & \\
\hline & Baabda+Aley & 2 & & 3 & & 5 & 1 & & & \\
\hline & Chouf & & 2 & 2 & & 3 & & 1 & & \\
\hline \multirow{2}{*}{$\begin{array}{l}\text { North } \\
\text { Lebanon } \\
\text { (28) }\end{array}$} & Akkar, Dinniyeh, Bsharreh & & 5 & & 1 & 3 & 2 & & & \\
\hline & Tripoli, Zgharta, Batrun, Kurah & & 6 & & 1 & 6 & 4 & & & \\
\hline \multirow{2}{*}{$\begin{array}{l}\text { South } \\
\text { Lebanon } \\
\text { (23) }\end{array}$} & Saida, Tyre & 9 & 2 & & & & & 1 & & \\
\hline & Hasbaya, Nabatiyeh, Jezzine & 5 & 1 & 1 & & 2 & 1 & 1 & & \\
\hline \multicolumn{2}{|l|}{ Total (128) } & 27 & 27 & 8 & 2 & 34 & 14 & 8 & 5 & 3 \\
\hline
\end{tabular}

Há de se considerar, ainda, que a exclusão dos xiitas da burocracia estatal e a ausência do Estado nas regiões habitadas por esse grupo foram fatores preponderantes que colaboraram na erupção das duas guerras civis que o Líbano viveu. Dessa forma, se passarmos a aventar a possibilidade de que, em 1990, poderia ter sido instaurado um regime democrático com a assinatura do acordo de Taif, teríamos que retornar às premissas iniciais de Dahl para averiguar. De fato houve a redução do poder presidencial e transferência desse para o Gabinete e, ainda, cristãos e muçulmanos passaram a serem representados igualmente no Parlamento. Assim, pode ser entendido que houve apenas um acerto entre as oligarquias, mas não a possibilidade de alternância de grupos distintos - e de oposição - no poder.

A indagação que deve ser feita, então, diz respeito aos efeitos que a maior participação muçulmana no Parlamento trouxe para o regime e se esse fato pode ser considerado como relevante no caminho à poliarquia. Aventando-se a possibilidade de uma resposta positiva, teríamos que considerar que mesmo assim ainda há uma sub-representatividade, haja vista os muçulmanos perfazerem 65\% da população libanesa mas não possuírem meios para alcançarem o poder através de eleições. Retorna-se ao problema relativo à nulidade da 
oposição e o efeito que esse fato provoca no sistema político. De fato, somente fortalece o poder oligárquico.

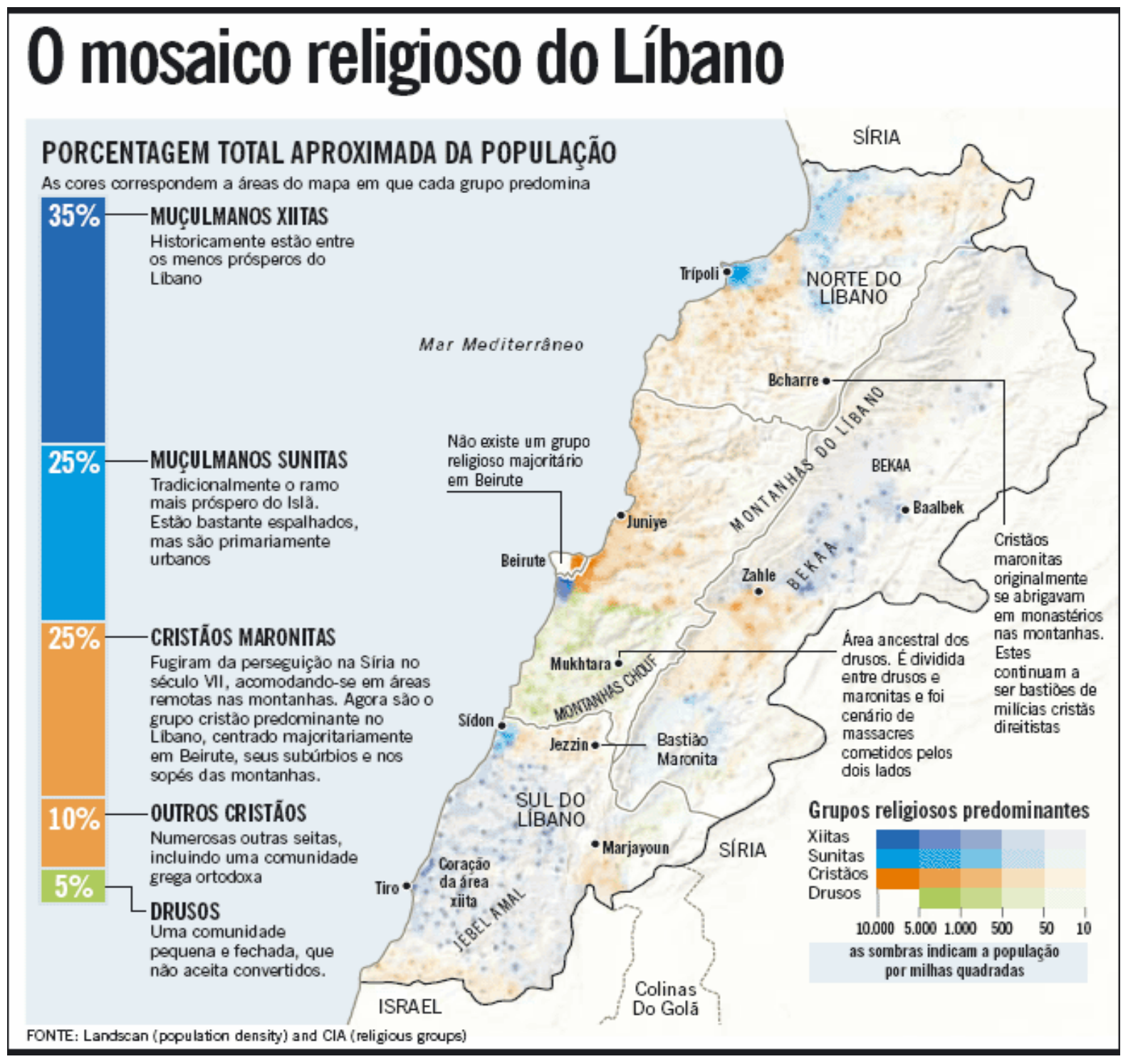

Por outro lado, a interferência de outro agente estatal na política interna libanesa limita as possibilidades de o Estado conseguir desenvolver-se no sentido de transformar-se numa poliarquia. A Síria, que conseguiu ratificar sua influência sobre o Líbano através da assinatura do 'Tratado de Fraternidade, Cooperação e Coordenação' (1991), acabou por estabelecer um sistema de tutela extra-oficial. Legalmente era um sistema que visava a cooperação entre Estados ligados por uma história comum, contudo, como foi apresentado no transcorrer dessa dissertação, o governo sírio utilizava sua influência política e militar para resolver seus problemas com o Estado de Israel.

Dessa forma, somente com a saída da Síria do território libanês (2005) surgiu a possibilidade para o sistema político libanês se desenvolver no sentido de transformar-se 
numa poliarquia, mas para isso tem de resolver os problemas de representatividade gerados pelo sistema confessional e abolir a política sectarista ainda vigente.

Se a análise do sistema político libanês através do modelo proposto por Dahl acaba sendo prejudicada devido à peculiaridade do sistema confessional estabelecido no Líbano, Lijphart salienta que, por razão da existência de tamanha heterogeneidade social, a assimilação do modelo Consociacional (ou Consensual) poderia facilitar a democratização.

De fato, segundo Lijphart, a opção pelo modelo Consociacional, em detrimento ao sistema majoritário (ou de Westminster ${ }^{97}$ ) diz respeito diretamente a não-exclusão dos membros que não fazem parte do governo. No sistema majoritário apenas o grupo (bloco ou partido) que vence a eleição governa e usufrui as benesses do Estado - haja vista ser a maioria que toma as decisões -, os derrotados, dessa forma, acabam formando uma oposição - que constitui apenas uma minoria - que torna-se sem forças para mudar a linha de governo ou mesmo participar dele efetivamente.

Nas sociedades mais profundamente divididas, como a Irlanda do Norte [e Líbano], o governo majoritário implica não propriamente uma democracia, mas sim uma ditadura da maioria e enfrentamento civil. Essas sociedades precisam é de um regime democrático que estimule o consenso, em vez da oposição; que promova a inclusão, em vez da exclusão, e que tente ampliar a maioria governante, em vez de se satisfazer com uma pequena maioria: essa é a democracia de consenso [ou consociacional]. (Lijphart, 2003: 53)

No sistema consociacional a função principal das elites políticas representativas, ou mesmo dos dirigentes dos grupos sociais, é fazer com que haja uma redução de divergências no interior da sociedade e seja formado um governo de muitas minorias. Assim, a proposta consociacional é que seja feito um pacto ou compromisso e dele nasça o princípio de divisão e descentralização do poder político. Contudo, Lijphart nos alerta para os dois requisitos indispensáveis e que servem como pré-condição para que haja um governo baseado no princípio consociacional, quais sejam, a manutenção da paz e a estabilidade na sociedade.

Aventemos a possibilidade de que o Líbano tenha seguido o modelo consociacional ao transformar-se num Estado independente. De fato houve a preservação dos direitos de todos os grupos religiosos de participar do processo eleitoral - cuja representatividade estava ligada

\footnotetext{
${ }^{97}$ O termo é utilizado para referir-se ao sistema majoritário e advém do modelo genérico de democracia adotado pelos britânicos. Apesar de suas variações, o sistema caracteriza-se por dez elementos inter-relacionados: 1) Concentração do Poder Executivo em Gabinetes unitários e de maioria mínima; 2) Gabinete dominante em relação à legislatura; 3) Sistema bipartidário; 4) Sistema de eleições majoritário e desproporcional; 5) Pluralismo de grupos de interesse; 6) Governo unitário e centralizado; 7) Concentração do poder legislativo numa legislatura unicameral; 8) Flexibilidade constitucional; 9) Ausência de revisão judicial; e, 10) Um banco central controlado pelo Poder Executivo. (Lijphart, 2003: 26-47)
} 
diretamente à proporção estabelecida pelo Censo de 1932 -; estabeleceu-se um sistema eleitoral que seguiria o modelo proporcional e não o de maioria relativa, comum no sistema majoritário; dividiram-se os cargos da burocracia estatal de acordo com a participação de cada grupo religioso no montante da população libanesa - pelo menos em tese deveria ter sido feito dessa maneira -; e procurou estabelecer princípios constitucionais claros para todos os cidadãos libaneses.

Então, qual teria sido a razão para que o modelo consociacional não conseguisse ter êxito no Líbano? Para aprofundamos nessa questão torna-se necessário elencarmos os dez pontos elementares (Lijphart, 2003: 49-65) para o estabelecimento de um sistema consociacional e verificarmos se o Líbano encaixa-se nele:

1) Partilha do Poder Executivo por meio de gabinetes de ampla coalizão;

2) Equilíbrio de Poder entre o Executivo e o Legislativo;

3) Sistema multipartidário;

4) Representação proporcional;

5) Corporativismo de grupos de interesse;

6) Governo federal e descentralizado;

7) Forte bicameralismo;

8) Rigidez constitucional;

9) Revisão judicial; e,

10) Independência do Banco Central.

Segundo a elaboração do Pacto Nacional e da Constituição, o Poder Executivo sobrepunha-se ao Poder Legislativo e a composição desse seguia critérios relativos à representatividade social, mais que a busca de um governo de coalizão. A redução do poder do Executivo, com distribuição desse para o Gabinete, somente tomou forma após a Segunda Guerra Civil, com a assinatura do Acordo de Taif. Assim, por haver uma disputa clara entre o chefe do Executivo - um presidente cristão maronita - e o Primeiro-ministro - muçulmano sunita -, agravado com o fato de a chefia do Parlamento ser desempenhada por um muçulmano xiita, a luta pelo poder sobrepôs-se aos interesses nacionais e o desequilíbrio de poder entre essas três lideranças gerou instabilidade social e política.

Como foi apresentado nos capítulos iniciais dessa dissertação, o Líbano sempre foi um espaço para a difusão de idéias e ideais, dessa forma houve a propagação de inúmeros periódicos e livros. Com base nessa diversidade, o surgimento de partidos políticos tornou-se algo natural conforme o Estado assumia suas formas, entretanto, além dos partidos com teor 
ideológico, havia aqueles que representavam apenas os interesses dos zuama. Dessa forma, o sistema político libanês acabou assumindo a característica de um sistema multipartidário.

A representação proporcional adveio da necessidade de preservar o status das elites que controlavam o país desde o período do Mandato - basicamente os cristãos maronitas que eram aliados dos franceses - e evitar que o Líbano viesse a integrar-se ao mundo árabe de forma que a minoria cristã fosse excluída dos desígnios do Estado. Entretanto, o sistema foi levado a extremos e o sectarismo passou a balizar as relações políticas e sociais entre as comunidades libanesas.

Com relação ao item de número 5, podemos salientar o fato de que o tipo de corporativismo que prevalece no Líbano continua sendo o liberal, sobrepondo-se ao social onde os sindicatos de trabalhadores predominam. O enfraquecimento do corporativismo social também pode ser explicado pela força das famílias dentro de suas regiões e o poder que exercem sobre os habitantes. Nesse panorama adverso, a concentração de poder dos zuama é potencializada inibindo setores da sociedade de se manifestarem. Um risco grave para o sistema democrático.

No tocante à organização federativa do Líbano, apesar de haver governos regionais o poder do Executivo tendia a sobrepor-se a ele. Esse fato também foi um dos elementos que provocou as guerras civis que o Líbano viveu. A relação entre o Poder Executivo Central e os membros da federação torna-se mais complicada na medida que os governadores deixavam de reconhecer a verdadeira representatividade de um presidente cristão num país, nitidamente, de maioria muçulmana. Quanto à representatividade bicameral - que reforçaria o poder dos membros da federação, independentemente de seu tamanho, haja vista serem representados igualmente no Senado -, apesar de constar na Constituição de 1926 a função do Senado, logo com as primeiras emendas (1927) sofreu modificação e foi excluída. Adotou-se, assim, o sistema unicameral.

Mais outra característica libanesa que destoa do exigido pelo modelo consociacional diz respeito à rigidez da constituição. Criada para fortalecer o sistema confessional - apesar de salientar que o objetivo principal da nação seria aboli-lo -, sempre foi um documento passível de alterações que visassem responder aos interesses dos grupos dominantes. Para a aprovação de emendas constitucionais é necessária a aprovação da maioria de dois terços da Casa, sem necessidade de que haja qualquer referendo popular. Com isso, mesmo considerando as modificações necessárias - como a supressão da legitimidade que a Constituição dava ao sistema de Mandato -, houve cinco modificações substanciais até 1947 e uma última em 1989, para adaptar-se ao Acordo de Taif. Também aconteceram emendas que 
visavam prorrogar os mandatos de presidentes, as quais geraram forte repulsa por parte de segmentos da população que se viram prejudicados.

Sobre a revisão judicial, o Líbano possui, conforme a própria Constituição esclarece, um Conselho Constitucional para esclarecimentos acerca de dúvidas no tocante à aplicação da lei:

\section{Article 19 [Constitutional Council]}

A Constitutional Council is established to supervise the constitutionality of laws and to arbitrate conflicts that arise from parliamentary and presidential elections. The President, the President of the Parliament, the Prime Minister, along with any ten Members of Parliament, have the right to consult this Council on matters that relate to the constitutionality of laws. The officially recognized heads of religious communities have the right to consult this Council only on laws relating to personal status, the freedom of belief and religious practice, and the freedom of religious education. The rules governing the organization, operation, composition, and modes of appeal of the Council are decided by a special law.

No que concerne à independência do Banco Central libanês (Banque Du Liban), o BDL foi estabelecido pelo Código Monetário e de Crédito promulgado em $1^{\circ}$ de augusto de 1963, pelo Decreto $n^{\circ} 13513$, porém, somente passou a operar efetivamente em $1^{\circ}$ de abril de 1964. Possui uma administração autônoma - nem por isso ausente de críticas por beneficiar determinados setores econômicos e políticos - conforme informações disponibilizadas pelo próprio Banco.

BDL is a legal public entity enjoying financial and administrative autonomy. It is not subject to the administrative and management rules and controls applicable to the public sector. Its capital is totally appropriated by the State.

The BDL is vested by law with the exclusive right to issue the national currency. As stipulated by article 70 of the Code of Money and Credit, the BDL is entrusted with the general mission of safeguarding the national currency in order to ensure the basis for sustained social and economic growth. This mission consists specifically in:

- the safeguard of monetary and economic stability

- the safeguard of the soundness of the banking sector

- the development of money and financial markets

- the development and regulation of the payment systems and instruments

- the development and regulation of money transfer operations including electronic transfers

- Development and regulation of the clearing and settlement operations relative to different financial and payment instruments and marketable bonds. (http://www.bdl.gov.lb/bdl/role.htm)

Mesmo que haja uma mescla de fatores que possibilitassem caracterizar o sistema político libanês como sendo potencialmente democrático, Lijphart faz mais uma observação 
que relativiza o seu potencial desenvolvimento, qual seja, a necessidade de que a sociedade apresente característica secular que a permita modernizar-se em termos social e econômico. De antemão exclui-se o Hizbullah devido a sua plataforma islamista. Entretanto, cabe retornar ao questionamento acerca do pragmatismo do partido xiita e o quão ele poderá interferir no destino do Estado. Para isso, voltaremos a recolocar essa questão no capítulo final.

Para efeito de conclusão desse capítulo, seria útil nos atermos a mais algumas considerações que estão presentes em Sartori, haja vista o fato de que poderão delinear o caminho a ser seguido para a análise da proposta islamista do Hizbullah e verificação de seu grau de interferência no sistema político libanês.

Primeiramente devemos considerar que “os sistemas políticos são sistemas, isto é, totalidades finitas caracterizadas por mecanismos e princípios constitutivos que ou bem estão presentes (embora de maneira imperfeita), ou bem estão ausentes (embora de maneira imperfeita).” (Sartori, 1994: 249) Dessa forma, por mais que determinados sistemas políticos sejam idealizados para funcionarem de forma tal que consigam alcançar os objetivos propostos para um Estado democrático, sua manipulação por parte dos membros - nacionais e/ou internacionais - pode vir a acarretar desvios que comprometeriam o resultado.

Assim, a opção por um sistema majoritário pode alcançar êxito se as decisões do bloco vencedor não forem excludentes - contrariando toda a camada social que saiu derrotada na eleição -, ao mesmo tempo, um sistema consensual pode representar as minorias se houver interesse das lideranças sociais e partidárias, caso contrário, pode desvirtuar para uma oligarquia sectária.

Sartori, através de seu pensamento liberal, entende que para dirimir os problemas causados pelos sistemas representativos, a figura do indivíduo é de grande valor. Até porque, a partir dela que se desenvolvem os partidos políticos. Isso posto, para que haja melhores condições para que as sociedades modernas, ou modernizadas, encontrem solo fértil para o desenvolvimento do sistema democrático, de acordo com Sartori, é necessário que exista ampla possibilidade de se alcançar à informação e formar, dessa maneira, uma opinião pública. No entanto, Sartori faz distinção entre (a) 'opinião pública’ no sentido de liberdade de expressão através dos meios de comunicação e (b) 'opinião pública' significando o desenvolvimento de idéias próprias. (1994: 137) A primeira seria apenas uma reprodução de pensamentos sem qualquer aspecto crítico; a segunda levaria a formação de uma opinião autônoma.

Essa questão é de grande relevância porque está ligada diretamente ao desenvolvimento de uma massa crítica e de partidos políticos livres e ideologizados; 
conseqüentemente, mais aptos a participar do processo eleitoral - o que seria o ideal para o sistema consociacional, uma vez que poderiam trabalhar em prol do consenso e da integração das minorias. Sartori estabelece duas condições necessárias para que surja uma 'opinião pública’ relativamente autônoma, quais sejam, “(a) um sistema de educação que não seja um sistema de doutrinação; e (b) uma estrutura global de centros de influência e informação plurais e diversos.” (1994: 139)

Mais uma vez, olhando para a história do Líbano não podemos afirmar que existe (ou existiu) condições propícias para o surgimento desse tipo de ‘opinião pública' apontado por Sartori. A separação imposta pela religião estabeleceu diferentes propostas educacionais e culturais. O que vem reforçar a propositura de que o poder dos zuama teria atuado contrário ao interesse nacional e, por isso, o sistema partidário transformou-se apenas num prolongamento dos braços dos clãs.

Também, com a inserção de um partido político islamista no sistema eleitoral libanês e, considerando que o Hizbullah sempre evidenciou sua proposta de estabelecer uma república islâmica no Líbano, cria-se o paradigma do partido 'anti-sistema' de Sartori. Nega-se o valor do sistema democrático a partir de uma visão própria de sua construção ideológica - no caso do Hizbullah, de forte teor religioso -, porém participa dele no intuito de não ficar à margem do Estado. Essa postura assemelha-se à maneira com que o Hizbullah procedeu após as primeiras eleições que participou. Apesar de conseguir representatividade no Parlamento, recusava assumir qualquer vaga ministerial para que pudesse continuar sendo um crítico do governo e do sistema político.

Com base nas considerações feitas por Dahl, Lijphart e Sartori é possível constatar que a Democracia é um sistema idealizado, no entanto, os sistemas políticos adotados pelos Estados e considerados democráticos não possuem todos os valores da Democracia. Isso posto, retomamos a razão pela qual Dahl opta pela utilização do termo poliarquia. No entanto, Sartori não entende que essa deva ser a melhor maneira para conceituar os sistemas políticos reais, ou seja, simplesmente afirmando que por serem imperfeitos - no que tange a possuírem todos os requisitos democráticos - deveriam ser desqualificados como democracias e considerados poliarquias. A esse respeito, Sartori afirma que:

O que a democracia é não pode ser separado do que a democracia deve ser. Uma democracia só existe à medida que seus ideais e valores dão-lhe existência. As poliarquias não são compreendidas por Dahl em termos literais (isso é, como sistemas caracterizados por multiplicidade de comando e, por isso, pela difusão do poder), mas, muito além da mera conotação literal do termo, como "em que o poder sobre as autoridades é amplamente [...] 
partilhado”98 através de um grau relativamente grande de controle dos líderes por parte do cidadão comum. (Sartori, 1994: 23)

Independentemente da polêmica acerca da utilização do termo, cabe ressaltar que estamos trabalhando com um conceito que elabora a idéia de um sistema perfeito, contudo, impossível de ser alcançado de maneira plena. Com isso, o alerta de Sartori de que primeiramente devemos delimitar o que vem a ser democracia para somente depois estabelecermos o nível democrático de um Estado é de fundamental importância para essa análise. E pautará o método estabelecido para o desenvolvimento das conclusões finais dessa dissertação.

Definir o que vem a ser democracia demanda iniciarmos fazendo uma série de questionamentos e, em seguida, estabelecermos sua relevância com o objeto em estudo. Muito mais que perceber a existência de tal característica num determinado sistema político, torna-se fundamental analisar a maneira com que é colocada em prática. Assim, a primeira etapa se cumpriria estabelecendo quais características seriam compatíveis com um sistema democrático. Daí Sartori já nos alerta para as dificuldades impostas:

\begin{abstract}
A primeira é que há miríades de características ou propriedades aceitáveis para a seleção; não apenas princípio de maioria e participação, mas também igualdade, liberdade, consenso, coerção, competição, pluralismo, princípios constitucionais, e outros. A segunda dificuldade é que essas características são tão inter-relacionadas que provavelmente qualquer avaliação isolada de qualquer categoria produza ordenamentos hierárquicos extremamente erráticos. A terceira e, a meu ver, a mais importante, se partirmos, como de fato o fazemos, de um atoleiro conceitual, é que as operacionalizações (lembremos que se presume estarmos em busca de medições) só podem aumentar a confusão com extravagâncias. (Sartori, 1994: 249)
\end{abstract}

À luz desse processo traçado por Sartori será possível respondermos às questões à que essa dissertação se propõe, quais sejam: Seria o Líbano um Estado democrático? E, o sendo, é possível mensurar o nível democrático de seu sistema político? A interferência de atores externos teria influído de que maneira no desenvolvimento do sistema político libanês?

Respondidas essas primeiras três questões, passaremos a questionar o envolvimento de uma organização islamista no sistema político libanês, porém, antes de focarmos nessa questão seria fundamental levantar um questionamento acerca do valor democrático. Seria ele um valor universal, e por isso mesmo também inerente ao pensamento islâmico, ou apenas mais uma forma de colonização cultural? A partir desse questionamento concluiremos o

\footnotetext{
${ }^{98}$ Citação de Sartori à obra de Dahl: Dahl, Robert. Modern Political Analysis. (Englewood Cliffs, N.J., PrenticeHall, 1963), p. 73.
} 
estudo com mais duas perguntas: Como o sistema político libanês assimilou a entrada de uma organização islamista no jogo político? E, a partir do momento em que uma organização islamista passa a integrar-se ao sistema político-partidário libanês, estaria ela se afastando de seus ideais ou buscando uma maneira de alcançar o poder através da via democrática? 


\section{CONSIDERAÇÕES FINAIS}

\section{O LÍBANO NA \\ “SENDA RETA ${ }^{99}$ PARA O ISLÃ”?}

Esposito e Voll, em "Islam and Democracy” traçam um panorama bastante claro das transformações que o pensamento islâmico sofreu ao entrar em contato com a cultura ocidental. Transformações tão substanciais quanto àquelas vividas pelo Ocidente através de suas revoluções e da chegada à Modernidade. No entanto, talvez o maior desafio tenha sido o confronto que os islamistas, a partir do século XX, viriam a ter contra os valores assumidos pelo Ocidente como universais. Dentre eles, o que ora estudamos, a Democracia.

Se por um lado, Kelsen afirma que a democracia, como ideal, traz consigo os sentimentos de liberdade e igualdade como os verdadeiros valores universais, por outro lado, não podemos deixar de considerar que liberdade e igualdade podem não estar presente de modo absoluto numa determinada sociedade mas ainda assim é possível classificar um Estado como democrático. Isso porque, por definição, liberdade e igualdade se opõem. Voltamos, assim, ao alerta de Sartori, o qual reitera a necessidade de buscarmos uma definição mais precisa sobre o fenômeno estudado antes de questionarmos o nível de desenvolvimento de democracia no Estado.

Mas há uma observação ainda mais pertinente para o desenvolvimento dessas impressões finais. Como Esposito e Voll observam, quando se discute a questão acerca de democracia, não há um modelo único, absoluto e que se encerre em si. A concepção de democracia foi se transformando com o passar dos anos e adaptando-se às necessidades e realidades de quem a empregava. Isso posto, os muçulmanos poderiam trilhar um outro caminho democrático através de questionamentos distintos, haja vista terem tido contato com ‘a democracia’ num momento muito posterior com relação ao Ocidente.

\footnotetext{
${ }^{99}$ Citação do Corão (1:1-7) “1. Em nome de Deus, o Clemente, o Misericordioso. 2. Louvado seja Deus, Senhor do Universo, 3. Clemente, o Misericordioso, 4. Soberano do Dia do Juízo. 5. Só a Ti adoramos e só de Ti imploramos ajuda! 6. Guia-nos à senda reta, 7. À senda dos que agraciaste, não à dos abominados, nem à dos extraviados." (grifo meu)
} 
Democracy is really a contested term. There may be a dominant discourse, but multiple discourses have existed and can continue to exist or be formulated. The term "democracy" is capable of multiple interpretations and applications. Contrary to the belief or presuppositions of some, the Western experience of democracy reveals a rich mosaic rather than a single paradigm. Similarly, the history and implementation of democracy in the West revels the extent to which the emergence and development of democracy, of democracy values and institutions, was itself a "messy" process fraught with the tension and conflicts that accompany all great periods of historical and social transformation. (1996: 193)

Opinião similar acerca de que a experiência distinta das trajetórias das civilizações ocidental e muçulmana resulta em diferentes demandas é partilhada por Armstrong. A autora salienta que, enquanto a Europa de final do século XIX vivia uma corrida por armas que resultaria nas duas Grandes Guerras do século seguinte e, ao mesmo tempo, passava por um processo de florescimento de regimes totalitários (nazismo, fascismo e comunismo) conseqüente desilusão do pensamento Iluminista, que passara a ser "tão utópico quanto qualquer outra das velhas fantasias messiânicas” (2001b: 212) - certos grupos muçulmanos não questionavam o poder divino estabelecido pelas leis corânicas.

A sociedade moderna [ocidental] estava comprometida com a democracia, e isso, em geral, fizera com que ela fosse mais justa e mais eqüitativa para as pessoas na Europa e na América. Entretanto, as pessoas do Ocidente tiveram séculos para se prepararem para a experiência democrática. Seria muito diferente quando os sistemas parlamentares modernos se impusessem a sociedades agrárias ou imperfeitamente modernizadas, e onde a vasta maioria da população considerasse incompreensível o discurso político moderno. (Armstrong, 2001b: 212)

Assim, cabe fazer algumas considerações acerca dos pressupostos básicos - os valores liberdade e igualdade - que fizeram com que os ocidentais optassem pela democracia e como são percebidos pelos muçulmanos. Conforme Lewis nos expõe, igualdade é um princípio constante na doutrina islâmica, como tal, foi expressa pelas palavras do profeta.

Se compararmos o islã na época de seu advento com as sociedades que o cercam - o feudalismo estratificado do Irã e o sistema de castas da Índia ao leste, as aristocracias privilegiadas da Europa tanto bizantina quanto latina oeste - a doutrina islâmica traz realmente uma mensagem de igualdade. O islã não apenas não endossa [o] sistema de diferenciação social; rejeita-os explícita e resolutamente. As ações e os pronunciamentos do Profeta, os reverenciados precedentes dos primeiros governantes do islã tal como preservados na tradição, são esmagadoramente contra o privilégio por descendência, por status, por fortuna, ou até por raça, e insistem em que a posição social e a honra no islã são determinados unicamente por piedade e mérito. (2002: 96) 
No entanto, Lewis esclarece que nem sempre o desenvolvimento da sociedade muçulmana deu-se fundamentado no princípio da igualdade. Em grande parte, isto se devia à elitização do poder no império muçulmano. Mas três outras questões que denotam diferença na maneira de perceber igualdade são trazidas da raiz do Islã, quais sejam

O igualitarismo do islã tradicional, no entanto, não é completo. Desde o início o islã admitiu certas desigualdades sociais, que são sancionadas e de fato santificadas pela sagrada Escritura. Mesmo nas três desigualdades básicas, entre senhor e escravo, homem e mulher, fiel e infiel, porém a situação da civilização islâmica clássica era sob alguns aspectos melhor que alguns lugares. (...) Mas essas três desigualdades básicas permaneceram arraigadas e incontestadas. Ao longo dos séculos, toda uma série de movimentos radicais de protesto social e religioso surgiu no mundo islâmico, tentando derrubar as barreiras que vez por outra se erguiam entre os de estirpe nobre e os de origem humilde, os ricos e os pobres, os árabes e os não-árabes, os brancos e os negros, tudo isso encarado como contrário ao verdadeiro espírito da confraternidade islâmica; mas nenhum desses movimentos jamais questionou as três distinções sacrossantas que estabeleciam o status subordinado do escravo, da mulher e do infiel. (2002: 97)

E, dessas "três distinções sacrossantas”, talvez, hodierno, duas delas sejam as que mais se afastam do pensamento ocidental: a questão da mulher e dos infiéis. Considerando o princípio de igualdade entre os seres humanos, a distinção feita à mulher - aos olhos ocidentais -, cai como uma violência desmedida. Também é fundamental mencionar a questão dos infiéis. Isso porque, o tão propagado jihad dos movimentos islamistas advém da distinção que se faz entre muçulmanos e não-muçulmanos. Entretanto, é fundamental ressaltar que essa leitura distorcida do jihad, como “guerra santa”, não é compartilhada por todos os muçulmanos. Em sua grande maioria a integração Islã-Ocidente não representa uma luta no sentido de "guerra santa”, mas sim no intuito de não haver a descaracterização de uma cultura com o processo de massificação cultural desenvolvido pelo Ocidente.

Retomando ao objeto dessa dissertação, antes de discutirmos a questão acerca de o Líbano ser um país democrático ou não, precisaríamos recuperar suas referências históricas para verificarmos se teremos que observá-lo como um país islâmico ou ocidental. Esse seria o ponto de partida porque, partilhando da opinião de Esposito e Voll, a democracia que o Líbano possa estar vivendo hoje talvez seja a mesma que um país europeu viveu há alguns anos, ou ainda, pode ter sido criado um modelo completamente distinto do ocidental por ter sido influenciado por eventos outros - ligados à história islâmica. Ainda assim, poderíamos ter uma democracia no sentido de "governo do povo". Desconsiderando, evidentemente, a 
premissa defendida pelos islamistas de que não seria possível haver um "governo do povo" uma vez que o governo é sempre de Deus e qualquer sistema desenvolvido pelos homens seria contrário aos princípios corânicos.

O primeiro problema que se apresenta diz respeito à identidade libanesa. De fato, essa nacionalidade foi criada pelos europeus ao fazerem a divisão do Império Otomano. Na região do Monte Líbano havia cristãos e muçulmanos sem integração - no sentido de expressarem-se como nação. Assim, ao ser criado o Estado libanês, impôs-se a referência ocidental de modelo organizacional, ou seja, o Estado-nação. No entanto, conforme Hobsbawn salienta, o conceito de nação também pode ser talhado por uma elite dominante para atender aos seus anseios. Dessa forma, criam-se vínculos históricos que nem sempre existiam e faz-se com que os distintos povos que viviam em determinada região passem a ter vínculos. Partilha-se uma história ‘criada' e desenvolve-se um projeto nacional. Como no episódio em que foi feito o Pacto Nacional. A partir do momento que se é criado esse sentimento de nação, ele, de fato, pode vir a desenvolver-se e ser assimilado pela população. Então, mesmo que a história libanesa pré-Mandato não possibilitasse o entendimento de que ali vivia uma nação, a conjuntura formada pela dominação francesa, aliada à vontade da elite local, fez com que fosse possível nascer um projeto de nação para os povos que habitavam o Líbano.

Mas a assimilação não foi pacífica e passiva, de antemão percebemos que o modelo utilizado - Estado-nação - não serviu como referencial necessário para unir os grupos que foram incorporados ao território libanês. Grande parte dos muçulmanos que foi separada da Síria nutria vínculos mais efetivos com o povo sírio, até um possível sentimento de nacionalidade síria - ou mesmo com a umma - que, necessariamente, com seus compatriotas cristãos, com os quais passaram a compartilhar “a cidadania”. Dessa forma, podemos perceber que a ação do Ocidente no mundo islâmico ocorreu de forma bastante violenta, no entanto, pelo menos nos anos iniciais da independência do Estado libanês, não conseguiu fazer com que o paradigma ocidental de Estado-nação fosse assimilado completamente pela população local.

Num país tão heterogêneo com o Líbano, um dos maiores desafios, no intuito de tentar criar o sentimento de nação para o povo, seria não impedir a participação qualquer grupo religioso às instâncias de poder. Nesse sentido, o modelo confessional adotado apresentou-se como uma fórmula perfeita. Conforme Lijphart ressalta, a adoção do sistema consociacional possibilita que não haja a tirania da maioria, ao mesmo tempo, estimula as minorias a se integrarem ao sistema político no intuito de participarem efetivamente do governo. 
Lijphart salienta, ainda, que para esse tipo de sistema conseguir obter êxito é fundamental que haja o entendimento entre as elites. Quem, de fato, deve ditar as regras do jogo deve ser a elite do país. Nesse sentido, mais uma vez, o modelo consociacional refletiu exatamente a realidade libanesa pré-independência. Graças aos entendimentos entre a elite representada pelos maronitas e sunitas -, foi possível firmar o Pacto Nacional que levou à independência.

No momento subseqüente à independência, é possível dizer que o Líbano desenvolviase no sentido de transformar-se numa poliarquia, ou seja, saia de um sistema hegemônico fechado para constituir-se numa oligarquia competitiva, segundo pressupostos de Dahl. O Líbano possuía uma Constituição, direito de votos aos cidadãos, instituições estabelecidas, etc. No entanto, como podemos perceber nos capítulos anteriores, dois fatores concorreram para que o Líbano estagnasse num determinado nível de desenvolvimento e não se desenvolvesse no sentido de transformar-se numa poliarquia: o sectarismo e a preservação de determinados cargos políticos para grupos religiosos específicos. E, como fator acessório, mas que computou para reforçar a divisão interna da população libanesa, a presença dos refugiados palestinos e o conflito com Israel foi determinante, uma vez que estabeleceu aliados em segmentos distintos e intensificou a guerra civil que já estava em curso.

Lijphart reforça a tese de que é necessário que as minorias, num sistema consociacional, vislumbrem a possibilidade de que poderão exercer o poder, caso contrário, há a estratificação dos segmentos políticos e aqueles que detém o poder corrompem o sistema. Esse parece ter sido o caso libanês. No intuito de preservarem-se no poder os maronitas instituíram o sectarismo no sistema político de forma tal que a exclusão de quem não era desse grupo religioso, muito mais que não participar da vida política do país, não recebia qualquer assistência do Estado e tinha o direito de cidadania apenas relativa ao nascimento.

Prova da rejeição à política instituída pelos maronitas, por parte dos segmentos sociais excluídos do Estado, tivemos as duas guerras-civis (1958 e 1975-90). Juntamente com a falência do projeto de criar um Estado-nação, o Líbano passou a ter uma segunda força atuando em seu território: o pensamento islamista xiita que surgira através de Musa Sadr, a partir da década de 1960.

Se, no início do processo de unificação da comunidade xiita libanesa o vínculo também deu-se a partir de um discurso impregnado do pensamento da Esquerda, a partir dos final dos anos de 1970 a influência dos ideólogos de Najaf e Qom passaram a ganhar espaço no discurso de Sadr. 
Tendo, por um lado, a comunidade xiita - e os muçulmanos, de modo geral questionando a legitimidade dos maronitas de exercerem, com exclusividade, o poder - uma vez que não mais constituíam a maioria da população -, por outro lado, havia uma comunidade cristã alegando que esse direito não poderia ser modificado. Sua justificativa dava-se sob a alegação de que fora ela quem desenvolvera o país economicamente e, também, porque essa seria a única maneira de conseguir preservar-se "no oceano de muçulmanos” que o Líbano estava inserido.

Novamente, suscitando o posicionamento de Sartori: para que um sistema político seja democrático faz-se necessário que haja a alternância no poder, caso contrário estabelece-se uma oligarquia - independentemente de sua ideologia. E, por definição, uma oligarquia pode até ter algum grau de participação dos cidadãos, no entanto, fica longe do modelo de democracia idealizado, ou mesmo da poliarquia de Dahl.

Para que possamos analisar, de fato, a influência que o Hizbullah possa ter tido no sistema político libanês, temos que chegar a 1990 e rever o que levou a, então milícia xiita, transformar-se em partido político. Essa data também é fundamental porque até o Acordo de Taif, basicamente a luta do Hizbullah dava-se contra a presença israelense no sul do Líbano. Outra data significativa é o ano 2000 - saída das tropas israelenses do território libanês -, porque representou uma modificação no discurso do Hizbullah e, por isso, também deve ser percebido.

A opção estratégica adotada pela organização, conforme foi exposto no capítulo 4, fez com que os membros do Hizbullah, temporariamente, não questionassem a legitimidade de os maronitas continuarem detendo o poder embora não mais constituíam a maioria da população. E, ainda, se a base do sistema confessional era a representatividade, a sub-representação dos muçulmanos na política libanesa já vinha ocorrendo há anos.

Para que fosse firmado o Acordo de Taif e, por conseguinte, havido a ampliação da representatividade da comunidade muçulmana e redução dos poderes do Executivo - dentre outras medidas que visavam equiparar os direitos de cristãos e muçulmanos -, não houve influência direta do Hizbullah. Havia o interesse da população libanesa de que a guerra-civil acabasse e, mais ainda, que tal fato viesse a acorrer pelas mãos da Síria. Então, diante de uma conjuntura internacional favorável e, possuindo condições suficientes para influir no governo libanês, assim como em vários outros grupos aliados, Assad impôs a paz ao Líbano.

A partir de então passamos a ter a presença do Hizbullah como partido político. Atuando diretamente no sistema político-partidário libanês. Convém questionarmos se a partir de Taif o Líbano passou a corresponder ao paradigma de país democrático. O 
parlamento voltou a ter eleições livres a partir de 1992; foi estabelecido um novo equilíbrio de poder - Presidente, Primeiro-ministro e Chefe do Parlamento (esse, xiita) acabaram por dividir a área de influência sobre o Estado -; e, as milícias depuseram as armas - exceção feita ao Hizbullah.

Algumas questões ficaram pendentes: o Estado não recuperou o monopólio da violência, haja vista a Síria assumir a responsabilidade pela segurança do Líbano e o Hizbullah ter continuado em sua luta contra a presença israelense no sul do país; também, o acerto feito em Taif não propiciou a alternância de poder no Executivo, tampouco nos cargos de Primeiro-ministro e Chefe do Parlamento. Esse último, apesar de ser destinado a um xiita, exclusivamente é exercido por Nabih Berri, líder do Amal (partido político xiita), no entanto com proposta secular.

A longa permanência de Berri no cargo, além de não corresponder a um pressuposto democrático, também chama a atenção para outra característica da política libanesa, essa, fortemente centrada na figura do zaim, como foi apresentado nos capítulos anteriores. Os partidos políticos, que deveriam evoluir no sentido de libertarem-se do vínculo com os zuama, trilharam um caminho distinto e não obtiveram ganho institucional, ou seja, preservaram a função de serem, basicamente, um mecanismo de os zuama legitimarem seu poder local no nível nacional.

Aqui cabe, também, uma observação acerca do sistema eleitoral libanês. A utilização de voto distrital com listas abertas, em tese, traria uma representatividade mais justa para as comunidades e, ao mesmo tempo, reforçaria os partidos políticos. No entanto, o sistema libanês de listas não funciona com apenas um partido político apresentando seus candidatos. Muitas vezes são formados blocos entre os partidos cristãos e muçulmanos e estabelece-se uma lista que contemple a quantidade específica que cada grupo religioso tem direito de eleger no distrito. Também há a possibilidade de o eleitor designar o voto nominalmente para cada parlamentar que deseje. A questão da manipulação do alcance dos distritos acabou sendo objeto de críticas desse sistema, haja vista, desde as eleições de 1992 nunca foi preservada a dimensão dos distritos. Assim, abre-se a possibilidade de ampliar ou reduzir a quantidade de membros que cada grupo religioso tenha direito de eleger no distrito.

Mesmo com esses desvios estruturais do sistema político-eleitoral libanês, o Hizbullah integra-se perfeitamente a ele e consegue eleger seus parlamentares. No entanto, duas características se sobressaem na postura do partido xiita: (a) a incisiva negação de fazer parte do Gabinete, segundo Nasrallah, porque assim poderia continuar opondo-se ao governo e ao sistema político, reiterando sua opção por um modelo islâmico não-secular; e, (b) o domínio 
que o Hizbullah tem sobre a vontade de seus parlamentares, inclusive colocando-os como meros repetidores das decisões da Shura (Hamzeh). De fato, o parlamentar teria de expressar a opinião do partido, mesmo num partido político secular essa é a premissa principal, no entanto, o que chama a atenção no caso do Hizbullah é a impossibilidade de o parlamentar expressar-se individualmente.

Apesar de o sistema político libanês ser possuidor de várias características que o afastam do modelo ideal de democracia, é possível reconhecer a presença de algumas instituições que aproximá-lo ia de um Estado Liberal. Talvez sua própria fundação já apresentasse essa característica. Haja vista, segundo Bobbio,

O Estado liberal nasce de uma contínua e progressiva erosão do poder absoluto do rei [no caso libanês, o poder mandatário francês] e, em períodos históricos de crise mais aguda, de uma ruptura revolucionária (...); racionalmente, o Estado liberal é justificado como o resultado de um acordo entre indivíduos inicialmente livres que convencionam estabelecer vínculos estritamente necessários a uma convivência pacífica e duradoura. (2005: 14)

Da forma com que Bobbio apresenta a instauração do Estado, segundo os preceitos liberais, é possível perceber as mesmas características em que o Pacto Nacional foi firmado (1943) e, por conseguinte, pôs fim ao sistema de Mandato fazendo com que o Líbano alcançasse a status de país independente.

A partir desse estágio, o Líbano desenvolveu-se da seguinte maneira: reconhecendo o direito natural de seus cidadãos - jusnaturalismo ${ }^{100}$-, no entanto, preservando o poder do Estado nas mãos de uma elite (zuama) que já havia sido instituída historicamente na região e que era legitimamente reconhecida em seus grupos religiosos.

Dessa forma, se, no início dessas considerações foi aventada a possibilidade de que houvesse duas maneiras distintas de perceber os valores universais - uma pelo Ocidente e outra pelos muçulmanos -, agora, a partir da utilização do pressuposto de jusnaturalismo para a criação do Estado libanês e, considerando que uma das partes envolvida na negociação era formada por muçulmanos sunitas, essa possibilidade torna-se ainda menos plausível de ser ratificada. Excetuando, é claro, a visão mais purista que alguns segmentos islamistas acabaram criando dos dizeres corânicos e que levaram a interpretação distinta acerca dos

\footnotetext{
100 "Pode-se definir o jusnaturalismo como a doutrina a qual existem leis não postas pela vontade humana - que por isso mesmo precedem à formação de todo grupo social e são reconhecíveis através de pesquisa racional - das quais derivam, como em toda e qualquer lei oral ou jurídica, direitos e deveres que são, pelo próprio fato de serem derivados de uma lei natural, direitos e deveres naturais” (Bobbio, 2005: 12)
} 
valores universais. Assim, pode-se até negar a vontade de que se estabelecesse no Líbano uma democracia, no entanto, os valores eram reconhecidos por todos indistintamente.

No aspecto econômico o Líbano também reforça essa tese liberal, haja vista o país ter tido grande progresso durante as décadas de 1950 e 1960 graças a sua abertura de mercado. Os poderes político e econômico numa deixaram de estar nas mãos dos zuama e a ruptura do Estado liberal - durante as guerras-civis - somente se deu com o crescimento dos grupos que não tinham acesso ao poder e que passaram a questionar a perniciosidade do sectarismo. Ao deterem os poderes político e econômico, as elites corromperam o Estado e o clientelismo foi instituído.

O novo cenário que se apresenta ao Líbano pós-Taif suscita a necessidade de responder a última questão proposta nessa dissertação. Fazendo, no entanto, uma recolocação dos termos, haja vista ter-se entendido que o Líbano mais caracteriza-se como um Estado liberal que, necessariamente, democrático. Entendendo também, conforme Bobbio, que o Estado liberal possa ser uma etapa anterior ao democrata. No entanto, apesar de Zacaria concordar com esse posicionamento, acrescenta que essa evolução não é automática.

Nesse Estado liberal, em que as elites, no intuito de preservarem o poder para si, criaram mecanismos políticos-eleitorais que impediram a ascensão dos grupos religiosos ao poder, se, por um lado logrou êxito, por outro, permitiu que o Hizbullah estruturasse "um Estado dentro do Estado” para suprir as necessidades da população xiita. O que passamos a ter, nos dias de hoje - esse "Estado dentro do Estado" -, é resultado do sistema político libanês que, por sua vez, devido às enormes diferenças entre os grupos religiosos, acaba permitindo que isso aconteça, haja vista os governantes não pretenderem agir nas regiões ocupadas pelo Hizbullah.

Agora, integrado ao sistema político libanês e, concomitantemente, dirigindo a estrutura sócio-religiosa que a organização havia criado durante seu processo de desenvolvimento, será que a instituição “Estado libanês” corre risco de ser desestruturada?

Preservado o modelo político-eleitoral libanês, a resposta seria não. O limite imposto pela legislação torna impossível ao Hizbullah alcançar o poder e implementar um Estado islâmico. Contudo, hoje a comunidade cristã corresponde a apenas 35\% da totalidade da população libanesa, contra $65 \%$ de muçulmanos.

O que está mais em jogo nesse momento é a sustentação de alguns privilégios para os cristãos (com p.ex. o direito do exercício da presidência) e a representatividade no parlamento. A fórmula de Taif (50\% muçulmanos - 50\% cristãos) já não corresponde à 
realidade e não há muitos argumentos para que seja preservada. Isso porque, a base do sistema confessional é a representatividade proporcional dos grupos religiosos no poder.

Assim, as mudanças provocadas pelo Taif não foram motivadas por influência de uma organização islamista, tampouco sua participação nos pleitos eleitorais têm gerado mudança no panorama nacional, no entanto, nas eleições regionais a base de apoio do Hizbullah tem se ampliado expressivamente. Grande parte desse sucesso, segundo Hamzeh,

Given the assumption that the nature of municipal work - the provision of social services to the community - is a fundamental tenet of faith, Hizbullah has struck at the heart of the Lebanese old and new zu'ama' and their clientelism that has persisted in one form or another for more than one hundred years. Equally important, the functions and powers of municipalities drew the attention of Hizbullah to the importance of subordinate-level power sharing. Although Lebanon is a unitary form of state in which municipalities or local governments do not enjoy effective autonomy as in federal system, Lebanon is famous for its weak mechanism of central government. Furthermore, Legislative Decree 118 reinforced the concept of autonomy and decentralizations, at least on paper. (2004: 122)

É provável que o mesmo pragmatismo que levou o Hizbullah a flexibilizar sua plataforma islamista para que pudesse transformar-se num partido político, venha a prevalecer em qualquer nível de negociação que leve à alteração do equilíbrio de poder entre os grupos religiosos. Explica-se: Apesar de 65\% da população libanesa ser muçulmana, apenas 35\% é xiita e, mesmo dentre os xiitas, muitos já acreditam num Líbano secular, como os partidários do Amal. Sendo assim, o Hizbullah tem uma limitação que o impede de ditar as regras do jogo. O máximo que ser-lhe-ia permitido, num ‘futuro Líbano redimensionado’, é participar como um partido grande, no entanto, sem representatividade política suficiente para implementar qualquer mudança radical no sistema de governo. Nesse sentido, ao invés do partido islamista ter condições para impor-se ao sistema, o sistema democrático faria com que o partido se adaptasse. Não quer dizer com isso que o Hizbullah assimilaria o secularismo como um ideal, no entanto, poderia aceitá-lo para continuar usufruindo o direito de influir na política libanesa.

É bem provável que o partido continue forte em sua ideologia enquanto houver um inimigo com que lutar, a partir do momento que a situação com Israel for resolvida e houver uma melhora na qualidade de vida da população xiita - equiparando-os aos demais libaneses -, a doutrina islamista poderá ser mais tolerante. No entanto, ainda assim poderá haver alas do partido que não aceitem a flexibilização da doutrina e procure trilhar o caminho pela via da radicalização. Um exemplo recente pode ser percebido no IRA, que, após ter deposto as armas 
num acordo com o governo britânico, alguns segmentos mais radicais, e contrários à paz, criaram o Real-IRA para continuar a luta segundo os ideais anteriores da organização.

Por outro lado, há de se considerar que a manutenção do Hizbullah como milícia - ou Resistência, como é reconhecido no Líbano -, só é possível porque ainda não foi encontrada uma fórmula que reduza os desequilíbrios sociais existentes no país. Na qualidade de representante do "Estado dentro do Estado", o Hizbullah é respeitado e tratado como tal, haja vista prestar assistência para grande porcentagem de libaneses que o governo abandonou. Assim, a deslegitimização do Hizbullah como milícia, perpassa, anteriormente, pelo Estado libanês assumindo suas funções também nas localidades xiitas.

Hoje, a força do Hizbullah está contida pela limitação imposta pela lei. Essa barreira só poderá ser quebrada quando houver uma mudança substancial na maneira de agir da população. Quando o sentimento de nação, como aquele explicitado durante os protestos da 'Revolução do Cedro' (2005), for, de fato, incorporado pelos libaneses e as diferenças entre as comunidades religiosas deixem de ser o diferencial para preterir um grupo a outro. Quando surgir um sentimento de nação distinto daquele anteriormente forjado no processo de colonização perpetrado pelo Ocidente.

Há de se considerar, também, que o islamismo xiita libanês foi talhado sob a influência do pensamento de esquerda e, dessa forma, procura lutar contra as desigualdades sociais. Assim, para reduzir o poder de influência das idéias islamistas na população xiita fazse necessário que o Líbano implemente uma reforma que dirima as diferenças sociais, acabe com o sectarismo e reduza o poder dos zuama - sem que elimine sua importância, haja vista ser um referencial para a população. Só assim o sistema consociacional proposto por Lijphart encontrará solo fértil para prosperar e as idéias islamistas terão pouca propensão para se desenvolverem. 


\section{APÊNDICE}

\section{ELEIÇÕES 2005 E NOVA INVASÃO ISRAELENSE 2006}

Essa dissertação objetivou estudar os eventos ocorridos no Líbano até a saída das tropas sírias de seu território, ou seja, abril de 2005. No entanto, aquele mesmo ano apresentase como sendo emblemático para o futuro dos libaneses. Em tese, pelo menos, ocorreram as primeiras ‘eleições livres’ no país, haja vista, oficialmente, não mais existir qualquer órgão repressor - sírio - atuando no Líbano. É necessário salientar que, segundo informações da imprensa local, agentes do serviço secreto sírio continuaram (talvez até continuem) atuando clandestinamente no território libanês.

No entanto, como foi ressaltado por esse estudo, após a morte do primeiro-ministro Rafiq Hariri o Líbano passou a viver um período intensamente nacionalista. Nos movimentos populares, o que mais chamava a atenção era a presença de bandeiras libanesas sendo empunhadas por todos os grupos religiosos do país. Talvez, depois de tantos anos de conflitos internos, o libanismo tenha vencido o arabismo e a população libanesa tenha encontrado o sentimento de nação, o qual, pela sua ausência, tantas vezes foi pontuado nesse estudo como sendo o grande problema do Líbano.MB

Na eleição de 2005, Saad Hariri, filho do ex-primeiro-ministro assassinado, tornou-se uma figura chave e, a partir da criação do bloco Rafiq Hariri Martyr List, conseguiu fazer com que os grandes aliados contra a presença Síria no país se tornassem vitoriosos. A grande coalizão formada, basicamente, por sunitas e cristãos conseguiu eleger 72 parlamentares. No entanto, o Hizbullah ampliou ainda mais sua representatividade elegendo 14 parlamentares. Com outros 15 membros do Amal e 6 de partidos aliados, a Síria conseguiu o apoio do bloco formado para opor-se a Saad Hariri. Assim, o Resistance and Development Bloc passou a contar com 35 cadeiras no Parlamento. A terceira força vitoriosa na eleição foi liderada por Michel Auon e sua Aoun Alliance, que conseguiu eleger 21 parlamentares, também contra a presença síria. 
Com isso, o novo cenário político mostrava-se bastante restritivo à interferência síria; contudo, a manutenção de Lahoud na presidência ainda preservara certo grau de influência, por parte de Assad, no país, porém, de maneira menos direta e abertamente questionada.

Mas cabe fazer outra observação acerca das mudanças provocadas pela eleição de 2005. Reforçando a tese de que o Hizbullah é uma organização islamista, no entanto, cada vez mais está priorizando sua característica de partido político - num sentido mais tradicional possível - ao tomar decisões, podemos constatar que, pela primeira vez em sua existência, o partido xiita aceitou fazer parte do Gabinete do Primeiro-ministro Fouad Siniora.

A partir dessa decisão, pode-se aventar a possibilidade de que o islamismo do Hizbullah esteja sendo flexibilizado ainda mais e, gradualmente, poderá caracterizar-se como um partido político convencional. Entretanto, essa é uma visão bastante simplista e que estaria apostando demasiadamente no pragmatismo do Hizbullah que visasse meramente o poder. $\mathrm{O}$ partido possui um projeto político-religioso para o Líbano, e isso é notório, então, talvez tenha que repensá-lo de maneira tal que possa incluir o povo libanês, e não os xiitas libaneses. Nesse sentido, a invasão israelense em julho de 2006 significou um passo atrás no processo de ‘normalização’ do Hizbullah.

O que parecer ser mais provável nessa postura assumida pelo Hizbullah ao tomar parte do governo, conforme foi apresentado na dissertação, é que a base ideológica do partido não tenha se modificado, ou seja, ainda continua entendendo que um Estado islâmico atende melhor aos anseios da população que qualquer outro regime laico. E, como não há em seu modelo islamista algo que explique com clareza qual seria a posição dos grupos religiosos minoritários num provável 'Líbano islâmico', é provável que o sistema confessional ainda continuará funcionando com uma forma de defesa das minorias. Um papel que, de fato, cabe ao sistema consociacional, mas que no Líbano atuou contra os xiitas, devido ao sectarismo.

Por outro lado, a vitória parlamentar do Hizbullah, sem dúvida o colocou numa posição melhor para rediscutir o Pacto Nacional, entretanto, parece que, com a aceitação de participar do governo, o Hizbullah possa ter vislumbrado uma possibilidade ainda mais urgente de obter benefícios para os xiitas das regiões mais pobres do país, ante discutir com mais agrura um novo equilíbrio confessional.

Contando com Mohamad Fneich no Ministério de Energia e Água, Trade Hamadé no Ministério do Trabalho e Faouzi Salloukh no Ministério de Relações Exteriores - esse último não faz parte do Hizbullah mas compõe o Resistance and Development Bloc e vota com ele - o poder do partido xiita foi potencializado. O que pode fazer com que haja a equiparação dos níveis 
sócio-econômicos da população xiita com as demais libanesas, ou, simplesmente capitalize lucros para os projetos do partido.

Apesar das intensas transformações, bastante positivas, que a sociedade política libanesa estava vivenciando, a partir da eleição de 2005, não foi possível descobrir que caminho que o Hizbullah assumiria. Com o ataque israelense sobre o Líbano em julho de 2006, os questionamentos modificaram-se completamente. Conforme alegações dos israelenses, e reconhecido por Nasrallah, a milícia do Hizbullah teria assassinado soldados de seu país e seqüestrado outros dois.

Pressionado a devolver os militares, o Hizbullah condicionou a uma troca de prisioneiros. Não foi aceita a condição e Israel marchou sobre o Líbano provocando grandes estragos ao país em pouco mais de um mês de ataques. Mais de mil libaneses foram mortos e pouco mais de cem israelenses foram vitimados pelos katyushas lançados do sul do Líbano em direção aos povoados ao norte de Israel. (www.asianews.it, 18/08/2006)

Com grande parte de sua infra-estrutura destruída - principalmente a região sul do país, no entanto havendo grandes estragos em Beirute -, o Líbano passou a viver como nos seus piores momentos da guerra civil. Muitos libaneses deixaram o país e outros fugiram do sul - área mais intensamente afetada pelos ataques israelenses - em direção ao norte.

Israel alegou ter implementado o ataque contra o Líbano porque necessitava destruir as bases do Hizbullah antes que a milícia se tornasse forte demais para ser destruída. A represália desproporcional, fundamentava-se, assim, no princípio da guerra preventiva utilizada por George Bush para atacar o Iraque.

Ehud Olmert, primeiro-ministro israelense, talvez procurasse fazer com que a população libanesa se voltasse contra o Hizbullah, atribuindo-lhe a culpa pelos ataques. No entanto, sua expectativa não logrou êxito. Apesar de o Hizbullah ter tido grande parte de seu armamento destruído e não ter podido repô-lo - devido ao bloqueio (por terra e ar) estabelecido por Israel que impediu a circulação entre Síria e Líbano -, a partir do momento em que a população libanesa viu-se sendo atacada pelos israelenses de forma tão violenta, a grande maioria, independentemente de ser xiita, sunita ou cristã, passou a reconhecer a luta do Hizbullah contra Israel. A Resistência, assim, ganhou ainda mais adeptos.

Passados os 34 dias de ataques, o Líbano volta a fazer o que aprendeu durante os quase vinte anos que viveu sob guerra-civil, ou seja, ter força para reconstruir o país. No entanto, com um Hizbullah fortalecido e Olmert sem ter conseguido, sequer, obter os corpos dos soldados israelenses que haviam sido presos pelo Hizbullah.

A crise ainda não teve um final. A ONU passou a intermediar negociações que visam o desarmamento do Hizbullah, no entanto, como foi apresentado nessa dissertação, esse processo só 
será viabilizado se as questões internas forem resolvidas antes, caso contrário, o Hizbullah continuará sendo uma milícia e o país não terá uma nação. 


\section{REFERÊNCIAS BIBLIOGRÁFICAS}

ABUKHALIL, As'ad. “Lebanon One Year After The Israeli Withdrawal”. In: MERIP (Middle East Report Online), 29/05/2001. Disponível em: <www.merip.org>

AHMED, Akbar S. Pós-Modernismo e Islão. Lisboa: Instituto Piaget, 1992.

AJAMI, Fouad. The Dream Palace of the Arabs. New York: Vintage Books, 1999.

AL-KHAZRAJI, Sheikh Taleb Hussein. O Líder da Revolução Islâmica - Al-Imam AlKhomeini (K.S.). São Paulo: Centro Islâmico Brasileiro, 2005.

APPENZELLER, Uri. “Israeli Public Disillusioned with Lebanon Occupation” In: Middle East Intelligence Bulletin, vol. 2, $\mathrm{n}^{\circ}$ 2. Fevereiro, 2000. Disponível em: <www.meib.org>. Acesso em 19/06/2003.

ARMSTRONG, Karen. Em Nome de Deus - O Fundamentalismo no Judaísmo, no Cristianismo e no Islamismo. São Paulo: Cia das Letras, 2001a.

Islã. Rio de Janeiro: Objetiva, 2001b.

AZIZ, T.M. The Role Of Muhammad Baqir Al-Sadr In Shi'a Political Activism In Iraq From 1958 TO 1980. Disponível em: $<$ http://www.victorynewsmagazine.com/ShahidBaqirShiaPolitics.htm>

BLANFORD, Nicholas. “Lebanon Catches Its Breath” In: Middle East Report Online, 23/03/2005. Disponível em: <www.merip.org>. Acesso em 25/10/2005.

BOBBIO, Norberto. Liberalismo e Democracia. São Paulo: Editora Brasiliense, 2005.

BREGMAN, Ahron. Israel's wars - A History since 1947. London: Routledge, 2004.

BROWNE, Walter L. The Political History of Lebanon, 1920-1950, Vol. I, U.S.A.: Documentary Publications, 1976 , p. 149.

BRICHS, Ferran Izquierdo. Guerra y Agua: Objetivos y Actitudes de los Actores en el Conflicto por Palestina. Tese de doutorado apresentada ao Departamento de Directo Publico y Ciencias Histórico-Jurídicas da Universitat Autônoma de Barcelona, Julio/2002.

CAIRO AGREEMENT. Disponível em:

<http://www.lebanonwire.com/prominent/historic_documents/lebanon/index.asp>

CEDARLAND. Disponível em:

<http://www.geocities.com/CapitolHill/Parliament/287/index.html>. Acesso em 09/08/2003.

CHIRRI, Shaykh Muhammad Jawad. Shi’ites Under Attack. Disponível em: < http://alislam.org/underattack/>. Acesso em 26/05/2003. 
COBBAN, Helena. "The Growth of Shi'i Power in Lebanon and Its Implications for the Future” in Shi'ism and Social Protest. Londres: Cole and Keddie Edt, 1986.

COLLELO, Thomas (ed.). "Lebanon - A Country Study” In: Federal Research Division Library of Congress (1987). Disponível em: <http://memory.loc.gov/frd/cs/lbtoc.html>. Acesso em 16/05/2003.

COMISSÃO KAHAN. Disponível em: <http://www.usisrael.org/jsource/History/kahan.html>. Acesso em 24/11/2003 às 21h32.

CONVENÇÃO SOBRE O ESTATUTO DOS REFUGIADOS. Disponível em: $<$ http://www.acnur.org/biblioteca/pdf/0005.pdf > . Acesso em 22/11/2003.

DAHL, Robert A. Poliarquia. São Paulo: EDUSP, 1ª ed., 1ª reimpressão, 2005.

Sobre a Democracia. Brasília: Editora UNB, 2001.

DEEB, Lara. “Lebanon: Na Occupation Ends.” In: MERIP (Middle East Report Online), 31/05/2000. Disponível em: <www.merip.org>

DEL PINO, Domingo. A Tragédia do Líbano: retrato de uma guerra civil. São Paulo: Editora Clube do Livro, 1989.

DEMANT, Peter. “Israel x Palestinos - A camuflagem internacional de um conflito” In: Revista Ciência Hoje, volume 30, nº 177 - pp. 22 a 29. Edição Novembro/2001.

O Mundo Muçulmano. São Paulo: Editora Contexto, 2004.

DINIZ, Eugênio. Compreendendo o fenômeno do Terrorismo. Apresentado no $3^{0}$ Encontro Nacional da ABCP - Associação Brasileira de Ciência Política. Niterói, 2002. Disponível em: <http://www.cienciapolitica.org.br/encontro/relint6.3.doc>.

DUPAS, Gilberto e VIGEVANI, Tullo (orgs.). Israel-Palestina, A construção da paz vista de uma perspectiva global. São Paulo: Editora Unesp, 2001.

ENCYCLOPEDIA PHOENICIANA, THE MASSACRES OF 1840-1860. Disponível em: $<$ http://phoenicia.org/persecution1860.html>. Acesso em 25/03/2005.

ESPOSITO, John L. Islam - The Straight Path. New York: Oxford University Press, 2005.

ESPOSITO, John L, e VOLL, John O. Islam and Democracy. New York: Oxford University Press, 1996.

FATTAH, Hassan M. "Last Syria Force Leaves Lebanon.” In: The New York Times, 27/04/2005. Disponível em: <www.nytimes.com>

FISK, Robert. Pity the Nation: Lebanon at War. Oxford: Oxford University Press, 2001.

-. “The killing of 'Mr Lebanon': Rafiq Hariri assassinated in Beirut bomb blast” In: The Independent, 15/02/2005. Disponível em: <http://news.independent.co.uk/world/fisk/story.jsp?story=611221>. Acesso em 01/11/2005. 
FRIEDMAN, Thomas. As Vinhas da Ira. Disponível em: <http://www.geocities.com/monicabo/atualidades160.htm>. Acesso em 15/11/2003. De Beirute a Jerusalém. São Paulo: Bertrand, $3^{\text {a }}$ edição, 1991.

GAMBILL, Gary C. “Michel Auon - Former Lebanese prime Minister” In: Middle East Intelligence Bulletin. Vol. 3, n ${ }^{\circ}$ 1, Janeiro de 2001. <www.meib.org>. Acesso em 20/05/2003. " “Sponsoring Terrorism: Syria and the PFLP-GC” In: Middle East Intelligence Bulletin. Vol. 4, $\mathrm{n}^{0}$ 9, Setembro de 2002. <www.meib.org>. Acesso em 20/11/2005.

GAMBILL, Gary C. e ABDELNOUR, Ziad K. "Rafiq Hariri - Prime Minister of Lebanon” In: Middle East Intelligence Bulletin. Vol. 3, n 7, Julho de 2001. <www.meib.org>. Acesso em 30/09/2003.

GATTAZ, André. A Guerra da Palestina. São Paulo: Usina do Livro, 2003.

GERGES, Fawas A. The Lebanese Crisis of 1958: The Risks of Inflated Self-Importance. Disponível em <http://www.lcps-lebanon.org/pub/breview/br5/gergesbr5pt1.html\#top>. Acesso em 14/05/2005.

GOFFMAN, Daniel. The Ottoman Empire and Early Modern Europe. Cambridge University Press, 2002.

GUZMÁN, Roberto Marín. El fundamentalismo islámico y su reacción contra la globalización. Apresentado no X Congresso Internacional Cultura, Poder e Tecnologia: África e Ásia face à Globalização no Rio de Janeiro em 2000. Disponível em: <http://www.clacso.edu.ar/ libros/aladaa/marin.rtf. Acesso em 15/06/2003>.

HAMZEH, Ahamad Nizar. In the Path of Hizbullah. Syracuse: Syracuse University Press, 2004.

“Islamism in Lebanon: A Guide.” In: MERIA Journal, Volume 1, No. 3 - $\quad$ September $1997 . \quad$ Disponível em: <http://meria.idc.ac.il/journal/1997/issue3/jv1n3a2.html\#hamzeh> "Lebanon's Hizbullah: from Islamic revolution to parliamentary accommodation.” In: Third World Quarterly, Vol 14, No 2, 1993. Disponível em: $<$ www.aub.edu.lb $>$

HÄRDIG, C. A. Brothers in Arms - An Analysis of the Syrian Military and Political Domination of Lebanon. Tese de Mestrado em Ciências Políticas. University of Linköping: Suécia, 2002.

HARIK, Judith Palmer. Hizbullah, the changing face of terrorism. Londres: I. B. Tauris, 2004. 
HECKER, Steven. "Hizballah Kidnapping and the Potential for a Second Front" In: Policywatch $\mathrm{n}^{\mathrm{o}}$ 493. Edição de 12/10/2000. Disponível em: $<$ http://washingtoninstitute.org/watch/Policywatch/policywatch1996/493.htm>. Acesso em 19/03/2003.

HELD, David. Models of Democracy. Cambridge: Polity Press, 1987.

HIZBULLAH.ORG. Disponível em: <http://www.hizbollah.org>. Acesso em 14/04/2003.

HOBSBAWN, Eric J. Nações e Nacionalismo desde 1780. $3^{\mathrm{a}}$ edição, Rio de Janeiro: Paz e terra, 2002

HOURANI, Albert. O pensamento árabe na era liberal : 1798-1939. São Paulo: Cia das Letras, 2005.

Political Society in Lebanon: a Historical Introduction. Oxford: Centre for Lebanese Studies, 1986.

Uma história dos Povos Árabes. 2a edição, São Paulo: Cia das Letras, 2001.

BRICHS, Ferran Izquierdo. Guerra y Água: Objectivos y Actitudes de los Actores en el Conflicto por Palestina. Tese de Doutorado defendida em 2002, Universidad Autónoma de Barcelona, Departamento de Derecho Público y Ciencias Histórico-Jurídicas.

JABER, Hala. Hizbullah, born with a vengeance. New York: Columbia University Press, 1997.

KELSEN, Hans. A Democracia. São Paulo: Martins Fontes, 2000.

KRAMER, Martin. "Hizbullah: The Calculus of Jihad” In: Fundamentalisms and the State: Remaking Polities, Economies, and Militance (The Fundamentalism Project, vol. 3), eds. M. Marty and R.S. Appleby (Chicago: University of Chicago Press, 1993), pp. 539-56.

"Sacrifice and 'Self-Martyrdom' in Shi'ite Lebanon” In: Terrorism and Political Violence, vol. 3, no. 3 (Autumn 1991), pp. 30-47.

Martin Kramer (Tel Aviv: The Moshe Dayan Center for Middle Eastern and African Studies, 1997), pp. 161-73.

KRAYEM, Hassan. The Lebanese Civil War and the Taif Agreement. Disponível em: <www.aub.edu.lb>. Acesso em: 17/05/2003.

LEWIS, Bernard. A Linguagem Política do Islão. Lisboa: Edições Colibri, 2001a. . A Middle East Mosaic - Fragments of life, Letters and History. New York: The Modern Library, 2001b. O Oriente Médio. Rio de Janeiro: Editora Jorge Zahar, 1996. 
O que deu errado no Oriente Médio? Rio de Janeiro: Editora Jorge Zahar, 2002.

Os Assassinos - os primórdios do terrorismo no Islã. Rio de Janeiro: Jorge Zahar Editor, 2003.

The Arabs in History. Oxford: Oxford University Press, 2002.

LIJPHART, Arend. Modelos de Democracia. Rio de Janeiro: Civilização Brasiliera, 2003.

MACKEY, Sandra. The Iranians - Persia, Islam and the Soul of a Nation. New York: Plume Book, 1998.

McDOWALL, David. “Lebanon: a conflict of minorities” In: Minority Rights Group. Report n. 61. London, 1986.

MAKDISI, Ussama. “The Modernity of Sectarianism in Lebanon” In: Middle East Report, Summer/1996.

MALLAT, Chibli. “Aspects of Shi'I thought from the South Lebanon: Al-'Irfan, Muhammad Jawad Mughniyya, Muhammad Mahdi Shamseddin, Muhammad Husain Fadlallah” In: Papers on Lebanon, number 7. Centre for Lebanese Studies.

PANEBIANCO, Angelo. Modelos de Partidos - Organização e Poder nos Partidos Políticos. São Paulo: Martins Fontes, 2005.

PECEQUILO, Cristina Soreanu. A Política Externa dos Estados Unidos. Porto Alegre: UFRGS/Editora, 2003.

PIPES, Daniel. The road to Damascus: What Netanyahu almost gave away. Disponível em: <www.danielpipes.org>. Acesso em: 30/10/2005.

RUBIN, Barry. The Long War for Freedom - The Arab Struggle for Democracy in the Middle East. New Jersey: Wiley, 2006.

RIBEIRO, Renato Janine. A Democracia. São Paulo: Publifolha, 2001.

. “Democracias não Ocidentais”. In: Jornal Valor Econômico, São Paulo, 24/03/2005.

RUTHVEN, Malise. Islam - A Very Short Introduction. Londres: Penguin Books, $1^{\mathrm{a}}$ edição, 2000.

SAAD-GHORAYEB, Amal. Hizbu'llah - Politics Religion. London: Pluto Press, 2002.

SAID, EDWARD W. From Osto to Iraq and the Road Map. New York: Pnatheon Books, 2004.

SALIBI, Kamal. A House of Many Mansions - The History of Lebanon. California: University of California Press, 1988.

SARTORI, Giovanni. A Teoria da Democracia Revisada. São Paulo: Editora Ática, 1994. 
SCHIFF, Ze'ev e YA'ARI, Ehur. Israel's Lebanon War. Londres: Unwin, 1986.

SCHULZE, Kirsten E. "Perceptions and Misperceptions: Influences on Israeli Intelligence Estimates During the 1982 Lebanon War” In: Conflict Studies Journal at the University of New Brunswick. Vol. XVI No. 1, Fall 1997.

SEALE, Patrick. The struggle for Syria. A study of post-war Arab politics 1945-1958. London: Oxford University Press, 1966.

SHLAIM, Avi. A Muralha de Ferro - Israel e o Mundo Árabe. Rio de Janeiro: Fissus Editora, 2004.

TABATABA'I, 'Allamah Sayyid Muhammad Husayn. A Shi'iteAnthology. Disponível em: $<$ http://al-islam.org/anthology/index.htm>. Acesso em 25/07/2003.

TAIF AGREEMENT. Dispoinível em:

$<$ http://www.lebanonwire.com/prominent/historic_documents/lebanon/index.asp>

TANBOURIT. Disponível em: <http://www.tanbourit.com/lebanon_mandate.htm>. Acesso em $14 / 03 / 2005$.

THE LIBRARY OF CONGRESS COUNTRY STUDIES. Disponível em : <http://www.photius.com/countries/lebanon/national_security/lebanon_national_security_the _early_stages_of_ 9570.html>. Acesso em 10/12/2003.

WITKER, Ivan. Occidente Ante Las Nuevas Tipologías Del Terrorismo. Este artigo faz parte do projeto de investigação Fondecyt 1030017 “Estado, Sociedad y Terrorismo”. Chile: Estudios Públicos, 98 (otoño 2005). Disponível em: <www.cepchile.cl>.

ZÂDEH, Kâdzim Qâdî. "Principios Generales sobre el Pensamiento Político de Imam Jomeini” In: Revista Islámica Kauzaur, Qom, n 41, 42 e 43. Ano XII, $2^{\circ}$ trimestre 2005.

ZISSER, Eyal. "Hizballah in Lebanon: at the Crossroads” in MERIA (Middle East Review of International Affairs) Journal, Volume 1, $\mathrm{n}^{\circ}$ 3, Setembro de 1997. Disponível em: <http://meria.idc.ac.il/journal/1997/issue3/jv1n3a1.html>. Acesso em 01/04/2003.

. "Hizballah: New Course or Continued Warfare” In: MERIA (Middle East Review of International Affairs) Journal, Volume 4, n 3, Setembro de 2000. Disponível em: <http://meria.idc.ac.il/journal/2000/issue3/jv4n3a3html>. Acesso em 04/04/2003.

ZUHUR, Sherifa. Neonationalism in the Middle East. New York: XLibris, 2003.

Sites:

http://www.bbc.co.uk

http://www.bdl.gov.lb

http://www.hizbollah.org 


\section{ÍNDICE DE ANEXOS}

1. Acordo Sykes-Picot - 1916

Fonte: http://www.lebanonwire.com/prominent/historic_documents/lebanon/index.asp

2. Declaração Balfour - 1917 .

Fonte: http://www.lebanonwire.com/prominent/historic_documents/lebanon/index.asp

3. Constituição Libanesa - 1926 (atualizada)

Fonte: http://www.lebanonwire.com/prominent/historic_documents/lebanon/index.asp

4. Acordo do Cairo - 1969

Fonte: http://www.lebanonwire.com/prominent/historic_documents/lebanon/index.asp

5. Resolução 425 do Conselho de Segurança da ONU - 1978

Fonte: http://www.lebanonwire.com/prominent/historic_documents/lebanon/index.asp

6. Carta Aberta da Hizbullah - 1985

Fonte: http://www.ict.org.il/Articles/Hiz_letter.htm

7. Acordo de Taif - 1989

Fonte: http://www.lebanonwire.com/prominent/historic_documents/lebanon/index.asp

8. Tratado de Fraternidade, Cooperação e Coordenação - 1991

Fonte: http://www.lebanonwire.com/prominent/historic_documents/lebanon/index.asp

9. “Entendimento" de Abril - 1996

Fonte: http://www.lebanonwire.com/prominent/historic_documents/lebanon/index.asp

10. Legislação Eleitoral Libanesa, Lei 171 - 2000

Fonte: http://www.library.uu.nl/wesp/populstat/Asia/syriap.htm

11. Resolução 1559 do Conselho de Segurança da ONU - 2004

Fonte: http://www.lebanonwire.com/prominent/historic_documents/lebanon/index.asp

12. Mapa da Divisão Administrativa do Líbano

Fonte: http://en.wikipedia.org/wiki/Lebanon

13. Tabela da Divisão Administrativa do Líbano 


\section{TRATADO SYKES-PICOT 15 e 16 de maio de 1916}

\section{Sir Edward Grey to Paul Cambon, 15 May 1916:}

I shall have the honour to reply fully in a further note to your Excellency's note of the 9th instant, relative to the creation of an Arab State, but I should meanwhile be grateful if your Excellency could assure me that in those regions which, under the conditions recorded in that communication, become entirely French, or in which French interests are recognised as predominant, any existing British concessions, rights of navigation or development, and the rights and privileges of any British religious, scholastic, or medical institutions will be maintained.

His Majesty's Government are, of course, ready to give a reciprocal assurance in regard to the British area.

\section{Sir Edward Grey to Paul Cambon, 16 May 1916:}

I have the honour to acknowledge the receipt of your Excellency's note of the 9th instant, stating that the French Government accept the limits of a future Arab State, or Confederation of States, and of those parts of Syria where French interests predominate, together with certain conditions attached thereto, such as they result from recent discussions in London and Petrograd on the subject.

I have the honour to inform your Excellency in reply that the acceptance of the whole project, as it now stands, will involve the abdication of considerable British interests, but, since His Majesty's Government recognise the advantage to the general cause of the Allies entailed in producing a more favourable internal political situation in Turkey, they are ready to accept the arrangement now arrived at, provided that the co-operation of the Arabs is secured, and that the Arabs fulfil the conditions and obtain the towns of Homs, Hama, Damascus, and Aleppo.

\section{It is accordingly understood between the French and British Governments:}

1. That France and Great Britain are prepared to recognize and protect an independent Arab State or a Confederation of Arab States in the areas (A) and (B) marked on the annexed map, under the suzerainty of an Arab chief. That in area (A) France, and in area (B) Great Britain, shall have priority of right of enterprise and local loans. That in area (A) France, and in area (B) Great Britain, shall alone supply advisers or foreign functionaries at the request of the Arab State or Confederation of Arab States.

2. That in the blue area France, and in the red area Great Britain, shall be allowed to establish such direct or indirect administration or control as they desire and as they may think fit to arrange with the Arab State or Confederation of Arab States. 3. That in the brown area there shall be established an international administration, the form of which is to be decided upon 
after consultation with Russia, and subsequently in consultation with the other Allies, and the representatives of the Shereef of Mecca.

4. That Great Britain be accorded (1) the ports of Haifa and Acre, (2) guarantee of a given supply of water from the Tigris and Euphrates in area (A) for area (B). His Majesty's Government, on their part, undertake that they will at no time enter into negotiations for the cession of Cyprus to any third Power without the previous consent of the French Government.

5. That Alexandretta shall be a free port as regards the trade of the British Empire, and that there shall be no discrimination in port charges or facilities as regards British shipping and British goods; that there shall be freedom of transit for British goods through Alexandretta and by railway through the blue area, whether those goods are intended for or originate in the red area, or (B) area, or area (A); and there shall be no discrimination, direct or indirect against British goods on any railway or against British goods or ships at any port serving the areas mentioned.

That Haifa shall be a free port as regards the trade of France, her dominions and protectorates, and there shall be no discrimination in port charges or facilities as regards French shipping and French goods. There shall be freedom of transit for French goods through Haifa and by the British railway through the brown area, whether those goods are intended for or originate in the blue area, area (A), or area (B), and there shall be no discrimination, direct or indirect, against French goods on any railway, or against French goods or ships at any port serving the areas mentioned.

6. That in area (A) the Baghdad Railway shall not be extended southwards beyond Mosul, and in area (B) northwards beyond Samarra, until a railway connecting Baghdad with Aleppo via the Euphrates Valley has been completed, and then only with the concurrence of the two Governments.

7. That Great Britain has the right to build, administer, and be sole owner of a railway connecting Haifa with area (B), and shall have a perpetual right to transport troops along such a line at all times.

It is to be understood by both Governments that this railway is to facilitate the connexion of Baghdad with Haifa by rail, and it is further understood that, if the engineering difficulties and expense entailed by keeping this connecting line in the brown area only make the project unfeasible, that the French Government shall be prepared to consider that the line in question may also traverse the polygon Banias-Keis Marib-Salkhab Tell Otsda-Mesmie before reaching area $(B)$.

8. For a period of twenty years the existing Turkish customs tariff shall remain in force throughout the whole of the blue and red areas, as well as in areas (A) and (B), and no increase in the rates of duty or conversion from ad valorem to specific rates shall be made except by agreement between the two Powers.

There shall be no interior customs barriers between any of the above-mentioned areas. The customs duties leviable on goods destined for the interior shall be collected at the port of entry and handed over to the administration of the area of destination. 
9. It shall be agreed that the French Government will at no time enter into any negotiations for the cession of their rights and will not cede such rights in the blue area to any third Power, except the Arab State or Confederation of Arab States without the previous agreement of His Majesty's Government, who, on their part, will give a similar undertaking to the French Government regarding the red area.

10. The British and French Governments, as the protectors of the Arab State, shall agree that they will not themselves acquire and will not consent to a third Power acquiring territorial possessions in the Arabian Peninsula, nor consent to a third Power installing a naval base either on the east coast, or on the islands, of the Red Sea. This, however, shall not prevent such adjustment of the Aden frontier as may be necessary in consequence of recent Turkish aggression.

11. The negotiations with the Arabs as to the boundaries of the Arab State or Confederation of Arab States shall be continued through the same channel as heretofore on behalf of the two Powers.

12. It is agreed that measures to control the importation of arms into the Arab territories will be considered by the two Governments.

I have further the honour to state that, in order to make the agreement complete, His Majesty's Government are proposing to the Russian Government to exchange notes analogous to those exchanged by the latter and your Excellency's Government on the 26th April last. Copies of these notes will be communicated to your Excellency as soon as exchanged.

I would also venture to remind your Excellency that the conclusion of the present agreement raises, for practical consideration, the question of the claims of Italy to a share in any partition or rearrangement of Turkey in Asia, as formulated in article 9 of the agreement of the 26th April, 1915, between Italy and the Allies.

His Majesty's Government further consider that the Japanese Government should be informed of the arrangement now concluded. 


\section{DECLARAÇÃO BALFOUR 2 de novembro de 1917}

Foreign Office, November 2nd, 1917

Dear Lord Rothschild,

I have much pleasure in conveying to you, on behalf of His Majesty's Government, the following declaration of sympathy with Jewish Zionist aspirations which has been submitted to, and approved by, the Cabinet.

"His Majesty's Government view with favour the establishment in Palestine of a national home for the Jewish people, and will use their best endeavours to facilitate the achievement of this object, it being clearly understood that nothing shall be done which may prejudice the civil and religious rights of existing non-Jewish communities in Palestine, or the rights and political status enjoyed by Jews in any other country."

I should be grateful if you would bring this declaration to the knowledge of the Zionist Federation.

Yours sincerely, Arthur James Balfour 


\section{CONSTITUIÇÃO LIBANESA 23 de maio de 1926 (atualizada)}

\section{Preamble}

a. Lebanon is a sovereign, free, and independent country. It is a final homeland for all its citizens. It is unified in its territory, people, and institutions within the boundaries defined in this constitution and recognized internationally.

b. Lebanon is Arab in its identity and in its association. It is a founding and active member of the League of Arab States and abides by its pacts and covenants. Lebanon is also a founding and active member of the United Nations Organization and abides by its covenants and by the Universal Declaration of Human Rights. The Government shall embody these principles in all fields and areas without exception.

c. Lebanon is a parliamentary democratic republic based on respect for public liberties, especially the freedom of opinion and belief, and respect for social justice and equality of rights and duties among all citizens without discrimination.

d. The people are the source of authority and sovereignty; they shall exercise these powers through the constitutional institutions.

e. The political system is established on the principle of separation, balance, and cooperation amongst the various branches of Government.

f. The economic system is free and ensures private initiative and the right to private property.

g. The even development among regions on the educational, social, and economic levels shall be a basic pillar of the unity of the state and the stability of the system.

h. The abolition of political confessionalism is a basic national goal and shall be achieved according to a gradual plan.

i. Lebanese territory is one for all Lebanese. Every Lebanese has the right to live in any part of it and to enjoy the sovereignty of law wherever he resides. There is no

segregation of the people on the basis of any type of belonging, and no fragmentation, partition, or colonization. j. There is no constitutional legitimacy for any authority which contradicts the 'pact of communal coexistence'. This Constitutional Law shall be published in the Official Gazette.

\section{[Part] A. Fundamental Provisions}

\section{[Chapter] I. On the State and its Territories}

\section{Article 1 [Territory]}

Lebanon is an independent, indivisible, and sovereign state. Its frontiers are those which now bound it: On the North: From the mouth of al-Kabir River, along a line following the course of this river to its point of junction with Khalid Valley opposite al-Qamar Bridge.

On the East: The summit line separating the Khalid Valley and al-Asi River (Orontes) and passing by the villages of Mu'aysarah, Harbanah, Hayt, Ibish, Faysan to the height of the two villages of Brina and Matraba. This line follows the northern boundary of the Ba`albak District at the northeastern and south eastern directions, thence the eastern boundaries of the districts of Ba`albak, Biqa', Hasbayya, and Rashayya.

On the South: The present southern boundaries of the districts of Sûr (Tyre) and Marji yun.

On the West: The Mediterranean.

\section{Article 2 [Territorial Integrity]}

No part of the Lebanese territory may be alienated or ceded. 


\section{Article 3 [Administrative Areas]}

The boundaries of the administrative areas may not be modified except by law.

\section{Article 4 [Republic, Capital]}

Greater Lebanon is a Republic the capital of which is Beirut.

\section{Article 5 [Flag]}

The Lebanese flag is composed of three horizontal stripes, a white stripe between two red ones. The width of the white stripe is equal to that of both red stripes. In the center of and occupying one third of the white stripe is a green Cedar tree with its top touching the upper red stripe and its base touching the lower red stripe.

\section{[Chapter] II. The Rights and Duties of the Citizen}

\section{Article 6 [Nationality]}

Lebanese nationality and the manner in which it is acquired, retained, and lost is to be determined in accordance with the law.

\section{Article 7 [Equality]}

All Lebanese are equal before the law. They equally enjoy civil and political rights and equally are bound by public obligations and duties without any distinction.

\section{Article 8 [Personal Liberty, nulla poena sine lege]}

Individual liberty is guaranteed and protected by law. No one may be arrested, imprisoned, or kept in custody except according to the provisions of the law. No offense may be established or penalty imposed except by law.

\section{Article 9 [Conscience, Belief]}

There shall be absolute freedom of conscience. The state in rendering homage to the Most High shall respect all religions and creeds and guarantees, under its protection, the free exercise of all religious rites provided that public order is not disturbed. It also guarantees that the personal status and religious interests of the population, to whatever religious sect they belong, is respected.

\section{Article 10 [Education, Confessional Schools]}

Education is free insofar as it is not contrary to public order and morals and does not interfere with the dignity of any of the religions or creeds. There shall be no violation of the right of eligious communities to have their own schools provided they follow the general rules issued by the state regulating public instruction.

\section{Article 11 [Official National Language]}

Arabic is the official national language. A law determines the cases in which the French language may be used.

\section{Article 12 [Public Office]}

Every Lebanese has the right to hold public office, no preference being made except on the basis of merit and competence, according to the conditions established by law. A special statute guarantees the rights of state officials in the departments to which they belong.

\section{Article 13 [Expression, Press, Assembly, Association]}

The freedom to express one's opinion orally or in writing, the freedom of the press, the freedom of assembly, and the freedom of association are guaranteed within the limits established by law. 


\section{Article 14 [Home]}

The citizen's place of residence is inviolable. No one may enter it except in the circumstances and manners prescribed by law.

\section{Article 15 [Property]}

Rights of ownership are protected by law. No one's property may be expropriated except for reasons of public utility in cases established by law and after fair compensation has been paid beforehand.

\section{[Part] B. Powers}

\section{[Chapter] I. General Provisions}

\section{Article 16 [Legislative Power, One Chamber]}

Legislative power is vested in a single body, the Chamber of Deputies.

\section{Article 17 [Executive Power, Council of Ministers]}

Executive power is entrusted to the Council of Ministers to be exercised it in accordance with the conditions laid down in this constitution.

\section{Article 18 [Bills]}

The Parliament and the Council of Ministers have the right to propose laws. No law shall be promulgated until it has been adopted by the Chamber.

\section{Article 19 [Constitutional Council]}

A Constitutional Council is established to supervise the constitutionality of laws and to arbitrate conflicts that arise from parliamentary and presidential elections. The President, the President of the Parliament, the Prime Minister, along with any ten Members of Parliament, have the right to consult this Council on matters that relate to the constitutionality of laws. The officially recognized heads of religious communities have the right to consult this Council only on laws relating to personal status, the freedom of belief and religious practice, and the freedom of religious education. The rules governing the organization, operation, composition, and modes of appeal of the Council are decided by a special law.

\section{Article 20 [Judicial Power]}

Judicial power is to be exercised by the tribunals of various levels and jurisdictions. It functions within the limits of an order established by the law and offering the necessary guarantees to judges and litigants. The limits and conditions for the protection of the judges are determined by law. The judges are independent in the exercise of their duties. The decisions and judgments of all courts are rendered and executed in the name of the Lebanese People.

\section{Article 21 [Electoral Rights]}

Every Lebanese citizen who has completed his twenty-first year is an elector provided he fulfills the conditions laid down in the electoral law.

\section{[Chapter] II. The Legislative Power}

\section{Article 22 [Senate]}

With the election of the first Parliament on a national, non-confessional basis, a Senate is established in which all the religious communities are represented. Its authority is limited to major national issues.

\section{Article 23 [Eligibility to the Senate]}




\section{Article 24 [Electoral Laws]}

(1) The Chamber of Deputies is composed of elected members; their number and the method of their election is determined by the electoral laws in effect. Until such time as the Chamber enacts new electoral laws on a non-confessional basis, the distribution of seats is according to the following principles:

a. Equal representation between Christians and Muslims.

b. Proportional representation among the confessional groups within each religious community. c. Proportional representation among geographic regions.

(2) Exceptionally, and for one time only, the seats that are currently vacant, as well as the new seats that have been established by law, are to be filled by appointment, all at once, and by a majority of two thirds of the Government of National Unity. This is to establish equality between Christians and Muslims as stipulated in the Document of National Accord [The Taif Agreement]. The electoral laws will specify the details regarding the implementation of this clause.

\section{Article 25 [Dissolution]}

Should the Chamber of Deputies be dissolved, the Decision of dissolution must provide for the holding of new elections in accordance with Article 24 and within a period not exceeding three months.

\section{Article 26 [Location of Government and Parliament]}

The Government and the Chamber of Deputies shall be located in Beirut.

\section{Article 27 [Representation]}

A member of the Chamber represents the whole nation. No

restriction or stipulation may be imposed upon his mandate by his electors.

\section{Article 28 [No Incompatibility]}

A Deputy may also occupy a ministerial position. Ministers, all or in part, may be selected from among the members of the Chamber or from persons outside the Chamber.

\section{Article 29 [Incompatibility by Law]}

Cases in which persons are disqualified from becoming Deputies are determined by law.

\section{Article 30 [Validating Elections]}

The Deputies alone have competence to judge the validity of their mandate. No Deputy's mandate may be invalidated except by a majority of two thirds of the votes of the entire membership. This clause is automatically cancelled as soon as the Constitutional Council is established and as soon as the laws relating to it are implemented.

\section{Article 31 [Illegal Sessions]}

Meetings of the Chamber outside those set for legal sessions are unlawful and ipso facto null and void.

\section{Article 32 [Ordinary Sessions]}

The Chamber meets each year in two ordinary sessions. The first session opens on the first Tuesday following 15 March and continues until the end of May. The second session begins on the first Tuesday following 15 Oct; its meetings is reserved for the discussion of and voting on the budget before any other work. This session lasts until the end of the year.

\section{Article 33 [Extraordinary Sessions]}

The ordinary sessions begin and end automatically on the dates fixed in Article 32. The President of the Republic in consultation with the Prime Minister may summon the Chamber to extraordinary sessions by a Decree specifying the dates of the opening and closing of the extraordinary sessions as 
well as the agenda. The President of the Republic is required to convoke the Chamber if an absolute majority of the total membership so requests.

\section{Article 34 [Quorum]}

The Chamber is not validly constituted unless the majority of the total membership is present. Decisions are to be taken by a majority vote. Should the votes be equal, the question under consideration is deemed rejected.

\section{Article 35 [Publicity]}

The meetings of the Chamber are public. However, at the request of the Government or of five Deputies, the Chamber may sit in secret sessions. It may then decide whether to resume the discussion of the same question in public.

\section{Article 36 [Voting Process]}

Votes are to be cast verbally or by the members standing, except for elections when the ballot is secret. With respect to laws in general and on questions of confidence, the vote is always taken by roll call and the responses are made in an audible voice.

\section{Article 37 [Vote of No-Confidence]}

Every Deputy has the absolute right to raise the question of no-confidence in the government during ordinary or extraordinary sessions. Discussion of and voting on such a proposal may not take place until at least five days after

submission to the secretariat of the Chamber and its communication to the ministers concerned.

\section{Article 38 [Reintroduction of Bills]}

No Bill that has been rejected by the Chamber may be re-

introduced during the same session.

\section{Article 39 [Indemnity]}

No member of the Chamber may be prosecuted because of ideas and opinions expressed during the period of his mandate.

\section{Article 40 [Immunity]}

No member of the Chamber may, during the sessions, be prosecuted or arrested for a criminal offense without the permission of the Chamber, except when he is caught in the act.

\section{Article 41 [Re-election]}

Should a seat in the Chamber become vacant, the election of a successor begins within two months. The mandate of the new member does not exceed that of the old member whose place he is taking; however, should the seat in the Chamber become vacant during the last six months of its mandate, no successor may be elected.

\section{Article 42 [General Elections]}

General elections for the renewal of the Chamber shall take place within a sixty day period preceeding the expiration of its mandate.

\section{Article 43 [Rules of Procedure]}

The Chamber draws up its own internal rules and procedures.

\section{Article 44 [First Session]}

(1) Each time a new Chamber is elected, the Chamber meets under the presidency of the oldest member and the secretariat or the two youngest. It will then elect separately, by a secret ballot and by an absolute majority of the votes cast, the President and the Vice President of the Chamber to hold 
office for the length or the Chamber's term. At the third ballot, a relative majority is sufficient. Should the votes be equal, the oldest candidate is considered elected.

(2) Every time a new Chamber or Deputies is elected, as well as in the October session or each year, the Chamber elects two Secretaries by secret ballot according to the majority stipulated in the first part or this article.

(3) The Chamber may, once only, two years after the election or its President and his Deputy, and in the first session it holds, withdraw its confidence from the President of the Chamber or his Deputy by a Decision of two thirds of the Chamber, based on a petition signed by at least ten Deputies. The Chamber, at such point, must hold an immediate session to fill the vacant post.

\section{Article 45 [Presence]}

Members of the Chamber may only vote when they are present at the meeting. Voting by proxy shall not be permitted.

\section{Article 46 [Parliamentary Order]}

The Chamber has the exclusive right to maintain order in its meetings through its President.

\section{Article 47 [Petitions]}

Petitions to the Chamber may not be presented except in writing. They may not be presented verbally or at the bar of the Chamber.

\section{Article 48 [Remuneration]}

The remuneration of members of the Chamber is determined by law.

\section{[Chapter] III. The Executive Power}

\section{[Section] 1. The President of the Republic}

\section{Article 49 [Presidential Powers]}

(1) The President of the Republic is the bead of the state and the symbol of the nation's unity. He shall safeguard the constitution and Lebanon's independence, unity, and territorial integrity. The President shall preside over the Supreme Defense Council and be the Commander-in-Chief of the Armed Forces which fall under the authority of the Council of Ministers.

(2) The President of the Republic shall be elected by secret ballot and by a twothirds majority of the Chamber of Deputies. After a first ballot, an absolute majority shall be sufficient. The President's term is for six years. He may not be re-elected until six years after the expiration of his last mandate. No one may be elected to the Presidency of the Republic unless he fulfills the conditions of eligibility for the Chamber of Deputies.

(3) It is also not possible to elect judges, Grade One civil servants, or their equivalents in all public institutions to the Presidency during their term or office or within two years following the date of their resignation or their leaving office for whatever reason.

\section{Article 50 [Oath]}

Upon assuming office, the President of the Republic shall take an oath of fidelity before the Parliament to the Lebanese Nation and the constitution in the following terms:

"I swear by Almighty God to observe the Constitution and the laws of the Lebanese Nation and to maintain the independence of Lebanon and its territorial integrity."

\section{Article 51 [Promulgation of Laws]}

The President of the Republic promulgates the laws after they have been approved by the Chamber in accordance with the time limits specified by the constitution. He asks for the publication or these laws, and he may not modify these laws or exempt anyone from complying with their provisions. 


\section{Article 52 [Negotiation of International Treaties]}

The President of the Republic negotiates international treaties in coordination with the Prime Minister. These treaties are not considered ratified except after agreement of the Council of Ministers. They are to be made known to the Chamber whenever the national interest and security of the state permit. However, treaties involving the finances of the state, commercial treaties, and in general treaties that cannot be renounced every year are not considered ratified until they have been approved by the Chamber.

\section{Article 53 [List of Additional Presidential Powers]}

1. The President presides over the Council of Ministers when he wishes without participating in voting.

2. The President designates the Prime Minister in consultation with the President of the Chamber of Deputies based on parliamentary consultations which are binding and the content of which the President formally discloses to the Prime Minister.

3. The President alone issues the Decree which designates the Prime Minister.

4. He issues, in agreement with the Prime Minister, the decree appointing the Cabinet and the decrees accepting the resignation

of Ministers.

5. He issues, on his own authority, the decrees accepting the resignation of the Cabinet or considering it resigned.

6. He forwards to the Chamber of Deputies Bills that are delivered to him by the Council of Ministers.

7. He accredits ambassadors and accept the credentials of ambassadors.

8. He presides over official functions and grants official decorations by Decree.

9. He grants particular pardons by Decree, but a general amnesty cannot be granted except by a law.

10. He addresses, when necessary, letters to the Chamber of Deputies.

11. He may introduce, from outside the agenda, any urgent matter to the council of Ministers.

12. He may, in agreement with the Prime Minister, call the Council of Ministers to an extraordinary session, whenever he deems this necessary.

\section{Article 54 [Countersignature]}

The decisions of the President must be countersigned by the Prime Minister and the Minister or Ministers concerned except the Decree designating a new Prime Minister and the Decree accepting the resignation of the Cabinet or considering it resigned. Decrees issuing laws must be countersigned by the Prime Minister.

\section{Article 55 [Dissolution of Parliament by Decree]}

(1) The President of the Republic may, in accordance with the conditions stipulated in Articles 65 and 77 of this constitution, ask the Council of Ministers to dissolve the Chamber of Deputies before the expiration of its mandate. If the Council, based on this request, decides to dissolve the Chamber of Deputies, the President issues the Decree dissolving it, and in this case, the electoral bodies meets as provided for in Article 25, and the new Chamber is to be called to convene within fifteen days after the proclamation of the election.

(2) The administrative staff of the Chamber of Deputies continues to function until the election or a new Chamber.

(3) If elections are not held within the time limit specified in Article 25 of the constitution, the Decree dissolving the Chamber is considered null and void, and the Chamber of Deputies continues to exercise its powers according to the stipulations of the constitution.

\section{Article 56 [Promulgation Time Limits]}

(1) The President of the Republic promulgates the laws which have been adopted within one month of their transmission to the Government. He must promulgate laws that were declared urgent by a special Decision of the Chamber within five days. 
(2) The President issues decrees and requests their promulgation; he has the right to ask the Council of Ministers to review any Decision that the Chamber has taken within fifteen days of the decision's transmission to the Presidency. If the Council of Ministers insists on the Decision or if the time limit passes without the Decree being issued or returned, the Decision or Decree is considered legally operative and must be promulgated.

\section{Article 57 [Presidential Veto]}

The President of the Republic, after consultation with the Council of Ministers, has the right to request the reconsideration of a law once during the period prescribed for its promulgation. This request may not be refused. When the President exercises this right, he is not required to promulgate

this law until it has been reconsidered and approved by an absolute majority of all the members legally composing the Chamber. If the time limits pass without the law being issued or returned, the law is considered legally operative and must be promulgated.

\section{Article 58 [Urgent Bills]}

Every Bill the Council of Ministers deems urgent and in which this urgency is indicated in the decree of transmission to the Chamber of Deputies may be issued by the President within forty days following its communication to the Chamber, after including it on the agenda of a general meeting, reading it aloud before the Chamber, and after the expiration of the time limit without the Chamber acting on it.

\section{Article 59 [Adjourning the Chamber]}

The President of the Republic may adjourn the Chamber for a period not exceeding one month, but he may not do so twice during the same session.

\section{Article 60 [Responsibility]}

(1) While performing his functions, the President of the Republic may not be held responsible except when he violates the constitution or in the case of high treason.

(2) However, his responsibility in respect of ordinary crimes is subject to the ordinary laws. For such crimes, as well as for violation of the constitution and for high treason, he may not be impeached except by a majority of two thirds of the total membership of the Chamber of Deputies. He is to be tried by the Supreme Council provided for in Article 80. The functions of Public Prosecutor of the Supreme Council are performed by a judge appointed by the Supreme Council in plenary session.

\section{Article 61 [Suspension after Impeachement]}

Should the President of the Republic be impeached, he is suspended from his functions. The presidency remains vacant until the Supreme Council has settled the matter.

\section{Article 62 [Vacancy]}

Should the Presidency become vacant for any reason whatsoever, the Council of Ministers exercises the powers of the President by delegation.

\section{Article 63 [Remuneration]}

The remuneration of the President of the Republic is determined by a law. It may not be increased or reduced during his term of office.

\section{[Section] 2. The Prime Minister}

\section{Article 64 [Responsibility and Powers]}

The Prime Minister is the Head of Government and its representative. He speaks in its name and is responsible for executing the general policy that is set by the Council of Ministers. He exercises the following powers: 1. He heads the Council of Ministers and is ex officio Deputy Head of the Supreme Defense Council. 2. He conducts the parliamentary consultations involved in forming a Cabinet. He 
signs, with the President, the Decree forming the Cabinet. The Cabinet must present its general statement or policy to the Chamber and gain its confidence within thirty days of the date of issuance of the Decree in which the Cabinet was formed. The Cabinet does not exercise its powers before it gains the Chamber's confidence nor after it has resigned or is considered resigned, except in the narrow sense of managing affairs.

3. He presents the Government's general policy statements before the Chamber of Deputies.

4. He signs, along with the President, all decrees, except the Decree which designates him the head of the Government, and the Decree accepting the Cabinet's resignation or considering it resigned.

5. He signs the Decree calling for an extraordinary parliamentary session, decrees issuing laws, and requests for reviewing laws.

6. He calls the Council of Ministers into session and sets its agenda, and he informs the President and the Ministers beforehand of the subjects included on the agenda and of the urgent subjects that will be discussed.

7. He supervises the activities of the public administrations and institutions, coordinates among the Ministers and provides general guidance to ensure the proper progress of affairs.

8. He holds working meetings with the competent authorities in the Government in the presence of the concerned Minister.

\section{[Section] 3. The Council of Ministers}

\section{Article 65 [Powers]}

Executive authority is vested in the Council of Ministers. It is the authority to which the armed forces are subject. Among the powers that it exercises are the following:

1. It sets the general policy of the Government in all fields, prepares Bills and organizational Decrees and makes the decisions necessary for implementing them.

2. It watches over the execution of laws and regulations and supervises the activities of all the Government's branches including the civil, military, and security administrations and institutions without exception.

3. It appoints Government employees and dismisses them and accepts their resignations according to the law.

4. It dissolves the Chamber of Deputies upon the request of the President of the Republic if the Chamber of Deputies, for no compelling reasons, fails to meet during one of its regular periods and fails to meet throughout two successive extraordinary periods, each longer than one month, or if the Chamber returns an annual budget plan with the aim or paralyzing the Government. This right cannot be exercised a second time if it is for the same reasons which led to the dissolution of the Chamber the first time.

5. The Council of Ministers meets in a locale specifically set aside for it, and the President chairs its meetings when he attends. The legal quorum for a Council meeting is a majority of two thirds of its members. It makes its decisions by consensus. If that is not possible, it makes its decisions by vote of the majority of attending members. Basic national issues require the approval of two thirds of the members of the Council named in the Decree forming the Cabinet. Basic national issues are considered the following:

The amendment of the constitution, the declaration of a state of emergency and its termination, war and peace, general mobilization, international agreements and treaties, the annual government budget, comprehensive and longterm development projects, the appointment of Grade One government employees and their equivalents, the review of the administrative map, the dissolution of the Chamber of Deputies, electoral laws, nationality laws, personal status laws, and the dismissal of Ministers.

\section{Article 66 [Ministries, Responsibility]}

Only Lebanese who satisfy the conditions for deputization may assume ministerial posts. The Ministers administer the

Government's services and assume the responsibility of applying the laws and regulations, each one according to the affairs of his administration and what is specific to them. Ministers are collectively 
responsible before the Chamber for the general policy of the Government and individually responsible for their personal actions.

\section{Article 67 [Ministers in Parliament]}

Ministers may attend the Chamber if they so desire, and they have the right to be heard whenever they request to speak. They may be assisted by whomever they select from among the officials of their Departments.

\section{Article 68 [Vote of No-Confidence]}

When the Chamber, in accordance with Article 37, passes a vote of noconfidence in a Minister, that Minister is required to resign.

\section{Article 69 [Government Resignation]}

(1) The Government is considered resigned in the following circumstances:

a. if the Prime Minister resigns;

b. if it loses more than a third of the members specified in the Decree forming it;

c. if the Prime Minister dies;

d. at the beginning of the term of the President of the Republic;

e. at the beginning of the term of the Chamber of Deputies;

f. when it loses the confidence of the Chamber of Deputies based on the Chamber's initiative or based on the Council's initiative to gain the Chamber's confidence.

(2) Ministers are to be dismissed by a Decree signed by the President and the Prime Minister in accordance with Article 65 of the constitution.

(3) When the Council resigns or is considered resigned, the Chamber of Deputies is automatically considered in extraordinary session until a new Council has been formed and has gained the Chamber's confidence.

\section{Article 70 [Impeachment]}

(1) The Chamber of Deputies has the right to impeach the Prime Minister and Ministers for high treason or for serious neglect of their duties. The Decision to impeach may not be taken except by a majority of two thirds of the total membership of the Chamber.

(2) A special law is to be issued to determine the conditions of the civil responsibility of the Prime Minister and individual Ministers.

\section{Article 71 [Judicial Impeachment Proceedings]}

The impeached Prime Minister or Minister are tried by the Supreme Council.

\section{Article 72 [Consequences of Impeachment]}

A Prime Minister or Minister leaves office as soon as the Decision of impeachment concerning him is issued. If he resigns, his resignation does not prevent judicial proceedings from being instituted or continued against him.

\section{[Part] C. Procedural Provisions}

\section{[Chapter] I. Election of the President of the Republic}

\section{Article 73 [Election of the President]}

One month at least and two months at most before the expiration of the term of office of the President of the Republic, the Chamber is summoned by its President to elect the new President of the Republic. However, should it not be summoned for this purpose, the Chamber meets of its own accord on the tenth day preceding the expiration of the President's term of office. 


\section{Article 74 [Vacancy of Presidency]}

Should the Presidency become vacant through the death or resignation of the President or for any other cause, the Chamber meets immediately and by virtue of the law to elect a successor. If the Chamber happens to be dissolved at the time the vacancy occurs, the electoral bodies are convened without delay and, as soon as the elections have taken place, the Chamber meets by virtue of the law.

\section{Article 75}

The Chamber meeting to elect the President of the Republic is considered an electoral body and not a legislative assembly. It must proceed immediately, without discussion or any other act, to elect the Head of the State.

\section{[Chapter] II. Amending the Constitution}

\section{Article 76 [Proposal]}

The constitution may be revised upon the proposal of the President of the Republic. In such a case the Government submits a draft law to the Chamber of Deputies.

\section{Article 77 [Request]}

The constitution may also be revised upon the request of the Chamber of Deputies. In this case the following procedures are to be observed:

During an ordinary session and at the request of at least ten of its members, the Chamber of Deputies may recommend, by a majority of two thirds of the total members lawfully composing the Chamber, the revision of the constitution.

However, the articles and the questions referred to in the recommendation must be clearly defined and specified. The President of the Chamber then transmits the recommendation to the Government requesting it to prepare a draft law relating thereto. If the Government approves the recommendation of the Chamber by a majority of two thirds, it must prepare the draft amendment and submit it to the Chamber within four months; it it does not agree, it shall return the Decision to the Chamber for reconsideration. If the Chamber insists upon the necessity of the amendment by a majority of three fourths of the total members lawfully composing the Chamber, the President of the Republic has then either to accede to the Chamber's recommendation or to ask the Council of Ministers to dissolve the Chamber and to hold new elections within three months. If the new Chamber insists on the necessity of amending the constitution, the Government must yield and submit the draft amendment within four months.

\section{Article 78 [Priority]}

When a draft law dealing with a constitutional amendment is submitted to the Chamber, it must confine itself to its discussion before any other work until a final vote is taken. It may discuss and vote only on articles and questions clearly enumerated and defined in the draft submitted to it.

\section{Article 79 [Majority, Promulgation]}

(1) When a draft law dealing with a constitutional amendment is submitted to the Chamber, it cannot discuss it or vote upon it except when a majority of two thirds of the members lawfully composing the Chamber are present. Voting is by the same majority.

(2) The President of the Republic is required to promulgate the law of the constitutional amendment under the same conditions and in the same form as ordinary laws. He has the right, within the period established for the promulgation, to ask the Chamber to reconsider the draft, after consultation with the council of Ministers, in which case the vote is by a majority of two thirds.

\section{[Part] D. Miscellaneous Provisions}

\section{[Chapter] I. The Supreme Council}




\section{Article 80 [Function, Composition, Organizational Law]}

The Supreme Council, whose function is to try Presidents and Ministers, consists of seven deputies elected by the Chamber of Deputies and of eight of the highest Lebanese judges, according to their rank in the judicial hierarchy, or, in case of equal ranks, in the order of seniority. They meet under the presidency of the judge of the highest rank. The Decisions of condemnation by the Supreme Council is rendered by a majority of ten votes. A special law is to be issued to determine the procedure to be followed by this Council.

\section{[Chapter] II. Finances}

\section{Article 81 [Integral Tax Law]}

No public taxes may be imposed and no new taxes established or collected in the Lebanese Republic except by a comprehensive law which applies to the entire Lebanese territory without exception.

\section{Article 82 [Rule of Law]}

No tax may be modified or abolished except by virtue of law.

\section{Article 83 [Yearly Budget]}

Each year at the beginning of the October session, the Government has to submit to the Chamber of Deputies the general budget estimates of state expenditures and revenues for the following year. The budget is voted upon article by article.

\section{Article 84 [Budget Discussion]}

During the discussion of the budget and draft laws involving the opening of supplementary or extraordinary credits, the Chamber may not increase the credits proposed in the budget or in the draft laws mentioned above either by way of amendment Or by means of a proposal. The Chamber may, however, adopt, by way of proposal, laws involving further expenditures after the close of this discussion.

\section{Article 85 [Extraordinary Credit]}

No extraordinary credit may be opened except by a special law. Nevertheless, should unforseen circumstances render urgent expenditures necessary, the President of the Republic may issue a Decree, based on a Decision of the Council or Ministers, to open extraordinary or supplementary credits or transfer appropriations in the budget as long as these credits do not exceed a maximum limit specified in the budget law. These measures are to be submitted to the Chamber for approval at the first ensuing session.

\section{Article 86 [Provisional Budget]}

If the Chamber of Deputies has not given a final decision on the budget estimates before the expiration of the session devoted to the examination of the budget, the President of the Republic, in coordination with the Prime Minister, immediately convenes the Chamber for an extraordinary session which lasts until the end of January in order to continue the discussion of the budget; if, at the end of this extraordinary session, the budget estimates have not been finally settled, the Council of Ministers may take a decision on the basis of which a decree is issued by the President giving effect to the above estimates in the form in which they were submitted to the Chamber. However, the Council of Ministers may not exercise this right unless the budget estimates were submitted to the Chamber at least fifteen days before the commencement of its session. Nevertheless, during the said extraordinary session, taxes, charges, duties, imposts, and other kinds of revenues continue to be collected as before. The budget of the previous year is adopted as a basis. To this must be added the permanent credits which have been dropped, and the Government fixes the expenditures for the month of January on the basis of the 'provisional twelfth.'

\section{Article 87 [Final Financial Accounts, Auditing Bureau]}

The final financial accounts of the administration for each year must be submitted to the Chamber for 
approval before the promulgation of the budget of the year following. A special law is to be issued for the setting up of an Auditing Bureau.

\section{Article 88 [Public Loan]}

No public loan or undertaking involving an expenditure from the treasury funds may be contracted except by virtue of a law.

\section{Article 89 [Contracts, Concessions, Resources, Monpolies]}

No contract or concession for the exploitation of the natural resources of the country, or a public utility service, or a monopoly may be granted except by virtue of a law and for a limited period.

\section{[Part] E. Provisions Relating to the Mandatory Power and the Leage of Nations}

\section{Article 90 [...]}

\{Abolished in 1943\}

\section{Article 91 [...]}

\{Abolished in 1943\}

Article 92 [...]

\{Abolished in 1943\}

Article 93 [...]

\{Abolished in 1947\}

Article 94 [...]

\{Abolished in 1943\}

\section{[Part] F. On the Abolition of Political Confessionalism}

\section{Article 95 [National Committee]}

(1) The first Chamber or Deputies which is elected on the basis of equality between Muslims and Christians takes the appropriate measures to realize the abolition of political confessionalism according to a transitional plan. A National Committee is to be formed, headed by the President of the Republic, including, in addition to the President of the Chamber of Deputies and the Prime Minister, leading political, intellectual, and social figures.

(2) The tasks of this Committee are to study and propose the means to ensure the abolition of confessionalism, propose them to the Chamber of Deputies and the Ministers, and supervise the execution of the transitional plan.

(3) During the transitional phase:

a. The confessional groups are to be represented in a just and equitable fashion in the formation of the Cabinet.

b. The principle of confessional representation in public service jobs, in the judiciary, in the military and security institutions, and in public and mixed agencies are to be cancelled in accordance with the requirements of national reconciliation; they shall be replaced by the principle of expertise and competence. However, Grade One posts and their equivalents are exempt from this rule, and the posts must be distributed equally between Christians and Muslims without reserving any particular job for any confessional group but rather applying the principles of expertise and competence.

[Part] G. Provisions Relating to the Election and Functions of the Senate 
Article 96 [...]

\{Abolished in 1947\}

Article 97 [...]

\{Abolished in 1947\}

Article 98 [...]

\{Abolished in 1947\}

Article 99 [...]

\{Abolished in 1947\}

Article 100 [...]

\{Abolished in 1947\}

[Part] H. Additional Provisions

Article 101 [Greater Lebanon, The Lebanese Republic]

Beginning 1 Sep 1926, the state of 'Greater Lebanon' is to be known as 'The Lebanese Republic' without any other change or modification.

Article 102 [Abrogation of Old Laws]

All legislative provisions contrary to the present constitution are abrogated. 


\section{ACORDO DO CAIRO 3 de novembro de 1969}

On Monday, 3rd November 1969, the Lebanese delegation headed by Army Commander General Emile al-Bustani, and the Palestine Liberation Organization delegation, headed by Mr. Yasir 'Arafat, chairman of the organization, met in Cairo in the presence of the United Arab Republic Minister of Foreign Affairs Mahmud Riyad, and the War Minister, General Muhammad Fawzi.

In consonance with the bonds of brotherhood and common destiny, relations between Lebanon and the Palestinian revolution must always be conducted on the bases of confidence, frankness, and positive cooperation for the benefit of Lebanon and the Palestinian revolution and within the framework of Lebanon's sovereignty and security. The two delegations agreed on the following principles and measures:

\section{The Palestinian Presence}

It was agreed to reorganize the Palestinian presence in Lebanon on the following bases:

1. The right to work, residence, and movement for Palestinians currently residing in Lebanon;

2. The formation of local committees composed of Palestinians in the camps to care for the interests of Palestinians residing in these camps in cooperation with the local Lebanese authorities within the framework of Lebanese sovereignty;

3. The establishment of posts of the Palestinian Armed Struggle [PASC] inside the camps for the purpose of cooperation with the local committees to ensure good relations with the Lebanese authorities. These posts shall undertake the task of regulating and determining the presence of arms in the camps within the framework of Lebanese security and the interests of the Palestinian revolution;

4. Palestinians resident in Lebanon are to be permitted to participate in the Palestinian revolution through the Armed Struggle and in accordance with the principles of the sovereignty and security of Lebanon.

\section{Commando Activity}

It was agreed to facilitate commando activity by means of:

1. Facilitating the passage of commandos and specifying points of passage and reconnaissance in the border areas;

2. Safeguarding the road to the 'Arqub region; 
3. The Armed Struggle shall undertake to control the conduct of all the members of its organizations and [to ensure] their non-interference in Lebanese affairs;

4. Establishing a joint command control of the Armed Struggle and the Lebanese Army;

5. Ending the propaganda campaigns by both sides;

6. Conducting a census of Armed Struggle personnel in Lebanon by their command.

7. Appointing Armed Struggle representatives at Lebanese Army headquarters to participate in the resolution of all emergency matters;

8. Studying the distribution of all suitable points of concentration in border areas which will be agreed with the Lebanese Army command;

9. Regulating the entry, exit, and circulation of Armed Struggle personnel;

10. Removal of the Jiyrun base.

11. The Lebanese Army shall facilitate the operation of medical, evacuation, and supply centers for commando activity;

12. Releasing detained personnel and confiscated arms;

13. It is understood that the Lebanese authorities, both civil and military, shall continue to exercise all their prerogatives and responsibilities in all areas of Lebanon in all circumstances;

14. The two delegations affirm that the Palestinian armed struggle is in the interest of Lebanon as well as in that of the Palestinian revolution and all Arabs;

15. This agreement shall remain Top Secret and for the eyes of the commands only.

\section{Head of Lebanese delegation}

Emile Bustani

\section{Head of Palestinian delegation}

Yasir 'Arafat

Resolution adopted by the Lebanese Chamber of Deputies, 21 May 1987

1. Abrogation of the law issued by the Chamber of Deputies on 14 June 1983, authorizing the Government to ratify the agreement signed by the Government of the Lebanese Republic and the Government of the State of Israel on 17 May 1983.

2. The agreement signed on 3 November 1969 between the head of the Lebanese delegation General Emile Bustani and the Chairman of the PLO and which is known as the "Cairo Agreement" is hereby null and void as if it had never existed. Further, all annexes and measures related to the Cairo Agreement are hereby null and void as if they had never existed. 
3. This law will become effective upon its publication in the Official Gazette.

\section{RESOLUÇÃO 425 DO CONSELHO DE SEGURANÇA DA ONU 19 de maio de 1978}

The Security Council,

Taking note of the letters from the Permanent Representative of Lebanon and from the Permanent Representative of Israel, Having heard the statement of the Permanent Representatives of Lebanon and Israel,

Gravely concerned at the deterioration of the situation in the Middle East and its consequences to the maintenance of international peace,

Convinced that the present situation impedes the achievement of a just peace in the Middle East,

1. Calls for strict respect for the territorial integrity, sovereignty and political independence of Lebanon within its internationally recognized boundaries;

2. Calls upon Israel immediately to cease its military action against Lebanese territorial integrity and withdraw forthwith its forces from all Lebanese territory;

3. Decides, in the light of the request of the Government of Lebanon, to establish immediately under its authority a United Nations interim force for Southern Lebanon for the purpose of confirming the withdrawal of Israeli forces, restoring international peace and security and assisting the Government of Lebanon in ensuring the return of its effective authority in the area, the Force to be composed of personnel drawn from Member States;

4. Requests the Secretary-General to report to the Council within twenty-four hours on the implementation of the present resolution. 


\section{CARTA ABERTA DO HIZBULLAH 16 de fevereiro de 1985}

\section{Our Identity}

We are often asked: Who are we, the Hizballah, and what is our identity? We are the sons of the umma (Muslim community) - the party of God (Hizb Allah) the vanguard of which was made victorious by God in Iran. There the vanguard succeeded to lay down the bases of a Muslim state which plays a central role in the world. We obey the orders of one leader, wise and just, that of our tutor and faqih (jurist) who fulfills all the necessary conditions: Ruhollah Musawi Khomeini. God save him!

By virtue of the above, we do not constitute an organized and closed party in Lebanon. nor are we a tight political cadre. We are an umma linked to the Muslims of the whole world by the solid doctrinal and religious connection of Islam, whose message God wanted to be fulfilled by the Seal of the Prophets, i.e., Muhammad. This is why whatever touches or strikes the Muslims in Afghanistan, Iraq, the Philippines and elsewhere reverberates throughout the whole Muslim umma of which we are an integral part. Our behavior is dictated to us by legal principles laid down by the light of an overall political conception defined by the leading jurist (wilayat al-faqih).

As for our culture, it is based on the Holy Koran, the Sunna and the legal rulings of the faqih who is our source of imitation (marja' al-taqlid). Our culture is crystal clear. It is not complicated and is accessible to all.

No one can imagine the importance of our military potential as our military apparatus is not separate from our overall social fabric. Each of us is a fighting soldier. And when it becomes necessary to carry out the Holy War, each of us takes up his assignment in the fight in accordance with the injunctions of the Law, and that in the framework of the mission carried out under the tutelage of the Commanding Jurist.

\section{Our Fight}

The US has tried, through its local agents, to persuade the people that those who crushed their arrogance in Lebanon and frustrated their conspiracy against the oppressed (mustad'afin) were nothing but a bunch of fanatic terrorists whose sole aim is to dynamite bars and destroy slot machines. Such suggestions cannot and will not mislead our umma, for the whole world knows that whoever wishes to oppose the US, that arrogant superpower, cannot indulge in marginal acts which may make it deviate from its major objective. We combat abomination and we shall tear out its very roots, its primary roots, which are the US. All attempts made to drive us into marginal actions will fail, especially as our determination to fight the US is solid. 
We declare openly and loudly that we are an umma which fears God only and is by no means ready to tolerate injustice, aggression and humiliation. America, its Atlantic Pact allies, and the Zionist entity in the holy land of Palestine, attacked us and continue to do so without respite. Their aim is to make us eat dust continually. This is why we are, more and more, in a state of permanent alert in order to repel aggression and defend our religion, our existence, our dignity. They invaded our country, destroyed our villages, slit the throats of our children, violated our sanctuaries and appointed masters over our people who committed the worst massacres against our umma. They do not cease to give support to these allies of Israel, and do not enable us to decide our future according to our own wishes.

In a single night the Israelis and the Phalangists executed thousands of our sons, women and children in Sabra and Shatilla. No international organization protested or denounced this ferocious massacre in an effective manner, a massacre perpetrated with the tacit accord of America's European allies, which had retreated a few days, maybe even a few hours earlier, from the Palestinian camps. The Lebanese defeatists accepted putting the camps under the protection of that crafty fox, the US envoy Philip Habib.

We have no alternative but to confront aggression by sacrifice. The coordination between the Phalangists and Israel continues and develops. A hundred thousand victims - this is the approximate balance sheet of crimes committed by them and by the US against us. Almost half a million Muslims were forced to leave their homes. Their quarters were virtually totally destroyed in Nab'a, my own Beirut suburb, as well as in Burj Hammud, Dekonaneh, Tel Zaatar, Sinbay, Ghawarina and Jubeil - all in areas controlled today by the 'Lebanese Forces',. The Zionist occupation then launched its usurpatory invasion of Lebanon in full and open collusion with the Phalanges. The latter condemned all attempts to resist the invading forces. They participated in the implementation of certain Israeli plans in order to accomplish its Lebanese dream and acceded to all Israeli requests in order to gain power.

And this is, in fact, what happened. Bashir Jumayyil, that butcher, seized power with the help also of OPEC countries and the Jumayyil family. Bashir tried to improve his ugly image by joining the six-member Committee of Public Safety presided over by former President Elias Sarkis, which was nothing but an American-Israeli bridge borrowed by the Phalangists in order to control the oppressed. Our people could not tolerate humiliation any more. It destroyed the oppressors, the invaders and their lackeys. But the US persisted in its folly and installed Amin Jumayyil to replace his brother. Some of his first so called achievements were to destroy the homes of refugees and other displaced persons, attack mosques, and order the army to bombard the southern suburbs of Beirut, where the oppressed people resided. He invited European troops to help him against us and signed the May 17th, [1984] accord with Israel making Lebanon an American protectorate.

Our people could not bear any more treachery. It decided to oppose infidelity - be it French, American or Israeli - by striking at their headquarters and launching a veritable war of resistance against the Occupation forces. Finally, the enemy had to decide to retreat by stages.

\section{Our Objectives}

Let us put it truthfully: the sons of Hizhallah know who are their major enemies in the Middle East - the Phalanges, Israel, France and the US. The sons of our umma are now in a state of 
growing confrontation with them, and will remain so until the realization of the following three objectives:

(a) to expel the Americans. the French and their allies definitely from Lebanon, putting an end to any colonialist entity on our land;

(b) to submit the Phalanges to a just power and bring them all to justice for the crimes they have perpetrated against Muslims and Christians;

(c) to permit all the sons of our people to determine their future and to choose in all the liberty the form of government they desire. We call upon all of them to pick the option of Islamic government which, alone, is capable of guaranteeing justice and liberty for all. Only an Islamic regime can stop any further tentative attempts of imperialistic infiltration into our country.

These are Lebanon's objectives; those are its enemies. As for our friends, they are all the world's oppressed peoples. Our friends are also those who combat our enemies and who defend us from their evil. Towards these friends, individuals as well as organizations, we turn and say:

Friends, wherever you are in Lebanon... we are in agreement with you on the great and necessary objectives: destroying American hegemony in our land; putting an end to the burdensome Israeli Occupation; beating back all the Phalangists' attempts to monopolize power and administration.

Even though we have, friends, quite different viewpoints as to the means of the struggle, on the levels upon which it must be carried out, we should surmount these tiny divergencies and consolidate cooperation between us in view of the grand design.

We are an umma which adheres to the message of Islam. We want all the oppressed to be able to study the divine message in order to bring justice, peace and tranquillity to the world. This is why we don't want to impose Islam upon anybody, as much as we that others impose upon us their convictions and their political systems. We don't want Islam to reign in Lebanon by force as is the case with the Maronites today. This is the minimum that we can accept in order to be able to accede by legal means to realize our ambitions, to save Lebanon from its dependence upon East and West, to put an end to foreign occupation and to adopt a regime freely wanted by the people of Lebanon.

This is our perception of the present state of affairs. This is the Lebanon we envision. In the light of our conceptions, our opposition to the present system is the function of two factors; (1) the present regime is the product of an arrogance so unjust that no reform or modification can remedy it. It should be changed radically, and (2) World Imperialism which is hostile to Islam.

We consider that all opposition in Lebanon voiced in the name of reform can only profit, ultimately, the present system. All such opposition which operates within the framework of the conservation and safeguarding of the present constitution without demanding changes at the level of the very foundation of the regime is, hence, an opposition of pure formality which cannot satisfy the interests of the oppressed masses. Likewise, any opposition which confronts the present regime but within the limits fixed by it, is an illusory opposition which renders a great service to the Jumayyil system. Moreover, we cannot be concerned by any proposition of political reform which accepts the rotten system actually in effect. We could not care less 
about the creation of this or that governmental coalition or about the participation of this or that political personality in some ministerial post, which is but a part of this unjust regime.

The politics followed by the chiefs of political Maronism through the 'Lebanese Front' and the 'Lebanese Forces' cannot guarantee peace and tranquillity for the Christians of Lebanon, whereas it is predicated upon 'asabiyya (narrow-minded particularism), on confessional privileges and on the alliance with colonialism. The Lebanese crisis has proven that confessional privileges are one of the principal causes of the great explosion which ravaged the country. It also proved that outside help was of no use to the Christians of Lebanon, just when they need it most. The bell tolled for the fanatic Christians to rid themselves of denominational allegiance and of illusion deriving from the monopolization of privileges to the detriment of other communities. The Christians should answer the appeal from heaven and have recourse to reason instead of arms, to persuasion instead of confessionalism.

\section{To the Christians}

If you, Christians, cannot tolerate that Muslims share with you certain domains of government, Allah has also made it intolerable for Muslims to participate in an unjust regime, unjust for you and for us, in a regime which is not predicated upon the prescriptions (ahkam) of religion and upon the basis of the Law (the Shari'a) as laid down by Muhammad, the Seal of the Prophets. If you search for justice, who is more just than Allah? It is He who sent down from the sky the message of Islam through his successive prophets in order that they judge the people and give everyone his rights. If you were deceived and misled into believing that we anticipate vengeance against you - your fears are unjustified. For those of you who are peaceful, continue to live in our midst without anybody even thinking to trouble you.

We don't wish you evil. We call upon you to embrace Islam so that you can be happy in this world and the next. If you refuse to adhere to Islam, maintain your ties with the Muslims and don't take part in any activity against them. Free yourselves from the consequences of hateful confessionalism. Banish from your hearts all fanaticism and parochialism. Open your hearts to our Call ( $\left.d a^{\prime} w a\right)$ which we address to you. Open yourselves up to Islam where you'll find salvation and happiness upon earth and in the hereafter. We extend this invitation also to all the oppressed among the non-Muslims. As for those who belong to Islam only formally, we exhort them to adhere to Islam in religious practice and to renounce all fanaticisms which are rejected by our religion.

\section{World Scene}

We reject both the USSR and the US, both Capitalism and Communism, for both are incapable of laying the foundations for a just society.

With special vehemence we reject UNIFIL as they were sent by world arrogance to occupy areas evacuated by Israel and serve for the latter as a buffer zone. They should be treated much like the Zionists. All should know that the goals of the Phalangists regime do not carry any weight with the Combatants of the Holy War, i.e., the Islamic resistance. This is the quagmire which awaits all foreign intervention. 
There, then, are our conceptions and our objectives which serve as our basis and inspire our march. Those who accept them should know that all rights belong to Allah and He bestows them. Those who reject them, we'll be patient with them, till Allah decides between us and the people of injustice.

\section{The Necessity for the Destruction of Israel ${ }^{101}$}

We see in Israel the vanguard of the United States in our Islamic world. It is the hated enemy that must be fought until the hated ones get what they deserve. This enemy is the greatest danger to our future generations and to the destiny of our lands, particularly as it glorifies the ideas of settlement and expansion, initiated in Palestine, and yearning outward to the extension of the Great Israel, from the Euphrates to the Nile.

Our primary assumption in our fight against Israel states that the Zionist entity is aggressive from its inception, and built on lands wrested from their owners, at the expense of the rights of the Muslim people. Therefore our struggle will end only when this entity is obliterated. We recognize no treaty with it, no cease fire, and no peace agreements, whether separate or consolidated.

We vigorously condemn all plans for negotiation with Israel, and regard all negotiators as enemies, for the reason that such negotiation is nothing but the recognition of the legitimacy of the Zionist occupation of Palestine. Therefore we oppose and reject the Camp David Agreements, the proposals of King Fahd, the Fez and Reagan plan, Brezhnev's and the French-Egyptian proposals, and all other programs that include the recognition (even the implied recognition) of the Zionist entity.

\footnotetext{
${ }^{101}$ Este parágrafo não apareceu na tradução original publicada (em língua inglesa) pelo ‘Jerusalem Quaterly’. É possível que essa omissão seja devida ao fato de que a fonte (al-Safir) não incluiu este texto para a tradução, o qual aparece no original do Programa do Hizbullah. O Programa original foi publicado em 16 de fevereiro de 1985. O porta-voz da organização, Sheikh Ibrahim al-Amim, leu o Programa na Mesquita al-Ouzai em Beirute ocidental e, mais tarde, foi publicado como uma carta aberta "para todos os Oprimidos no Líbano e no Mundo". Tem de ser enfatizado o fato de que em nenhum lugar o Hizbullah publicou o texto completo da propaganda da organização, eles preferiram publicar o programa eleitoral de 1996, o qual estava destinado à específica campanha de propaganda da organização, antes das eleições Parlamentares libanesas de 1996. (ICT - The Institute for Counter-Terrorism, www.ict.org.il)
} 


\section{ACORDO DE TAIF Setembro de 1989}

First, General Principles and Reforms:

I. General Principles:

A. Lebanon is a sovereign, free, and independent country and a final homeland for all its citizens.

B. Lebanon is Arab in belonging and identity. It is an active and founding member of the Arab League and is committed to the league's charter. It is an active and founding member of the United Nations Organization and is committed to its charters. Lebanon is a member of the nonaligned movement. The state of Lebanon shall embody these principles in all areas and spheres, without exception.

C. Lebanon is a democratic parliamentary republic founded on respect for public liberties, especially the freedom of expression and belief, on social justice, and on equality in rights and duties among all citizens, without discrimination or preference.

D. The people are the source of authority. They are sovereign and they shall exercise their sovereignty through the constitutional institutions.

E. The economic system is a free system that guarantees individual initiative and private ownership.

F. Culturally, socially, and economically-balanced development is a mainstay of the state's unity and of the system's stability.

G. Efforts (will be made) to achieve comprehensive social justice through fiscal, economic, and social reform.

H. Lebanon's soil is united and it belongs to all the Lebanese. Every Lebanese is entitled to live in and enjoy any part of the country under the supremacy of the law. The people may not be categorized on the basis of any affiliation whatsoever and there shall be no fragmentation, no partition, and no repatriation [of Palestinians in Lebanon].

I. No authority violating the common co-existence charter shall be legitimate

II. Political Reforms

A. Chamber of Deputies: The Chamber of Deputies is the legislative authority which exercises full control over government policy and activities.

1. The Chamber spokesman and his deputy shall be elected for the duration of the chamber's term. 
2. In the first session, two years after it elects its speaker and deputy speaker, the chamber my vote only once to withdraw confidence from its speaker or deputy speaker with a 2/3 majority of its members and in accordance with a petition submitted by at least 10 deputies. In case confidence is withdrawn, the chamber shall convene immediately to fill the vacant post.

3. No urgent bill presented to the Chamber of Deputies may be issued unless it is included in the agenda of a public session and read in such a session, and unless the grace period stipulated by the constitution passes without a resolution on such a bill with the approval of the cabinet.

4. The electoral district shall be the governorate.

5. Until the Chamber of Deputies passes an election law free of sectarian restriction, the parliamentary seats shall be divided according to the following bases:

a. Equally between Christians and Muslims.

b. Proportionately between the denominations of each sect.

c. Proportionately between the districts.

6. The number of members of the Chamber of Deputies shall be increased to 108, shared equally between Christians and Muslims. As for the districts created on the basis of this document and the districts whose seats became vacant prior to the proclamation of this document, their seats shall be filled only once on an emergency basis through appointment by the national accord government that is planned to be formed.

7. With the election of the first Chamber of Deputies on a national, not sectarian, basis, a senate shall be formed and all the spiritual families shall be represented in it. The senate powers shall be confined to crucial issues.

B. President of Republic: The president of republic is the head of the state and a symbol of the country's unity. He shall contribute to enhancing the constitution and to preserving Lebanon's independence, unity, and territorial integrity in accordance with the provisions of the constitution. He is the supreme commander of the armed forces which are subject to the power of the cabinet. The president shall exercise the following powers:

1. Head the cabinet [meeting] whenever he wishes, but without voting.

\section{Head the Supreme Defense Council.}

3. Issues decrees and demand their publication. He shall also be entitled to ask the cabinet to reconsider any resolution it makes within 15 days of the date of deposition of the resolution with the presidential office. Should the cabinet insist on the adopted resolution, or should the grace period pass without issuing and returning the decree, the decree of the resolution shall be valid and must be published.

4. Promulgate laws in accordance with the grace period stipulated by the constitution and demand their publication upon ratification by the Chamber of Deputies. After notifying the cabinet, the president may also request reexamination of the laws within the grace periods 
provided by the constitution, and in accordance with the articles of the constitution. In case the laws are not issued or returned before the end of the grace periods, they shall be valid by law and they must be published.

5. Refer the bills presented to him by the Chamber of Deputies.

6. Name the prime minister-designate in consultation with the Chamber of Deputies speaker on the basis of binding parliamentary consultation, the outcome of which the president shall officially familiarize the speaker on.

7. Issue the decree appointing the prime minister independently.

8. On agreement with the prime minister, issue the decree forming the cabinet.

9. Issue decrees accepting the resignation of the cabinet or of cabinet ministers and decrees relieving them from their duties.

10. Appoint ambassadors, accept the accreditation of ambassadors, and award state medals by decree.

11. On agreement with the prime minister, negotiate on the conclusion and signing of international treaties which shall become valid only upon approval by the cabinet. The cabinet shall familiariaze the Chamber of Deputies with such treaties when the country's interest and state safety make such familiarization possible. As for treaties involving conditions concerning state finances, trade treaties, and other treaties which may not be abrogated annually, they may not be concluded without Chamber of Deputies' approval.

12. When the need arises, address messages to the Chamber of Deputies.

13. On agreement with the prime minister, summon the Chamber of Deputies to hold special sessions by decree.

14. The president of the republic is entitled to present to the cabinet any urgent issue beyond the agenda.

15. On agreement with the prime minister, call the cabinet to hold a special session whenever he deems it necessary.

16. Grant special pardon by decree.

17. In the performance of his duty, the president shall not be liable unless he violates the constitution or commits high treason.

C. Prime Minister: The prime minister is the head of the government. He represents it and speaks in its name. He is responsible for implementing the general policy drafted by the cabinet. The prime minister shall exercise the following powers:

1. Head the cabinet. 
2. Hold parliamentary consultations to form the cabinet and co-sign with the president the decree forming it. The cabinet shall submit its cabinet statement to the Chamber of Deputies for a vote of confidence within 30 days [of its formation]. The cabinet may not exercise its powers before gaining the confidence, after its resignation, or when it is considered retired, except within the narrow sense of disposing of affairs.

3. Present the government's general policy to the Chamber of Deputies.

4. Sign all decrees, except for decrees naming the prime minister and decrees accepting cabinet resignation or considering it retired.

5. Sign the decree calling for a special session and decrees issuing laws and requesting the reexamination of laws.

6. Summon the cabinet to meet, draft its agenda, familiarize the president of the republic in advance with the issues included in the agenda and with the urgent issues to be discussed, and sign the usual session minutes.

7. Observe the activities of the public departments and institutions, coordinate between the ministers, and issue general instructions to ensure the smooth progress of work.

8. Hold working sessions with the state agencies concerned in the presence of the minister concerned.

9. By law, act as the Supreme Defense Council's deputy chairman. D. Cabinet:

[ No item 1. as published ]

2. Watch over the implementation of laws and regulations and supervise the activities of all the state agencies without exception, including the civilian, military, and security departments and institutions.

3. The cabinet is the authority which controls the armed forces.

4. Appoint, dismiss, and accept the resignation of state employees in accordance with the law.

5. It has the right to dissolve the Chamber of Deputies at the request of the president of the republic if the chamber refuses to meet throughout an ordinary or a special session lasting no less than one month, even though it is summoned twice consecutively, or if the chamber sends back the budget in its entirety with the purpose of paralyzing the government. This right may not be exercised again for the same reasons which called for dissolving the chamber in the first instance.

6. When the president of the republic is present, he heads cabinet sessions. The cabinet shall meet periodically at special headquarters. The legal quorum for a cabinet meeting is $2 / 3$ the cabinet members. The cabinet shall adopt its resolutions by consent. If impossible, then by vote. The resolutions shall be adopted by a majority of the members present. As for major issues, they require the approval of $2 / 3$ the cabinet members. The following shall be considered major issues: The state of emergency and it abolition, war and peace, general mobilization, international agreements and treaties, the state's general budget, comprehensive and long-term development plans, the appointment of top-level civil servants or their 
equivalent, reexamination of the administrative division, dissolving the Chamber of Deputies, the election law, the citizenship law, the personal status laws, and the dismissal of cabinet ministers.

E. Minister: The minister's powers shall be reinforced in a manner compatible with the government's general policy and with the principle of collective responsibility. A minister shall not be relieved from his position unless by cabinet decree or unless the Chamber of Deputies withdraws its confidence from him individually.

F. Cabinet Resignation, Considering Cabinet Retired, and Dismissal of Ministers:

1. The cabinet shall be considered retired in the following cases: a. If its chairman resigns.

b. If it looses more than $1 / 3$ of its members as determined by the decree forming it.

c. If its chairman dies.

d. At the beginning of a president's term.

e. At the beginning of the Chamber of Deputies' term.

f. When the Chamber of Deputies withdraws its confidence from it on an initiative by the chamber itself and on the basis of a vote of confidence.

2. A minister shall be relieved by a decree signed by the president of the republic and the prime minister, with cabinet approval.

3. When the cabinet resigns or is considered retired, the Chamber of Deputies shall, by law, be considered to be convened in a special session until a new cabinet is formed. A vote-ofconfidence session shall follow.

G. Abolition of Political Secterianism: Abolishing political secterianism is a fundamental national objective. To achieve it, it is required that efforts be made in accordance with a phased plan. The Chamber of Deputies elected on the basis of equal sharing by Christians and Muslims shall adopt the proper measures to achieve this objective and to form a national council which is headed by the president of the republic and which includes, in addition to the prime minister and the Chamber of Deputies speaker, political, intellectual, and social notables. The council's task will be to examine and propose the means capable of abolishing sectarianism, to present them to the Chamber of Deputies and the cabinet, and to observe implementation of the phased plan. The following shall be done in the interim period:

a. Abolish the sectarian representation base and rely on capability and specialization in public jobs, the judiciary, the military, security, public, and joint institutions, and in the independent agencies in accordance with the dictates of national accord, excluding the top-level jobs and equivalent jobs which shall be shared equally by Christians and Muslims without allocating any particular job to any sect.

b. Abolish the mention of sect and denomination on the identity card.

III. Other Reforms: 


\section{A. Administrative Decentralism:}

1. The State of Lebanon shall be a single and united state with a strong central authority.

2. The powers of the governors and district administrative officers shall be expanded and all state administrations shall be represented in the administrative provinces at the highest level possible so as to facilitate serving the citizens and meeting their needs locally.

3. The administrative division shall be recognized in a manner that emphasizes national fusion within the framework of preserving common coexistence and unity of the soil, people, and institutions.

4. Expanded administrative decentralization shall be adopted at the level of the smaller administrative units [ district and smaller units ] through the election of a council, headed by the district officer, in every district, to ensure local participation.

5. A comprehensive and unified development plan capable of developing the provinces economically and socially shall be adopted and the resources of the municipalities, unified municipalities, and municipal unions shall be reinforced with the necessary financial resources.

\section{B. Courts:}

[1] To guarantee that all officials and citizens are subject to the supremacy of the law and to insure harmony between the action of the legislative and executive authorities on the one hand, and the givens of common coexistence and the basic rights of the Lebanese as stipulated in the constitution on the other hand:

1. The higher council which is stipulated by the constitution and whose task it is to try presidents and ministers shall be formed. A special law on the rules of trial before this council shall be promulgated.

2. A constitutional council shall be created to interpret the constitution, to observe the constitutionality of the laws, and to settle disputes and contests emanating from presidential and parliamentary elections.

3. The following authorities shall be entitled to revise the constitutional council in matters pertaining to interpreting the constitution and observing the constitutionality of the laws:

a. The president of the republic. b. The Chamber of Deputies speaker.

c. The prime minister.

d. A certain percentage of members of the Chamber of Deputies.

[2] To ensure the principle of harmony between religion and state, the heads of the Lebanese sects may revise the constitutional council in matters pertaining to:

1. Personal status affairs. 
2. Freedom of religion and the practice of religious rites.

3. Freedom of religious education.

C. To ensure the judiciary's independence, a certain number of the Higher Judiciary Council shall be elected by the judiciary body.

D. Parliamentary Election Law: Parliamentary elections shall be held in accordance with a new law on the basis of provinces and in the light of rules that guarantee common coexistence between the Lebanese, and that ensure the sound and efficient political representation of all the people's factions and generations. This shall be done after reviewing the administrative division within the context of unity of the people, the land, and the institutions.

E. Creation of a socioeconomic council for development: A socioeconomic council shall be created to insure that representatives of the various sectors participate in drafting the state's socioeconomic policy and providing advice and proposals.

\section{F. Education:}

1. Education shall be provided to all and shall be made obligatory for the elementary stage at least.

2. The freedom of education shall be emphasized in accordance with general laws and regulations.

3. Private education shall be protected and state control over private schools and textbooks shall be strengthened.

4. Official, vocational, and technological education shall be reformed, strengthened, and developed in a manner that meets the country's development and reconstruction needs. The conditions of the Lebanese University shall be reformed and aid shall be provided to the university, especially to its technical colleges.

5. The curricula shall be reviewed and developed in a manner that strengthens national belonging, fusion, spiritual and cultural openness, and that unifies textbooks on the subjects of history and national education.

G. Information: All the information media shall be reorganized under the canopy of the law and within the framework of responsible liberties that serve the cautious tendencies and the objective of ending the state of war.

Second, spreading the sovereignty of the State of Lebanon over all Lebanese territories: Considering that all Lebanese factions have agreed to the establishment of a strong state founded on the basis of national accord, the national accord government shall draft a detailed one-year plan whose objective is to spread the sovereignty of the State of Lebanon over all Lebanese territories gradually with the state's own forces. The broad lines of the plan shall be as follows:

A. Disbanding of all Lebanese and non-Lebanese militias shall be announced. The militias' weapons shall be delivered to the State of Lebanon within a period of 6 months, beginning 
with the approval of the national accord charter. The president of the republic shall be elected. A national accord cabinet shall be formed, and the political reforms shall be approved constitutionally.

B. The internal security forces shall be strengthened through:

1. Opening the door of voluntarism to all the Lebanese without exception, beginning the training of volunteers centrally, distributing the volunteers to the units in the governorates, and subjecting them to organized periodic training courses.

2. Strengthening the security agency to insure control over the entry and departure of individuals into and out of the country by land, air, and sea.

C. Strengthening the armed forces:

1. The fundamental task of the armed forces is to defend the homeland, and if necessary, protect public order when the danger exceeds the capability of the internal security forces to deal with such a danger on their own.

2. The armed forces shall be used to support the internal security forces in preserving security under conditions determined by the cabinet.

3. The armed forces shall be unified, prepared, and trained in order that they may be able to shoulder their national responsibilities in confronting Israeli aggression.

4. When the internal security forces become ready to assume their security tasks, the armed forces shall return to their barracks.

5. The armed forces intelligence shall be reorganized to serve military objectives exclusively.

D. The problem of the Lebanese evacuees shall be solved fundamentally, and the right of every Lebanese evicted since 1975 to return to the place from which he was evicted shall be established. Legislation to guarantee this right and to insure the means of reconstruction shall be issued. Considering that the objective of the State of Lebanon is to spread its authority over all the Lebanese territories through its own forces, represented primarily by the internal security forces, and in view of the fraternal relations binding Syria to Lebanon, the Syrian forces shall thankfully assist the forces of the legitimate Lebanese government to spread the authority of the State of Lebanon within a set period of no more than 2 years, beginning with ratification of the national accord charter, election of the president of the republic, formation of the national accord cabinet, and approval of the political reforms constitutionally. At the end of this period, the two governments -- the Syrian Government and the Lebanese National Accord Government -- shall decide to redeploy the Syrian forces in Al-Biq'a area from Dahr al-Baydar to the Hammana-al-Mudayrij-'Ayn Darah line, and if necessary, at other points to be determined by a joint Lebanese-Syrian military committee. An agreement shall also be concluded by the two governments to determine the strength and duration of the presence of Syrian forces in the above-mentioned area and to define these forces' relationship with the Lebanese state authorities where the forces exist. The Arab Tripartite Committee is prepared to assist the two states, if they so wish, to develop this agreement. 
Third, liberating Lebanon from the Israeli occupation: Regaining state authority over the territories extending to the internationally-recognized Lebanese borders requires the following:

A. Efforts to implement resolution 425 and the other UN Security Council resolutions calling for fully eliminating the Israeli occupation.

B. Adherence to the truce agreement concluded on 23 March 1949.

C. Taking all the steps necessary to liberate all Lebanese territories from the Israeli occupation, to spread state sovereignty over all the territories, and to deploy the Lebanese army in the border area adjacent to Israel; and making efforts to reinforce the presence of the UN forces in South Lebanon to insure the Israeli withdrawal and to provide the opportunity for the return of security and stability to the border area.

Fourth, Lebanese-Syrian Relations: Lebanon, with its Arab identity, is tied to all the Arab countries by true fraternal relations. Between Lebanon and Syria there is a special relationship that derives its strength from the roots of blood relationships, history, and joint fraternal interests. This is the concept on which the two countries' coordination and cooperation is founded, and which will be embodied by the agreements between the two countries in all areas, in a manner that accomplishes the two fraternal countries' interests within the framework of the sovereignty and independence of each of them. Therefore, and because strengthening the bases of security creates the climate needed to develop these bonds, Lebanon should not be allowed to constitute a source of threat to Syria's security, and Syria should not be allowed to constitute a source of threat to Lebanon's security under any circumstances. Consequently, Lebanon should not allow itself to become a pathway or a base for any force, state, or organization seeking to undermine its security or Syria's security. Syria, which is eager for Lebanon's security, independence, and unity and for harmony among its citizens, should not permit any act that poses a threat to Lebanon's security, independence, and sovereignty. 


\section{TRATADO DE FRATERNIDADE, COOPERAÇÃO E COORDENAÇÃO - SÍRIA E LÍBANO 20 de maio de 1991}

The Lebanese Republic and the Syrian Arab Republic on the basis of the distinguished brotherly relations between them which serve their strength from the roots of kinship history common affiliation common destiny and joint strategic interests; out of their belief that the achievement of the broadest cooperation and coordination between them will serve their strategic interests and provide the means for ensuring their development and progress and for defending their pan-Arab and national security be a source of prosperity and stability enable them to face all regional and international developments and meet the aspirations of peoples of the two countries; and in implementation of the Lebanese national accord which was ratified by the Lebanese Chamber of Deputies on 5 November 1989 have agreed on the following:

Article 1. The two states will work to achieve the highest level of cooperation and coordination in all political economic security cultural scientific and other fields in a manner that will realize the interests of the two fraternal countries within the framework of respect for their individual sovereignty and independence and will enable the two countries to use their political economic and security resources to provide prosperity and stability ensure their pan-Arab and national security and expand and strengthen their common interests as an affirmation of the brotherly relations and guarantee of their common destiny.

Article 2. The two states will work to achieve cooperation and coordination in the economic agricultural industrial and commercial fields as well as in the fields of transportation communications customs the establishment of joint profits and coordination of development plans.

Article 3. The connection between the security of the two countries requires that Lebanon not become a threat to Syria's security and vice versa under any circumstances. Therefore Lebanon will not allow itself to become a transit point or base for any force state or organization that seeks to undermine its security or that of Syria. Syria which cherishes Lebanon's security independence and unity and the agreement among its people will not allow any action that threatens Lebanon's security independence and sovereignty.

Article 4. After the political reforms are approved in a constitutional manner as stipulated in the Lebanese national accord and after the deadlines specified in this accord have expired the Syrian and Lebanese Governments will decide on the redeployment of the Syrian forces in the al-Biqa' area and the entrance to western al-Biqa' in Dahr as-Baydar up to the Haammanahal-Mudayri-'Any Dara line and if necessary in other points to be specified by a joint Lebanese-Syrian military committee. The two governments will conclude an agreement specifying the size and duration of the Syrian forces' presence in these areas and the relationship of these forces with the authorities of the Lebanese state.

Article 5. The two states' Arab and international foreign policy shall be based on the following principles: 
1. Lebanon and Syria are Arab states which are committed to the Arab League Charter the Arab defense pact and joint economic cooperation and all agreements ratified within the framework of the Arab League. They are members of the United Nations and are committed to its Charter. They are also members of the Non-aligned Movement.

2. The two countries share a common destiny and common interests.

3. Each country supports the other in issues related to its security and national interests in accordance of the contents of this treaty. Therefore the governments of the two countries shall coordinate their Arab and international policies cooperate to the fullest extent possible in Arab and international institutions and organizations and coordinate their stands on regional and international issues.

Article 6. The following bodies shall be formed to achieve the goals of this treaty. Other bodies can be established by a decision from the Supreme Council.

\section{The Supreme Council:}

A. The supreme council will consist of the presidents of the two contracting countries and a number of other members from both countries.

B. The supreme council will meet at least once a year and more often when necessary at a venue to be agreed upon.

C. The supreme council charts the general policy for coordination and cooperation between the two states in the political economic security military and other fields. It also supervises the implementation of this policy and adopts the plans and decisions that are made by the executive body the foreign affairs committee the economic and social affairs committee the defense and security affairs committee or any committee that is established in the future provided that the constitutional provisions of the two countries are respected.

D. The supreme council's decisions are binding and effective within the framework of the constitutional laws and rules of the two countries except for those decisions which require the approval of the executive or legislative authorities in the two countries under their constitutional provisions.

E. The supreme council defines the subjects on which the committees concerned have the right to make decisions. Once they are issued these decisions assume an executive nature within the framework of the constitutional laws and rules of the two countries except for those decisions which require the approval of the executive or legislative authorities in the two countries under their constitutional provisions.

\section{The Executive Body:}

The executive body will consist of the prime ministers of the two countries and a number of ministers concerned with the relations between them. This body will assume the following tasks: 
A. To follow up on the implementation of the decisions and to submit reports to the supreme council on the phases of implementation.

B. To coordinate the recommendations and decisions of the specialized committees and to submit the proposals to the supreme council.

C. To hold meetings with the specialized committees whenever the need arises.

D. The executive body will meet at least once every six months and more often when necessary at a venue to be agreed upon.

3. The Foreign Affairs Committee:

A. The foreign affairs committee will consist of the two countries' foreign ministers.

B. The foreign affairs committee will meet at least once every two months and more often when necessary in the two countries' capitals on a rotating basis.

C. The foreign affairs committee will seek to coordinate the foreign policy of the two countries with regard to their relations with all countries. The committee will work to coordinate their activities and stands at Arab and international organizations. The relevant plans will be drawn up and submitted to the supreme council.

4. The Economic and Social Affairs Committee:

A. The economic and social affairs committee will consist of the ministers concerned in the two countries in economic and social sectors.

B. The economic and social affairs committee will meet in the two countries' capitals on a rotating basis at least once every two months and more often when necessary.

C. The economic and social affairs committee will be responsible for working to attain economic and social coordination between the two countries and for drawing up the recommendations that will lead to such coordination.

D. The recommendations adopted by the economic and social affairs committee will take effect after they have been endorsed by the supreme council in accordance with the constitutional provisions of the two countries.

5. The Defense and Security Affairs Committee:

A. The defense and security affairs committee will consist of the two countries' ministers of defense and interior.

B. The defense and security affairs committee will be responsible for studying the adequate measures needed to safeguard the two countries' security and for suggesting joint measures to confront any aggression or threat endangering their national security or any unrest that may disturb their internal security. 
C. All plans recommendations and measures prepared by the defense and security affairs committee will be submitted to the supreme council for endorsement after taking into consideration the constitutional rules of the two countries.

6. The General Secretariat:

A. A general secretariat will be created to follow up on the implementation of the provisions of this treaty.

B. The general secretariat will be headed by a secretary general who will be appointed by the supreme council.

C. The headquarters specialization basis and budget of the general secretariat will be determined by the supreme council.

Closing Provisions:

A. Special agreements shall be concluded between the two countries in the fields covered by this treaty such as the economic security defense and other fields in accordance with the constitutional rules in each of the two countries and shall complement this treaty.

B. This treaty shall take effect after being ratified by the authorities of the two countries in accordance with their constitutional provisions.

C. Each of the two countries will abrogate any law or regulation which is not in line with this treaty. Such abrogation will be done in a way that does not violate any constitutional provision in either country. 


\section{“ENTENDIMENTO” DE ABRIL 26 de abril de 1996}

Following is the text of the "understanding" reached on Friday, April 26, 1996, for the cease-fire in Lebanon:

The United States understands that after discussions with the governments of Israel and Lebanon, and in consultation with Syria, Lebanon and Israel will ensure the following:

1) Armed groups in Lebanon will not carry out attacks by Katyusha rockets or by any kind of weapon into Israel.

2) Israel and those cooperating with it will not fire any kind of weapon at civlians or civilian targets in Lebanon.

3) Beyond this, the two parties commit to ensuring that under no circumstances will civilians be the target of attack and that civilian populated areas and industrial and electrical installations will not be used as launching grounds for attacks.

4) Without violating this understanding, nothing herein shall preclude any party from exercising the right of self-defense.

A Monitoring Group is stablished consisting of the United States, France, Syria, Lebanon and Israel. Its task will be to monitor the application of the understanding stated above. Complaints will be submitted to the Monitoring Group.

In the event of a claimed violation of the understanding, the party submitting the complaint will do so within 24 hours. Procedures for dealing with the complaints will be set by the Monitoring Group.

The United States will also organize a Consultative Group, to consist of France, the European Union, Russia and other interested parties, for the purpose of assisting in the reconstruction needs of Lebanon.

It is recognized that the understanding to bring the current crisis between Lebanon and Israel to an end cannot substitute for a permanent solution. The United States understands the importance of achieving a comprehensive peace in the region.

Toward this end, the United States proposes the resumption of negotiations between Syria and Israel and between Lebanon and Israel at a time to be agreed upon, with the objective of reaching comprehensive peace.

The United states understands that it is desirable that these negotiations be conducted in a climate of stability and tranquility.

This understanding will be announced simultaneously at 1800 hours, April 26, 1996, in all countries concerned.

The time set for implementation is 0400 hours, April 27, 1996. 


\title{
LEGISLAÇÃO ELEITORAL Lei $\mathbf{n}^{0} 171$ de 6 de janeiro de 2000
}

Chapitre 1er: Nombre des députés, circonscriptions électorales, appel au vote et conditions de dépôt des candidatures.

Chapitre 2: Conditions pour être électeur.

Chapitre 3: Listes électorales.

Chapitre 4: Éligibilité, incapacité et incompatibilité entre le mandat parlementaire et les fonctions publiques

Chapitre 5: Dépôt de la candidature.

Chapitre 6: Déroulement des élections.

Chapitre 7: Campagne électorale.

Chapitre 8: Sanctions.

Chapitre 9: Dispositions diverses.

Séance de ratification du projet de loi sur les élections parlementaires.

\section{Chapitre 1er: Nombre des députés, circonscriptions électorales, appel au vote et conditions de dépôt des candidatures -}

\author{
- Article premier \\ La Chambre des députés est formée de cent vingt-huit membres élus pour un mandat de quatre ans. Le mandat \\ du premier Conseil élu après la promulgation de cette loi s’étend jusqu’au 31 mai 2005.
}

\footnotetext{
- Article 2

Les circonscriptions électorales sont établies comme suit, le nombre de sièges correspondants étant déterminé conformément au Tableau $\mathrm{N}^{\circ} 1$ annexé à la présente loi :
}

1- La première circonscription de la ville de Beyrouth formée des quartiers suivants : Achrafieh, Mazraa et Saifi.

2- La deuxième circonscription de la ville de Beyrouth formée des quartiers suivants : Mousaytbé, Bachoura et Rmeil.

3- La troisième circonscription de la ville de Beyrouth formée des quartiers suivants : Dar el Mreissé, Ras Beyrouth, Zkak el Blat, Moudawar, Le port et Mina el Hosn

4- La première circonscription du Mont Liban comprenant les cazas de Jbeil et du Kesrouan

5- La deuxième circonscription du Mont Liban comprenant le caza du Metn

6- La troisième circonscription du Mont Liban comprenant les cazas de Baabda et de Aley.

7- La quatrième circonscription du Mont Liban comprenant le caza du Chouf

8- La première circonscription du Nord comprenant les cazas et régions de : Akkar, Dinniyé et Bécharré

9- La deuxième circonscription du Nord comprenant les cazas et régions de : Tripoli, Mina, Zghorta, Batroun et Koura

10- La première circonscription du Sud comprenant les cazas et régions de : Ville de Saida, Zahrani, Tyr et Bint Jbeil

11- La deuxième circonscription du Sud comprenant les cazas de : Marjeyoun, Hasbaya, Nabatiyé et Jezzine.

12- La première circonscription de la Békaa comprenant les cazas de Baalbek et du Hermel

13- La deuxième circonscription de la Békaa comprenant le caza de Zahlé

14- La troisième circonscription de la Békaa comprenant les cazas de La Békaa occidentale et de Rachaya

\section{- Article 3}

Le nombre des députés de chaque confession est déterminé dans chaque région ou caza dans les circonscriptions électorales où les candidatures parlementaires sont présentées conformément au Tableau $\mathrm{N}^{\circ} 2$ annexé à la présente loi.

\section{- Article 4}

Tous les électeurs appartenant à la même circonscription électorale, votent, de quelque confession qu'ils soient, pour les candidats de cette circonscription. 


\title{
- Article 5
}

Le scrutin est public, secret et à pied d’égalité.

\section{- Article 6}

Ne peut être élu membre au Parlement que celui qui est titulaire de la nationalité libanaise depuis plus de dix ans, qui est inscrit sur la liste des électeurs, qui a 25 ans révolus, qui est instruit et qui jouit des ses droits civils et politiques.

\section{- Article 7}

Les organes électoraux sont convoqués par décret et la rencontre de ces organes ne se produit que dans un délai de 30 jours au moins à dater de la publication dudit décret. Les élections générales ont lieu durant les 60 jours précédant l'expiration du mandat des députés, sauf en cas de dissolution du Conseil.

La date des élections est fixée pour le même jour dans toutes les circonscriptions. Le cas échéant et pour des raisons de sécurité, une ou plusieurs dates spécifiques peuvent être fixées pour chaque circonscription, à condition que les élections se tiennent dans toutes les circonscriptions dans les délais prévus au paragraphe précédent.

\section{- Article 8}

En cas de vacance suite à un décès ou à une démission ou pour toute autre raison, les élections pour le siège vacant se déroulent dans un délai de 60 jours à compter de la date où il a été déclaré vacant. Le siège est considéré vacant à compter de la date du décès ; de la date de la prise de décision de la Chambre, dans les autres cas ; ou à compter de la date de publication au journal officiel de la décision du Conseil Constitutionnel invalidant le mandat d’un député. Il n'en reste pas moins que les successeurs devant remplir les sièges vacants ne peuvent être élus dans une période de 6 mois ou moins avant l'expiration du mandat du Parlement.

\section{-- Chapitre 2: Conditions pour être Electeur -}

\section{- Article 9}

Tout libanais ou libanaise ayant 21 ans révolus et jouissant de ses droits civils et politiques et ne manifestant aucun état d’incapacité prévu par loi, dispose du droit au vote.

\section{- Article 10}

Sont privées de l'exercice de leurs droits électoraux :

1- les personnes déchues de leurs droits civils.

2- les personnes condamnées à perpétuité à être privées des grades et des fonctions publiques.

Quant aux personnes dépossédées de leurs fonctions à terme, elles ne peuvent figurer sur la liste qu'après expiration de ce terme.

3- les personnes condamnées pour avoir commis un crime ou un délit

Sont considérés outrageants les crimes suivants : le vol, l'escroquerie, l'émission d'un chèque sans provision, l'abus de confiance, la soustraction, les pots-de-vin, les faux témoignages, le viol, l'intimidation, la falsification, l'usage de faux certificats, l'atteinte aux mœurs publiques visée au Titre 7 du Code pénal ainsi que les crimes relatifs à la culture, à la production et au commerce des stupéfiants.

4- les internés judiciaires jusqu’à la fin de l’internement.

5- les personnes dont la faillite a été déclarée.

6- les personnes condamnées aux sanctions prévues aux Articles 329 à 334 du Code pénal.

Les personnes susmentionnées ne récupèrent leurs droits électoraux qu’après réhabilitation.

\section{-- Chapitre 3: Listes électorales -}

\author{
- Article 11 \\ L'enregistrement sur les listes électorales est obligatoire. Personne ne peut cependant être inscrit sur \\ plus d'une liste.
}




\section{- Article 12}

La Direction Générale de l'Etat Civil établit, pour chaque circonscription électorale, et conformément aux registres de l'Etat Civil, des listes électorales informatisées où figure le nom de tous les électeurs qui résident dans la circonscription électorale depuis 6 mois au moins à dater du jour où la révision de ces listes a été entamée, à savoir le 15 décembre de chaque année.

\section{- Article 13}

Les listes électorales comprennent, pour chaque électeur, le numéro du registre de sa famille tel qu'inscrit sur les fiches de l'Etat Civil, son nom de famille, son prénom, sa nationalité, le nom de son père, sa date de naissance ainsi que son rite.

\section{- Article 14}

Les listes électorales sont permanentes. Toutefois, elles sont révisées annuellement une semaine après l'annonce du début de la période de révision par l’intermédiaire des publications officielles, des journaux et de la radio.

\section{- Article 15}

Est créée, dans chaque circonscription électorale, une ou plusieurs Commissions d'enregistrement ; chacune, sauf indication contraire, étant présidée par un juge en poste et comprenant l'un des présidents des conseils municipaux de la circonscription ou l'un des membres de ces conseils ainsi que le fonctionnaire de l'Etat Civil faisant fonction de rapporteur. La Commission peut consulter le mokhtar en ce qui concerne son village.

Le cas échéant, un ou plusieurs fonctionnaires de l'Etat Civil sont appelés à se joindre à chaque Commission en vertu d'une décision prise par le directeur général de l'Etat Civil.

Les présidents des Commissions d'enregistrement et les membres sont désignés par des décrets émis sur proposition des Ministres de la Justice et de l’Intérieur.

\section{- Article 16}

Les Commissions d'enregistrement se chargent de :

a- Vérifier les demandes de rectification des listes électorales conformément aux dispositions des articles 23 et 25 de la présente loi, prendre des décisions à leur sujet et les notifier aux personnes concernées et à la Direction Générale de l'Etat Civil pour procéder à la rectification en vertu de la teneur de ces décisions.

b- Recevoir les résultats des élections après fermeture des bureaux de vote, étudier les procès-verbaux et les documents, prendre les décisions convenables à leur sujet, faire le décompte des voix, dresser un tableau général regroupant le total des voix obtenues par chaque candidat, le soumettre aux présidents des Hautes Commissions d'enregistrement compétentes, conformément aux dispositions des Articles 58 et 59 de la présente loi.

\footnotetext{
- Article 17

« Le service technique » de la Direction Générale de l’Etat Civil note annuellement les ajouts et les suppressions sur les listes électorales comme suit :

a- Les chefs de département et les fonctionnaires de l'Etat Civil doivent soumettre annuellement au service technique, entre le 15 décembre et le 5 janvier :

- les noms des personnes remplissant les conditions légales pour l’enregistrement

- les noms des personnes qui rempliront ces conditions le jour où la liste électorale sera clôturée.

- les noms des personnes dont l’enregistrement a été négligé, qui sont décédées ou qui ont été rayées des registres de l'Etat Civil.
}

Les électeurs de plus de 100 ans doivent soumettre à leur bureau d'Etat Civil, entre le 15 décembre et le 5 janvier, un certificat de vie dûment signé par eux et par le mokhtar de leur lieu de résidence.

Si ledit certificat n’a pas été présenté dans les délais visés au paragraphe précédent, la Direction Générale de l'Etat Civil devra rayer le nom de la personne en question de la liste électorale de la circonscription. Cette dernière peut cependant procéder à un nouvel enregistrement dans un délai d’un mois à dater de la publication des listes en vertu des dispositions de l’Article 23 de la présente loi.

\section{- Article 18}

b- le département du casier judiciaire dans chaque mohafazat envoie annuellement à la Direction Générale de l'Etat civil entre le 15 décembre et le 5 janvier un relevé des noms des personnes condamnées pour des crimes les privant de leur droit de vote conformément à l'Article 10 de la présente loi. 


\begin{abstract}
- Article 19
c- les tribunaux judiciaires envoient annuellement à la Direction Générale de l'Etat civil entre le 15 décembre et le 5 janvier un relevé des sentences finales relatives à la faillite et à l'internement.
\end{abstract}

\title{
- Article 20
}

Avant le premier février de chaque année, le service technique près la Direction Générale de l'Etat Civil vérifie les listes électorales rectifiées, les approuve et les signe.

Les raisons de la rectification sont notées dans une marge réservée à cette fin en face de chaque ajout ou suppression de la liste. Si le nom d'un électeur est transféré d'une liste à une autre, il faut mentionner la ville ou le quartier où il était inscrit avec la date de la suppression.

\section{- Article 21}

Avant le 10 février de chaque année, la Direction Générale de l’Etat Civil envoie, par l’intermédiaire des Forces de Sécurité Intérieure ou des agents de police, des copies des listes électorales rectifiées et signées aux municipalités, aux mokhtars ainsi qu'aux sièges des mohafazats et des caïmacams et ce afin de les publier de façon à ce que tout le monde puisse en prendre connaissance ou les copier. L'annonce se fait dans les médias pendant 5 jours au moins.

Les Forces de Sécurité Intérieure ou les agents de police dressent un procès-verbal de dépôt, le signent conjointement avec le mokhtar, le maire ou son suppléant et le soumettent à la Commission visée à l'Article 15 de la présente loi à travers le mohafez, le caïmacam ou la personne agissant en leur qualité.

\begin{abstract}
- Article 22
Toute personne peut avoir les disquettes comprenant les listes électorales à compter de la date de leur publication conformément à l'article précédent, et ce dans le département compétent auprès du service technique. Le prix de la disquette est fixé à 10000 LL et celui du CD ROM à 50000 LL, perçues par le biais de timbres apposés à la demande.
\end{abstract}

\section{- Article 23}

Les électeurs peuvent, à dater de la publication et de l'annonce des listes électorales, à savoir le 10 février de chaque année, présenter aux Commissions d’enregistrement compétentes dans les circonscriptions électorales les demandes de rectification de toute erreur dans les listes électorales.

- L’électeur dont l'enregistrement est erroné ou a été négligé par mégarde ou erreur ou pour toute autre raison, doit soumettre sa demande à la Commission d'enregistrement dans un délai d'un mois à compter de la date de publication des listes électorales, tout en y attachant les preuves et les documents justificatifs.

- Tout électeur enregistré sur l'une des listes des circonscriptions électorales peut demander à la Commission d'enregistrement de rayer ou d'enregistrer le nom d'une personne qui y a été enregistrée contrairement à la loi. Le mohafez ainsi que le caïmacam et le mokhtar compétents doivent exercer ce droit et ce, durant un délai d'un mois venant à terme le 10 mars de chaque année.

- Les Commissions d'enregistrement étudient les demandes l'une après l'autre et prennent des décisions à leur sujet avant le 15 mars de chaque année. Des copies de ces décisions sont envoyées aux personnes concernées et à la Direction Générale de l’Etat Civil pour exécution.

\section{- Article 24}

Dans chaque circonscription électorale, une Haute Commission d'enregistrement est créée ; elle est présidée par le président de la chambre d'appel du mohafazat et comprend comme membres un juge en poste et un inspecteur de l'Inspection Centrale et comme membre rapporteur un chef de département ou un président du bureau de l'Etat Civil ou un fonctionnaire de l'Etat Civil .

-Les présidents et les membres des Hautes Commissions d’enregistrement sont désignés par décret émis sur proposition des Ministres de la Justice et de l’Intérieur.

Les Hautes Commissions d'enregistrement se chargent de :

a- examiner les demandes d'appel des décisions prises par les Commissions d'enregistrement. Les personnes concernées présentent des demandes d’appel des décisions prises par les Commissions d'enregistrement par simple voie d’appel dans un délai de 5 jours à compter du jour où les décisions de ces Commissions leur ont été notifiées.

-les Hautes Commissions d'enregistrement doivent se prononcer sur les demandes d'appel avant le 25 mars de chaque année.

b- recevoir et étudier les procès-verbaux des résultats de vote dressés par les Commissions d'enregistrement et les tableaux annexés, faire le décompte des voix et dresser un procès-verbal mentionnant les résultats finals de vote de chaque candidat dans la circonscription conformément à l'Article 60 de la présente loi. 
- Article 25

La Direction Générale de l'Etat Civil envoie au Ministre de l'Intérieur, avant le 30 mars de chaque année, des copies des listes électorales signées et rectifiées dans leur forme définitive conformément aux décisions des Commissions d'enregistrement. Si le Ministre de l'Intérieur découvre ultérieurement des erreurs ou des lacunes dans les listes électorales, de quelque nature qu 'elles soient, il renvoie immédiatement l'affaire à la Commission d'enregistrement compétente qui en prend une décision à cet effet dans un délai de trois jours.

\title{
- Article 26
}

Le Ministre de l'Intérieur envoie des copies des listes électorales définitives envoyées par la Direction Générale de l'Etat Civil au service des affaires politiques et administratives de la Direction Générale de l'Intérieur pour procéder à leur adoption durant toute élection ayant lieu entre le 30 mars et le 30 mars de l'année suivante.

- Article 27

Après toute modification effectuée conformément à l'Article 25 de la présente loi, la liste électorale est clôturée le 30 mars de chaque année et demeure en vigueur jusqu'au 30 mars de l'année suivante.

\section{-- Chapitre 4: Eligibilité, incapacité et incompatibilité entre le mandat parlementaire et les fonctions publiques -}

\begin{abstract}
- Article 28
Les militaires et ceux considérés comme tels, quel que soit leur grade, qu’ils fassent partie de l'armée, de la Sécurité de l’Etat, des Forces de Sécurité Intérieure, de la Sécurité Générale ou de la police douanière, exceptés les membres du service militaire, ne participent pas au vote et sont rayés des listes électorales.

Les militaires et ceux considérés comme tels, quel que soit leur grade, qu’ils fassent partie de l'armée, de la Sécurité d’Etat, des Force de Sécurité Intérieure, de la Sécurité Générale ou de la police douanière, ne peuvent être élus députés à la Chambre même s’ils sont mis à la retraite anticipée ou s’ils font partie du cadre de réserve. Par contre, ils sont éligibles s’ils sont retraités ou démissionnaires 6 mois avant la date des élections.
\end{abstract}

\section{- Article 29}

Sont incompatibles avec l'exercice d'un mandat parlementaire, les fonctions de président ou membre du conseil d'administration d'une institution publique, d'une fonction publique, de tout poste dans les institutions publiques indépendantes, les sociétés concessionnaires et les mairies, et toute fonction religieuse donnant droit à un salaire ou à une rémunération du Trésor public. Tout fonctionnaire élu député est déclaré démissionnaire d'office s’il ne fait pas part de son refus de la députation dans un délai d’un mois à dater de la publication des résultats électoraux.

Sont également incompatibles l'exercice d'un mandat parlementaire et la représentation juridique de l'Etat, de l'un de ses intérêts, de ses institutions publiques indépendantes ou des municipalités.

Aucune concession ne peut être accordée au député ; aucun contrat d’entreprise ne peut lui être confié.

\section{- Article 30}

Sous réserve des dispositions des Articles 22 et 31 de la loi No 665 du 29/12/1997, les personnes mentionnées ci-dessous ne peuvent être candidats, dans aucune circonscription électorale, pendant l'exercice de leurs fonctions et la période de 6 mois suivant leur démission et l'interruption effective de leurs fonctions :

1- les employés des première et deuxième catégories,

2- les juges de toutes catégories et grades,

3- les présidents des conseils d'administration des institutions publiques ainsi que leurs directeurs et membres.

\section{- Article 31}

1- Si un siège parlementaire est déclaré vacant suite à un décès ou une démission ou pour n’importe quelle autre raison, ou si la Chambre est dissoute 6 mois avant le terme de son mandat, les employés cités à l'article précédent ainsi que les militaires et ceux considérés comme tels, quel que soit leur grade, qu’ils fassent partie de l’armée, de la Sécurité de l’Etat, des Forces de Sécurité Intérieure, de la Sécurité Générale ou de la police douanière sont éligibles s'ils démissionnent et interrompent effectivement leurs fonctions 15 jours à compter de la date du décret relatif à la convocation des organes électoraux. La démission est acceptée dès que présentée. 2-Les fonctionnaires et personnes qui démissionnent et présentent leur candidature aux élections parlementaires ont le droit de réclamer le salaire de la retraite ou l'indemnité de fin de service à condition d’obtenir, à titre légal, $20 \%$ au moins des voix. 
- Article 32

Est écarté, par décision prise par la Chambre, tout député condamné, durant son mandat, à un état le privant de l'exercice de ses droits électoraux conformément à l'Article 10 de la présente loi.

- Article 33

Toute représentation électorale liée à une condition ou à une restriction est considérée annulée et ne fait pas foi.

\title{
-- Chapitre 5: Dépôt de la candidature -
}

\begin{abstract}
- Article 34
Toute personne remplissant les conditions requises pour être député à la Chambre, peut déposer sa candidature dans n'importe quelle circonscription. Personne ne peut toutefois présenter sa candidature dans plus d'une circonscription électorale en même temps. Lorsque les élections se déroulent par étapes, le candidat s'étant présenté dans une circonscription n'a pas le droit de se présenter de nouveau dans une autre circonscription à la même période où se tiennent les élections générales.
\end{abstract}

\section{- Article 35}

Celui qui se présente aux élections générales ou partielles doit indiquer dans une déclaration certifiée par le notaire et signée par lui, le caza ou la région où il désire se présenter au sein de la circonscription électorale ; il doit également déposer à la caisse des finances la somme de 10 millions de Livres Libanaises.

Toute personne qui gagne aux élections récupère la garantie déposée. Quant à ceux qui échouent, ils ne peuvent être remboursés que s'ils obtiennent $10 \%$ et plus des suffrages dans la circonscription électorale.

La déclaration est déposée au Ministère de l’Intérieur contre un récépissé provisoire 15 jours au moins avant la tenue des élections. Cinq jours plus tard, le récépissé définitif est délivré s'il ne s’avère pas que la candidature est contraire aux dispositions de la présente loi.

Si l'autorité compétente refuse de lui délivrer le récépissé pour des raisons non citées ci-haut, le candidat pourra avoir recours au Conseil d'Etat par simple demande exempte de droits. Ledit Conseil doit trancher cette objection de façon définitive en chambre de conseil dans un délai de trois jours.

Toutefois, si le délai de dépôt de candidature expire et qu'un seul candidat se serait présenté à un siège déterminé, ce candidat est considéré comme élu à l'unanimité. Le Ministre de l'Intérieur soumet immédiatement une lettre à ce sujet au président de la Chambre sans qu'il n’y ait lieu de tenir des élections pour ledit siège.

\section{- Article 36}

Toute déclaration contraire aux dispositions de l'article précédent est considérée caduque. Les déclarations présentées par une seule personne dans une circonscription sont considérées caduques si elles portent la même date. Mais si elles sont présentées à des dates différentes, seule la dernière sera prise en considération et les autres déclarations sont jugées caduques.

\section{- Article 37}

Le candidat ne peut retirer sa candidature qu'en vertu d'une déclaration légale certifiée par le notaire qui sera déposée au Ministère de l'Intérieur 10 jours au moins avant la tenue des élections. Si l'élection du nombre requis de députés dans la circonscription est compromise par ce retrait, de nouveaux dépôts de candidatures seront acceptés 3 jours avant le vote.

Tout candidat qui retire sa candidature conformément aux dispositions du présent article a le droit de récupérer la moitié de la somme versée.

\section{- Article 37}

Les noms des candidats qui auraient reçu les récépissés définitifs sont immédiatement notifiés aux mohafez et aux caïmacams et affichés dès leur arrivée dans les endroits réservés aux publications officielles.

\section{-- Chapitre 6: Déroulement des élections -}

\author{
- Article 39 \\ En vertu d'une décision du Ministre de l'Intérieur, la circonscription électorale est divisée en plusieurs bureaux \\ de vote. Chaque village dont le nombre des électeurs atteint les 100 disposera d'un bureau de vote au moins. \\ Quant aux villes et villages dont le nombre des électeurs dépasse les 100 ; tous les 400 électeurs auront un \\ bureau de vote au moins.
}


Il est possible d'aménager plus d'un bureau de vote pour plus de 400 électeurs afin de garantir le bon déroulement des élections, à condition que le nombre des électeurs ne dépasse pas les 600 . Le centre électoral ne peut cependant avoir plus de 16 bureaux de vote.

La décision relative à la répartition et à la distribution des bureaux de vote doit être prise en l'espace de 15 jours après l'émission du décret convoquant les électeurs au vote.

Cette décision ne peut être amendée durant la semaine qui précède la date prévue des élections.

\title{
- Article 40
}

Les députés sont élus dans des bureaux de vote expressément déterminés.

\section{- Article 41}

Les élections se tiennent pendant une journée de dimanche, de 7 heures à 20 heures.

\begin{abstract}
- Article 42
Dans le cadre de son mohafazat, le mohafez nomme, pour chaque bureau de vote, un président, un greffier ou plus, et ce 5 jours au moins avant la tenue des élections. Quatre assistants aident le président. Ce dernier en choisit la moitié, les électeurs alphabètes présents à l'ouverture du bureau de vote en choisissent l'autre moitié. Le mohafez désigne des remplaçants, si besoin est.

Le président et la moitié de ses assistants au moins doivent être présents pendant toute la durée des élections.

Le candidat a le droit de mandater un des électeurs de la circonscription électorale pour accéder à un bureau de vote, plusieurs électeurs de la même circonscription pour accéder à plusieurs bureaux de vote, à titre d'un délégué par bureau de vote dans les villages, et un délégué pour 5 bureaux de vote dans les villes, et ce par le moyen de déclarations certifiées par le mohafez ou le caïmacam.
\end{abstract}

\begin{abstract}
- Article 43
Le président du bureau de vote a, lui seul, l'autorité de faire respecter le règlement au sein de son bureau. Aucune force armée n'a le droit de se positionner à l'intérieur du bureau à moins que le président ne l'ait demandé. Les autorités civiles et les forces armées doivent se plier à sa demande.

La requête déposée par le président du bureau ne peut néanmoins empêcher ni les candidats ni leurs délégués d'exercer leur droit de surveiller le déroulement des élections. Il est interdit de renvoyer un délégué de candidat, à moins qu'il n’ait violé le règlement ou en cas de flagrant délit qui justifie son arrestation. Dans ce cas-là, un procès-verbal est dressé, faisant mention des raisons et de l'heure du renvoi.
\end{abstract}

\section{- Article 44}

Le président du bureau de vote règle de manière provisoire les problèmes en relation avec le déroulement électoral et note ses décisions dans un procès-verbal. Les documents, les enveloppes et les bulletins de vote doivent être annexés au procès-verbal, une fois signés par tous les membres du bureau.

\section{- Article 45}

Durant les élections, une copie officielle de la liste électorale et une copie de l'arrêté ministériel en vertu duquel les bureaux de vote sont établis et déterminés, sont affichées à l'entrée du bureau. Une copie de la loi électorale et une copie de la liste des délégués des candidats sont déposées sur la table du bureau et mises à la disposition des électeurs, des candidats ou de leurs délégués.

\section{- Article 46}

Tous les électeurs déposent leurs bulletins dans des enveloppes uniformes, non transparentes et enduites de colle, que le Ministère de l'Intérieur met à la disposition des électeurs sur la table du bureau devant le président. L'expression "Ministre de l'Intérieur", accompagnée du cachet du mohafazat ou du caza, y compris la date, est imprimée sur les enveloppes. Lesdites enveloppes sont envoyées par le mohafez ou le caïmacam à chaque bureau de vote avant la tenue des élections, par l'intermédiaire des Forces de Sécurité Intérieure ou des agents de la police. Leur nombre doit être égal à celui des électeurs enregistrés sur les listes électorales du bureau. Le président du bureau reçoit aussi des enveloppes non cachetées, soit $20 \%$ du nombre de celles cachetées. Les Forces de Sécurité Intérieure ou les agents de la police rédigent un procès-verbal que le président du bureau signe pour accuser réception des enveloppes. Ledit procès-verbal est ensuite envoyé à la Commission d'enregistrement dans la circonscription par l'intermédiaire du caïmacam ou de son suppléant.

Avant l'ouverture des bureaux de vote, le président du bureau est tenu de s'assurer que le nombre des enveloppes cachetées correspond à celui des électeurs enregistrés.

Si les enveloppes cachetées s'avèrent insuffisantes en raison d'une force majeure ou d'une fraude visant à falsifier les résultats des élections ou pour toute autre raison, le président du bureau met à la disposition des électeurs les enveloppes non cachetées sur lesquelles il appose lui-même le cachet du bureau de vote, ainsi que la 
date. La raison de cet échange d'enveloppes est signalée dans le procès-verbal. Les enveloppes non cachetées qui n’ont pas été utilisées seront annexées au procès verbal.

\section{- Article 47}

A son entrée au bureau de vote, l'électeur a le droit de porter sur lui discrètement le bulletin qui comprend les noms des candidats qu'il désire élire, de prendre une feuille blanche de la table dans l'isoloir et d'y inscrire les noms des candidats qu'il désire élire.

La liste des candidats est aussi affichée dans l'isoloir prévu dans l'article 50 de la présente loi. Les électeurs y trouvent aussi des feuilles blanches et des crayons mine à leur disposition.

\section{- Article 48}

Nul n'a le droit de voter à moins que son nom ne soit inscrit sur la liste électorale ou que la Commission ait émis une décision pour enregistrer son nom. Est suspendu le droit de vote de ceux qui sont arrêtés ou placés dans des asiles psychiatriques, même s’ils ne sont pas légalement internés, et dont les noms sont inscrits sur la liste électorale.

\section{- Article 49}

La carte électorale est gratuite. L'électeur n’a pas le droit de voter s'il ne présente pas cette carte.

Les cartes électorales sont délivrées jusqu'au septième jour avant la tenue des élections. La carte électorale comprend:

Le numéro de registre de la famille, le prénom et le nom, le nom du père, la date de naissance, le rite et une photo passeport.

A son entrée au bureau de vote, l'électeur est tenu de présenter sa carte électorale pour qu'il soit autorisé à voter après vérification.

Le président du bureau, son greffier et l'un de ses assistants susmentionnés à l'article 42 de la présente loi signent, devant l'électeur, l'enveloppe / les enveloppes de vote, le/les remet à l'électeur selon les procédures électorales en vigueur. L'électeur est tenu d'entrer dans l'isoloir qui garantit la confidentialité de son vote et glisse dans chaque enveloppe un seul bulletin qui comprend les noms des députés qu'il désire élire, les membres du conseil municipal, le mokhtar ou le conseil relatif au mokhtar. Le bulletin ne doit comporter que le nombre des députés à élire. Quand l'électeur est appelé par son nom, il se présente et montre au président du bureau qu’il ne porte que le bulletin / les bulletins de vote. Le président vérifie les bulletins sans le/les toucher, puis autorise l'électeur à le/les déposer dans l'urne. Le président du bureau perce ensuite la carte électorale de l'électeur à l'endroit spécifié et la lui rend.

L'électeur n'a pas le droit de charger un tiers de déposer le bulletin dans l'urne. Cependant, l'électeur atteint d'un handicap qui le rend incapable d'introduire la feuille dans l'enveloppe et de déposer le bulletin dans l'urne a le droit de recourir à l'aide d'un autre électeur qu'il choisit lui-même.

Le président du bureau est tenu de s'assurer que l'électeur respecte littéralement le texte du présent article et qu'il s'isole dans l'isoloir, sinon, il lui sera interdit de voter.

Le vote de l'électeur est confirmé par sa propre signature ou empreinte digitale, ou la signature de l'un des membres du bureau près de son nom sur la liste des électeurs propre à chaque opération électorale.

\section{- Article 50}

Chaque bureau de vote dispose d'un isoloir au moins ; cet isoloir ne peut être placé de manière à dissimuler le déroulement des élections.

\section{- Article 51}

La liste des électeurs doit être conforme à la liste électorale et comprendre en plus 3 cases, la première consacrée à la signature de l'électeur, la deuxième à celle du membre du bureau de vote chargé de confirmer le vote, et la troisième aux observations concernant le vote de l'électeur. Les feuilles de cette liste sont attachées et numérotées. Le caïmacam ou son suppléant appose son cachet sur chaque page.

En haut de la page une, le nombre des pages de la liste des électeurs est signalé, certifié, signé et daté par le caïmacam ou son suppléant.

\section{- Article 52}

L'urne n'a qu'une seule fente destinée à y introduire le bulletin de vote.

Avant de procéder au vote, le président du bureau ouvre l'urne et vérifie qu'elle est vide, puis la referme par deux clés différentes. Le président en garde une clé, son assistant le plus âgé, l'autre. A la fermeture du scrutin, si les deux clés ne sont pas disponibles auprès du président, ce dernier prend toutes les mesures nécessaires pour ouvrir l'urne dans les plus brefs délais. 


\title{
- Article 53
}

Le président ne clôt le scrutin que quand les électeurs qui se sont présentés au bureau de vote durant les heures prévues pour le vote auront voté.

\section{- Article 54}

Après la clôture du scrutin, l'urne est ouverte, les bulletins décomptés. Si leur nombre ne correspond pas à celui des noms rayés, le procès-verbal en fait mention. Le président ou l'un de ses assistants décachette les enveloppes, une à une, et lit, à haute voix, le nom / les noms inscrit(s) sur le bulletin de vote et ce sous la surveillance des candidats, de leurs délégués, ou des électeurs en l'absence des autres.

Les noms et les voix remportés par chaque candidat sont enregistrés sur le bulletin de dépouillement fait en deux copies, sous la supervision des électeurs, des candidats, ou de leurs délégués. Le président et tous les membres du bureau de vote signent ces bulletins.

Le Ministère de l'Intérieur est tenu d'équiper les bureaux de vote de rétroprojecteurs pour projeter le contenu du bulletin de vote sur un écran et permettre aux membres du bureau et aux délégués des candidats de bien voir les noms inscrits sur les bulletins de vote lors du dépouillement.

\section{- Article 55}

Si un bulletin de vote englobe un nombre de candidats qui dépasse celui des députés à élire, les noms des candidats de chaque confession cités en premier sont seulement pris en considération lors du dépouillement des voix.

\begin{abstract}
- Article 56
a- Sont annulés les bulletins qui comprennent des indications, des expressions diffamatoires à l'encontre de candidats ou d'autres personnes, ou déposés dans des enveloppes qui portent de telles marques.

b- Ne sont pas annulés les noms des candidats écrits d'une manière différente de celle en usage, tels les noms étrangers ou composés, s'ils désignent clairement les candidats, particulièrement s'il n'existe pas d'autre candidat dans la circonscription qui porte le même nom ou un nom similaire.

Si un bulletin de vote fait mention de deux noms de candidats similaires et qu'il est impossible de faire la différence, ce bulletin, ainsi que ceux annulés, sera annexé au procès-verbal. Sont annexées aussi au procèsverbal les enveloppes rendues et signées par le président du bureau de vote. Ce dernier est tenu de signaler dans le procès-verbal les raisons qui sont à la base de cette annexe.
\end{abstract}

\section{- Article 57}

A l'issue du dépouillement et de la vérification des voix, le président affiche le résultat provisoire à la porte du bureau de vote et donne à chaque candidat ou délégué de candidat, à sa demande, une copie conforme certifiée dudit résultat.

Une fois les résultats révélés comme indiqué ci dessus, tous les bulletins et enveloppes, sauf ceux à annexer au procès-verbal, sont brûlés.

\section{- Article 58}

Lorsque le résultat provisoire du vote est annoncé dans le bureau, le président du bureau rédige un procès-verbal fait en deux copies, dont chaque page est signée par tous les membres du bureau.

Le président du bureau est tenu de mettre dans une enveloppe les listes des électeurs signées par ces derniers, ainsi que les bulletins de vote annulés, les enveloppes y afférentes, le procès-verbal susmentionné et le bulletin de dépouillement. Ces documents ne sont adoptés que par les Commissions d'enregistrement ou toute autre autorité de référence.

Cette enveloppe est cachetée avec de la cire. Le président et le greffier du bureau de vote la transmettent à la Commission d'enregistrement sous haute protection sécuritaire et la remettent au président de la Commission ou à son délégué. Ce dernier l'ouvre ultérieurement en présence des représentants des candidats. Le président et le greffier du bureau sont tenus responsables si l'enveloppe est remise ouverte.

\section{- Article 59}

Les Commissions d'enregistrement examinent les procès et les documents, prennent les décisions nécessaires à cet égard et annoncent, aux parties présentes (candidats ou délégués), les chiffres figurant dans chaque procès. Elles se chargent aussi de dépouiller et de décompter les voix de chaque candidat et de transmettre, aux Hautes Commissions dans les circonscriptions électorales, le résultat du dépouillement sous forme d'un procès-verbal et d’un tableau annexé, signés par tous les membres de la Commission.

La Direction Générale du Ministère de l'Intérieur nomme un fonctionnaire qui reçoit au fur et à mesure les enveloppes et les documents de la Commission d'enregistrement après que cette dernière les eut étudiés. Ledit fonctionnaire signe un accusé de réception de l'enveloppe et des documents. Quand la Commission termine la 
rédaction et la composition du procès-verbal des résultats, ledit fonctionnaire reçoit une copie signée du procès, ainsi que de tableau de résultats annexé, et signe un accusé de réception.

\section{- Article 60 :}

Quand la Haute Commission reçoit les procès-verbaux et les tableaux de résultats, elle lit le nombre de voix remportées par chaque candidat, prend en compte les résultats des Commissions d'enregistrement, puis inscrit le résultat final dans la circonscription électorale sur le tableau final, en chiffres et en lettres avec la mention «seulement». Elle rédige ensuite un procès-verbal que tous ses membres signent; ils signent également le tableau général des résultats annexé.

Le résultat final de chaque candidat est ensuite annoncé devant les candidats ou leurs délégués. La Haute Commission d'enregistrement remet au mohafez le procès-verbal final et le tableau général des résultats et rédige un document pour établir la remise et la réception desdits procès-verbal et tableau; document que le mohafez, son suppléant ou l'un des membres de la Haute Commission d'enregistrement désigné par le président, signe.

Le mohafez soumet les résultats, dans le cadre d'un procès-verbal final et d'un tableau général annexé, directement au Ministère de l'Intérieur qui se charge d'annoncer officiellement les résultats des élections et les noms des candidats vainqueurs à travers les médias. Le Ministre de l'Intérieur adresse immédiatement une lettre au président de la Chambre pour l'informer des noms des candidats qui ont remporté les élections et le nombre de voix obtenues par chaque candidat.

En ce qui concerne les élections municipales et des mokhtars, le Ministre de l'Intérieur adresse une lettre au mohafez et au caïmacam pour les informer des noms des candidats vainqueurs. Il informe de même le Ministère des Affaires municipales et rurales des noms des candidats qui ont remporté les élections municipales.

\section{- Article 61}

Les conflits et les difficultés survenus lors des élections dans un bureau de vote sont soumis à la décision prise par la Commission prévue par l'article 15 de la présente loi. La Commission note dans son procès-verbal final les décisions prises à cet égard si elle juge cela nécessaire.

\section{- Article 62}

Est considéré gagnant aux élections celui qui obtient le plus grand nombre de voix des électeurs dans la circonscription, parmi les candidats d'une même confession, du même caza ou de la même région, dans les limites des sièges consacrés à chaque confession dans ce caza ou cette région, selon le tableau $\mathrm{N}^{\circ} 2$ annexé à la présente loi.

Au cas où deux candidats sont ex æquo, le candidat le plus âgé remporte les élections.

\section{-- Chapitre 7: Campagne Electorale -}

\section{- Article 63}

La campagne électorale est exempte des droits de timbre.

\section{- Article 64}

L'autorité administrative désigne dans chaque ville ou lieu commun des emplacements spécifiques réservés à l'apposition des affiches électorales pour la durée de la période électorale et interdit les enseignes suspendues d'un bout à l'autre de la rue.

Toute affiche ou photo des candidats ne peut être apposée que dans les endroits réservés à cette fin.

\section{- Article 65}

Il est défendu à tout fonctionnaire ou employé municipal ainsi qu'aux mokhtars de distribuer des bulletins de vote, écrits ou publications versant dans l'intérêt d'un (ou de plusieurs) candidat(s) ou en sa (leur) défaveur.

\section{- Article 66}

La distribution de toute publication ou écrit versant dans l'intérêt d'un (ou de plusieurs) candidat(s) ou en sa (leur) défaveur est interdite le jour des élections. Si une telle contravention survient, les bulletins, publications et écrits sont saisis et le contrevenant sera passible de l'amende maximale visée à l’Article 69 de la présente loi.

\section{- Article 67}

Il est interdit aux candidats de receler, à travers leurs représentants, les cartes d'identité, extraits d'Etat civil individuels ou cartes électorales avant les élections ou le jour du vote. Toute contravention de ce genre sera passible de l'amende maximale visée à l'article 69 de la présente loi. 


\title{
- Article 68
}

Il est interdit à tous les médias audiovisuels ainsi qu'à la presse écrite, non politiques de faire de la publicité politique électorale tout au long de la durée de la campagne électorale allant de la date de la convocation des organes électoraux jusqu'à la tenue des élections et la publication des résultats finals. Les médias qui ne respectent pas cette disposition sont passibles de fermeture totale par une décision prise par le Tribunal des Imprimés, réuni en chambre de conseil.

\section{-- Chapitre 8: Sanctions -}

\begin{abstract}
- Article 69
Toute violation des dispositions de la présente loi non prévue par le code pénal, notamment les Articles 329 à 334, sera passible d'une amende allant de 3 millions à 5 millions de Livres Libanaises.

- Article 70

Tout fonctionnaire qui ne rallie pas, sans raison valable, le bureau de vote où il a été nommé président ou greffier, sera condamné d'un mois de prison ou d'une amende s'élevant à 1 million de Livres Libanaises. Dans ce cas, seuls les rapports médicaux présentés par le comité médical officiel sont pris en considération.

Tout président de bureau de vote ou son greffier manquant à ses obligations et aux dispositions stipulées dans la présente loi, sera condamné à une peine allant de 3 mois à 3 ans de prison ou à une amende allant de 1 à 3 millions de Livres Libanaises.

Dans ce cas, contrairement aux dispositions de l'Article 61 de la loi relative aux fonctionnaires promulguée par le décret-loi $\mathrm{N}^{\circ} 112 / 59$ en date du 12/6/1959, un procès est intenté à titre personnel par le candidat auprès du parquet ou conformément à la demande du procureur général ou du président de la Commission d'enregistrement compétente. Cette poursuite n'est pas soumise à l'approbation de la Direction de laquelle relève ce fonctionnaire.
\end{abstract}

\section{-- Chapitre 9: Dispositions diverses -}

\section{- Article 71}

Vu la situation exceptionnelle de certaines régions du Sud et pour le tour de scrutin qui aura lieu après la publication de la présente loi, y compris les élections partielles qui se tiendraient lors de ce tour, la première et deuxième circonscriptions électorales du Sud prévues à l'Article 2 de la présente loi forment une seule circonscription et les élections y prendront place sur la base de ce principe.

\section{- Article 72}

En attendant la finalisation de la carte électorale unifiée servant aux élections parlementaires, municipales et des mokhtars, sera adoptée dans les opérations électorales qui auront lieu après la publication de la présente loi, la carte électorale réservée aux élections municipales et des mokhtars émise par le Ministère de l'Intérieur- la Direction Générale de l’Etat Civil.

\section{- Article 73}

L’application des dispositions de la présente loi sera détaillée dans des décrets pris au Conseil des Ministres sur proposition du Ministre de l’Intérieur.

\section{- Article 74}

Est annulé tout texte s'opposant aux dispositions de la présente loi ou contraire à sa teneur, notamment la loi du 26 avril 1960 et ses amendements, et les articles 1,3,4,5,6,7,8,9,10,11,12,13,14,15,16,17,18 et 19 de la loi $\mathrm{N}^{\circ} 665$ du 29/12/1997 ainsi que les dispositions exécutives dérogatoires de la loi $N^{\circ} 75$ du 27/9/1975.

- Article 75

La présente loi entre en vigueur dès sa publication au journal officiel. 


\section{Séance de Ratification du Projet de Loi Electorale Parlementaire}

\section{Résumé de la séance plénière le mercredi 22/12/1999:}

Le Parlement a ratifié la loi électorale parlementaire, avec une majorité de 81 voix. 17 députés s’y sont opposés, quatre se sont abstenus de voter.

Les députés qui s’y opposaient étaient :

Rafic Hariri, Najah Wakim, Ahmed Fatfat, Mesbah El Ahdab, Khaled Daher, Hussein Yatim, Adnan Araqji, Khaled Saab, Hagop Demerdjian, Salim Diab, Yaghya Gergian, Bchara Merhej, Bahaeddine Itani, Nadim Salem, Tammam Salam, Nassib Lahoud, Camille Ziadé.

Quatre députés se sont abstenus de voter :

Le Président Hussein El Husseini, Nayla Moawada, Mahmoud Awad et Boutros Harb.

Le Parlement avait tenu sa séance plénière en deux temps, le matin et le soir. Le Président Berry a inauguré la séance matinale à 10 heures 52 minutes, en présence du Président du Conseil, Dr Salim El Hoss, et le reste des membres du gouvernement. 100 députés y étaient aussi présents.

Les noms des députés dont l'absence est justifiée ont été lus :

Habib Hakim, Wajih El Baarini, Issam Fares, Ahmad Habbous, Pierre Daccache, Gibran Taouq, Saleh El Kheir.

\section{Les questions à l'ordre du jour:}

Dans le cadre de l'ordre du jour, 18 députés ont pris la parole et exposé les demandes relatives à la vie quotidienne et aux revendications des employés des municipalités qui ont manifesté devant le Parlement et les Offices des Eaux pour condamner l'odieux massacre qu'Israël a commis dans la localité d'Arabsalim et appeler le gouvernement à réagir à cet égard.

Le député Boutros Harb a pris la parole :

Il ne fait aucun doute que l'attitude syrienne à l'égard des négociations et l'attachement de la Syrie à la concomitance des volets libano-syriens garantissent au Liban une position de force dans le cadre de ses négociations avec Israël.

Cependant, il ne faut pas que la Syrie assume à elle seule la responsabilité des négociations. Il incombe au gouvernement libanais d'affirmer son rôle, d'intensifier ses contacts et de valoriser ses amitiés et ses relations de par le monde afin de soutenir la position du Liban dans le processus des négociations, ce qui permet au Liban d’éviter tout projet de paix qui ne lui garantit ni ses droits ni ses intérêts.

Il a aussi mis en garde contre un complot d'implantation, qui nous pousse à craindre que la paix se fasse aux dépens du Liban, des Accords de Taëf et de l'unité et de l'avenir du Liban.

Il a appelé le gouvernement à mettre en place un plan pour lutter contre une telle conspiration si dangereuse, pour que le Liban ne paye pas cher le prix de la paix, comme il a déjà payé le prix de la guerre. Dans le cadre des questions portées à l'ordre du jour, j’appelle le Parlement ou ses commissions spécialisées de tenir, avant qu’il ne soit trop tard, une séance urgente afin d'étudier ce sujet si dangereux.

Le député Robert Ghanem a pris la relève à son tour et appelé le gouvernement à garder le Parlement au courant du déroulement des négociations.

Le Président Berry a répondu: Nous débattrons de cette question dans le cadre de la loi électorale. Nous sommes toujours à l'ordre du jour.

Le Président de la Commission des Affaires Etrangères Ali Khalil a pour sa part condamné l'ignoble massacre perpétré par Israël à Arabsalim, qui a blessé des enfants de la localité. Il a exhorté le gouvernement à ne pas se contenter de dénoncer un tel acte auprès du Comité des Accords d’Avril, mais de déposer une plainte auprès du Conseil de Sécurité des Nations Unies, pour mettre l'opinion publique internationale courant de l'ignominie d'un tel massacre.

Il a souligné l’importance de régler les infractions foncières et d'accélérer la mise en application de la loi sur les contraventions de construction dans laquelle le Ministère des Finances et le Département de l'Urbanisme sont appelés à trancher. 
Le député Zaher El Khatib a considéré que la simple reprise des négociations au point où elles s'étaient arrêtées représentait une victoire pour la Syrie et soulignait l'importance de la concomitance des volets. Il a de même appelé à ne pas nous départir de notre résistance dont l'ennemi israélien tente de nous priver.

Il a aussi appelé à traiter avec équité les ingénieurs qui seront désignés, les employés des municipalités, les employés des Offices des Eaux au Sud et à Tripoli et les militaires à la retraite des années 1994 et 1995.

Le député Ibrahim Bayan a de son côté fait la lumière sur le chômage et appelé à régler ce problème social. Il a interrogé le gouvernement sur les mesures mises en place pour protéger les habitants des villages et des régions rurales en hiver. Il l'a de même exhorté à poursuivre l'étude du dossier sur la réforme administrative, saluant les efforts de la résistance et de ses héros.

Le député Talal El Merabi a condamné le massacre israélien contre des enfants à Arabsalim. Il a de même salué la position du Ministre syrien des Affaires Etrangères, Farouq Charaa, à l'égard des négociations, insistant sur l’importance de la concomitance des volets libano-syrien.

Le député Nazih Mansour a pour sa part appelé le gouvernement à libérer la localité de Aïta El Chaab, soumise, depuis longtemps, au blocus israélien. Il l'a de même exhorté à verser, aux agriculteurs du Sud, des indemnités pour leur compenser les pertes encourues en raison des agressions israéliennes.

Le députés Khaled Daher a appelé le gouvernement à examiner les problèmes sociaux et à accorder à certains salariés et travailleurs leurs droits.

Le député Mesbah El Ahdab a déclaré : «Le peuple s’attendait à ce que le gouvernement applique les slogans qu'il a tant scandés. Où en est-il ? »

Le député Najah Wakim a souligné que la situation sociale prévalente était particulièrement étouffante. Le taux des jeunes qui quittent le pays augmente d'année en année. Quelle est la politique économique et financière du gouvernement ? Où en est-elle?

Le député Ammar Moussaoui a estimé que le retour à la paix ne se ferait pas de sitôt. Il a appelé à faire face à l'avenir, une étape qui s'avère difficile et périlleuse.

Il a déclaré à cet égard : « Nous comptons sur la résistance qui, elle seule est capable de garantir la restitution des territoires occupés. »

Le député Jamil Chammas a considéré que la concomitance des volets libano-syriens a contribué à pousser Israël à reprendre les négociations.

Le député Abdel Latif El Zein a soulevé la question de l'implantation et affirmé le droit des Palestiniens au retour, un droit qui nous protège nous aussi. Il s'est demandé : «L'odieux massacre commis par Israël contre Arabsalim est-il un signe de paix ? »

Le député Abdallah Kassir s'est demandé : «L'incident d'Arabsalim est-il un exemple du règlement auquel nous aspirons? » Il a de même évoqué les questions des biens-fonds au Sud. Il a indiqué que certaines régions du Sud, notamment à Tyr, avaient besoin d'une politique d'urbanisme et a appelé le gouvernement à régler ce problème.

Le député Mahmoud Awad a souhaité la libération du Liban de l'occupation israélienne en l'an 2000, saluant le rôle de la résistance et de l'armée libanaise. Il a de même fait la lumière sur l'importance de la concomitance des volets et a dénoncé le massacre israélien contre Arabsalim.

Le député Nayla Moawad a, à son tour, condamné le massacre d'Arabsalim commis par Israël et appelé à une condamnation générale d'un tel acte, particulièrement de la part du gouvernement.

Le député Fares Boueiz a qualifié cette étape de cruciale et estimé que la reprise des négociations représentait une victoire libano-syrienne.

Il a déclaré à cet égard : Nous luttons fermement pour récupérer nos terres. Le gouvernement est pour sa part tenu à mettre en place une vision claire à ce sujet et à respecter les constantes sur lesquelles il s'est toujours basé. Il a de même exposé le problème des réfugiés palestiniens et appelé le Ministre des Affaires Etrangères a effectué une tournée dans les Etats concernés, en commençant par Damas, afin de soulever ce problème. Le Liban a pour sa part décidé, à l'unanimité, de refuser leur implantation. 
Le Président Rafic Hariri a interrogé le gouvernement sur l'exemption du service militaire dont les juges bénéficiaient en vertu d'un décret promulgué par l'ancien gouvernement.

Le Parlement a ratifié après amendement un projet de loi anticipé (bis) non porté à l'ordre du jour qui concerne les tarifs d'exploitation des lignes de transmission et de réception prévus dans la Loi $\mathrm{N}^{\mathrm{o}} 531$ en date du 24/7/1996, en vertu d'un décret du Conseil des Ministres, basé sur la proposition des Ministres des Finances, de l'Information, de la Poste et des Télécommunications.

Le projet de loi visant à amender les dispositions de la loi électorale parlementaire a été soumis au débat. De nombreux députés ont discuté des normes adoptées et des divisions administratives et ont longuement débattu durant les deux étapes de la séance, le matin et le soir. D’aucuns ont affirmé que le projet ne répondait pas aux ambitions des citoyens, alors que d'autres ont jugé que l'on ne pouvait pas trouver de meilleur à l'ombre des tiraillements politiques prévalents, particulièrement les multiples échéances au niveau régional.

Les députés ont soulevé la question de la réduction de l'âge de vote à 18 ans. Le Président Berry a assuré que cette question ferait l'objet d'une attention particulière, d'autant plus qu'une telle proposition a été soumise à la Commission de l'Administration et de la Justice.

Le Président Hoss a ensuite pris la parole :

Nous avons écouté avec attention les observations des députés et nous les en remercions. Ce projet n'est pas idéal, nous le savons bien. Mais sachez que nous travaillons dans des conditions particulières et qu'il est impossible de réaliser toutes nos attentes. Il a de même ajouté : "Le gouvernement a formé une commission ministérielle pour élaborer un projet de loi électoral et a appelé toutes les parties à soumettre des projets à cet égard. Ces projets ont fait l'objet d'une importance et d'une attention particulière. Le débat au sein du gouvernement a été long et varié : opter pour une seule circonscription électorale, garder les mohafazats, opter pour de petites circonscriptions. Il a enfin été décidé d'adopter des circonscriptions moyennes. Trois propositions de loi avaient appelé à adopter les circonscriptions moyennes. Le projet que le Parlement a commencé à discuter n'est pas celui soumis par le gouvernement, mais celui amendé par la Commission de l'Administration et de la Justice, celui que nous débattons maintenant. Le gouvernement était représenté par la Commission. Il est de notre droit de débattre du projet amendé au Parlement. Je voudrais rassurer ceux qui ont insisté sur la nécessité de promulguer une loi pour contrôler les dépenses électorales et organiser les campagnes de propagande électorale et de médiatisation. En effet, nous espérons soumettre prochainement un projet de loi à cet égard. Nous soutenons la réduction de l'âge de vote à 18 ans. Le gouvernement pour sa part étudie cette question avec soin.

Les articles ont été lus et votés. Le projet de loi sur les élections parlementaires a été ratifié avec une majorité de 81 voix. 17 s'y sont opposés, 4 s’y sont abstenus.

Le procès de la séance a été lu et approuvé. Le Président Berri a levé la séance à 9h 50mn. 


\section{RESOLUÇÃO 1559 DO CONSELHO DE SEGURANÇA DA ONU 8 de outubro de 2004}

United Nations S/2004/777/Security Council. Issued October 1, 2004, Published October 8, 2004.

\section{Introduction}

1. The present report is submitted pursuant to resolution 1559 (2004) adopted on 2 September 2004 by the Security Council. In paragraph 7 of that resolution, the Council requested that I report within 30 days on the implementation by the parties of that resolution.

\section{Background}

2. From 1975 to 1990, Lebanon suffered a tragic and bloody civil war that resulted in the deaths of an estimated 120,000 people. Much of the fighting in that war was carried out by militias that corresponded to Lebanon's confessional communities. Various Palestinian militant groups also took part in the violence. Over the years, at various times, France, Italy, the Libyan Arab Jamahiriya, Yemen, Saudi Arabia, the Sudan, the Syrian Arab Republic, the United Arab Emirates, the United Kingdom of Great Britain and Northern Ireland and the United States of America deployed forces in Lebanon at the request of its Government to bring the fighting to an end and to stabilize the situation. Israel carried out frequent military operations during this period, including shellings, air attacks, two large-scale incursions into Lebanon and an extended occupation of the southern part of the country.

3. The Security Council has been engaged in the issue since 1978 and has adopted 76 resolutions that called, inter alia, for an end to violence, the protection of civilians, respect for Lebanese sovereignty, the withdrawal of Israeli forces from Lebanese territory and the extension of Lebanese authority throughout the country's territory.

4. The Syrian Arab Republic first deployed troops in Lebanon in May 1976, at the request of Lebanese President Franjieh. In October 1976, the League of Arab States established the Arab Deterrent Force (ADF) to keep the peace in Lebanon. In the Force, the Syrian Arab Republic was joined by the Libyan Arab Jamahiriya, Yemen, Saudi Arabia, the Sudan, and the United Arab Emirates. Syrian forces constituted the majority of ADF troops, accounting at initial deployment for approximately 27,000 of its total strength of 30,000 .

5. After a Palestinian attack in northern Israel that had resulted in the deaths of over 30 civilians, Israel carried out a major military operation in southern Lebanon in March 1978. The Security Council adopted resolution 425 (1978), calling upon Israel immediately to cease its military action against Lebanese territorial integrity and withdraw forthwith its forces from all Lebanese territory. Also, in March 1978, pursuant to Council resolutions 425 (1978) and 426 (1978), the United Nations Interim Force in Lebanon (UNIFIL) was deployed with three purposes as set forth in resolution 425 (1978): (a) confirming the withdrawal of Israeli forces; (b) restoring international peace and security; and (c) assisting the Government of Lebanon in ensuring the return of its effective authority in the area. The UNIFIL mandate has been regularly renewed, most recently on 29 July 2004 through Security Council resolution 1553 (2004).

6. In June 1982, Israel launched an invasion of Lebanon, the trigger for which was an assassination attempt on the Israeli ambassador to the United Kingdom. The United States took the lead in achieving an agreement in August 1982 for the evacuation of Palestinian forces from Beirut and the deployment of a Multinational Force (MNF) to oversee the evacuation. France, Italy and the United States provided troops to the Multinational Force, and the evacuation was completed by September 1982. MNF forces withdrew from Lebanon later in September. 
7. After the assassination of Lebanese president-elect Bashir Gemayel in mid-September 1982, followed by an Israeli incursion into west Beirut and the criminal massacre of Palestinians in the Sabra and Shatila refugee camps by Phalangist militias in late September, the Multinational Force returned to Lebanon. Forces from the United Kingdom joined the original three members of the Force. The Security Council adopted resolution 520 (1982) on 17 September 1982, in which it condemned the Israeli incursion into Beirut, demanded a return to the positions occupied by Israel before 15 September and called for the strict respect of the sovereignty, territorial integrity, unity and political independence of Lebanon under the sole and exclusive authority of the Government of Lebanon through the deployment of the Lebanese Army throughout Lebanon. In May 1983, representatives of Israel, Lebanon and the United States reached an agreement intended to lead to the withdrawal of Israeli forces and the establishment of a "security region" in southern Lebanon. On 23 October 1983, 241 United States Marines and 56 French paratroopers were killed in twin suicide bombings. Against a backdrop of rising violence, the Government of Lebanon cancelled its agreement with Israel in March 1984. The Multinational Force withdrew in April of that year.

8. On 22 October 1989, as a result of efforts by the League of Arab States, members of the Lebanese Chamber of Deputies, meeting in Taif, Saudi Arabia, agreed to the Taif Agreement. The Agreement called for national reconciliation and for "spreading the sovereignty of the State of Lebanon over all Lebanese territory" through a one-year plan that included the "disbanding of all Lebanese and nonLebanese militias". The militias' weapons were to "be delivered to the State of Lebanon within a period of six months". In the agreement, Lebanon thanked the Syrian Arab Republic for the assistance provided by its forces to enable the Lebanese Government to extend its authority throughout Lebanon "within a set period of no more than two years". At the end of that period, the two Governments were to decide on the redeployment of the Syrian forces in the region of the Bekaa as far as the line Hammana-Mdairej-Ain Dara and, in case of need, at other points to be determined by a joint Lebanese-Syrian military committee. The two Governments were also to conclude an agreement to "determine the strength and

duration of the presence of Syrian forces in those areas and to define these forces' relationship with the Lebanese State authorities where the forces are present”. The Syria-Lebanon Treaty of Cooperation of May 1991 reiterated this provision.

9. Over the years, the Security Council maintained its commitment to Lebanon's territorial integrity, sovereignty and independence. The Secretariat worked to persuade Israel to withdraw from southern Lebanon. In April 2000, I received formal notification from the Government of Israel that it would withdraw its forces from Lebanon by July 2000. On 25 May 2000, the Government of Israel notified me that Israel had redeployed its forces in compliance with Council resolutions 425 (1978) and 426 (1978). On 16 June, I reported to the Council that Israel had withdrawn its forces in accordance with resolutions 425 (1978) and 426 (1978) and had met the requirements set out in my 22 May report (S/2000/460) to the Council. I informed the Council that Lebanon had started to re-establish its authority in the area and was considering deploying its armed forces in southern Lebanon. On 18 June, the Council welcomed my report and confirmed my conclusions.

\section{Security Council resolution 1559 (2004)}

10. On 2 September 2004, the Security Council adopted resolution 1559 (2004) which reiterated the Council's strong support for the territorial integrity, sovereignty and political independence of Lebanon. It called upon all parties concerned to cooperate fully and urgently with the Council for the full implementation of that and other relevant Council resolutions concerning the restoration of the territorial integrity, full sovereignty and political independence of Lebanon. In addition, in its resolution 1559 (2004), the Council:

(a) Called upon all remaining foreign forces to withdraw from Lebanon;

(b) Called for the disbanding and disarmament of all Lebanese and non-Lebanese militias;

(c) Supported the extension of the control of the Government of Lebanon over all Lebanese territory; 
(d) Declared its support for a free and fair electoral process in Lebanon's then upcoming presidential election conducted according to Lebanese constitutional rules devised without foreign interference or influence.

The Council also reaffirmed its call for the strict respect of the sovereignty, territorial integrity, unity, and political independence of Lebanon under the sole and exclusive authority of the Government of Lebanon throughout Lebanon.

11. The Governments of Lebanon and the Syrian Arab Republic submitted to the President of the Security Council and to me letters (A/58/879-S/2004/699 and A/58/883-S/2004/706, respectively) regarding the resolution.

\section{A. Foreign forces deployed in Lebanon}

12. Security Council resolution 1559 (2004) calls for the withdrawal of all remaining foreign forces from Lebanon. Apart from the United Nations Interim Force in Lebanon (UNIFIL), to the best of our ability to ascertain, the only significant foreign forces deployed in Lebanon, as of 30 September 2004, are Syrian.

13. As I have described, the Syrian Arab Republic has maintained forces in Lebanon since 1976. The troops were initially deployed at the request of Lebanese President Franjieh. That deployment was transformed into an Arab Deterrent Force sanctioned by the League of Arab States, at the request of the Government of Lebanon, and was joined by troops from other Arab countries. The Governments of both Lebanon and the Syrian Arab Republic have told me that the Syrian forces present in Lebanon - which at one point numbered 40,000, according to the Government of Lebanon - are there at the invitation of Lebanon and that their presence is therefore by mutual agreement. Specifically, they are said to be deployed pursuant to the Taif Agreement of 1989 and the Syria-Lebanon Treaty of Cooperation ratified by both countries in 1991. As far as I am aware, the two Governments have not, to date, concluded the further agreement "to determine the strength and duration of the presence of Syrian forces" that is provided for in both those instruments.

14. In addition to the uniformed armed forces the Syrian Arab Republic has deployed in Lebanon, the Syrian Government has informed the United Nations that there is also a substantial presence of nonuniformed military intelligence officials that, it says, are usual components of military units. These officials, together with the uniformed forces, constitute the full Syrian troop strength.

15. The Syrian military and intelligence apparatus in Lebanon had not been withdrawn as of 30 September 2004. However, according to announcements by the Lebanese and Syrian Governments, the Syrian Arab Republic has in recent weeks redeployed approximately 3,000 of its forces formerly deployed south of Beirut. It has not been made clear to the United Nations whether these redeployments are confined to regular troops or include non-uniformed military intelligence, and whether they have all returned to the Syrian Arab Republic. According to the parties, this is the fifth such redeployment since the signing of the Taif Agreement.

16. The Syrian Government has indicated to me that a total of about 14,000 Syrian troops remains in Lebanon. It says that a majority of these forces are now based near the Syrian border and that they are not deployed deep inside Lebanon. The Lebanese and Syrian Governments have told me that the timing of further withdrawals would be determined by the security situation in Lebanon and the region and through the joint military committee established pursuant to the Taif Agreement. 17. The Government of Lebanon has further informed me that the current fragile security situation in the region, and its concern regarding potential risks to Lebanon's domestic stability, render it difficult to establish a timetable for the full withdrawal of Syrian forces. The Government of Lebanon has stated to me that its ultimate goal is the complete withdrawal of all foreign forces from Lebanese territory. In addition, the two Governments have told me that they are actively discussing the nature 
and extent of the current deployment of Syrian forces in Lebanon. In this context, the Government of the Syrian Arab Republic has informed me that it cannot provide me with numbers and timetables for any future withdrawal.

\section{B. Lebanese and non-Lebanese militias}

18. Security Council resolution 1559 (2004) calls for the disbanding and disarmament of all Lebanese and non-Lebanese militias. Since the end of the civil war, the Government of Lebanon has made great strides in significantly reducing the

number of militias present in Lebanon. Nevertheless, as of 30 September 2004, several armed elements remain in the South. The Government of Lebanon has told me that it intends that all irregular armed groups should ultimately be disarmed and disbanded.

19. The most significant remaining armed group is Hezbollah. The Government of Lebanon objects to the characterization of Hezbollah as a Lebanese militia, and refers to it as a "national resistance group" that has as its goal the defence of Lebanon from Israel and the removal of Israeli forces from Lebanese soil, namely, the Shab'a farms. Lebanon maintains that the Shab'a farms are Lebanese territory, not Syrian. However, in my report of 16 June 2000 (S/2000/590), I had confirmed that Israel had fulfilled as of that date the requirements of Security Council resolutions 425 (1978) and 426 (1978) that it "withdraw forthwith its forces from all Lebanese territory". The Council endorsed this conclusion in the statement made on behalf of the Council by its President (S/PRST/2000/21), on 18 June 2000. Notwithstanding the Government of Lebanon's position that the Shab'a farms area lies within Lebanon, the Government has confirmed that it would respect the Blue Line as identified by the United Nations. The Council noted this in the statement by the President on 18 June 2000, and both in that statement and in subsequent resolutions, has called upon Lebanon to respect the commitment that it has made to respect fully that line. ${ }^{1}$

20. As of 30 September 2004, United Nations staff on the ground had not discerned any change in the status of Hezbollah since the adoption of resolution 1559 (2004). In this connection, the Government of Lebanon has informed me that the fragile security situation in the region, the risk to Lebanon's stability and the lack of a comprehensive regional peace process would make it difficult to implement the resolution immediately and fully.

21. Regarding Palestinian armed groups, the Government of Lebanon has given me assurances that Palestinian militants are not allowed to leave their refugee camps with weapons. United Nations personnel in the region have indicated that the Government of Lebanon has positioned the Lebanese armed forces outside the camps, apparently to enforce this policy. The Government has told me that the security situation in the camps makes it inadvisable for its forces to enter the camps to disarm the militants. The Government of Lebanon expresses particular concern regarding the presence of a large Palestinian refugee population on its territory and Lebanese public discussion regularly raises fears that this community might be settled permanently in Lebanon. The Government insists that a final Middle East settlement should contain provisions for the resettlement of these refugees.

\section{Extension of Lebanese government control over all Lebanese territory}

22. Security Council resolution 1559 (2004) declares Council support for the extension of the control of the Government of Lebanon over all Lebanese territory. Since the end of the civil war, Lebanon has deployed some security forces in the southern part of the country, in accordance with relevant Council resolutions and the Taif Agreement. However, as of 30 September 2004, the Government of Lebanon had not extended its control over all of its territory.

23. Although Lebanon held peaceful municipal elections in the south in May 2004, the area around the Blue Line remains tense. The calm that followed the withdrawal has too often been shattered by violence. The Lebanese army has not deployed along the Blue Line. UNIFIL has reported that there have been violations from both sides of the Blue Line; on the Lebanese side, they have come from 
Hezbollah and Palestinian groups. Hezbollah operations have frequently violated the Blue Line. It is widely asserted that Hezbollah operations are carried out independently of Lebanese government control or sanction. I have previously urged the Government of Lebanon to exert control over the use of force on its entire territory and to prevent all attacks from its territory across the Blue Line.

24. More than four years after the Israeli withdrawal from the south of Lebanon, movement in the region remains restricted. Hezbollah has established checkpoints throughout southern Lebanon. Movements of Lebanese officials, UNIFIL personnel and diplomats are hindered at times by armed elements. 25. The Government of Lebanon has stated to me that it is constrained in its ability to deploy its forces in parts of southern Lebanon by the terms of the Israeli-

Lebanese General Armistice Agreement of 23 March 1949, which set limits to the numbers and types of military forces the parties might deploy in the region of the boundary between the two countries. According to the Government, it has deployed in the region the full complement of 1,500 troops permitted to it by that Agreement.

\section{Presidential election process}

26. Resolution 1559 (2004) declares the Security Council's "support for a free and fair electoral process in Lebanon's upcoming presidential election conducted according to Lebanese constitutional rules devised without foreign interference or influence”. Lebanese President Lahoud's term in office was to have expired in November 2004. According to the Lebanese Constitution, the Chamber of Deputies is required to meet at least a month before the expiration of the president's term to elect a successor. The Constitution allows for a single six-year term for the president, with a possibility of a return to office only after the passage of six years.

27. On 3 September 2004, less than 24 hours after resolution 1559 (2004) was adopted, the Chamber of Deputies approved Constitutional Law 585 by a vote of 96 to 29 with three members not present, thereby extending President Lahoud's term by three years. The law stated that "for a one and exceptional time, the mandate of the current President of the Republic will be renewed to three additional years that should end on 23 November 2007”. The Government of Lebanon has informed me that this law was adopted in accordance with Lebanese constitutional rules. In 1947 and 1995, the Chamber of Deputies had voted to allow one-time extensions of the terms of sitting presidents. It was widely contended in Lebanon, and asserted by the co-sponsors of resolution 1559 (2004), that the extension of President Lahoud's term in office was the result of a direct intervention by the Government of the Syrian Arab Republic. Ten members of the Chamber of Deputies have tabled a motion in the Chamber to abrogate the law extending President Lahoud's term. Both the Lebanese and Syrian Governments have denied Syrian influence on the extension.

\section{E. Sovereignty, territorial integrity, unity and political independence of Lebanon}

28. In resolution 1559 (2004), the Security Council reaffirmed its call for the strict respect of the sovereignty, territorial integrity, unity and political independence of Lebanon under the sole and exclusive authority of the Government of Lebanon throughout Lebanon.

29. It is widely alleged in Lebanon that the Syrian military presence, including a substantial component of non-uniformed intelligence officials, affords the Syrian Arab Republic considerable leverage over Lebanese domestic affairs. The Governments of Lebanon and the Syrian Arab Republic have denied to me that the Syrian Arab Republic intervenes in Lebanon's internal affairs.

30. Despite the closeness of official ties between Lebanon and the Syrian Arab Republic, it has been noted that the countries have never had formal diplomatic relations. There is no Lebanese diplomatic mission in Damascus, nor is there a Syrian diplomatic mission in Beirut.

31. Since October 2000, Israeli aircraft have regularly violated Lebanese sovereignty by flying into Lebanese airspace, at times crossing the Blue Line. They frequently penetrate deep into Lebanese 
territory and generate sonic booms over

populated areas. The Government of Israel claims that these overflights are carried out for security reasons. Hezbollah anti-aircraft fire has fallen across the Blue Line into Israel. Such fire has caused Israeli casualties.

32. I, and my representatives in the region, have called upon the parties to cease violations of the Blue Line in either direction and refrain from escalatory acts, which have caused casualties on both sides. As we have stated, one violation does not justify another.

\section{Observations}

33. Security Council resolution 1559 (2004), pursuant to which this report has been drafted, lays specific requirements on various parties. As will be apparent from this report, I cannot certify that these requirements have been met. While their objections to the resolution are well known, the Governments of Lebanon and the Syrian Arab Republic have assured me of their respect for the Council, and that consequently they will not contest it. The parties have provided me with information and given me certain assurances that are set forth above. I note these assurances and await their fulfilment. I have requested from the parties a timetable for their full implementation.

34. As regards the electoral process, it has long been my strong belief — reiterated most recently at the African Union summit in July of this year - that Governments and leaders should not hold on to office beyond prescribed term limits.

35. Lebanese public opinion appears to be divided over such issues as the Syrian military presence in Lebanon, the constitutional situation as it relates to presidential elections, and the continued existence of armed groups not under the direct control of the Government. However, many are of the view that full implementation of resolution 1559 (2004) would be in the interest not just of Lebanon, but of the Syrian Arab Republic, too, and of the region and the wider international community. It is time, 14 years after the end of hostilities and four years after the Israeli withdrawal from Lebanon, for all parties concerned to set aside the remaining vestiges of the past. The withdrawal of foreign forces and the disbandment and disarmament of militias would, with finality, end that sad chapter of Lebanese history.

36. As I noted above, the requirements imposed on the various parties as set out in Security Council resolution 1559 (2004) have not been met. In this connection, I remain ready to assist the parties, as needed, in the full implementation of Council resolution 1559 (2004), and, if required, to keep the Council regularly updated with any information in this regard.

37. I continue to look forward to the ultimate achievement of a just, lasting and comprehensive peace in the Middle East. 


\section{MAPA DA DIVISÃO ADMINISTRATIVA DO LÍBANO Seis Províncias (Mohafazat) e 25 Distritos (Aqdya)}

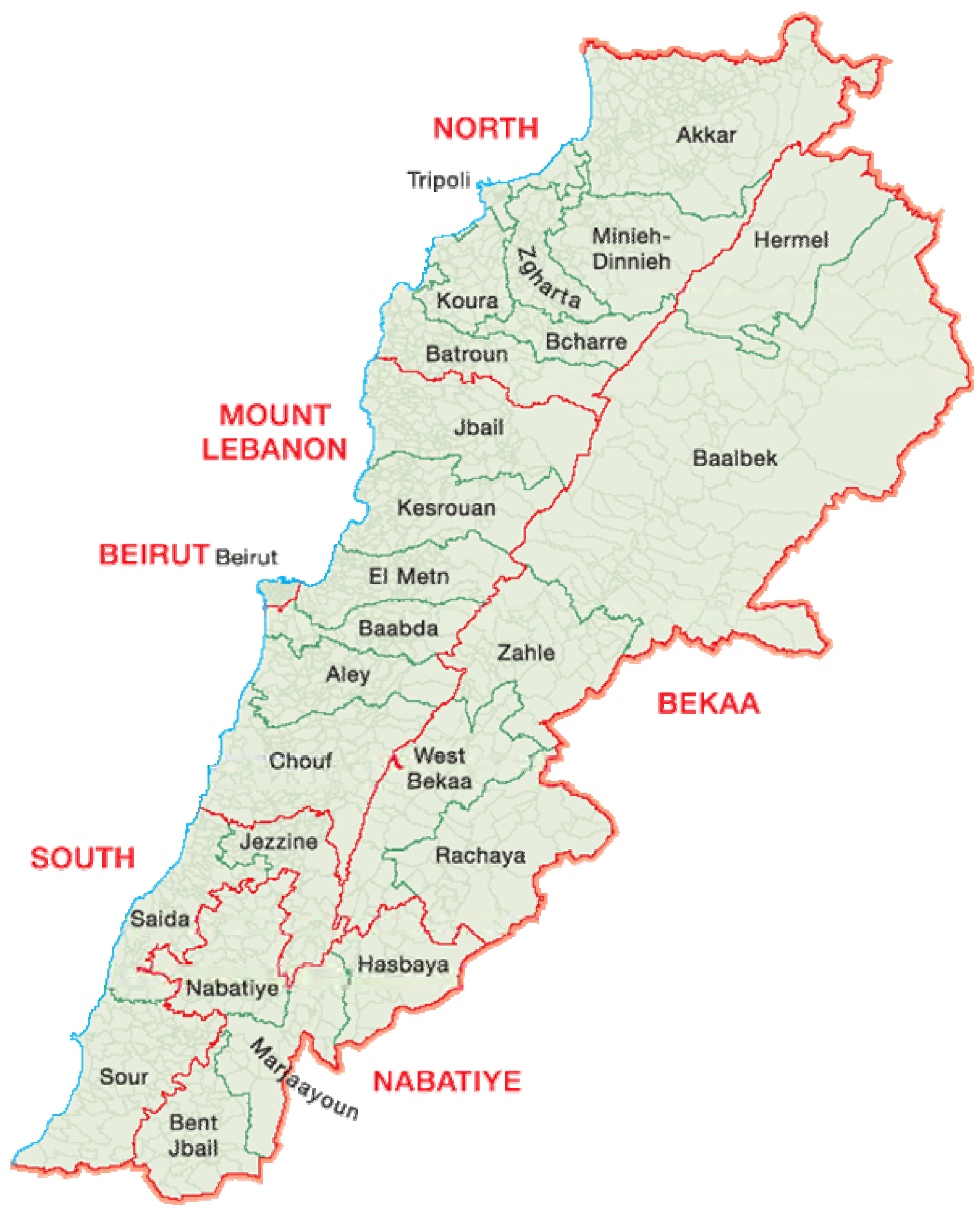




\section{TABELA DA DIVISÃO ADMINISTRATIVA DO LÍBANO Seis Províncias (Mohafazat) e 25 Distritos (Aqdya)}

\begin{tabular}{|c|c|}
\hline $\begin{array}{l}\text { Beirut Governorate } \\
\text { The Beirut Governorate is not divided into } \\
\text { districts and is limited to the city of Beirut. }\end{array}$ & $\begin{array}{l}\text { Nabatiyeh Governorate } \\
\text { (Jabal Amel) - } 4 \text { districts } \\
\text { - Al-Nabatiyé } \\
\text { - Hasbyya } \\
\text { - Marji'youn } \\
\text { - Bint Jbeil }\end{array}$ \\
\hline $\begin{array}{l}\text { Beqaa Governorate } \\
5 \text { districts } \\
\text { - Al-Hirmil } \\
\text { - Baalbeck } \\
\text { - Zahlé } \\
\text { - Western Beqaa (al-Beqaa al- } \\
\text { - } \text { Gharbi) } \\
\text { Rashyya }\end{array}$ & $\begin{array}{l}\text { North Governorate } \\
\text { (al-Shamal) - } 7 \text { districts } \\
\text { - Akar } \\
\text { - Tripoli } \\
\text { - Zgharta } \\
\text { - Bshirri } \\
\text { - Batroun } \\
\text { - Koura } \\
\text { - Miniyeh-Danniyeh }\end{array}$ \\
\hline $\begin{array}{l}\text { Mount Lebanon Governorate } \\
\text { (Jabal Lubnan) - } 6 \text { districts } \\
\text { - Jbeil } \\
\text { - Kisirwan } \\
\text { - Al-Matn (Dhour Choeir and } \\
\text { Bikfaya) } \\
\text { - Ba'abda } \\
\text { - Alay } \\
\text { - Al-Shouf }\end{array}$ & $\begin{array}{l}\text { South Governorate } \\
\text { (al-Janoub) - } 3 \text { districts } \\
\begin{array}{l}\text { - } \quad \text { Saida } \\
\text { - } \quad \text { Tyre (Sur) } \\
\text { - Jezzine }\end{array}\end{array}$ \\
\hline
\end{tabular}

